\begin{tabular}{l} 
2. To: (Receiving Organization) \\
Distribution \\
\hline 5. Proj./Prog./Dept./Div.: \\
TWRS
\end{tabular}

3. From: (Originating organization)

A. B. Carlson, NHC

6. Design Authority/ Design Agent/Cog. NA Engr:: A.B. Carlson
8. Originator Renarks:

For approval and release.
4. Related EDT No.:

NA

7. Purchase Order No.:

NA

9. Equip./Component No.: NA

10. System/8ldg./Facility:

11. Receiver Remarks: 11A. Design Baseline Document? [] Yes [X] No
NA

12. Major Assm. Dwg. No.: NA

13. Permit/Permit Application No.: NA

14. Required Response Date: NA

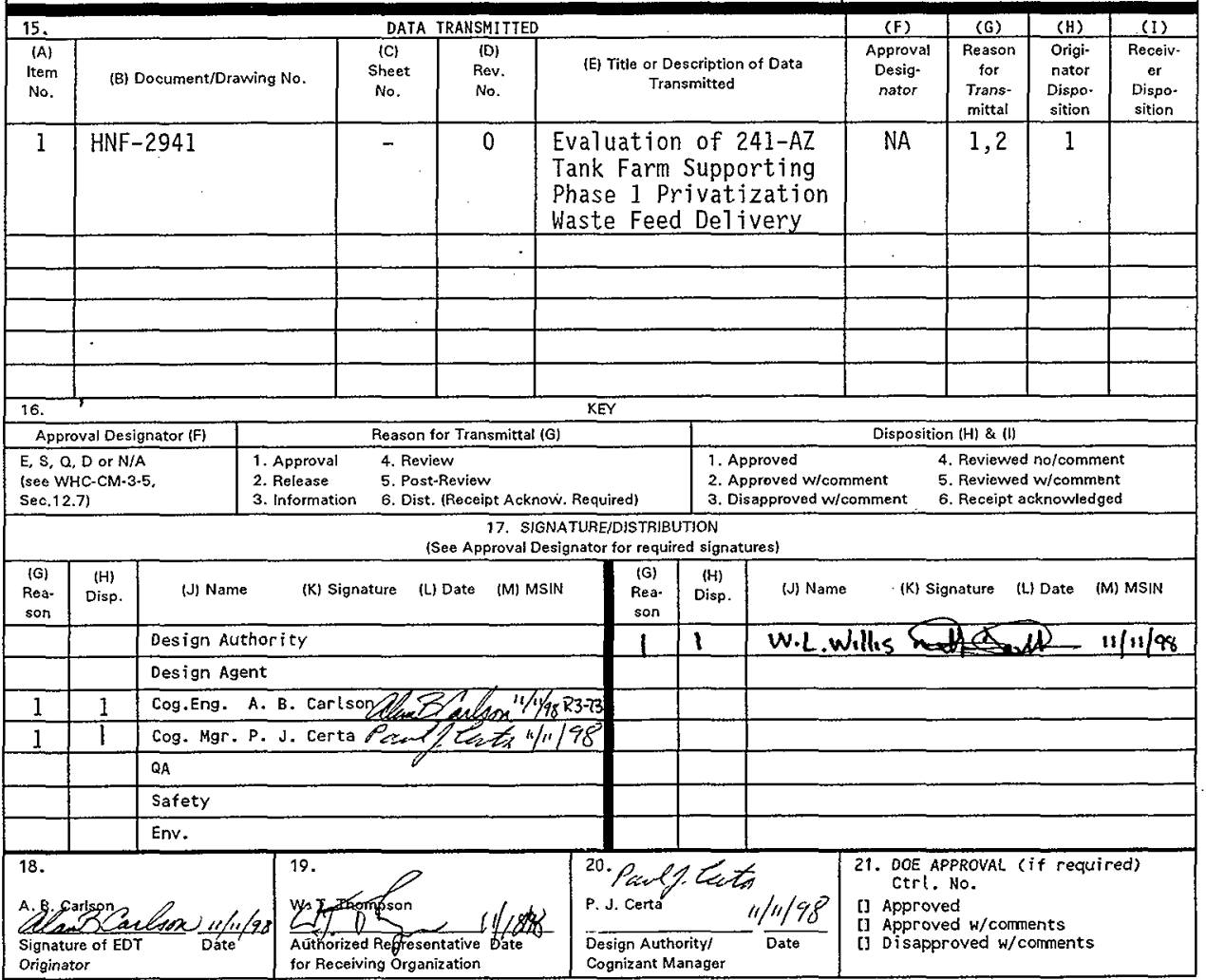

$\mathrm{BD}-7400-172-2(05 / 96)$ GEF097 


\title{
Evaluation of 241-AZ Tank Farm Supporting Phase 1 Privatization Waste Feed Delivery
}

\author{
A. B. Carlson, W. L. Willis, and T. R. Benegas (Cogema) \\ Numatec Hanford Corporation, Richland, WA 99352 \\ U.S. Department of Energy Contract DE-AC06-96RL13200
EDT/ECN: 623480
Org Code: 81100
B\&R Code:
UC: 721
Charge Code: CACN 105443 108537
Total Pages: 327

Key Words: privatization, waste feed delivery, 241-AZ

Abstract: This evaluation is one in a series of evaluations determining the process needs and assessing the adequacy of existing and planned equipment in meeting those needs at varjous double-shell tank farms in support of Phase 1 privatization. A number of tank-to-tank transfers and waste preparation activities are needed to process and feed waste to the private contractor in support of Phase 1 privatization. The scope of this evaluation is 1 imited to process needs associated with $241-A Z$ tank farm during the Phase 1 privatization.

TRADEMARK DISCLAIMER. Reference herein to any specific comercial product, process, or service by trade name, trademark, manufacturer, or otherwise, does not necessarily constitute or imply its endorsement, recomendation, or favoring by the United states Government or any agency thereof or $i$ ts contractors or subcontractors.

Printed in the United States of America. To obtain copies of this document, contact: Document Control Services, P.O. Box 950, Mailstop H6-08, Richland WA 99352, Phone (509) 372-2420;

Fax (509) 376-4989.
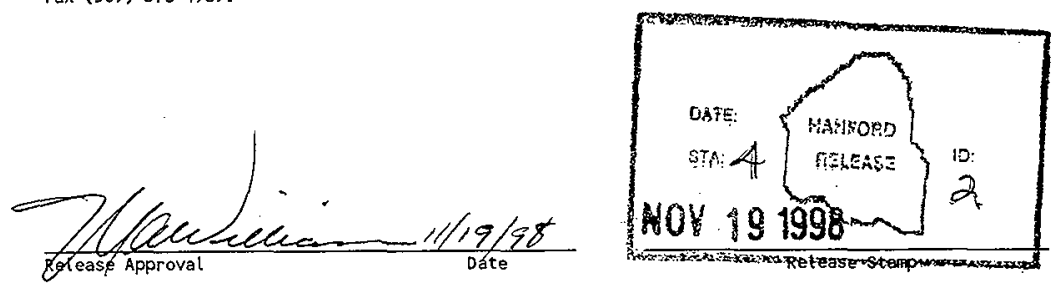

Approved for Public Release. 
HNF-2941

Revision 0

\title{
EVALUATION OF 241-AZ TANK FARM, SUPPORTING PHASE 1 WASTE FEED DELIVERY
}

November 1998

\author{
A. B. Carlson \\ W. L. Willis \\ Numatec Hanford Corporation \\ Richland, Washington
}

T. R. Benegas

Cogema Engineering

Richland, Washington

Prepared for

U.S. Department of Energy

Richland, Washington 
HNF-2941

Revision 0

This page intentionally left blank. 
HNF-2941

Revision 0

\section{EXECUTIVE SUMMARY}

The mission of the Tank Waste Remediation System (TWRS) Project is to provide safe storage and management of past and future tank waste; retrieval, treatment, and disposal of the waste; decontamination and disposal of TWRS facilities; and final closure of the tanks. To reduce the potential for additional contamination to the environment, the U.S. Department of Energy (DOE) plans to transfer the tank waste to privately owned and operated waste immobilization facilities. This approach is referred to as TWRS privatization. DOE intends to conduct the waste retrieval and immobilization mission using a phased approach. During Phase 1 privatization, the sources of wastes fed to the immobilization facilities will largely be from double-shell tanks (DSTs). Waste from both of the tanks in the 241-AZ Tank Farm are planned to be delivered to the private contractor as high-level waste (HLW) feed during Phase 1 privatization. Both tanks $241-A Z-101$ and $241-A Z-102$ contain aging waste. The solids will be suspended in the liquid contained in the two AZ tank farm tanks to create a slurry. The slurry will be transferred in several batches to the private contractor facility. The private contractor will separate the slurry into HLW and low-activity waste $(L A W)$ fractions. The HLW fraction will be immobilized. The LAW fraction will be returned to the tank farms for staging. Once the two AZ tank farm tanks have been emptied of the waste currently stored, the tanks are scheduled to become staging tanks for other HLW from 241-AY tank farm and for waste retrieved from waste stored in the 241-C tank farm tanks 241-C-106, -104, and potentially -102. During Phase 1 privatization, in addition to delivering feed to the private contractor, other tank-to-tank waste transfers will also occur in support of 242-A Evaporator operation, saltwell pumping from single-shell tanks (SSTs), and other ongoing TWRS operations.

This evaluation is one in a series of evaluations determining the process needs and assessing the adequacy of existing and planned equipment in meeting those process needs at various DST farms in support of Phase I privatization. The purpose of this evaluation is twofold: establish the process needs associated with waste processing and tank-to-tank transfers to support feed delivery to the private contractor during Phase 1 privatization; and 


\section{HNF-2941}

Revision 0

evaluate the identified process needs against existing and planned structures, systems, and components (SSCS) for 241-AZ tank farm to determine whether existing and planned SSCs are capable of supporting the Phase l privatization mission. The scope of this evaluation is limited to process needs associated with 241-AZ tank farm during the Phase 1 privatization. The scope is consistent with the alternative case identified in DeLozier (1998). The SSCs examined are associated with waste preparation and transfer, utilities, instrumentation and control, and ventilation. Where information is not available to establish a quantitative process need or adequately assess whether existing and planned SSCs are capable of supporting the privatization mission, an issue is identified and a recommended approach to arrive at the necessary information is provided.

An issues list is developed where deficiencies in the system are identified. Where issues are identified, recommended actions are proposed. Issues have been categorized according to the system to which they apply, namely, waste preparation and transfer; utilities; instrumentation, monitoring, and control; and ventilation. The following list highlights some of the key issues and recommended actions that have been identified by this assessment:

\section{Waste Preparation and Control Issues}

Issue -A dilution/flush system in AN farm is identified as part of the scope of Project W-211. The AN dilution/flush system will service 241-AZ-102, but it is not clear that piping for the diluent or flush to 241-AZ-101 is included.

Recommendation -Piping from $A N$ dissolution/flush system to $241-A Z-101$ needs to be included as work scope.

Issue - It is not clear that mixer pumps installed in 241-AZ-101 can be started after a period of inactivity in the tank and provide the necessary level of solids mobilization. A full scale mixer pump test, which demonstrated the ability of mixer pumps to start after long periods of inactivity in a solids layer, has not been performed in a tank with 
HNF-2941

Revision 0

Hanford Site or similar waste.

Recommendation - Testing of the 241-AZ-101 mixer pumps shall help to establish whether the mixer pumps can run after a period of inactivity and help in determining the effectiveness of the mixer pumps.

Issue - Two large mixer pumps and a transfer pump will be required in each tank. The interference between the mixer pump discharge stream and the transfer pump is not adequately developed. The transfer pump may need to be operated during mixer pump operation to support slurry transfers.

Recommendation - Model the settling of solids in the 24I-AZ-101 tanks to determine whether it is necessary to provide slurry transfer pumps that can be operated during mixer pump operation and withstand forces imparted by full speed mixer pump . operation and remain operable and retrievable from the DST or specify a transfer pump that can operate and withstand forces imparted by full speed mixer pump operation.

Issue - The current configuration of 241-AZ-101 and -102 requires a minimum heel of $1.63 \mathrm{~m}$ (64 in.) above the tank bottom. The annulus pump pits in each tank drain into the tanks at a level of $1.63 \mathrm{~m}$ (64 in.) above the tank bottom. If the level in the tanks is drained to below $1.63 \mathrm{~m}$ (64 in.), a pathway would exist for contaminated vapors to be, drawn from the primary tank into the annulus.

Recommendation - Perform an evaluation to determine the best course of action to allow the tanks to be drained past the $1.63 \mathrm{~m}$ (64 in.) level. Options to be considered to solve this issue include plugging the annulus pump pit drains or interlocking the primary and annulus ventilation systems to shutdown annulus ventilation if the primary ventilation system is not operating. OSD-T-151-00017 would need to be revised to reflect the change. 
HNF-2941

Revision 0

\section{Utilities Issues}

" Issue - The existing tank farms electrical supply may not be adequate to supply the process need maximum electrical load (simultaneous operation of eight $224-\mathrm{kW}$ mixer pumps and four 44- $k W$ transfer pumps).

Recommendation - Perform an evaluation to determine the feasibility of either transferring some tank farms loads to other electrical supply lines in the area or refine the schedule constraints associated with simultaneous mixer pump operation to limit total electrical load.

\section{Instrumentation, Monitoring and Control Issues}

Issue - Existing temperature monitoring system may not be adequate to monitor for waste solids suspension during mixer pump operation.

Recommendation - Complete the mixer pump test in tank 241-AZ-101. Data gathered from this test will support a decision whether existing temperature monitoring is adequate.

\section{Ventilation Issues}

Issue - Thermal analysis of heat removal and ventilation system performance for waste feed delivery activities (e.g., degassing and solids dissolution) for the 241-AZ Tank Farm are preliminary in nature.

Recommendation - Perform additional refined thermal analysis for the retrieval functions to be performed in the 241-AZ Tank Farm.

Issue -The existing primary ventilation exhaust fan does not provide the specified level of vacuum and airflow as installed. Too much air in leakage is occurring into the Aging Waste Facility (AWF) tanks to allow control of the ventilation flows through each tank. 
Recommendation - For the $A W F$ to meet the design and performance requirements for Project W-030, the fan and drive apparatus will require design modifications. These - modifications are currently being reviewed by TWRS operations. Alternatively, the possibility of eliminating air in leakage sources could be evaluated.

Issue - Equipment (thermocouple tree, transfer pumps, and mixing pumps) will require installation or removal from the DST, which will create openings in the DST dome to atmosphere during this operation. To insure the containment of the DST vapors, a negative pressure in the tank dome needs to be maintained. The ventilation system may not have enough capacity to insure that the tank dome can be maintained at a negative pressure while inserting equipment and perform all its other functions for the other three tanks in the system.

Recommendation -Verification needs to be performed to assure that the ventilation system will be capable of maintaining a negative pressure in the tank dome during equipment change out. Portable exhausters could be used if it is determined that the current ventilation system is inadequate for equipment changeout.

Issue - The annulus system for the 24I-AZ tanks is a combined system for both tanks. At this time the annulus system is not operational and leak detection for the primary tank is provided by conductivity probes in the tank annulus.

Recommendation - It is not known at this time if the mixer pump operation will require a functional annulus exhaust system for heat removal or if the system will be functional. Additional, refined thermal analysis for the retrieval functions to be performed in the 241-AZ tank farm need to be completed to confirm the preliminary calculations presented here. 
HNF-2941

Revision 0

This page intentionally left blank. 
HNF-2941

Revision 0

\section{CONTENTS}

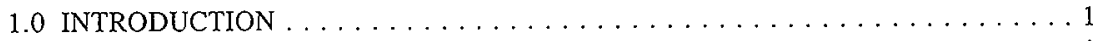

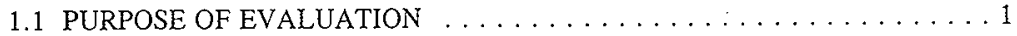

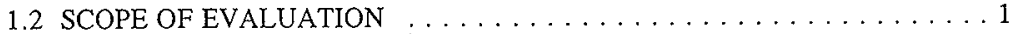

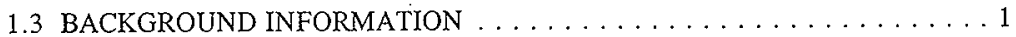

1.4 DOCUMENT ORGANIZATION $\ldots \ldots \ldots \ldots \ldots \ldots \ldots \ldots \ldots \ldots \ldots \ldots \ldots$

2.0 CONCLUSIONS, ISSUES AND RECOMMENDATIONS $\ldots \ldots \ldots \ldots \ldots \ldots$

2.1 WASTE PREPARATION AND TRANSFER SYSTEMS $\ldots \ldots \ldots \ldots \ldots 3$

2.2 UTILITY DISTRIBUTION SYSTEMS $\ldots \ldots \ldots \ldots \ldots \ldots \ldots \ldots \ldots$

2.3 INSTRUMENTATION, MONITORING AND CONTROL SYSTEM $\ldots \ldots \ldots 5$

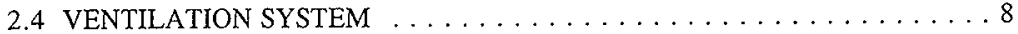

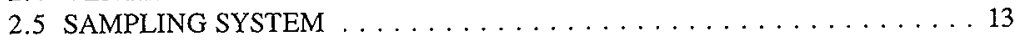

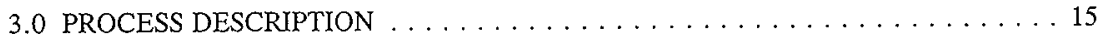

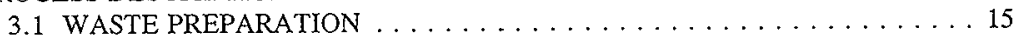

3.2 WASTE TRANSFERS TO AND FROM $241-A Z \ldots \ldots \ldots \ldots \ldots \ldots$

3.3 COMPARISON OF PROCESS STEPS TO FUNCTIONAL ANALYSIS . . . . 17

4.0 IDENTIFICATION OF PROCESS NEEDS . . . . . . . . . . . . . . . . . 29

5.0 WASTE PREPARATION AND TRANSFER SYSTEMS $\ldots \ldots \ldots \ldots \ldots \ldots . \ldots 51$

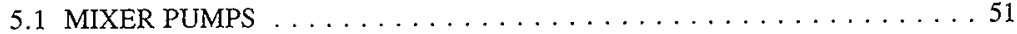

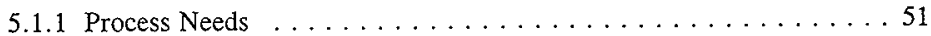

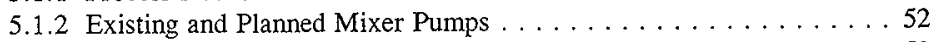

5.1.3 Comparison of Existing and Planned Equipment to Expectations . . . . 52

5.2 TRANSFER PUMPS AND PIPING AND VALVE ROUTINGS . . . . . . 52

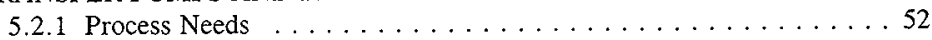

5.2.2 Existing and Planned Transfer Pumps and Piping and Valve Routings 55

5.2.3 Comparison of Existing and Planned Equipment to Process Needs . . . 55

5.3 CHEMICAL ADDITION AND FLUSHING SYSTEMS $\ldots \ldots \ldots \ldots \ldots 5$

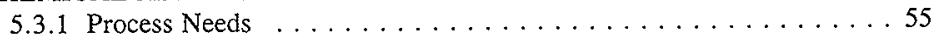

5.3.2 Existing and Planned Chemical Addition and Flushing System . . . . 56

5.3.3 Comparison of Existing and Planned Equipment to Process Needs . . 56

6.0 UTILITY DISTRIBUTION SYSTEMS $\ldots \ldots \ldots \ldots \ldots \ldots \ldots \ldots \ldots \ldots$

6.1 COMPRESSED/INSTRUMENT AIR SYSTEMS $\ldots \ldots \ldots \ldots \ldots \ldots, 57$

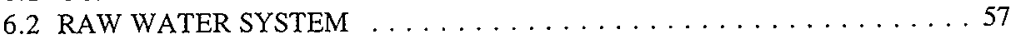

6.3 ELECTRICAL DISTRIBUTION SYSTEM $\ldots \ldots \ldots \ldots \ldots \ldots \ldots . \ldots \ldots$

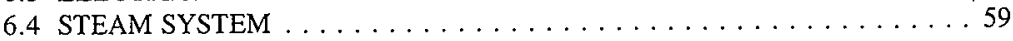

7.0 INSTRUMENTATION, MONITORING, AND CONTROL SYSTEM . . . . . 61

7.1 PROCESS MONITORING AND CONTROL STRATEGY $\ldots \ldots \ldots \ldots 61$ 
HNF-2941

Revision 0

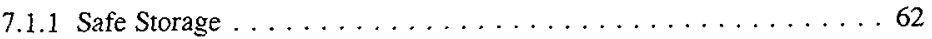

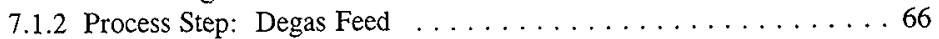

7.1.3 Process Step: Settle Solids . . . . . . . . . . . . . 66

7.1.4 Process Step: Dissolve Solids . . . . . . . . . . . 66

7.1 .5 PROCESS STEP: MOBILIZE AND SUSPEND SOLIDS . . . . . 66

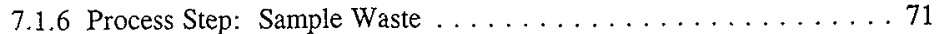

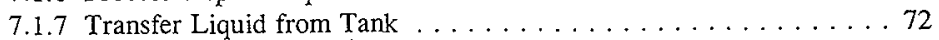

7.1 .8 Receive Liquid into Tank . . . . . . . . . . . 72

7.2 SUMMARY OF PROCESS MONITORING AND CONTROL ISSUES . . . 75

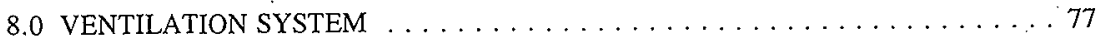

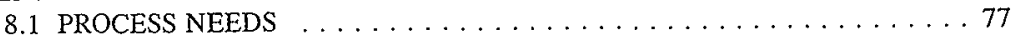

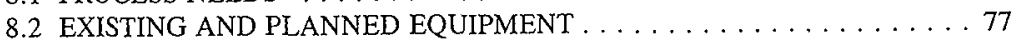

8.3 COMPARISON OF EXISTING AND PLANNED EQUIPMENT TO

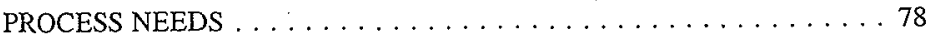

9.0 SAMPLING SYSTEM $\ldots \ldots \ldots \ldots \ldots \ldots \ldots \ldots \ldots \ldots \ldots \ldots \ldots \ldots$

10.0 REFERENCES $\ldots \ldots \ldots \ldots \ldots \ldots \ldots \ldots \ldots \ldots \ldots \ldots \ldots \ldots \ldots \ldots$

APPENDIXES

A - WASTE PREPARATION AND TRANSFER SYSTEMS PROCESS NEEDS

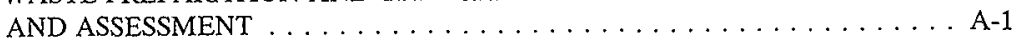

B - UTILITY DISTRIBUTION SYSTEM PROCESS NEEDS AND ASSESSMENT . . B-1

C - INSTRUMENTATION, MONITORING, AND CONTROL PROCESS NEEDS AND ASSESSMENT $\ldots \ldots \ldots \ldots \ldots \ldots \ldots \ldots \ldots \ldots \ldots$

D - VENTILATION SYSTEM PROCESS NEEDS AND ASSESSMENT . . . . . D-1

E - SAMPLING SYSTEM PROCESS NEEDS AND ASSESSMENT . . . . . E-1

F- CALCULATIONS AND ANALYSES $\ldots \ldots \ldots \ldots \ldots \ldots \ldots \ldots$ F-1

\section{LIST OF FIGURES}

5-1. Tank Farms 241-AY and 241-AZ Waste Feed Delivery System ......... 53 
HNF-2941

Revision 0

\section{LIST OF TABLES}

2-1. Waste Preparation and Transfer System Issues and Recommendations. . . . . . . 4

2-2. 241-AZ Instrumentation, Monitoring and Control System Issues. . . . . . . . . 5

2-3. Ventilation System Issues and Recommendations. $\ldots \ldots \ldots \ldots \ldots$

3-1. Matrix of Process Steps for Each Tank in 241-AZ Tank Farm. . . . . . . . 16

3-2. Comparison of Top Level System Assessment Process Steps in This Document to Level 3.2.1 Function, Double-Shell Tank System in Attachment B of Review of Performance Requirements for Phase 1 Waste Feed Delivery Components, HNF-1985 (Claghorn et al. 1998) . . . . . . . . . . . . . . . . . . . . . . . . . . 19

3-3. Comparison of System Assessment Process Steps in This Document to 3.2.1.1 Maintain Safe and Compliant Waste within the Double-Shell Tank System Function in Attachment B of Review of Performance Requirements for Phase 1 Waste Feed Delivery Components, HNF-1985 (Claghorn et al. 1998). . . . . . . . . . . . . 20

3-4. Comparison of System Assessment Process Steps in This Document to 3.2.1.2 Deliver Low Activity Waste Feed for Phase 1 Treatment Function in Attachment B of Review of Performance Requirements for Phase 1 Waste Feed Delivery Components, HNF-1985

(Claghorn et al. 1998). . . . . . . . . . . . . . . . . . . 21

3-5. Comparison of System Assessment Process Steps in This Document to 3.2.1.3 Deliver High-Level Waste Sludge to Low-Activity Waste/ High-Level Waste Plant Function in Attachment B of Review of Performance Requirements for Phase 1 Waste Feed Delivery Components, HNF-1985 (Claghorn et al. 1998). . . . . . . . . . . 22

3-7. Comparison of System Assessment Process Steps in This Document to 3.2.1.5 Receive Waste into Double-Shell Tanks Function in Attachment B of Review of Performance Requirements for Phase I Waste Feed Delivery Components, HNF-1985 (Claghorn et

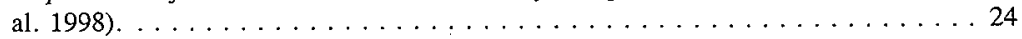

3-8. Comparison of System Assessment Process Steps in This Document to 3.2.1.6 Distribute Utilities in Double-Shell Tank System Function in Attachment B of Review of Performance Requirements for Phase I Waste Feed Delivery Components, HNF-1985

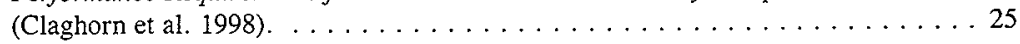

3-9. Comparison of System Assessment Process Steps in This Document to 3.2.1.10 Support Double-Shell Tank System Function in Attachment B of Review of Performance Requirements for Phase I Waste Feed Delivery Components, HNF-1985, (Claghorn et

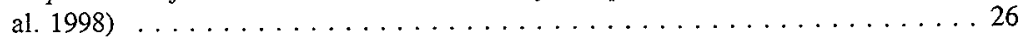


HNF-2941

Revision 0

LIST OF TABLES (CONTINUED)

3-10. Comparison of System Assessment Structures, Systems and Component Categorization in This Document to System Architecture Tree in Review of Performance Requirements for Phase 1 Waste Feed Delivery, HNF-1985 (Claghorn et al. 1998). . . . . . . . 27

4-1. Process Needs Assessment for 241-AZ Tank Farm Supporting Phase 1 Feed Delivery. 30

4-2. Safety Requirements Assessment for 241-AZ Tank Farm in Support of Phase 1 Feed

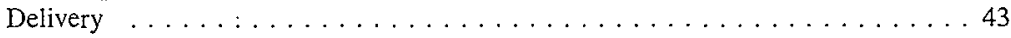


HNF-2941

Revision 0

\section{LIST OF TERMS}

$A B$

ALARA

AWF

$\mathrm{BIO}$

CAM

DOE

DST

GRE

HEGA

HEME

HEPA

HLW

LAW

$\mathrm{LCO}$

LFL

M\&I

MIT

NPSH

NPSHa

PLC

PUREX

Ri

RTP

$\mathrm{SS}$

SSC

TMACS

TSR

TWRS

TWRSO\&UP

URSILLA

VFD
Authorization bases

As low as reasonably achievable

Aging Waste Facility

Basis for Interim Operation

Continuous air monitor

U.S. Department of Energy

Double-shell tank

Gas release event

High-efficiency gas adsorber

High-efficiency mist eliminator

High-efficiency particulate air

High-level waste

Low-activity waste

Limiting condition for operation

Lower flammable limit

Management and Integration

Multi-Function Instrument Tree

Net positive suction head

Net positive suction head (available)

Programmable Logic Controller

Plutonium-uranium extraction

U.S. Department of Energy Richland Operations Office

Readiness to proceed

Safety significant

Structures, systems, and components

Tank Monitoring and Control System

Technical safety requirement

Tank Waste Remediation System

Tank Waste Remediation System Operation and Utilization Plan

Ultrasonic Interface Level Analyzer

Variable frequency drive 
HNF-2941

Revision 0

This page intentionally left blank. 
HNF-2941

Revision 0

\section{EVALUATION OF 24I-AZ TANK FARM, SUPPORTING \\ PHASE 1 WASTE FEED DELIVERY}

\subsection{INTRODUCTION}

This evaluation is one in a series of evaluations determining the process needs and assessing the adequacy of existing and planned equipment in meeting those needs at various double-shell tank (DST) farms in support of Phase 1 privatization. A number of tank-to-tank transfers and waste preparation activities are needed to process and feed waste to the private contractor in support of Phase 1 privatization. Other tank-to-tank waste transfers also occur during the Phase 1 privatization time frame in support of 242-A Evaporator operation, saltwell pumping from single-shell tanks (SSTs), and other ongoing Tank Waste Remediation System (TWRS) operations.

\subsection{PURPOSE OF EVALUATION}

The purpose of this evaluation is to establish the process needs associated with waste processing and tank-to-tank transfers to support feed delivery to the private contractor in support of Phase 1 privatization. Additionally, the process needs are evaluated against existing and planned structures, systems, and components (SSCs) for 241-AZ tank farm to determine whether existing and planned SSCs are capable of supporting the privatization mission.

\subsection{SCOPE OF EVALUATION}

The scope of this evaluation is limited to process needs associated with 241-AZ tank farm during the Phase 1 privatization. The scope is consistent with the alternative case identified in DeLozier (1998). The time frame examined is through 2016. The SSCs examined are associated with waste preparation and transfer, utilities, instrumentation and control, ventilation and sampling. Where information is not available to establish a quantitative process need an issue is identified stating how to arrive at the necessary information.

\subsection{BACKGROUND INFORMATION}

The mission of the TWRS Project is to provide safe storage and management of past and future tank waste, retrieval, treatment, and disposal of the waste, decontamination and disposal of TWRS facilities, and final closure of the tanks. To reduce the potential for additional contamination to the environment, the U.S. Department of Energy (DOE) plans to transfer the tank waste to privately owned and operated waste immobilization facilities. This 
HNF-2941

Revision 0

approach is referred to as TWRS privatization. Immobilized low-activity waste (LAW) will be returned to DOE and disposed onsite in engineered facilities. Immobilized high-level waste (HLW) will be returned to DOE and stored until a repository is available for final disposal. Waste removal from the DST system also creates room for waste removed from SST systems. DOE intends to conduct the waste retrieval and immobilization mission using a phased approach. In Phase 1, the sources of wastes fed to the immobilization facilities will largely be from DSTs. Most SST waste will be treated during a Phase 2, a follow-on phase to the Phase 1 effort.

In January 1998, the Hanford Site management and integration (M\&I) contractor team submitted to U.S. Department of Energy, Richland Operations Office (RL) analyses demonstrating readiness to proceed (RTP) with Phase 1B, TWRS privatization (Umek 1998). Subsequent to demonstrating readiness to proceed with Phase 1B, TWRS privatization, the Hanford Site M\&I contractor team was requested by DOE (Taylor 1998) to evaluate a second alternative within privatization to the baseline. The key features associated with this second alternative are discussed in DeLozier (1998). Although formal direction from RL has not been given to proceed with the features associated with this second alternative, this second alternative forms the basis for the evaluation of 241-AZ tank farm.

\subsection{DOCUMENT ORGANIZATION}

The main body of this document contains a summary of the conclusions and issues and recommendations associated with this evaluation, process description, process needs related to processing and transfers occurring during the Phase 1 privatization period, and summaries of the assessments completed for the waste preparation and transfer systems, utilities distribution system, instrumentation and control system, ventilation system and sampling system.

Appendices contain detailed information related to the assessments completed for the waste preparation and transfer systems (Appendix A), utilities distribution system (Appendix B), instrumentation and control system (Appendix C), ventilation system (Appendix D) and sampling system (Appendix E). Appendix $\mathrm{F}$ contains calculations and analyses that have been prepared to support the bases for various process needs as well as the system assessments performed as part of this evaluation. 
HNF-2941

Revision 0

\subsection{CONCLUSIONS, ISSUES AND RECOMMENDATIONS}

Below is a summary compilation of issues identified through this assessment requiring resolution to support waste feed delivery for the Phase 1 privatization mission.

Recommendations consist of either change to existing project scope if planned equipment is inadequate, establishment of new project scope where specific equipment deficiencies are identified, or further process development work where unknowns exist. This section is divided into subsections which correspond to the major systems reviewed in this assessment: waste preparation and transfer; utility distribution; instrumentation, monitoring, and control; ventilation; sampling.

\subsection{WASTE PREPARATION AND TRANSFER SYSTEMS}

The alternative case identified in DeLozier (1998) was the starting point for the evaluation of transfers in 241-AZ. All of the transfers originating or ending in $241-\mathrm{AZ}$ were extracted from the transfer list, and paths were defined for each of the different tank to tank transfers. The transfer equipment in the different transfer paths was considered. It is important to note that equipment in the transfer route included existing equipment, planned equipment (where project scope is definite and definitive design is proceeding), and conceptual equipment (where project scope is indefinite and definitive design has not yet been started). Table 2-1 lists issues identified with the 241-AZ waste preparation and transfer system and suggested work scope to address each issue. 
Table 2-1. Waste Preparation and Transfer System Issues and Recommendations.

\begin{tabular}{|c|c|c|c|}
\hline Issue & Process need & Basis for issue & $\begin{array}{l}\text { Suggested scope of } \\
\text { work to address issue }\end{array}$ \\
\hline $\begin{array}{l}\text { 1. A dilution/flush system in } \\
\text { AN farm is identified as part } \\
\text { of the scope of Project } \\
\text { W-211. The AN } \\
\text { dilution/flush system will } \\
\text { service } 241-A Z-102 \text { but it is } \\
\text { not clear that piping the } \\
\text { diluent or flush to } \\
241-A Z-101 \text { is included. }\end{array}$ & $\begin{array}{l}\text { 9.P4.1. Provide a diluent } \\
\text { system to flush the transfer } \\
\text { lines with inhibited water at } \\
530 \mathrm{~L} / \mathrm{min} \text { ( } 140 \mathrm{gal} / \mathrm{min}) \text {. } \\
9 . \mathrm{P} 4.2 \text {. The flush direction } \\
\text { should be from the } \\
\text { applicable } 241-\mathrm{AZ} \text { pump pit } \\
\text { to the Privatization } \\
\text { Contractor facility. } \\
\text { 9.P4.3. Flush transfer lines } \\
\text { with water volumes } \\
\text { equivalent to } 1.5 \text { times the } \\
\text { transfer line internal } \\
\text { volume. }\end{array}$ & $\begin{array}{l}\text { Dilution/flush capability is } \\
\text { needed in tank } 241-\mathrm{AN}-101 \\
\text { and the capability is not } \\
\text { included in current project } \\
\text { scope. }\end{array}$ & $\begin{array}{l}\text { Piping from AN } \\
\text { dissolution/flush } \\
\text { system to } \\
241-A Z-101 \text { needs to } \\
\text { be included as work } \\
\text { scope. }\end{array}$ \\
\hline $\begin{array}{l}\text { 2. It is not clear that mixer } \\
\text { pumps installed in tanks can } \\
\text { be started either initially or } \\
\text { after a period of inactivity in } \\
\text { a tank with several feet of } \\
\text { solids above the pump } \\
\text { intake, nor that the mixers } \\
\text { will be capable of interim } \\
\text { operation for the entire six } \\
\text { plus years necessary to } \\
\text { support waste feed delivery. }\end{array}$ & $\begin{array}{l}\text { 5.P1.1. Mixer pump } \\
\text { operation should mobilize } \\
>90 \% \text { of the solids } \\
\text { initially in } 241-\mathrm{AZ}-101 \text {, } \\
>60 \% \text { of the solids } \\
\text { initially in } 241-\mathrm{AZ}-102 \text {, } \\
\text { and }>99 \% \text { of the solids } \\
\text { transferred to these tanks } \\
\text { from } 241-\mathrm{AY}-102 \text {. }\end{array}$ & $\begin{array}{l}\text { A full scale mixer pump } \\
\text { test which demonstrated the } \\
\text { ability of mixer pumps to } \\
\text { start after long periods of } \\
\text { inactivity in a solids layer } \\
\text { has not been performed in a } \\
\text { tank with Hanford Site or } \\
\text { similar waste. }\end{array}$ & $\begin{array}{l}\text { Modeling of mixer } \\
\text { pump operation, and } \\
\text { the testing of the } \\
241-\mathrm{AZ}-101 \text { mixer } \\
\text { pumps. }\end{array}$ \\
\hline $\begin{array}{l}\text { 3. Two large mixer pumps } \\
\text { and a transfer pump are } \\
\text { planned in each of the } \\
241-\mathrm{AZ} \text { tanks. The mixer } \\
\text { pump discharge stream has } \\
\text { not been adequately shown } \\
\text { not to cause damage to the } \\
\text { transfer pumps. It may be } \\
\text { necessary to operate the } \\
\text { mixer and trnasfer pumps } \\
\text { simultaneously. }\end{array}$ & $\begin{array}{l}\text { 9.P3.6. Provide slurry } \\
\text { transfer pumps which can } \\
\text { be operated during mixer } \\
\text { pump operation and } \\
\text { withstand forces imparted } \\
\text { by full speed mixer pump } \\
\text { operation and remain } \\
\text { operable and retrievable } \\
\text { from the DST. }\end{array}$ & $\begin{array}{l}\text { Although not well } \\
\text { documented, anecdotal } \\
\text { information indicates that } \\
\text { line shaft driven vertical } \\
\text { turbine pumps have } \\
\text { experianced early failure } \\
\text { when used in agitated } \\
\text { tanks. It has been } \\
\text { hypothesized that the early } \\
\text { failure is due to the } \\
\text { bending of the shaft caused } \\
\text { by the forces of the } \\
\text { agitation. }\end{array}$ & $\begin{array}{l}\text { Modeling and scale } \\
\text { testing of the transfer } \\
\text { system is planned for } \\
\text { this fiscal year. } \\
\text { Results of the } \\
\text { modeling and rests } \\
\text { should be evaluated } \\
\text { and mixer and or } \\
\text { transfer pump designs } \\
\text { changed as necessary } \\
\text { to ensure } \\
\text { compatibility. }\end{array}$ \\
\hline $\begin{array}{l}\text { 4. The current configuration } \\
\text { of } 241-A Z-101 \text { and } \\
2241-A Z-102 \text { requires a } \\
\text { minimum heel of } 1.63 \mathrm{~m} \\
(64 \text { in.) }\end{array}$ & $\begin{array}{l}\text { 9.P2,?. Provide the } \\
\text { capability of removing } \\
\text { waste from the tank to } \\
\text { within } 0.25 \mathrm{~m}(10 \mathrm{in} \text {.) of } \\
\text { the tank bottom. }\end{array}$ & $\begin{array}{l}\text { The annulus pump pits in } \\
\text { each tank drain into the } \\
\text { tanks at a level of } 1.63 \mathrm{~m} \\
\text { ( } 64 \text { in.) above the tank } \\
\text { bottom. If the level in the } \\
\text { tanks are drained to below } \\
1.63 \mathrm{~m} \text { ( } 64 \text { in.) the annulus } \\
\text { ventilation system may } \\
\text { draw contaminated vapor } \\
\text { into the annulus pump pit. }\end{array}$ & $\begin{array}{l}\text { Perform an evaluation } \\
\text { to determine the best } \\
\text { course of action to } \\
\text { allow the tanks to be } \\
\text { drained past the } \\
1.63 \mathrm{~m} \text { ( } 64 \text { in.) level. } \\
\text { Options include } \\
\text { plugging the drain or } \\
\text { interlocking the } \\
\text { ventilation system. }\end{array}$ \\
\hline
\end{tabular}


HNF-2941

Revision 0

\subsection{UTILITY DISTRIBUTION SYSTEMS}

The existing tank farms electrical supply may not be adequate to supply either the process need maximum load or the postulated maximum schedule based electrical load. The pröcess need load is more conservative than the postulated schedule load. The process need requires the independent operation of retrieval equipment in each of the four 200 East Area DST farms. This is equivalent to running two mixer pumps and one transfer pump in each farm, or, eight $224-\mathrm{kW}(300-\mathrm{hp}$ ) mixer pumps and four $44-\mathrm{kW}$ (60-hp) transfer pumps. The postulated schedule load is based on the integrated schedules. The integrated schedules show that at least once in each of the first three years of processing up to nine mixer pumps and one transfer pump may be needed simultaneously to suspend and transfer solids.

The simultaneous operation of nine mixer pumps (one set of mixers in each of 241-AY-102 (four $112 \mathrm{~kW}$ [150 hp]), AZ Farm (two $224 \mathrm{~kW}$ [300 hp]) and AN (or AW) Farm (two $224 \mathrm{~kW}$ [300 hp]) and one (224 kW [300 hp]) mixer in AP Farm) cannot be achieved. Load flow and voltage drop analysis of $13.8 \mathrm{kV}$ line C8-L6, which serves the tank farms in 200 East Area, indicates that the line cannot provide power to the postulated schedule maximum TWRS load of nine mixer pumps and one transfer pump operating simultaneously without experiencing excessive voltage drop in the tank farm area. The voltage drop will also be excessive for the process need requirement since it is more conservative than the postulated schedule load. To resolve this potential issue the possibility of transferring some tank farm loads to other electrical supply lines in the area (lines C8-L5 and C8-L8 are the most likely candidates) could be explored. Or, a more detailed examination of schedule constraints for simultaneous operation of nine mixer pumps could be examined and the process need for independent operation of each farm can be modified.

\subsection{INSTRUMENTATION, MONITORING AND CONTROL SYSTEM}

Issues specific to instrumentation, monitoring and control are summarized in Table 2-2. These issues were developed only for existing equipment and planned equipment where project scope is definite and definitive design is proceeding. Additional issues may arise as project designs mature. 


\section{Revision 0}

Table 2-2. 241-AZ Instrumentation, Monitoring and Control System Issues. (3 Sheets)

\begin{tabular}{|c|c|c|c|}
\hline Issue & Process need & Basis for issue & $\begin{array}{c}\text { Suggested scope of work } \\
\text { to address issue }\end{array}$ \\
\hline $\begin{array}{l}\text { 1. Existing } 702-A Z \text { (Project } \\
\text { W-030) ventilation system } \\
\text { provides primary ventilation } \\
\text { to the four aging waste tanks } \\
(241-\mathrm{AZ}-101,241-\mathrm{AZ}-102 \text {, } \\
241-\mathrm{AY}-101 \text {, and } \\
241-\mathrm{AY}-102) \text {. This ventilation } \\
\text { system is permitted for a } \\
\text { maximum total flow of } 28.3 \\
\mathrm{~m}^{3} / \mathrm{min} \text { (1000 scfm). If mixer } \\
\text { pump or transfer pump } \\
\text { operation requires a total } \\
\text { ventilation flow beyond } \\
28.3 \mathrm{~m} / \mathrm{min} \text { (1000 scfm) for } \\
\text { acceptable operating } \\
\text { conditions, some changes to } \\
\text { the systems- such as } \\
\text { verification of isokinetic } \\
\text { nozzles and recalibration of } \\
\text { flow monitoring loop are } \\
\text { required. }\end{array}$ & $\begin{array}{l}\text { 5.PI. } 1 \text { Mixer pump } \\
\text { operation should } \\
\text { mobilize }>90 \% \text { of the } \\
\text { solids initially in } \\
241-A Z-101,>60 \% \text { of } \\
\text { the solids initially in } \\
241-A Z-102 \text {, and } \\
>99 \% \text { of the solids } \\
\text { transferred to these } \\
\text { tanks from } 241-A Y- \\
102 \text {. } \\
\text { (note: mobilization of } \\
\text { solids occurs through } \\
\text { mixer pump operation) }\end{array}$ & $\begin{array}{l}\text { Ventilation requirements } \\
\text { for maintaining waste } \\
\text { temperatures below limits } \\
\text { during mixer pump } \\
\text { operation are not currently } \\
\text { defined. There is a } \\
\text { potential that primary } \\
\text { ventilation flows may } \\
\text { require greater than } \\
28.3 \mathrm{~m}^{3} / \mathrm{min} \text { ( } 1000 \mathrm{scfm} \text { ) } \\
\text { to maintain waste } \\
\text { temperatures during feed } \\
\text { delivery activities. }\end{array}$ & $\begin{array}{l}\text { Refined thermal analysis } \\
\text { for the retrieval functions } \\
\text { to be performed in the } \\
241-A Z \text { tank farm need } \\
\text { to be completed to } \\
\text { confirm whether the } \\
\text { existing primary } \\
\text { ventilation system is } \\
\text { adequate. } \\
\text { Note that increased flows } \\
\text { will require regulatory } \\
\text { approval. Additionally, } \\
\text { the isokinetic system is } \\
\text { controlled by an } \\
\text { instrument which } \\
\text { currently can be } \\
\text { programmed only by the } \\
\text { vendor. Also, losses } \\
\text { with the system at higher } \\
\text { flows may be significant } \\
\text { enough to force a } \\
\text { redesign of the sample } \\
\text { transport lines. }\end{array}$ \\
\hline $\begin{array}{l}\text { 2. The existing temperature } \\
\text { trend recorder system is not } \\
\text { calibrated for needed } \\
\text { temperature gradient data as } \\
\text { well as rate of change } \\
\text { anmunciation }\end{array}$ & $\begin{array}{l}2 . \mathrm{S} 3.2 \text { Temperature } \\
\text { changeover time for } \\
\text { solutions in tanks shall } \\
\text { be } \leq 5.5^{\circ} \mathrm{C} / \mathrm{hr}(\leq 10 \\
\left.{ }^{\circ} \mathrm{F} / \mathrm{hr}\right)\left(<52^{\circ} \mathrm{C}[125\right. \\
\left.\left.{ }^{\circ} \mathrm{F}\right]\right) \text { or } \leq 11^{\circ} \mathrm{C} / \text { day } \\
\left(\leq 20^{\circ} \mathrm{F} / \text { day }\right) \\
\left(\geq 52^{\circ} \mathrm{C}\left[125^{\circ} \mathrm{F}\right]\right) \\
\text { AND } \\
2 . S 3.3 \text { Temperature } \\
\text { gradients of solution in } \\
\text { tanks shall be } \\
\left.\leq 100^{\circ} \mathrm{C} / \mathrm{m} \text { ( } 55^{\circ} \mathrm{F} / \mathrm{ft}\right) \\
\text { within the solution and } \\
\text { at the solution/vapor } \\
\text { interface }\end{array}$ & $\begin{array}{l}\text { Temperature gradient data } \\
\text { as well as rate of change } \\
\text { annunciation are required } \\
\text { to meet the process need. }\end{array}$ & $\begin{array}{l}\text { Issue work package to } \\
\text { recalibrate the existing } \\
\text { temperature trend } \\
\text { recorder system for } \\
\text { temperature gradient data } \\
\text { record as well as rate of } \\
\text { change annunciation }\end{array}$ \\
\hline
\end{tabular}


HNF-2941

Revision 0

Table 2-2. 241-AZ Instrumentation, Monitoring and Control System Issues. (3 Sheets)

\begin{tabular}{|c|c|c|c|}
\hline Issue & Process need & Basis for issue & $\begin{array}{c}\text { Suggested scope of work } \\
\text { to address issue }\end{array}$ \\
\hline $\begin{array}{l}\text { 3. Existing temperature } \\
\text { monitoring system may not be } \\
\text { adequate to monitor for waste } \\
\text { homogeneity during mixer } \\
\text { pump operation. }\end{array}$ & $\begin{array}{l}5 . \text { P2.2 Mix tank } \\
\text { contents to provide } \\
\text { <TBD\% variability of } \\
\text { suspended HLW solids } \\
\text { concentrations over the } \\
\text { full depth prior to } \\
\text { sampling and prior to } \\
\text { beginning each feed } \\
\text { transfer. }\end{array}$ & $\begin{array}{l}\text { One method for evaluating } \\
\text { success of waste } \\
\text { mobilization and } \\
\text { homogenization is to } \\
\text { monitor the temperature } \\
\text { gradient over the entire } \\
\text { length of liquid column } \\
\text { during waste mixing. } \\
\text { RTDs or thermocouples are } \\
\text { required at several } \\
\text { elevations to give } \\
\text { temperature gradients at } \\
\text { various tank levels } \\
\text { (primary tank). } \\
\text { At present, there are Type } \\
\text { J, thermocouples (set of } \\
\text { three thermocouples spaced } \\
\text { at } 0.10 \text { m, } 0.36 \text { m, and } \\
3.56 \text { m [4 in., } 14 \text { in., and } \\
140 \text { in.] } \\
\text { from bottom) installed in } \\
\text { risers } 13 \mathrm{~B}, 13 \mathrm{C}, 13 \mathrm{D} \text {, and } \\
13 \mathrm{~A} . \text { Another set of three } \\
\text { thermocouples are located } \\
4 \text { in. from bottom in risers } \\
16 \mathrm{~A}, \mathrm{~B} \text {, and C. It is likely } \\
\text { that this will not provide } \\
\text { temperature gradient } \\
\text { information required } \\
\text { during transfer. } \\
\text { The use of other } \\
\text { instruments can also be } \\
\text { used to determine the } \\
\text { success of waste } \\
\text { mobilization and } \\
\text { homogenization such as the } \\
\text { use of the suspended solids } \\
\text { profiler. }\end{array}$ & $\begin{array}{l}\text { Complete the mixer } \\
\text { pump test in tank } \\
241-A Z-101 \text {. Data } \\
\text { gathered from this test } \\
\text { will support a decision } \\
\text { whether existing } \\
\text { temperature monitoring } \\
\text { is adequate. In addition, } \\
\text { the use of other } \\
\text { instruments, such as the } \\
\text { suspended solids profiler } \\
\text { should also be considered } \\
\text { for use. }\end{array}$ \\
\hline
\end{tabular}


HNF-2941

Revision 0

Table 2-2. 241-AZ Instrumentation, Monitoring and Control System Issues. (3 Sheets)

\begin{tabular}{|c|c|c|c|}
\hline Issue & Process need & Basis for issue & $\begin{array}{l}\text { Suggested scope of work } \\
\text { to address issue }\end{array}$ \\
\hline $\begin{array}{l}\text { 4. Current ENRAF }{ }^{\text {TI }} \text { systems } \\
\text { in } 241-\mathrm{AZ}-101 \text { and } 241-\mathrm{AZ} \text { - } \\
102 \text { use analog data signal. } \\
\text { Improved accuracy can be } \\
\text { obtained using a digital data } \\
\text { signal. }\end{array}$ & $\begin{array}{l}\text { 9.P2.1 Determine total } \\
\text { HLW solids mass } \\
\text { (expressed as non- } \\
\text { volatile oxides) } \\
\text { transferred to the } \\
\text { Privatization Vendor to } \\
\text { within a variability of } \\
\text { TBD\%. }\end{array}$ & $\begin{array}{l}\text { Tanks } 241-\mathrm{AZ} \text { and } \\
241-\mathrm{AZ}-102 \text { will be used } \\
\text { as the staging tanks for } \\
\text { transfer of HLW feed to } \\
\text { the privatization contractor. } \\
\text { Waste volume } \\
\text { measurements of HLW } \\
\text { batches transferred from } \\
\text { these tanks to the } \\
\text { privatization contractor will } \\
\text { form part of the basis of } \\
\text { payment. As such } \\
\text { accuracy in this } \\
\text { measurement will be very } \\
\text { important. }\end{array}$ & $\begin{array}{l}\text { Install ENRAF' }{ }^{\mathrm{TM}} \mathrm{CIU} \text { to } \\
\text { transmit digital signal. }\end{array}$ \\
\hline
\end{tabular}

\subsection{VENTILATION SYSTEM}

The 241-AZ ventilation system consists of a primary ventilation systein and an annulus ventilation system for each tank within the tank farm. The primary ventilation system must remove heat, air, evaporated water and evolved gases from the primary tank during Phase 1 privatization waste feed delivery activities. The annulus ventilation system currently is not operable.

Table 2-3 lists issues identified with the 241-AZ ventilation system and its ability to support Phase 1 privation waste feed delivery. Suggested work scope to address each issue is also presented within the table. 
HNF-2941

Revision 0

Table 2-3. Ventilation System Issues and Recommendations. (4 Sheets)

\begin{tabular}{|c|c|c|c|}
\hline Issue & Process need & Basis for issue & $\begin{array}{l}\text { Suggested scope of } \\
\text { work to address issue }\end{array}$ \\
\hline $\begin{array}{l}\text { Primary Ventilation } \\
\text { Exhaust Fall - } \\
\text { The existing primary } \\
\text { ventilation exhaust fan } \\
\text { does not provide the } \\
\text { specified level of vacuum } \\
\text { and airflow as installed. } \\
\text { Too much air in leakage is } \\
\text { occurring into the Aging } \\
\text { Waste Facility tanks to } \\
\text { allow control of the } \\
\text { ventilation flows through } \\
\text { each tank. }\end{array}$ & 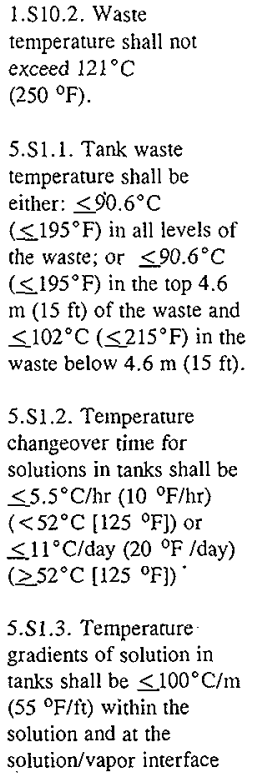 & $\begin{array}{l}\text { The ventilation system must } \\
\text { be adequately sized to } \\
\text { accommodate the tank } \\
\text { mixing operations during } \\
\text { Phase } 1 \text { privatization feed } \\
\text { delivery by removing heat, } \\
\text { particulate, and water while } \\
\text { maintaining yacuum within } \\
\text { the tank headspace }\end{array}$ & $\begin{array}{l}\text { For the Aging Waste } \\
\text { Facility. (AWF) to meet } \\
\text { the design and } \\
\text { performance } \\
\text { requirements for Project } \\
702-A Z \text { (W-030) the } \\
\text { fan and drive apparatus } \\
\text { will require design } \\
\text { modifications. These } \\
\text { modifications are } \\
\text { currently being } \\
\text { reviewed by TWRS } \\
\text { operations. The } \\
\text { primary ventilation } \\
\text { system fans } \\
\text { performance need to be } \\
\text { upgraded to meet the } \\
\text { Procurement } \\
\text { Specification W-030-P3 } \\
\text { fan design condition of } \\
28 \mathrm{~m}^{3} / \text { min ( } 1000 \text { cfm) } \\
\text { at } 956 \text { Pa ( } 32 \text { in. } \mathrm{H}_{2} 0 \text { ) } \\
\text { with operation in a } \\
\text { stable portion of the fan } \\
\text { pressure curve (negative } \\
\text { sloped portion of the } \\
\text { pressure curve), }\end{array}$ \\
\hline
\end{tabular}


Table 2-3. Ventilation System Issues and Recommendations. (4 Sheets)

\begin{tabular}{|c|c|c|c|}
\hline Issue & Process need & Basis for issue & $\begin{array}{l}\text { Suggested scope of } \\
\text { work to address issue }\end{array}$ \\
\hline $\begin{array}{l}\text { Primary Ventilation } \\
\text { System Filter Train - } 1 . \\
\text { During operation of the } \\
702-A Z \text { (Project W-030) } \\
\text { upgraded system there } \\
\text { have been two instances } \\
\text { where the filter plenum } \\
\text { housings have had } \\
\text { moisture collection } \\
\text { problems. } \\
\text { 2. The primary ventilation } \\
\text { system HEPA and HEGA } \\
\text { filter plenums are not in } \\
\text { conpliance with ANSI } \\
\text { N509, Section } 5.6 .2 \text {. } \\
\text { "The drain system shall be } \\
\text { designed so that no } \\
\text { unacceptable backup of } \\
\text { liquids into the housing } \\
\text { will occur" and "Each } \\
\text { housing compartment shall } \\
\text { have floor drains which } \\
\text { meet all allowable air } \\
\text { leakage criteria.". }\end{array}$ & $\begin{array}{l}\text { 1.S8.1. An active primary } \\
\text { tank ventilation system for } \\
\text { DSTs and AWF tanks shall } \\
\text { be operable. }\end{array}$ & $\begin{array}{l}\text { 1. There is only a single } \\
\text { HEME and condenser in the } \\
\text { primary ventilation system. } \\
\text { There is no way to replace } \\
\text { either without bypassing } \\
\text { them potentially loading } \\
\text { moisture on the downstream } \\
\text { filters. } \\
\text { 2. Code requirements }\end{array}$ & $\begin{array}{l}\text { 1. Assess adding an } \\
\text { additional HEME in the } \\
\text { primary ventilation } \\
\text { system. } \\
\text { 2. Both filter housings } \\
\text { should have drain } \\
\text { capability added for all } \\
\text { compartments }\end{array}$ \\
\hline $\begin{array}{l}\text { Ventilation Flow During } \\
\text { Equipment Installation and } \\
\text { Removal from Aging } \\
\text { Waste Facility. Tanks }\end{array}$ & $\begin{array}{l}\text { Not a process need but an } \\
\text { installation need. }\end{array}$ & $\begin{array}{l}\text { Equipment (thermocouple } \\
\text { tree, transfer pumps and } \\
\text { mixing pumps) will require } \\
\text { installation or removal from } \\
\text { the DST which will create } \\
\text { openings in the DST dome } \\
\text { to atmosphere during this } \\
\text { operation. To insure the } \\
\text { containment of the DST } \\
\text { vapors, a negative pressure } \\
\text { in the tank dome needs to be } \\
\text { maintained. The largest riser } \\
\text { in the DST dome is } 1.07 \mathrm{~m} \\
\text { ( } 42 \text { in.) in diameter which } \\
\text { has an area of } 0.89 \mathrm{~m}{ }^{2} \\
\text { (9.6 } \mathrm{ft}^{2} \text { ) open to the } \\
\text { atmosphere. The existing } \\
\text { ventilation system may not } \\
\text { have enough capacity to } \\
\text { insure that the tank dome } \\
\text { can be maintained at a } \\
\text { negative pressure and } \\
\text { perform all its other } \\
\text { functions for the other three } \\
\text { tanks in the system. }\end{array}$ & $\begin{array}{l}\text { The recirculation } \\
\text { module for each AWF } \\
\text { tank has two } 0.20-\mathrm{m} \\
\text { (8-in.) connections and } \\
\text { required valving options } \\
\text { to install a portable } \\
\text { exhauster to increase the } \\
\text { ventilation flow in } \\
\text { conjunction with the } \\
\text { existing ventilation } \\
\text { system capacity and a } \\
\text { negative pressure is. } \\
\text { expected to be } \\
\text { maintained in the } \\
\text { primary tank dome. } \\
\text { Verification needs to be } \\
\text { performed or existing } \\
\text { documentation } \\
\text { substantiated to assure } \\
\text { how the ventilation } \\
\text { system will be } \\
\text { configured to maintain a } \\
\text { negative pressure in the } \\
\text { tank dome during } \\
\text { equipment change out. }\end{array}$ \\
\hline
\end{tabular}


HNF-2941

Revision 0

Table 2-3. Ventilation System Issues and Recommendations. (4 Sheets)

\begin{tabular}{|c|c|c|c|}
\hline Issue & Process need & Basis for issue & $\begin{array}{l}\text { Suggested scope of } \\
\text { work to address issue }\end{array}$ \\
\hline $\begin{array}{l}\text { Radiation Levels in } \\
\text { Recirculation Modules }\end{array}$ & $\begin{array}{l}\text { Not process need but } \\
\text { operational/ALARA } \\
\text { concern. }\end{array}$ & $\begin{array}{l}\text { An evaluation was } \\
\text { performed (Kriskovich } 1998 \\
\text { Draft) stating higher } \\
\text { radiation in the re- } \\
\text { circulation module was } \\
\text { occurring due to } \\
\text { aerosol/moisture settling out } \\
\text { in piping, ductwork and } \\
\text { equipment. }\end{array}$ & $\begin{array}{l}\text { The report concluded in } \\
\text { order to reduce the } \\
\text { radiation buildup in the } \\
\text { re-circulation modules a } \\
\text { dropleg or some other } \\
\text { method of transferring } \\
\text { directly into the tank } \\
\text { contents is } \\
\text { recommended over the } \\
\text { current practice of using } \\
\text { a slurry distributor. }\end{array}$ \\
\hline $\begin{array}{l}\text { Operable Annulus } \\
\text { Ventilation System }\end{array}$ & $\begin{array}{l}\text { 1.S10.2. Waste } \\
\text { temperature shall not } \\
\text { exceed } 121^{\circ} \mathrm{C}\left(250^{\circ} \mathrm{F}\right) \text {. } \\
\text { 5.S1.1. Tank waste } \\
\text { temperature shall be } \\
\text { either: } \leq 90.6^{\circ} \mathrm{C}\left(195^{\circ} \mathrm{F}\right) \\
\text { in all levels of the waste; } \\
\text { or } \leq 90.6^{\circ} \mathrm{C}\left(195^{\circ} \mathrm{F}\right) \text { in } \\
\text { the top } 4.6 \mathrm{~m}(15 \mathrm{ft}) \text { of the } \\
\text { waste and } \leq 102^{\circ} \mathrm{C} \\
\left(215^{\circ} \mathrm{F}\right) \text { in the waste } \\
\text { below } 4.6 \mathrm{~m}(15 \mathrm{ft}) \text {. } \\
5.51 .2 \text {. Temperature } \\
\text { changeover time for } \\
\text { solutions in tanks shall be } \\
\leq 5.5^{\circ} \mathrm{C}\left(10^{\circ} \mathrm{F}\right) / \mathrm{hr} \\
\left(<52^{\circ} \mathrm{C}\left[125^{\circ} \mathrm{F}\right]\right) \text { or } \\
\leq 11^{\circ} \mathrm{C}\left(20^{\circ} \mathrm{F}\right) / \text { day } \\
\left(\geq 52^{\circ} \mathrm{C}\left[125^{\circ} \mathrm{F}\right]\right) \\
5 . \$ 1.3 . \text { Temperature } \\
\text { gradients of solution in } \\
\text { tanks shall be } \leq 100^{\circ} \mathrm{C} / \mathrm{m} \\
\left(55^{\circ} \mathrm{F} / \mathrm{ft}\right) \text { within the } \\
\text { solution and at the } \\
\text { solution/vapor interface }\end{array}$ & $\begin{array}{l}\text { The annulus system for the } \\
241-\mathrm{AZ} \text { tanks is a combined } \\
\text { system for both tanks. At } \\
\text { this time the annulus system } \\
\text { is not operational and leak } \\
\text { detection for the primary } \\
\text { tank is provided by } \\
\text { conductivity probes in the } \\
\text { tank annulus. }\end{array}$ & $\begin{array}{l}\text { It is not known at this } \\
\text { time if the mixer pump } \\
\text { operation will require a } \\
\text { functional annulus } \\
\text { exhaust system or if the } \\
\text { system will be } \\
\text { functional. } \\
\text { Additional, refined } \\
\text { thermal analysis for the } \\
\text { retrieval functions to be } \\
\text { performed in the } \\
241 \text {-AZ tank farm need } \\
\text { to be completed to } \\
\text { confirm the preliminary } \\
\text { calculations presented } \\
\text { here. }\end{array}$ \\
\hline
\end{tabular}


HNF-2941

Revision 0

Table 2-3. Ventilation System Issues and Recommendations. (4 Sheets)

\begin{tabular}{|c|c|c|c|}
\hline Issue & Process need & Basis for issue & $\begin{array}{l}\text { Suggested scope of } \\
\text { work to address issue }\end{array}$ \\
\hline $\begin{array}{l}\text { Air In Leakage and } \\
\text { Vacuum Control }\end{array}$ & $\begin{array}{l}\text { Not process need but an } \\
\text { operational control issue. }\end{array}$ & $\begin{array}{l}\text { The primary tank air inlet } \\
\text { stations are not now in } \\
\text { operation and are valved } \\
\text { shut. The infet air is from } \\
\text { air lift circulation (if } \\
\text { operating) and ourside air } \\
\text { drawn into the tank through } \\
\text { pit cover blocks, risers or } \\
\text { uncapped transfer lines that } \\
\text { are open to other sources } \\
\text { such as the } 241-\mathrm{AX}-152 \\
\text { diverter station. If the in } \\
\text { leakage air can be controlled } \\
\text { to a minimal amount then } \\
\text { the } 702-\mathrm{AZ} \text { (W-030) } \\
\text { primary tank air inlet } \\
\text { stations can be utilized in } \\
\text { the overall ventilation } \\
\text { control }\end{array}$ & $\begin{array}{l}\text { Perform analysis to } \\
\text { determine if the existing } \\
\text { air in leakage without } \\
\text { flows through the } \\
W-030 \text { installed air inlet } \\
\text { stations woulld still } \\
\text { allow acceptable control } \\
\text { of ventilation system } \\
\text { flow rates and negative } \\
\text { pressure in the primary } \\
\text { tank during waste feed } \\
\text { delivery activities. }\end{array}$ \\
\hline $\begin{array}{l}\text { Thermal analysis of waste } \\
\text { feed delivery activities } \\
\text { relative to } 241-\mathrm{AZ} \text { are } \\
\text { preliminary in nature. }\end{array}$ & $\begin{array}{l}\text { 1.S10.2. Waste } \\
\text { temperature shall not } \\
\text { exceed } 121^{\circ} \mathrm{C}\left(250^{\circ} \mathrm{F}\right) \text {. } \\
5 . S 1.1 \text {. Tank waste } \\
\text { temperature shall be } \\
\text { either: } \leq 90.6^{\circ} \mathrm{C}\left(195^{\circ} \mathrm{F}\right) \\
\text { in all levels of the waste; } \\
\text { or } \leq 90.6^{\circ} \mathrm{C}\left(195^{\circ} \mathrm{F}\right) \text { in } \\
\text { the top } 4.6 \mathrm{~m}(15 \mathrm{ft}) \text { of the } \\
\text { waste and } \leq 102^{\circ} \mathrm{C} \\
\left(215^{\circ} \mathrm{F}\right) \text { in the waste } \\
\text { below } 4.6 \mathrm{~m}(15 \mathrm{ft}) \text {. } \\
5 . \mathrm{S} 1.2 . \text { Temperature } \\
\text { changeover time for } \\
\text { solutions in tanks shall be } \\
\leq 5.5^{\circ} \mathrm{C}\left(10^{\circ} \mathrm{F}\right) / \mathrm{hr} \\
\left(<52^{\circ} \mathrm{C}\left[125^{\circ} \mathrm{F}\right]\right) \text { or } \\
\leq 11^{\circ} \mathrm{C}\left(20^{\circ} \mathrm{F}\right) / \text { day } \\
\left(\geq 52^{\circ} \mathrm{C}\left[125^{\circ} \mathrm{F}\right]\right) \\
5.51 .3 . \text { Temperature } \\
\text { gradients of solution in } \\
\text { tanks shall be } \leq 100^{\circ} \mathrm{C} \\
\left(55^{\circ} \mathrm{F}\right) / \mathrm{ft} \text { within the } \\
\text { solution and at the } \\
\text { solution/vapor interface }\end{array}$ & $\begin{array}{l}\text { The calculation does not } \\
\text { account for temperature } \\
\text { profiles within a non- } \\
\text { convective layer of solids } \\
\text { which would settle at the } \\
\text { bottom of the tank. } \\
\text { Duration of actual mixer } \\
\text { pump operation is not yet } \\
\text { well defined. }\end{array}$ & $\begin{array}{l}\text { Additional, refined } \\
\text { thermal analysis for the } \\
\text { retrieval functions to be } \\
\text { performed in the } \\
241-A Z \text { tank farm need } \\
\text { to be completed to } \\
\text { confirm the preliminary } \\
\text { calculations presented } \\
\text { here. }\end{array}$ \\
\hline
\end{tabular}


HNF-2941

Revision 0

\subsection{SAMPLING SYSTEM (Reserved)}


HNF-2941

Revision 0

This page intentionally left blank. 
HNF-2941

Revision 0

\subsection{PROCESS DESCRIPTION}

Both tanks in 241-AZ tank farm, 241-AZ-101 and 241-AZ-102, have been identified as HEW source tanks for feed delivery as part of Phase 1 privatization. The processing steps required to prepare the HLW feed from each of the tanks is discussed in Section 3.1 below. The transfer process of HLW from these source tanks to the private contractor is described in Section 3.2. Transfers associated with $241-\mathrm{C}$ tank farm material to $241-\mathrm{AZ}-101$ via 241-AY-102 and miscellaneous transfers, not directly related to feed delivery, into or out of 241-AZ tank farm are also discussed in Section 3.2. Table 3-1 summarizes the process steps associated with each tank in 241-AZ tank farm during the Phase 1 privatization contract.

\subsection{WASTE PREPARATION}

The baseline presented in Tank Waste Remediation System Retrieval and Disposal Mission Readiness-to-Proceed Memorandum (Jordan and Boston 1998) called for the supernate in tanks 241-AZ-101 and 241-AZ-102 being LAW feed and pretreating the sludge as HLW feed. A waste feed preparation and delivery flowsheet describing the steps in making waste feed deliveries from tank 241-AZ-101 is described in Volume II, Waste Feed Delivery Flowsheet of the Waste Feed Delivery Technical Baseline Document (Papp 1998). The alternative case in DeLozier (1998) transfers the responsibility for washing the HLW sludge from the M\&I contractor team to the private contractor. This eliminates the need for the M\&I contractor team to establish sludge washing capability and instead requires the M\&I contractor team to make more frequent (e.g., monthly) transfers. These transfers are slurry transfers requiring homogenous mixing to reduce feed variability to the private contractor. Water is added to retrieve the final batches of waste from 241-AZ-101.

The general waste preparation process steps described for 241-AZ-101 in the alternative case (DeLozier 1998) is also applicable to the waste currently in 241-AZ-102. Both 241-AZ-101 and 241-AZ-102 will be used as HLW feed staging tanks to the private contractor. These tanks will receive additional HLW currently in 241-AY-102, 241-C-106 and 241-C-104.

An assessment of the existing and planned waste feed preparation equipment is provided in Appendix A. Waste feed preparation equipment includes those pieces of equipment necessary to process the waste before to making a transfer. 
Table 3-1. Matrix of Process Steps for Each Tank in 241-AZ Tank Farm.

\begin{tabular}{|c|c|c|c|c|c|c|c|c|c|c|c|c|}
\hline \multirow{3}{*}{ Tank } & \multicolumn{12}{|c|}{ Process Step Required for Particular Tank (Yes/No) } \\
\hline & Store & \multicolumn{7}{|c|}{ Prepare waste } & \multicolumn{4}{|c|}{ Transfer waste } \\
\hline & $\begin{array}{l}\text { Safe } \\
\text { storage }\end{array}$ & Degas feed & $\begin{array}{c}\text { Separate } \\
\text { solids and } \\
\text { liquids }\end{array}$ & $\begin{array}{l}\text { Soften } \\
\text { crust }\end{array}$ & $\begin{array}{l}\text { Dissolve } \\
\text { solids }\end{array}$ & $\begin{array}{c}\text { Mobilize } \\
\text { solids }\end{array}$ & $\begin{array}{l}\text { Suspend } \\
\text { solids }\end{array}$ & $\begin{array}{c}\text { Sample } \\
\text { waste }\end{array}$ & $\begin{array}{l}\text { Transfer } \\
\text { liquid } \\
\text { from tank }\end{array}$ & $\begin{array}{c}\text { Receive } \\
\text { liquid } \\
\text { into tank }\end{array}$ & $\begin{array}{l}\text { Transfer } \\
\text { solids } \\
\text { slurry from } \\
\text { tank }\end{array}$ & \multirow[t]{3}{*}{$\begin{array}{l}\text { Receive } \\
\text { solids } \\
\text { slurry into } \\
\text { lank }\end{array}$} \\
\hline $241-A Z-101$ & Yes & No & No & No & No & Yes & Yes & Yes & No & No & Yes & \\
\hline $241-A Z-102$ & Yes & No & No & No & No & Yes & Yes & Yes & No & No & Yes & \\
\hline
\end{tabular}


HNF-2941

Revision 0

\subsection{WASTE TRANSFERS TO AND FROM 241-AZ}

Waste transfers will occur to and from tank farm 241-AZ during the time frame of Phase 1 privatization. All waste transfers will be slurry transfers, rather than liquid transfers. It should be noted that both tanks in 241-AZ are HLW feed staging tanks to the private contractor and all HLW destined for the private contractor will be transferred through one of these two tanks. During Phase 1 privatization additional $\mathrm{HLW}$ will be transferred to $241-\mathrm{AZ}$ via tank 241-AY-102 which will receive sluiced waste from tanks 241-C-106 and 241-C-104. Water is added to retrieve the final batches of waste being transferred from either tank in 241-AZ to the private contractor.

Appendix A provides a list of the set of transfers which are included in Appendix $\mathrm{H}$ of the Tank Waste Remediation System Operation and Utilization Plan (TWRSO\&UP) (Kirkbride et al. 1997) specifically related to 241-AZ tank farm and also an updated set of transfers expected to be consistent with the alternative case in DeLozier (1998). The actual set of transfers and their timing associated with the case identified in DeLozier 1998 varies with those identified in the TWRSO\&UP. The preliminary set of transfers based on DeLozier (1998) are used for the basis of this evaluation. The most notable differences relative to the baseline is that the alternative presented in DeLozier (1998) eliminates sludge washing and the associated transfers.

An assessment of the existing and planned waste transfer system is provided in Appendix A. Waste transfer equipment includes those pieces of equipment necessary to transfer the waste between tanks and include transfer pumps, piping, jumpers, and valving.

\subsection{COMPARISON OF PROCESS STEPS TO FUNCTIONAL ANALYSIS}

The preceding waste feed preparation steps are based on Volume II, Waste Feed Delivery Flowsheet of the Waste Feed Delivery Technical Baseline Document (Papp 1998). Waste transfers are based on the set of transfers consistent with DeLozier (1998). These process steps are not specifically based on the systems engineering functional analysis but are consistent with the functional analysis that is performed for Phase 1 privatization feed delivery. Tables 3-2 through 3-9 below map the process steps identified in Table 3-1 to the functional analysis documented in Attachment B of the Review of Performance Requirements for Phase $I$ Waste Feed Delivery Components (Claghorn et al. 1998). Tables 3-2 through 3-9 compare the process steps to the following functions:

Table 3-2 Function 3.2.1 Double-Shell Tank System

Table 3-3 Function 3.2.1.1 Maintain Safe and Compliant Waste within the Double-Shell Tank System

Table 3-4 Function 3.2.1.2 Deliver Low-Activity Waste Feed for Phase 1 Treatment 
HNF-2941

Revision 0

Table 3-5 Function 3.2.1.3 Deliver High-Level Waste Sludge to Low-Activity Waste/High-Level Waste Plant

Table 3-6 Function 3.2.1.4 Manage Double-Shell Tank Space

Table 3-7 Function 3.2.1.5 Receive Waste into Double-Shell Tanks

Table 3-8 Function 3.2.1.6 Distribute Utilities in Double-Shell Tank System

Table 3-9 Function 3.2.1.10 Support Double-Shell Tank System

Certain functions identified in Claghorn et al. (1998) are not applicable (N/A) to the specific processing associated with $241-\mathrm{AZ}$ tank farm. As an example, the low activity waste feed delivery activity (function 3.2.1.2) does not have any functions which would rely upon 241-AZ tank farm for execution of the function.

Table 3-10 compares the architecture presented in Claghorn et al. (1998) to the organizational outline of the assessment presented in this document. The assessment is organized in this document according to waste preparation and transfer systems (Section 5.0), utilities distribution systems (Section 6.0), instrumentation, monitoring and control systems (Section 7.0), ventilation system (Section 8.0), and sampling system (Section 9.0). These systems are described in more detail in each of the sections of the document. The comparison in Table 3-10 shows that this assessment does not consider DST structures, potable water, or sewage because they do not fall within the scope of the assessment. Additionally, maintenance and recovery systems are not considered within the scope of this assessment. 
Table 3-2. Comparison of Top Level System Assessment Process Steps in This Document to Level 3.2.1 Function, Double-Shell Tank System in Attachment B of Review of Performance Requirements for Phase 1 Waste Feed Delivery Components, HNF-1985 (Claghorn et al. 1998).

\begin{tabular}{|c|c|c|c|c|c|c|}
\hline \multicolumn{7}{|c|}{ Attachment B, Review of Performance Requirements for Phase I Waste Feed Delivery Components, HNF-1985 (Claghorn et al. 1998) } \\
\hline \multicolumn{7}{|c|}{ 3.2.1 Double-Shell Tank System } \\
\hline $\begin{array}{l}3.2 .1 .1 \text { Maintain } \\
\text { Safe and Compliant } \\
\text { Waste within the } \\
\text { Double-Shell Tank } \\
\text { System }\end{array}$ & $\begin{array}{l}\text { 3.2.1.2 Deliver } \\
\text { Low Activity Waste } \\
\text { Feed for Phase I } \\
\text { Treatment }\end{array}$ & $\begin{array}{l}\text { 3.2.1.3 Deliver } \\
\text { High-Level Waste } \\
\text { Feed for Phase } 1 \\
\text { Treatment }\end{array}$ & $\begin{array}{l}\text { 3.2.1.4 Manage } \\
\text { Double-Shell Tank } \\
\text { Space }\end{array}$ & $\begin{array}{l}\text { 3.2.1.5 Receive } \\
\text { Waste into Double- } \\
\text { Shell Tanks }\end{array}$ & $\begin{array}{l}\text { 3.2.1.6 Distribute } \\
\text { Utilities in Double- } \\
\text { Shell Tank System }\end{array}$ & $\begin{array}{l}\text { 3.2.1. I0 Support } \\
\text { Double-Shell Tank } \\
\text { System }\end{array}$ \\
\hline Store Waste & N/A & $\begin{array}{l}\text { Prepare Waste/ } \\
\text { Transfer Waste }\end{array}$ & Transfer Waste & Transfer Waste & N/A & N/A \\
\hline
\end{tabular}


Table 3-3. Comparison of System Assessment Process Steps in This Document to 3.2.1.1 Maintain Safe and Compliant Waste within the Double-Shell Tank System. Function in Attachment B of Review of Performance Requirements for Phase I Waste Feed Delivery Components, HNF-1985 (Claghorn et al. 1998).

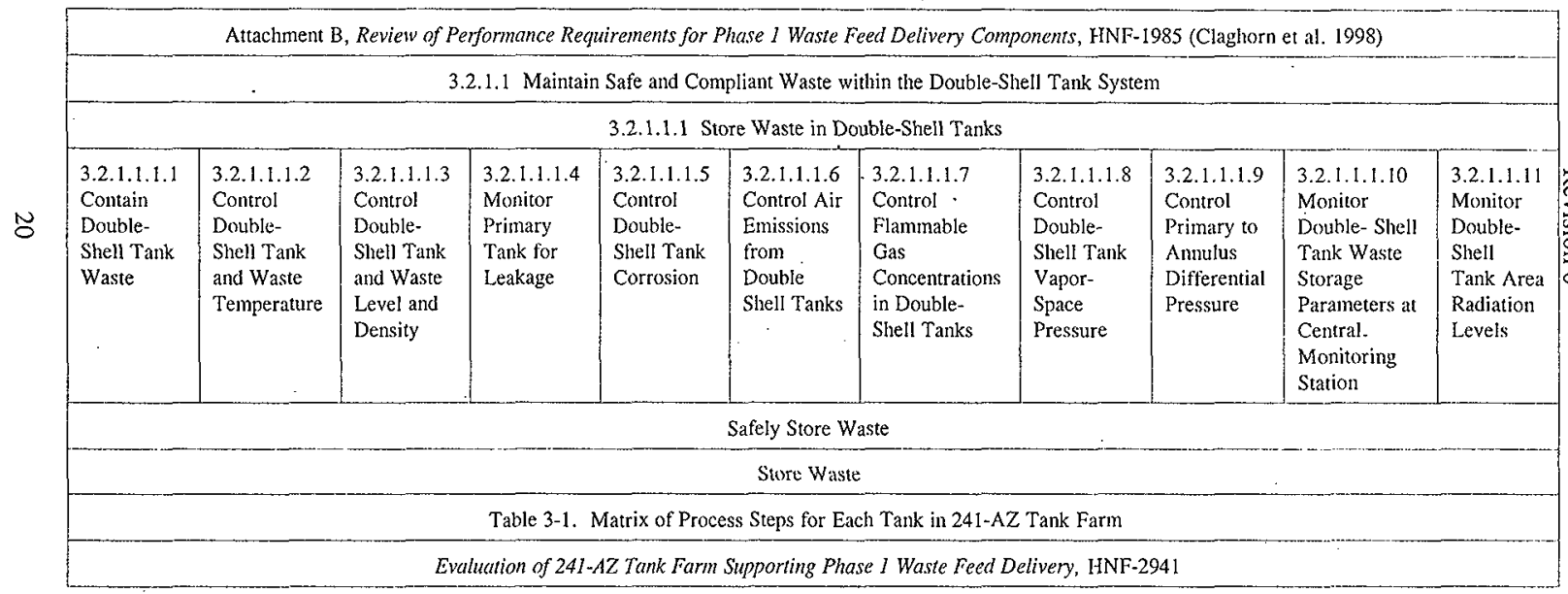


Table 3-4. Comparison of System Assessment Process Steps in This Document to 3.2.1.2 Deliver Low Activity Waste Feed for Phase 1 Treatment Function in Attachment B of Review of Performance Requirements for Phase I. Waste Feed Delivery Components, HNF-1985 (Claghorn et al. 1998).

\begin{tabular}{|c|c|c|c|c|c|}
\hline \multicolumn{6}{|c|}{ Attachment B, Review of Performance Requirements for Phase I Waste Feed Delivery, HNF-1985 (Claghorn et al. 1998) } \\
\hline \multicolumn{6}{|c|}{ 3.2.1.2 Deliver Low Activity Waste Feed for Phase 1 Treatment } \\
\hline $\begin{array}{l}\text { 3.2.1.2.1 Prepare Low } \\
\text { Activity Waste } \\
\text { Supernatant for } \\
\text { Transfer }\end{array}$ & $\begin{array}{l}\text { 3.2.1.2.2 Transfer } \\
\text { Low Activity Waste } \\
\text { Supernatant to Staging } \\
\text { Tanks }\end{array}$ & $\begin{array}{l}\text { 3.2.1.2.3 Prepare Low } \\
\text { Activity Waste Salts for } \\
\text { Transfer }\end{array}$ & $\begin{array}{l}\text { 3.2.1.2.4 Transfer } \\
\text { Low-Activity Waste } \\
\text { Salt Solution to Staging } \\
\text { Tanks }\end{array}$ & $\begin{array}{l}\text { 3.2.1.2.5 Blend Low } \\
\text { Activity Waste in Low- } \\
\text { Activity Waste Staging } \\
\text { Tanks }\end{array}$ & $\begin{array}{l}\text { 3.2.1.2.6 Transfer } \\
\text { Low-Activity Waste to } \\
\text { Vendor Feed Storage }\end{array}$ \\
\hline N/A & N/A & N/A & N/A & $\mathrm{N} / \mathrm{A}$ & N/A \\
\hline \multicolumn{6}{|c|}{$\mathrm{N} / \mathrm{A}$} \\
\hline \multicolumn{6}{|c|}{ Table 3-1. Matrix of Process Steps for Each Tank in 241-AZ Tank Farm } \\
\hline \multicolumn{6}{|c|}{ Evaluation of 241-AZ Tank Farm Supporting Phase I Waste Feed Delivery, HNF-2941 } \\
\hline
\end{tabular}


Table 3-5. Comparison of System Assessment Process Steps in This Document to 3.2.1.3 Deliver High-Level Waste Sludge to Low-Activity Waste/ High-Level Waste Plant Function in Attachment B of Review of Performance Requirements for Phase 1 Waste Feed Delivery Components, HNF-1985 (Claghorn et al. 1998).

\begin{tabular}{|c|l|}
\hline \multicolumn{2}{|c|}{ Attachment B, Review of Performance Requirements for Phase 1 Waste Feed Delivery, HNF-1985 (Claghorn et al. 1998) } \\
\hline 3.2.1.3 Deliver High-Level Waste Sludge to Low-Activity Waste/High-Level Waste Plant \\
\hline 3.2.1.3.1 Prepare High-Level Waste Solids for Transfer & $\begin{array}{l}\text { 3.2.1.3.2 Transfer High-Level Waste Sludge to Low-Activity } \\
\text { Waste/High-Level Waste Plant }\end{array}$ \\
\hline Add Diluent, Mix Tank Contents, Sample Waste & Transfer Solids Slurry from Tank \\
\hline Prepare Waste & \multicolumn{1}{|c|}{ Transfer Waste } \\
\hline Table 3-1. Matrix of Process Steps for Each Tank in 241-AZ Tank Farm \\
\hline Evaluation of 241-AZ Tank Farm Supporting Phase 1 Waste Feed Delivery, HNF-2941 \\
\hline
\end{tabular}


Tabie 3-6. Comparison of System Assessment Process Steps in This Document to 3.2.1.4 Manage Double-Shell Tank Space Function in Attachment B of Review of Performance Requirements for Phase 1 Waste Feed Delivery Components, HNF-1985

(Claghorn et aI. 1998).

\begin{tabular}{|c|c|c|c|}
\hline \multicolumn{4}{|c|}{ Attachment B, Review of Performance Requirements for Phase 1 Waste Feed Delivery, HNF-1985 (Claghorn et al. 1998) } \\
\hline \multicolumn{4}{|c|}{ 3.2.1.4 Manage Double-Tank Space } \\
\hline $\begin{array}{l}\text { 3.2.1.4.1 Prepare Waste in } \\
\text { Double-Shell Tank }\end{array}$ & $\begin{array}{l}\text { 3.2.1.4.2 Transfer Waste } \\
\text { Between Double-Shell Tanks } \\
\text { Inside Areas }\end{array}$ & $\begin{array}{l}\text { 3.2.1.4.3 Transfer Waste } \\
\text { Cross-Site Between Double- } \\
\text { Shell Tanks }\end{array}$ & $\begin{array}{l}\text { 3.2.1.4.4 Transfer Waste for } \\
\text { Concentration }\end{array}$ \\
\hline N/A & $\begin{array}{l}\text { Transfer Solids Slurry from } \\
\text { Tank, Receive Solids Slurry } \\
\text { into Tank }\end{array}$ & $\begin{array}{l}\text { Receive Solids Slurry into } \\
\text { Tank }\end{array}$ & N/A \\
\hline N/A & \multicolumn{2}{|c|}{ Transfer Waste } & $\mathrm{N} / \mathrm{A}$ \\
\hline \multicolumn{4}{|c|}{ Table 3-1. Matrix of Process Steps for Each Tank in 241-AZ Tank Farm } \\
\hline \multicolumn{4}{|c|}{ Evaluation of 241-AZ Tank Farm Supporting Phase 1 Waste Feed Delivery, HNF-2941, } \\
\hline
\end{tabular}


Table 3-7. Comparison of System Assessment Process Steps in This Document to 3.2.1.5 Receive Waste into Double-Shell

Tanks Function in Attachment B of Review of Performance Requirements for Phase 1 Waste Feed Delivery Components, HNF-1985 (Claghorn et al. 1998).

\begin{tabular}{|c|c|c|c|c|}
\hline \multicolumn{5}{|c|}{ Attachment B, Review of Performance Requirements for Phase I Waste Feed Delivery, HNF-1985 (Claghorn et al. 1998) } \\
\hline \multicolumn{5}{|c|}{ 3.2.1.5 Receive Waste into Double-Shell Tanks } \\
\hline $\begin{array}{l}\text { 3.2.1.5.1 Receive } \\
\text { Waste from Waste } \\
\text { Unloading Facility }\end{array}$ & $\begin{array}{l}3.2 .1 .5 .2 \text { Receive New } \\
\text { Liquid Waste from } \\
\text { External Waste } \\
\text { Generators }\end{array}$ & $\begin{array}{l}\text { 3.2.1.5.3 Receive } \\
\text { Concentrated Waste } \\
\text { from Evaporator }\end{array}$ & $\begin{array}{l}\text { 3.2.1.5.4 Receive } \\
\text { Emergency Purge } \\
\text { Waste from Evaporator }\end{array}$ & $\begin{array}{l}\text { 3.2.1.5.5 Receive } \\
\text { Waste Products from } \\
\text { Low Activity Waste / } \\
\text { High Level Waste and } \\
\text { Low Activity Waste } \\
\text { Treatment }\end{array}$ \\
\hline N/A & $\begin{array}{l}\text { Receive Solids Slurry } \\
\text { into Tank }\end{array}$ & N/A & N/A & N/A \\
\hline N/A & Transfer Waste & \multicolumn{3}{|c|}{ N/A } \\
\hline \multicolumn{5}{|c|}{ Evaluation of 24I-AZ Tank Farm Supporting Phase 1 Waste Feed Delivery, HNF-2941. } \\
\hline
\end{tabular}


Table 3-8. Comparison of System Assessment Process Steps in This Document to 3.2.1.6 Distribute Utilities in Double-Shell Tank System Function in Attachment B of Review of Performance Requirements for Phase 1 Waste Feed Delivery Components, HNF-1985 (Claghorn et al. 1998).

\begin{tabular}{|c|c|c|}
\hline \multicolumn{3}{|c|}{ Attachment B, Review of Performance Requirements for Phase 1 Waste Feed Delivery, HNF-1985. (Claghorn et al. 1998) } \\
\hline \multicolumn{3}{|c|}{ 3.2.1.6 Distribute Utilities in Double- Shell Tank System } \\
\hline 3.2.1.6.1. Provide Electrical Power & 3.2.1.6.2 Provide Watèr & $\begin{array}{l}\text { 3.2.1.6.3 Provide Compressed and } \\
\text { Instrument Air }\end{array}$ \\
\hline N/A & N/A & N/A \\
\hline \multicolumn{3}{|c|}{$\mathrm{N} / \mathrm{A}^{*}$} \\
\hline \multicolumn{3}{|c|}{ Table 3-1. Matrix of Process Steps for Each Tank in 241-AZ Tank Farm } \\
\hline \multicolumn{3}{|c|}{ Evaluation of 24I-AZ Tank Farm Supporting Phase I Waste Feed Delivery, HNF-2941 } \\
\hline
\end{tabular}

* "Distribute Utilities in Double-Shell Tank System" is not considered a process step in the context of HNF-2983. Utilities are discussed in Section 6 of HNF-2983. 
Table 3-9. Comparison of System Assessment Process Steps in This Document to 3.2.1.10 Support Double-Shell Tank System Function in Attachment B of Review of Performance Requirements for Phase 1 Waste Feed Delivery Components, HNF-1985, (Claghorn et al. 1998).

$\approx$\begin{tabular}{|c|}
\hline Attachment B, Review of Performance Requirements for Phase 1 Waste Feed Delivery, HNF-1985 (Claghorn et al. 1998) \\
\hline 3.2 .1 .10 Support Double-Shell Tank System \\
\hline N/A \\
\hline N/A* \\
\hline Table 3-1. Matrix of Process Steps for Each Tank in 241-AZ Tank Farm \\
\hline Evaluation of 24I-AZ Tank Farm Supporting Phase I Waste Feed Delivery, HNF-2941
\end{tabular}

* "Support Double-Shell Tank System" is not considered a process step in the context of HNF-2983. 


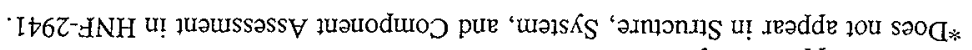

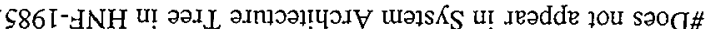

\begin{tabular}{|c|c|c|c|c|c|c|c|c|c|c|c|c|c|c|c|c|c|c|}
\hline \multicolumn{19}{|c|}{ 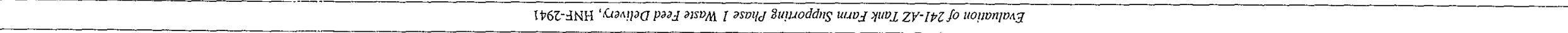 } \\
\hline \multicolumn{19}{|c|}{ 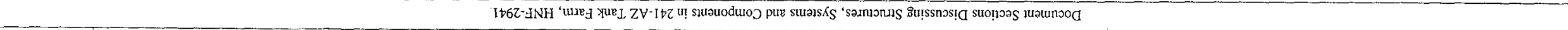 } \\
\hline & \multicolumn{6}{|c|}{ 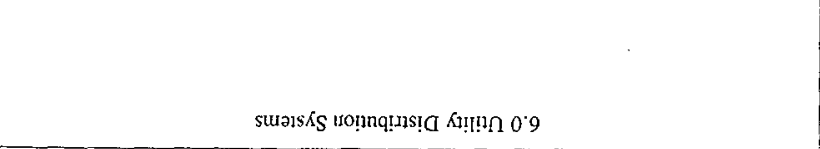 } & 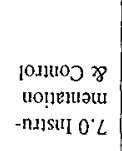 & \multicolumn{3}{|c|}{ 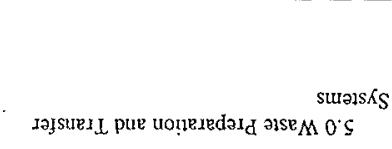 } & \multicolumn{5}{|c|}{ 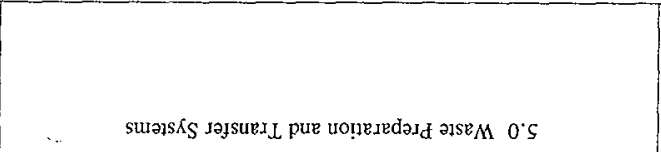 } & 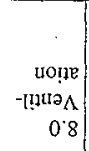 & 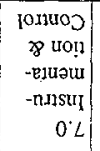 & \\
\hline * & $\begin{array}{r}\text { uगנs } K_{S} \\
\text { uाears } \\
+99\end{array}$ & * & 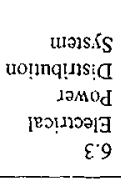 & 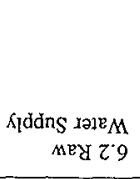 & * & 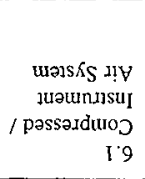 & ; & 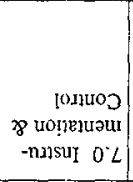 & 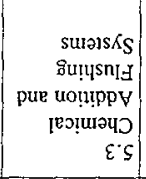 & sdumn & 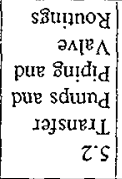 & 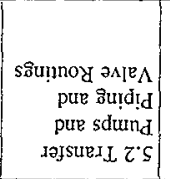 & 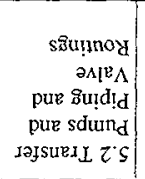 & 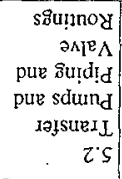 & 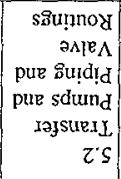 & & -1 & \\
\hline & $\#$ & 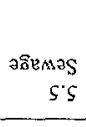 & 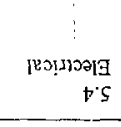 & 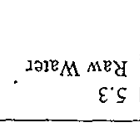 & $\begin{array}{r}\operatorname{rap}_{M} \\
\text { शlqe10d } \\
z^{\circ} \mathcal{C}\end{array}$ & $\begin{array}{r}\text { IIV } \\
\text { passadduo } \\
\text { I'S }\end{array}$ & & 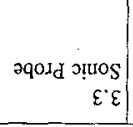 & 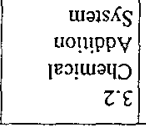 & 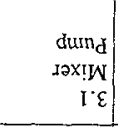 & $\begin{array}{r}\text { dung } \\
\text { alewradns } \\
\varsigma \mathrm{Z}\end{array}$ & 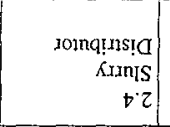 & $\begin{array}{r}\text { yxoməN } \\
\text { suidld } \\
\varepsilon z\end{array}$ & $\begin{array}{r}\text { dunnd } \\
\text { sinnts } \\
z z\end{array}$ & $\begin{array}{r}\text { durnd }_{d} \\
\text { suesad } \\
I^{\prime} Z\end{array}$ & 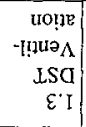 & $\begin{array}{r}\partial x_{1} \\
\mathrm{LSA} \\
\tau \cdot \mathrm{I}\end{array}$ & $\begin{array}{r}\text { ammonus } \\
\text { LSA } \\
I \cdot I\end{array}$ \\
\hline 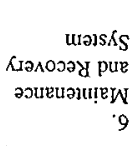 & \multicolumn{6}{|c|}{ 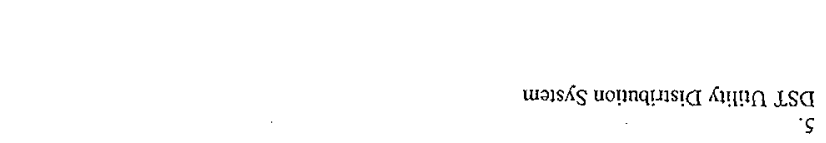 } & 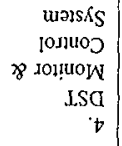 & \multicolumn{3}{|c|}{ məưd!nb } & \multicolumn{5}{|c|}{ 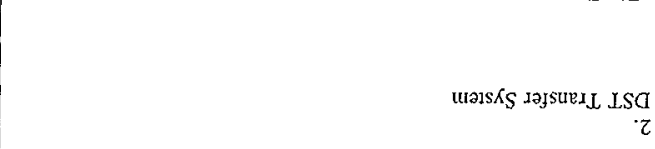 } & \multicolumn{3}{|c|}{ 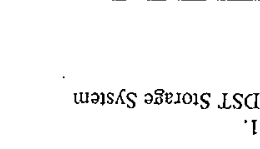 } \\
\hline \multicolumn{19}{|c|}{ 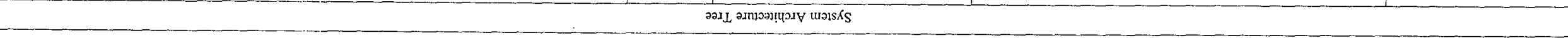 } \\
\hline & & & & & & anilad paj & MI I $25 D_{1}$ & иалщацивау & y a subutuofiog $d$ & salnay' $s$ & SI-JNH & & & & & & & \\
\hline
\end{tabular}

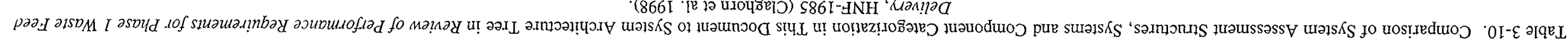


HNF-2941

Revision 0

\subsection{IDENTIFICATION OF PROCESS NEEDS}

The process needs associated with waste processing and tank-to-tank transfers at 241AZ tank farm to support feed delivery to the private contractor in support of Phase 1 privatization are identified within this section of the document. Quantified process needs are identified where available. However, an adequate technical basis does not exist in all cases to provide quantified limits. In these cases qualitative needs are identified which require a further level of analysis than available at the time of this evaluation to establish technically based quantitative needs.

Process needs will vary according to the activity or process step being performed. Process needs are grouped according to process step. The process steps which will be used for categorizing the process needs are the process steps identified in Table 3-1 above, namely: safe storage; add diluent; mix tank contents; sample waste; transfer solids slurry from tank; transfer solids slurry to tank.

The scope of this evaluation is limited to process needs associated with 241-AZ tank farm during the Phase 1 privatization. The scope is consistent with the alternative case identified in DeLozier 1998. The time frame examined is through 2016. The SSCs examined are associated with waste preparation and transfer, utilities, instrumentation and control, ventilation and sampling. Table 4-1 presents process needs associated with the various operational steps which will be completed in tanks 241-AZ-101 and 241-AZ-102 (refer to Table 3-1 above). For each quantitative process need a technical basis is identified as well as the systems which are affected or required to meet the process need. Where information is not available to define or establish a quantitative process need, an issue is identified.

Additionally, this evaluation identifies existing safety-related needs applicable to current operation (i.e., safe storage) of 241-AZ tank farm. These authorization basis requirements are based on the existing set of technical safety requirements for tank farm operations and are not intended to be a complete set of safety-related requirements which will be in place during Phase 1 privatization activities. An initial assessment of the safety-related requirements for waste feed delivery (Grams et al. 1997) has been completed and additional work is ongoing to establish safety-related requirements. However, this work is not complete. Table 4-2 presents current safety requirements that may be associated with the various operational steps which will be completed at 241-AZ tank farm during Phase 1 privatization feed delivery (refer to Table 3-1 above). These safety-related requirements are included here as an assumed minimum set of safety-related needs expected during Phase 1 privatization. 
Table 4-1. Process Needs Assessment for 241-AZ Tank Farm Supporting Phase 1 Feed Delivery.

\begin{tabular}{|c|c|c|c|c|}
\hline Process step & Qualitative process need & Quantitative tank-specific process need & Basis & $\begin{array}{l}\text { Affected systems } \\
\text { (applicable SSCs) }\end{array}$ \\
\hline 1. Safe Storage & None (see Table 4.2) & & & \\
\hline \multirow[t]{9}{*}{ 2. Degas Feed } & \multirow[t]{2}{*}{$\begin{array}{l}\text { P1. Remove trapped flammable } \\
\text { gases from waste prior to } \\
\text { transfer to eliminate or reduce } \\
\text { probability of occurrence of a } \\
\text { gas release event. }\end{array}$} & 1. Reserved (None) & & \\
\hline & & 2. Reserved (None) & & \\
\hline & \multirow[t]{7}{*}{$\begin{array}{l}\text { P2. Control rate of gas release } \\
\text { from flammable gas watch list } \\
\text { tanks. }\end{array}$} & 1. Reserved (None) & & \\
\hline & & 2. Reserved (None) & & \\
\hline & & 3. Reserved (None) & & \\
\hline & & 4. Reserved (None) & & \\
\hline & & 5. Reserved (None) & & \\
\hline & & 6. Reserved (None) & & \\
\hline & & 7. Reserved (None) & & \\
\hline $\begin{array}{l}\text { 3. Separate } \\
\text { Solids and } \\
\text { Liquids }\end{array}$ & $\begin{array}{l}\text { P1. Provide LAW feed to the } \\
\text { private contractor within the } \\
\text { contract envelope limits for } \\
\text { insoluble solids. }\end{array}$ & 1. Reserved (None) & : & \\
\hline \multirow[t]{5}{*}{$\begin{array}{l}\text { 4. Dissolve } \\
\text { Solids }\end{array}$} & \multirow{5}{*}{$\begin{array}{l}\text { PI. Dissolve soluble precipitated } \\
\text { salts in selected DSTs. Selected } \\
\text { DSTs are 241-AN-103, AN-104, } \\
\text { AN-105, AW-101, SY-101, and } \\
\text { SY-103. }\end{array}$} & 1. Reserved (None) & & \\
\hline & & 2. Reserved (None) & & \\
\hline & & 3. Reserved (None) & & \\
\hline & & 4. Reserved (None) & & \\
\hline & & 5. Reserved (None) & & \\
\hline
\end{tabular}


Table 4-1. Process Needs Assessment for 241-AZ Tank Farm Supporting Phase 1 Feed Delivery.

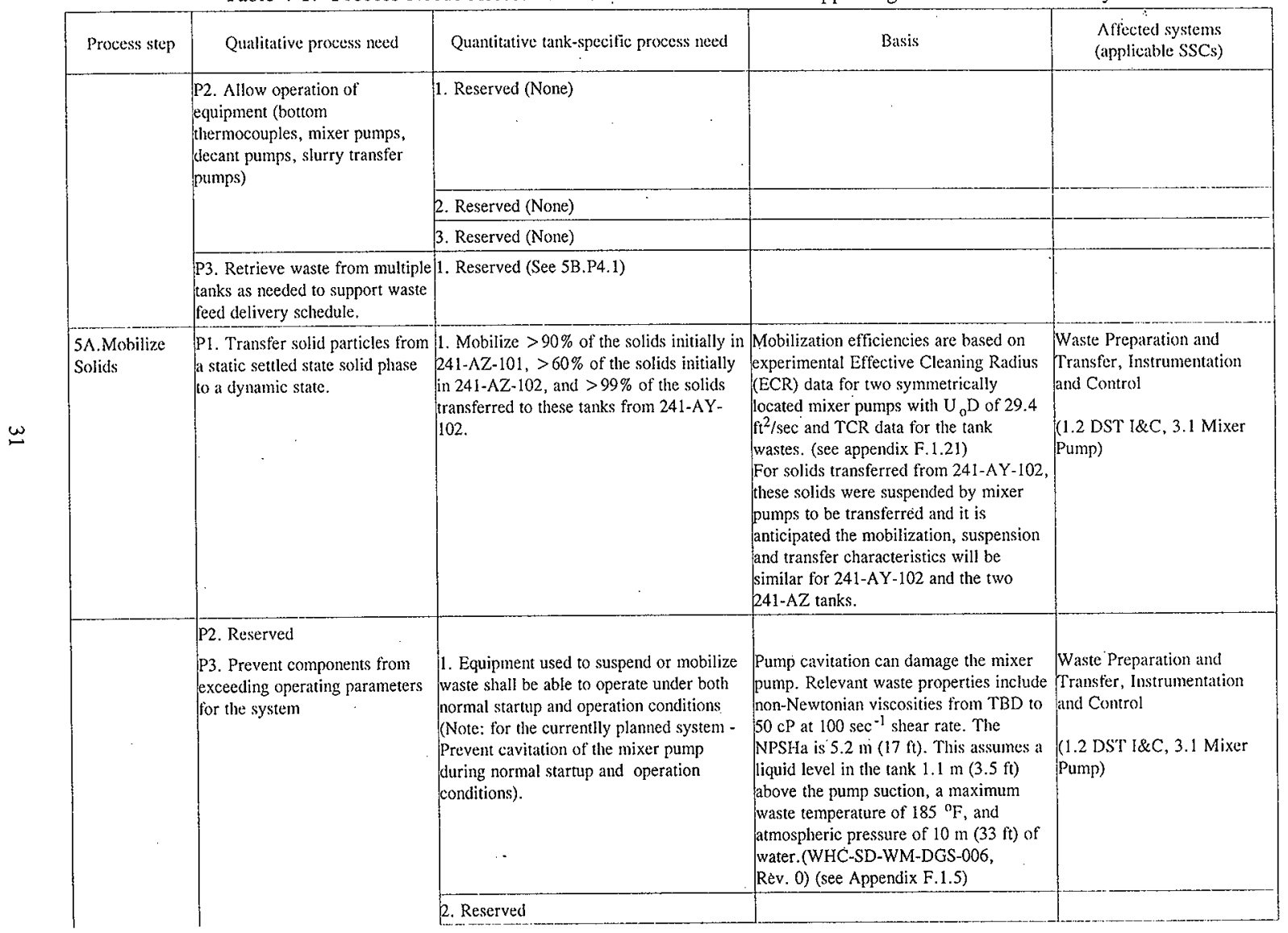


Table 4-1. Process Needs Assessment for 241-AZ Tank Farm Supporting Phase 1 Feed Delivery.

\begin{tabular}{|c|c|c|c|c|}
\hline Process step & Qualitative process need & Quantitative tank-specific process need & Basis & $\begin{array}{l}\text { Affected systems } \\
\text { (applicable SSCs) }\end{array}$ \\
\hline \multirow[t]{4}{*}{. } & & $\begin{array}{l}\text { 3. Equipment used to mobilize or suspend } \\
\text { waste shall not impart excessive force to } \\
\text { the tank structure. (Note: for the } \\
\text { currently planned system - Provide mixer } \\
\text { pumps which will not damage the tank } \\
\text { structure during normal and/or off-normal } \\
\text { operation.) }\end{array}$ & $\begin{array}{l}\text { The tank structure, risers, and pits must } \\
\text { not be damaged by operation of the } \\
\text { mixer pump (WHC-SD-WM-DGS-006, } \\
\text { Rev. 0) }\end{array}$ & $\begin{array}{l}\text { Waste Preparation and } \\
\text { Transfer } \\
\text { (1.1 DST Structure) }\end{array}$ \\
\hline & & $\begin{array}{l}\text { 4. Provide a diluent system and water } \\
\text { addition line to allow addition of up to } \\
341 \mathrm{~m}^{3}(90,000 \text { [TBR] gal) raw water near } \\
\text { the intake of each mixer pump. The } \\
\text { dilution system should be capable of } \\
\text { providing this quantity at a flow rate of } \\
\text { TBD gal/min and a temperature range of } \\
20 \text { "C to } 50 \text { "C ( }+/-\mathrm{TBD} \text { "C). No cooling } \\
\text { capacity is required. }\end{array}$ & $\begin{array}{l}\text { Provides both a flushing capability to } \\
\text { reduce concentration of saturated salts } \\
\text { near the pump intake and provides a } \\
\text { means to dilute the slurry concentration } \\
\text { near the intake to minimize pump } \\
\text { cavitation during startup. (see Appendix } \\
\text { F.1.6) }\end{array}$ & $\begin{array}{l}\text { Waste Preparation and } \\
\text { Transfer, Instrumentation } \\
\text { and Control, Utility } \\
\text { Distribution } \\
\\
\text { (1.2 DST I\&C, } 3.1 \text { Mixer } \\
\text { Pump, 3.2 Chemical } \\
\text { Addition System, 5.3 Raw } \\
\text { Water) }\end{array}$ \\
\hline & & $\begin{array}{l}\text { 2. Provide a diluent system and water } \\
\text { addition line to allow addition of up to } \\
379 \mathrm{~m}^{3} \text { (100,000 gal) raw water near the } \\
\text { intake of each mixer pump. The dilution } \\
\text { system should be capable of providing this } \\
\text { quantity at a flow rate of TBD gal/min and } \\
\text { a temperature range of } 200^{\circ} \mathrm{C} \text { to } 50 \text { "C } \\
\text { (+/- TBD "C). No cooling capacity is } \\
\text { required. }\end{array}$ & $\begin{array}{l}\text { Provides both a flushing capability to } \\
\text { reduce concentration of saturated salts } \\
\text { mear the pump intake and provides a } \\
\text { means to dilute the slurry concentration } \\
\text { near the intake to minimize pump } \\
\text { cavitation during startup. (see Appendix } \\
\text { F,1.6) }\end{array}$ & $\begin{array}{l}\text { Waste Preparation and } \\
\text { Transfer, Instrumentation } \\
\text { and Control, Utility } \\
\text { Distribution } \\
\\
\text { (1.2 DST I\&C, 3.1 Mixer } \\
\text { Pump, 3.2 Chemical } \\
\text { Addition System, 5.3 Raw } \\
\text { Water) }\end{array}$ \\
\hline & & $\begin{array}{l}\text { 5. Control the rate of operation of } \\
\text { equipment used to mobilize and suspend } \\
\text { solids. (Note: for the currently planned } \\
\text { system - Provide mixer pumps with a } \\
\text { variable frequency drive (VFD) capable of } \\
\text { operating the pump from a minimum speed } \\
\text { of approximately } 58 \% \text { speed to full speed } \\
\text { operation.) }\end{array}$ & $\begin{array}{l}\text { This provides the flexibility to allow a } \\
\text { slow start during initial mobilization to } \\
\text { minimize cavitation. } \\
\text { (WHC-SD-WM-DGS-006, Rev. 0) }\end{array}$ & $\begin{array}{l}\text { Waste Preparation and } \\
\text { Transfer, Instrumentation } \\
\text { and Control } \\
\text { (1.2 DST I\&C, 3.1 Mixer } \\
\text { Pump) }\end{array}$ \\
\hline
\end{tabular}


Table 4-1. Process Needs Assessment for 241-AZ Tank Farm Supporting Phase 1 Feed Delivery.

\begin{tabular}{|c|c|c|c|c|}
\hline Process step & Qualitative process need & Quantitative tank-specific process need & Basis & $\begin{array}{l}\text { Affected systems } \\
\text { (applicable SSCs) }\end{array}$ \\
\hline \multirow[b]{3}{*}{. } & \multirow[t]{3}{*}{. } & $\begin{array}{l}\text { 6. Provide in-tank components which can } \\
\text { withstand forces imparted by solids } \\
\text { mobilization and suspension equipment and } \\
\text { remain operable and retrievable from the } \\
\text { DST. (Note: for the currently planned } \\
\text { system - Provide (or replace) in-tank } \\
\text { components which can withstand forces } \\
\text { imparted by full speed mixer pump } \\
\text { operation and remain operable and } \\
\text { retrievable from the DST) }\end{array}$ & $\begin{array}{l}\text { Operation of mixer pumps must not } \\
\text { cause in-tank components to fail or bend } \\
\text { them such that they can not be retrieved. } \\
\text { (WHC-SD-WM-DGS-006, Rev. 0). A } \\
\text { documented assessment is needed to } \\
\text { justify not meeting this process need for } \\
\text { specific components. }\end{array}$ & $\begin{array}{l}\text { Waste Preparation and } \\
\text { Transfer } \\
\text { (1.2 DST I\&C, 2.1 Decant } \\
\text { Pump, 2.2 Slurry Pump, } 2.5 \\
\text { Supernate Pump) }\end{array}$ \\
\hline & & $\begin{array}{l}\text { 7. Provide solids mobilization and } \\
\text { suspension equipment which will not } \\
\text { damage the tank structure during normal } \\
\text { and/or off-normal operation. (Note: for } \\
\text { the currently planned system - Provide } \\
\text { mixer pumps which will not damage the } \\
\text { tank structure during normal and/or off- } \\
\text { normal operation.) }\end{array}$ & $\begin{array}{l}\text { The tank structure, risers, and pits are } \\
\text { considered Safety Class or safety } \\
\text { significant and thus must not be } \\
\text { damaged by operation of the mixer } \\
\text { pump. (WHC-SD-WM-DGS-006, } \\
\text { Rev. 0) }\end{array}$ & $\left\{\begin{array}{l}\text { Waste Preparation and } \\
\text { Transfer } \\
\text { (1.1 DST Structure) }\end{array}\right.$ \\
\hline & & $\begin{array}{l}\text { 8. Monitor the rate of operation of } \\
\text { equipment used to eflect solids } \\
\text { mobilization and suspension. (Note: for } \\
\text { the currently planned system - Provide, at } \\
\text { a minimum, the following mixer pump } \\
\text { instrumentation: remote readout of pump } \\
\text { motor amperage, shaft rotational speed, } \\
\text { and nozzle orientation.) }\end{array}$ & $\begin{array}{l}\text { Pump motor amperage may be obtained } \\
\text { through the VFD. Provides indication of } \\
\text { motor condition and pump operating } \\
\text { parameters. Shaft rotational speed } \\
\text { provides indication of pump operating } \\
\text { parameters. Nozzle orientation is } \\
\text { required to allow flexibility to direct } \\
\text { nozzle flows toward or away from areas } \\
\text { of interest. (WHC-SD-WM-DGS-006, } \\
\text { Rev. } 0 \text { ) }\end{array}$ & Instrumentation and Control \\
\hline $\begin{array}{l}\text { 5B. Suspend } \\
\text { Solids }\end{array}$ & $\begin{array}{l}\text { P1. Suspend mobilized solid } \\
\text { particles in the liquid phase. } \\
\text { (Note: for currently planned } \\
\text { system - Mixer pump operation } \\
\text { should mix liquids and suspend } \\
\text { mobilized solids uniformly } \\
\text { throughout the waste solution.) }\end{array}$ & 1. Reserved & . & \\
\hline
\end{tabular}


Table 4-1. Process Needs Assessment for 241-AZ Tank Farm Supporting Phase 1 Feed Delivery.

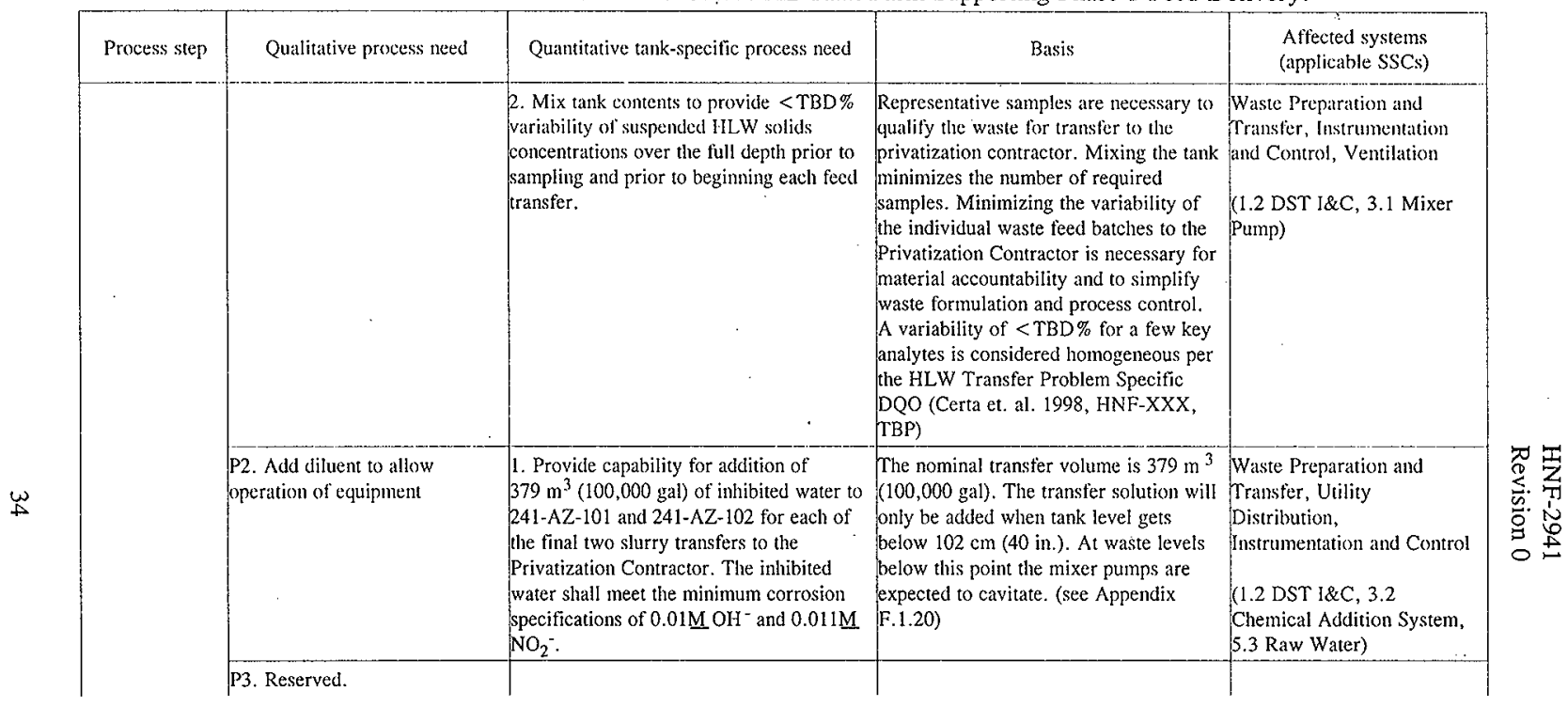


Table 4-1. Process Needs Assessment for 241-AZ Tank Farm Supporting Phase 1 Feed Delivery.

\begin{tabular}{|c|c|c|c|c|}
\hline \multirow[t]{2}{*}{ Process step } & Qualitative process need & Quantitative tank-specific process need & Basis & $\begin{array}{l}\text { Affected systems } \\
\text { (applicable SSCs) }\end{array}$ \\
\hline & $\begin{array}{l}\text { P4. Retrieve waste from } \\
\text { multiple tanks as needed to } \\
\text { support waste feed delivery } \\
\text { schedule. }\end{array}$ & $\begin{array}{l}\text { 1. Provide for the independent operation of } \\
\text { one set of mixer pumps in each of four } 200 \\
\text { East Area DST farms and one transfer } \\
\text { pump in a } 200 \text { Eust Area DST farm. } \\
\text { Provide control systems and electrical } \\
\text { distribution systems which can support the } \\
\text { simultaneous operation of up to nine mixer } \\
\text { pumps and one transfer pump. }\end{array}$ & $\begin{array}{l}\text { Integrated sclyedules show that at least } \\
\text { once in each of the tirst three years of } \\
\text { processing, up to nine mixer pumps and } \\
\text { one transfer pump may be needed } \\
\text { simultaneously (DeLozier to Umek, } \\
\text { letter no. LMHC-9854671A R1, } \\
\text { attacliment 1). } \\
\text { Potentially simultaneous operations } \\
\text { include } \\
\text { 1) transfer HLW from } 241-\mathrm{AY}-102 \text { to } \\
\text { one of the } 241-\mathrm{AZ} \text { tanks (four } 112-\mathrm{kW} \\
\text { [150-hp] mixer pumps and one } 45-\mathrm{kW} \\
\text { [60-hp] transfer pump in } 241-\mathrm{AY}-102 \text { ), } \\
\text { 2) mixing of HLW in one of the } 241-\mathrm{AZ} \\
\text { tanks in preparation for transfer to the } \\
\text { Privatization Contractor (two } 224-\mathrm{kW} \\
\text { [300-hp] mixer pumps), } \\
\text { 3) degassing or solids dissolution in } \\
\text { 241-AN-105 or } 241-\mathrm{AN}-104 \text { (two } \\
\text { 224-kW [300-hp] mixer pumps), and } \\
\text { 4) mixing and sampling of LAW feed in } \\
\text { 241-AP-102 or } 241-\mathrm{AP}-104 \text { (one } \\
\text { 224-kW [300-hp] mixer pump). }\end{array}$ & $\begin{array}{l}\text { Utility Distribution, } \\
\text { Instrumentation and Control } \\
\text { (1.2 DST I\&C, } 5.4 \\
\text { Electrical) } \\
\end{array}$ \\
\hline \multirow[t]{2}{*}{$\begin{array}{l}\text { 6. Sample } \\
\text { Waste }\end{array}$} & $\begin{array}{l}\text { P1. Ensure compatibility } \\
\text { between sending and receiving } \\
\text { tanks }\end{array}$ & $\begin{array}{l}\text { 1. Provide capability for taking multiple } \\
\text { representative grab samples of the waste } \\
\text { from one or more risers. Waste } \\
\text { compatibility testing is performed per } \\
\text { existing DQOs. }\end{array}$ & $\begin{array}{l}\text { HNF-SD-WM-DQO-001, Data Quality } \\
\text { Objectives for Tank Farm Waste. } \\
\text { Compatibility Program }\end{array}$ & $\begin{array}{l}\text { Sampling System and } \\
\text { Analysis System } \\
\text { (1.1 DST Structure) }\end{array}$ \\
\hline & $\begin{array}{l}\text { P2. Confirm waste composition } \\
\text { and inventory within contract } \\
\text { specifications }\end{array}$ & 1. Reserved & & \\
\hline
\end{tabular}


Table 4-1. Process Needs Assessment for 241-AZ Tank Farm Supporting Phase 1 Feed Delivery.

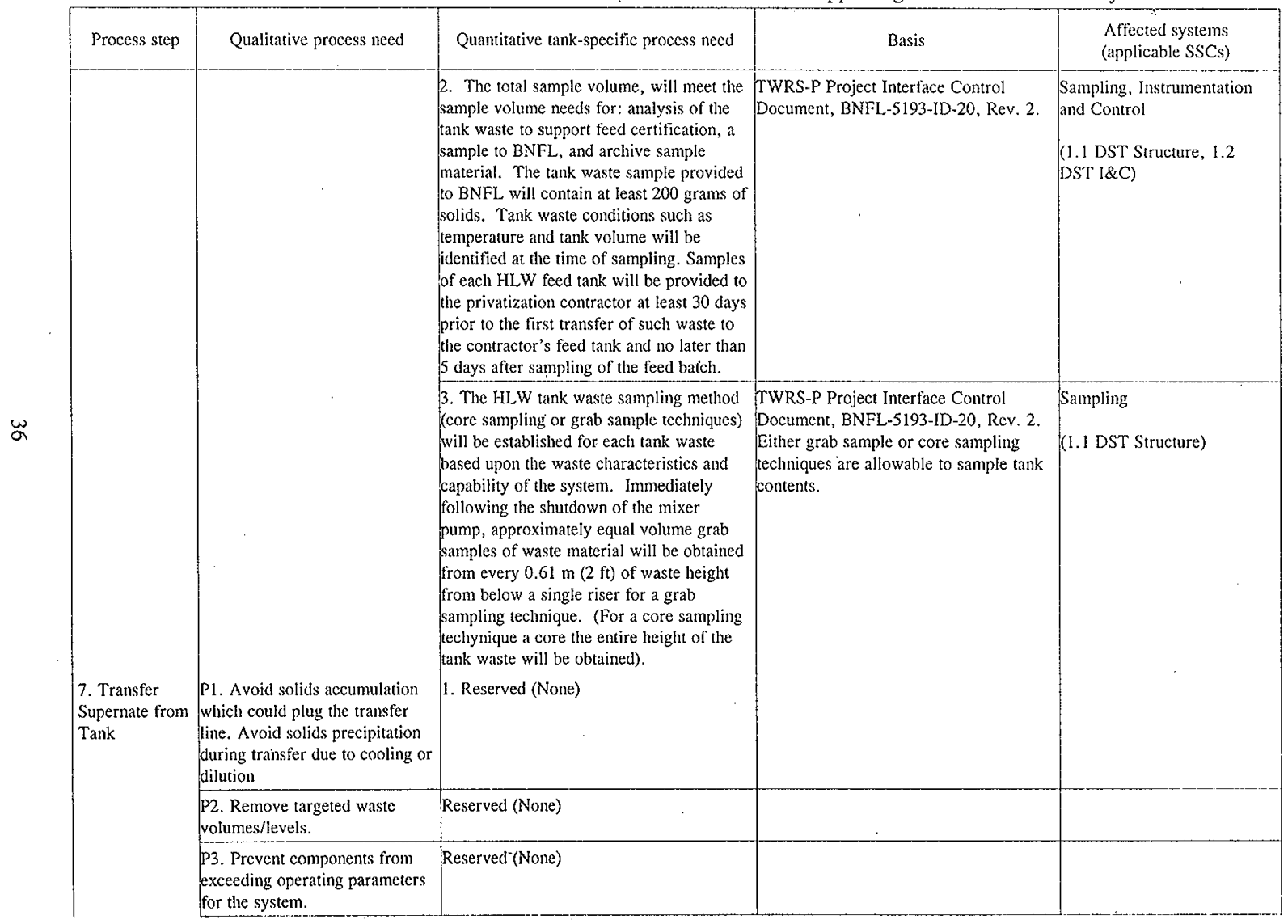


Table 4-1. Process Needs Assessment for 241-AZ Tank Farm Supporting Phase 1 Feed Delivery.

\begin{tabular}{|c|c|c|c|c|}
\hline \multirow[t]{2}{*}{ Process step } & Qualitative process need & Quantitative tank-specific process need & Basis & $\begin{array}{l}\text { Affected systems } \\
\text { (applicable SSCs) }\end{array}$ \\
\hline & $\begin{array}{l}\text { P4. Capability to flush the } \\
\text { transfer lines with inhibited } \\
\text { water. }\end{array}$ & Reserved (None) & & \\
\hline $\begin{array}{l}\text { 8. Receive } \\
\text { Supernate into } \\
\text { Tank }\end{array}$ & P1. Do not overfill tank. & Reserved (None) & & \\
\hline \multirow[t]{3}{*}{$\begin{array}{l}\text { 9. Transfer } \\
\text { Solids Slurry } \\
\text { from Tank }\end{array}$} & \multirow[t]{2}{*}{$\begin{array}{l}\text { P1. Avoid solids accumulation } \\
\text { which could plug the transfer } \\
\text { line. }\end{array}$} & $\begin{array}{l}\text { 1. Provide transfer system capable of } \\
\text { achieving a waste transter velocity of } \\
1.8 \text { to } 2.7 \mathrm{msec}(6 \text { to } 9 \mathrm{ft} / \mathrm{sec} \text { ). }\end{array}$ & $\begin{array}{l}\text { This transfer velocity provides sufficient } \\
\text { energy to keep all expected solids } \\
\text { suspended during the waste transfer } \\
\text { without causing excessive erosion within } \\
\text { the piping system (Rockwell } 198 \mathrm{x} \text { ). }\end{array}$ & $\begin{array}{l}\text { Waste Preparation and } \\
\text { Transfer, Instrumentation } \\
\text { and Control } \\
\text { (1.2 DST I\&C, } 2.2 \text { Slurry } \\
\text { Pump) }\end{array}$ \\
\hline & & $\begin{array}{l}\text { 2. Provide transfer pumps with a water } \\
\text { addition feature that will provide slurry } \\
\text { dilution capability at the pump suction. } \\
\text { The needed dilution water flow rate is } \\
530 \mathrm{~L} / \mathrm{min}(140 \mathrm{gat} / \mathrm{min}) \text {. }\end{array}$ & $\begin{array}{l}\text { Provides a means to dilute the slurry } \\
\text { concentration near the pump intake if } \\
\text { line pressure and flowrate indicate that a } \\
\text { line blockage is forming. Dilution water } \\
\text { flowrate equivalent to the minimum } \\
\text { design flow rate allows flow to be } \\
\text { established with dilution water prior to } \\
\text { transferring waste. This also allows the } \\
\text { capability to continue to operate the } \\
\text { pump without terminating a transfer if } \\
\text { blockage is thought to be forming. The } \\
\text { minimum acceptable linear flow rate for } \\
\text { slurries is } 1.8 \text { m/s ( } 6 \mathrm{ft} / \mathrm{s} \text { ) (Rockwell } \\
198 \mathrm{x} \text { ) which is equivalent to } 530 \mathrm{~m} 3 / \mathrm{min} \\
(140 \text { gal/min) through a } 7.6-\mathrm{cm}(3-\mathrm{in} \text {.) } \\
\mathrm{SCH}-40 \text { pipe. }\end{array}$ & $\begin{array}{l}\text { Waste Preparation and } \\
\text { Transfer, Instrumentation } \\
\text { and Control, Utility } \\
\text { Distribution } \\
\text { (1.2 DST I\&C, } 2.2 \text { Slurry } \\
\text { Pump, } 3.2 \text { Chemical } \\
\text { Addition System, 5.3 Raw } \\
\text { Water) }\end{array}$ \\
\hline & $\begin{array}{l}\text { P2. Remove targeted waste } \\
\text { volumes/levels. }\end{array}$ & $\begin{array}{l}\text { 1. Determine total HLW solids mass } \\
\text { (expressed as non-volatile oxides) } \\
\text { transferred to the Privatization Vendor to } \\
\text { within a variability of TBD\%. }\end{array}$ & $\begin{array}{l}\text { The accuracy will be determined based } \\
\text { on best reasonably achievable sampling } \\
\text { and analysis. Specific requirements will } \\
\text { be developed as part of the HLW } \\
\text { Transfer Problem-Specific DQO (TBP, } \\
\text { Certa, et. al, 1998, HNF-XXX) }\end{array}$ & $\begin{array}{l}\text { Instrumentation and Control, } \\
\text { Sampling } \\
\text { (1.2 DST I\&C). }\end{array}$ \\
\hline
\end{tabular}


Table 4-1. Process Needs Assessment for 241-AZ Tank Farm Supporting Phase 1 Feed Delivery.

\begin{tabular}{|c|c|c|c|c|}
\hline Process step & Qualitative process need & Quantitative tank-specific process need & Basis & $\begin{array}{l}\text { Affected systems } \\
\text { (applicable SSCs) }\end{array}$ \\
\hline \multirow{3}{*}{. } & \multirow[t]{3}{*}{$\begin{array}{l}\text { P3. Prevent components from } \\
\text { exceeding operating parameters } \\
\text { for the system }\end{array}$} & $\begin{array}{l}\text { 1. In normal operation, maintain the } \\
\text { transfer system pressure drop below the } \\
\text { transfer line operating pressure. The } \\
\text { maximum line operating pressure can vary } \\
\text { between } 16.9 \text { to } 28.2 \mathrm{kPa}(230 \text { to } 400 \mathrm{psi} \text { ) } \\
\text { depending on the transfer line. }\end{array}$ & $\begin{array}{l}\text { The transfer system needs to be designed } \\
\text { to either linit the maximum provided } \\
\text { pump head below such that the } \\
\text { maximum operating pressure can not be } \\
\text { exceeded or a provide a pressure relief } \\
\text { mechanism. In the past, the tested } \\
\text { operating pressure has varied from } \\
16.9 \mathrm{kPa}(230 \mathrm{psi}) \text { to the current } \\
28.2 \mathrm{kPa}(400 \text { psi) based on tank farm } \\
\text { construction specification } \mathrm{B}-131-\mathrm{Cl} \text {, } \\
\text { Section } 15490 \text {, Pipe Code } \mathrm{M}-25 \text {. }\end{array}$ & $\begin{array}{l}\text { Waste Preparation and } \\
\text { Transfer, Instrumentation } \\
\text { and Control } \\
\text { (1.2 DST I\&C, 2.2 Slurry } \\
\text { Pump, } 2.3 \text { Piping Network) }\end{array}$ \\
\hline & & $\begin{array}{l}\text { 2. Provide transfer pumps with a } \\
\text { maximum design head of } 137 \mathrm{~m} \text { ( } 450 \mathrm{ft}) \\
\text { (TBR) total dynamic head at the target } \\
\text { flow rate of } 530 \mathrm{~L} / \mathrm{min}(140 \mathrm{gal} / \mathrm{min}) \text {. }\end{array}$ & $\begin{array}{l}\text { The operating philosophy is that a } \\
\text { transfer pump be sized to meet the head } \\
\text { requirements for the longest expected } \\
\text { routing. For transfers with less head } \\
\text { loss, a variable speed device is used to } \\
\text { lower the pump's operating curve to the } \\
\text { system curve so that operation is near } \\
\text { the best efficiency } \\
\text { point.(WHC-SD-WM-DGS-006, Rev, 0) } \\
\text { (see Appendix F.1.13). }\end{array}$ & $\begin{array}{l}\text { Waste Preparation and } \\
\text { Transfer } \\
\text { (2.2 Slurry Pump) }\end{array}$ \\
\hline & & $\begin{array}{l}\text { 3. Equipment used to transfer waste shall } \\
\text { be able to operate under both normal } \\
\text { startup and operation conditions. (Note: } \\
\text { for the currently planned system, prevent } \\
\text { cavitation of the transfer pump during } \\
\text { normal startup and operation conditions. } \\
\text { Net positive suction head required should } \\
\text { not exceed Net Positive Suction Head } \\
\text { Available at highest reasonable operating } \\
\text { temperatures.) }\end{array}$ & $\begin{array}{l}\text { Pump cavitation can damage the transfer } \\
\text { pump. Relevant waste properties are } \\
\text { determined for each transfer. } \\
\text { (WHC-SD-WM-DGS-006, Rev. 0) }\end{array}$ & $\begin{array}{l}\text { Waste Preparation and } \\
\text { Transfer } \\
\text { (2.2 Slurry Pump) }\end{array}$ \\
\hline
\end{tabular}


Table 4-1. Process Needs Assessment for 241-AZ Tank Farm Supporting Phase 1 Feed Delivery.

\begin{tabular}{|c|c|c|c|c|}
\hline Process step & Qualitative process need & Quantitative tank-specific process need & Basis & $\begin{array}{l}\text { Affected systems } \\
\text { (applicable SSCs) }\end{array}$ \\
\hline \multirow[t]{3}{*}{. } & \multirow{3}{*}{. } & $\begin{array}{l}\text { 4. Control the rate of operation used to } \\
\text { eransfer. (Note: for the currently planned } \\
\text { system, provide transfer pumps with a } \\
\text { VFD capable of operating the pump from a } \\
\text { minimum speed of approximately } 25 \% \\
\text { speed to full speed operation.) }\end{array}$ & $\begin{array}{l}\text { This provides the flexibility to allow a } \\
\text { slow start during startup to allow fluids } \\
\text { to reach process-lubricated bearings } \\
\text { prior to full speed operation. Variable } \\
\text { speeds on transfer pumps enhance pump } \\
\text { life by allowing them to be operated at a } \\
\text { speed which will achieve the desired } \\
\text { waste flow rate while running the pump } \\
\text { near its best efficiency point. } \\
\text { (WHC-SD-WM-DGS-006, Rev. 0). }\end{array}$ & $\begin{array}{l}\text { Waste Preparation and } \\
\text { Transfer, Instrumentation } \\
\text { and Control } \\
\text { (1.2 DST I\&C, } 2.2 \text { Slurry } \\
\text { Pump) }\end{array}$ \\
\hline & & $\begin{array}{l}\text { 5. Protect equipment from off normal } \\
\text { transfer conditions. (Note: for the } \\
\text { currently planned system, provide reverse } \\
\text { rotation and back flow protection for } \\
\text { transfer pumps.) }\end{array}$ & $\begin{array}{l}\text { Reverse flow can result from back } \\
\text { flushing prior to startup and after } \\
\text { shutdown, drain back due to transfer line } \\
\text { holdup and elevation differences when } \\
\text { pump is shut off, and incorrect phase } \\
\text { connection during wiring. } \\
\text { (WHC-SD-WM-DGS-006, Rev. 0). }\end{array}$ & $\begin{array}{l}\text { Waste Preparation and } \\
\text { Transfer } \\
\text { (2.2 Slurry Pump) }\end{array}$ \\
\hline & & $\begin{array}{l}\text { 6. Provide in-tank components that can } \\
\text { withstand forces imparted by mobilization } \\
\text { and suspension equipment and remain } \\
\text { operable and retrievable from the DST. } \\
\text { (Note: for the currently planned system, } \\
\text { provide slurry transfer pumps which can } \\
\text { be operated during mixer pump operation } \\
\text { and withstand forces. imparted by full } \\
\text { speed mixer pump operation and remain } \\
\text { operable and retrievable from the DST }\end{array}$ & $\begin{array}{l}\text { Minimization of feed batch variability } \\
\text { necessitates that the transfer pump } \\
\text { operates while the mixer pumps are } \\
\text { operating to maintain a uniform waste } \\
\text { suspension. Operation of mixer pumps } \\
\text { must not cause the transfer pump to fail } \\
\text { or bend such that it can not be retrieved. } \\
\text { (see Appendix F.1.14) }\end{array}$ & $\begin{array}{l}\text { Waste Preparation and } \\
\text { Transfer } \\
\text { (2.2 Slurry Pump) }\end{array}$ \\
\hline
\end{tabular}


Table 4-1. Process Needs Assessment for 241-AZ Tank Farm Supporting Phase 1 Feed Delivery.

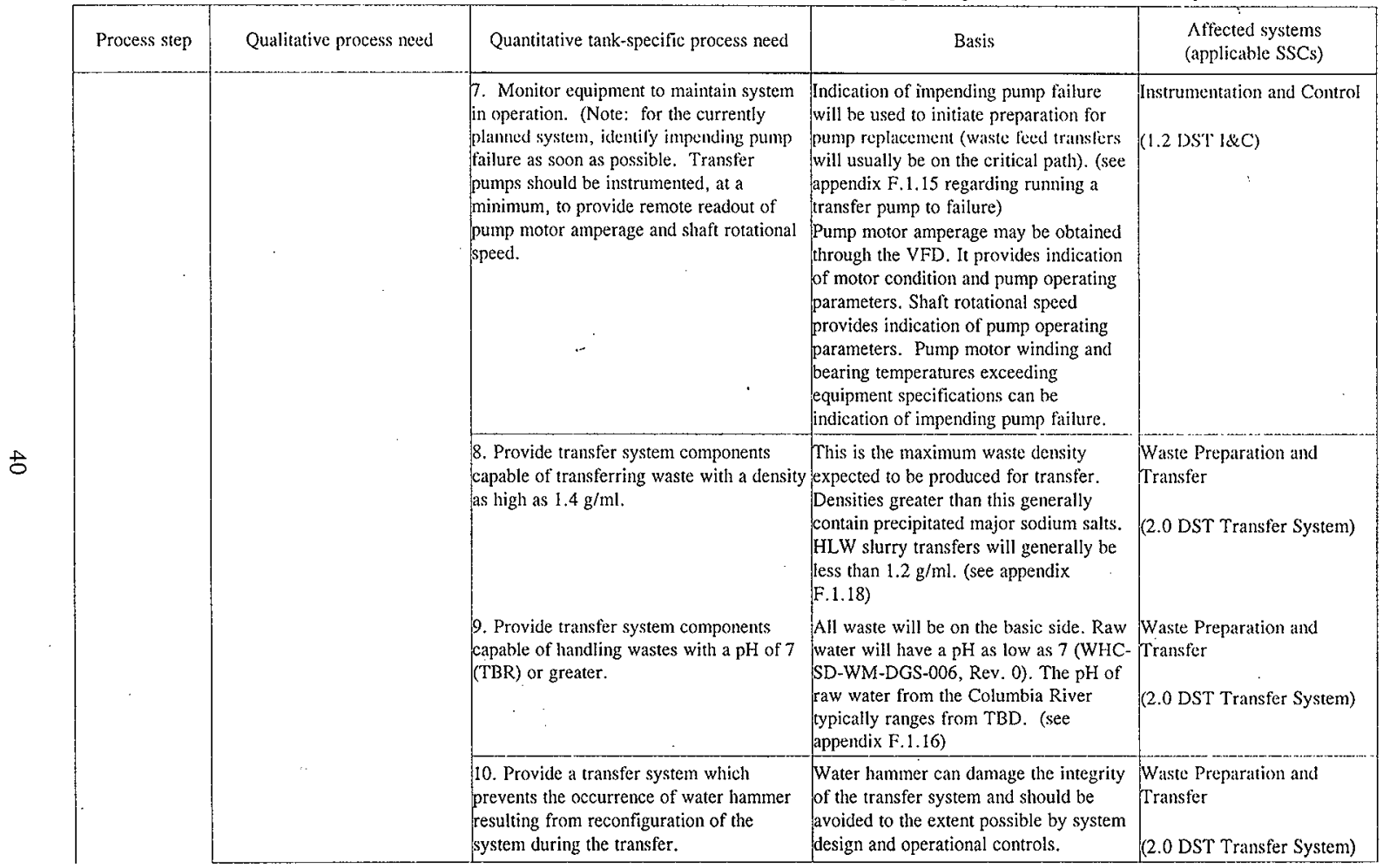


Table 4-1. Process Needs Assessment for 241-AZ Tank Farm Supporting Phase 1 Feed Delivery.

\begin{tabular}{|c|c|c|c|c|}
\hline Process step & Qualitative process need & Quantitative tank-specific process need & Basis & $\begin{array}{l}\text { Affected systems } \\
\text { (applicable SSCs) }\end{array}$ \\
\hline \multirow{4}{*}{ v } & \multirow[t]{4}{*}{$\begin{array}{l}\text { P4. Capability to flush the } \\
\text { rransfer lines with inhibited } \\
\text { water. }\end{array}$} & $\begin{array}{l}\text { 1. Provide a diluent system to flush the } \\
\text { transfer lines with inhibited water at } \\
530 \mathrm{~L} / \mathrm{min}(140 \mathrm{gal} / \mathrm{min} \text { ) (TBR). }\end{array}$ & $\begin{array}{l}\text { Flushing of the transfer lines is } \\
\text { necessary to remove any deposited soltds } \\
\text { and to flush high ionic strength waste } \\
\text { out of the lines to avoid line pluggage } \\
\text { and minimize corrosion. The identified } \\
\text { flow rate provides the ability to flush the } \\
\text { transfer lines at a tlow rate that is } \\
\text { equivalent to the actual transfer activity. } \\
\text { (see appendix F.1.3 and F.1.4) }\end{array}$ & $\begin{array}{l}\text { Waste Preparation and } \\
\text { Transfer, Instrumentation } \\
\text { and Control, Utility } \\
\text { Distribution } \\
\\
\text { (1.2 DST I\&C, } 2.0 \text { DST } \\
\text { Transfer System, 3.2 } \\
\text { Chemical Addition System, } \\
\text { 5.3 Raw Water) }\end{array}$ \\
\hline & & $\begin{array}{l}\text { 2. The flush direction should be from the } \\
\text { applicable } 241-A Z \text { pump pit to the } \\
\text { Privatization Contractor facility (TBR). }\end{array}$ & $\begin{array}{l}\text { The current W-314 design is configured } \\
\text { to drain from the HLW privatization } \\
\text { contractor interface back to } 241-\mathrm{AZ} \text {.. } \\
\text { Interfaces with the privatization } \\
\text { contractor have not been finalized. } \\
\text { therefore assume that PHMC must } \\
\text { provide flushing capability. (see } \\
\text { Appendix F.1.19) }\end{array}$ & $\begin{array}{l}\text { Waste Preparation and } \\
\text { Transfer } \\
\\
\text { (2.3 Piping Network, } 3.2 \\
\text { Chemical Addition System) }\end{array}$ \\
\hline & & $\begin{array}{l}\text { 3. Flush transfer lines with water volumes } \\
\text { equivalent to } 1.5 \text { times the transfer line } \\
\text { internal volume. }\end{array}$ & $\begin{array}{l}\text { The standard flush volumes are } 1-2 \\
\text { equivalent line volumes. (see appendix } \\
\text { F.1.17) }\end{array}$ & $\begin{array}{l}\text { Waste Preparation and } \\
\text { Transfer, Instrumentation } \\
\text { and Control, Utility } \\
\text { Distribution } \\
\text { (1.2 DST I\&C, } 3.2 \\
\text { Chemical Addition System, } \\
\text { 5.3 Raw Water) }\end{array}$ \\
\hline & & $\begin{array}{l}\text { 4. Flush water inlet can be at the transfer } \\
\text { pump inlet or in the pump discharge line. }\end{array}$ & $\begin{array}{l}\text { The flush water will serve the same } \\
\text { purpose with either inlet point. (see } \\
\text { appendix F.1.19) }\end{array}$ & $\begin{array}{l}\text { Waste Preparation and } \\
\text { Transfer } \\
\text { (2.2 Slurry Pump, } 2.3 \\
\text { Piping Network) }\end{array}$ \\
\hline $\begin{array}{l}\text { 10. Receive } \\
\text { Solids Slurry } \\
\text { into Tank }\end{array}$ & P1. Do not overfill tank & $\begin{array}{l}\text { 1. Provide tank level monitoring and alarm } \\
\text { systems }\end{array}$ & $\begin{array}{l}\text { Tank level monitoring is a standard } \\
\text { material balance approach for } \\
\text { monitoring progress of a waste transfer. } \\
\text { Material balance calculations are used } \\
\text { for detection of leaks or misroutings per } \\
\text { HNF-SD-WM-TSR-006, 5.12.2.b. (see } \\
\text { Table } 4.2 \text { Safety Requirement } 7 . \mathrm{SI} \text {. } 1 \text { ) }\end{array}$ & $\begin{array}{l}\text { Instrumentation and Control } \\
\text { (1.2 DST I\&C, } 4.0 \text { DST } \\
\text { Monitor and Control } \\
\text { System) }\end{array}$ \\
\hline
\end{tabular}


Table 4-1. Process Needs Assessment for 241-AZ Tank Farm Supporting Phase 1 Feed Delivery.

\begin{tabular}{|c|c|c|c|c|}
\hline Process step & Qualitative process need & Quantitative tank-specific process need & Basis & $\begin{array}{l}\text { Affected systems } \\
\text { (applicable SSCs) }\end{array}$ \\
\hline & $\begin{array}{l}\text { P2. Minimize generation of } \\
\text { aerosols in } 241-A Y \text { and } 241-A Z \\
\text { Tank Farms }\end{array}$ & $\begin{array}{l}\text { 1. In } 241-A Z \text { and } 24 I-\Lambda Y \text { tanks, provide a } \\
\text { drop leg or other method of discharging } \\
\text { liquid beneath tank waste surface. }\end{array}$ & $\begin{array}{l}\text { HNF-2783, Slurry Distributor Affects on } \\
\text { Ventilation System, Unacceptably high } \\
\text { radiation fields would be produced in the } \\
702-A Z \text { ventilation system ductwork and } \\
\text { piping resulting from settling out of } \\
\text { aerosols generated by waste discharges } \\
\text { into the tank headspace. }\end{array}$ & $\begin{array}{l}\text { Waste Preparation and } \\
\text { Transfer } \\
\text { (2.3 Piping Nerwork, } 2.4 \\
\text { Slurry Distributor) }\end{array}$ \\
\hline
\end{tabular}


Table 4-2. Safety Requirements Assessment for 241-AZ Tank Farm in Support of Phase 1 Feed Delivery.

\begin{tabular}{|c|c|c|c|c|}
\hline Process step & $\begin{array}{l}\text { Qualitative process safety } \\
\text { objective }\end{array}$ & $\begin{array}{c}\text { Quantitative Tank-Specific Process Safety } \\
\text { Requirement }\end{array}$ & Safety Basis Reference & Aftected Systems \\
\hline \multirow[t]{5}{*}{$\begin{array}{l}\text { 1. Safe } \\
\text { Storage }\end{array}$} & \multirow[t]{3}{*}{$\begin{array}{l}\text { S1. Manage flammable gas } \\
\text { hazards }\end{array}$} & 1. Reserved & & \\
\hline & & $\begin{array}{l}\text { 2. Manage tanks } A Z-101 \text { and } A Z-102 \text { as } \\
\text { Facility Group } 2 \text { assignments. }\end{array}$ & $\begin{array}{l}\text { HNF-SD-WM-TSR-006, Rev. } 0 \text {, } \\
\text { Section 5.9, Administrative Controls, } \\
\text { Flammability Controls }\end{array}$ & $\begin{array}{l}\text { Waste Preparation and } \\
\text { Transfer, Instrumentation } \\
\text { and Control } \\
\text { (1.2 DST I\&C, 2.1 Decant } \\
\text { Pump, } 2.5 \text { Supernate } \\
\text { Pump, 3.2 Chemical } \\
\text { Addition System, } 4.0 \text { DST } \\
\text { Monitor and Control } \\
\text { System) }\end{array}$ \\
\hline & & $\begin{array}{l}\text { 3. Maintain flammable gases } \\
\text { concentrations no greater than } 25 \% \text { of the } \\
\text { lower flammability limit }\end{array}$ & $\begin{array}{l}\text { HNF-SD-WM-TSR-006, Rev. } 0 \text {, } \\
\text { Section 5.9, Administrative Controls, } \\
\text { Flammability Controls }\end{array}$ & $\begin{array}{l}\text { Waste Preparation and } \\
\text { Transfer, Instrumentation } \\
\text { and Control, Ventilation } \\
\text { (1.2 DST I\&C, } 1.3 \text { DST } \\
\text { Ventilation, } 3.1 \text { Mixer } \\
\text { Pump, } 4.0 \text { DST Monitor } \\
\text { and Control System) }\end{array}$ \\
\hline & \multirow[t]{2}{*}{$\begin{array}{l}\text { S2. Manage potential ignition } \\
\text { sources that can initiate a fire } \\
\text { or flammable gas deflagration. }\end{array}$} & 1. Reserved & & \\
\hline & & $\begin{array}{l}\text { 2. Flammable gas ignition source controls } \\
\text { for Tanks } A Z \text { - } 101 \& A Z \text { - } 102 \text { are Facility } \\
\text { Group } 2 \text { requirements. }\end{array}$ & $\begin{array}{l}\text { HNF-SD-WM-TSR-006, Rev. } 0 \text {, } \\
\text { Section 5. } 10, \text { Administrative Controls, } \\
\text { Ignition Controls }\end{array}$ & $\begin{array}{l}\text { Waste Preparation and } \\
\text { Transfer } \\
\text { (2.1 Decant Pump, } 2.5 \\
\text { Supernate Pump, } 3.2 \\
\text { Chemical Addition System) }\end{array}$ \\
\hline
\end{tabular}


Table 4-2. Safety Requirements Assessment for 241-AZ Tank Farm in Support of Phase 1 Feed Delivery.

\begin{tabular}{|c|c|c|c|c|}
\hline Process step & $\begin{array}{l}\text { Qualitative process safety } \\
\text { objective }\end{array}$ & $\begin{array}{c}\text { Quantitative Tank-Specific Process Safety } \\
\text { Requirement }\end{array}$ & Safety Basis Reference & Affected Systems \\
\hline & & $\begin{array}{l}\text { 3. An active primary ventilation system } \\
\text { shall be operable for all DSTs and AWF } \\
\text { tanks }\end{array}$ & $\begin{array}{l}\text { Limiting condition for operation (LCO) } \\
3.2 .1 \text {, active ventilation provides } \\
\text { control of airborne contamination, } \\
\text { active ventilation also serves to } \\
\text { maintain flammable gas concentrations } \\
\text { below } 25 \% \text { of the LFL. }\end{array}$ & $\begin{array}{l}\text { Ventilation, } \\
\text { Instrumentation and } \\
\text { Control } \\
\text { (1.2 DST I\&C, 1.3 DST } \\
\text { Ventilation, 4.0 DST } \\
\text { Monitor and Control } \\
\text { System) }\end{array}$ \\
\hline & $\begin{array}{l}\text { S3. Monitor flammable gas } \\
\text { concentrations to prevent } \\
\text { deflagration }\end{array}$ & 1. Reserved & & \\
\hline & $\begin{array}{l}\text { S4. Provide operable transfer } \\
\text { system covers }\end{array}$ & $\begin{array}{l}\text { 1. Transfer system covers associated } \\
\text { with structures that are physically } \\
\text { connected to an active waste transfer } \\
\text { pump not under administrative lock or } \\
\text { under the control of AC 5.22, "Transfer } \\
\text { System Cover Removal Controls" slatll } \\
\text { be operable. }\end{array}$ & $\begin{array}{l}\text { HNF-SD-WM-TSR-006, Rev. 0, } \\
\text { Section 3.1.1, Limiting Conditions for } \\
\text { Operation, Transfer System Covers }\end{array}$ & $\begin{array}{l}\text { Waste Preparation and } \\
\text { Transfer } \\
\text { (1.1 DST Structure) }\end{array}$ \\
\hline & $\begin{array}{l}\text { S5. Provide service water } \\
\text { pressure detection }\end{array}$ & $\begin{array}{l}\text { 1. Service water pressure detection } \\
\text { systems that are physically connected to } \\
\text { an active waste transfer pump not under } \\
\text { administrative lock shall be operable. }\end{array}$ & $\begin{array}{l}\text { HNF-SD-WM-TSR-006, Rev. } 0 \text {, } \\
\text { Section 3.1.2, Limiting Conditions for } \\
\text { Operation, Service Water Pressure } \\
\text { Detection Systems }\end{array}$ & $\begin{array}{l}\text { Utility Distribution } \\
\text { Instrumentation and } \\
\text { Control } \\
\text { (1.2 DST I\&C, } 2.1 \text { Decant } \\
\text { Pump, } 2.2 \text { Slurry Pump, } \\
2.5 \text { Supernate Pump, } 3.2 \\
\text { Chemical Addition System, } \\
4.0 \text { DST Monitor and } \\
\text { Control System, 5.3 Raw } \\
\text { Water) }\end{array}$ \\
\hline & $\begin{array}{l}\text { S6. Provide transfer leak } \\
\text { detection }\end{array}$ & $\begin{array}{l}\text { 1. Leak detection in all process pits, } \\
\text { diversion boxes, vault pits, and cleanout } \\
\text { boxes physically comected to an active } \\
\text { waste transfer pump that is not under } \\
\text { administrative lock shall be operable. }\end{array}$ & $\begin{array}{l}\text { HNF-SD-WM-TSR-006, Rev. 0, } \\
\text { Section 3.1.3, Limiting Conditions for } \\
\text { Operation, Transfer Leak Detection } \\
\text { Systems }\end{array}$ & $\begin{array}{l}\text { Instrumentation and } \\
\text { Control } \\
\text { (1.2 DST 1\&C, } 4.0 \text { DST } \\
\text { Monitor and Control } \\
\text { System) }\end{array}$ \\
\hline
\end{tabular}


HNF-2941

Revision 0

\begin{tabular}{|c|c|c|c|c|c|c|}
\hline 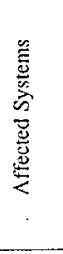 & 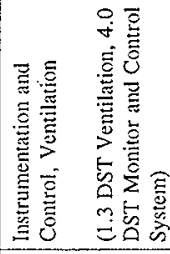 & 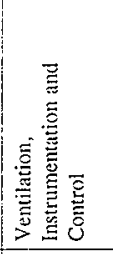 & 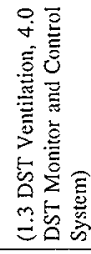 & 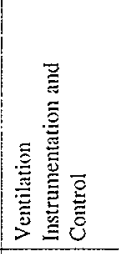 & 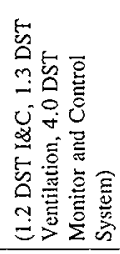 & 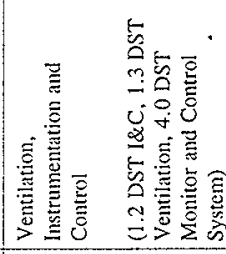 \\
\hline 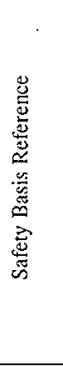 & 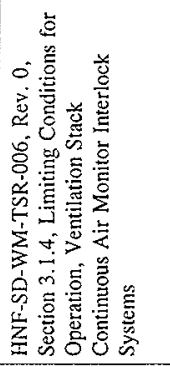 & 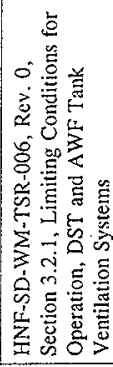 & & 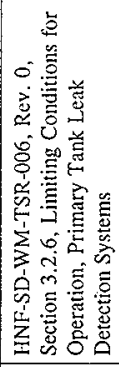 & & 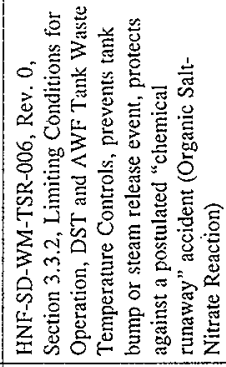 \\
\hline 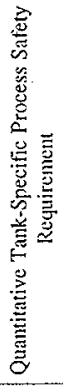 & 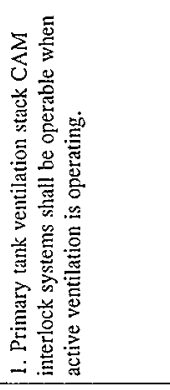 & 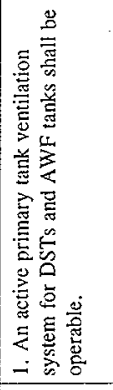 & & 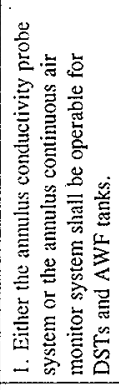 & & 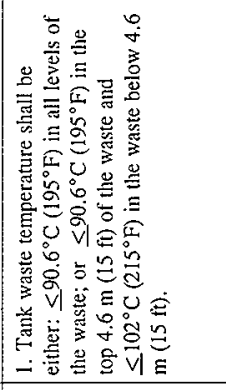 \\
\hline 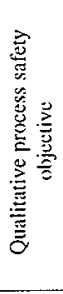 & 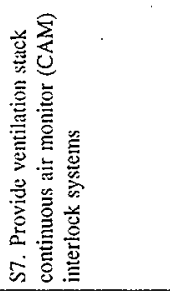 & 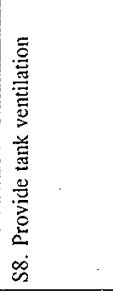 & & 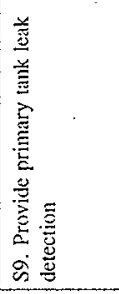 & & 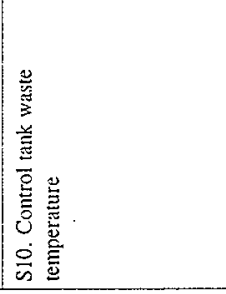 \\
\hline 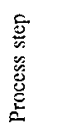 & & & & & & \\
\hline
\end{tabular}


Table 4-2. Safety Requirements Assessnent fọr 241-AZ Tank Farm in Support of Phase 1 Feed Delivery.

\begin{tabular}{|c|c|c|c|c|}
\hline Process step & $\begin{array}{l}\text { Qualitative process safety } \\
\text { objective }\end{array}$ & $\begin{array}{c}\text { Quantitative Tank-Specific Process Safety } \\
\text { Requirement }\end{array}$ & Safety Basis Reference & Affected Systems \\
\hline & & $\begin{array}{l}\text { 2. Waste temperature shall not exceed } \\
121^{\circ} \mathrm{C}\left(250^{\circ} \mathrm{F}\right) \text {. }\end{array}$ & BIO Safety Limit 2.1.1 & $\begin{array}{l}\text { Ventilation, } \\
\text { Instrumentation and } \\
\text { Control } \\
\text { (1.2 DST I\&C, } 1.3 \mathrm{DST} \\
\text { Ventilation, } 4.0 \mathrm{DST} \\
\text { Monitor and Control } \\
\text { System) }\end{array}$ \\
\hline & $\begin{array}{l}\text { S11. Prevent primary tank } \\
\text { overtilling }\end{array}$ & $\begin{array}{l}\text { 1. Provide instrumentation, monitoring } \\
\text { and controls for service water to avoid } \\
\text { overfilling a waste tank in the event of a } \\
\text { water line break. }\end{array}$ & $\begin{array}{l}\text { A service water flow totalizer is } \\
\text { specified by the BIO (pg. } 5.4-58 \text { ) as a } \\
\text { preventative and mitigative SSC against } \\
\text { a water line break overfilling a tank. }\end{array}$ & $\begin{array}{l}\text { Instrumentation and } \\
\text { Control } \\
\text { (1.2 DST I\&C, } 4.0 \text { DST } \\
\text { Monitor and Control } \\
\text { System) }\end{array}$ \\
\hline & $\begin{array}{l}\text { S12. Prevent subsurface } \\
\text { release of radioactive materials } \\
\text { due to leaks in multiple tanks. }\end{array}$ & $\begin{array}{l}\text { 1. Provide primary tank leak detection, } \\
\text { tank level monitoring, and temperature } \\
\text { monitoring, and transfer controls on } \\
\text { waste } \mathrm{pH} \text {. }\end{array}$ & $\begin{array}{l}\text { Controls and Instrumentation specified } \\
\text { by the BIO (pg. 5.4-153) to prevent } \\
\text { and mitigate leaks resulting from tank } \\
\text { and tank component corrosion. } \\
\text { Temperature monitoring prevents one } \\
\text { possible cause of tank failure and is a } \\
\text { possible indicator of tank heat up } \\
\text { resulting from a leak. }\end{array}$ & $\begin{array}{l}\text { Instrumentation and } \\
\text { Control } \\
\text { (1.2 DST I\&C, } 4.0 \mathrm{DST} \\
\text { Monitor and Control } \\
\text { System) }\end{array}$ \\
\hline
\end{tabular}


Table 4-2. Safety Requirements Assessment for 241-AZ Tank Farm in Support of Phase 1 Feed Delivery.

\begin{tabular}{|c|c|c|c|c|}
\hline Process step & $\begin{array}{l}\text { Qualitative process safety } \\
\text { objective }\end{array}$ & $\begin{array}{c}\text { Quantitative Tank-Specific Process Safety } \\
\text { Requirement }\end{array}$ & Safety Basis Reference & Affected Systems \\
\hline $\begin{array}{l}\text { 4. Add } \\
\text { Diluent to } \\
\text { Tank }\end{array}$ & $\begin{array}{l}\text { S1. Prevent contamination of } \\
\text { service water systems }\end{array}$ & $\begin{array}{l}\text { 1. Prevent backflow of waste from active } \\
\text { waste transfer pump into service water } \\
\text { systems that are physically connected } \\
\text { during transfer }\end{array}$ & $\begin{array}{l}\text { TSR Control LCO } 3.1 .2 \text { requires that } \\
\text { service water pressure detection } \\
\text { systems be operable. Flushing system } \\
\text { pressure switches and associated } \\
\text { interlocks with waste transfer pumps or } \\
\text { alarm response are used to stop } \\
\text { inadvertent waste flow into tlushing } \\
\text { systems in transfer-associated } \\
\text { structures that do not have covers. This } \\
\text { prevents potential leaks from } \\
\text { developing outside the transfer path. } \\
\text { The pressure switches and associated } \\
\text { interlocks or alarm response also } \\
\text { prevent radioactive material from } \\
\text { contaminating the service water supply } \\
\text { system. }\end{array}$ & $\begin{array}{l}\text { Waste Preparation and } \\
\text { Transfer, Instrumentation } \\
\text { and Control } \\
\text { (1.2 DST I\&C, } 3.2 \\
\text { Chemical Addition System) }\end{array}$ \\
\hline \multirow[t]{2}{*}{$\begin{array}{l}\text { 5. Mix Tank } \\
\text { Contents }\end{array}$} & \multirow[t]{2}{*}{$\begin{array}{l}\text { S1. Control tank waste } \\
\text { temperature }\end{array}$} & $\begin{array}{l}\text { 1. Tank waste temperature shall be } \\
\text { either: } \leq 90.6^{\circ} \mathrm{C}\left(195^{\circ} \mathrm{F}\right) \text { in all levels of } \\
\text { the waste; or } \leq 90.6\left(195^{\circ} \mathrm{F}\right) \text { in the top } \\
4.6 \mathrm{~m}(15 \mathrm{ft}) \text { of the waste and } \leq 102^{\circ} \mathrm{C} \\
\left(215^{\circ} \mathrm{F}\right) \text { in the waste below } 4.6 \mathrm{~m}(15 \mathrm{ft}) \text {. }\end{array}$ & $\begin{array}{l}\text { HNF-SD-WM-TSR-006, Rev. 0, } \\
\text { Section 3.3.2, Limiting Conditions for } \\
\text { Operation, DST and AWF Tank Waste } \\
\text { Temperature Controls, prevents tank } \\
\text { bump or steam release event, protects } \\
\text { against a postulated "chemical } \\
\text { runaway" accident (Organic Salt- } \\
\text { Nitrate Reaction) }\end{array}$ & $\begin{array}{l}\text { Ventilation, } \\
\text { Instrumentation and } \\
\text { Control, Waste Preparation } \\
\text { and Transfer } \\
\text { (1.2 DST I\&C, 1.3 DST } \\
\text { Ventilation, 3.1 Mixer } \\
\text { Pump, } 4.0 \text { DST Monitor } \\
\text { and Control System) }\end{array}$ \\
\hline & & $\begin{array}{l}\text { 2. Temperature changeover time for } \\
\text { solutions in tanks shall be } \leq 5.5^{\circ} \mathrm{C}(10 \\
\left.{ }^{\circ} \mathrm{F}\right) / \mathrm{hr}\left(<52^{\circ} \mathrm{C}\left[125^{\circ} \mathrm{F}\right]\right) \text { or } \leq 11^{\circ} \mathrm{C}(20 \\
\left.{ }^{\circ} \mathrm{F}\right) / \text { day }\left(\geq 52^{\circ} \mathrm{C}\left[125^{\circ} \mathrm{F}\right]\right)\end{array}$ & $\begin{array}{l}\text { OSD-T-151-00007, rev H-19, Waste } \\
\text { temperatures are limited to prevent } \\
\text { excessive stress to the primary tank and } \\
\text { structural degradation of the concrete } \\
\text { shell. High temperatures, rapid } \\
\text { temperature cycling and extreme } \\
\text { temperature gradients can cause } \\
\text { concrete deterioration and cracking. }\end{array}$ & $\begin{array}{l}\text { Ventilation, } \\
\text { Instrumentation and } \\
\text { Control, Waste Preparation } \\
\text { and Transfer } \\
\text { (1.2 DST I\&C, 1.3 DST } \\
\text { Ventilation, 3.1 Mixer } \\
\text { Pump, 4.0 DST Monitor } \\
\text { and Control System) }\end{array}$ \\
\hline
\end{tabular}


Table 4-2. Safety Requirements Assessment fọr 241-AZ Tank Farm in Support of Phase 1 Feed Delivery.

\begin{tabular}{|c|c|c|c|c|}
\hline Process step & $\begin{array}{c}\text { Qualitative process safety } \\
\text { objective }\end{array}$ & $\begin{array}{c}\text { Quantitative Tank-Specific Process Safety } \\
\text { Requirement }\end{array}$ & Safety Basis Reference & Affected Systems \\
\hline & \multirow[b]{2}{*}{. } & $\begin{array}{l}\text { 3. Temperature gradients of solution in } \\
\text { tanks shatl he } \leq 102^{\circ} \mathrm{C} / \mathrm{m}\left(55^{\circ} \mathrm{F} / \mathrm{ft}\right) \\
\text { within the solution and at the } \\
\text { solution/vapor interface }\end{array}$ & $\begin{array}{l}\text { OSD-T-15I-00007, rev H-19, Waste } \\
\text { temperatures are limited to prevent } \\
\text { excessive stress to the primary tank and } \\
\text { structural degradation of the concrete } \\
\text { shell. High temperatures, rapid } \\
\text { temperature cycling and extreme } \\
\text { temperature gradients can cause } \\
\text { concrete deterioration and cracking. }\end{array}$ & $\begin{array}{l}\text { Ventilation, } \\
\text { Instrumentation and } \\
\text { Control, Waste Preparation } \\
\text { and Transfer } \\
\text { (1.2 DST I\&C, 1.3 DST } \\
\text { Ventilation, 3.1 Mixer } \\
\text { Pump, 4.0 DST Monitor } \\
\text { and Control System) }\end{array}$ \\
\hline & & $\begin{array}{l}\text { 4. Tank } 241-A Z-101 \text { air lift circulation } \\
\text { must be operable when waste solution } \\
\text { temperature is }>93^{\circ} \mathrm{C}\left(200^{\circ} \mathrm{F}\right) \text { and } \\
\text { when sludge temperature is }>110^{\circ} \mathrm{C} \\
\left(230^{\circ} \mathrm{F}\right) \text {. } \\
\text { Note: it is asstumed that this will also be } \\
\text { applicable to tank } 241-A Z-102 \text {. }\end{array}$ & $\begin{array}{l}\text { BIO Addendum } 1 \text {, Section } 3.4 .4 \text {. } \\
\text { Required to avoid a steam bump. This } \\
\text { requirement is currently only } \\
\text { applicable to performance of the } A Z \text { - } \\
101 \text { Mixer Pump Process Test. It is } \\
\text { assumed that a similar requirement will } \\
\text { be in place during waste feed delivery } \\
\text { activities for both } 241-\mathrm{AZ} \text { aging waste } \\
\text { tanks. }\end{array}$ & $\begin{array}{l}\text { Waste Preparation and } \\
\text { Transfer, Instrumentation } \\
\text { and Control, DST Utility } \\
\text { Distribution System } \\
\text { (1.1 DST Structure, } 1.2 \\
\text { DST I\&C, } 4.0 \text { DST } \\
\text { Monitor and Control } \\
\text { System, 5.1 Compressed } \\
\text { Air) }\end{array}$ \\
\hline & $\begin{array}{l}\text { S2. Monitor for leaks or line } \\
\text { misroutings }\end{array}$ & $\begin{array}{l}\text { 1.Provide instrument air to weight factor } \\
\text { leak detection systems at an appropriate } \\
\text { flow rate and pressure. }\end{array}$ & $\begin{array}{l}\text { TSR Control LCO } 3.1 .3 \text { requires } \\
\text { transfer system leak detection systems } \\
\text { to be operable during a transfer. If the } \\
\text { weight factor leak detection systems do } \\
\text { not receive instrument air they will not } \\
\text { function. }\end{array}$ & $\begin{array}{l}\text { Utility Distribution, } \\
\text { Instrumentation and } \\
\text { Control } \\
\text { (1.2 DST I\&C, } 4.0 \text { DST } \\
\text { Monitor and Control } \\
\text { System, 5.1 Compressed } \\
\text { Air) }\end{array}$ \\
\hline
\end{tabular}


Table 4-2. Safety Requirements Assessment for 241-AZ Tank Farm in Support of Phase 1 Feed Delivery.

\begin{tabular}{|c|c|c|c|c|}
\hline Process step & $\begin{array}{l}\text { Qualitative process safety } \\
\text { objective }\end{array}$ & $\begin{array}{c}\text { Quantitative Tank-Specitic Process Satety } \\
\text { Requirement }\end{array}$ & Safety Basis Reference & Affected Systems \\
\hline \multirow[t]{4}{*}{$\begin{array}{l}\text { 9. Transfer } \\
\text { Solids Slurry } \\
\text { from Tank }\end{array}$} & \multirow[t]{2}{*}{$\begin{array}{l}\text { S1. Monitor for leaks or line } \\
\text { misroutings }\end{array}$} & $\begin{array}{l}\text { 1. Perform material balance calculations } \\
\text { during each waste transfer. Calculations } \\
\text { shall be performed at } 30 \text { and } 60 \text { minutes } \\
\text { following waste transfer initiation and } \\
\text { every } 2 \text { hours thereafter until the transfer } \\
\text { is complete (safety constraint) }\end{array}$ & $\begin{array}{l}\text { HNF-SD-WM-TSR-006, 5.12.2.b. } \\
\text { Timely detection of leaks or } \\
\text { misroutings. }\end{array}$ & $\begin{array}{l}\text { Instrumentation and } \\
\text { Control } \\
\text { (1.2 DST' I\&C, } 4.0 \text { DST } \\
\text { Monitoring and Control } \\
\text { System) }\end{array}$ \\
\hline & & $\begin{array}{l}\text { 2. Provide instrument air to weight factor } \\
\text { leak detection systems at an appropriate } \\
\text { flow rate and pressure. }\end{array}$ & $\begin{array}{l}\text { TSR Control LCO } 3.1 .3 \text { requires } \\
\text { transfer system leak detection systems } \\
\text { to be operable during a transfer. If the } \\
\text { weight factor leak detection systems do } \\
\text { not receive instrument air they will not } \\
\text { function. }\end{array}$ & $\begin{array}{l}\text { Utility Distribution, } \\
\text { Instrumentation and } \\
\text { Control } \\
\\
\text { (1.2 DST I\&C, } 4.0 \text { DST } \\
\text { Monitor and Control } \\
\text { System, } 5.1 \text { Compressed } \\
\text { Air) }\end{array}$ \\
\hline & $\begin{array}{l}\text { S2. Prevent contamination of } \\
\text { service water systems }\end{array}$ & $\begin{array}{l}\text { 1. Prevent backflow of waste from active } \\
\text { waste transfer pump into service water } \\
\text { systems that are physically connected } \\
\text { during transfer }\end{array}$ & $\begin{array}{l}\text { TSR Control LCO } 3.1 .2 \text { requires that } \\
\text { service water pressure detection } \\
\text { systems be operable. Flushing system } \\
\text { pressure switches and associated } \\
\text { interlocks with waste transfer pumps or } \\
\text { alarm response are used to stop } \\
\text { inadvertent waste flow into flushing } \\
\text { systems in transfer-associated } \\
\text { structures that do not have covers. This } \\
\text { prevents potential leaks from } \\
\text { developing outside the transfer path. } \\
\text { The pressure switches and associated } \\
\text { interlocks or alarm response also } \\
\text { prevent radioactive material from } \\
\text { contaminating the service water supply } \\
\text { system. }\end{array}$ & $\begin{array}{l}\text { Waste Preparation and } \\
\text { Transfer, Instrumentation } \\
\text { and Control } \\
\text { (1.2 DST I\&C, } 3.2 \\
\text { Chemical Addition System) }\end{array}$ \\
\hline & $\begin{array}{l}\text { S3. Detect subsurface leaks } \\
\text { that remain subsurfice }\end{array}$ & $\begin{array}{l}\text { 1. Transfer leak detection systems in } \\
\text { systems and structures connected to a } \\
\text { waste transfer pump and pipe-in-pipe } \\
\text { encasements shall be operable }\end{array}$ & $\begin{array}{l}\text { TSR Control LCO } 3.1 .3 \text { requires } \\
\text { transfer system leak detection systems } \\
\text { to be operable during a transfer. }\end{array}$ & $\begin{array}{l}\text { Instrumentation and } \\
\text { Control } \\
\text { (1:2 DST I\&C, } 4.0 \mathrm{DST} \\
\text { Monitor and Control } \\
\text { System) }\end{array}$ \\
\hline
\end{tabular}


Table 4-2. Safety Requirements Assessment for 241-AZ Tank Farm in Support of Phase 1 Feed Delivery.

\begin{tabular}{|c|c|c|c|c|}
\hline Process step & $\begin{array}{c}\text { Qualitative process safety } \\
\text { objective }\end{array}$ & $\begin{array}{c}\text { Quantitative Tank-Specific Process Safety } \\
\text { Requirement }\end{array}$ & Safety Basis Reference & Affected Systems \\
\hline . & S4. Mitigate transfer spray leak & $\begin{array}{l}\text { 1. Ventilation stack CAM interlock } \\
\text { systems shall be operable }\end{array}$ & $\begin{array}{l}\text { TSR Control LCO } 3.1 .4 \text { requires that } \\
\text { ventilation stack CAMs and interlock } \\
\text { systems be operable. The ventilation } \\
\text { CAM interlock detects increasing } \\
\text { radiological effluent release and stops } \\
\text { the ventilation exhaust fan on DSTs, } \\
\text { AWF tanks, and actively ventilated } \\
\text { SSTs (C and SX tank farms) within } 10 \\
\text { minutes. Stopping the exhaust fan } \\
\text { protects against the continued } \\
\text { unfiltered release of radioactive and } \\
\text { toxic materials following the breach of } \\
\text { the filter. }\end{array}$ & $\begin{array}{l}\text { Instrumentation and } \\
\text { Control } \\
\text { (1.2 DST I\&C, } 4.0 \text { DST } \\
\text { Monitor and Control } \\
\text { System) }\end{array}$ \\
\hline $\begin{array}{l}\text { 10. Receive } \\
\text { Solids Slurry } \\
\text { into Tank }\end{array}$ & $\begin{array}{l}\text { S1. Control tank waste } \\
\text { temperature }\end{array}$ & $\begin{array}{l}\text { 1. Tank waste temperature shall be } \\
\text { either: } \leq 90.6^{\circ} \mathrm{C}\left(195^{\circ} \mathrm{F}\right) \text { in all levels of } \\
\text { the waste; or } \leq 90.6^{\circ} \mathrm{C}\left(195^{\circ} \mathrm{F}\right) \text { in the } \\
\text { top } 4.6 \mathrm{~m}(15 \mathrm{ft}) \text { of the waste and } \\
\leq 102^{\circ} \mathrm{C}\left(215^{\circ} \mathrm{F}\right) \text { in the waste below } 4.6 \\
\mathrm{~m}(15 \mathrm{ft})\end{array}$ & $\begin{array}{l}\text { HNF-SD-WM-TSR-006, Rev. 0, } \\
\text { Section 3.3.2, Limiting Conditions for } \\
\text { Operation, DST and AWF Tank Waste } \\
\text { Temperature Controls, prevents tank } \\
\text { bump or steam release event, protects } \\
\text { against a postulated "chemical } \\
\text { runaway" accident (Organic Salt- } \\
\text { Nitrate Reaction) }\end{array}$ & $\begin{array}{l}\text { Ventilation, } \\
\text { Instrumentation and } \\
\text { Control, Waste Preparation } \\
\text { and Transfer } \\
\text { (1.2 DST I\&C, 1.3 DST } \\
\text { Ventilation, 3.1 Mixer } \\
\text { Pump, 4.0 DST Monitor } \\
\text { and Control System) }\end{array}$ \\
\hline
\end{tabular}


HNF-2941

Revision 0

\subsection{WASTE PREPARATION AND TRANSFER SYSTEMS}

The 241-AZ tank farm feed delivery system is graphically depicted in Figure 5-1. The wäste transfer routes from $241-\mathrm{AZ}-101$ and $241-\mathrm{AZ}-102$ are depicted in red showing proposed routings through the new transfer lines and valve pits defined under Project W-314 and terminating at the HLW vendor interface. Diluent addition and primary exhaust routes are also depicted in Figure 5-1. Appropriate new mixer and transfer pumps to support process needs are shown in each 241-AZ tank. Current tank volumes and relative levels of sludge and supernate are also shown.

\subsection{MIXER PUMPS}

Properly designed mixer pumps will perform the following functions:

- Degas the waste. In some of the waste tanks hydrogen gas (which results from radiolytic processes) builds up in the sludge and crust layers and then is released in a gas release event. Controlled waste degassing prevents the release event from occurring during waste transfers.

- Mobilize and suspend/homogenize solids into the liquid thus allowing solid materials to be transferred and removed from a tank.

- $\quad$ Provide contact between soluble solids (salts) and the diluent liquid in the tank to aid in the dissolution process.

The alternative case in DeLozier (1998) identifies tanks 241-AZ-101 and 241-AZ-102. as being retrieved as HLW feed. Only one of the mixer pump functions (solids suspension) is required in these two tanks. These two tanks will also serve as HLW feed staging tanks for additional HLW retrieved from other tanks. Although the M\&I contractor team no longer is responsible for establishing sludge washing capability, the HLW feed must consist of relatively homogenous slurry transferred in batches as often as once monthly. Mixer pumps must be installed in both tanks which can homogeneously suspend the solids now present in the tanks as well as future HLW transferred to these HLW feed staging tanks.

\subsubsection{Process Needs}

The quantitative process needs which apply to the waste preparation and transfer system, including mixer pumps, are summarized as part of Table A-1. The mixer pumps are required to suspend the solids in tanks 241-AZ-101 and 241-AZ-102. 
HNF-2941

Revision 0

\subsubsection{Existing and Planned Mixer Pumps}

Project W-151 has installed two 224-kW (300-hp) mixer pumps into 241-AZ-101. These mixer pumps will be tested during fiscal year 1999.

\subsubsection{Comparison of Existing and Planned Equipment to Expectations}

Based on sludge mobilization testing (Powell et al. 1995), the mixer pumps are thought to be capable of mobilizing waste solids. It is important to note that a full scale test of a two mixer pump systems ability to mobilize sludge has not yet been performed. There are two mixer pumps located in tank 241-AZ-101, and a full scale test using this system is scheduled to occur in May or June 1999.

A potential issue with the mixer pumps is that the intake and outlet of the mixer pumps are located near the bottom of the pump. The sludge in at least some of the tanks is extremely viscous, and will resist pumping. It is not clear from the current design how the pumps are to be started either initially, or after a period of inactivity. If a sufficient amount of water cannot be added to the tank near the inlet of the mixer pumps, it will be very difficult or perhaps impossible to start the pumps without causing cavitation and potential failure of the mixer pumps. It may be necessary to redesign the mixer pumps such that the intake is located in the supernate and the discharge at the bottom to allow the mixer pumps to be started without cavitating. Ideally, the mixer pump design would include two or more intake heights which could be controlled such that the intake would remain in the liquid as the level in the tank were drawn down.

\subsection{TRANSFER PUMPS AND PIPING AND VALVE ROUTINGS}

\subsubsection{Process Needs}

Table H-1 of the TWRSO\&UP (Kirkbride et al. 1997) identifies the projected transfers occurring in all tank farms through October 2011. The projected transfers are no longer fully consistent with the alternative case identified in DeLozier (1998). Both the previous set of transfers associated with sludge washing and the new set of transfers associated with DeLozier (1998) are identified in Table A-2. The set of transfers consistent with DeLozier (1998) will be examined as the set of transfers supporting waste feed delivery and all other relevant tank farm operations specific to $241-\mathrm{AZ}$. 


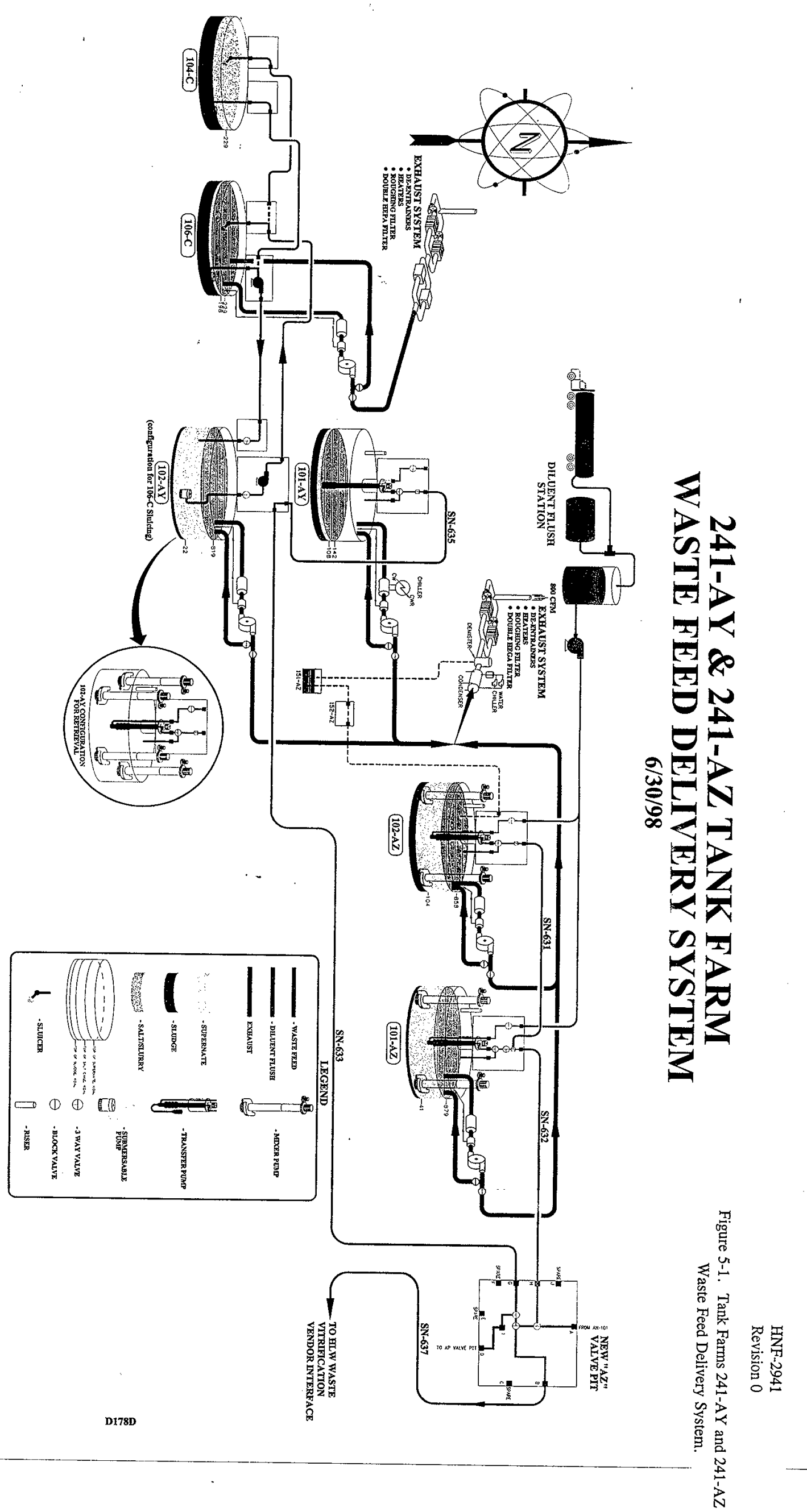




\subsubsection{Existing and Planned Transfer Pumps and Piping and Valve Routings}

Table A-3 postulates a route for each transfer between tanks that is identified in Table A-2 consistent with DeLozier (1998). Table A-3 identifies whether all transfer equipment for tank to tank transfers either exists or is planned based on best available drawings, project documents, and other available information. Table A-3 is also used to compare the existing and planned transfer route equipment to the process needs. This comparison is discussed below.

\subsubsection{Comparison of Existing and Planned Equipment to Process Needs}

\subsubsection{Comparison of Existing and Planned Piping and Valving Routings to Process}

Needs. Table A-3 provides a transfer equipment availability matrix identifying whether equipment is currently installed (and planned to remain installed rather than removed as part of an existing project) or whether the equipment is within the planned scope of a project.

\subsubsection{Comparison of Existing and Planned Transfer Pumps to Process Needs. All} planned transfers from 241-AZ tank farm are slurry transfers with up to 200 grams of unwashed solids per liter (DOE 1998). Table A-4 provides a transfer pump matrix identifying whether a transfer pump is currently installed (and planned to remain installed rather than removed as part of an existing project) or whether the necessary equipment is within the planned scope of a project. The type of pump planned for each transfer is also identified as well as the equivalent length of the transfer. The equivalent length of the transfer is used in determining the adequacy of the particular pump in meeting the process needs. The equivalent length is calculated by combining straight line length with length factors for various fittings and bends. Equivalent length and overall changes. in height (hydraulic head) for portions of the various transfer routes is identified in Table A-5.

Of issue in the $\mathrm{AZ}$ tank farm is the current waste minimum in the tank. Both 241-AZ-101 and 102 currently have a minimum waste level of $1.6 \mathrm{~m}$ (64 in.) in the tanks as listed in OSD-T-151-00017. The annulus pump pits in each tank drain into tanks at a level of $1.63 \mathrm{~m}$ (64 in.) above the tank bottom. If the level in the tanks are drained to below $1.63 \mathrm{~m}$ (64 in.), the annulus ventilation system may draw contaminated vapor into the annulus pump pit, if the primary ventilation system is not operating but the annulus ventilation system is operating.

\subsection{CHEMICAL ADDITION AND FLUSHING SYSTEMS}

\subsubsection{Process Needs}

Liquids are added to the waste or to the transfer lines to dilute the waste, disolve soluable solids in the waste, adjust a characteristic of the waste such as $\mathrm{pH}$, and to remove 
HNF-2941

Revision 0

waste residuals from the transfer line. The liquids used consist of water with added caustic, nitrite, or nitrate compounds to inhibit corrosion or to adjust the waste characteristic. It is anticipated that most of the additions in tanks 241-AZ-101 and -102 will most likely consist of water flushes, which are used to remove residual waste from the transfer lines, will likely consist of dilute caustic and nitrite solutions. The dilute caustic and nitrite solutions are used to prevent corrosion of the transfer lines.

The diluent added to the tanks is introduced either at the transfer pump intake in the initial stages of waste retrieval from the tanks that are full, or directly to the tank once the tank level allows suficient volume to allow direct addition. The quantitative process needs associated with the additions of diluent or flush are presented in Appendix A, Table A-1.

\subsubsection{Existing and Planned Chemical Addition and Flushing System}

The current flush system is not capable of delivering dilution water or flush solution at the required rate of $530 \mathrm{~L} / \mathrm{min}$, and the new chemical addition and flushing system design for the 241-AN Tank Farm has not yet been completed. (Note: The 241-AN tank farm chemical addition and flushing system will be used for dilution and flushing in the 241-AZ Tank Farm consistent with Rieck 1998). For the purpose of this document it is assumed that the chemical addition and flushing system design for the 241-AZ Tank Farm will be functionally identical to the chemical addition and flushing system design for the 241-AP Tank Farm. The chemical addition and flushing system design for the 241-AP Tank Farm consists of a tank, heater(s), chemical metering pumps, and piping systems to deliver the flush/diluent. The system is designed to deliver up to $530 \mathrm{~L} / \mathrm{min}$ of chemical adjusted $\left(\mathrm{NaOH}, \mathrm{NO}_{2}\right.$, etc.) water at a țemperature up to $66^{\circ} \mathrm{C}$.

\subsubsection{Comparison of Existing and Planned Equipment to Process Needs}

With the assumption that the 241-AN Tank Farm dilution system design will be functionally identical to the 241-AP Tank Farm dilution system design, the system will be capable of meeting the process needs identified in Table A-1. 
HNF-2941

Revision 0

\subsection{UTILITY DISTRIBUTION SYSTEMS}

\subsection{COMPRESSED/INSTRUMENT AIR SYSTEMS}

The 241-AZ and 241-AY tank farms share a compressed/instrument air system which is located in the 701-A Building. It consists of two large capacity air compressors with a large capacity reservoir. Additionally, there are two emergency backups and generators. The system is capable of providing sufficient air to the Air Lift Circulators in the Aging Waste Facility (AWF). Therefore, any instrument air requirements will be easily met. This equipment is currently installed and can be verified as meeting the requirements for performing their safety significant functions.

The instrument air system supports the transfer systems into or out of the Aging Waste Facility. It provides instrument air to the weight factor leak detection system which are required to be operational per the Authorization Basis, technical safety reqirement (TSR) limiting condition for operation (LCO) 3.1.3, Transfer Leak Detection Systems. Normally redundant air source may be required; however, the weight factor leak detection system is backed up by portable conductivity probes.

The system also supplies air to an instrument enclosure (241-AZ-102A) and to various other instruments. Refer to Drawing H-2-68355, Sheets 1-7, IEFD Tank Farm.

\subsection{RAW WATER SYSTEM}

Raw water is supplied via a raw water line and trucks. Tanker trucks transport hot raw water used in 241-AZ tank farm. The raw water is then delivered to the transfer line or tank, via the tanker truck booster pump and some sort of jumper or connection to the transfer line. The use of "flush"jumper connections or other means will require additional steps by Operations to perform a flush after a transfer. Planned transfers routes from the 241-AZ tank farm may be as long as one mile. A one line volume flush would require approximately $30.3 \mathrm{~m}^{3}(8,000 \mathrm{gal})$ of raw water. Tanker truckers typical capacity is in the range of 15 to $19 \mathrm{~m}^{3}$ (4,000 to $\left.5,000 \mathrm{gal}\right)$. Therefore, two to three water trucks would be required to perform the flush. Performing flushes on a routine basis, i.e., two to three times a month and more, may be difficult for operations to support; therefore, additional equipment may be necessary to ease the operational burden.

The raw water system in 241-AN tank farm is planned to be upgraded by Project W-211 for 241-AZ-102 waste dilution and pipeline flushing (Rieck 1998). Although a specific interface point has not been chosen, a number of options exist (Rieck 1998). 
HNF-2941

Revision 0

\subsection{ELECTRICAL DISTRIBUTION SYSTEM}

The existing tank farms electrical supply may not be adequate to supply either the process need maximum load or the schedule based maximum electrical load. The process need load is more conservative than the postulated schedule load. The process need requires the independent operation of retrieval equipment in each of the four 200 East Area DST farms. This is equivalent to running two mixer pumps and one transfer pump in each farm, or, eight $224-\mathrm{kW}(300-\mathrm{hp})$ mixer pumps and four $44-\mathrm{kW}(60-\mathrm{hp})$ transfer pumps. The postulated schedule load is based on the integrated schedules. The integrated schedules show that at least once in each of the first three years of processing up to nine mixer pumps and one transfer pump may be needed simultaneously to suspend and transfer solids.

The substation installed by Project W-151 is fed from $13.8 \mathrm{KV}$ line number C8-L6. The capacity of this line is approximately $7 \mathrm{MW}$ and the existing average demand load is approximately $3 \mathrm{MW}$. The power requirement for a pair of 224-kW (300-hp) mixing pumps and a $44-\mathrm{kW}$ (60-hp) transfer pump is about $640 \mathrm{KVA}$. The simultaneous operation of nine mixer pumps (one set of mixers in each of 241-AY-102 [four $112 \mathrm{~kW}$ (150 hp)], AZ Farm [two $224 \mathrm{~kW}(300 \mathrm{hp})$ ] and AN [or AW] Farm [two $224 \mathrm{~kW}(300 \mathrm{hp})$ ] and one [224-kW (300-hp)] mixer in AP Farm) cannot be achieved. Load flow and voltage drop analysis of $13.8 \mathrm{KV}$ line C8-L6 indicates that the line cannot provide power to the postulated schedule maximum TWRS load of nine mixer pumps and one transfer pump operating simultaneously without experiencing excessive voltage drop in the tank farm area. The voltage drop will also be excessive for the process need requirement since it is more conservative than the postulated schedule load. To resolve this potential issue the possibility of transferring some tank farm loads to other electrical supply lines in the area (lines C8-L5 and C8-L8 are the most likely candidates) could be explored. Or, a more detailed examination of schedule constraints for simultaneous operation of nine mixer pumps could be examined and the process need for independent operation of each farm can be modified. The load flow study is summarized in Appendix F.3.1. A load projection study is also in progress to evaluate the changes in other . loads on the distribution line in future years.

Project W-151 installed a substation that is adequately sized (1000 KVA) to support operation of a portion of the AZ retrieval system, although power availability will be limited to the concurrent operation of two mixer pumps and two transfer pumps for the combined AN farm and AZ farm retrieval systems. The AN system will allow for the flexibility of running one mixer pump in each of two tanks. If it is determined that simultaneous full speed mixing with two pumps is required in both tank farms or more than two mixer pumps must be operated in the 241-AZ tank farm (i.e., four mixer pumps total), then an upgrade of the existing substation would be required. In addition, the modifications being made by project W-211 will result in the existence of enough VFDs to operate four mixing pumps simultaneously, and, again, the existing transformer is only adequate to run two mixer pumps and two transfer pumps simultaneously. (However, it is uncertain at this time whether the 241-AZ tank farm ventilation system would be able to support the effects of heat input from more than two mixer pumps operating at full speed [Rieck 1998]). 


\section{HNF-2941}

Revision 0

Thus, in the event that more than two mixer pumps are required to be run simultaneously in AN farm and/or AZ farm, the substation will require upgrading, including replacement of the existing transformer with a larger one.

\subsection{STEAM SYSTEM}

No process needs for steam have been identified for 241-AZ tank farm. There is no steam in the aging waste complex.

These steam coils do not support any transfer system process needs. Therefore the steam coil non-operation is acceptable. 
HNF-2941

Revision 0

This page intentionally left blank.

- 
HNF-2941

Revision 0

\subsection{INSTRUMENTATION, MONITORING, AND CONTROL SYSTEM}

The mobilization, retrieval, transfer, pretreatment, staging, and delivery of feed to the private contractor takes place within the DST system. Operations within the existing DST system are controlled within the Basis of Interim Operation (BIO) authorization. Many of the in-tank processing steps associated with waste feed delivery will require new equipment and procedures for completion of the program objectives. These new operations must be monitored and controlled to stay within an approved authorization safety basis as well as to deliver waste feed within the constraints established by the Phase I privatization contract.

Successful waste retrieval and delivery of the proper composition waste feed to the private contractor within schedule requires that in-tank processing and transfers be effectively controlled. Development and implementation of a successful process monitoring and control system requires that overall process operational needs be clearly defined. These process needs consist of both objectives and constraints. Objectives are variables which are controlled around an optimal value whereas constraints are variables which must fall within certain bounds. Based on these control objectives and constraints, data requirements and variables to be monitored can be established. Plans can then be put in place to gather the needed data and/or provide monitoring instrumentation and control systems if existing systems are not adequate.

This section summarizes, develops, and documents the bases for a process monitoring and control strategy which will provide for the safe and successful delivery of HLW feed to the privatization contractor. The process monitoring and control strategy for each general process activity is developed separately. A list of expected monitoring instrumentation is developed for each process activity based on the control strategy. Each tank is then assessed individually to determine if existing and planned systems can successfully implement the monitoring and control strategy. As part of this assessment, expected instrument ranges, accuracies, and precision are developed. The basis for the process monitoring and control strategy is developed and documented in Appendix $\mathrm{C}$ of this document.

\subsection{PROCESS MONITORING AND CONTROL STRATEGY}

The following sections provide a proposed process control strategy for each of the applicable process steps described in Section 3. Descriptions of the equipment, the system requirements, the instrumentation requirements, and the system operation (startup, normal, and off-normal) are given for each process step. 
HNF-2941

Revision 0

\subsubsection{Safe Storage}

Tanks 241-AZ-101 and 241-AZ-102 are DSTs designed to provide aging waste storage space for high-level waste generated at the PUREX plant. To accommodate high-heat generating wastes, air lift circulators, steam coils, and exhaust condensers have been installed to minimize the probability of a loss of structural integrity.

The TWRS BIO requires that several systems and components used to monitor tank conditions be operable to prevent or mitigate certain analyzed accident scenarios. These BIO requirements provide much of the basis for the monitoring and control equipment needed to ensure safe storage of the existing inventory as well as material that will be transferred to the tanks as a part of future waste transfers. The current BIOS controls are used as the basis for determining what will probably be minimum requirements. It is noted here that further Authorization Bases $(\mathrm{AB})$ requirements may be forthcoming.

7.1.1.1 Description of Primary Equipment. The primary equipment used to safely store waste (other than the inner and outer tanks and supporting structures) include the following.

a. Active ventilation system. Equipment includes high-efficiency particulate air (HEPA)-filtered air inlets to the primary tank (with vacuum breakers), annulus air inlets, a recirculation system for cooling, tank pressure controls, variable speed fans, and a common annulus exhaust with HEPA filtration.

b. Air lift circulators. Each tank has 21 air lift circulators installed. These circulators are long, open-ended cylinders of varying lengths immersed in the tanks' contents. Compressed air from the instrument air discharges into the air circulator and exits at the base of each cylinder causes a flow of waste from the bottom to the top of the tank, thus mixing the contents.

c. Service water system. Filtered, raw water from the site water system is available for priming, pump seals, and flushing for mixer and transfer pump operations and can also be used to maintain waste temperature within requirements. The BIO does not take credit for the availability of mixer pumps during storage, but relies on the air lift circulators for the removal of "hot spots" in the stored waste.

7.1.1.2 Description of Instrumentation. The instrumentation needed for monitoring and control to ensure that wastes are stored safely are divided into two categories in the following discussion. The measuring and control equipment (instrumentation) needed was determined by evaluating the process step (safe storage) in more detail to establish needs and requirements based on process needs (Table $\mathrm{C}-1$ ), safety requirements (Table $\mathrm{C}-2$ ) and postulated off-normal operational occurrences (Table $\mathrm{C}-3$ ). The resulting process parameters to be controlled are captured from all three of the foregoing tables in Table C-4 in which the expected monitoring and control approach is specified. The approach is, for the most part, at this point independent 
of existing or planned instrumentation. The following discussion explains the rationale for the selected monitoring and control approach in Table C-4.

\section{Primary Equipment Instrumentation}

a. Active ventilation system. Instrumentation is needed to measure exhaust stack air flow rate, presence of radiation in the exhaust stack, and differential pressure across the inlet and exhaust HEPA filters for both the primary tank and annulus ventilation systems. Refer to Section 7.0 for details.

Exhaust stack air flow rate: The active ventilation system is required to be operable at all times. Measurement and display of air flow rate will provide the indication that the ventilation system is operable. Using an isokinetic air sampler is recommended since the sampler is needed for radiation monitoring [continuous air monitor CAM system] and air flow rate is available from the same system.

Exhaust stack radiation: A continuous air monitor (CAM) to detect beta and gamma radiation is required by the BIO. Presence of high radiation must also be interlocked to trip the ventilation fan to preclude the release of contamination. The CAM will alert the operator that HEPA filters have been breached due to aerosol saturation, high temperature (fire) or breakthrough (low differential pressure). Radiation values need to be indicated, recorded, and alarm (hi) at greater than $10,000 \mathrm{cpm}$. (BIO TSR LCO 3.1.4)

HEPA filter differential pressure: High differential pressure is an indication that the filter needs to be replaced before its capabilities degrade to the point of failure. High differential pressure can be easily monitored with a differential pressure transmitter, with displays locally and in a central control area.

b. Air lift circulators: Instrumentation is needed to measure instrument air supply pressure and flow rates. The air lift circulators are required to be operable in $241-\mathrm{AZ}-101$ when the average waste solution temperature is greater that $88^{\circ} \mathrm{C}$ $\left(190^{\circ} \mathrm{F}\right)$. and when the sludge temperature is greater than $110^{\circ} \mathrm{C}\left(230^{\circ} \mathrm{F}\right)$. To prevent excessive temperature gradients which in turn could lead to the release of radioactive gases due to excessive boil-off rates (bumps). Pressure and flow transmitters are needed to provide indication of pressure and flow values and provide alarms for low pressure and low flow. No interlocks are required since operator action will be required to re-establish the air supply. To satisfy LCO 3.3.4, when the air supply is inoperable, mixer pump operation must stop, cover blocks must be in place, the primary tank ventilation system must be operating, and the circulators must be returned to operable status within 20 hours. 
c. Service water system. The service water system supplies filtered raw water and raw water with added inhibitors for use as tank waste diluent; mixer and transfer pump initial column fill, seals, flushing, and decontamination; transfer piping flushing; and slurry transfer diluent. The system can also be used for tank waste temperature control during the "safe storage" process step along with mixer pump needs if the latter is used to keep temperature gradients within limits. Instrumentation needed for the service water system includes pressure indication and alarms to determine system operability and a water flow totalizer (TSR AC 5.21) to preclude overfilling of the primary tank. The latter will be used in conjunction with primary tank level readings.

\section{Tank Specific Instrumentation}

a. Primary tank: The following instrumentation is needed to monitor and control parameters required to maintain the tank's integrity and to mitigate flammable gas and tank "bump" concerns regarding the waste.

Vapor space pressure. The air space between the top of the waste and the tank's dome must be monitored for pressure. The pressure must remain negative, i.e., $<0 \mathrm{~m}$ ( 0 in.) of water (vacuum), (Ref: TSR Bases B 3.2.1). Vapor space pressure is the primary indication of proper operation of the active ventilation system (TSR Bases B 3.2.1). An absolute pressure transmitter with remote indication, high and low alarms, and a recorder (to record trends) are needed to instrument vapor space pressure.

Hydrogen gas monitoring system. The 241-AZ tanks are classified as Facility Group 2 which means that they are subject to large induced gas release events (GRE) but a small spontaneous GRE. This means that operations such as mixing that disturb the waste (induced GRE) have the potential to release quantities of flammable gas into the vapor space that would exceed 25 percent of the lower flammability limit (LFL). Also, the effects of a spontaneous GRE (undisturbed waste) would not be sufficient to cause the vapor space to see greater than 25 percent of the lower flammability limit (Ref. TSR AC 5.9). Although several flammable gases could be released, analysis shows that a limit of 7500 ppmv of hydrogen accommodates concentrations of mixtures of flammable gases (BIO 5.3.2.14).

A hydrogen monitoring system that withdraws samples from the tank vapor space is needed with hydrogen concentrations verified by sampling at least once each 72 hour period. (Ref. TSR LCO 3.2.1) A continuous sampler is recommended to better establish trends. Hydrogen concentrations need to be indicated, recorded (with trending capability), and alarmed when they exceed 7500 ppmv. 
Waste temperature. The BIO limits waste temperatures to less than $91^{\circ} \mathrm{C}$ $\left(195^{\circ} \mathrm{F}\right)$ in all levels of the waste $\mathrm{OR}$ to less than $91^{\circ} \mathrm{C}\left(195^{\circ} \mathrm{F}\right)$ in the top $4.6 \mathrm{~m}$ $(15 \mathrm{ft})$ of the waste and less than $102^{\circ} \mathrm{C}\left(215^{\circ} \mathrm{F}\right)$ in the waste below $4.6 \mathrm{~m}$ $(15 \mathrm{ft})$. This requires temperature detection at various levels within the waste. Under static conditions, temperature should be measured at the supernate layer, in the sludge layer, and at the air lift circulators (when they are in operation). Additional measuring locations will be needed for process steps of mixing tank waste and transferring waste from the tank. Temperature monitoring of the waste includes obtaining, transmitting, receiving, recording, and displaying temperature values with alarms set so as not to exceed the LCO limits. The required accuracy is $\pm 0.6^{\circ} \mathrm{C}\left(1^{\circ} \mathrm{F}\right)$ according to WHC-SD-W314-ES-007 (Trade Study for Tank Waste Temperature). The expected accuracy using thermocouples would be about $\pm 1.6^{\circ} \mathrm{C}\left(2.8^{\circ} \mathrm{F}\right)$. In order to obtain the required accuracy, resistance temperature detectors (RTDs) are needed to obtain the temperature values.

Primary tank level monitoring. During the safe storage process step, waste level in the primary tank is required, in conjunction with primary tank leak detection and waste temperature, to prevent subsurface release of radioactive materials due to leaks in multiple tanks (TSR AC 5.21). Tank level is also required to prevent overfilling of the tank and to prevent uplifting of the bottom (insufficient heel). The level of tank contents needs to be through direct means to ensure that an accurate value is obtained that is independent of layering in the tank and the condition of the interior tank wall. The recommended approach is to use a float attached to a sensing system in a riser, similar to ENRAF ${ }^{\text {s. }}$ equipment used for chemical storage tanks. The level values need to be indicated (displayed), recorded, and alarms set at $1.6 \mathrm{~m}$ (64 in.) (10), $9.25 \mathrm{~m}$ (364 in.) (hi), and $9.40 \mathrm{~m}$ (370 in.) (hi-hi, safety limit). High alarm needs to be interlocked to shutdown diluent addition while the low alarm is interlocked to shutdown an operable transfer pump.

b. Secondary tank: The following instrumentation is needed to monitor and control parameters required to detect leaks from the primary tank, transfer line mis-routings, and to maintain temperatures within limits that maintain primary and secondary tank structural integrity.

Annulus liquid level. Any waste leakage from the primary tank will be collected in the annulus where it is channeled to the outside of the secondary tank. Leak detector (conductivity) probes are needed to detect a liquid leak and must be set within $2.54 \mathrm{~cm}$ (1 in.) of the bottom of the annulus (TSR LCO 3.2.6). At least one probe must be operable at all times. The presence of a liquid is conveyed to the operator via audible and visible alarms. 
Radiation level. The second method of leak detection is the monitoring the annular space for gamma radiation. Radiation is monitored using a CAM that obtains a sample of the annulus ventilation exhaust downstream of the HEPA filters. The CAM provides indication over a range of 0 to $10,000 \mathrm{dps}$ with a high radiation alarm set at 4,000 dps (WHC-SD-W314-ES-008, Trade Study for Leak Detection). The high alarm is interlocked to shut down the annulus ventilation fan.

7.1.1.3 Description of Other Support Systems. Not applicable to this process step.

7.1.1.4 Description of System Operation. See Section 7.1.1.2 above. Degassing the waste is not applicable to $241-\mathrm{AZ}$ tanks.

\subsubsection{Process Step: Degas Feed}

Degassing the waste is not applicable to $241-\mathrm{AZ}$ tanks.

\subsubsection{Process Step: Settle Solids}

Settling solids is not applicable to 241-AZ tanks.

\subsubsection{Process Step: Dissolve Solids}

Disolving solids is not applicable to 241 -AZ tanks..

\subsubsection{PROCESS STEP: MOBILIZE AND SUSPEND SOLIDS}

The purpose of the mixer pump is to mobilize greater than 90 percent of solids initially in 241-AZ-101 and greater than 60 percent of the solids initially in 241-AZ-102. In addition, these mixer pumps will be capable of mixing greater than 99 percent of solids transferred from tank 241-AY-102.

7.1.5.1 Description of Equipment. Two Mixer pumps will be installed in tank 241-AZ-101 and 241-AZ-102. Each pump will be capable of rotating between $0-180^{\circ}$ such that the discharge nozzles can be aimed in any radial direction in the tank. The Diluent system will be a skid mounted system consisting of caustic metering pumps, caustic supply truck bay, eye wash down center, caustic storage tank heating system, and encased pipes for caustic delivery to the 241- $\mathrm{AZ}$ tanks. Table $\mathrm{C}-5$ tabulates the monitoring and control instrumentation parameters needed in support of Phase 1 delivery. Table C- 6 tabulates the monitoring and 
control equipment available for 241-AZ tank farm in support of Phase 1 feed delivery. Table C-7 summarizes the basis for adequacy of the existing equipment and any comments.

\subsubsection{Description of Instrumentation}

7.1.5.2.1 Mixer Pump Instrumentation. Each mixer pump is instrumented to provide the following monitoring and control capability. In addition, each mixer pump will have safety interlocks integrated in the controls to ensure tank integrity at all times.

Each Mixer pump will have following instrumentation:

a. Speed Control- Variable frequency drive to adjust mixer pump speed from 58 percent to 100 percent of full speed.

b. Motor winding temperature - to indicate pump motor temperature.

c. Motor Bearing temperature- to indicate pump bearings temperature.

d. Motor Current: - to indicate pump current usage.

e. Nozzle Position Indication- To provide indication of mixer nozzle position orientation.

\subsection{Instrumentation Specific to the Tank.}

aa. Tank Temperature - To monitor tank temperature at various levels and locations to provide temperature gradient and differential temperature information.

ab. Tank Dome Pressure- to monitor tank pressure.

ac. Tank Content Consistency- To verify liquid and sludge in the tank has been mixed uniformly over the length of the liquid level.

ad. Tank Level- to provide tank level indication.

ae. Radiation Monitoring- To monitor radiation level changes during mixer operation.

7.1.5.2.3 Diluent Systems Instrument Description. Diluent system - Provide diluent in the tank for flushing or reducing the solid content of waste for transfer. The diluent system is a major system and must meet the following meet the following requirements:

- Diluent liquid will have $\mathrm{pH}$ and conductivity controlled to meet specific parameters which are to be determined. 
HNF-2941

Revision 0

- Diluent system will provide liquid at $5.8 \mathrm{kPa}(70 \mathrm{psig})$ pressure at mixer pump intake.

- Diluent liquid will contain solids less than $30 \mathrm{wt} \%$.

- Diluent system will have the capacity to dilute the waste such that a minimum velocity of $1.2 \mathrm{~m} / \mathrm{sec}$ can be achieved.

- Transfer system will be designed such that it will not exceed operating pressures and maintain the minimum critical settling velocity of $>1.2 \mathrm{~m} / \mathrm{sec}$ $(4 \mathrm{ft} / \mathrm{sec})$.

- Diluent system monitoring and controls will use state of the art PC based system for data transmission and trending .

The Diluent system will have the following instrumentation .

- $\mathrm{pH}$ monitoring and/or Conductivity Monitoring - to ensure diluent liquid meets corrosion specification.

- Pressure Monitoring at tank inlet.

- Flow Totalizer (Non Resettable).

- Caustic temperature monitoring.

\subsection{Description of Other Support Systems.}

1. Service Water System- To provide water for mechanical seals, initial column fill prior to mixer pump operation, and for șparge ring operation.

2. Tank HVAC system- To maintain tank dome at negative pressure.

3. Tank Imaging System- To monitor internal tank operations or component integrity.

4. Air Lift Circulation System- To maintain sludge temperature below $110^{\circ} \mathrm{C}$ $\left(230^{\circ} \mathrm{F}\right)$ and waste temperature below $88^{\circ} \mathrm{C}\left(190^{\circ} \mathrm{F}\right)$.

\subsubsection{Description of System Operation.}

\subsection{Mixer Pump Operation.}


HNF-2941

Revision 0

\section{Startup}

Mixer pump(s) can be operated at any time provided sufficient net positive suction head (NPSH) is available or per an approved operating procedure. If the transfer pump is operating, mixer pump(s) speed may be automatically reduced.

Prior to startup of mixer pump, liquid will be measured by ENRAF ${ }^{\mathrm{TM}}$ instrument. To protect the ENRAF ${ }^{\mathrm{T}}$, the float will be retracted out of liquid and locked in safe position (below High- Level alarm ).

On the initial startup of the mixer pump(s), or after any prolong ideal period when intakes may be immersed in a layer of sludge, flush water or diluent will be added in the mixer pump suction area to dislodge any sludge to avoid motor over current trip or locked rotor trip. Service water may be added to the mechanical seals to ensure seal life and allow proper seal operation and to the sparge rings to flush the nozzle

Mixer pumps will be started from the VFD control panel. The mixer pump speed should be controlled by a programmable logic controller (PLC). During mixer pump operation, the following parameters will be monitored at various locations.

\section{AT VFD PANEL}

- Motor Current and Voltage

- Motor Winding Temperature

- Motor Bearing Temperature

- Motor Speed

AT PLC and TMACS

- Liquid and Sludge Temperature from thermocouple tree (MIT)

- Tank Dome Pressure

- Tank Dome Radiation Level

- Liquid/Solids sludge level monitoring

- Motor current, winding temperature, motor bearing temperature, motor speed, and motor/pump vibration

- System alarms monitoring. 
HNF-2941

Revision 0

\section{Normal Operation}

Mixer pump speed will be controlled by a PLC. The PLC based control will have an industrial PC with Pentium ${ }^{\mathrm{TM}}$ processor with visual monitoring and control capability. Visual monitoring will be in the graphic format to assist an operator to get an information instantly by depressing a function key. The graphic screen displays will be arranged as follows:

1. Overall system configuration showing mixer pump, nozzles, mixer pump statusOn/OFF, etc.

2. Mixer pump screen display will have:

Motor status -ON/OFF lights

AUTO/REMOTE/LOCAL switch

Motor current

Winding temperature

Bearing temperature

Vibration indication and alarm indication

Nozzle position indication

Service water pressure and flow.

Mixer pump speed will be increased in steps until the desired pump operating speed is obtained. The MIT temperatures will be monitored for readings that indicate a $5.6{ }^{\circ} \mathrm{C}$ $\left(10^{\circ} \mathrm{F}\right) / \mathrm{hr}$ change or a maximum heat up rate limit of $11^{\circ} \mathrm{C}\left(20^{\circ} \mathrm{F}\right) /$ day will be exceeded. In addition temperature will be monitored to ensure that temperature gradient does not exceed $100^{\circ} \mathrm{C} / \mathrm{m}\left(55^{\circ} \mathrm{F} / \mathrm{ft}\right)$ within the solution or at the waste liquid/vapor interface. If any of these limits are approached, mixer pump operation may be modified accordingly or other corrective action may be taken, e.g., operation of air lift circulators. The ramp up rate and the temperature monitoring frequencies need to be developed.

Once temperatures are within allowable limits, speed will be increased and mixing will continue until temperature readings on the MIT over the entire length show uniform temperature. The required tolerance on the temperature readings is to be determined. Mixer pump operation may be stopped for tank level monitoring by the ENRAF ${ }^{\mathrm{s}}$. In addition, during mixer pump operation, the tank imaging system may be used as well as the ultrasonic interface level analyzer (URSILLA). The tank imaging system may be required for various purposes, e.g, visual observations of components, tank level changes, etc. The URSILLA will be used to detect a liquid/solids interface for a determination of mixing effectiveness.

\section{Off Normal}

Mixer pump operation will automatically stop on the following events:

- Electrical power failure. 
- Loss of mechanical system integrity, e.g. pipe break, ALC failure, etc.

- Seismic Event.

- Emergency STOP (Manual operator action).

7.1.5.3.2 Diluent System Operation. The purpose of diluent addition is to dissolve solids, provide flush water, prevent pump cavitation, and to maintain waste temperature within allowable limits. Diluent will be added to the tank in the last two transfers to be made to the privatization contractor.

Diluent will be added to the tank at a predetermined tank level which yet to be determined within a tolerance which is also yet to be determined or where pump cavitation begins . Prior to addition, diluent will be analyzed to verify that $\mathrm{pH}$ is at an appropriate level. Diluent will then be added to the tank by opening/closing of appropriate valves. Flow totalizer in diluent discharge line and tank level will be monitored. When flow totalizer indicates $379 \mathrm{~m}^{3}(100,000 \mathrm{gal})$, diluent addition will cease. Concurrently the waste temperatures from the MIT will be monitored. The mixer pump may be in operation during this process or may not operate until the diluent addition is complete.

If diluent addition terminates due to manual operator action or equipment /component failure, diluent flow totalizer will not be reset until it reads $379 \mathrm{~m}^{3}(100,000 \mathrm{gal})$.

\subsubsection{Process Step: Sample Waste}

The waste contained within 241-AZ-101 and 241-AZ-102 needs to be characterized before it is transferred to the privatization contractor. Characterization will be done by analyzing samples of the waste for chemical constituents, $\mathrm{pH}$, density, viscosity, and other parameters in accordance with existing Data Quality Objectives (DQO). Representative samples (200 grams of solids) will be provided to the privatization contractor at least 30 days prior to the first transfer of the waste to the contractor's feed tank. These samples will be used to ensure compatibility between the sending and receiving tank inventories and to confirm that waste composition is within contract specifications.

7.1.6.1 Description of Primary Equipment. The waste sampling system needs to have the following capabilities:

a. Obtain grab samples from any level within the waste

b. Obtain multiple samples from the same location

c. Be able to handle waste of varying specific gravities (1.0 to 1.5) and densities

d. Transfer samples to a shielded container for transport to an analysis facility 
e. Be easily and reliably decontaminated and cleaned so that multiple samples remain truly representative of the in situ waste

In addition, the waste sample must be extracted through an existing riser keeping radiation and contamination as low as reasonably achieveable (ALARA). Sample labeling must be provided to satisfy chain of custody and traceability requirements.

7.1.6.2 Description of Instrumentation. No permanent instrumentation is required in addition to that specified in 7.1.6.1. Radiation can be ascertained using portable equipment. Analytical instrumentation will be provided by the laboratory doing the required analyses and will be dependent on the characteristics of interest. Parameters which may considered include density, viscosity, percent entrained solids, concentration of sodium, pH, etc.

7.1.6.3 Description of Other Support Systems. Potentially, support systems that could be needed include dry air or nitrogen (see in-tank camera discussion in Section 7.1.5) and service water for flushing or decontamination.

\subsubsection{Transfer Liquid from Tank}

Transfer of liquids from tanks is not applicable to $241-\mathrm{AZ}$ tanks.

\subsubsection{Receive Liquid into Tank}

Receipt of liquids into tanks is not applicable to 241-AZ tanks.

\subsubsection{Transfer Solids Slurry from Tank .}

The purpose of the Solids Slurry Transfer system is to transfer the solids slurry to the privatized vendor for processing. Solids slurry transfer system will be operated once the 241 AZ tank contents are properly mixed .

7.1.9.1 Description of Primary Equipment. Slurry transfer system consists of Slurry transfer pump(s) and above ground (properly shielded) encased transfer line.

7.1.9.2 Description of Instrumentation. Slurry transfer line will be instrumented to provide following monitoring and control utilizing state of the art PC based system. In addition, it will have an automatic interlock from other dependent systems to ensure that transfer operation will not jeopardize the equipment and personnel safety, as well as will not create an environmental hazards. 
HNF-2941

Revision 0

\subsection{Transfer Line Instrumentation.}

- Transfer line pump discharge pressure monitoring and Low and High pressure alarms and trip.

- Flow monitoring and totalizer (Non Resettable automatically).

- Leak detection monitoring system at $305-\mathrm{m}(1,000 \mathrm{ft})$ spacing, and at either end of pipe, with automatic trip function.

- Transfer line pressure monitoring along the length of pipe to monitor evidence of Settling of solids (pipe plug).

\subsection{Transfer Pump Instrumentation}

- Speed Control-VFD to adjust pump speed from 58 percent to 100 percent of speed.

- Motor winding temperature- to provide motor winding temperature information.

- Motor Bearing Temperature- to provide bearings temperature information.

- Motor Current and Voltage- to control pump speed.

- Motor Vibration- to indicate occurrence of cavitation.

\subsection{Other instrumentation required for slurry transfer}

- Tank level monitoring-to indicate and provide trip function.

7.1.9.3 Description of System Operation. Solids slurry from tanks will be transferred to privatization contractor by an encased above ground pipe. This pipe will have berm around it to reduce radiation dose to the workers in the vicinity, and its size will be based upon the velocity of transfer which will ensure that, once the transfer is initiated, it will not accumulate solids on the pipe walls.

Slurry transfer will be done in 379 to $1140 \mathrm{~m}^{3}$ (100,000 to $\left.300,000 \mathrm{gal}\right)$ batch and will be terminated, in normal operation, when the tank level reaches mixer pump inlet.

\subsubsection{Other systems required to be operational during slurry transfer.}

- Diluent/flush system - to provide enough diluent volume to flush transfer lines after transfer is completed or when the pump trips due to protective interlock 
HNF-2941

Revision 0

actuation.

7.1.9.5 Slurry Transfer System Description. Slurry Transfer System will have the following operational modes.

7.1.9.5.1 Ready Mode. In this mode, all pump status, valve status, system instrumentation- pressure, flow, leak detection, tank level, will be displayed. Automatic system operation may be required. In addition, mixer pump and dilution system status will also be displayed.

7.1.9.5.2 Dilution/Flush Mode. In this mode, dilution system will be checked for its readiness to supply enough quantity of diluent/flush liquid at required discharge pressure and volume.

7.1.9.5.3 In Tank Recirculation Mode. In this mode the transfer pump will be started and the liquid will be recirculated back to the tank. During this operation pump operation may be adjusted to optimizing waste transfer to the privatization contractor.

7.1.9.5.4 Transfer Mode. In this mode, the transfer will be initiated to the privatization contractor. During this mode, transfer operation, transfer line, and tank level parameters are monitored. When flow totalizer indicates total volume transferred is equal to a set point, transfer to the privatized contractor will be stopped. At this point the transfer pump discharge may be automatically recirculated for a period of time before a trip or stop action occurs. When the transfer operation is stopped, flushing may be initiated to flush the transfer line. In addition, transfer operations may be interrupted by a transfer line leak detection system trip, transfer pump motor trip, power loss, or other events. The flush of the transfer system may also occur for these events. At the end of flush operation, flow totalizer reading will be taken to correlate the volume transfer with privatized contractor tank volume data.

\subsubsection{Process Step: Receive Solids Slurry Into Tank}

As a part of inter-tank waste transfers, 241-AZ-101 and 241-AZ-102 will receive waste from other storage tanks for interim storage and treatment prior to transfer to the privatization contractor. The major instrumentation need during the transfer itself is to ensure that the receiver tank (241-AZ-101 or 241-AZ-102) is not overfilled. Other process steps apply to this situation once the waste is received, specifically safe storage (7.1.1), add diluent to tank (7.1.5), mix tank contents (7.1.5), and sample waste (7.1.6). This process step, receiving solids slurry into tank, contains no additional monitoring and control equipment beyond that described in the above sections.

7.1.10.1 Description of Primary Equipment. The primary equipment needed for this process step are the tanks and connected piping, pits, diversion boxes, and a drop leg on the fill line (or other method of discharging liquid below the tank waste surface) to minimize 
generation of aerosols.

7.1.10.2 Description of Instrumentation. The only instrumentation pertaining directly to this process step is that necessary to monitor the level of waste in the tanks. This instrumentation, described in detail in Section 7.1.1.2, should be a float attached to a sensing system in a riser (ENRAF system). The level values need to be displayed, recorded, and alarms set at $9.25 \mathrm{~m}$ (364 in) (hi), and $9.40 \mathrm{~m}$ (370 in) (hi-hi, safety limit). High alarm can be used by the operator to terminate the waste transfer and to shut down any diluent addition.

\subsection{SUMMARY OF PROCESS MONITORING AND CONTROL ISSUES}

Issues specific to instrumentation, monitoring and control are summarized in Table 2-2. These issues were developed only for existing equipment and planned equipment where project scope is definite and definitive design is proceeding. Additional issues may arise as project dẹsigns mature. 
HNF-2941

Revision 0

This page intentionally left blank. 
HNF-2941

Revision 0

\subsection{VENTILATION SYSTEM}

\subsection{PROCESS NEEDS}

The quantitative process needs in Table 4-1 and the safety-related requirements in Table 4-2 of this document which apply to the ventilation system are summarized in Appendix D. The primary ventilation system must remove heat, air, evaporated water and evolved gases from the primary tank. The annulus ventilation system must remove heat and moisture and sweep the annular space to radiation detectors.

\subsection{EXISTING AND PLANNED EQUIPMENT}

The original AWF primary ventilation system was replaced by a new ventilation system (241-AZ-702) provided by Project 702-AZ (W-030). The primary tank ventilation system contains individual controlled air inlets and a common ventilation off-gas exhaust for the four AY and AZ Tank Farm waste tanks (241-AY-101, 241-AY-102, 241-AZ-101, and 241-AZ102). The individual tank air inlet consists of a heater, pre-filter, HEPA filter, flow control valve. A recirculation ventilation cooling system is provided for each waste tank to help reduce emissions and remove heat generated in the tanks. The cooling equipment includes a condenser, moisture separator and recirculation fan for each system. Heat is rejected the recirculation condenser cooling system which consists of an evaporative fluid cooler, two circulation pumps, an expansion tank, an air separator, and instruments for monitoring the closed loop cooling system. Each tank is manifolded into a common exhaust stream. The combined exhaust stream from all four tanks flows through a condenser and then through a high-efficiency mist eliminator (HEME) to eliminate any water droplet carry over into the filter system. Upon exiting the HEME, the gas stream is heated by electric heaters to protect the downstream HEPA and HEGA filter banks. Each bank consists of two HEPA filters and a High-Efficiency Gas Absorber (HEGA). The ventilation gas stream, after passing through one of the two filter banks, is exhausted by one of two exhaust fans up the exhaust stack to the atmosphere. One fan is in standby while the operating fan maintains a vacuum on the four storage tank vapor spaces.

The annulus system for the 241-AZ tanks is a combined system for both tanks. At this time the annulus system is not operational and leak detection for the primary tank is provided by conductivity probes in the tank annulus. Next year plant maintenance plans to restore the system to operation under its original configuration (one for one replacement of failed components). It is not known at this time if the Project W-151 mixer pump tests will require a functional annulus exhaust system or if the system will be functional to support the testing. 


\subsection{COMPARISON OF EXISTING AND PLANNED EQUIPMENT TO PROCESS NEEDS}

\subsubsection{Primary Ventilation Exhaust Fan}

Suspension of solids within the Aging Waste Facility tanks is provided by operation of mixer pumps. The mixer pumps generate heat which in turn increases water and particulate generation. The ventilation system must be adequately sized to accommodate the tank mixing operations during Phase 1 privatization feed delivery by removing heat, particulate, and water while maintaining vacuum within the tank headspace. Table D-1 identifies that the existing primary ventilation exhaust fan is not adequate to provide the necessary level of vacuum and too much air in leakage is occurring into the Aging Waste Facility tanks to allow control of the ventilation flows through each tank.

\subsubsection{Primary Ventilation System Filter Train}

During operation of the 241-AZ-702 (W-030 upgraded) system, there have been two instances where the filter plenum housings have had moisture collection problems. When the system initially started up the sealpot drain line tie in at 241-151-AX catch tank was blocked and liquid flooded the sealpot and backed up into the filter plenum housings. The next time moisture collected in the filter plenum housings the condenser and HEME in the 702-AZ building were operated in a by-pass mode and after 4 days approximately $132 \mathrm{~L}$ ( 35 gal) had accumulated in the housing. The operations engineers stated there was no time for planned butages of the condenser and HEME because of the flooding problem and a redundant system (condenser and HEME or just HEME) would be desired.

The primary ventilation system HEPA and HEGA filter plenums are not in compliance with ANSI N509, Section 5.6.2. "The drain system shall be designed so that no unacceptable backup of liquids into the housing will occur" and "Each housing compartment shall have floor drains which meet all allowable air leakage criteria." Both filter housings should have drain capability added for all compartments.

\subsubsection{Equipment Installation and Removal from Aging Waste Facility Tanks}

Equipment (thermocouple tree, transfer pumps and mixing pumps) will require installation or removal from the DST which will create openings in the DST dome to atmosphere during this operation. To insure the containment of the DST vapors, a negative pressure in the tank dome needs to be maintained. The largest riser in the DST dome is $1.07 \mathrm{~m}$ (42 in.) in diameter which has an area of $0.89 \mathrm{~m}^{2}\left(9.6 \mathrm{ft}^{2}\right)$ open to the atmosphere. The existing ventilation system may not have enough capacity to insure that the tank dome can be maintained at a negative pressure and perform all its other functions for the other three tanks in 
HNF-2941

Revision 0

the system.

\subsubsection{Slurry Distribution}

An evaluation was performed (Kriskovich 1998 Draft) stating higher radiation in the recirculation module was occurring due to aerosol/moisture settling out in piping, ductwork and equipment. The report concluded in orderer to reduce the radiation buildup in the re-circulation modules a dropleg or some other method of transferring directly into the tank contents is recommended over the current practice of using a slurry distributor.

\subsubsection{Annulus Ventilation System}

The annulus system for the 241-AZ tanks is a combined system for both tanks. At this time the annulus system is not operational. It is not known at this time if the mixer pump operation will require a functional annulus exhaust system or if the system will be functional to support mixer pump operation.

\subsubsection{Air In Leakage and Vacuum Control}

The primary tank air inlet stations are not now in operation and are valved shut. The inlet air is from air lift circulation (if operating) and outside air drawn into the tank through pit cover blocks, risers or uncapped transfer lines that are open to other sources such as the 241-AX-152 diverter station. Air in leakage and vacuum level can not be well controlled - under the existing configuration.

\subsubsection{Thermal Analysis of Tank 241-AZ-101 Waste Removal}

A preliminary thermal analysis (Appendix E-1) of tank temperature rise with mixer pump operation in tank $241-\mathrm{AZ}-101$ predicts a temperature increase of $17^{\circ} \mathrm{C}\left(31^{\circ} \mathrm{F}\right)$ after 138 hours of operation associated with the first transfer of slurry to the private contractor. This preliminary calculation does not account for temperature profiles within the non-convective layer of solids at the bottom of the tank. Upon settling, this solids layer is expected to rise in temperature above the bulk temperature of the solution (i.e., higher than the temperature increase calculated in the preliminary calculations). 
HNF-2941

Revision 0

This page intentionally left blank. 
HNF-2941

Revision 0

\subsection{SAMPLING SYSTEM}

Waste sampling activities in the 241-AZ tank farm will be required prior to transfer to the BNFL facility. The need for sampling before a waste transfer is required per the BNFL Interface Control Document (ICD) (BNFL 1998). All tanks in the 241-AZ tank farm have adequate numbers of free risers to allow sample taking. The ICD allows the use of grab sampling or core sampling. As a precondition of sampling the mixer pumps are to be run to mobilize the tank waste.

The use of grab sampling and or core sampling will be established for each tank waste based on the characteristics and capability of the sampling systems. Per the ICD:

"Immediately following the shutdown of the mixer pump, approximately equal volume grab samples of waste material will be obtained from every two feet of waste height from below a single riser for a grab sampling technique. (For a core sampling technique a core the (sic) entire height of the tank waste will be obtained.) The total sample volume, will meet the sample volume needs for: analysis of the tank waste to support feed certification, a sample to BNFL, and archive sample material. The tank waster sample provided to BNFL will contain at least 200 grams of solids. Tank waste conditions such as temperature and tank volume will be identified at the time of sampling. Tank sample material will be stored in archive until treatment service has been completed and the IHLW waste products have been accepted by DOE."

In addition there are several other additional requirements that must be satisfied including:

- Prepare a composite Tank Waste Sample.

- Analyze Sub-samples to verify Composition; at least 3 sub samples of the composite sample will be used for feed certification analysis.

- Certify Tank composition and inventory the feed by combining information on the tank volume and tank waste composition.

- Volume to be measured by use of the ENRAF 854 ATG level detector

- Tank waste composition to be reported to an accuracy as stated in section 4.3.4 I the ICD.

- Provide certification that tank waste meets the requirements of section 8 of the ICD. 
HNF-2941

Revision 0

It is noted here that the grab sampling and the core sampling systems and procedures are well developed. However, it is not known at this time where the waste will be certified. In addition the time requirement to have a sample certification complete, i.e., less than 30 days is a major issue. 
HNF-2941

Revision 0

\subsection{REFERENCES}

BNFL, 1998, TWRS-P Project Interface Control Document, BNFL-5293-ID-20, Rev. 2, BNFL, Inc., Richland, Washington.

Claghorn, R. D., I. G. Papp, and B. B. Peters, 1998, Performance Requirements for Phase 1 Waste Feed Delivery Components, HNF-1985, Rev. 0, Numatec Hanford Corporation, Richland, Washington.

DeLozier, M. P., 1998, Subcontract number 80232764-9-K001, Evaluation of Tank Waste Disposal Alternatives Within Privatization, Letter LMHC-9854671A R1, to A. M. Umek, FDH, (June 15), Lockheed Martin Hanford Corporation, Richland, Washington.

DOE, 1998, BNFL Inc., TWRS Privatization Contract Number DE-RP06-96RL13308, U.S. Department of Energy, Richland, Washington.

Grams, W. H., W. L. Cowley, and K. H. Morris, 1997, Authorization Basis Assessment of Waste Feed Delivery, HNF-1948, Rev. 0, Duke Engineering Services, Hanford, Richland, Washington.

Jordan, K. N. and H. L. Boston, 1998, Tank Waste Remediation System Retrieval and Disposal Mission Readiness-to-Proceed Memorandum, HNF-2019, Rev. 1, Lockheed

: Martin Hanford Corporation, Richland, Washington.

Kirkbride, R. A., G. K. Allen; P. J. Certa, A. F. Manuel, R. M. Orme, L. W. Shelton, E. J. Slaathaug, R. S. Wittman, and G. T. MacLean and D. L. Penwell (SESC), 1997, Tank Waste Remediation System Operation and Utilization Plan, HNF-SD-WM-SP-012, Rev. 0, Vol. I and II, Numatec Hanford Corporation, Richland, Washington.

Kriskovich, J. R., 1998, Slurry Distributor Affects on Ventilation System, HNF-2783, Rev. 0, Lockheed Martin Hanford Corporation, Richland, Washington.

Papp, I. G., 1998, Waste Feed Delivery Technical Baseline Document, Volume II Waste Feed Delivery Flowsheet, HNF-1939, Rev. 0, Numatec Hanford Corporation, Richland, Washington.

PHMC, 1997, Operating Specifications for Aging Waste Operations in 241-AY and 241-AZ, OSD-T-151-00017, Fluor Daniel Hanford, Richland, Washington. 
HNF-2941

Revision 0

Powell, M. R., G. R. Golcar, C. R. Hymas, and R.L. McKay, 1995, Fiscal Year 1993 1/25Scale Sludge Mobilization Testing, PNL-10464, Pacific Northwest Laboratory, Richland, Washington.

Rieck, C. A., 1998, Interface Document, Project W-211, Initial Tank Retrieval Systems, HNF-1507, Rev. 0, Numatec Hanford Corporation, Richland, Washington.

Taylor, W. J., 1998, Contract No. DE-AC06-96Rl13200 - Evaluation of Tanks Waste Disposal Second Alternative Within Privatization, Letter 98-WDD-062, to R. F. Green, FDH (May 27), U.S. Department of Energy-Richland Operations Office, Richland, Washington.

Umek, A. M., 1998, A Tank Waste Remediation System Privatization - Hanford Management Contractor Declaration of Readiness to Proceed with Phase IB, Tank Waste Remediation System Privatization (Performance Agreement TWR 2.4.2), Letter FDH-9757162A R2, to W. J. Taylor, RL, (January 12), Fluor Daniel Hanford, Inc., Richland, Washington. 
HNF-2941

Revision 0

\section{APPENDIX A}

\section{WASTE PREPARATION AND TRANSFER SYSTEMS PROCESS NEEDS AND ASSESSMENT}


HNF-2941

Revision 0

This page intentionally left blank. 
HNF-2941

Revision 0

\section{APPENDIX A}

\section{WASTE PREPARATION AND TRANSFER SYSTEMS PROCESS NEEDS AND ASSESSMENT}

Table 4-1 contains quantitative process needs that must be met in order to enable the Tank Waste Remediation System (TWRS) to adequately deliver appropriate waste feed during Phase 1 privatization. A number of these quantitative process needs are specific to and rely on specific performance of the waste preparation and transfer systems which must be present to support feed delivery to the Phase 1 privatization contractor as well as ongoing TWRS operations (e.g., single-shell tank [SST] waste retrieval) during the Phase 1 privatization time frame. For the purposes of this evaluation of 241-AZ tank farm, the waste preparation and transfer systems have been categorized into three major subsystems: mixer pumps; transfer pumps, piping and valving; chemical addition and flushing. The quantitative process needs identified in Table 4-1 that apply to each of these subsystems is presented in the sections below.

\section{A.1 MIXER PUMPS}

The alternative case in DeLozier (1998) identifies tanks 241-AZ-101 and 241-AZ-102 as being retrieved as high-level waste (HLW) feed. Additionally, these two tanks serve as HLW feed staging tanks for additional HLW retrieved from other tanks. Although the Management and Integration (M\&I) contractor team no longer is responsible for establishing sludge washing capability, the HLW feed must consist of relatively homogenous slurry transferred in batches as often as once monthly. Mixer pumps must be installed in both tanks which can homogeneously suspend the solids now present in the tanks as well as future HLW transferred to these HLW feed staging tanks.

\section{A.1.1 PROCESS NEEDS}

The quantitative process needs which apply to the waste preparation and transfer system, including mixer pumps, are summarized as part of Table A-1 below. The mixer pumps are required to suspend the solids in tanks 241-AZ-101 and 241-AZ-102.

\section{A.1.2 EXISTING AND PLANNED MIXER PUMPS}

Project W-151 has installed two 224-kW (300-hp) mixer pumps into 241-AZ-101. These mixer pumps are scheduled to be tested during fiscal year 1999. Project W-211 is scheduled to put two 224-kW (300-hp) mixer pumps into 241-AZ-102. Design of the system to be installed into tank 241-AZ-102 is scheduled to begin in September of 1998 and 
construction is scheduled to be complete in September of 2002 (DeLozier 1998). It is important to note that these dates are a departure from the current W-211 Project schedule.

\section{A.1.3 COMPARISON OF EXISTING AND PLANNED EQUIPIMENT TO EXPECTATIONS}

Table A-1 lists process needs and compares those process needs to capabilities of existing and planned equipment. Mixer pumps are not currently installed in tank 241-AZ-102 Project W-211 has planned to place two $224 \mathrm{~kW}$ (300 horse power) mixer pumps into 241-AZ-102 Based on sludge mobilization testing (Powell et al. 1995), the mixer pumps are thought to be capable of mobilizing waste solids. It is important to note that a full scale test of a two mixer pump systems ability to mobilize sludge has not yet been performed. There are two mixer pumps located in Tank 241-AZ-101, and a full scale test using this system is scheduled to occur in May or June 1999.

A potential issue with the current Project W-211 mixer pump design is that the intake and outlet of the mixer pumps are located near the bottom of the pump. The sludge in at least some of the tanks is extremely viscous, and will resist pumping. It is not clear from the current design how the pumps are to be started. If a sufficient amount of water cannot be added to the tank near the inlet of the mixer pumps, it will be very difficult or perhaps impossible to start the pumps without causing cavitation and potential failure of the pumps. It may be beneficial to redesign mixer pumps which will be added to tanks in the future such that the intake is located in the supernate and the discharge at the bottom to allow the mixer pumps to be started without cavitating.

\section{A.2 TRANSFER PUMPS, PIPING, AND VALVE ROUTINGS}

The RTP (Jordan and Boston 1998) identifies the projected transfers occurring in all tank farms through October 2011. The projected transfers are no longer fully consistent with the alternative case identified in DeLozier (1998). Both the previous set of transfers associated with sludge washing and the new set of transfers associated with DeLozier 1998 are identified in Table A-2. The set of transfers consistent with DeLozier 1998 will be examined as the set of transfers supporting waste feed delivery and all other relevant tank farm operations specific to $241-\mathrm{AZ}$.

\section{A.2.1 PROCESS NEEDS}

The quantitative process needs associated with transfer pumps and pipe routings are identified in table A-1 below. The transfer pumps and piping systems design must satisfy the process needs identified here. It is important to note that at the time of this writing, transfer pump design for the 241-AZ Tank Farm is not complete. An alternatives generation and 
HNF-2941

Revision 0

analysis process should be followed to select an optimum transfer pump design. Piping systems are planned but not currently in place.

\section{A:2.2 EXISTING AND PLANNED TRANSFER PUMPS AND PIPING AND VALVE ROUTINGS}

Table A-3 postulates a route for each transfer between tanks that is identified in table A-2 consistent with DeLozier 1998. Table A-3 identifies whether all transfer equipment for tank to tank transfers either exists or is planned based on best available drawings, project documents, and other available information. Table A-3 is also used to compare the existing and planned transfer route equipment to the process needs. This comparison is discussed below.

\section{A.2.3 COMPARISON OF EXISTING AND PLANNED EQUIPMENT TO PROCESS NEEDS}

\section{A.2.3.1 Comparison of Existing and Planned Piping and Valving Routings to Process Needs}

Table A-3 provides a transfer equipment availability matrix identifying whether equipment is currently installed (and planned to remain installed rather than be removed as part of an existing project) or whether the equipment is within the planned scope of a project.

\section{A.2.3.2 Comparison of Existing and Planned Transfer Pumps to Process Needs}

All planned transfers from 241-AZ tank farm are slurry transfers with up to 200 grams solids per liter. Table A-4 provides a transfer pump matrix identifying whether a transfer pump is currently installed (and planned to remain installed rather than be removed as part of an existing project) or whether the necessary equipment is within the planned scope of a project. The type of pump planned for each transfer is also identified as well as the equivalent length of the transfer. The equivalent length of the transfer is used in determining the adequacy of the particular pump in meeting the process needs. The equivalent length is calculated by combining straight line length with length factors for various fittings and bends. Equivalent length and overall changes in height (hydraulic head) for portions of the various transfer routes is identified in Table A-5.

Figures A-1 through A-4 show operating curves for each of the routings for solutions with a specific gravity of 1.41 and viscosities of $0.10,0.15,0.20$, and $0.30 \mathrm{~Pa} \cdot \sec (10,15,20$ and $30 \mathrm{cP}$ ) plotted against the head curve provided by a pump design for Project W-211. For the purpose of this document it is assumed that the transfer pumps selected for the 241-AZ 
tanks will have characteristics equivalent to those of the W-211 Project pump design for 241-AP-102 and 104. The flow rate for a transfer is estimated by the location where the operating curve intersect the pump curve. A sample calculation which demonstrates how the curves were developed is included in Appendix F. The planned pumps for the 241-AN tank Farm are capable of delivering waste at 1.8 to $2.7 \mathrm{M} / \mathrm{sec}$. for transfers from the $241-\mathrm{AZ}$ tanks provided the viscosity is maintained at $0.03 \mathrm{~Pa} \cdot \sec (30 \mathrm{cP})$ or below.

\section{A.2.4 TRANSFER LINE DRAINING FOLLOWING FLUSHING}

Most of the transfer piping is sloped allowing waste and flush solutions to drain. Peaks and valleys in transfer pipelines are unfavorable because these sections can cause holdup of solids, eventually leading to line plugging. Peak or valley sections also lead to siphoning. Abrupt changes in slope in transfer pipelines can also be areas which favor solids build up and eventual line plugging. For 241-AZ-101 tank, the transfer line between 241-AZ-101 and the new AZ Valve Pit is sloped toward AZ-101. The transfer line between 241-AZ-01A pump pit and 241- AZ-02A pump pit slopes toward 241-AZ-02A pump pit. Table A-5 lists the hydraulic change in each line. Table A-5 lists the beginning and ending points of each line for convenience because solutions can flow in either directions in the lines. A positive hydraulic change indicates a rise and a negative change indicates a drop. Figure A-5 graphically portrays the hydraulic diagrams for tranșfers to and from 241-AZ tank farm.

Figure A-5 is a hydraulic diagram of the transfers originating or terminating in the 241-AZ Tank Farm. In some cases lines not involved in the transfer may need to be used to route draining and/or flush solutions. As an example, transfers from 241-AY-101 or -102 will most likely pass through the new AZ-Valve Pit. The new AZ-Valve Pit will be hydraulically lower than either 241-AY-101 or 102 Pump Pits Tanks in 241-AP are hydraulically higher than the new $A Z$ Valve Pit, tanks in 241-AN and in 241-AZ are hydraulically lower than the new, AZ Valve Pit. Transfers from either 241-AY-101 or 102 to the AP Tank Farm or to the Private Vendor will tend to drain to the new AZ Valve Pit.

\section{A.3 CHEMICAL ADDITION AND FLUSHING SYSTEM}

\section{A.3.1 PROCESS NEEDS}

The first need for water addition is during the retrieval of the final batches of waste being transferred from either tank in 241-AZ to the private contractor. This water is added to aid in suspension of solids during transfer of the last few batches of solids from the tanks. Also, inhibited water is added to the transfer line upon completion of a transfer to remove residual material from the line. The quantitative process needs associated with these water additions is presented in Table A-1. 
HNF-2941

Revision 0

\section{A.3.2 EXISTING AND PLANNED CHEMICAL ADDITION AND FLUSHING SYSTEM}

The current flush system is not capable of delivering dilution water or flush solution at the required rate of $530 \mathrm{~L} / \mathrm{min}$, and the new chemical addition and flushing system design for the 241-AN Tank Farm has not yet been completed. For the purpose of this document it is assumed that the chemical addition and flushing system design will be functionally identical to the chemical addition and flushing system design for the 241-AP Tank Farm. The chemical addition and flushing system design for the 241-AP Tank Farm consists of a tank, heater(s), chemical metering pumps, and piping systems to deliver the flush/diluent. The system is designed to deliver up to $530 \mathrm{~L} / \mathrm{min}$ of chemical adjusted $\left(\mathrm{NaOH}, \mathrm{NO}_{2}\right.$, etc.) water at a temperature up to $66^{\circ} \mathrm{C}$.

\section{A.3.3 COMPARISON OF EXISTING AND PLANNED EQUIPMENT TO EXPECTATIONS}

With the assumption that the 241-AN Tank Farm dilution system design will be functionally identical to the 241-AP Tank Farm dilution system design, the system will be capable of meeting the process needs identified in Table A-1. It is important to note, however, that the most likely diluent and flush solution is water without any added caustic or other chemicals.

\section{A.4 REFERENCES}

DeLozier, M. P., 1998, Evaluation of Tank Waste Disposal Alternatives Within Privatization, Letter LMHC-9854671A R1, to A. M. Umek, FDH, Subonctract number 80232764-9-K001, (June 15), Lockheed Martin Hanford Corporation, Richland, Washington.

Jordan, K. N., and Boston, H. L., 1998, Rev. 1, Tank Waste Remediation System Retrieval and Disposal Mission Readiness-to-Proceed Memorandum, HNF-2019, prepared by Lockheed Martin Hanford Corporation for Fluor Daniel Hanford, Inc., Richland, Washington.

Julyk, L. J., 1997, Evaluation of the Effect of Project W-151 Mixer Pump Jets on In-Tank Equipment Considering Potential Sludge Buildup on Equipment in Waste Tank 241-AZ-101 Hanford Site, Richland, Washington, HNF-SD-W151-DA-008, Rev. 0, Fluor Daniel Northwest, Richland, Washington.

LANL, 1995, A Safety Assessment for Proposed Pump Operations to Mitigate Episodic Gas Releases in Tank 241-SY-101, LA-UR-92-3196, Rev. 14, Los Alamos National Laboratory, Los Alamos, New Mexico. 
HNF-2941

Revision 0

Powell, M. R., 1995, Fiscal Year 1993 1/25-Scale Sludge Mobilization Testing, PNL-10464, Pacific Northwest Laboratory, Richland Washington.

Rieck, C. A., 1998, Interface Document, Project W-211, Initial Tank Retrieval Systems, HNF-1507, Rev. 0.

Willis, W. L., W. A. Peiffer, B. B. Peters, and T. L. Waldo ,1998, Evaluation of Tank Waste Transfers at 241-AW Tank Farm, HNF-2238, Rev. 0, Numatec Hanford Corporation, Richland, Washington. 
Table A-1. Comparison of Process Needs to Existing and Planned Equipment for Waste Preparation and Transfer Systems in 241-AZ Tank Farm.

\begin{tabular}{|c|c|c|c|c|}
\hline $\begin{array}{c}\text { Quantitative tank-specific } \\
\text { process need }\end{array}$ & $\begin{array}{l}\text { Existing or planned structure, } \\
\text { system, or component }\end{array}$ & $\begin{array}{l}\text { Is existing or planned } \\
\text { equipment adequate } \\
\text { (Yes/No) }\end{array}$ & Basis for adequacy & Comments/issues \\
\hline $\begin{array}{l}\text { SA.P1.1.mohilize }>90 \% \\
\text { of the solids intially in } \\
241-\wedge Z-101,>60 \% \text { of the } \\
\text { solids initially in } 241-A Z- \\
102 \text {, and }>99 \% \text { of the } \\
\text { solids transferred to these } \\
\text { tanks from } 241-A Y-102 \text {. }\end{array}$ & $\begin{array}{l}\text { Existing mixer pumps in } A Z \text { - } \\
101 \text { and Project } W-211 \\
\text { provided mixer pumps in } A Z \text { - } \\
102\end{array}$ & TBD & $\begin{array}{l}\text { Although there are two } 300 \text { lip mixer } \\
\text { pumps currently installed in tank } 241 \text { - } \\
\text { AZ-101, these pumps have not yet } \\
\text { been tested. The test to verify the } \\
\text { ability of the mixer pumps to } \\
\text { mobilize the waste solids is scheduled } \\
\text { to occur early summer of } 1999 \text {. }\end{array}$ & $\begin{array}{l}\text { Although there are two } 300 \mathrm{lp} \\
\text { mixer pumps currently installed } \\
\text { in tank } 241-\wedge Z-101 \text {, these } \\
\text { pumps have not yet been tested. } \\
\text { The test to verify the ability of } \\
\text { the mixer pumps to mobilize the } \\
\text { waste solids is scheduled to } \\
\text { occur early summer of } 1999 \text {. }\end{array}$ \\
\hline $\begin{array}{l}\text { SA.P3.1. Equipment used } \\
\text { to suspend or mobilize } \\
\text { waste shall be able to } \\
\text { operate under both normal } \\
\text { startup and operation } \\
\text { conditions (Note: for the } \\
\text { currently installed system } \\
\text { fin } A Z-101 \text { and the } \\
\text { planned system for AZ- } \\
102 \text {, prevent cavitation of } \\
\text { the mixer pump during } \\
\text { normal startup and } \\
\text { operation conditions). }\end{array}$ & $\begin{array}{l}\text { Existing mixer pumps in } A Z \text { - } \\
101 \text { and Project } W-211 \\
\text { provided mixer pumps in } A Z \text { - } \\
102\end{array}$ & TBD & $\begin{array}{l}\text { The mixer pumps currently installed } \\
\text { in AZ-101 have not been operated as } \\
\text { of the date of this writing. The mixer } \\
\text { pumps include the ability to add } \\
\text { diluent water near the pump intake } \\
\text { through a sparge ring. Drawing H- } \\
\text { 14-102086 shows a typical mixer } \\
\text { pump design which includes a sparge } \\
\text { ring which will allow the addition of } \\
\text { water near the pump intake. It is not } \\
\text { known if this feature will be sufficient } \\
\text { to allow the mixer pumps to start and } \\
\text { prevent cavitation. }\end{array}$ & $\begin{array}{l}\text { The mixer pumps currently } \\
\text { installed in } \mathrm{AZ}-101 \text { include the } \\
\text { ability to add dilnent water near } \\
\text { the pump intake. Drawing } \mathrm{H}- \\
14-102086 \text { shows a typical mixer } \\
\text { pump design which includes a } \\
\text { sparge ring which will allow the } \\
\text { addition of water near the pump } \\
\text { intake. It is not known if this } \\
\text { feature will be sufficient to allow } \\
\text { the mixer pumps to start or } \\
\text { operate. }\end{array}$ \\
\hline
\end{tabular}


Table A-1. Comparison of Process Needs to Existing and Planned Equipment for Waste Preparation and Transfer Systems in 241-AZ Tank Farm.

\begin{tabular}{|c|c|c|c|c|}
\hline $\begin{array}{l}\text { Quantitative tank-specific } \\
\text { process need }\end{array}$ & $\begin{array}{l}\text { Existing or planned structure, } \\
\text { system, or component }\end{array}$ & $\begin{array}{l}\text { Is existing or plamned } \\
\text { equipment adequate } \\
\text { (Yes/No) }\end{array}$ & Basis for adequacy & Comments/issues \\
\hline $\begin{array}{l}\text { 5A.P3.3. Equipment used } \\
\text { to mobilize or suspend } \\
\text { waste shall not impart } \\
\text { excessive force to the tank } \\
\text { structure. (Note: for the } \\
\text { currently planned system - } \\
\text { Provide mixer pumps } \\
\text { which will not damage the } \\
\text { tank structure during } \\
\text { nomal and/or off-normal } \\
\text { operation.) }\end{array}$ & $\begin{array}{l}\text { Existing mixer pumps in AZ- } \\
101 \text { and Project W-211 } \\
\text { provided mixer pumps in AZ- } \\
102\end{array}$ & Yes & $\begin{array}{l}\text { The loads of the mixer pump jets on } \\
\text { in-tank equipment were evaluated in } \\
\text { HNF-SD-W151-DA-008, Rev. 0 } \\
\text { (Julyk 1997) indicates that for clean } \\
\text { components, only minor damage may } \\
\text { occur to a radiation dry well and to } \\
\text { five air lift circulator thermowells. } \\
\text { The damage postulated does not fail } \\
\text { the equipment. In the case of } \\
\text { components with a sludge buildup, the } \\
\text { same components which were } \\
\text { damaged in the case of clean } \\
\text { equipment evaluated above, but the } \\
\text { postulated foces may cause failure of } \\
\text { those components. }\end{array}$ & \\
\hline $\begin{array}{l}\text { 5A.P3.4. Provide a diluent } \\
\text { system and a water } \\
\text { addition line to allow } \\
\text { addition of up to } 379 \mathrm{~m}^{3} \\
(100,000 \mathrm{gal}) \text { of raw water } \\
\text { near the intake of each } \\
\text { mixer pump. The dilution } \\
\text { system should be capable } \\
\text { of providing the quantity at } \\
\text { a flow rate of } T B D \text { liters } \\
\text { per minute and a } \\
\text { temperature range of } 20^{\circ} \mathrm{C} \\
\text { to } 50^{\circ} \mathrm{C}\left(+/-\mathrm{TBD}^{\circ} \mathrm{C}\right) \text {. } \\
\text { No cooling capacity is } \\
\text { required. }\end{array}$ & $\begin{array}{l}\text { Existing mixer pumps in AZ- } \\
101 \text { and Project } W-211 \\
\text { provided mixer pumps in } A Z \text { - } \\
102 \text { which allow liquid to be } \\
\text { introduced into the pump } \\
\text { intake }\end{array}$ & Yes & $\begin{array}{l}\text { Drawing H-14-102451 shows a } 1 \frac{1 / 2}{} \\
\text { in. hose connection to a sparge ring } \\
\text { near the pump intake. This } \\
\text { configuration can be used to introduce } \\
\text { water near the mixer pump intake. } \\
\text { The total volume of water is not } \\
\text { limited by the diluent addition system } \\
\text { but it is limited by the allowable } \\
\text { volume in the tank. }\end{array}$ & . \\
\hline
\end{tabular}


Table A-1. Comparison of Process Needs to Existing and Planned Equipment for Waste Preparation and Transfer Systems in 241-AZ Tank Farm.

\begin{tabular}{|c|c|c|c|c|}
\hline $\begin{array}{l}\text { Quantitative tank-specilic } \\
\text { process need }\end{array}$ & $\begin{array}{l}\text { Existing or planned structure, } \\
\text { system, or component }\end{array}$ & $\begin{array}{l}\text { Is existing or planned } \\
\text { equipment adecuate } \\
\text { (Yes/No) }\end{array}$ & Basis for adequacy & Comments/issues \\
\hline $\begin{array}{l}5 \Lambda . P 3.5 \text {. Control the rate } \\
\text { of operation of equipment } \\
\text { used to mobilize and } \\
\text { suspend solids. (Note: for } \\
\text { the currently planmed } \\
\text { system - Provide mixer } \\
\text { pumps with a variable } \\
\text { frequency drive (VFD) } \\
\text { capable of operating the } \\
\text { pump from a minimum } \\
\text { speed of approximately } \\
58 \% \text { speed to full speed } \\
\text { operation.) }\end{array}$ & $\begin{array}{l}\text { W-151 for } \wedge Z-101 \\
W-211 \text { will provide mixer } \\
\text { pumps and Variable } \\
\text { Frequency Drive unit for } A Z \text { - } \\
102\end{array}$ & $\begin{array}{l}\text { Yes for } 101-\Lambda Z \\
\text { Yes for } 102-\Lambda Z\end{array}$ & $\begin{array}{l}\text { VFD for } A Z-101 \text { mixer pump } \\
\text { installed under W-151. } \\
\text { HNF-1507 (Rieck } 1998 \text { ) page } 85 \text { and } \\
14 \text { indicates that a mixer pump with a } \\
\text { VFD is to be installed into } 102-A Z \text {, } \\
\text { the lower limits in the range of the } \\
\text { VFD are not listed. }\end{array}$ & $\begin{array}{l}\text { Project documentation needs to } \\
\text { identify the range of operation of } \\
\text { planned equipment. }\end{array}$ \\
\hline $\begin{array}{l}\text { 5A.P3.6. Provide in-tank } \\
\text { components which can } \\
\text { withstand forces imparted } \\
\text { by solids mobilization and } \\
\text { suspension equipment and } \\
\text { remain operable and } \\
\text { retrievable from the DST. } \\
\text { (Note for the currently } \\
\text { planned system - Provide } \\
\text { (or replace) in-tank } \\
\text { components which can } \\
\text { withstand forces imparted } \\
\text { by full speed mixer pump } \\
\text { operation and remain } \\
\text { operable and retrievable } \\
\text { from the DST.) }\end{array}$ & $\begin{array}{l}\text { All existing and future in tank } \\
\text { equipment }\end{array}$ & TBD & $\begin{array}{l}\text { HNF-SD-W151-DA-008 is an } \\
\text { evaluation of the effect of the mixer } \\
\text { pump outtlow on tank and tank } \\
\text { internals. LANL document LA-UR- } \\
92-3196 \text { (LANL 1995) for SY-101 is } \\
\text { an evaluation of the effects of mixer } \\
\text { pump generated missles on the tank } \\
\text { and tank internals. This report needs } \\
\text { to be repeated using two } 224 \mathrm{~kW} \mathrm{(300} \\
\text { hp) mixer pumps versus the one } 112 \\
\text { kW (150 hp) pump as in the SY-101 } \\
\text { report. }\end{array}$ & $\begin{array}{l}\text { HNF-SD-W 151-DA-008 is an } \\
\text { evaluation of the effect of the } \\
\text { mixer pump outflow on tank and } \\
\text { tank internals. LANL document } \\
\text { LA-UR-92-3196 (LANL 1995) } \\
\text { for SY-101 was an evaluation of } \\
\text { the effects of mixer pump } \\
\text { generated missles on the tank } \\
\text { and tank internals. This report } \\
\text { needs to be repeated using two } \\
224 \mathrm{~kW} \text { ( } 300 \text { hp) mixer pumps } \\
\text { versus the one } 112 \mathrm{~kW} \text { (150 hp) } \\
\text { pump as in the SY-101 report. }\end{array}$ \\
\hline
\end{tabular}


Revision 0

\begin{tabular}{|c|c|c|c|}
\hline 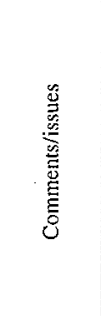 & 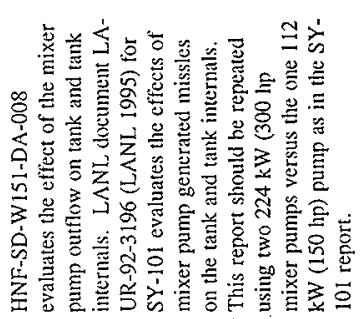 & & 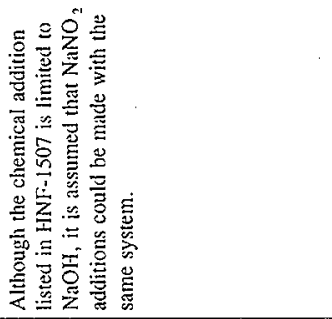 \\
\hline 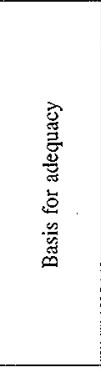 & 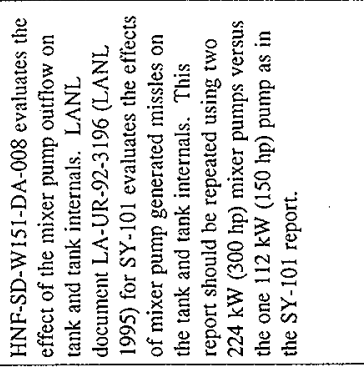 & 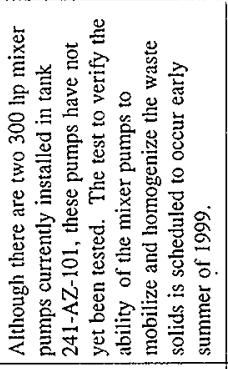 & 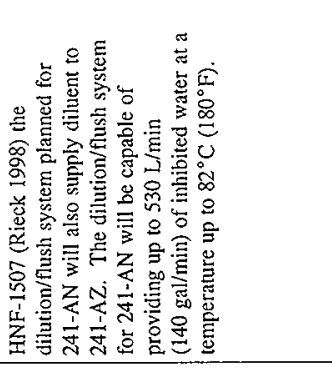 \\
\hline 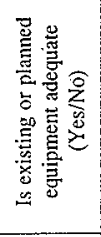 & 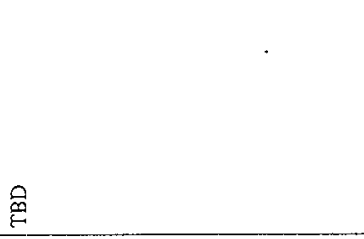 & $\stackrel{0}{\circ}$ & $\ddot{\nu}$ \\
\hline 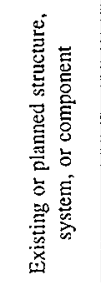 & 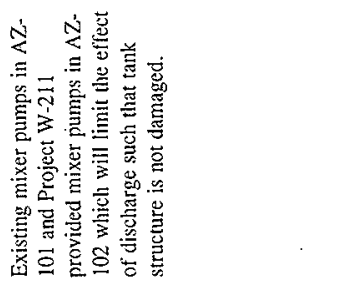 & 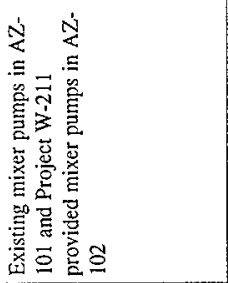 & 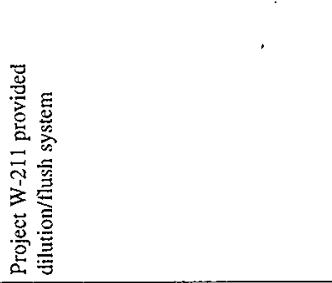 \\
\hline 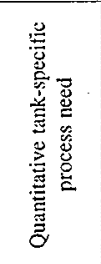 & 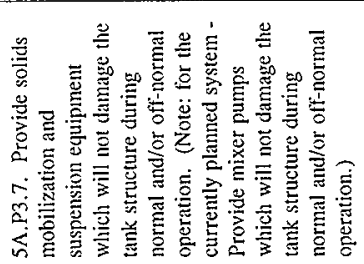 & 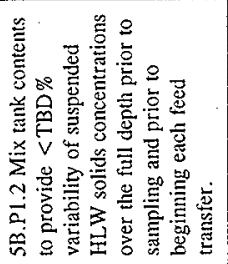 & 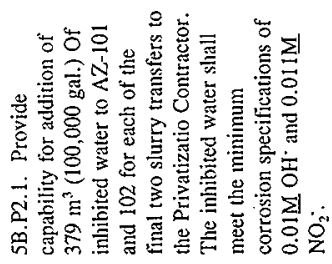 \\
\hline
\end{tabular}


Table A-1. Comparison of Process Needs to Existing and Planned Equipment for Waste Preparation and Transfer Systems in 241-AZ Tank Farm.

\begin{tabular}{|c|c|c|c|c|}
\hline $\begin{array}{l}\text { Quantitative tank-specific } \\
\text { process need }\end{array}$ & $\begin{array}{l}\text { Existing or planned structure, } \\
\text { system, or component }\end{array}$ & $\begin{array}{l}\text { Is existing or planned } \\
\text { equipment adequate } \\
\text { (Yes/No) }\end{array}$ & Basis for adequacy & Comments/issues \\
\hline $\begin{array}{l}\text { 9.P1.1. Provide transfer } \\
\text { system capable of } \\
\text { achieving a waste transfer } \\
\text { velocity of } 1.8-2.7 \mathrm{~m} / \mathrm{sec} \\
(6-9 \mathrm{ft} / \mathrm{sec})\end{array}$ & $\begin{array}{l}\text { AZ-101 - Project W-521 } \\
\text { AZ-102 Project W-211 } \\
\text { provided transfer Pump and } \\
\text { existing and project provided } \\
\text { piping system. }\end{array}$ & $\begin{array}{l}\text { Yes (See caveat in } \\
\text { Comments/Issues) } \\
\text { Yes (See caveat in } \\
\text { Comments/Issues) }\end{array}$ & $\begin{array}{l}\text { Project W-521 is planning to install a } \\
\text { transfer pump into Tank AZ-101 } \\
\text { Project W-21l is scheduled to insrall a } \\
\text { transfer pump into Tank } A Z-102 \text {. } \\
\text { Appendix A develops the adequacy of } \\
\text { the transfer system to transfer waste at } \\
1.8 \text { to } 2.7 \mathrm{~m} / \mathrm{sec}(6 \text { to } 9 \mathrm{ft} / \mathrm{sec}) \text { with } \\
\text { the assumption that the transfer pumps } \\
\text { in } \mathrm{AZ} \text { will have a pump curve } \\
\text { equivalent to the Sulzer Pump curve } \\
\text { used in the evaluation. See figures } \\
\text { A.1 - A.4 and Section F. } 2.1 \text { in } \\
\text { Appendix F. }\end{array}$ & $\begin{array}{l}\text { It is important to note that } \\
\text { although the flex hose will likely } \\
\text { not be used in AZ-101 or } 102 \text {, } \\
\text { the pump curve for the Sulzer - } \\
\text { Bingham Pump was used to } \\
\text { estimate flow performance. }\end{array}$ \\
\hline $\begin{array}{l}\text { 9.P1.2. Provide transfer } \\
\text { pumps with a water } \\
\text { addition feature that will } \\
\text { provide slurry dilution } \\
\text { capability at the pump } \\
\text { suction. The needed } \\
\text { dilution water flow rate is } \\
530 \mathrm{~L} / \mathrm{min}(140 \mathrm{gal} / \mathrm{min}) \text {. }\end{array}$ & $\begin{array}{l}\text { AZ-101 W-521 project } \\
\text { provided transfer pump } \\
\text { AZ-102 W-211 project } \\
\text { provided transfer pump with } \\
\text { provision for in-line dilution } \\
\text { at transfer pump suction, and } \\
\text { flush/diluent piping }\end{array}$ & $\begin{array}{l}A Z-101-T B D \\
A Z-102-Y e s\end{array}$ & $\begin{array}{l}\text { Design for a transfer pump for } A Z \text { - } \\
101 \text { has not been initiated. } \\
\text { HNF-1507 (Rieck 1998) Pages } 85 \text { \& } \\
14 \text {. The diluent/flush system for } 241- \\
\text { AN, AY and AZ is not currently } \\
\text { designed. The flush dilution system } \\
\text { for } 241-A P \text { has been designed and is } \\
\text { designed to be capable of delivering } \\
\text { the required flow rate of diluent to } \\
\text { the transfer pump intake. Assuming } \\
\text { the design for } 241-A Z \text { will be } \\
\text { functionally identical to the } 241-A P \\
\text { design, the system will be adequate. }\end{array}$ & \\
\hline
\end{tabular}


Table A-1. Comparison of Process Needs to Existing and Planned Equipment for Waste Preparation and Transfer Systems in 241-AZ Tank Farm.

\begin{tabular}{|c|c|c|c|c|}
\hline $\begin{array}{c}\text { Quantitative tank-specific } \\
\text { process need }\end{array}$ & $\begin{array}{l}\text { Existing or planned structure, } \\
\text { system, or component }\end{array}$ & $\begin{array}{l}\text { Is existing or planned } \\
\text { equipment adequate } \\
\text { (Yes } / \mathrm{No})\end{array}$ & Basis for adequacy & Comments/issues \\
\hline $\begin{array}{l}\text { 9.P3.1. In normal } \\
\text { operation, maintain the } \\
\text { transfer system pressure } \\
\text { drop below the transfer } \\
\text { line operating pressure. } \\
\text { The maximum line } \\
\text { operating pressure can vary } \\
\text { between } 15.8 \mathrm{kPa} \text { to } 27.6 \\
\mathrm{kPa}(230 \text { to } 400 \text { psi) } \\
\text { depending on the transfer } \\
\text { line. }\end{array}$ & $\begin{array}{l}\text { AZ-101: Project W-521 } \\
\text { AZ-102: Project W-211 } \\
\text { provided transfer pump and } \\
\text { existing and project provided } \\
\text { piping system. }\end{array}$ & Yes & $\begin{array}{l}\text { The largest operating pressure in the } \\
\text { piping system uncer normal } \\
\text { conditions is in the transfers from } \\
\text { AZ-102 to the private vendor where } \\
\text { the pressure is } 130 \mathrm{~m} \text { ( } 425 \mathrm{ft} \text { ) of head } \\
\text { which for a } 1.41 \text { specific gravity } \\
\text { solution is approximately } 17.9 \mathrm{kPa} \\
(260 \text { psi). See figures A.1 through } \\
\text { A.4 and the calculation in Section } \\
\text { F.2.1. }\end{array}$ & $\begin{array}{l}\text { The maximum allowable } \\
\text { operating pressure of the piping } \\
\text { system is } 27.6 \mathrm{kPa}(400 \mathrm{psi}) \text {, } \\
\text { this pressure must not be } \\
\text { exceeded in normal operation }\end{array}$ \\
\hline $\begin{array}{l}\text { 9.P3.2. Provide transfer } \\
\text { pumps with a maximum } \\
\text { design head of } 137 \mathrm{~m} \\
\text { ( } 450 \mathrm{ft} \text { ) (TBR) total } \\
\text { dynamic head at the target } \\
\text { flow rate of } 0.73 \mathrm{ML} / \mathrm{day} \\
\text { (140 gal } / \mathrm{min}) \text {. }\end{array}$ & $\begin{array}{l}\text { AZ-101 - Project W-521 to } \\
\text { provide transfer pump } \\
\text { AZ-102 - Project W-211 } \\
\text { provided transfer pump and } \\
\text { existing and W-314 Project } \\
\text { provided Piping System }\end{array}$ & Yes & $\begin{array}{l}\text { The largest operating pressure in the } \\
\text { piping system under normal } \\
\text { conditions is in the transfers from } \\
\text { AZ-102 to the private vendor where } \\
\text { the head is } 130 \mathrm{~m}(425 \mathrm{ft}) \text {. See } \\
\text { figures } A .1 \text { through } A .4 \text { and the } \\
\text { calculation in Section F.2.1. }\end{array}$ & \\
\hline $\begin{array}{l}\text { 9.P3.3. Prevent cavitation } \\
\text { of the transfer pump } \\
\text { during normal startup and } \\
\text { operation conditions. Net } \\
\text { positive suction head } \\
\text { required should not exceed } \\
\text { Net Positive Suction Head } \\
\text { Available at highest } \\
\text { reasonable operating } \\
\text { temperatures. }\end{array}$ & $\begin{array}{l}\text { AZ-101 - Project W-521 } \\
\text { provided transfer pump } \\
\text { AZ-102 - Project W-211 } \\
\text { provided transfer pump }\end{array}$ & TBD & $\begin{array}{l}\text { The net positive suction head } \\
\text { requirements are calculated in HNF- } \\
2238 \text {, Appendix E (Willis et al. 1998) } \\
\text { and are met by the system. }\end{array}$ & $\begin{array}{l}\text { Although the net positive suction } \\
\text { head requirements are met by } \\
\text { the system, it is not known } \\
\text { wether the system will be } \\
\text { capable of preventing the } \\
\text { transfer pump intake from being } \\
\text { buried in a sludge layer which } \\
\text { may induce cavitation and lead } \\
\text { to damage to or failure of the } \\
\text { transfer pump. }\end{array}$ \\
\hline
\end{tabular}


Table A-1. Comparison of Process Needs to Existing and Planned Equipment for Waste Preparation and Transfer Systems in 241-AZ Tank Farm.

\begin{tabular}{|c|c|c|c|c|}
\hline $\begin{array}{l}\text { Quantitative tank-specific } \\
\text { process need }\end{array}$ & $\begin{array}{l}\text { Existing or planned structure, } \\
\text { system, or component }\end{array}$ & $\begin{array}{l}\text { Is existing or planned } \\
\text { equipment adequate } \\
\text { (Yes/No) }\end{array}$ & Basis for adequacy & Comments/issues \\
\hline $\begin{array}{l}\text { 9.P3.4. Provide transfer } \\
\text { pumps with a VFD capable } \\
\text { of operating the pump } \\
\text { from a minimum speed of } \\
\text { approximately } 25 \% \text { speed } \\
\text { to full speed operation } \\
\text { (WHC-SD-WM-DGS-006, } \\
\text { Rev. 0). }\end{array}$ & $\begin{array}{l}\text { AZ-101 - Project W-52I } \\
\text { provided transfer pump } \\
\text { W-211 provided transfer } \\
\text { pump and Variable Frequency } \\
\text { Drive unit for } A Z-102\end{array}$ & $\begin{array}{l}\text { TBD for } 101-A Z \\
\text { TBD for } 102-A Z\end{array}$ & $\begin{array}{l}\text { Transfer pump for } A Z-101 \text { has not } \\
\text { yet been designed. } \\
\text { HNF-1507 (Rieck 1998) page } 85 \text { and } \\
14 \text { indicates that a transfer pump with } \\
\text { a VFD is to be installed into } 102-A Z \text {, } \\
\text { the lower limits in the range of the } \\
\text { VFD are not listed. }\end{array}$ & $\begin{array}{l}\text { Project documentation needs to } \\
\text { identify the range of operation of } \\
\text { planned equipment. }\end{array}$ \\
\hline $\begin{array}{l}\text { 9.P3.5. Provide reverse } \\
\text { rotation and back flow } \\
\text { protection for transfer } \\
\text { pumps (WHC-SD-WM- } \\
\text { DGS-006, Rev. 0). }\end{array}$ & $\begin{array}{l}\text { AZ-101 - none } \\
\text { AZ-102 - Project W-211 } \\
\text { provided transfer pump }\end{array}$ & TBD & $\begin{array}{l}\text { Transfer pumps for } A Z-101 \text { and } 102 \\
\text { have not yet been selected. HINF- } \\
1507 \text { does not indicate back flow } \\
\text { prevention for the transfer pumps. }\end{array}$ & $\begin{array}{l}\text { Transfer pumps for } \wedge Z-101 \text { and } \\
102 \text { have not yet been selected. } \\
\text { HNF-1507 does not indicate } \\
\text { back flow prevention for the } \\
\text { transfer pumps. }\end{array}$ \\
\hline $\begin{array}{l}\text { 9.P3.6. Provide slurry } \\
\text { transfer pumps which can } \\
\text { be operated during mixer } \\
\text { pump operation and } \\
\text { withstand forces imparted } \\
\text { by full speed mixer pump } \\
\text { operation and remain } \\
\text { operable and retrievable } \\
\text { from the DST }\end{array}$ & $\begin{array}{l}\text { AZ-101 - none* } \\
\text { AZ-102 Project W-211 } \\
\text { provided mixer and } \\
\text { compatible transfer Pumps }\end{array}$ & TBD & $\begin{array}{l}\text { Although both mixer pumps and } \\
\text { transfer pumps are included in the W- } \\
211 \text { design documentation no } \\
\text { evaluation of the compatibility of the } \\
\text { two were found. }\end{array}$ & $\begin{array}{l}\text { * Any transfer pump to be } \\
\text { installed into } \triangle Z-101 \text { will need } \\
\text { to be shown to be compatible } \\
\text { with the existing mixer pumps in } \\
\text { that tank. } \\
\text { Although both mixer pumps and } \\
\text { transfer pumps are included in } \\
\text { the W-21l design documentation } \\
\text { no evaluation of the } \\
\text { compatibility of the two were } \\
\text { found. }\end{array}$ \\
\hline
\end{tabular}


Table A-1. Comparisoñ of Process Needs to Existing and Planned Equipment for Waste Preparation and Transfer Systems in 241-AZ Tank Farm.

\begin{tabular}{|c|c|c|c|c|}
\hline $\begin{array}{l}\text { Quantitative tank-specific } \\
\text { process need }\end{array}$ & $\begin{array}{l}\text { Existing or planned structure, } \\
\text { system, or component }\end{array}$ & $\begin{array}{l}\text { Is existing or planned } \\
\text { equipment adequate } \\
\text { (Yes/No) }\end{array}$ & Basis for adequacy & Comments/issues \\
\hline $\begin{array}{l}\text { 9.P3.8. Provide transfer } \\
\text { system components capable } \\
\text { of transferring waste with a } \\
\text { density as high as } 1.4 \\
\mathrm{~g} / \mathrm{ml} \text {. }\end{array}$ & $\begin{array}{l}\text { AZ-101- none } \\
\text { AZ-102 Project W-211 } \\
\text { provided transfer Pump }\end{array}$ & $\begin{array}{l}\text { AZ-101 - No } \\
\text { AZ-102 - Yes }\end{array}$ & $\begin{array}{l}\text { No project currently has scope to } \\
\text { install a transfer pump into 101-AZ } \\
\text { Sulzer-Bingham Pump curve included } \\
\text { in HNF-2238 page D-16 (same pump } \\
\text { assumed here) shows a horse power } \\
\text { required curve for a Specific gravity } \\
\text { of } 1.5 \text {. }\end{array}$ & $\begin{array}{l}\text { It is important to note that } \\
\text { although the flex hose will likely } \\
\text { not be used in AZ-101 or } 102 \text {, } \\
\text { the pump curve for the Sulzer- } \\
\text { Bingham Pump was used to } \\
\text { estimate flow performance. }\end{array}$ \\
\hline $\begin{array}{l}\text { 9.P3.9. Provide transfer } \\
\text { system components capable } \\
\text { of handling wastes with a } \\
\text { pH of } 7 \text { or greater. }\end{array}$ & $\begin{array}{l}\text { AZ-101 - none } \\
\text { Transfer Pump Design }\end{array}$ & $\begin{array}{l}\text { AZ-101 - No } \\
\text { AZ-102 - TBD }\end{array}$ & to be developed & to be developed \\
\hline $\begin{array}{l}\text { 9.P3.10 Provide a transfer } \\
\text { system which prevents the } \\
\text { occurrence of water } \\
\text { hammer resulting from } \\
\text { reconfiguration of the } \\
\text { system during the transfer. }\end{array}$ & $\begin{array}{l}\text { Existing and Projects } W-314 \\
\text { and } W-211 \text { provided transfer } \\
\text { piping and jumper systems }\end{array}$ & TBD & $\begin{array}{l}\text { An evaluation of the system will need } \\
\text { to be performed which will } \\
\text { demonstrate adequacy. }\end{array}$ & \\
\hline $\begin{array}{l}\text { 9.P4.1. Provide a diluent } \\
\text { system to flusin the transfer } \\
\text { lines with raw or inlibited } \\
\text { water at } 530 \mathrm{~L} / \mathrm{min} \\
\text { (140 gal } / \mathrm{min})(\mathrm{TBR})\end{array}$ & $\begin{array}{l}\text { Project W-211 provided } \\
\text { dilution/flush system }\end{array}$ & . & $\begin{array}{l}\text { HNF-1507 pages } 65-66 \text { and } 36-38 \text {. } \\
\text { The diluent/flush system for } 241-\mathrm{AN} \text {, } \\
\mathrm{AY} \text { and } \mathrm{AZ} \text { is not currently designed. } \\
\text { The flush dilution system for } 241-\mathrm{AP} \\
\text { has been designed and is designed to } \\
\text { be capable of delivering the required } \\
\text { volume of diluent required. } \\
\text { Assuming the design for } 241-\Lambda \mathrm{N} \text { will } \\
\text { be functionally identical to the } 241 \text { - } \\
\Lambda \mathrm{P} \text { design, the system will be } \\
\text { adequate. }\end{array}$ & $\begin{array}{l}\text { It is important to note that } \\
\text { while AZ-102 is included within } \\
\text { the scope of Project W-211, AZ- } \\
101 \text { is not it has been assumed } \\
\text { here that } A Z-101 \text { would have } \\
\text { flush and diluent provided by the } \\
\text { same system as } A Z-102 \text {. }\end{array}$ \\
\hline
\end{tabular}


Table A-1. Comparison of Process Needs to Existing and Planned Equipment for Waste Preparation and Transfer Systems in 241-AZ Tank Farm.

\begin{tabular}{|c|c|c|c|c|}
\hline $\begin{array}{l}\text { Quantitative tank-specific } \\
\text { process need }\end{array}$ & $\begin{array}{l}\text { Existing or planned structure, } \\
\text { system, or component }\end{array}$ & $\begin{array}{l}\text { Is existing or planned } \\
\text { equipment adequate } \\
\text { (Yes/No) }\end{array}$ & Basis for adequacy & Comments/issues \\
\hline $\begin{array}{l}\text { 9.P4.2. The flush direction } \\
\text { should be from the } \\
\text { applicable } 241-A Z \text { pump } \\
\text { pit to the Privatization } \\
\text { Contractor facility (TBR). }\end{array}$ & $\begin{array}{l}\text { Project W-211 provided } \\
\text { dilution/flush System and } \\
\text { existing and project provided } \\
\text { Transfer Piping System }\end{array}$ & ${ }^{*}$ Yes & $\begin{array}{l}\text { H-14-102086 shows typical design for } \\
\text { diluent/flush delivery in } 241-A P \text {. } \\
\text { Assuming that the design for } 241-A Z \\
\text { will be functionally identical to the } \\
241-A P \text { design, the flush delivery will } \\
\text { be from } 241-A Z \text { to the private } \\
\text { contractor facility }\end{array}$ & $\begin{array}{l}\text { *It is important to note that while } \\
\text { the flush solution is introduced } \\
\text { at } 241-A Z \text {, and the overall slope } \\
\text { of the transfer lines is toward the } \\
\text { private vendor, a high spot } \\
\text { exists in the transfer route at the } \\
\text { private vendor interface point. } \\
\text { Siphoning will need to be } \\
\text { evaluated as the design of the } \\
\text { private facility matures. }\end{array}$ \\
\hline $\begin{array}{l}\text { 9.P4.3. Flush transfer lines } \\
\text { with water volumes } \\
\text { equivalent to } 1.5 \text { times the } \\
\text { transfer line internal } \\
\text { volume. }\end{array}$ & $\begin{array}{l}\text { Project W-211 provided } \\
\text { dilution/Flush system }\end{array}$ & Yes & $\begin{array}{l}\text { HNF-1507 (Rieck 1998) Pages } 36-38 \\
\& 65-66 \text {. The diluent/flush system } \\
\text { for } 241-A N, A Y \text { and } A Z \text { is not } \\
\text { currently designed. The flush ditution } \\
\text { system for } 241-A P \text { has been designed } \\
\text { and is designed to be capable of } \\
\text { delivering the required volume of } \\
\text { diluent. Assuming the design for } \\
241-A N \text { will be functionally identical } \\
\text { to the } 241-A P \text { design, the system will } \\
\text { be adequate. The total amount of } \\
\text { diluent which can be added to a tank } \\
\text { is not limited by the dilution/flush } \\
\text { system but by the volume of the waste } \\
\text { tank. }\end{array}$ & . \\
\hline $\begin{array}{l}\text { 9.P4.4. Flush water inlet } \\
\text { can be at the transfer pump } \\
\text { inlet or in the pump } \\
\text { discharge line. }\end{array}$ & $\begin{array}{l}\text { Project W-211 provided } \\
\text { dilution/llush System and } \\
\text { existing and project provided } \\
\text { Piping System }\end{array}$ & Yes & $\begin{array}{l}\text { H-14-102086 shows a typical layout } \\
\text { for the dilution/flush delivery at the } \\
\text { pump intake. The specific .design for } \\
241-A Z \text { has not been started. } \\
\text { Assuming that earlier designs are } \\
\text { typical the design will be adequate. }\end{array}$ & \\
\hline
\end{tabular}


Table A-1. Comparison of Process Needs to Existing and Planned Equipment for Waste Preparation and Transfer Systems in 241-AZ Tank Farm.

\begin{tabular}{|c|l|l|l|l|}
\hline $\begin{array}{c}\text { Quantitative tank-specific } \\
\text { process need }\end{array}$ & $\begin{array}{c}\text { Existing or planned structure, } \\
\text { system, or component }\end{array}$ & $\begin{array}{c}\text { Is existing or planned } \\
\text { equipment adequate } \\
\text { (Yes/No) }\end{array}$ & Basis for adequacy & Comments/ssues \\
\hline $\begin{array}{l}\text { 10.P2.1. In 24l-AZ and } \\
\begin{array}{l}241-\mathrm{AY} \text { tanks, provide a } \\
\text { drop leg or other method } \\
\text { of discharging liquid } \\
\text { beneath tank waste surface. }\end{array}\end{array}$ & None & $\begin{array}{l}\text { No project currently has this work } \\
\text { within its identified scope. }\end{array}$ & \\
\hline
\end{tabular}


HNF-2941

Rvision 0

Table A-2. Summary of Tank Transfers to and from 241-AZ Tank Farm.

\begin{tabular}{|c|c|c|c|}
\hline \multicolumn{2}{|c|}{ Transfer path } & \multicolumn{2}{|c|}{ Transfer period } \\
\hline From & To & Start date & End date \\
\hline \multicolumn{4}{|c|}{ Transfers Under Baseline (Umek 1998) } \\
\hline $\mathrm{AZ}-101$ & AN-105 & $11 / 21 / 03$ & $3 / 7 / 04$ \\
\hline $\mathrm{AZ}-101$ & AW-105 & $10 / 9 / 00$ & $1 / 22 / 01$ \\
\hline $\mathrm{AZ}-101$ & AY-101 & $8 / 17 / 00$ & $8 / 20 / 00$ \\
\hline AZ-101 & P1HLW FEED TANK & $5 / 17 / 02$ & $10 / 27 / 07$ \\
\hline $\mathrm{AZ}-102$ & $A N-105$ & $1 / 5 / 02$ & $2 / 26 / 07$ \\
\hline $\mathrm{AZ}-102$ & AP-107 & $11 / 15 / 01$ & $11 / 16 / 01$ \\
\hline $\mathrm{AZ}-102$ & $A Y-101$ & $11 / 14 / 01$ & $11 / 15 / 01$ \\
\hline $\mathrm{AZ}-102$ & PIHLW_FEED_TANK & $11 / 14 / 03$ & $11 / 12 / 09$ \\
\hline AP-107 & AZ-101 & $6 / 11 / 09$ & $6 / 13 / 09$ \\
\hline AY -102 & $A Z-101$ & $11 / 16 / 03$ & $11 / 21 / 03$ \\
\hline WASH-WATER & AZ-101 & $8 / 20 / 00$ & $3 / 11 / 04$ \\
\hline $\mathrm{AY}-102$ & AZ-102 & $8 / 1 / 05$ & $8 / 3 / 05$ \\
\hline WASH-WATER & AZ-102 & $11 / 16 / 01$ & $2 / 28 / 07$ \\
\hline \multicolumn{4}{|c|}{ Transfers Under Alternative Case (DeLozier 1998) } \\
\hline $\mathrm{AZ}-101$ & P1HLW_FEED_TANK & $6 / 2004$ & $3 / 2005$ \\
\hline AZ-102 & P1HLW_FEED_TANK & $4 / 2005$ & $2 / 2006$ \\
\hline $\begin{array}{l}\mathrm{AY}-102 \text { (with } \mathrm{C}- \\
106)\end{array}$ & $A Z-101$ & $5 / 2006$ & $8 / 2007$ \\
\hline $\begin{array}{l}\mathrm{AY}-102 \text { (from } \mathrm{C}- \\
104 \text { ) }\end{array}$ & $\mathrm{AZ}-102$ & $8 / 2007$ & $6 / 2009$ \\
\hline WATER & $A Z-101$ & $6 / 2004$ & $8 / 2007$ \\
\hline WATER & AZ-102 & $4 / 2005$ & $6 / 2009$ \\
\hline
\end{tabular}


Table A-3. 241-AZ Transfer System Equipment Availability Matrix.

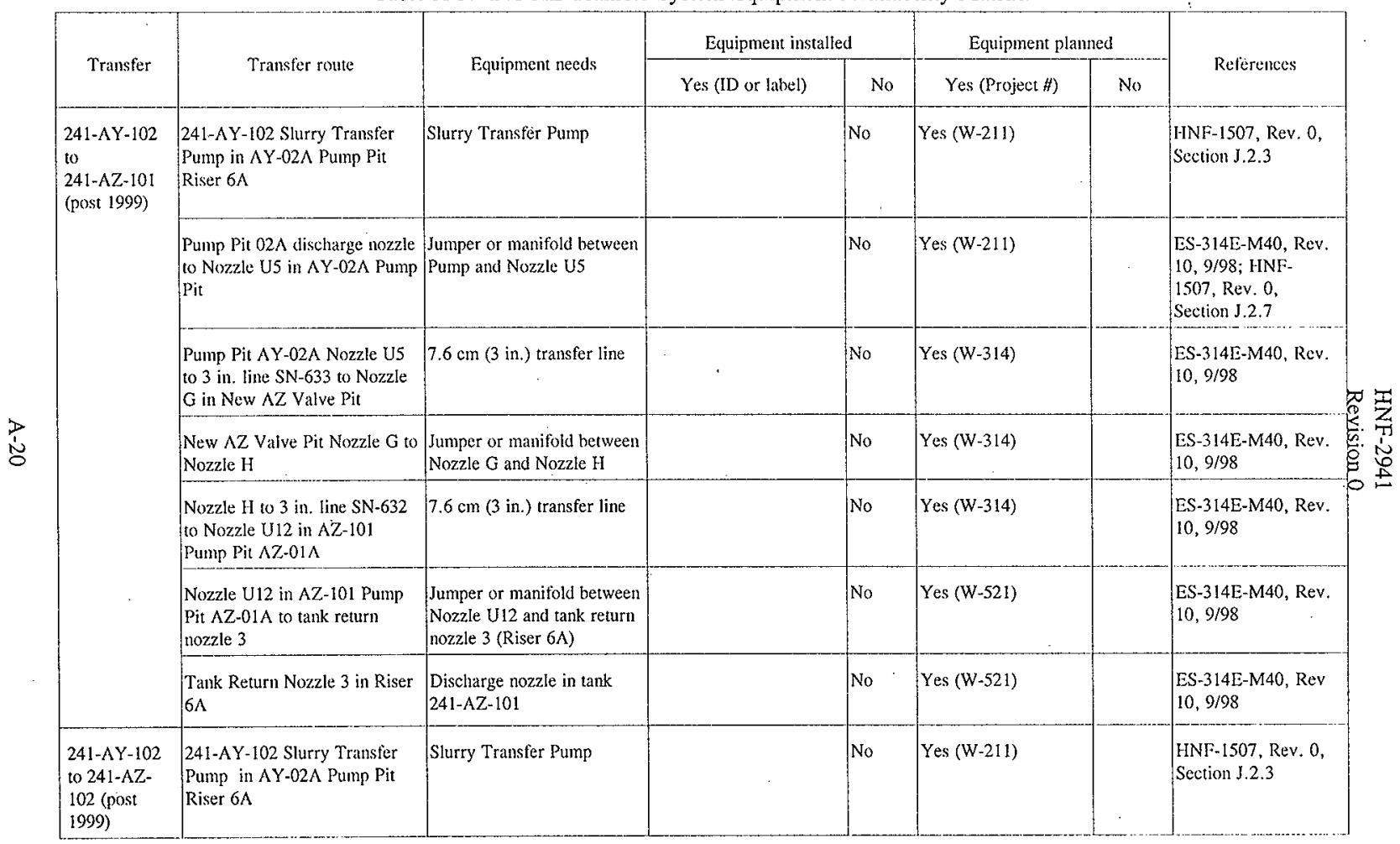


Table A-3, 241-AZ Transfer System Equipment Availability Matrix.

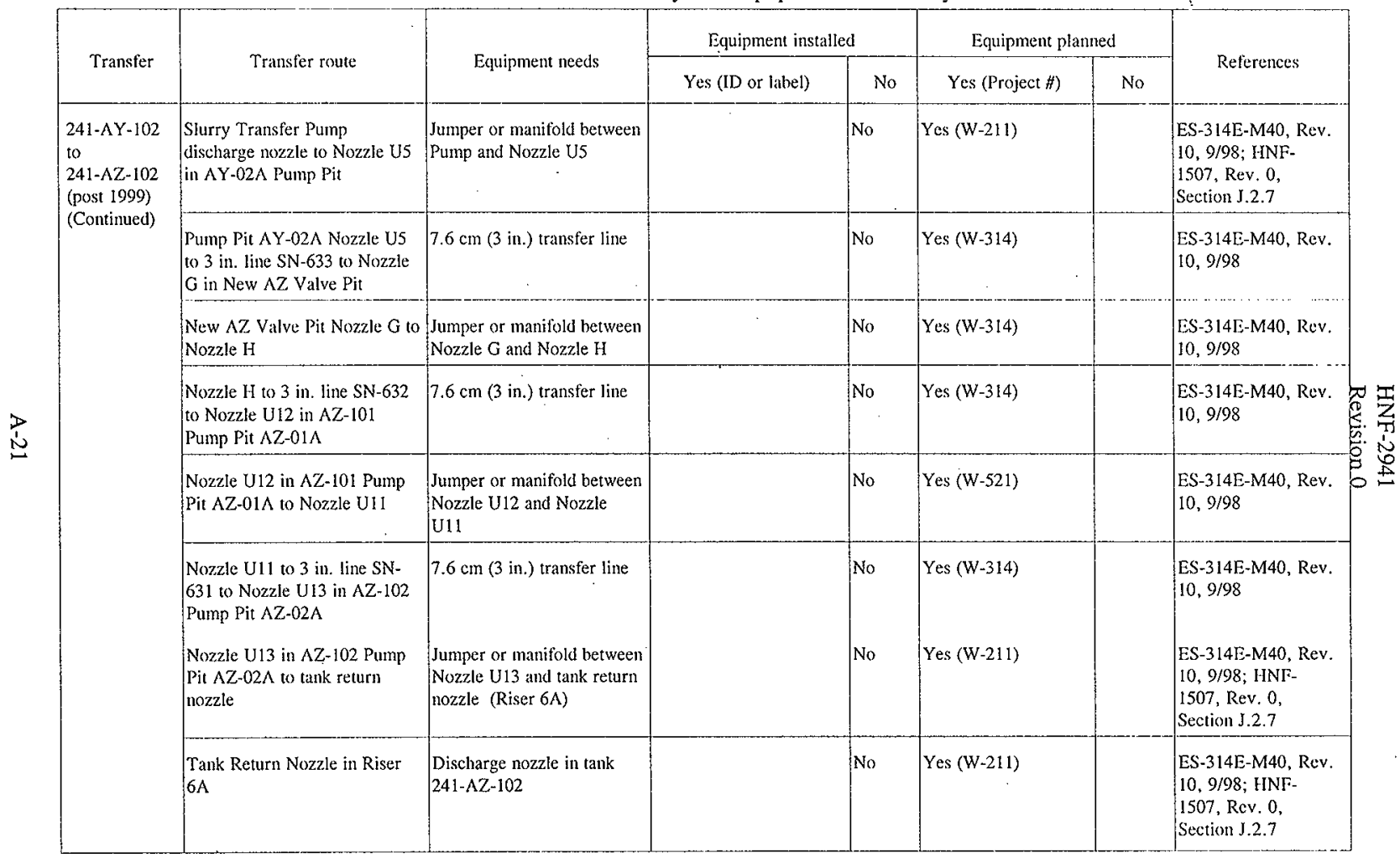


Table A-3. 241-AZ Transfer System Equipment Availability Matrix.

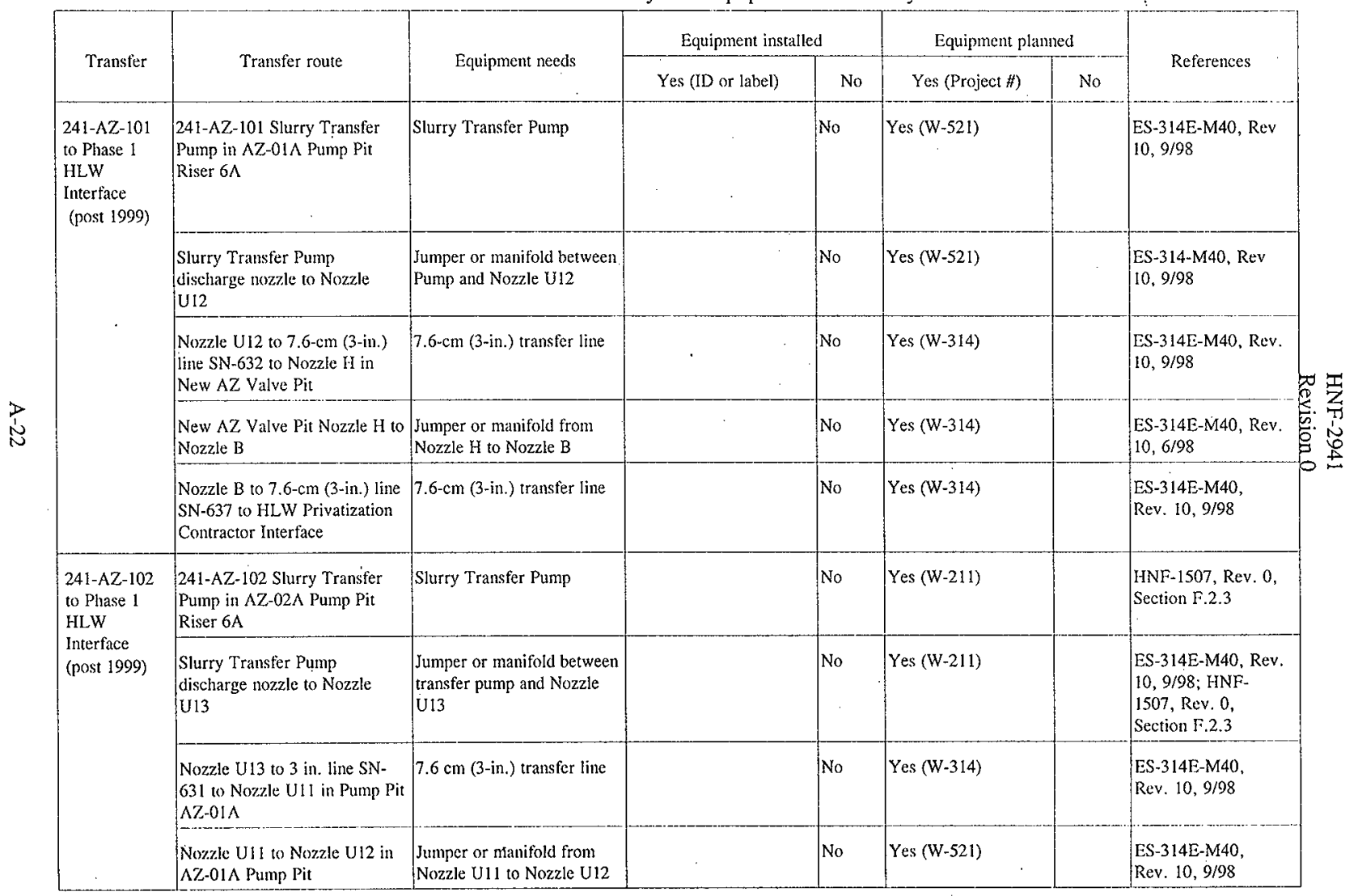


Table A-3. 241-AZ Transfer System Equipment Availability Matrix.

\begin{tabular}{|c|c|c|c|c|c|c|c|}
\hline \multirow{2}{*}{ Transfer } & \multirow{2}{*}{ Transter route } & \multirow{2}{*}{ Equipment needs } & \multicolumn{2}{|c|}{ Equipment installed } & \multicolumn{2}{|c|}{ Equipment planmed } & \multirow{2}{*}{ References } \\
\hline & & & Yes (ID or label) & No & Yes (Project \#) & No & \\
\hline & $\begin{array}{l}\text { Nozzle U12 to } 7.6-\mathrm{cm}(3-\mathrm{in} \text {.) } \\
\text { line SN-632 to Nozzle HI in } \\
\text { New AZ VALVE Pit }\end{array}$ & $7.6 \mathrm{~cm}(3$-in.) transfer line & & No & Yes (W-314) & & $\begin{array}{l}\text { ES-314E-M40, Rev. } \\
10,9 / 98\end{array}$ \\
\hline & $\begin{array}{l}\text { Nozzle } H \text { to Nozzle B in New } \\
\text { AZ Valve Pit }\end{array}$ & $\begin{array}{l}\text { Jumper or manifold from } \\
\text { Nozzle H to Nozzle B }\end{array}$ & & No & Yes (W-314) & & $\begin{array}{l}\text { ES-314E-M40, Rev. } \\
10,9 / 98\end{array}$ \\
\hline & $\begin{array}{l}\text { Nozzle B to } 7.6-\mathrm{cm}(3 \mathrm{in} .) \text { line } \\
\text { SN- } 637 \text { to HLW Privatization } \\
\text { Contractor Interface }\end{array}$ & $7.6 \mathrm{~cm}$ (3-in.) transfer line & & No & Yes (W-314) & & $\begin{array}{l}\text { ES-314E-M40, Rev. } \\
10,9 / 98\end{array}$ \\
\hline
\end{tabular}


Table A-4. -Transfer Pump Availability Matrix.

\begin{tabular}{|c|c|c|c|c|c|}
\hline \multirow{2}{*}{ Transfer } & \multirow{2}{*}{ Transfer pump type needed } & \multirow{2}{*}{ Equivalent length of transfer } & Equipment installed & Equipment planned & \multirow{2}{*}{ References } \\
\hline & & & Yes (ID or label)/No & Yes (Project \#)/No & \\
\hline $\begin{array}{l}\text { AZ-101 to HLW } \\
\text { Interface } \\
\text { (post 1999) }\end{array}$ & $\begin{array}{l}\text { Slurry Transfer Pump/ } \\
\text { Flexible Receiver Pump } \\
\text { (Sulzer Pump) }\end{array}$ & $1459 \mathrm{~m}(4788 \mathrm{ft})$ & No & & \\
\hline $\begin{array}{l}\text { AZ-102 to HLW } \\
\text { Interface (post } \\
1999 \text { ) }\end{array}$ & $\begin{array}{l}\text { Slurry Transfer Pump/ } \\
\text { Flexible Receiver Pump } \\
\text { (Sulzer Pump) }\end{array}$ & $1715 \mathrm{~m}(5627 \mathrm{ft})$ & No & Yes (W-211) & $\begin{array}{l}\text { HNF-1507, Rev. 0, } \\
\text { Interface Document, } \\
\text { Project W-211, Initial } \\
\text { Tank Retricval Systems }\end{array}$ \\
\hline $\begin{array}{l}\Lambda Y-102 \text { to } \Lambda Z-101 \\
\text { (post 1999) }\end{array}$ & $\begin{array}{l}\text { Slurry Transfer Pump/ } \\
\text { Flexible Receiver Pump } \\
\text { (Sulzer Pump) }\end{array}$ & $329 \mathrm{~m}(1081 \mathrm{ft})$ & No & Yes $(W-211)$ & HNF-1507, Rev. 0 \\
\hline $\begin{array}{l}\text { AY-102 to AZ-102 } \\
\text { (post 1999) }\end{array}$ & $\begin{array}{l}\text { Slurry Transfer Pump/ } \\
\text { Flexible Receiver Pump } \\
\text { (Sulzer Pump) }\end{array}$ & $561 \mathrm{~m}(1841 \mathrm{ft})$ & No & Yes $(W-211)$ & HNF-1507, Rev. 0 \\
\hline
\end{tabular}


Table A-5. Equivalent Line Length and Hydraulic Rise Values for Lines Involved in Waste Transfers.

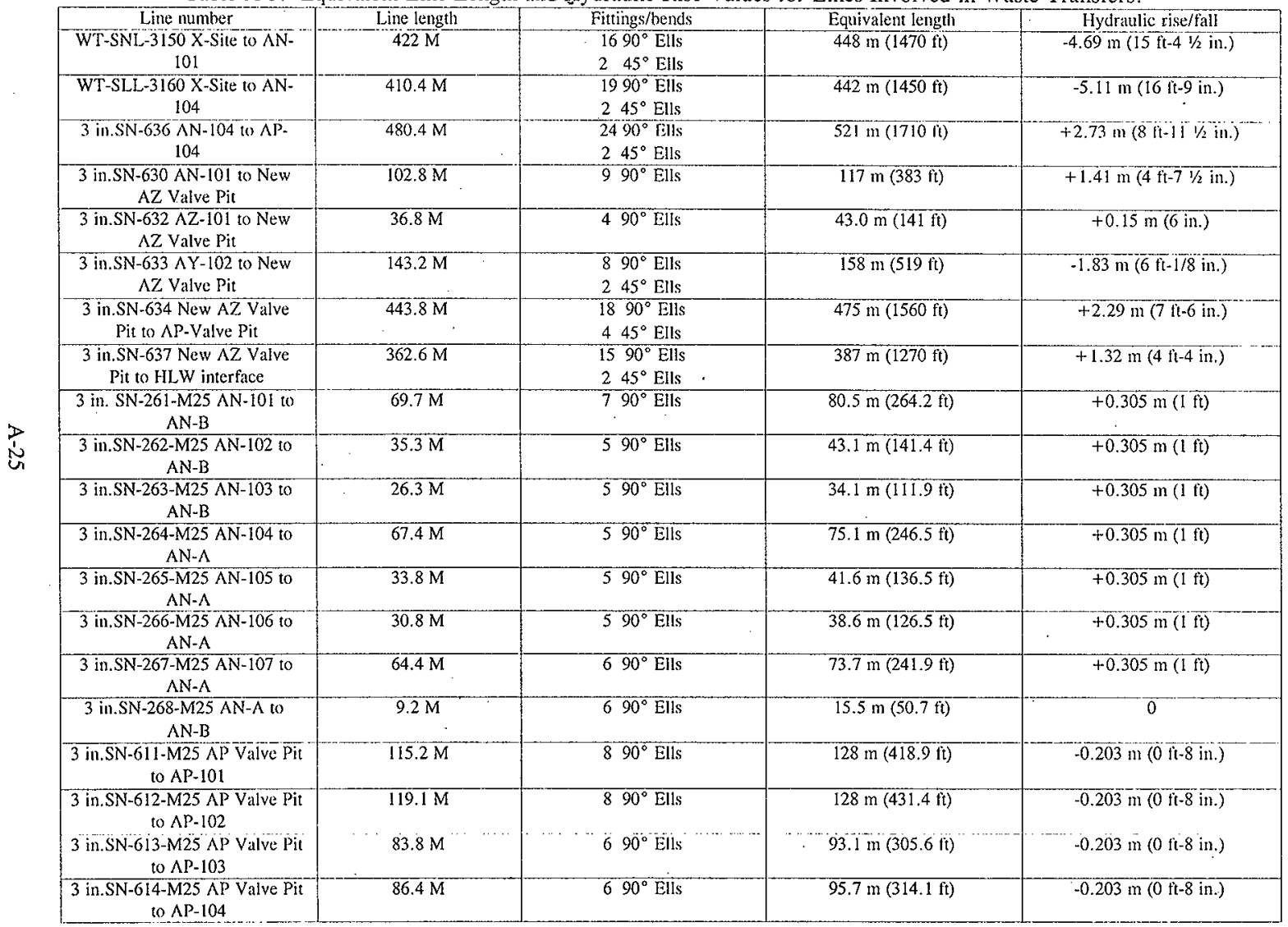


Table A-5. Equivalent Line Length and Hydraulic Rise Values for Lines Involved in Waste Transfers.

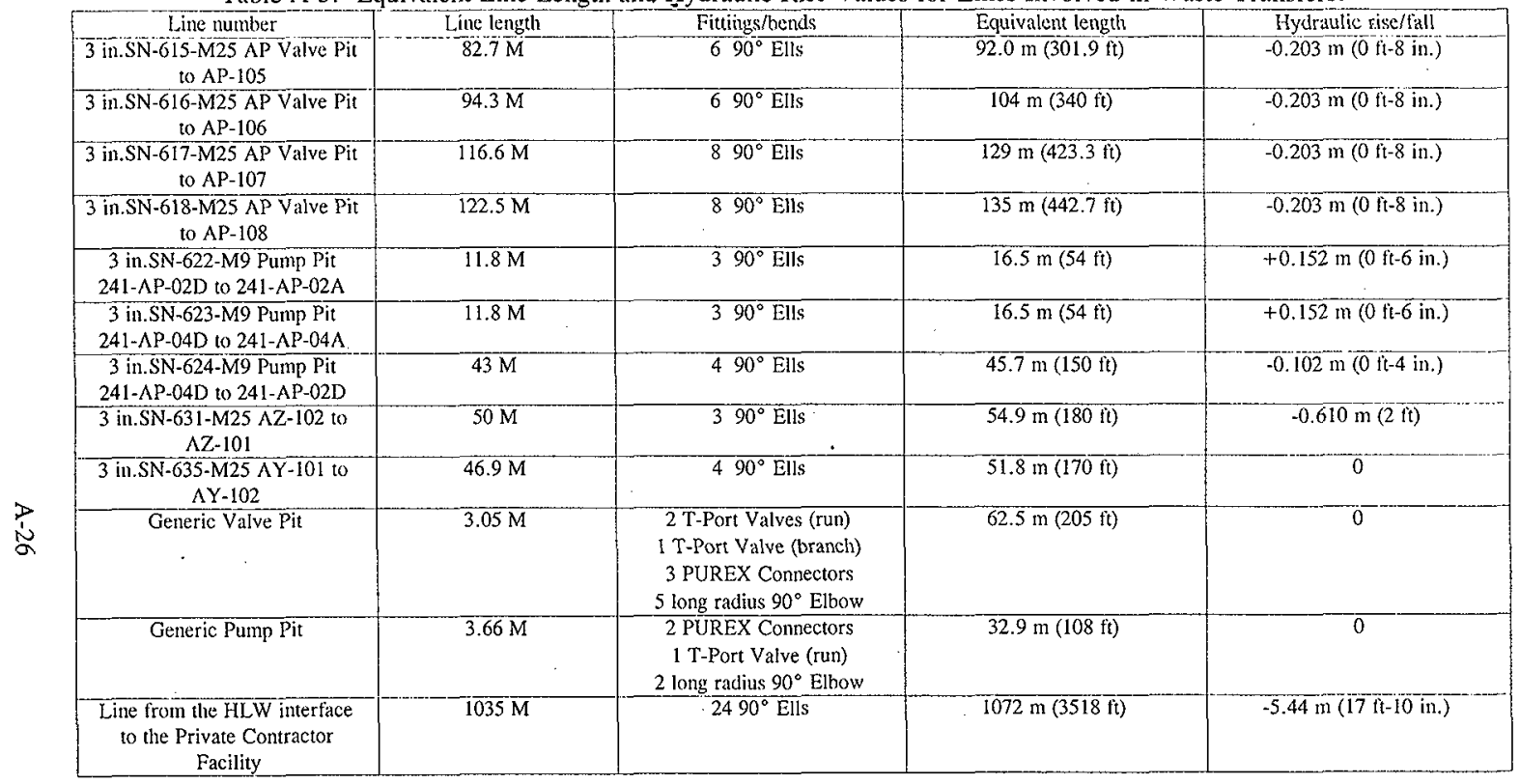


HNF-2941

Revision 0
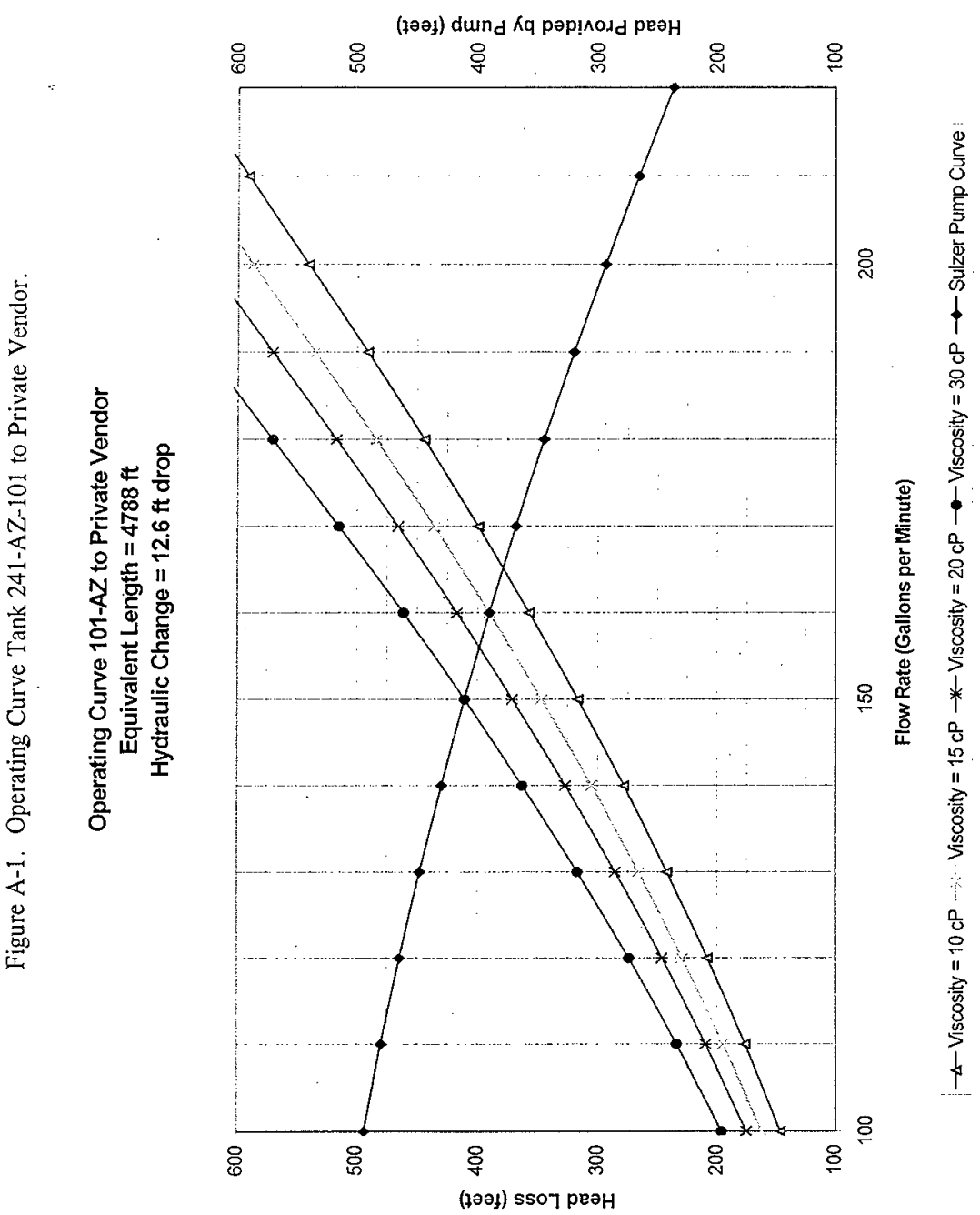
Figure A-2. Operating Curve Tank 241-AY-102 to 241-AZ-101.

\section{Operating Curve 102-AY to 101-AZ}

Equivalent Length $=1081 \mathrm{ft}$

Hydraulic Change $=6.5 \mathrm{ft}$ drop

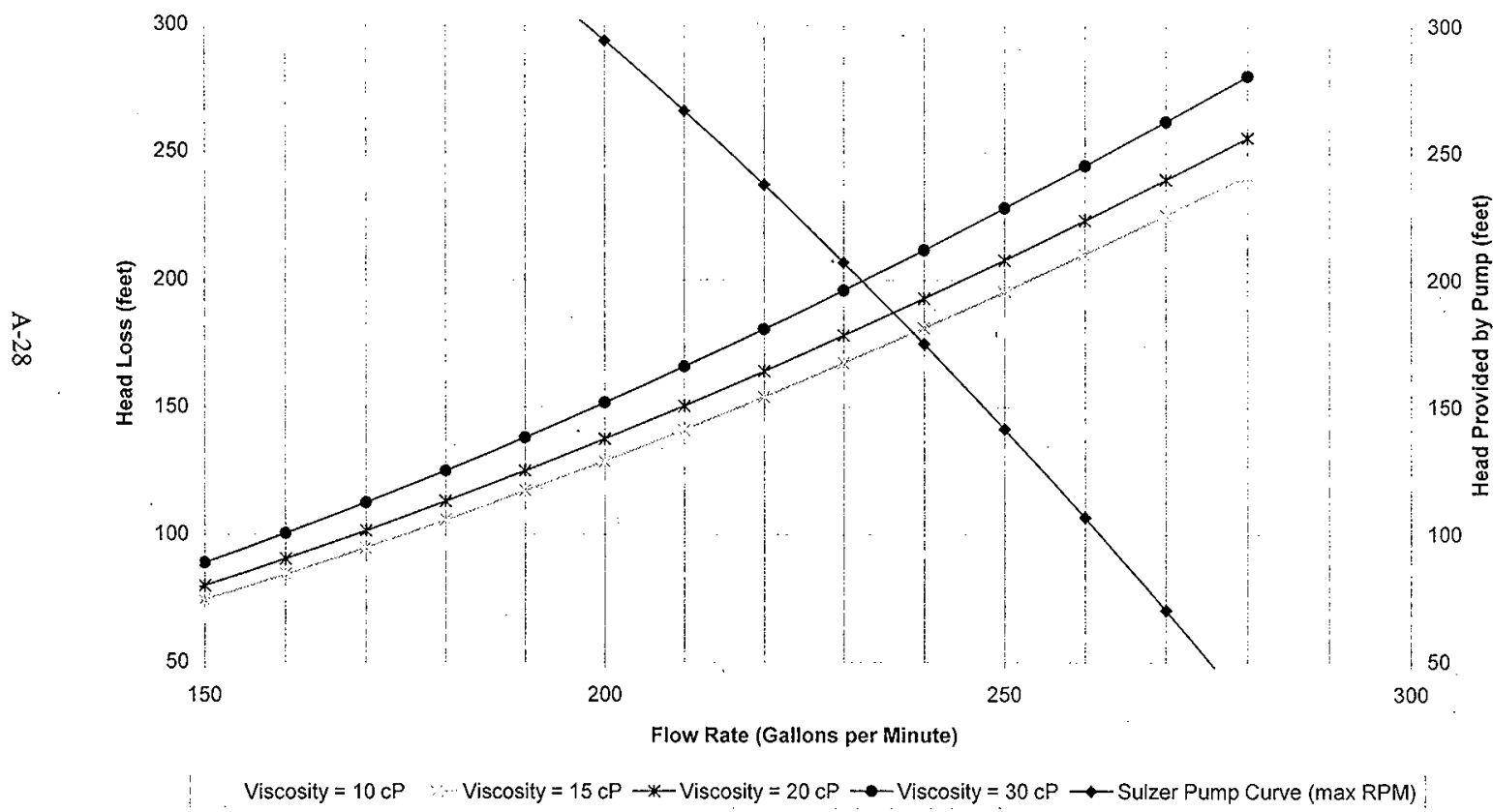


HNF-2941

Revision 0

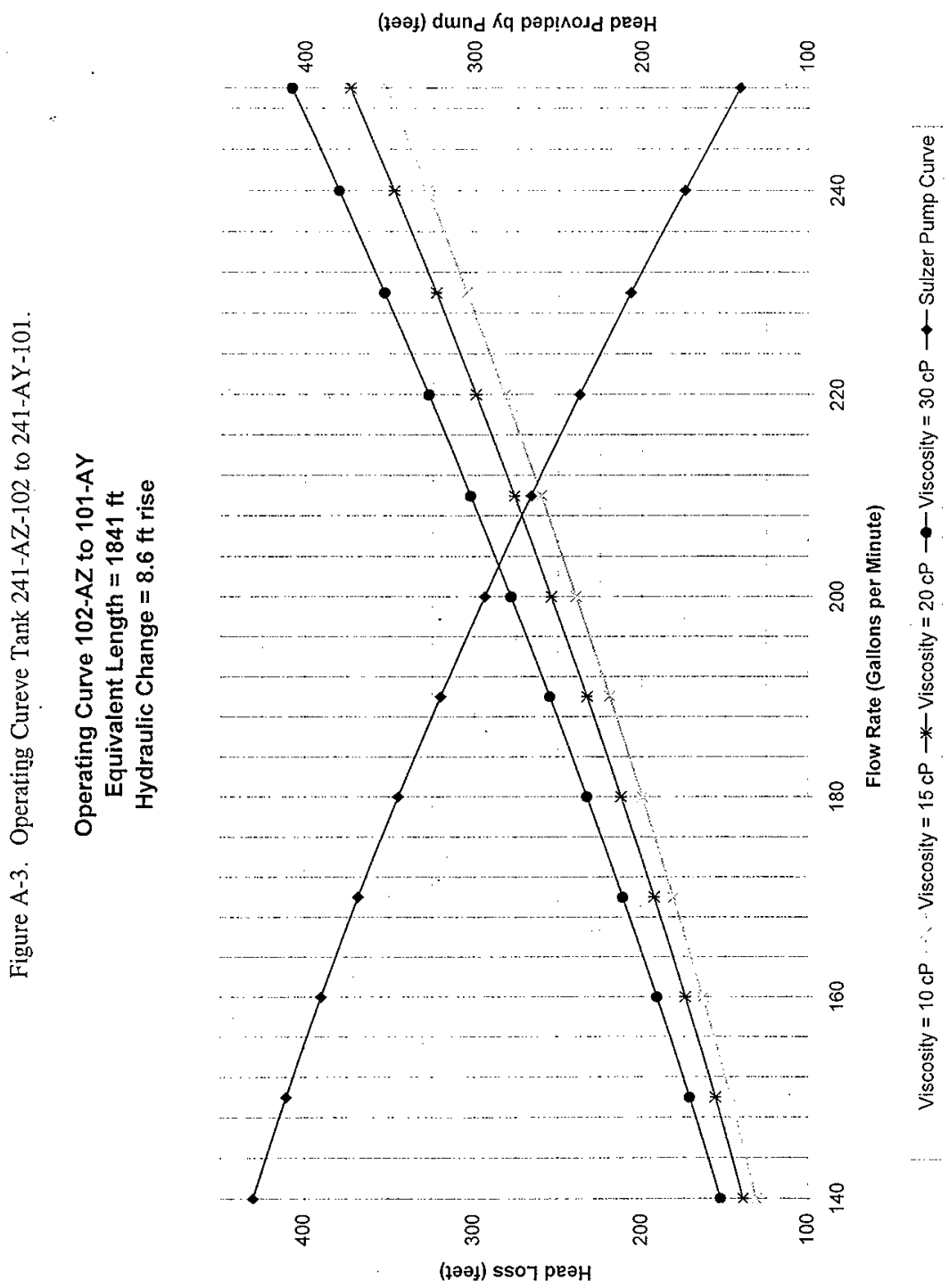


HNF-2941

Revision 0
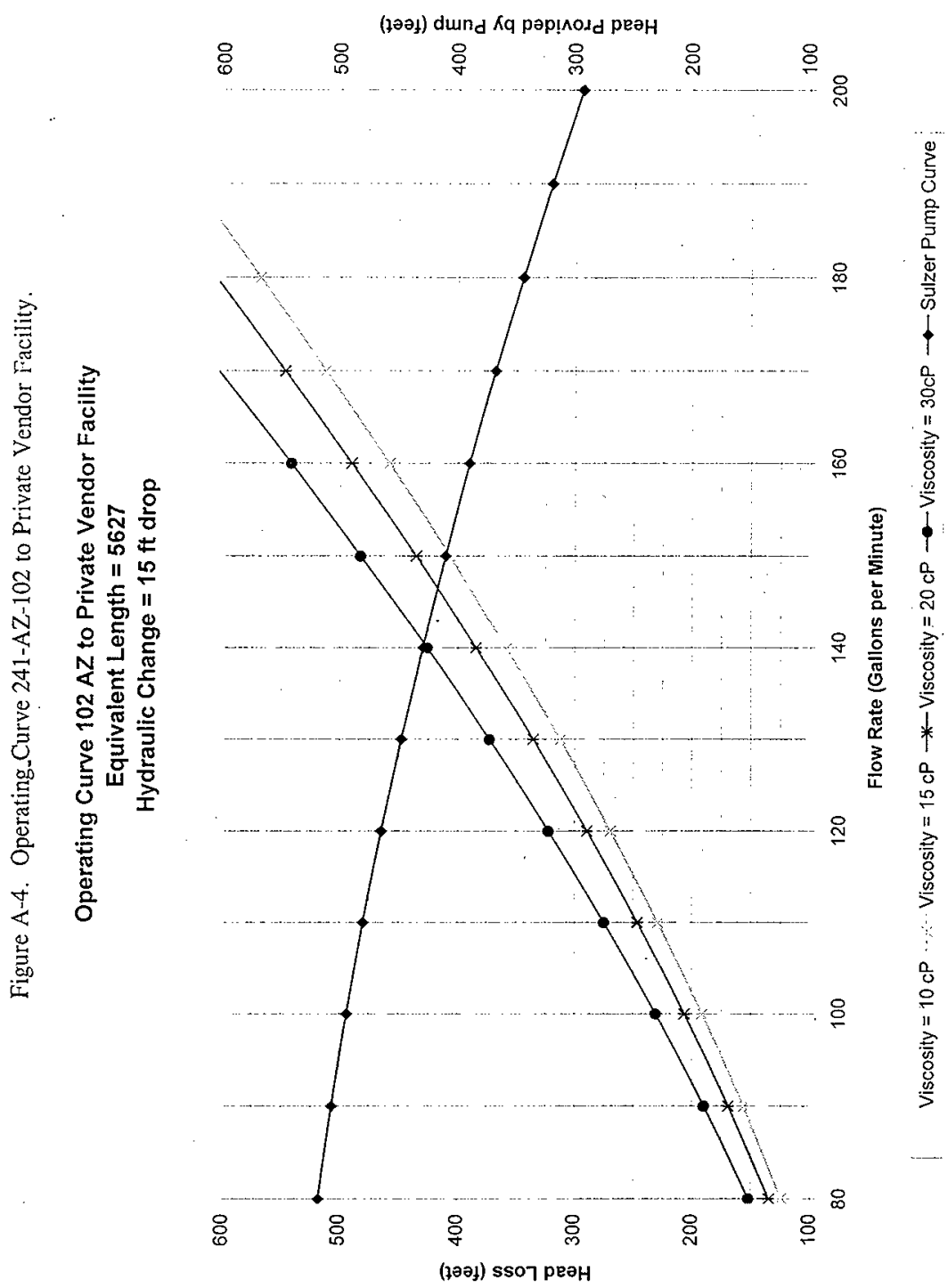


\section{$Z \varepsilon-\forall / I \varepsilon-\forall$}

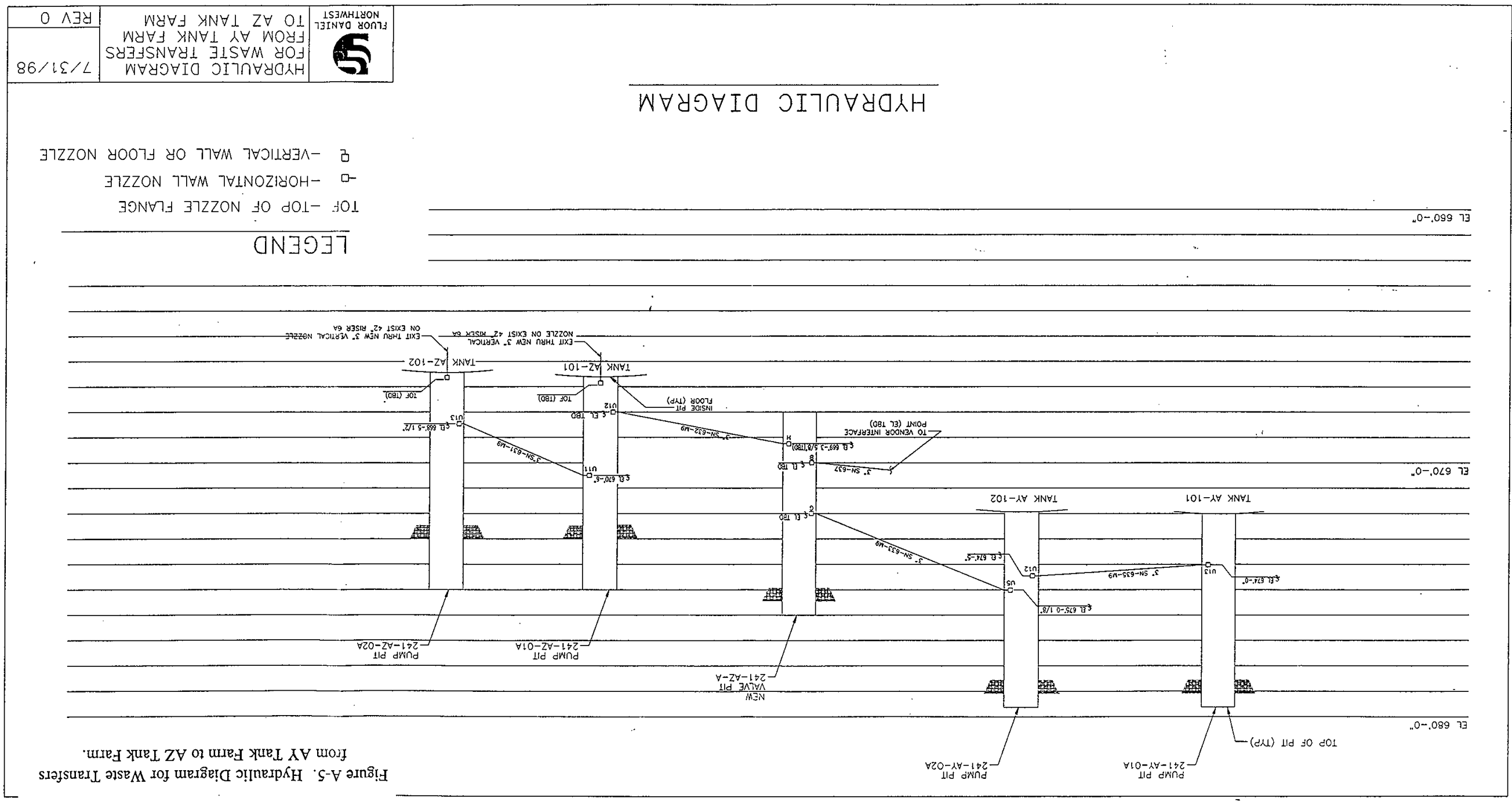

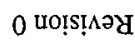

I $62-\mathrm{ANH}$ 
HNF-2941

Revision 0

\section{APPENDIX B}

\section{UTILITY DISTRIBUTION SYSTEM PROCESS NEEDS AND ASSESSMENT}


HNF-2941

Revision 0

This page intentionally left blank.

B-2 
HNF-2941

Revision 0

\section{APPENDIX B}

\section{UTILITY DISTRIBUTION SYSTEM PROCESS NEEDS AND ASSESSMENT}

Table 4-1 contains quantitative process needs that must be met in order to enable Tank Waste Remediation System (TWRS) to adequately deliver appropriate waste feed during Phase 1 privatization. A number of these quantitative process needs are specific to and rely on specific performance of the utility distribution systems which must be present to support feed delivery to the Phase 1 privatization contractor as well as ongoing TWRS operations (e.g., single-shell tank (SST) waste retrieval) during the Phase 1 privatization time frame. For the purposes of this evaluation of 241-AZ tank farm, the utility distribution systems have been categorized into four major subsystems: compressed and instrument air; raw water; electrical power and steam. The quantitative process needs identified in Table 4-1 that apply to each of these subsystems is discussed in the sections below. Table B-1 identifies whether existing or planned utility distribution systems are adequate to meet the process needs associated with Phase 1 privatization feed delivery.

\section{B.1 COMPRESSED/INSTRUMENT AIR SYSTEM}

\section{B.1.1 PROCESS NEEDS}

, The quantitative process needs which apply to the utility distribution system, including -compressed/instrument air, are summarized as part of Table B-1 below. Any transfer system instrumentation requiring compressed/instrument air is expected to receive it from the compressed/instrument air system for the 241-AZ tank farm.

\section{B.1.2 EXISTING AND PLANNED COMPRESSED/INSTRUMENT AIR SYSTEM}

The 241-AZ and 241-AY tank farms share an instrument air system which is located in the 701-A Building. It consists of two large capacity air compressors with a large capacity reservoir. Additionally, there are two emergency backups and generators. The system is capable of providing sufficient air to the Air Lift Circulators (ALCs) in the Aging Waste Facility. Therefore, any instrument air requirements can easily be accommodated by this

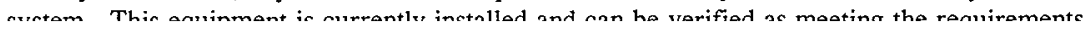




\section{B.1.3 COMPARISON OF EXISTING AND PLANNED EQUIPMENT TO PROCESS NEEDS}

The 241-AZ tank farm transfer system contains one instrument requiring instrument air: the weight factor leak detectors in the leak detections pits. Because the compressed/instrument air system is sized to provide sufficient air flow to the ALCs, it is sufficient to provide instrument air to the weight factor leak detectors.

\section{B.2 RAW WATER SYSTEM}

\section{B.2.1 PROCESS NEEDS}

The quantitative process needs which apply to the utility distribution system, including raw water, are summarized as part of Table B-1 below. Raw water is expected to be supplied at variable flows with maximum flow rate of at least $530 \mathrm{~L} / \mathrm{min}(140 \mathrm{gal} / \mathrm{min})$ at $5.84 \mathrm{kPa}$ (70 psi) to allow for in-line dilution for the transfer pumps, in-tank dilution and pipeline preheating and flushing.

\section{B.2.2 EXISTING AND PLANNED RAW WATER SYSTEM}

Currently, tanker trucks transport all raw water used in 241-AZ tank farm (Powell, 1998). The raw water is then delivered to the transfer line or tank via the tanker truck booster pump and some sort of jumper or connection to the transfer line.

The raw water system in 241-AZ tank farm will be upgraded by Project W-211 for 102-AZ waste dilution and pipeline flushing. Although a specific interface point has not been chosen, a number of options exist, Refer to HNF-1507, Interface Document, Project W-211, Initial Tank Retrieval System. The existing system will adequately support transfer line flushing operations.

\section{B.2.3 COMPARISON OF EXISTING AND PLANNED EQUIPMENT TO PROCESS NEEDS}

The Project W-211 raw water system upgrade will provide raw water at $530 \mathrm{~L} / \mathrm{min}$ (140 gal $/ \mathrm{min})$ and $5.84 \mathrm{kPa}(70 \mathrm{psi})$ (Rieck 1998). Therefore, the future upgrade to the 241-AZ tank farm raw water system will be sufficient to support dilution and flushing activities. 
HNF-2941

Revision 0

\section{B.3 ELECTRICAL POWER}

\section{B.3.1 PROCESS NEEDS}

The quantitative process needs that apply to the utility distribution system, including electrical power, are summarized as part of Table B-1 below. The existing power distribution system for 241-AZ tank farm is not expected to allow operation of all existing equipment. Historical electrical metering data indicate that spare capacity does not exist to support the planned waste retrieval and transfer operations.

\section{B.3.2 EXISTING AND PLANNED ELECTRICAL POWER DISTRIBUTION SYSTEM}

The power system is described via two main functions, the electrical distribution system to the $\mathrm{AZ}$ farm and distribution within the farm.

The substation installed by Project W-151 is fed from $13.8 \mathrm{KV}$ line number C8-L6. The capacity of this line is approximately $7 \mathrm{MW}$ and the existing average demand load is approximately $3 \mathrm{MW}$.

The new substation installed by Project W-151 for AZ tank farm is being modified by Project W-211 to add variable frequency drives (VFDs) for two mixing pumps and a transfer pump in tank 241-AN-105, and to provide a dilution system to serve the AN, AY, and AZ tank farms. Transfer switches will be provided by Project W-211 to facilitate connection of future retrieval systems in other AN farm tanks. The system configuration will also allow operation of one mixer pump in each of $\mathrm{AN}$ and $\mathrm{AZ}$ farms simultaneously.

\section{B.3.3 COMPARISON OF EXISTING AND PLANNED EQUTPMENT TO PROCESS NEEDS}

The power system is also evaluated by examining the two main required functions, the electrical distribution system to the $\mathrm{AZ}$ farm and the distribution within the farm.

The existing tank farms electrical supply may not be adequate to supply either the process need maximum load or the schedule based maximum electrical load. The process need load is more conservative than the postulated schedule load. The process need requires the independent operation of retrieval equipment in each of the four 200 East Area DST farms. This is equivalent to running two mixer pumps and one transfer pump in each farm, or, eight 224-kW (300-hp) mixer pumps and four $44 \mathrm{~kW}(60-\mathrm{hp})$ transfer pumps. The postulated schedule load is based on the integrated schedules. The integrated schedules show that at least 
once in each of the first three years of processing up to nine mixer pumps and one transfer pump may be needed simultaneously to suspend and transfer solids.

The capacity of the C8-L6 line is approximately $7 \mathrm{MW}$ and the existing average demand load is approximately $3 \mathrm{MW}$. The power requirement for a pair of 224-kW (300-hp) mixing pumps and a $44-\mathrm{kW}(60-\mathrm{hp})$ transfer pump is about $640 \mathrm{KVA}$. The simultaneous operation of nine mixer pumps (one set of mixers in each of 241-AY-102 (four 112-kW [150-hp]), AZ Farm (two 224-kW [300-hp]) and AN (or AW) Farm (two 224-kW [300-hp]) and one (224-kW [300-hp]) mixer in AP Farm) cannot be achieved. Load flow and voltage drop analysis of $13.8 \mathrm{KV}$ line C8-L6 indicates that the line cannot provide power to the postulated schedule maximum TWRS load of nine mixer pumps and one transfer pump operating simultaneously without experiencing excessive voltage drop in the tank farm area. The voltage drop will also be excessive for the process need requirement since it is more conservative than the postulated schedule load. To resolve this potential issue the possibility of transferring some tank farm loads to other electrical supply lines in the area (lines C8-L5 and C8-L8 are the most likely candidates) could be explored. Or, a more detailed examination of schedule constraints for simultaneous operation of nine mixer pumps could be examined and the process need for independent operation of each farm can be modified. The load flow study is summarized in Appendix F.3.1. A load projection study is also in progress to evaluate the changes in other loads on the distribution line in future years.

The modifications being made by.project W-211 will result in the existence of enough VFDs to operate four mixing pumps simultaneously. The 1000 KVA substation in 241-AN tank farm currently will have enough capacity to run two mixer pumps and two transfer pumps for the AN and AZ farms combined. However, the transformer will need to be upgraded to operate two mixer pumps and a transfer pump in each farm simultaneously. Overall, the process need to provide for the simultaneous operation of nine mixer pumps (one set of mixers in each of 241-AY-102 [four $112 \mathrm{~kW}(150 \mathrm{hp})$ ], AZ Farm [two $224 \mathrm{~kW}$ (300 hp)] and AN [or AW] Farm [two $224 \mathrm{~kW}$ (300 hp)] and one 224-kW [300-hp] mixer in AP Farm) cannot be achieved.

In addition, it is uncertain at this time whether the 241-AN tank farm ventilation system would be able to support the effects of heat input from more than two mixer pumps operating at full speed (Rieck 1998).

In summary, the substation will operate two mixer pumps and two transfer pumps simultaneously in AN farm and/or AZ farm. However, the substation will require a transformer upgrade in order to operate two mixer pumps and a transfer pump in each farm simultaneously. In addition, the possibility of transferring some tank farm loads to other electrical supply lines in the area, e.g., lines C8-L5 and C8-L8 should be explored. Conversely, a detailed examination of schedule constraints for simultaneous operation of nine mixer pumps or the process need for independent operation of each farm may also be considered or required. 
HNF-2941

Revision 0

\section{B.4 STEAM}

\section{B.4.1 PROCESS NEEDS}

No process needs for steam have been identified for 241-AZ tank farm. Any 241-AZ tank farm transfer system components requiring steam are expected to receive it from the 241AY tank farm steam coil system.

\section{B.4.2 EXISTING AND PLANNED STEAM SYSTEM}

The 241-AY tank farm steam coil system is capable of providing steam to the steam heater units in each of the waste tanks in the 241-AZ tank farm. However, these steam heater units are non-operational. The last time they were operated was in 1983, in support of plutonium-uranium extraction (PUREX) startup. The coils had developed considerable leaks at that time. Presently, the steam system is isolated from the steam heater coils (Powell 1998).

\section{B.4.3 COMPARISON OF EXISTING AND PLANNED EQUIPMENT TO PROCESS NEEDS}

The existing steam heaters are not required to meet any transfer system process needs. No needs for steam have been identified within the 241-AZ tank farm to support Phase 1 privatization. Therefore, the 241-AZ tank farm steam system is sufficient for waste feed delivery.

\section{B.5 REFERENCES}

Rieck, C. A., 1998, Interface Document, Project W-211, Initial Tank Retrieval Systems, HNF-1507, Rev. 0, Numatec Hanford Corporation, Richland, Washington.

LMHC, 1998, TWRS Administration Manual, Volume IV, Section 5.4, HNF-IP-0842, Rev. 10g, Lockheed Martin Hanford Corporation, Richland, Washington.

LMHC, 1997, Tank Waste Remediation System Technical Safety Requirements, HNF-SD-WM-TSR-006, Rev 0-L, Lockheed Martin Hanford Corporation, Richland, Washington. 
Table B-1. Comparison of Process Needs to Existing and Planned Equipment for Utilities in 241-AZ Tank Farm.

\begin{tabular}{|c|c|c|c|c|}
\hline $\begin{array}{l}\text { Quantitative tank-specific } \\
\text { process need }\end{array}$ & $\begin{array}{l}\text { Existing or planned structure, } \\
\text { system, or component }\end{array}$ & $\begin{array}{l}\text { Is existing and platned } \\
\text { equipment adequate } \\
\text { (Yes/No) }\end{array}$ & Basis & Comments/issues \\
\hline $\begin{array}{l}\text { 4.P2.1Provide capability } \\
\text { for addition of } \\
\text { approximately } 379 \mathrm{~m}^{3} \\
\text { (100,000 gal) of inhibited } \\
\text { water to } 241-\mathrm{AZ}-101 \text { and } \\
241-\mathrm{AZ}-102 \text { for each of the } \\
\text { final two slurry transfers to } \\
\text { the Privatization } \\
\text { Contractor. The inhibited } \\
\text { water shall meet the } \\
\text { minimum corrosion } \\
\text { specifications of } 0.01 \mathrm{M} \\
\mathrm{OH}^{-} \text {and } 0.011 \mathrm{M} \mathrm{NO}_{2}^{-}\end{array}$ & $\begin{array}{l}\text { Raw water system will feed } \\
\text { the } A Z \text { farm and the dilution } \\
\text { system. }\end{array}$ & Yes & $\begin{array}{l}\text { Per HNF-1507, Appendix D, Section } \\
\text { D.2.13. }\end{array}$ & $\begin{array}{l}\text { Raw Water System is capable of } \\
\text { providing water to the diluent } \\
\text { system for treatment. The } \\
\text { required flow rate must he } \\
\text { specified to complete the } \\
\text { evaluation of the system } \\
\text { adequacy. }\end{array}$ \\
\hline $\begin{array}{l}\text { 4.P2.2. Provide a diluent } \\
\text { system and water addition } \\
\text { line to allow addition of up } \\
\text { to } 341 \mathrm{~m}^{3} \text { (90,000 [TBR] } \\
\text { gal) raw water near the } \\
\text { intake of each mixer pump. } \\
\text { The dilution system should } \\
\text { be capable of providing this } \\
\text { quantity at a flow rate of } \\
\text { TBD gal/min. }\end{array}$ & $\begin{array}{l}\text { Raw water system will feed } \\
\text { the } A Z \text { farm and the dilution } \\
\text { system. }\end{array}$ & Yes & $\begin{array}{l}\text { Per HNF-1507, Appendix D, Section } \\
\text { D.2.13. }\end{array}$ & $\begin{array}{l}\text { Raw Water System is capable of } \\
\text { providing water to the mixer } \\
\text { pump systems. The required } \\
\text { flow rate must be specified to } \\
\text { complete the evaluation of the } \\
\text { system adequacy. }\end{array}$ \\
\hline
\end{tabular}


Table B-1. Comparison of Process Needs to Existing and Planned Equipment for Utilities in 241-AZ Tank Farm.

\begin{tabular}{|c|c|c|c|c|}
\hline $\begin{array}{c}\text { Quantitative tank-specific } \\
\text { process need }\end{array}$ & $\begin{array}{l}\text { Existing or planned structure, } \\
\text { system, or component }\end{array}$ & $\begin{array}{l}\text { Is existing and planned } \\
\text { equipment adequate } \\
\text { (Yes/No) }\end{array}$ & Basis & Comments/issues \\
\hline $\begin{array}{l}\text { 5.P4.1. Provide for the } \\
\text { independent operation of } \\
\text { one set of mixer pumps in } \\
\text { each of four } 200 \text { East Area } \\
\text { DST farms and one } \\
\text { transfer pump in a } 200 \text { East } \\
\text { Area DST farm. } \\
\text { Provide control systems } \\
\text { and electrical distribution } \\
\text { systems which can support } \\
\text { the simultaneous operation } \\
\text { of up to nine mixer pumps } \\
\text { and one transfer pump. } \\
\text { The electrical distribution } \\
\text { system shall have a } \\
\text { capacity to run } 9 \text { pumps } \\
\text { totaling } 1,600 \mathrm{~kW} \\
\text { (2,100 hp) or } 2 \mathrm{MVA} \text { with } \\
\text { capacity to hatdle inrush } \\
\text { currents }\end{array}$ & $\begin{array}{l}\text { The existing C8-L6 line is } \\
\text { adequate for loads up to } 10 \\
\text { MVA. Enough VSDs will } \\
\text { be present in building } \\
241-A Z-156 \text { to run two sets } \\
\text { of mixer and transfer pumps. } \\
\text { However, the transformer } \\
\text { only has capacity to run one } \\
\text { set. Therefore, If more than } \\
\text { two mixer pumps are to be } \\
\text { run simultaneously in the } \\
\text { AN/AZ farms, the } \\
\text { transformer will have to be } \\
\text { replaced. }\end{array}$ & No & $\begin{array}{l}\text { Refer to Analysis in } \Lambda \text { ppendix } F \text {, } \\
\text { Section F.3.1. } \\
\text { If more than two mixer pumps are to } \\
\text { be run simultaneously in the } A N / A Z \\
\text { farms, the transformer will have to be } \\
\text { replaced. }\end{array}$ & $\begin{array}{l}\text { In-rusll current capacity is not } \\
\text { expected to be an issue due to } \\
\text { the "soft" starts to be performed } \\
\text { via the VFD's. }\end{array}$ \\
\hline
\end{tabular}


Table B-1. Comparison of Process Needs to Existing and Planned Equipment for Utilities in 241-AZ Tank Farm.

\begin{tabular}{|c|c|c|c|c|}
\hline $\begin{array}{l}\text { Quantitative tank-specilic } \\
\text { process need }\end{array}$ & $\begin{array}{l}\text { Existing or planned structure, } \\
\text { system, or component }\end{array}$ & $\begin{array}{l}\text { Is existing and planned } \\
\text { equipment adequate } \\
\text { (Yes/No) }\end{array}$ & Basis & Comments/issues \\
\hline $\begin{array}{l}\text { 9.P1.2. Provide transfer } \\
\text { pumps with a water } \\
\text { addition feature that will } \\
\text { provide slurry dilution } \\
\text { capability at the pump } \\
\text { suction. The needed } \\
\text { dilution water flow rate is } \\
265 \mathrm{~L} / \mathrm{min} \text { ( } 70 \text { gal } / \mathrm{min} \text { ) } \\
\text { (TBR). Pipeline transfer } \\
\text { parameters of interest } \\
\text { include pressure drop and } \\
\text { solids deposition. The } \\
\text { quantity of diluent is } \\
\text { determined on a transfer by } \\
\text { transfer basis such that } \\
\text { pipeline operating pressures } \\
\text { are not exceeded and } \\
\text { calculated critical settling } \\
\text { velocities are < } 1.2 \mathrm{~m} / \mathrm{sec} \\
\text { (4 } \mathrm{ft} / \mathrm{sec} \text { ). }\end{array}$ & $\begin{array}{l}\text { Raw water system will feed } \\
\text { the } A Z \text { farm. }\end{array}$ & Yes & $\cdot$ & $\begin{array}{l}\text { Raw Water System is capable of } \\
\text { providing water to the Diluent } \\
\text { systems. The adequacy of the } \\
\text { raw water flow rate must be } \\
\text { verified at the design review. }\end{array}$ \\
\hline $\begin{array}{l}\text { 9.P4.1. Provide a diluent } \\
\text { system the transfer lines } \\
\text { with raw or inhibited water } \\
\text { at } 530 \mathrm{~L} / \mathrm{min}(140 \mathrm{gal} / \mathrm{min}) \\
\text { (rBR). }\end{array}$ & $\begin{array}{l}\text { Raw water system will feed } \\
\text { the } A Z \text { farm. }\end{array}$ & Yes & $\begin{array}{l}\text { Per HNF-1507, Appendix D. Section } \\
\text { D.2.13. }\end{array}$ & $\begin{array}{l}\text { Raw Water System is capable of } \\
\text { providing water to the Diluent } \\
\text { systems. The adequacy of the } \\
\text { raw water flow rate must be } \\
\text { verified at the design review. }\end{array}$ \\
\hline $\begin{array}{l}\text { 9.P4.3. Flush transfer lines } \\
\text { with water volumes } \\
\text { equivalent to } 1.5 \text { times the } \\
\text { transfer line internal } \\
\text { volume. }\end{array}$ & $\begin{array}{l}\text { Raw water system will feed } \\
\text { the } \Lambda Z \text { farm. }\end{array}$ & Yes & $\begin{array}{l}\text { Per HNF-1507, Appendix D, Section } \\
\text { D.2.13. }\end{array}$ & $\begin{array}{l}\text { Raw Water System is capable of } \\
\text { providing water to the Diluent } \\
\text { systems. The adequacy of the } \\
\text { raw water flow rate must be } \\
\text { verified at the design revicw. }\end{array}$ \\
\hline
\end{tabular}

General Noles

1. It is understood that several systems will require electrical utility support, i.e., monitoring and/or control systems, the ventilation systems, etc. An enabling assumption for this evaluation is that the existing electrical system is capable of meeting the requirements for these systems, i.e., low demand systems. The point is further made here that a low demand system is a system with an order of magnitude less power requirements than a $300 \mathrm{HP}$ pumps or large scale ventilation systems with large blowers, chillers, and associated support systems. 
Table B-2. Comparison of Safety Requirements to Existing And Planned Equipment For Utilities in 241-AZ Tank Farm.

\begin{tabular}{|c|c|c|c|c|}
\hline $\begin{array}{c}\text { Quantitative tank-specific } \\
\text { process need }\end{array}$ & $\begin{array}{c}\text { Existing or planned structure, } \\
\text { system or component }\end{array}$ & $\begin{array}{l}\text { Is existing and planned } \\
\text { equipment adequate } \\
\text { (Yes/No) }\end{array}$ & Basis & Comments/issues \\
\hline $\begin{array}{l}\text { 1.S5.1. Service water } \\
\text { pressure detection systems } \\
\text { that are physically } \\
\text { connected to an active } \\
\text { waste transfer pump not } \\
\text { under administrative lock } \\
\text { shall be operable. }\end{array}$ & $\begin{array}{l}\text { Equipment in place, planned } \\
\text { or to be covered by } \\
\text { procedure. }\end{array}$ & Yes & $\begin{array}{l}\text { Per HNF-IP-0842, Volume IV, } \\
\text { Section 5.4, a USQ review will be } \\
\text { required for all, ECN's, New Design } \\
\text { Media, operating procedures, or } \\
\text { changes to the facility, to ensure the } \\
\text { TSR requirements are met. }\end{array}$ & \\
\hline $\begin{array}{l}8 . S 3.4 \text { Tank } 241-A Z-101 \\
\text { air lift circulation must be } \\
\text { operable when waste } \\
\text { solution temperature is } \\
>93^{\circ} \mathrm{C}\left(200^{\circ} \mathrm{F}\right) \text { and } \\
\text { when sludge temperature is } \\
>110^{\circ} \mathrm{C}\left(230^{\circ} \mathrm{F}\right) \text {. } \\
\text { Note: it is assumed that this } \\
\text { will also be applicable to } \\
\text { tank } 241-A Z-102 \text {. }\end{array}$ & Equipment in place. & Yes & $\begin{array}{l}\text { Documented on H-2-68335. Per } \\
\text { HNF-IP-0842, Volume IV, Section } \\
5.4 \text {, a USQ review will be required } \\
\text { for all, ECN's, New Design Media, } \\
\text { operating procedures, or changes to } \\
\text { the facility, to ensure the TSR } \\
\text { requirements are met }\end{array}$ & - \\
\hline $\begin{array}{l}\text { 8.S2.1. Provide instrument } \\
\text { air to weight factor leak } \\
\text { detection systems at an } \\
\text { appropriate flow rate and } \\
\text { pressure. }\end{array}$ & Equipment in place & Yes & $\begin{array}{l}\text { Documented on H-2-68335. Per } \\
\text { HNF-IP-0842, Volume IV, Section } \\
5.4 \text {, a USQ review will be required } \\
\text { for all, ECN's, New Design Media, } \\
\text { operating procedures, or changes to } \\
\text { the facility, to ensure the TSR } \\
\text { requirements are met. }\end{array}$ & . \\
\hline $\begin{array}{l}\text { 9.S1.2. Provide instrument } \\
\text { air to weight factor leak } \\
\text { detection systems at an } \\
\text { appropriate flow rate and } \\
\text { pressure. }\end{array}$ & Equipment in place. & Yes & $\begin{array}{l}\text { Documented on H-2-68335. Per } \\
\text { HNF-IP-0842, Volume IV, Section } \\
5.4 \text {, a USQ review will be required } \\
\text { for all, ECN's, New Design Media, } \\
\text { operating procedures, or changes to } \\
\text { the facility, to ensure the TSR } \\
\text { requirements are met. }\end{array}$ & . \\
\hline
\end{tabular}


HNF-2941

Revision 0

This page intentionally left blank. 
HNF-2941

Revision 0

\section{APPENDIX C}

\section{INSTRUMENTATION, MONITORING, AND CONTROL PROCESS NEEDS AND ASSESSMENT}


HNF-2941

Revision 0

This page intentionally left blank. 


\section{APPENDIX C}

\section{INSTRUMENTATION, MONITORING, AND CONTROL PROCESS NEEDS AND ASSESSMENT}

Operations supporting waste feed delivery must be monitored and controlled to stay within an approved authorization safety basis as well as to deliver waste feed within the constraints established by the Phase 1 privatization contract. Successful waste retrieval and delivery of the proper composition waste feed to the private contractor within schedule requires that in-tank processing and tranșfers be effectively controlled. Development and implementation of a successful process monitoring and control system requires that overall process operational needs be clearly defined.

\section{C.1 PROCESS NEEDS}

Process control parameters for process operations, to maintain safe operation and to respond to off-normal conditions are presented in Tables $\mathrm{C}-1, \mathrm{C}-2$ and $\mathrm{C}-3$ respectively. Table $\mathrm{C}-4$ identifies manipulated parameter(s) and monitored variable(s) for each control parameter identified in Tables $\mathrm{C}-1$ through $\mathrm{C}-3$. Table $\mathrm{C}-5$ identifies monitoring and control instrumentation based on the monitoring methods established in Table $\mathrm{C}-4$.

\section{C.2 EXISTING AND PLANNED MONITORING, INSTRUMENTATION AND CONTROL EQUIPMENT}

Table C-6 identifies the existing and planned monitoring, instrumentation and control equipment for 241-AN tank farm. The project responsible for placement of the equipment in the tank farm is also identified for that monitoring, instrumentation and control equipment which is planned.

\section{C.3 COMPARISON OF EXISTING AND PLANNED MONITORING, INSTRUMENTATION AND CONTROL EQUIPMENT TO PROCESS NEEDS}

Table C-7 compares the process monitoring and control needs established in Tables $\mathrm{C}-1$ through $\mathrm{C}-5$ to the existing and planned monitoring, instrumentation and control equipment identified in Table $\mathrm{C}-6$. Table $\mathrm{C}-7$ identifies whether the existing and planned equipment is adequate to meet the process needs for monitoring and control and also establishes the technical basis for whether or not the existing or planned equipment is adequate. 
Table C-1. Process Control Parameters for 241-AZ Tank Farm Supporting Phase 1 Feed Delivery.

\begin{tabular}{|c|c|c|c|c|}
\hline Process step. & Qualitative process need & Quantitative tank-specific process need & Control parameter(s) & Comments/issues \\
\hline 1. Safe Storage & See Table 4.2 & See Table 4.2 & See Table 4.2 & $\cdot$ \\
\hline \multirow{2}{*}{$\begin{array}{l}\text { 2. Degas Feed } \\
\text { (This process } \\
\text { step/need } \\
\text { applies only to } \\
\text { flammable gas } \\
\text { watch list tanks } \\
241-A N-103 \text {, } \\
241-A N-104 \\
\text { and } \\
241-A N-105 \text {, } \\
241-A W-101 \text {, } \\
241-S Y-101 \text {, } \\
\text { and } \\
241-S Y-103 \text { ) }\end{array}$} & $\begin{array}{l}\text { P1. Remove trapped flammable } \\
\text { gases from waste prior to } \\
\text { transfer to eliminate or reduce } \\
\text { probability of occurrence of a } \\
\text { gas release event. }\end{array}$ & 1. Reserved (None) & $\begin{array}{l}\text { Process step Not Applicable to } 241 \text {-AZ } \\
\text { Tanks. (N/A) }\end{array}$ & \\
\hline & $\begin{array}{l}\text { P2. Control rate of gas release } \\
\text { from flamnable gas watch list } \\
\text { tanks. }\end{array}$ & 1. Reserved (None) & N/A & \\
\hline $\begin{array}{l}\text { 3. Separate } \\
\text { Solids and } \\
\text { Liquids }\end{array}$ & $\begin{array}{l}\text { P1. Provide LAW feed to the } \\
\text { private contractor within the } \\
\text { contract envelope limits for } \\
\text { insoluble solids. }\end{array}$ & 1. Reserved (None) & $\mathrm{N} / \mathrm{A}$ & \\
\hline \multirow[t]{3}{*}{$\begin{array}{l}\text { 4. Dissolve } \\
\text { Solids }\end{array}$} & $\begin{array}{l}\text { P1. Dissolve soluble precipitated } \\
\text { salts in selected DSTs. Selected } \\
\text { DSTs are } 241-A N-103 \text {, } \\
241-A N-104,241-A N-105 \text {, } \\
241-A W-101,241-S Y-101 \text {, and } \\
241-S Y-103 \text {. }\end{array}$ & 1. Reserved (None) & $\mathrm{N} / \mathrm{A}$ & . \\
\hline & $\begin{array}{l}\text { 2. Allow operation of } \\
\text { equipment (bottom } \\
\text { thermocouples, mixer pumps, } \\
\text { decant pumps, slurry transfer } \\
\text { pumps) }\end{array}$ & 1. Reserved (See 5B.P2.1) & See SB.P2.I & . \\
\hline & $\begin{array}{l}\text { P3. Retrieve waste from } \\
\text { multiple tanks as needed to } \\
\text { support waste feed delivery } \\
\text { schedule. }\end{array}$ & 1. Reserved (See 5B.P4.1) & See SB.P4.1 & \\
\hline
\end{tabular}


Table C-1. Process Control Parameters for 241-AZ Tank Farm Supporting Phase 1 Feed Delivery.

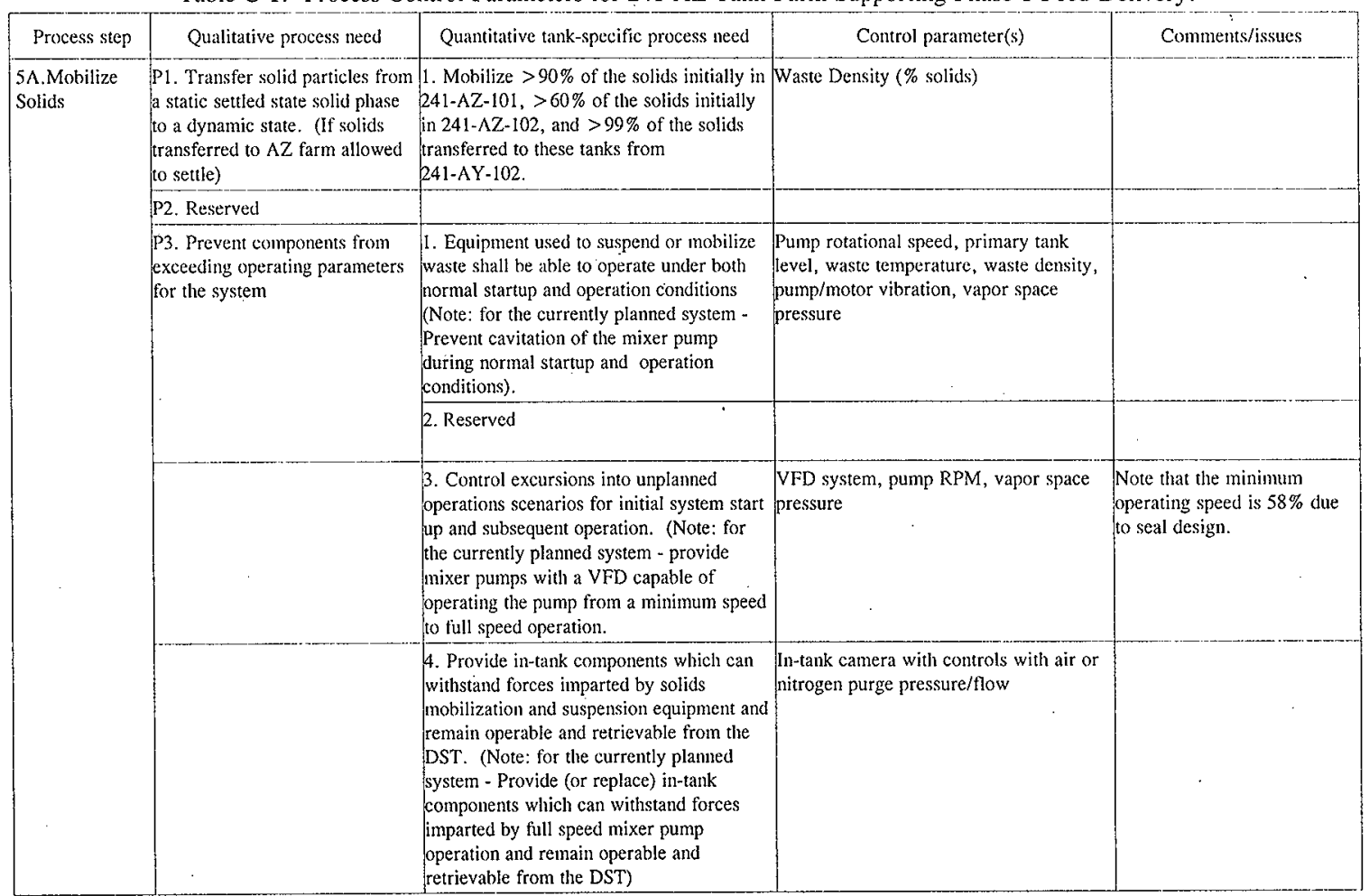


Table C-1. Process Control Parameters for 241-AZ Tank Farm Supporting Phase 1 Feed Delivery.

\begin{tabular}{|c|c|c|c|c|}
\hline Process step & Qualitative process need & Quantitative tank-specific process need & Control parameter(s) & Comments/issues \\
\hline \multirow[t]{2}{*}{$\begin{array}{l}\text { 5A.Mobilize } \\
\text { Solids (cont.) }\end{array}$} & & $\begin{array}{l}\text { 5. Provide solids mobilization and } \\
\text { suspension equipment which will not } \\
\text { damage the tank structure during normal } \\
\text { and/or off-normal operation. (Note: for } \\
\text { the currently planned system - Provide } \\
\text { mixer pumps which will not damage the } \\
\text { tank structure during normal and/or off- } \\
\text { normal operation.) }\end{array}$ & $\begin{array}{l}\text { In-tank camera with controls with air or } \\
\text { nitrogen purge pressure/flow }\end{array}$ & \\
\hline & & $\begin{array}{l}\text { 6. Monitor the rate of operation of } \\
\text { equipment used to effect solids } \\
\text { mobilization and suspension. (Note: for } \\
\text { the currently planned system - Provide, at } \\
\text { a minimum, the following mixer pump } \\
\text { instrumentation: remote readout of pump } \\
\text { motor amperage, shaft rotational speed, } \\
\text { and nozzle orientation.) }\end{array}$ & Motor current, RPM, nozzle orientation & \\
\hline \multirow[t]{4}{*}{$\begin{array}{l}\text { 5B. Suspend } \\
\text { Solids }\end{array}$} & $\begin{array}{l}\text { P1. Suspend mobilized solid } \\
\text { particles in the liquid phase. } \\
\text { (Note: for currently planned } \\
\text { system - Mixer pump operation } \\
\text { should mix liquids and suspend } \\
\text { mobilized solids uniformly } \\
\text { throughout the waste solution.) }\end{array}$ & 1.Reserved & Not Applicable to 241-AZ Tanks & \\
\hline & . & $\begin{array}{l}\text { 2. Mix tank contents to provide <TBD\% } \\
\text { variability of suspended HLW solids } \\
\text { concentrations over the full depth prior to } \\
\text { sampling and prior to beginning each feed } \\
\text { transfer. }\end{array}$ & Primary tank waste density (\% solids) & \\
\hline & $\begin{array}{l}\text { P2. Add diluent to allow } \\
\text { operation of equipment }\end{array}$ & $\begin{array}{l}\text { 1. Provide capability for addition of } \\
379 \mathrm{~m}^{3} \text { (100,000 gal) of inhibited water to } \\
241-\mathrm{AZ}-101 \text { and } 241-\mathrm{AZ}-102 \text { for each of } \\
\text { the tinal two slurry transfers to the } \\
\text { Privatization Contractor. The inhibited } \\
\text { water shall meet the minimum corrosion } \\
\text { specifications of } 0.01 \mathrm{M} \mathrm{OH}^{-} \text {and } 0.011 \mathrm{M} \\
\mathrm{NO}_{2}^{-} \text {. }\end{array}$ & $\begin{array}{l}\text { Diluent volume, diluent chemistry, } \\
\text { waste level, waste temperature. }\end{array}$ & \\
\hline & P3. Reserved. & & & \\
\hline
\end{tabular}


Table C-1. Process Control Parameters for 241-AZ Tank Farm Supporting Phase 1 Feed Delivery.

\begin{tabular}{|c|c|c|c|c|}
\hline Process step & Qualitative process need & Quantitative tank-specific process need & Control parameter(s) & Comments/issues \\
\hline $\begin{array}{l}\text { 5B. Suspend } \\
\text { Solids (cont.) }\end{array}$ & $\begin{array}{l}\text { P4. Retrieve waste from } \\
\text { multiple tanks as needed to } \\
\text { support waste feed delivery } \\
\text { schedule. }\end{array}$ & $\begin{array}{l}\text { 1. Provide for the independent operation of } \\
\text { one set of mixer pumps in each of four } 200 \\
\text { East Area DST farms and one transfer } \\
\text { pump in a } 200 \text { East Area DST farm. } \\
\text { Provide control systems and electrical } \\
\text { distribution systems which can support the } \\
\text { independent operation of retrieval } \\
\text { equipment in each of the four } 200 \text { East } \\
\text { Area DST farms and one transfer system } \\
\text { in a } 200 \text { East area DST farm. }\end{array}$ & $\begin{array}{l}\text { None-operational control required but } \\
\text { see note for automatic control limitations } \\
\text { imposed on VFD system for mixer } \\
\text { pumps. }\end{array}$ & $\begin{array}{l}\text { Note that Project W-211 } \\
\text { Initial Tank Retrieval } \\
\text { Systems Description of } \\
\text { Operations for AP-102/104 } \\
\text { (Rev. D, 6/1/98) limits the } \\
\text { simultaneous operation of } 2 \\
\text { mixer pumps to I } 100 \% \\
\text { and 1 @ } 60 \% \text { due to size of } \\
\text { the electrical transformer. }\end{array}$ \\
\hline \multirow[t]{3}{*}{$\begin{array}{l}\text { 6. Sample } \\
\text { Waste }\end{array}$} & $\begin{array}{l}\text { P1. Ensure compatibility } \\
\text { between sending and receiving } \\
\text { tanks }\end{array}$ & $\begin{array}{l}\text { 1. Provide capability for taking multiple } \\
\text { representative grab samples of the waste } \\
\text { trom one or more risers. Waste } \\
\text { compatibility testing is performed per } \\
\text { existing DQOs. }\end{array}$ & Grab sampling system for primary tank. & . \\
\hline & $\begin{array}{l}\text { P2. Confirm waste composition } \\
\text { and inventory within contract } \\
\text { specifications }\end{array}$ & 1.Reserved & & \\
\hline & & $\begin{array}{l}\text { 2. The total sample volume, will meet the } \\
\text { sample volume needs for: analysis of the } \\
\text { tank waste to support feed certification, a } \\
\text { sample to BNFL, and archive sample } \\
\text { material. The tank waste sample provided } \\
\text { to BNFL will contain at least } 200 \text { grams of } \\
\text { solids. Tank waste conditions such as } \\
\text { temperature and tank volume will be } \\
\text { identified at the time of sampling. Samples } \\
\text { of each HLW feed tank will be provided to } \\
\text { the privatization contractor at least } 30 \text { days } \\
\text { prior to the first transfer of such waste to } \\
\text { the contractor's feed tank and no later than } \\
5 \text { days after sampling of the feed batch. }\end{array}$ & \begin{tabular}{|c} 
Grab sampling system. \\
G. \\
\end{tabular} & \\
\hline
\end{tabular}


Table C-1. Process Control Parameters for 241-AZ Tank Farm Supporting Phase 1 Feed Delivery.

\begin{tabular}{|c|c|c|c|c|}
\hline Process step & Qualitative process need & Quantitative tank-specific process need & Control parameter(s) & Comments/issues \\
\hline $\begin{array}{l}\text { 6. Sample } \\
\text { Waste (cont.) }\end{array}$ & & $\begin{array}{l}\text { 3. The HLW tank waste sampling method } \\
\text { (core sampling or grab sample techniques) } \\
\text { will be established for each tank waste } \\
\text { based upon the waste characteristics and } \\
\text { capability of the system. Immediately } \\
\text { following the shutdown of the mixer } \\
\text { pump, approximately equal volume grab } \\
\text { samples of waste material will be obtained } \\
\text { from every } 0.61 \mathrm{~m} \text { ( } 2 \mathrm{ft} \text { ) of waste height } \\
\text { from below a single riser for a grab } \\
\text { sampling technique. (For a core sampling } \\
\text { technique a core the entire height of the } \\
\text { tank waste will be obtained). }\end{array}$ & Grab sampling system. & . \\
\hline \multirow[t]{4}{*}{$\begin{array}{l}\text { 7. Transfer } \\
\text { Supernate from } \\
\text { Tank }\end{array}$} & $\begin{array}{l}\text { P1. Avoid solids accumulation } \\
\text { which could plug the transfer } \\
\text { line. Avoid solids precipitation } \\
\text { during transfer due to cooling or } \\
\text { dilution }\end{array}$ & 1. Reserved (None) & 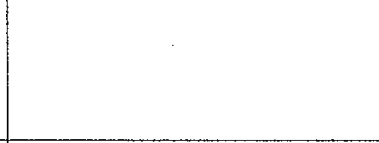 & . \\
\hline & $\begin{array}{l}\text { P2. Remove targeted waste } \\
\text { volumes/levels. }\end{array}$ & 1. Reserved (None) & & \\
\hline & $\begin{array}{l}\text { P3. Prevent components from } \\
\text { exceeding operating parameters } \\
\text { for the system. }\end{array}$ & 1. Reserved (None) & - & \\
\hline & $\begin{array}{l}\text { P4. Capability to flush the } \\
\text { transfer lines with inhibited } \\
\text { water. }\end{array}$ & 1. Reserved (None) & & \\
\hline $\begin{array}{l}\text { 8. Receive } \\
\text { Supernate into } \\
\text { Tank. }\end{array}$ & PI. Do not overfill tank. & 1. Reserved (None) & . & \\
\hline \multirow[t]{2}{*}{$\begin{array}{l}\text { 9. Transfer } \\
\text { Solids Slurry } \\
\text { from Tank }\end{array}$} & $\begin{array}{l}\text { P1. Avoid solids accumulation } \\
\text { which could plug the transfer } \\
\text { line. }\end{array}$ & $\begin{array}{l}\text { 1. Provide transfer system capable of } \\
\text { achieving a waste transfer velocity of } \\
1.8 \text { to } 2.7 \mathrm{~m} / \mathrm{s}(6 \text { to } 9 \mathrm{tt} / \mathrm{sec}) \text {. }\end{array}$ & Slurry flow rate & $\begin{array}{l}\text { Need to correlate flow rate } \\
\text { with transfer piping cross- } \\
\text { sectional aret. }\end{array}$ \\
\hline & & $\begin{array}{l}\text { 2. Provide transfer pumps with a water } \\
\text { addition feature that will provide slurry } \\
\text { dilution capability at the pump suction. } \\
\text { The needed dilution water flow rate is } \\
530 \mathrm{~L} / \mathrm{min}(140 \mathrm{gal} / \mathrm{min}) \text {. }\end{array}$ & $\begin{array}{l}\text { Diluent pressure, diluent flow rate, } \\
\text { Transfer piping pressure, transfer piping } \\
\text { tlow rate, transfer piping differential } \\
\text { pressure (source tank to receiver), slurry } \\
\text { viscosity, slurry density }\end{array}$ & \\
\hline
\end{tabular}


Table C-1. Process Control Parameters for 241-AZ Tank Farm Supporting Phase 1 Feed Delivery.

\begin{tabular}{|c|c|c|c|c|}
\hline Process step & Qualitative process need & Quantitative tank-specific process need & Control parameter(s) & Comments/issues \\
\hline \multirow[t]{7}{*}{$\begin{array}{l}\text { 9. Transfer } \\
\text { Solids Slurry } \\
\text { from Tank } \\
\text { (cont.) }\end{array}$} & $\begin{array}{l}\text { P2. Remove targeted waste } \\
\text { volumes/levels. }\end{array}$ & $\begin{array}{l}\text { 1. Determine total HLW solids mass } \\
\text { (expressed as non-yolatile oxides) } \\
\text { transferred to the Privatization Vendor to } \\
\text { within a variability of TBD\%. }\end{array}$ & $\begin{array}{l}\text { Sampling system (slurry } \\
\text { characterization) }\end{array}$ & - \\
\hline & $\begin{array}{l}\text { P3. Prevent components from } \\
\text { exceeding operating parameters } \\
\text { for the system }\end{array}$ & $\begin{array}{l}\text { 1. In normal operation, maintain the } \\
\text { transfer system pressure drop below the } \\
\text { transfer line operating pressure. The } \\
\text { maximum line operating pressure can vary } \\
\text { between, } 16.8 \text { to } 28.6 \mathrm{kPa} \text { ( } 230 \text { to } 400 \mathrm{psi} \text { ) } \\
\text { depending on the transfer line. }\end{array}$ & $\begin{array}{l}\text { Transfer piping differential pressure } \\
\text { (source to receiver) }\end{array}$ & \\
\hline & & $\begin{array}{l}\text { 2. Transfer system components within the } \\
\text { tanks shall withstand external forces } \\
\text { imparted by other equipment. (Note: for } \\
\text { currently planned system - In tanks } \\
\text { containing mixer pumps, provide slurry } \\
\text { transfer pumps which can be operated } \\
\text { during mixer pump operation and } \\
\text { withstand forces imparted by full speed } \\
\text { mixer pump operation and remain operable } \\
\text { and retrievable from the DST }\end{array}$ & None & $\begin{array}{l}\text { Note that present design } \\
\text { (Project W-211) does not } \\
\text { allow mixer pumps to } \\
\text { operate unless transfer } \\
\text { suction bell is fully raised. }\end{array}$ \\
\hline & & $\begin{array}{l}\text { 3. Provide transfer system components } \\
\text { capable of transferring waste with a density } \\
\text { as high as } 1.4 \mathrm{~g} / \mathrm{ml} \text {. }\end{array}$ & Waste density & $\begin{array}{l}\text { Requirements to be satisfied } \\
\text { by transfer system design. }\end{array}$ \\
\hline & & $\begin{array}{l}\text { 4. Provide transter system components } \\
\text { capable of handling wastes with a pH of } 7 \\
\text { or greater. }\end{array}$ & None. & $\begin{array}{l}\text { Requirements to be satistied } \\
\text { by transfer system design. }\end{array}$ \\
\hline & & $\begin{array}{l}\text { 5. Provide a transfer system which } \\
\text { prevents the occurrence of water hammer } \\
\text { resulting from reconfiguration of the } \\
\text { system during the transfer. }\end{array}$ & None & $\begin{array}{l}\text { Requirements to be satisfied } \\
\text { hy transfer system design. }\end{array}$ \\
\hline & & $\begin{array}{l}\text { 6. Transfer system equipment shall } \\
\text { function during normal startup and } \\
\text { operation conditions. Net positive suction } \\
\text { head required slould not exceed net } \\
\text { positive süction head available at most } \\
\text { restrictive expected operating conditions }\end{array}$ & $\begin{array}{l}\text { Primary tank waste level, waste } \\
\text { temperature, waste density, vapor space } \\
\text { pressure, transfer pump RPM, } \\
\text { pump/motor vibration. }\end{array}$ & \\
\hline
\end{tabular}


Table C-1. Process Control Parameters for 241-AZ Tank Farm Supporting Phase 1 Feed Delivery.

\begin{tabular}{|c|c|c|c|c|}
\hline Process step & Qualitative process need & Quantitative tank-specific process need & Control parameter(s) & Comments/issues \\
\hline \multirow{2}{*}{$\begin{array}{l}\text { 9. Transfer } \\
\text { Solids Slurry } \\
\text { from Tank } \\
\text { (cont.) }\end{array}$} & $\begin{array}{l}\text { P4. Capability to flush the } \\
\text { transfer lines with inllibited } \\
\text { water. }\end{array}$ & $\begin{array}{l}\text { 1. Provide a diluent system to flush the } \\
\text { transfer lines with inlribited water at } \\
530 \mathrm{~L} / \mathrm{min}(140 \mathrm{gal} / \mathrm{min}) \text {. }\end{array}$ & $\begin{array}{l}\text { Transfer pump discharge pressure, flow, } \\
\text { flush water chemistry }\end{array}$ & \\
\hline & & $\begin{array}{l}\text { 2. Flush transfer lines with water volumes } \\
\text { equivalent to } 1.5 \text { times the transfer line } \\
\text { internal volume. }\end{array}$ & Transfer Piping flush water volume. & \\
\hline \multirow{2}{*}{$\begin{array}{l}\text { 10. Receive } \\
\text { Solids Slurry } \\
\text { into Tank }\end{array}$} & PI. Do not overfill tank & $\begin{array}{l}\text { 1. Provide tank level monitoring and alarm } \\
\text { systems }\end{array}$ & Primary waste level (receiver tank) & \\
\hline & $\begin{array}{l}\text { P2. Minimize generation of } \\
\text { acrosols in } 241-\mathrm{AY} \text { and } 241-\mathrm{AZ} \\
\text { Tank Farms }\end{array}$ & $\begin{array}{l}\text { 1. In } 241-\mathrm{AZ} \text { and } 241-\mathrm{AY} \text { tanks, provide a } \\
\text { drop leg or other method of discharging } \\
\text { liquid beneath tank waste surface. }\end{array}$ & None, part of mechanical system design & . \\
\hline
\end{tabular}


Table C-2. Safety Control Parameters for 241-AZ Tank Farm in Support of Phase 1 Feed Delivery.

\begin{tabular}{|c|c|c|c|c|}
\hline $\begin{array}{l}\text { Flowsheet } \\
\text { process step }\end{array}$ & $\begin{array}{l}\text { Qualitative process safety } \\
\text { objective }\end{array}$ & $\begin{array}{l}\text { Quantitative tank-specific process safety } \\
\text { requirement }\end{array}$ & Control parameters & Comments/issues \\
\hline \multirow[t]{9}{*}{$\begin{array}{l}\text { 1. Safe } \\
\text { Storage }\end{array}$} & $\begin{array}{l}\text { S1. Manage flammable gas } \\
\text { hazards }\end{array}$ & 1. Reserved & Not Applicable for 241-AZ Tanks & \\
\hline & & $\begin{array}{l}\text { 2. Manage tanks } A Z-101 \text { and } \wedge Z-102 \text { as } \\
\text { Facility Group } 2 \text { assignments. }\end{array}$ & $\begin{array}{l}\text { Hydrogen gas monitoring, vapor space } \\
\text { pressure, annulus leak detection (air } \\
\text { stream) }\end{array}$ & $\begin{array}{l}\text { Per the BIO 5.3.2.14, } \\
\text { flammable gas can be } \\
\text { monitored by sampling for } \\
\text { lyydrogen only, with an } \\
\text { alarm at } 7500 \text { ppmv. }\end{array}$ \\
\hline & & $\begin{array}{l}\text { 3. Maintain flammable gases } \\
\text { concentrations no greater than } 25 \% \text { of the } \\
\text { lower flammability limit }\end{array}$ & $\begin{array}{l}\text { Hydrogen gas monitoring, vapor space } \\
\text { pressure }\end{array}$ & \\
\hline & $\begin{array}{l}\text { S2. Manage potential ignition } \\
\text { sources that can initiate a fire } \\
\text { or flammable gas deflagration. }\end{array}$ & 1. Reserved & Not Applicable for 241-AZ Tanks & \\
\hline & & $\begin{array}{l}\text { 2. Flammable gas ignition source controls } \\
\text { for Tanks AZ-101 \& AZ-102 are Facility } \\
\text { Group } 2 \text { requirements. }\end{array}$ & $\begin{array}{l}\text { Hydrogen gas monitoring, vapor space } \\
\text { pressure }\end{array}$ & \\
\hline & & $\begin{array}{l}\text { 3. An active primary ventilation system } \\
\text { shall be operable for all DST's and AWTs }\end{array}$ & $\begin{array}{l}\text { Ventilation stack flow rate, vapor space } \\
\text { pressure }\end{array}$ & \\
\hline & $\begin{array}{l}\text { S3. Monitor flammable gas } \\
\text { concentrations to prevent } \\
\text { deflagration }\end{array}$ & 1. Reserved & $\begin{array}{l}\text { Monitoring required since } A Z-101 \\
\text { tanks are a facility Group } 2 \text { tanks. }\end{array}$ & . \\
\hline & $\begin{array}{l}\text { \$4. Provide operable transfer } \\
\text { system covers }\end{array}$ & $\begin{array}{l}\text { 1. Transfer system covers associated with } \\
\text { structures that are physically connected to } \\
\text { an active waste transfer pump not under } \\
\text { administrative lock or under the control } \\
\text { of AC } 5.22 \text {, "Transfer System Cover } \\
\text { Removal Controls" shall be operable. }\end{array}$ & None & . \\
\hline & $\begin{array}{l}\text { S5. Provide service water } \\
\text { pressure detection }\end{array}$ & $\begin{array}{l}\text { 1. Service water pressure detection } \\
\text { systems that are physically connected to } \\
\text { an active waste transfer pump not under } \\
\text { administrative lock shall be operable. }\end{array}$ & Diluent pressure, raw water pressure & \\
\hline
\end{tabular}


Table C-2. Safety Control Parameters for 241-AZ Tank Farm in Support of Phase 1 Feed Delivery.

\begin{tabular}{|c|c|c|c|c|}
\hline $\begin{array}{l}\text { Flowsheet } \\
\text { process step }\end{array}$ & $\begin{array}{l}\text { Qualitative process safety } \\
\text { objective }\end{array}$ & $\begin{array}{l}\text { Quantitative tank-specific process safety } \\
\text { requirement }\end{array}$ & Control parameters & Comments/issues \\
\hline \multirow[t]{8}{*}{$\begin{array}{l}\text { 1. Safe } \\
\text { Storage (cont.) }\end{array}$} & $\begin{array}{l}\text { S6. Provide transfer leak } \\
\text { detection }\end{array}$ & $\begin{array}{l}\text { 1. Leak detection in all process pits, } \\
\text { diversion boxes, vault pits, and cleanout } \\
\text { boxes physically contrected to an active. } \\
\text { waste transfer pump that is not under } \\
\text { administrative lock shall be operable. }\end{array}$ & $\begin{array}{l}\text { Tank/diversion box level, encasement } \\
\text { conductivity probe }\end{array}$ & \\
\hline & $\begin{array}{l}\text { S7. Provide ventilation stack } \\
\text { continuous air monitor (CAM) } \\
\text { interlock systems }\end{array}$ & $\begin{array}{l}\text { 1. Primary tank ventilation stack CAM } \\
\text { interlock systems shall be operable when } \\
\text { active ventilation is operating. }\end{array}$ & $\begin{array}{l}\text { Radiation detector (exhaust stack), } \\
\text { HEPA filter differential pressure }\end{array}$ & \\
\hline & S8. Provide tank ventilation & $\begin{array}{l}\text { 1. An active primary tank ventilation } \\
\text { system for DSTs and AWF tanks shall be } \\
\text { operable. }\end{array}$ & $\begin{array}{l}\text { Ventilation stack flow rate, vapor space } \\
\text { pressure }\end{array}$ & \\
\hline & $\begin{array}{l}\text { S9. Provide primary tank leak } \\
\text { detection }\end{array}$ & $\begin{array}{l}\text { 1. Either the annulus conductivity probe } \\
\text { system or the anmulus continuous air } \\
\text { monitor system shall be operable for } \\
\text { DSTs and AWF tanks. }\end{array}$ & $\begin{array}{l}\text { Annulus conductivity sensor, } \\
\text { ventilation stack flow rate, radiation } \\
\text { detector (exhaust stack) }\end{array}$ & . \\
\hline & $\begin{array}{l}\text { \$10. Control tank waste } \\
\text { temperature }\end{array}$ & $\begin{array}{l}\text { 1. Tank waste temperature shall be } \\
\text { either: } \leq 90^{\circ} \mathrm{C}\left(195^{\circ} \mathrm{F}\right) \text { in all levels of } \\
\text { the waste; or } \leq 90{ }^{\circ} \mathrm{C}\left(195^{\circ} \mathrm{F}\right) \text { in the } \\
\text { top } 4.6 \mathrm{~m}(15 \mathrm{ft}) \text { of the waste and } \\
\leq 102^{\circ} \mathrm{C}\left(215^{\circ} \mathrm{F}\right) \text { in the waste below } \\
4.6 \mathrm{~m}(15 \mathrm{ft}) \text {. }\end{array}$ & Waste temperature & \\
\hline & & $\begin{array}{l}\text { 2. Waste temperature shall not exceed } \\
121^{\circ} \mathrm{C}\left(250^{\circ} \mathrm{F}\right) \text {. }\end{array}$ & Waste temperature & \\
\hline & $\begin{array}{l}\text { S11. Prevent primary tank } \\
\text { overtilling }\end{array}$ & $\begin{array}{l}\text { 1. Provide instrumentation, monitoring } \\
\text { and controls for service water to avoid } \\
\text { overfilling a waste tank in the event of a } \\
\text { water line break. }\end{array}$ & $\begin{array}{l}\text { Service water flow totalizer, primary } \\
\text { tank leve! }\end{array}$ & $\begin{array}{l}\text { Flow totalizer specified by } \\
\text { BIO (ng. 5.4-58) }\end{array}$ \\
\hline & $\begin{array}{l}\text { S12. Prevent subsurface } \\
\text { release of radioactive materials } \\
\text { due to leaks in multiple tanks. }\end{array}$ & $\begin{array}{l}\text { 1. Provide primary tank leak detection, } \\
\text { tank level monitoring, and temperature } \\
\text { monitoring, and transfer controls on } \\
\text { waste } \mathrm{pH} \text {. }\end{array}$ & $\begin{array}{l}\text { Primary tank temperature monitoring, } \\
\text { primary tank leak detection, primary } \\
\text { tank level monitoring system. }\end{array}$ & $\begin{array}{l}\text { Instrumentation specified } \\
\text { by BIO (pg. 5.4-153) }\end{array}$ \\
\hline $\begin{array}{l}\text { 4. Add } \\
\text { Diluent to } \\
\text { Tank }\end{array}$ & $\begin{array}{l}\text { S1. Prevent contamination of } \\
\text { service water systems }\end{array}$ & $\begin{array}{l}\text { 1. Prevent backflow of waste from active } \\
\text { waste transfer pump into service water } \\
\text { systems that are physically connected } \\
\text { during transfer }\end{array}$ & $\begin{array}{l}\text { Diluent/raw water differential pressure, } \\
\text { radiation detection system }\end{array}$ & \\
\hline
\end{tabular}


Table C-2. Safety Control Parameters for 241-AZ Tank Farm in Support of Phase 1 Feed Delivery.

\begin{tabular}{|c|c|c|c|c|}
\hline $\begin{array}{l}\text { Flowsheet } \\
\text { process step }\end{array}$ & $\begin{array}{c}\text { Qualitative process safety } \\
\text { objective }\end{array}$ & $\begin{array}{l}\text { Quantitative tank-specific process safety } \\
\text { requirement }\end{array}$ & Control parameters & Comments/issues \\
\hline \multirow[t]{5}{*}{$\begin{array}{l}\text { 5. Mix Tank } \\
\text { Contents }\end{array}$} & \multirow[t]{4}{*}{$\begin{array}{l}\text { S1. Control tank waste } \\
\text { temperature }\end{array}$} & $\begin{array}{l}\text { 1. Tank waste temperature shall be } \\
\text { either: } \leq 91^{\circ} \mathrm{C}\left(195^{\circ} \mathrm{F}\right) \text { in all levels of } \\
\text { the waste; or } \leq 91 \mathrm{C}\left(195^{\circ} \mathrm{F}\right) \text { in the top } \\
4.6 \mathrm{~m}(15 \mathrm{ft}) \text { of the waste and } \leq 102^{\circ} \mathrm{C} \\
\left(215^{\circ} \mathrm{F}\right) \text { in the waste below } 4.6 \mathrm{~m} \\
(15 \mathrm{ft}) \text {. }\end{array}$ & Waste temperature & . \\
\hline & & $\begin{array}{l}\text { 2. Temperature clangeover time for } \\
\text { solutions in tanks shall be } \leq 5.6^{\circ} \mathrm{C} / \mathrm{hr} \\
\left(10^{\circ} \mathrm{F} / \mathrm{hr}\left(<125^{\circ} \mathrm{F}\right) \text { or } \leq 11^{\circ} \mathrm{C} / \text { day }\right. \\
\left(20^{\circ} \mathrm{F} / \text { day }\left(\geq 125^{\circ} \mathrm{F}\right)\right.\end{array}$ & $\begin{array}{l}\text { Waste temperature, temperature trend } \\
\text { recorder }\end{array}$ & \\
\hline & & $\begin{array}{l}\text { 3. Temperature gradients of solution in } \\
\text { tanks shall be } \leq 100^{\circ} \mathrm{C} / \mathrm{ft}\left(55^{\circ} \mathrm{F} / \mathrm{ft}\right) \\
\text { within the solution and at the } \\
\text { solution/vapor interface. }\end{array}$ & Waste temperature & $\begin{array}{l}\text { Need to determine the } \\
\text { vertical and horizontal } \\
\text { placement of temperature } \\
\text { sensors to met the } \\
\text { gradient requirement }\end{array}$ \\
\hline & & $\begin{array}{l}\text { 4. Tank } 241-\mathrm{AZ}-101 \text { air lift circulation } \\
\text { must be operable when waste solution } \\
\text { temperature is }>93^{\circ} \mathrm{C}\left(200^{\circ} \mathrm{F}\right) \text { and } \\
\text { when sludge temperature is }>110^{\circ} \mathrm{C} \\
\left(230^{\circ} \mathrm{F}\right) \text {. }\end{array}$ & $\begin{array}{l}\text { Waste temperature, circulator air } \\
\text { pressure and air flow }\end{array}$ & $\begin{array}{l}\text { Note: it is assumed that } \\
\text { this will also be applicable } \\
\text { to tank } 241-\wedge Z-102\end{array}$ \\
\hline & $\begin{array}{l}\text { S2,Monitor for leaks or line } \\
\text { misroutings }\end{array}$ & $\begin{array}{l}\text { 1.Provide instrument air to weight factor } \\
\text { leak detection systems at an appropriate } \\
\text { tlow rate and pressure. }\end{array}$ & $\begin{array}{l}\text { Instrument air pressure, instrument air } \\
\text { flow rate }\end{array}$ & \\
\hline \multirow[t]{2}{*}{$\begin{array}{l}\text { 9. Transfer } \\
\text { Solids Slurry } \\
\text { from Tank }\end{array}$} & $\begin{array}{l}\text { S1. Monitor for leaks or line } \\
\text { misroutings }\end{array}$ & $\begin{array}{l}\text { 1. Perform material balance calculations } \\
\text { during each waste transfer. Calculations } \\
\text { shall be performed at } 30 \text { and } 60 \text { minutes } \\
\text { following waste transfer initiation and } \\
\text { every } 2 \text { hours thereafter until the transfer } \\
\text { is complete (safety constraint) }\end{array}$ & Waste mass flow meter & \\
\hline & & $\begin{array}{l}\text { 2.Provide instrument air to weight factor } \\
\text { leak detection systems at an appropriate } \\
\text { flow rate and pressure. }\end{array}$ & $\begin{array}{l}\text { Instrument air flow rate, instrument air } \\
\text { pressure }\end{array}$ & \\
\hline
\end{tabular}


Table C-2. Safety Control Parameters-for 241-AZ Tank Farm in Support of Phase 1 Feed Delivery.

\begin{tabular}{|c|c|c|c|c|}
\hline $\begin{array}{l}\text { Flowsheet } \\
\text { process step }\end{array}$ & $\begin{array}{l}\text { Qualitative process safety } \\
\text { objective }\end{array}$ & $\begin{array}{c}\text { Quantitative tank-specific process safety } \\
\text { requirement }\end{array}$ & Control parameters & Comments/issues \\
\hline \multirow[t]{3}{*}{$\begin{array}{l}\text { 9. Transter } \\
\text { Solids Slurry } \\
\text { from Tank } \\
\text { (cont) }\end{array}$} & $\begin{array}{l}\text { S2. Prevent contamination of } \\
\text { service water systems } \\
\end{array}$ & $\begin{array}{l}\text { 1. Prevent backflow of waste from active } \\
\text { waste transfer pump into service water } \\
\text { systems that are physically connected } \\
\text { during transfer }\end{array}$ & $\begin{array}{l}\text { Diluent/raw water differential pressure, } \\
\text { radiation detection system }\end{array}$ & \\
\hline & $\begin{array}{l}\text { S3. Detect subsurface leaks } \\
\text { that remain subsurface }\end{array}$ & $\begin{array}{l}\text { 1. Transfer leak detection systems in } \\
\text { systems and structures connected to a } \\
\text { waste transfer pump and pipe-in-pipe } \\
\text { encasements shall be operable }\end{array}$ & $\begin{array}{l}\text { Tank/diversion box level, chasement } \\
\text { conductivity probe }\end{array}$ & \\
\hline & S4. Mitigate transfer spray leak & $\begin{array}{l}\text { 1. Ventilation stack CAM interlock } \\
\text { systems shall be operable }\end{array}$ & $\begin{array}{l}\text { Exhaust stack radiation detector, } \\
\text { HEPA filter differential pressure }\end{array}$ & \\
\hline $\begin{array}{l}\text { 10. Receive } \\
\text { Solids Sturry } \\
\text { into Tank }\end{array}$ & $\begin{array}{l}\text { S1. Control tank waste } \\
\text { temperature }\end{array}$ & $\begin{array}{l}\text { 1. Tank waste temperature shall be } \\
\text { either: } \leq 91^{\circ} \mathrm{C}\left(195^{\circ} \mathrm{F}\right) \text { in all levels of } \\
\text { the waste; or } \leq 91{ }^{\circ} \mathrm{C}\left(195^{\circ} \mathrm{F}\right) \text { in the top } \\
4.6 \mathrm{~m}(15 \mathrm{ft}) \text { of the waste and } \leq 102^{\circ} \mathrm{C} \\
\left(215^{\circ} \mathrm{F}\right) \text { in the waste below } 4.6 \mathrm{~m} \\
(15 \mathrm{ft}) \text {. }\end{array}$ & $\begin{array}{l}\text { Waste temperature, mixer pump } \\
\text { controls (speed, orientation), air lift } \\
\text { circulator air supply pressure \& flow }\end{array}$ & \\
\hline
\end{tabular}


Table C-3. Off-normal Occurrence Control Parameters for 241-AZ Tank Farm

In Support of Phase 1 Feed Delivery.

\begin{tabular}{|c|c|c|c|c|c|}
\hline $\begin{array}{l}\text { Flowsheet } \\
\text { process step }\end{array}$ & Process need & $\begin{array}{c}\text { Postulated off-normal } \\
\text { occurrence }\end{array}$ & $\begin{array}{c}\text { Control parameter(s) } \\
\text { (from Tables } \mathrm{C}-1 \text { and } \mathrm{C}-2 \text { ) }\end{array}$ & $\begin{array}{l}\text { Additional control } \\
\text { parameter(s) needed }\end{array}$ & Comments/issues \\
\hline \multirow[t]{10}{*}{$\begin{array}{l}\text { 1. Safe } \\
\text { Storage }\end{array}$} & $\begin{array}{l}\text { S1. Manage flammable gas } \\
\text { hazards }\end{array}$ & $\begin{array}{l}\text { ftammable gas concentration } \\
\text { in vapor space exceeds } \\
\text { requirements }\end{array}$ & $\begin{array}{l}\text { hydrogen gas monitoring, } \\
\text { vapor space pressure, } \\
\text { ventilation flow rate }\end{array}$ & None & $\begin{array}{l}\text { BIO uses } \\
\text { Administrative } \\
\text { Controls for this } \\
\text { situation (e.g. AC } \\
5.10,5.12,5.14 \text { ) }\end{array}$ \\
\hline & $\begin{array}{l}\text { S2. Manage potential ignition } \\
\text { sources that can initiate a fire } \\
\text { or flammable gas } \\
\text { deflagration. }\end{array}$ & & & & \\
\hline & $\begin{array}{l}\text { S3. Monitor flammable gas } \\
\text { concentrations to prevent } \\
\text { deflagration }\end{array}$ & See $\mathrm{S} 1$ above. & . & & \\
\hline & $\begin{array}{l}\text { S4. Provide operable transfer } \\
\text { system covers }\end{array}$ & & & & \\
\hline & $\begin{array}{l}\text { S5. Provide service water } \\
\text { pressure detection }\end{array}$ & $\begin{array}{l}\text { pressure switch fails to } \\
\text { activate alarm/interlock }\end{array}$ & $\begin{array}{l}\text { diluent pressure, raw water } \\
\text { pressure }\end{array}$ & $\begin{array}{l}\text { diluent/raw water } \\
\text { radiation detector }\end{array}$ & \\
\hline & $\begin{array}{l}\text { S6. Provide transfer leak } \\
\text { detection }\end{array}$ & $\begin{array}{l}\text { indication received of a leak } \\
\text { in transfer line or diversion } \\
\text { box }\end{array}$ & $\begin{array}{l}\text { Tank/diversion box level, } \\
\text { encasement conductivity } \\
\text { probe }\end{array}$ & & \\
\hline & $\begin{array}{l}\text { S6. Provide ventilation stack } \\
\text { continuous air monitor } \\
\text { (CAM) interlock systems }\end{array}$ & CAM failure & $\begin{array}{l}\text { radiation detector (exhaust } \\
\text { stack), HEPA filter } \\
\text { differential pressure }\end{array}$ & CAM failure alarm & \\
\hline & S7. Provide tank ventilation & ventilation system failure & $\begin{array}{l}\text { vent stack flow, vapor space } \\
\text { pressure }\end{array}$ & $\begin{array}{l}\text { ventilation system } \\
\text { failure/trouble alarms }\end{array}$ & \\
\hline & $\begin{array}{l}\text { \$8. Provide primary tank } \\
\text { leak detection }\end{array}$ & & & & \\
\hline & $\begin{array}{l}\text { S9. Control tank waste } \\
\text { temperature }\end{array}$ & - & & & \\
\hline
\end{tabular}


Table C-3. Off-normal Oćcnrrence Control Parameters for 241-AZ Tank Farm In Support of Phase 1 Feed Delivery.

\begin{tabular}{|c|c|c|c|c|c|}
\hline $\begin{array}{l}\text { Flowsheet } \\
\text { process step }\end{array}$ & Process need & $\begin{array}{l}\text { Postulated off-normal } \\
\text { occurrence }\end{array}$ & $\begin{array}{c}\text { Control parameter(s) } \\
\text { (from Tables } \mathrm{C}-1 \text { and } \mathrm{C}-2 \text { ) }\end{array}$ & $\begin{array}{l}\text { Additional control } \\
\text { parameter(s) needed }\end{array}$ & Comments/issues \\
\hline \multirow{2}{*}{$\begin{array}{l}\text { 1. Safe } \\
\text { Storage } \\
\text { (cont.) }\end{array}$} & $\begin{array}{l}\text { S10. Prevent primary tank } \\
\text { overtilling }\end{array}$ & $\begin{array}{l}\text { service water flow totalizer } \\
\text { failure }\end{array}$ & $\begin{array}{l}\text { flow totalizer, primary tank } \\
\text { level }\end{array}$ & $\begin{array}{l}\text { service water low } \\
\text { and high flow alarms }\end{array}$ & \\
\hline & $\begin{array}{l}\text { S11. Prevent subsurface } \\
\text { release of radioactive } \\
\text { materials due to leaks in } \\
\text { multiple tanks. }\end{array}$ & & & & \\
\hline $\begin{array}{l}\text { 2. Degas } \\
\text { Feed }\end{array}$ & $\begin{array}{l}\text { Process step not applicable to } \\
241-A Z \text { tanks }\end{array}$ & - & . & & \\
\hline $\begin{array}{l}\text { 3. Settle } \\
\text { Solids }\end{array}$ & $\begin{array}{l}\text { Process step not applicable to } \\
241-A Z \text { tanks }\end{array}$ & & . & & \\
\hline \multirow[t]{3}{*}{$\begin{array}{l}\text { 4. Add } \\
\text { Diluent to } \\
\text { Tank }\end{array}$} & $\begin{array}{l}\text { P1. Add diluent to dissolve } \\
\text { soluble precipitated salts in } \\
\text { selected DSTs. Specifically, } \\
\text { tanks } 241-A N-103, A N-104 \text {, } \\
\text { AN-105, AW-101, SY-101, } \\
\text { and SY-103. }\end{array}$ & $\begin{array}{l}\text { Not Applicable to } 241-\mathrm{AZ} \\
\text { Tanks }\end{array}$ & . & & \\
\hline & $\begin{array}{l}\text { P2. Add diluent to allow } \\
\text { operation of equipment } \\
\text { (bottom thermocouples, } \\
\text { mixer pumps, decant pumps, } \\
\text { slurry transfer pumps) }\end{array}$ & : & & & \\
\hline & $\begin{array}{l}\text { P3. Add diluent to adjust } \\
\text { waste composition to meet } \\
\text { tank corrosion specifications }\end{array}$ & $\begin{array}{l}\text { Not Applicable to } 241-\wedge Z \\
\text { Tanks }\end{array}$ & & & \\
\hline $\begin{array}{l}\text { 5. Mix Tank } \\
\text { Contents }\end{array}$ & $\begin{array}{l}\text { S1. Control tank waste } \\
\text { temperature }\end{array}$ & & & & \\
\hline
\end{tabular}


Table C-3. Off-normal Occurrence Control Parameters for 241-AZ Tank Farm In Support of Phase 1 Feed Delivery.

\begin{tabular}{|c|c|c|c|c|c|}
\hline $\begin{array}{l}\text { Flowsheet } \\
\text { process step }\end{array}$ & Process need & $\begin{array}{l}\text { Postulated off-normal } \\
\text { occurrence }\end{array}$ & $\begin{array}{c}\text { Control parameter(s) } \\
\text { (from Tables C-1 and C-2) }\end{array}$ & $\begin{array}{l}\text { Additional control } \\
\text { parameter(s) needed }\end{array}$ & Comments/issues \\
\hline \multirow[t]{5}{*}{$\begin{array}{l}\text { 5. Mix Tank } \\
\text { Contents } \\
\text { (cont.) }\end{array}$} & $\begin{array}{l}\text { S2. Any instrument important } \\
\text { to process control requiring } \\
\text { instrument air shall receive } \\
\text { the air at an appropriate flow } \\
\text { rate and pressure }\end{array}$ & $\begin{array}{l}\text { instrument air supply to air } \\
\text { lift circulators fails }\end{array}$ & $\begin{array}{l}\text { instrument air supply } \\
\text { pressure and flow }\end{array}$ & $\begin{array}{l}\text { tank waste } \\
\text { temperature, mixer } \\
\text { pump controls }\end{array}$ & \\
\hline & $\begin{array}{l}\text { P1. Transfer solid particles } \\
\text { from settled solid phase to } \\
\text { suspended solids in a liquid } \\
\text { phase }\end{array}$ & & & & \\
\hline & $\begin{array}{l}\text { P2. Mixer pump operation } \\
\text { should mix liquids and } \\
\text { suspend mobilized solids } \\
\text { uniformly throughout the } \\
\text { waste solution. }\end{array}$ & - & . & & \\
\hline & $\begin{array}{l}\text { P3. Components should not } \\
\text { exceed operating parameters } \\
\text { for the system }\end{array}$ & $\begin{array}{l}\text { mixer pump cavitation } \\
\text { detected }\end{array}$ & $\begin{array}{l}\text { pump speed, tank level, } \\
\text { waste temperature and } \\
\text { density, pump/motor } \\
\text { vibration, vapor space } \\
\text { pressure }\end{array}$ & none & \\
\hline & $\begin{array}{l}\text { P4. Electrical distribution } \\
\text { system should provide for the } \\
\text { simultaneous operation of } 9 \\
\text { mixer pumps }\end{array}$ & $\begin{array}{l}\text { loss of power to one or more } \\
\text { mixer pumps }\end{array}$ & none & none & . \\
\hline \multirow[t]{2}{*}{$\begin{array}{l}\text { 6. Sample } \\
\text { Waste }\end{array}$} & $\begin{array}{l}\text { P1. Ensure compatibility } \\
\text { between sending and } \\
\text { receiving tanks }\end{array}$ & . & & & \\
\hline & $\begin{array}{l}\text { P2. Confirm waste } \\
\text { composition and inventory } \\
\text { within contract specifications }\end{array}$ & $\begin{array}{l}\text { Not applicable to } 241-\mathrm{AZ} \\
\text { tanks }\end{array}$ & & & \\
\hline $\begin{array}{l}\text { 7. Transfer } \\
\text { Liquid from } \\
\text { Tank }\end{array}$ & $\begin{array}{l}\text { Not Applicable to } 241-A Z \\
\text { Tanks }\end{array}$ & & & & \\
\hline
\end{tabular}


Table C-3. Off-normal Occurrence Control Parameters for 241-AZ Tank Farm

In Support of Phase 1 Feed Delivery.

\begin{tabular}{|c|c|c|c|c|c|}
\hline $\begin{array}{l}\text { Flowsheet } \\
\text { process step }\end{array}$ & Process need & $\begin{array}{l}\text { Postulated off-normal } \\
\text { occurrence }\end{array}$ & $\begin{array}{l}\text { Control parameter(s) } \\
\text { (from Tables } \mathrm{C}-1 \text { and } \mathrm{C}-2 \text { ) }\end{array}$ & $\begin{array}{l}\text { Additional control } \\
\text { parameter(s) needed }\end{array}$ & Comments/issues \\
\hline $\begin{array}{l}\text { 8. Receive } \\
\text { Liquid into } \\
\text { Tank }\end{array}$ & $\begin{array}{l}\text { Not Applicable to } 241-\mathrm{AZ} \\
\text { Tanks }\end{array}$ & & & & \\
\hline \multirow{6}{*}{$\begin{array}{l}\text { 9. Transfer } \\
\text { Solids Slurry } \\
\text { from Tank }\end{array}$} & $\begin{array}{l}\text { S1. Monitor for leaks or line } \\
\text { misroutings }\end{array}$ & $\begin{array}{l}\text { indication received of a leak } \\
\text { in transfer line or diversion } \\
\text { boxes }\end{array}$ & $\begin{array}{l}\text { waste mass flowmeter, } \\
\text { encasement/diversion box } \\
\text { leak detectors }\end{array}$ & $\begin{array}{l}\text { interlock to trip } \\
\text { transfer pump }\end{array}$ & \\
\hline & $\begin{array}{l}\text { S2. Any instrument important } \\
\text { to process control requiring } \\
\text { instrument air shall receive } \\
\text { the air at an appropriate flow } \\
\text { rate and pressure. }\end{array}$ & & . & & \\
\hline & $\begin{array}{l}\text { Pl. Avoid solids } \\
\text { accumulation which could } \\
\text { plug the transfer line. }\end{array}$ & $\begin{array}{l}\text { Transfer line plugs to allow } \\
\text { less than required flow rate, } \\
\text { pressure drop, or velocity }\end{array}$ & $\begin{array}{l}\text { transfer piping diff. pressure, } \\
\text { pressure, flow rate; diluent or } \\
\text { flush pressure, flow rate }\end{array}$ & $\begin{array}{l}\text { transfer piping flush } \\
\text { water pressure, flow } \\
\text { rate }\end{array}$ & \\
\hline & $\begin{array}{l}\text { P2. Transfer system should } \\
\text { be capable of removing } \\
\text { targeted waste volume/levels. }\end{array}$ & $\begin{array}{l}\text { Transfer pump trip during } \\
\text { transfer (e.g. from master } \\
\text { pump shutdown signal) }\end{array}$ & flush water pressure, flow & none & \\
\hline & $\begin{array}{l}\text { P3. Components should not } \\
\text { exceed operating parameters } \\
\text { for the system }\end{array}$ & & & & \\
\hline & $\begin{array}{l}\text { P4. The transfer system } \\
\text { should have capability to } \\
\text { flush transfer lines with raw } \\
\text { or inhibited water. }\end{array}$ & & & & \\
\hline \multirow{2}{*}{$\begin{array}{l}\text { 10. Receive } \\
\text { Solids Slurry } \\
\text { into Tank }\end{array}$} & P1. Do not overfill tank. & & & . & \\
\hline & $\begin{array}{l}\text { P2. Minimize generation of } \\
\text { aerosols in } 241-A Y \text { and } \\
241-A Z \text { Tank Farms }\end{array}$ & - & & & \\
\hline
\end{tabular}


Table C-4. Monitoring Methods fer 241-AZ Tank Farm Supporting Phase 1 Feed Delivery.

\begin{tabular}{|c|c|c|c|c|c|c|}
\hline $\begin{array}{l}\text { Flowsheet } \\
\text { process step }\end{array}$ & Control parameter(s) & $\begin{array}{l}\text { Manipulated } \\
\text { parameter(s) }\end{array}$ & Monitored variable(s) & $\begin{array}{l}\text { Expected monitoring } \\
\text { and control approach }\end{array}$ & $\begin{array}{l}\text { Alternative } M \& C \\
\text { approaches considered }\end{array}$ & Comments/issues \\
\hline \multirow[t]{10}{*}{ 1. Safe Storage } & $\begin{array}{l}1.1 \text { hydrogen gas } \\
\text { monitoring }\end{array}$ & $\begin{array}{l}\text { primary tank ventilation } \\
\text { air flow, mixer and } \\
\text { transfer pump operation }\end{array}$ & $\begin{array}{l}\text { hydrogen gas (vapor } \\
\text { space and pump pits) }\end{array}$ & $\begin{array}{l}\text { hydrogen analyzer } \\
\text { (continuous, on-line } \\
\text { sampling) }\end{array}$ & grab sample & \\
\hline & $\begin{array}{l}1.2 \text { vapor space } \\
\text { pressure }\end{array}$ & ventilation air flow & $\begin{array}{l}\text { vapor space pressure } \\
\text { (vacuum) }\end{array}$ & $\begin{array}{l}\text { pressure transmitter } \\
\text { (DP or absolute) with } \\
\text { remote indication/alarm }\end{array}$ & local pressure gage & \\
\hline & $\begin{array}{l}1.3 \text { ventilation stack air } \\
\text { flow }\end{array}$ & $\begin{array}{l}\text { fan speed, damper } \\
\text { position }\end{array}$ & stack air flow rate & $\begin{array}{l}\text { stack isokinetic } \\
\text { probe/control system }\end{array}$ & $\begin{array}{l}\text { pitot tube flow } \\
\text { transmitter }\end{array}$ & \\
\hline & 1.4 diluent pressure & pump speed & diluent presșure & $\begin{array}{l}\text { pressure transmitter } \\
\text { with remote switch and } \\
\text { indication }\end{array}$ & local pressure gage & \\
\hline & 1.5 raw water pressure & $\begin{array}{l}\text { pump speed, pressure } \\
\text { control valve }\end{array}$ & raw water pressure & $\begin{array}{l}\text { pressure transmitter } \\
\text { with remote switch and } \\
\text { indication }\end{array}$ & local pressure gage & \\
\hline & $\begin{array}{l}1.6 \text { exhaust stack } \\
\text { radiation }\end{array}$ & none & exhaust stack radiation & $\begin{array}{l}\text { CAM with interlock to } \\
\text { exhaust fan }\end{array}$ & - & \\
\hline & $\begin{array}{l}\text { 1.7 HEPA filter } \\
\text { differential pressure }\end{array}$ & none & $\begin{array}{l}\text { differential pressure } \\
\text { across HEPA filter }\end{array}$ & $\begin{array}{l}\text { differential pressure } \\
\text { transmitter with } \\
\text { local/remote indication } \\
\text { and interlock with } \\
\text { exhaust fan }\end{array}$ & . & \\
\hline & $\begin{array}{l}1.8 \text { annulus leak } \\
\text { detector }\end{array}$ & none & $\begin{array}{l}\text { liquid level in bottom of } \\
\text { DST (outside tank) }\end{array}$ & $\begin{array}{l}\text { conductivity probes set } \\
\text { at proper elevations }\end{array}$ & $\begin{array}{l}\text { level transmitter with } \\
\text { remote indication/alarm }\end{array}$ & \\
\hline & $\begin{array}{l}1.9 \text { primary tank waste } \\
\text { temperature }\end{array}$ & diluent volume & waste temperature & $\begin{array}{l}\text { RTDs at elevations to } \\
\text { give temperature } \\
\text { gradients at various } \\
\text { tank levels }\end{array}$ & $\begin{array}{l}\text { Thermocouples at } \\
\text { elevations to give } \\
\text { temperature gradients at } \\
\text { various tank levels }\end{array}$ & $\begin{array}{l}\text { RTDs will provide } \\
\pm \text { IF. accuracy; T/Cs } \\
\text { will provide } \pm 2.8 \mathrm{~F} \\
\text { Elevations and spatial } \\
\text { distribution of } \\
\text { temperature sensors } \\
\text { need to be determined } \\
\text { to give the needed } \\
\text { temperature proliles. }\end{array}$ \\
\hline & $\begin{array}{l}1.10 \text { diluent and raw } \\
\text { water volume }\end{array}$ & $\begin{array}{l}\text { diluent and raw water } \\
\text { flow }\end{array}$ & $\begin{array}{l}\text { diluent and raw water } \\
\text { volume }\end{array}$ & $\begin{array}{l}\text { diluent and raw water } \\
\text { flow totalizer }\end{array}$ & $\begin{array}{l}\text { flow transmitter with } \\
\text { indicator plus } \\
\text { stopwatch }\end{array}$ & . \\
\hline
\end{tabular}


Table C-4. Monitoring Methods for 241-AZ Tank Farm Supporting Phase 1 Feed Delivery.

\begin{tabular}{|c|c|c|c|c|c|c|}
\hline $\begin{array}{l}\text { Flowsheet } \\
\text { process step }\end{array}$ & Control parameter(s) & $\begin{array}{l}\text { Manipulated } \\
\text { parameter(s) }\end{array}$ & Monitored variable(s) & $\begin{array}{l}\text { Expected monitoring } \\
\text { and control approach }\end{array}$ & $\begin{array}{c}\text { Alternative M\&C } \\
\text { approaches considered }\end{array}$ & Comments/issues \\
\hline \multirow[t]{3}{*}{$\begin{array}{l}\text { 1. Sate Storage } \\
\text { (cont) }\end{array}$} & $\begin{array}{l}1.11 \text { primary tank } \\
\text { waste level }\end{array}$ & $\begin{array}{l}\text { diluent and raw water } \\
\text { volume }\end{array}$ & tank level & ENRAF ${ }^{\text {tx }}$ level system & $\begin{array}{l}\text { level sensors at fixed } \\
\text { locations, ultrasonic } \\
\text { system }\end{array}$ & $\begin{array}{l}\text { May not obtain } \\
\text { accurate level data } \\
\text { when mixer pump is in } \\
\text { operation and } \\
\text { ENRAF" is in "dip" } \\
\text { mode }\end{array}$ \\
\hline & $\begin{array}{l}1.12 \text { waste temperature } \\
\text { trending }\end{array}$ & diluent volume & $\begin{array}{l}\text { waste temperature } \\
\text { trending }\end{array}$ & $\begin{array}{l}\text { trend recorder } \\
\text { connected to } \\
\text { temperature monitoring } \\
\text { system (see CP 1.9) }\end{array}$ & & \\
\hline & $\begin{array}{l}1.13 \text { air lift circulator } \\
\text { air pressure }\end{array}$ & air pressure and flow & air pressure and flow & $\begin{array}{l}\text { pressure and flow } \\
\text { transmitters with local } \\
\text { and remote indication } \\
\text { (instrument air system) }\end{array}$ & $\begin{array}{l}\text { local gage and } \\
\text { rotameter }\end{array}$ & \\
\hline 2. Degas Feed & $\begin{array}{l}\text { Process step not } \\
\text { applicable to } 241-\mathrm{AZ} \\
\text { Tanks }\end{array}$ & & & & . & \\
\hline $\begin{array}{l}\text { 3. Separate } \\
\text { Solids and } \\
\text { Liquids }\end{array}$ & $\begin{array}{l}\text { Process step not } \\
\text { applicable to } 241-\wedge \mathrm{Z} \\
\text { Tanks }\end{array}$ & & & & & \\
\hline \multirow[t]{6}{*}{$\begin{array}{l}\text { 4. Dissolve } \\
\text { Solids }\end{array}$} & 4.1 diluent volume & See CP 1.10 & & & & $\begin{array}{l}\text { Although not } \\
\text { applicable to } A Z \\
\text { Farm, control } \\
\text { parameters apply to } \\
\text { diluent addition of } \\
\text { Process Step 5B. }\end{array}$ \\
\hline & 4.2 diluent chemistry & chemical additives & diluent chemistry & $\begin{array}{l}\text { on-line analyzer } \\
\text { (continuous) }\end{array}$ & $\begin{array}{l}\text { grab samples with } \\
\text { remote analysis }\end{array}$ & . \\
\hline & $\begin{array}{l}4.3 \text { primary tank waste } \\
\text { level }\end{array}$ & See CP 1.11 & & & & \\
\hline & $\begin{array}{l}4.4 \text { primary tank waste } \\
\text { temperature }\end{array}$ & See CP 1.9 & & & & \\
\hline & 4.5 diluent pressure & See CP 1.4 & & & & \\
\hline & 4.6 diluent flow rate & $\begin{array}{l}\text { diluent water pump } \\
\text { speed }\end{array}$ & diluent flow rate & $\begin{array}{l}\text { flow totalizer with } \\
\text { remote flow indicator }\end{array}$ & $\begin{array}{l}\text { local flow indicator } \\
\text { (c.g., rotameter) }\end{array}$ & \\
\hline
\end{tabular}


Revision 0

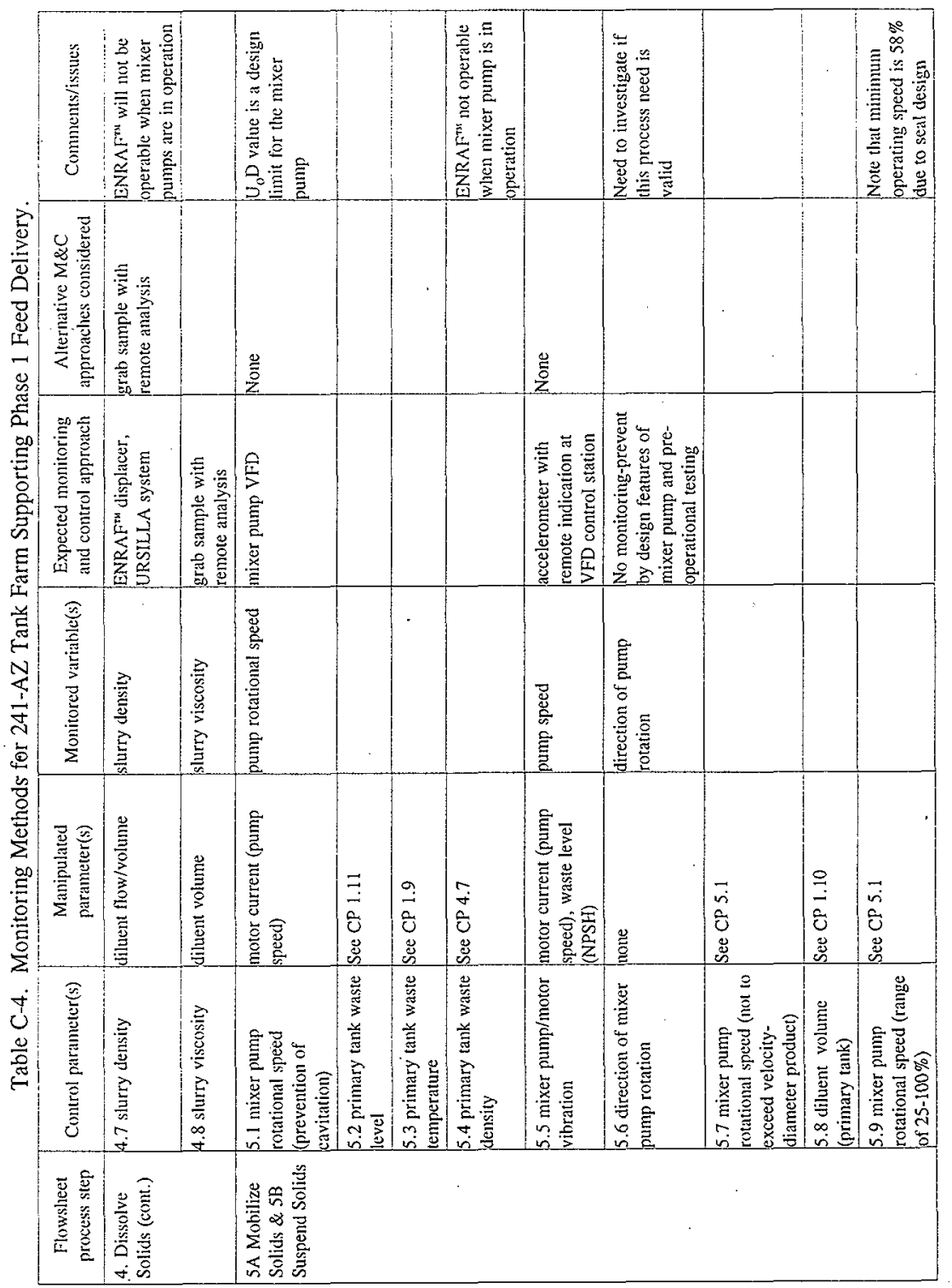




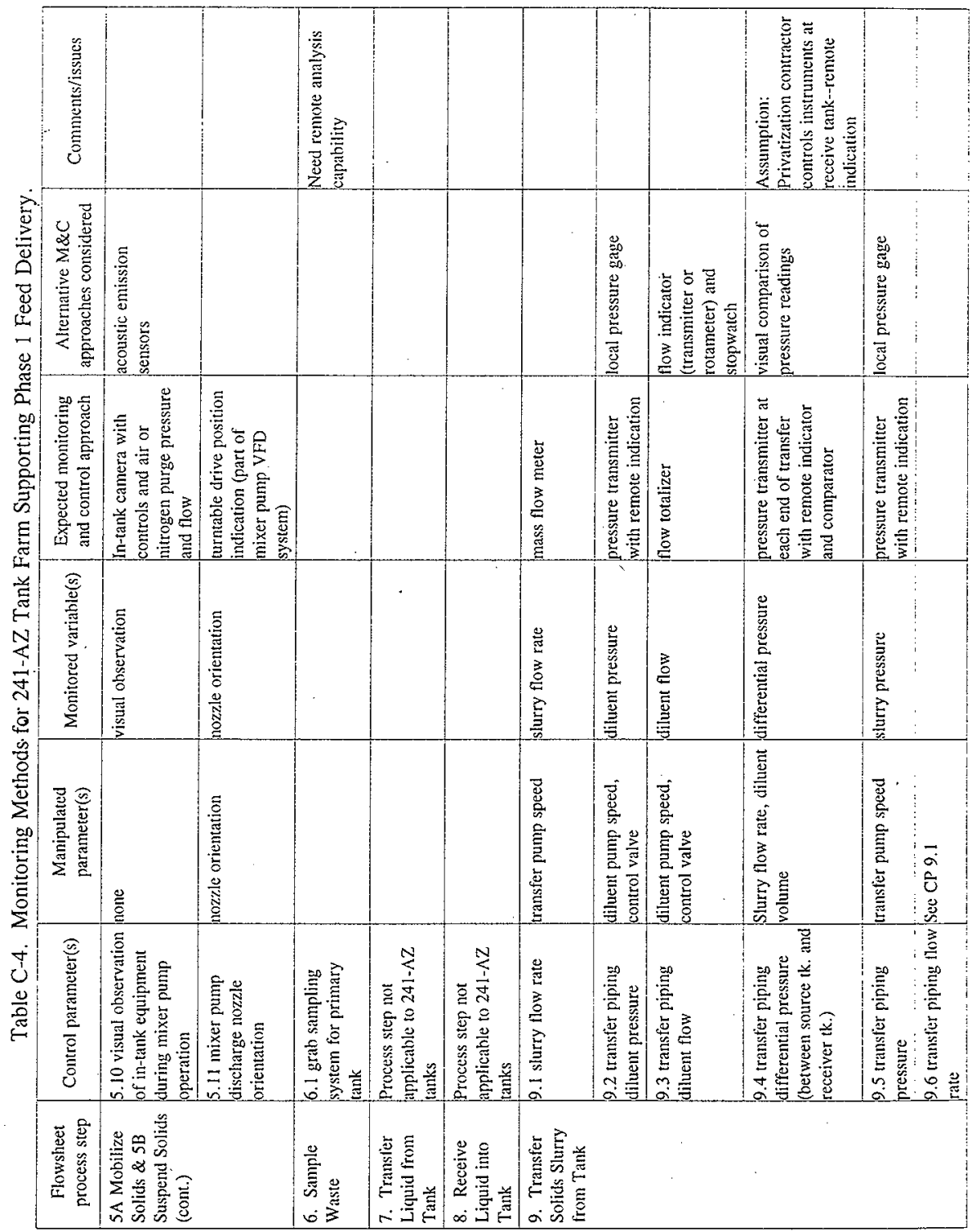


Table C-4. Monitoring Methods for 241-AZ Tank Farm Supporting Phase 1 Feed Delivery.

\begin{tabular}{|c|c|c|c|c|c|c|}
\hline $\begin{array}{l}\text { Flowsheet } \\
\text { process step }\end{array}$ & Control parameter(s) & $\begin{array}{l}\text { Manipulated } \\
\text { parameter(s) }\end{array}$ & Monitored variable(s) & $\begin{array}{l}\text { Expected monitoring } \\
\text { and control approach }\end{array}$ & $\begin{array}{c}\text { Alternative } M \& C \\
\text { approaches considered }\end{array}$ & Comments/issues \\
\hline \multirow{15}{*}{$\begin{array}{l}\text { 9. Transter } \\
\text { Solids Slurry } \\
\text { from Tank } \\
\text { (cont.) }\end{array}$} & 9.7 slurry viscosity & diluent volume, flow & slurry viscosity & grab sampler & on-line analyzer & \\
\hline & 9.8 slurry density & diluent volume, flow & slurry density & grab sampler & on-line analyzer & \\
\hline & $\begin{array}{l}9.9 \text { sampling system } \\
\text { for slurry } \\
\text { characterization }\end{array}$ & & shur ry chemistry & grab sampler & on-line analyzer & \\
\hline & $\begin{array}{l}9.10 \text { transfer pump } \\
\text { discharge pressure }\end{array}$ & pump speed & discharge pressure & $\begin{array}{l}\text { pressure transmitter } \\
\text { with remote indication }\end{array}$ & local pressure gage & \\
\hline & $\begin{array}{l}9.11 \text { primary tank } \\
\text { waste level }\end{array}$ & See CP 1.11 & & & & \\
\hline & $\begin{array}{l}9.12 \text { primary tank } \\
\text { waste temperature }\end{array}$ & See CP 1.9 & . & & & \\
\hline & 9.13 slurry density & See CP 4.7 & & & & \\
\hline & $\begin{array}{l}9.14 \text { primary tank } \\
\text { vapor space pressure }\end{array}$ & See CP 1.2 & & & & \\
\hline & $\begin{array}{l}9.15 \text { transfer pump } \\
\text { rotational speed }\end{array}$ & pump speed & pump speed & $\begin{array}{l}\text { pump VFD controls } \\
\text { and indication }\end{array}$ & & \\
\hline & $\begin{array}{l}9.16 \text { transfer } \\
\text { pump/motor vibration }\end{array}$ & pump speed, NPSH & vibration & $\begin{array}{l}\text { local accelerometers } \\
\text { with remote indication }\end{array}$ & & \\
\hline & $\begin{array}{l}9.17 \text { transfer pump } \\
\text { direction of rotation }\end{array}$ & pump on/off, speed & rotational direction & transfer pump VFD & & \\
\hline & $\begin{array}{l}9.18 \text { transfer pump } \\
\text { motor current }\end{array}$ & pump speed & motor current & VFD controls & & \\
\hline & $\begin{array}{l}9.19 \text { transfer pump } \\
\text { motor bearings and } \\
\text { windings temperature }\end{array}$ & pump speed & $\begin{array}{l}\text { motor winding and } \\
\text { bearing temperature }\end{array}$ & $\begin{array}{l}\text { T/C or RTD in motor, } \\
\text { indication with VFD } \\
\text { display }\end{array}$ & & \\
\hline & $\begin{array}{l}9.20 \text { transfer piping } \\
\text { flush water flow }\end{array}$ & flush water pump speed & flush water flow & $\begin{array}{l}\text { flow totalizer with } \\
\text { remote indication. }\end{array}$ & $\begin{array}{l}\text { flow indicator } \\
\text { (transmitter or } \\
\text { rotameter) and } \\
\text { stopwatch }\end{array}$ & \\
\hline & $\begin{array}{l}9.21 \text { transfer piping } \\
\text { flush water chemistry }\end{array}$ & chemical additives & flush water chemistry & on-line sampler & $\begin{array}{l}\text { grab sample witl } \\
\text { remote analysis }\end{array}$ & \\
\hline
\end{tabular}


Table C-4. Monitoring Methods for 241-AZ Tank Farm Supporting Phase 1 Feed Delivery.

\begin{tabular}{|c|c|c|c|c|c|c|}
\hline $\begin{array}{l}\text { Flowslieet } \\
\text { process step }\end{array}$ & Control parameter(s) & $\begin{array}{l}\text { Manipulated } \\
\text { parameter(s) }\end{array}$ & Monitored variable(s) & $\begin{array}{l}\text { Expected monitoring } \\
\text { and control approach }\end{array}$ & $\begin{array}{l}\text { Alternative } M \& C \\
\text { approaches considered }\end{array}$ & Comments/issues \\
\hline $\begin{array}{l}\text { 9. Transfer } \\
\text { Solids Slurry } \\
\text { from Tank } \\
\text { (cont) }\end{array}$ & $\begin{array}{l}9.22 \text { transfer piping } \\
\text { flush water volume }\end{array}$ & See CP 9.20 & & & & \\
\hline \multirow{4}{*}{$\begin{array}{l}\text { 10. Receive } \\
\text { Solids Slurry } \\
\text { into Tank }\end{array}$} & 10.1 tank waste level & $\begin{array}{l}\text { transfer volume, diluent } \\
\text { volume }\end{array}$ & tank waste level & ENRAF"x system & & \\
\hline & $\begin{array}{l}10.2 \text { tank waste } \\
\text { temperature }\end{array}$ & See CP 1.9 & & & & \\
\hline & $\begin{array}{l}10.3 \text { mixer pump speed } \\
\text { controls (speed, } \\
\text { orientation) }\end{array}$ & See CP 5.1 and 5.6 & & & & \\
\hline & $\begin{array}{l}10.4 \text { air lift circulator } \\
\text { air supply }\end{array}$ & $\operatorname{Sec} \mathrm{CP} 1.13$ & & & & \\
\hline
\end{tabular}


Table C-5. Monitoring And Contror Instrumentation Parameters Needed For 241-AZ Tank Farm In Support of Phase 1 Feed Delivery.

\begin{tabular}{|c|c|c|c|c|c|c|c|}
\hline \multirow{2}{*}{ Tank } & \multirow{2}{*}{ Monitoring and control instrumentation } & \multirow{2}{*}{ Range } & \multicolumn{4}{|c|}{ Setpoints functions } & \multirow{2}{*}{ Comment/issue } \\
\hline & & & HiFli & $\mathrm{Hi}$ & Lo & LoLo & \\
\hline \multirow[t]{8}{*}{ AZ-101 } & $\begin{array}{l}\text { hydrogen analyzer (continuous, on-line } \\
\text { sampling) }\end{array}$ & $\begin{array}{l}\mathrm{CH} 10-10 \% \mathrm{H} 2 \\
\mathrm{CH} 20-1 \% \mathrm{H} 2\end{array}$ & Not required & Required & $\begin{array}{l}\text { Low or FAIL } \\
\text { Required }\end{array}$ & Not required & $\begin{array}{l}\text { Existing system las } \\
\text { Hi and Fail alarms }\end{array}$ \\
\hline & $\begin{array}{l}\text { pressure transmitter (dp or absolute) with } \\
\text { remote indication/alarm (vapor space) }\end{array}$ & $\begin{array}{l}-25.4 \text { to }+12.7 \mathrm{~cm} \\
(-10 \text { to }+5 \mathrm{in} . \mathrm{WG})\end{array}$ & Required & Required & Required & Required & $\begin{array}{l}\text { Existing PIT is set } \\
\text { for to to cm } \\
(-6 \text { to }+4 \text { in. WG). } \\
\text { All alarms are } \\
\text { generated in Micon } \\
\text { unit. }\end{array}$ \\
\hline & $\begin{array}{l}\text { stack isokinetic probe/control system } \\
\text { (exhaust flow) }\end{array}$ & $\begin{array}{l}\text { Stack Flow: } 0 \text { to } \\
24.7 \mathrm{~m} / \mathrm{min}(0 \text { to } \\
871 \mathrm{scfm}) \\
\text { Sample Flow: } 0 \\
\text { to } 57 \mathrm{~L} / \mathrm{min}(0 \text { to } \\
2 \mathrm{scfm}) \\
\end{array}$ & . & Required & Required & & \\
\hline & $\begin{array}{l}\text { pressure transmitter with remote switch } \\
\text { and indication (tank diluent) }\end{array}$ & TBD & & Required & & & \\
\hline & $\begin{array}{l}\text { pressure transmitter with remote switch } \\
\text { and indication (raw water) }\end{array}$ & $\begin{array}{l}1.01 \text { to } 7.81 \mathrm{kPa} \\
(0 \text { to } 100 \mathrm{psig})\end{array}$ & & & & & \\
\hline & CAM with interlock to exhaust fan & 0 to $10,000 \mathrm{cps}$ & & Required & $\begin{array}{l}\text { Low or Fail } \\
\text { Required }\end{array}$ & & \\
\hline & $\begin{array}{l}\text { differential pressure transmitter with } \\
\text { local/remote indication and interlock with } \\
\text { exhaust fan (HEP } \Lambda \text { ) }\end{array}$ & TBD & - & Required & Required & Required & \\
\hline & $\begin{array}{l}\text { conductivity probes set at proper } \\
\text { elevations (annulus leak detectors) }\end{array}$ & $\begin{array}{l}\text { Radiation } 0 \text { to } \\
10,000 \mathrm{cps} \\
\text { Leak } 2.54 \mathrm{~cm} \\
(1 \text { in.) and } 25.4 \mathrm{~cm} \\
(10 \mathrm{in.}) \text { in leak } \\
\text { detection pit }\end{array}$ & . & Required & & $\begin{array}{l}\text { Required for } \\
\text { Rad Mon } \\
\text { Fetil. }\end{array}$ & $\begin{array}{l}\text { Existing } \\
\text { instrumentation } \\
\text { consists of } \\
\text { WFT } 101-1 \text { and 101- } \\
\text { 2. Also TE-101- } \\
\text { AZ-27 monitors } \\
\text { temperature in the } \\
\text { pit. }\end{array}$ \\
\hline
\end{tabular}


Table C-5. Monitoring And Control Instrumentation Parameters Needed For 241-AZ Tank Farm In Support of Phase 1 Feed Delivery.

\begin{tabular}{|c|c|c|c|c|c|c|c|}
\hline \multirow{2}{*}{ Tank } & \multirow{2}{*}{ Monitoring and control instrumentation } & \multirow{2}{*}{ Range } & \multicolumn{4}{|c|}{ Setpoints functions } & \multirow{2}{*}{ Comment/issue } \\
\hline & & & Hilli & $\mathrm{Hi}$ & Lo & LoLo & \\
\hline \multirow[t]{9}{*}{$\begin{array}{l}\mathrm{AZ}-10 \mathrm{I} \\
\text { (cont.) }\end{array}$} & $\begin{array}{l}\text { RTDs at elevations to give temperature } \\
\text { gradients at various tank levels (primary } \\
\text { tank) }\end{array}$ & TBD & Required & Required & Required & & $\begin{array}{l}\text { To provide } \\
\text { temperature } \\
\text { gradient information } \\
\text { to protect tank } \\
\text { integrity }\end{array}$ \\
\hline & raw water flow totalizer (primary tank) & O-TBD L & $\begin{array}{l}\text { Not } \\
\text { required. }\end{array}$ & Required & Required & & \\
\hline & ENRAF ${ }^{\text {th }}$ level system (primary $\mathrm{t} k$.) & $\begin{array}{l}0 \text { to } 9.25 \mathrm{~m} \\
(0 \text { to } 364 \mathrm{int})\end{array}$ & Required & Required & Required & & \\
\hline & $\begin{array}{l}\text { trend recorder connected to waste } \\
\text { temperature monitoring system }\end{array}$ & $0-\mathrm{TBD}$ & & $\begin{array}{l}\text { Delta } T \\
\text { between set of } \\
\text { TEs (TBD) }\end{array}$ & & & \\
\hline & $\begin{array}{l}\text { pressure and flow transmitters with local } \\
\text { and remote indication (instrument air } \\
\text { system for air lift circulators) and air lift } \\
\text { circulator temperature indication. }\end{array}$ & $\begin{array}{l}1.01 \text { to } 3.42 \mathrm{kPa} \\
(0 \text { to } 35 \mathrm{psig}) \text { and } \\
566 \mathrm{~L} / \mathrm{min} \\
(20 \mathrm{scfm})\end{array}$ & & $\begin{array}{l}\text { Temp Hi } \\
\text { required }\end{array}$ & $\begin{array}{l}\text { Press-Low } \\
\text { Flow-Low }\end{array}$ & & \\
\hline & $\begin{array}{l}\text { on-line analyzer (continuous) for diluent } \\
\text { water chemistry }\end{array}$ & $\begin{array}{l}\text { pH TBD- } \\
\text { TBD, Conductivity } \\
\text { TBD-TBD } \\
\text { micromho, Viscosity } \\
\text { TBE-TBD cP }\end{array}$ & & Required & & . & . \\
\hline & $\begin{array}{l}\text { flow totalizer with remote flow indicator } \\
\text { (diluent) }\end{array}$ & $\begin{array}{l}0 \text { to } 454 \mathrm{~m} 3(0 \text { to } \\
120,000 \mathrm{gal})\end{array}$ & & $\begin{array}{l}\text { Required to } \\
\text { indicate } \\
\text { approaching } \\
\text { set value. }\end{array}$ & & & \\
\hline & $\begin{array}{l}\text { ENRAF } F^{\text {tu }} \text { system; URSILLA system } \\
\text { (primary tank density) }\end{array}$ & & & Required & & & \\
\hline & $\begin{array}{l}\text { grab sample with remote analysis (slurry } \\
\text { viscosity) TBD if required. }\end{array}$ & TBD & & & & & \\
\hline
\end{tabular}


Table C-5. Monitoring And Contror Instrumentation Parameters Needed For 241-AZ Tank Farm

In Support of Phase 1 Feed Delivery.

\begin{tabular}{|c|c|c|c|c|c|c|c|}
\hline \multirow{2}{*}{ Tauk } & \multirow{2}{*}{ Monitoring and control instrumentation } & \multirow{2}{*}{ Range } & \multicolumn{4}{|c|}{ Setpoints functions } & \multirow{2}{*}{ Comment/issue } \\
\hline & & & IHiHi & $\mathrm{Hi}$ & Lo & LoLo & \\
\hline \multirow[t]{10}{*}{$\begin{array}{l}\text { AZ-101 } \\
\text { (cont.) }\end{array}$} & mixer pump VFD (rotational speed) & $0-\mathrm{TBD} \mathrm{rpm}$ & & Required & $\begin{array}{l}\text { Required - } \\
\text { pump/motor } \\
\text { protection }\end{array}$ & & \\
\hline & $\begin{array}{l}\text { accelerometer with remote indication at } \\
\text { VFD control station (mixer pump/motor } \\
\text { vibration) TBD if required. }\end{array}$ & $0-\mathrm{TBD}$ mils & & $\begin{array}{l}\text { Required- } \\
\text { pump/motor } \\
\text { protection }\end{array}$ & $\cdot$ & & \\
\hline & $\begin{array}{l}\text { In-tank camera with controls and air or } \\
\text { nitrogen purge pressure and flow }\end{array}$ & $\begin{array}{l}0 \text { to } 85 \mathrm{~L} / \mathrm{min} \\
(0 \text { to } 3 \mathrm{scfm}) \\
\text { pressure } 1.01 \text { to } \\
5.15 \mathrm{kPa} \\
(0 \text { to } 60 \mathrm{psig})\end{array}$ & & & Required & & \\
\hline & turntable drive position indication & $0-180^{\circ}$ & & & & & \\
\hline & mass flow meter (slurry transfer) & $0-\mathrm{TBD} \mathrm{kg} / \mathrm{hr}$ & . & $\begin{array}{l}\text { Required-to } \\
\text { indicate } \\
\text { approaching } \\
\text { the set value. }\end{array}$ & . & & \\
\hline & $\begin{array}{l}\text { pressure transmitter with remote indication } \\
\text { (transfer piping diluent) }\end{array}$ & $\begin{array}{l}1.01 \text { to } 32.0 \mathrm{kPa} \\
(0 \text { to } 450 \mathrm{psig})\end{array}$ & & Required- & & & \\
\hline & flow totalizer (transfer diluent) & & & $\begin{array}{l}\text { Required to } \\
\text { indicate } \\
\text { approaching } \\
\text { set value }\end{array}$ & & & \\
\hline & $\begin{array}{l}\text { pressure transmitter at each end of transfer } \\
\text { piping with remote indicator and } \\
\text { comparator }\end{array}$ & 1.01 to $\mathrm{TBD} \mathrm{kPa}$ & & $\begin{array}{l}\text { Required-line } \\
\text { protection \& } \\
\text { to indicate } \\
\text { line plug }\end{array}$ & & & \\
\hline & $\begin{array}{l}\text { pressure transmitter with remote indication } \\
\text { (transfer piping) }\end{array}$ & 1.01 to TBD kPa & & $\begin{array}{l}\text { Required-line } \\
\text { protection }\end{array}$ & & & \\
\hline & grab sampler (slurry transfer) & $N / \Lambda$ & & & & & \\
\hline
\end{tabular}


Table C-5. Monitoring And Control-Instrumentation Parameters Needed For 241-AZ Tank Farm In Support of Phase 1 Feed Delivery.

\begin{tabular}{|c|c|c|c|c|c|c|c|}
\hline \multirow{2}{*}{ Tank } & \multirow{2}{*}{ Monitoring and control instrumentation } & \multirow{2}{*}{ Range } & \multicolumn{4}{|c|}{ Setpoints functions } & \multirow{2}{*}{ Comment/issue } \\
\hline & & & $\mathrm{HiHi}$ & $\mathrm{Hi}$ & Lo & LoLo & \\
\hline \multirow[t]{7}{*}{$\begin{array}{l}\text { AZ-101 } \\
\text { (cont.) }\end{array}$} & $\begin{array}{l}\text { pressure transmitter with remote indication } \\
\text { (transfer pump discharge) }\end{array}$ & $\begin{array}{l}1.01 \text { to } 32.0 \mathrm{kPa} \\
(0 \text { to } 450 \mathrm{psig})\end{array}$ & & & & & \\
\hline & $\begin{array}{l}\text { transfer pump VFD controls and indication } \\
\text { (speed) }\end{array}$ & TBD & & & & & \\
\hline & $\begin{array}{l}\text { local accelerometers with remote } \\
\text { indication (transfer pump/motor vibration) } \\
\text { TBD if required. }\end{array}$ & TBD & & & & & \\
\hline & transfer pump VFD controls (motor speed) & TBD & & & & & \\
\hline & $\begin{array}{l}\text { T/C or RTD in transfer pump motor, } \\
\text { indication with VFD display }\end{array}$ & TBD & & & & & \\
\hline & $\begin{array}{l}\text { on-line sampier (transfer flush water } \\
\text { chemistry) TBD if required. }\end{array}$ & & & & & & \\
\hline & $\begin{array}{l}\text { flow totalizer with remote indication } \\
\text { (transfer flush water) }\end{array}$ & TBD & & . & & & \\
\hline \multirow[t]{5}{*}{ AZ-102 } & $\begin{array}{l}\text { lyydrogen analyzer (continuous, on-line } \\
\text { sampling) }\end{array}$ & $\begin{array}{l}\mathrm{CH} 10-10 \% \mathrm{H} 2 \\
\mathrm{CH} 20-1 \% \mathrm{H} 2\end{array}$ & Not required & Required & $\begin{array}{l}\text { Low or FAIL } \\
\text { Required }\end{array}$ & Not required & \\
\hline & $\begin{array}{l}\text { pressure transmitter (dp or absolute) with } \\
\text { remote indication/alarm (vapor space) }\end{array}$ & $\begin{array}{l}-25.4 \text { to }+12.7 \mathrm{~cm} \\
(-10 \text { to }+5 \text { in. WG })\end{array}$ & Required & Required & Required & Required & \\
\hline & $\begin{array}{l}\text { stack isokinetic probe/control system } \\
\text { (exhaust flow) }\end{array}$ & $\begin{array}{l}\text { Stack Flow: } \\
0 \text { to } 24.7 \mathrm{~m} / \mathrm{min} \\
(0 \text { to } 871 \mathrm{scfm}) \\
\text { Sample Flow: } 0 \text { to } \\
57 \mathrm{~L} / \mathrm{min} \\
\text { (0 to } 2 \mathrm{scfm})\end{array}$ & . & Required & Required & & \\
\hline & $\begin{array}{l}\text { pressure transmitter with remote switch } \\
\text { and indication (tank diluent) }\end{array}$ & $0 . T B D$ & & Required & & & \\
\hline & $\begin{array}{l}\text { pressure transmitter with remote switch } \\
\text { and indication (riw water) }\end{array}$ & $\begin{array}{l}1.01 \text { to } 7.81 \mathrm{kPa} \\
(0 \text { to } 100 \mathrm{psig})\end{array}$ & & & & & \\
\hline
\end{tabular}


Table C-5. Monitoring And Control Instrumentation Parameters Needed For 241-AZ Tank Farm In Support of Phise 1 Feed Delivery.

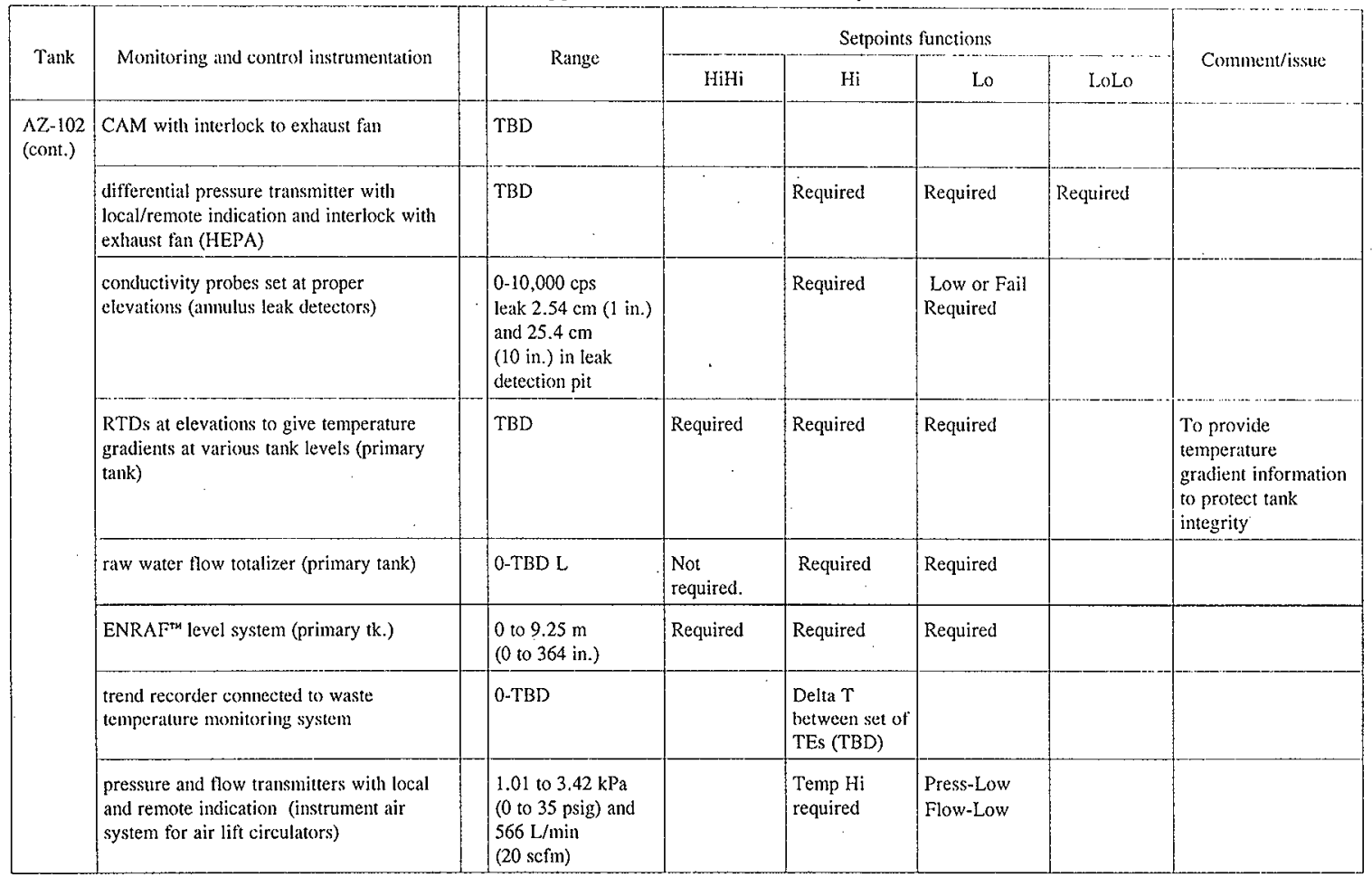




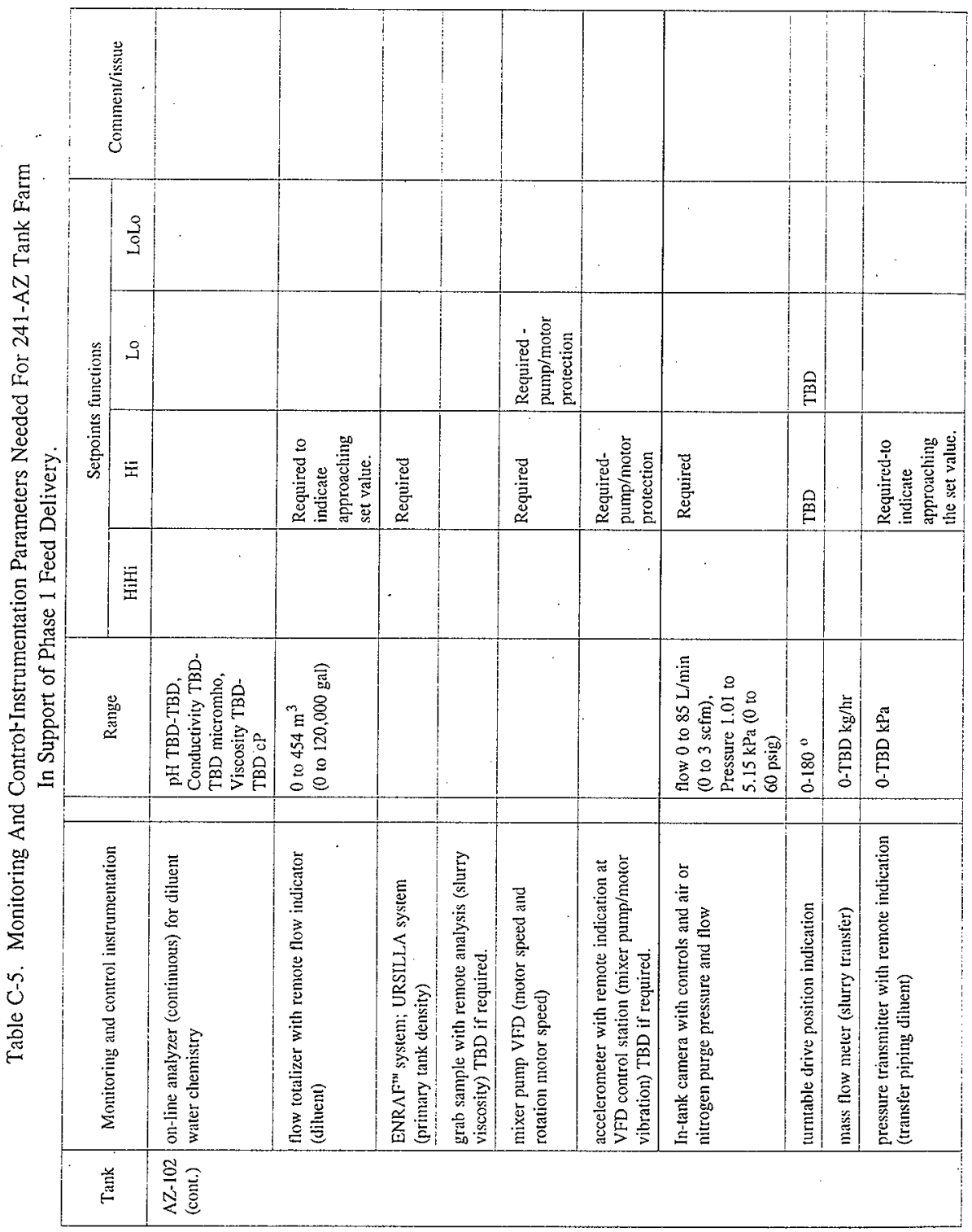


Revision 0

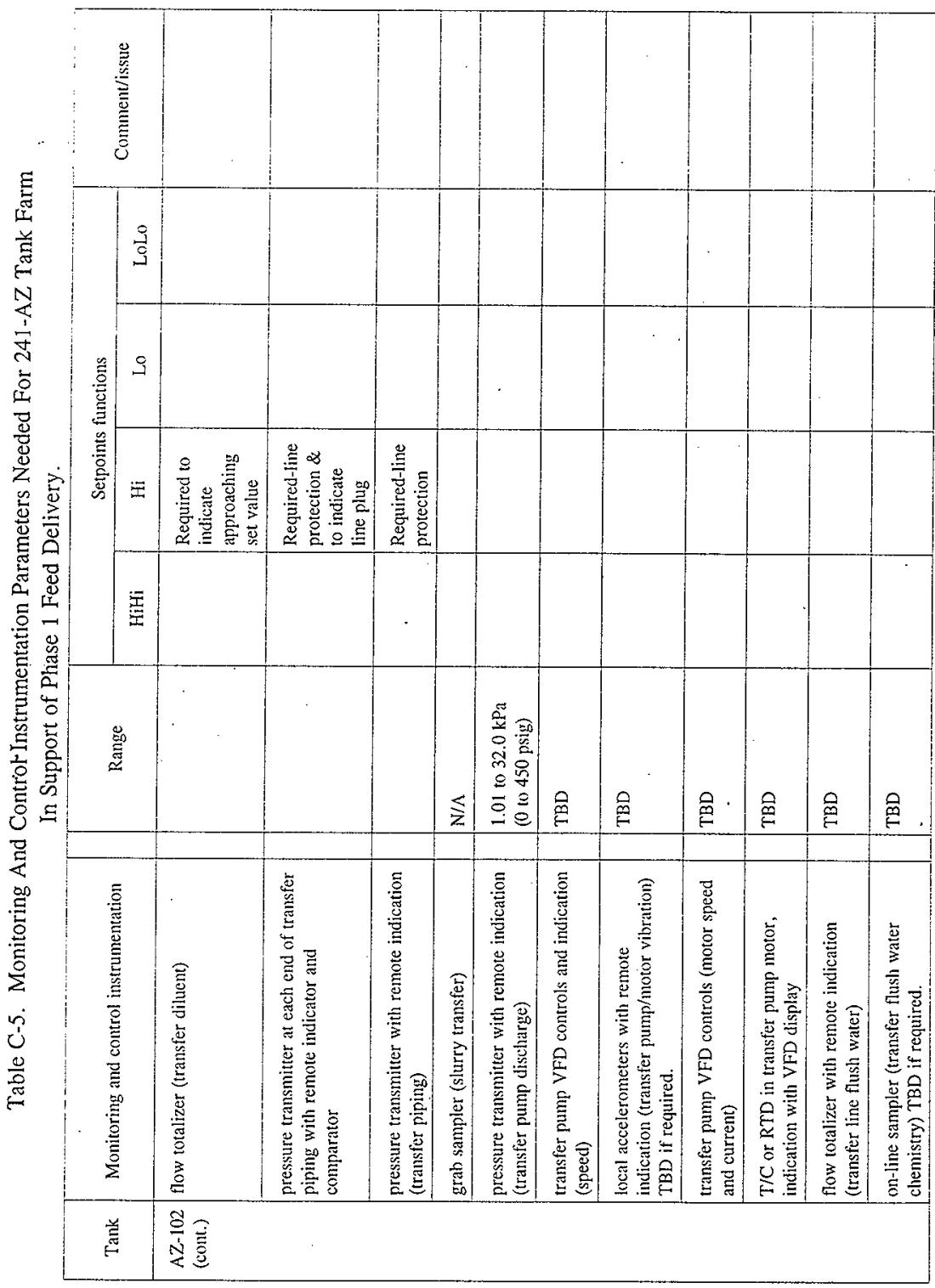


Table C-6. Monitoring and Control Equipment Available for 241-AZ Tank Farm in Support of Phase 1 Feed Delivery.

\begin{tabular}{|c|c|c|c|c|c|c|}
\hline \multirow{2}{*}{ Tank } & \multirow{2}{*}{$\begin{array}{c}\text { Monitoring and control ecquipment } \\
\text { needed }\end{array}$} & \multicolumn{2}{|c|}{ Equipment installed? } & \multicolumn{2}{|c|}{ Equipment plammed? } & \multirow{2}{*}{ References/comments } \\
\hline & & Yes/No & EIN or Label & Yes/No & Project No. & \\
\hline \multirow[t]{8}{*}{$A Z-101$} & $\begin{array}{l}\text { hydrogen analyzer (continuous, } \\
\text { on-line sampling) }\end{array}$ & Yes & $\begin{array}{l}\text { AZ101-SHM-NASH- } \\
054(0 \text { to } 10 \% \text { H2) and } \\
\text { AZ101-SHM-NASH- } \\
055(0 \text { to } 1 \% \mathrm{H} 2)\end{array}$ & & & $\begin{array}{l}\text { W-369 ( Dwg No.H-14- } \\
100835 \text {. }\end{array}$ \\
\hline & $\begin{array}{l}\text { pressure transmitter (dp or } \\
\text { absolute) with remote } \\
\text { indication/alarm (vapor space) }\end{array}$ & Yes & PIT-AZ101K1-1 & & & $\begin{array}{l}702-\mathrm{AZ}(\mathrm{W}-030)(\mathrm{Dwg} \not \mathrm{H}-2- \\
131075 \sin 2)\end{array}$ \\
\hline & $\begin{array}{l}\text { stack isokinetic probe/control } \\
\text { system (exhaust flow) }\end{array}$ & Yes & $\begin{array}{l}A E-A Z K 1-1 \text { and } \triangle E- \\
A Z K 1-2\end{array}$ & . & & $\begin{array}{l}702-A Z(W-030)(D w g / H 11-2- \\
131078 \operatorname{shl} 1)\end{array}$ \\
\hline & $\begin{array}{l}\text { pressure transmitter with remote } \\
\text { switch and indication (tank } \\
\text { diluent) }\end{array}$ & TBD & & & & \\
\hline & $\begin{array}{l}\text { pressure transmitter with remote } \\
\text { switch and indication (raw water) }\end{array}$ & Yes & PT-AZRW-1 & & & $\begin{array}{l}\text { Dwg \# H-2-131074 } \\
\text { H-2-131348 }\end{array}$ \\
\hline & CAM with interlock to exhaust fan & Yes & RAH-AZK1-1 & & & $\begin{array}{l}\text { 702-AZ (W-030), Interlocks } \\
\text { I-108 \& I-1 } 19 \text { from TMACS } \\
\text { (DWg \# H-2131078 }\end{array}$ \\
\hline & $\begin{array}{l}\text { differential pressure transmitter } \\
\text { with local/remote indication and } \\
\text { interlock with exhaust fan (HEPA) }\end{array}$ & Yes & $\begin{array}{l}\text { PDAH \& PDAHH- } \\
\text { AZK14-1B (IA) \& - } 2 B \\
(2 A) \text {. } \\
\text { PDAH\& PDAHH- } \\
\text { AZK110-1B (1A) }\end{array}$ & & & $\begin{array}{l}\text { 702-AZ (W-030) Interlock I- } \\
119 \text { ( Dwg \# H-2-131076. }\end{array}$ \\
\hline & $\begin{array}{l}\text { conductivity probes set at proper } \\
\text { elevations (annulus leak detectors) }\end{array}$ & Yes & $\begin{array}{l}\text { WFT 101-1,\&101-2, and } \\
\text { PAD101-1 }\end{array}$ & & & $\mathrm{H}-2-68335 \mathrm{Sh} 6$ \\
\hline
\end{tabular}


Table C-6. Monitoring and Control Equipment Available for 241-AZ Tank Farm in Support of Phase 1 Feed Delivery.

\begin{tabular}{|c|c|c|c|c|c|c|}
\hline \multirow{2}{*}{ Tank } & \multirow{2}{*}{$\begin{array}{l}\text { Monitoring and control equipment } \\
\text { needed }\end{array}$} & \multicolumn{2}{|c|}{ Equipment installed? } & \multicolumn{2}{|c|}{ Equipment planned? } & \multirow{2}{*}{ References/comments } \\
\hline & & Yes/No & EIN or Label & Yes/No & Project No. & \\
\hline \multirow[t]{7}{*}{$\begin{array}{l}\text { AZ-101 } \\
\text { (com.) }\end{array}$} & $\begin{array}{l}\text { RTDs at elevations to give } \\
\text { temperattre gratlients at various } \\
\text { tank levels (primary tank) }\end{array}$ & No & . & No & . & $\begin{array}{l}\text { At present, there are Type J } \\
\text { thermocouples (set of three } \\
\text { thermocouples spaced at } 4 \\
\text { in., } 14 \text { in., and } 140 \text { in. from } \\
\text { bottom) installed in risers } \\
13 \mathrm{~B}, 13 \mathrm{C}, 13 \mathrm{D} \text {, and } 13 \mathrm{~A} \text {. And } \\
\text { another set of three } \\
\text { thermocouples located at } 4 \\
\text { in. from bottom in risers } \\
16 \Lambda, B \text {, and } C \text {. This will not } \\
\text { provide temperature gradient } \\
\text { information required during } \\
\text { transfer. }\end{array}$ \\
\hline & $\begin{array}{l}\text { raw water flow totalizer (primary } \\
\text { tank }\end{array}$ & No & & Yes & $W-211$ & \\
\hline & $\begin{array}{l}\text { ENRAF }{ }^{\text {th }} \text { level system (primary } \\
\text { tk.) }\end{array}$ & Yes & . & & . & $\begin{array}{l}\text { Installed by W-151. For } \\
\text { accuracy purpose during } \\
\text { transfer, CIU will be } \\
\text { required. }\end{array}$ \\
\hline & $\begin{array}{l}\text { trend recorder connected to waste } \\
\text { temperature monitoring system }\end{array}$ & Yes & & & & \\
\hline & $\begin{array}{l}\text { pressure and flow transmitters } \\
\text { with local and remote indication. } \\
\text { (instrument air system for air lift } \\
\text { circulators) }\end{array}$ & $\begin{array}{l}\text { Flow- } \\
\text { Local } \\
\text { Pressure- } \\
\text { No }\end{array}$ & $\begin{array}{l}\text { AZ101-SA-FI- } \\
X X 01(X X=01 \text { thru22) }\end{array}$ & No & & . \\
\hline & $\begin{array}{l}\text { on-line analyzer (continuous) for } \\
\text { diluent water chemistry }\end{array}$ & No & & No & & \\
\hline & $\begin{array}{l}\text { flow totalizer with remote flow } \\
\text { indicator (diluent) }\end{array}$ & No & & Yes & W-211 & \\
\hline
\end{tabular}


Table C-6. Monitoring and Control Equipment Available for 241-AZ Tank Farm in Support of Phase 1 Feed Delivery.

\begin{tabular}{|c|c|c|c|c|c|c|}
\hline \multirow{2}{*}{ Tank } & \multirow{2}{*}{$\begin{array}{l}\text { Monitoring and control equipment } \\
\text { needed }\end{array}$} & \multicolumn{2}{|c|}{ Equipment installed? } & \multicolumn{2}{|c|}{ Equipment planned? } & \multirow{2}{*}{ References/comments } \\
\hline & & $\mathrm{Yes} / \mathrm{No}$ & EIN or Label & Yes/No & Project No. & \\
\hline \multirow[t]{11}{*}{$\begin{array}{l}\text { AZ-101 } \\
\text { (Cont.) }\end{array}$} & $\begin{array}{l}\text { ENRAF } \\
\text { system (primary tank density) }\end{array}$ & No & & Yes & $W-151$ & $\begin{array}{l}\text { CVI//22515, supp } 40,41 \text {. } \\
\text { ENRAF } \\
\text { planned or boughitiometer by } W-151 \text {. }\end{array}$ \\
\hline & $\begin{array}{l}\text { grab sample with remote analysis } \\
\text { (slurry viscosity) }\end{array}$ & Nó & & No & & \\
\hline & $\begin{array}{l}\text { mixer pump VFD (rotational } \\
\text { speed) }\end{array}$ & No & & Yes & $W-151$ & CVI\#22515, supp 32. \\
\hline & $\begin{array}{l}\text { accelerometer with remote } \\
\text { indication at VFD control station } \\
\text { (mixer pump/motor vibration) }\end{array}$ & No & & Yes & W-151 & CVIH22515, supp 32 \\
\hline & $\begin{array}{l}\text { In-tank camera with controls and } \\
\text { air or nitrogenl purge pressure and } \\
\text { flow }\end{array}$ & No & & Yes & $W-151$ & CVI\#22515, supp 44 \\
\hline & $\begin{array}{l}\text { turntable drive position indication } \\
\text { (part of mixer pump VFD system) }\end{array}$ & No & & Yes & W-151 & CVIH22515,supp 32. \\
\hline & mass flow meter (slurry transfer) & No & & $\begin{array}{l}\text { Yes } \\
\text { (TBR) }\end{array}$ & $\mathrm{W}-211$ & $\begin{array}{l}\text { Not in design yet, Discussion } \\
\text { with project Inst. engineer } \\
\text { indicates that this itstrument } \\
\text { will be part of design. Must } \\
\text { be verified at design review. }\end{array}$ \\
\hline & $\begin{array}{l}\text { pressure transmitter with remote, } \\
\text { indication (transfer piping diluent) }\end{array}$ & No & & TBR & & $\begin{array}{l}\text { Must be verified for inclusion } \\
\text { in design at design review. }\end{array}$ \\
\hline & flow totalizer (transfer diluent) & No & & TBR & & $\begin{array}{l}\text { Must be veritied for inclusion } \\
\text { in design at design review. }\end{array}$ \\
\hline & $\begin{array}{l}\text { pressure transmitter at each end of } \\
\text { transfer piping with remote } \\
\text { indicator and comparator }\end{array}$ & No & & No & & \\
\hline & $\begin{array}{l}\text { pressure transmitter with remore } \\
\text { indication (transfer piping) }\end{array}$ & No & & No & & \\
\hline
\end{tabular}


Revision 0

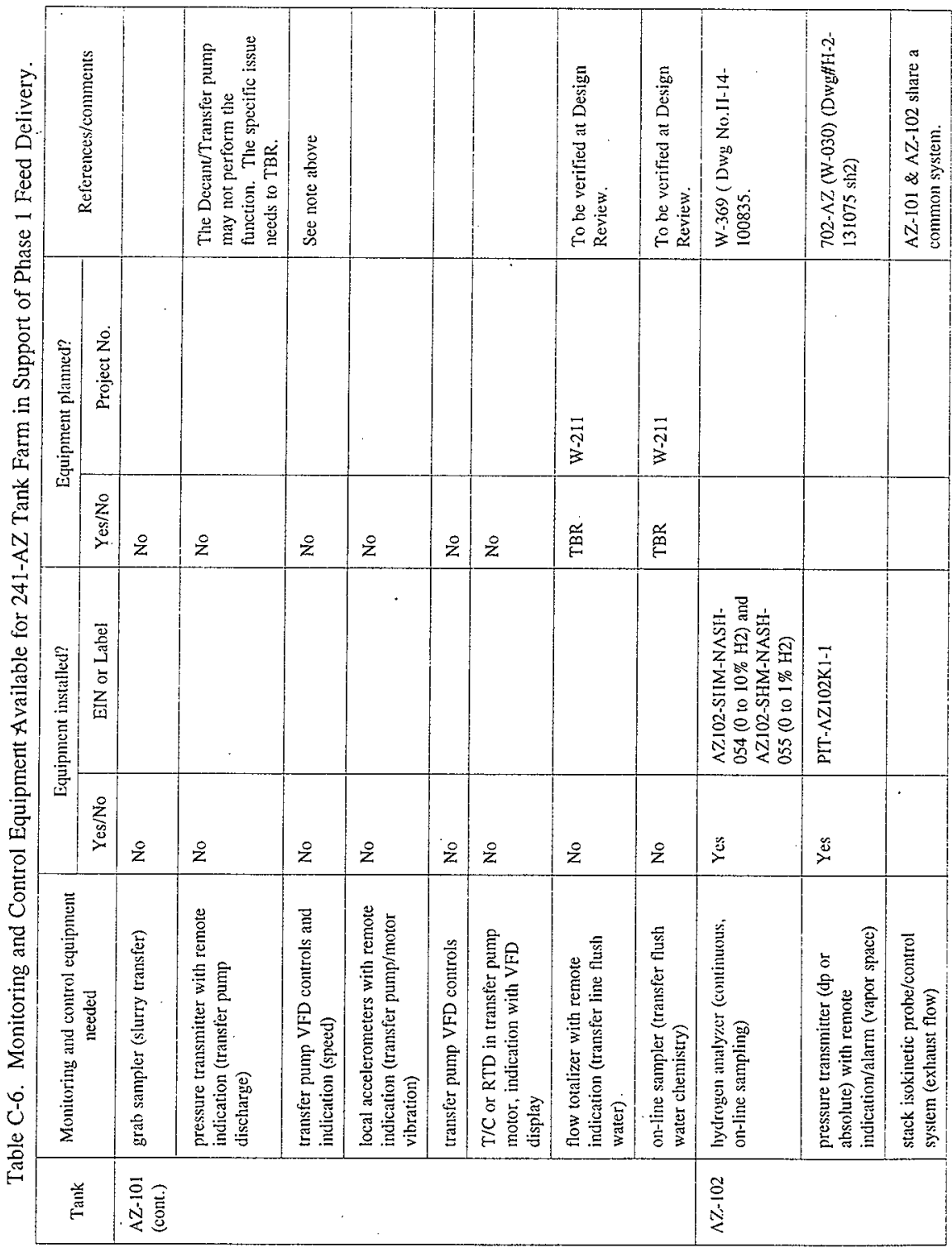


HNF-2941

Revision 0

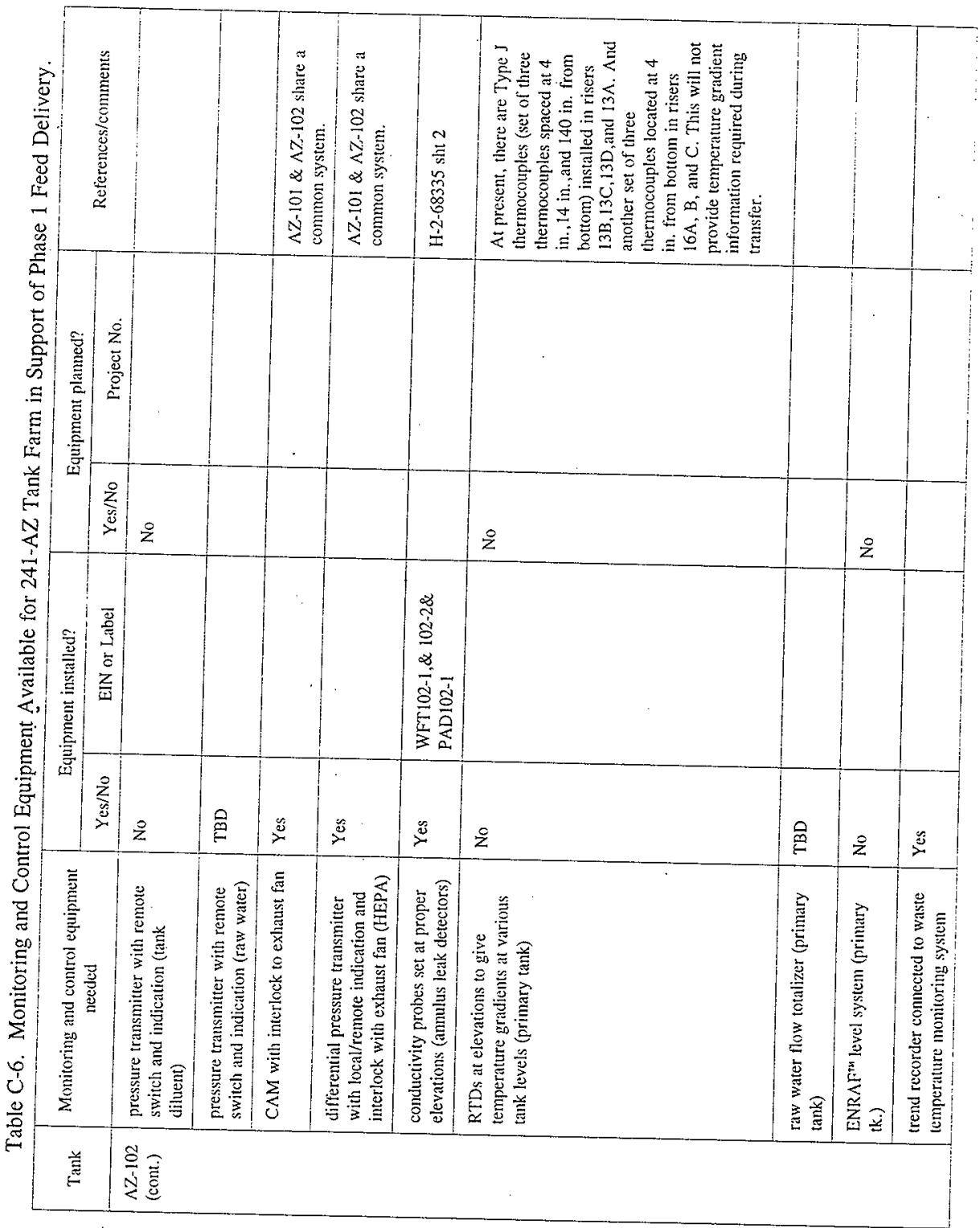


Table C-6. Monitoring and Control Equipment Available for 241-AZ Tank Farm in Support of Phase 1 Feed Delivery.

\begin{tabular}{|c|c|c|c|c|c|c|}
\hline \multirow{2}{*}{ Tank } & \multirow{2}{*}{$\begin{array}{c}\text { Monitoring and control equipment } \\
\text { needed }\end{array}$} & \multicolumn{2}{|c|}{ Equipment installed? } & \multicolumn{2}{|r|}{ Equipment plamed? } & \multirow{2}{*}{ References/comments } \\
\hline & & Yes/No & EIN or Label & Yes/No & Project No. & \\
\hline \multirow[t]{13}{*}{ AZ-102 } & $\begin{array}{l}\text { pressure and flow transmitters } \\
\text { with local and remote indication } \\
\text { (instrument air system for air lift } \\
\text { circulators) }\end{array}$ & $\begin{array}{l}\text { Pressure- } \\
\text { No Flow- } \\
\text { Local }\end{array}$ & $\begin{array}{l}\text { AZ102-SA-FI- } \\
X X 01(X X=01 \text { thru 22) }\end{array}$ & No & & \\
\hline & $\begin{array}{l}\text { on-line analyzer (contimuous) for } \\
\text { diluent water chemistry }\end{array}$ & No & & No & & \\
\hline & $\begin{array}{l}\text { flow rotalizer with remote flow } \\
\text { indicator (diluent) }\end{array}$ & No & & No & & \\
\hline & $\begin{array}{l}\text { ENRAF" system; URSILLA } \\
\text { system (primary tank density) }\end{array}$ & No & & No & & \\
\hline & $\begin{array}{l}\text { grab sample witl remote analysis } \\
\text { (slurry viscosity) }\end{array}$ & No & . & No & & \\
\hline & $\begin{array}{l}\text { mixer pump VFD (rotational } \\
\text { speed) }\end{array}$ & No & & Yes & $W-211$ & \\
\hline & $\begin{array}{l}\text { accelerometer with remote } \\
\text { indication at VFD control station } \\
\text { (mixer pump/motor vibration) }\end{array}$ & No & & Yes & $W-211$ & \\
\hline & $\begin{array}{l}\text { In-tank camera with controls and } \\
\text { air or nitrogen purge pressure and } \\
\text { flow }\end{array}$ & No & & Yes & $W-211$ & \\
\hline & $\begin{array}{l}\text { turntable drive position indication } \\
\text { (part of mixer pump VFD system) }\end{array}$ & No & & Yes & $W-211$ & \\
\hline & mass flow meter (slurry transfer) & No & & Yes & $W-211$ & \\
\hline & $\begin{array}{l}\text { pressure transmitter will remote } \\
\text { indication (transfer piping diluent) }\end{array}$ & No & & Yes & $\mathrm{W}-211$ & \\
\hline & flow totalizer (transfer ciluent) & No & & Yes & $\mathrm{W}-211$ & \\
\hline & $\begin{array}{l}\text { pressure transmitter at each end of } \\
\text { transfer piping with remote } \\
\text { indicator and comparator }\end{array}$ & No & & No & & \\
\hline
\end{tabular}


Table C-6. Monitoring and Control Equipment Available for 241-AZ Tank Farm in Support of Phase 1 Feed Delivery.

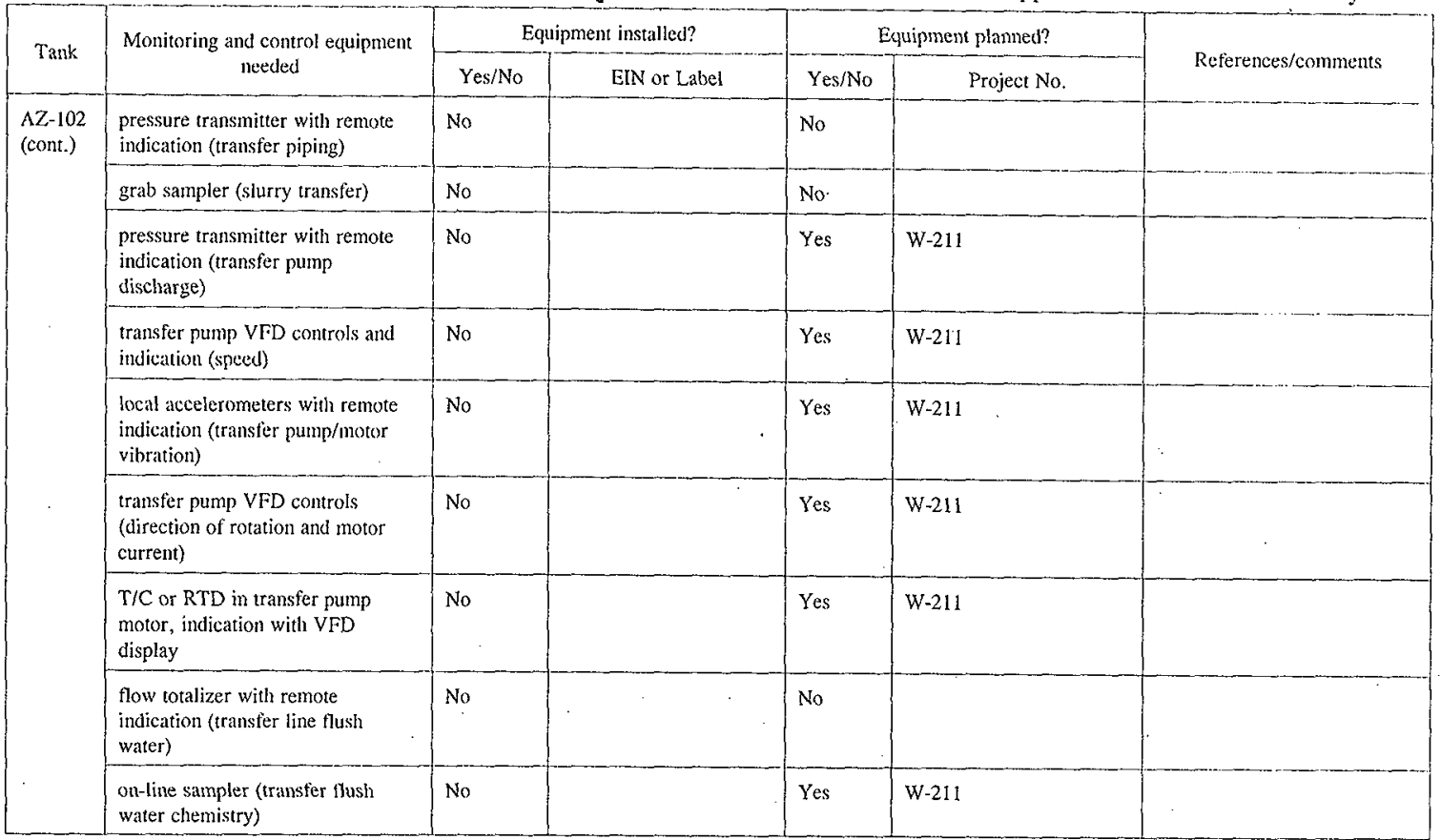


Table C-7. Comparison of Process Monitoring and Control Needs to Available Monitoring and Control Equipment in 241-AZ Tank Farm in Support of Phase 1 Feed Delivery.

\begin{tabular}{|c|c|c|c|c|}
\hline Tank & $\begin{array}{c}\text { Monitoring and control } \\
\text { instrumentation/equipm } \\
\text { ent }\end{array}$ & $\begin{array}{l}\text { Is existing and planned } \\
\text { instrumentation } \\
\text { adequate? }(Y / N)\end{array}$ & Basis for adequacy assessmem & Comments/issues \\
\hline \multirow[t]{7}{*}{$A Z-101$} & $\begin{array}{l}\text { hydrogen analyzer } \\
\text { (continuous, on-line } \\
\text { sampling) }\end{array}$ & Yes & $\begin{array}{l}\text { Existing system has two channels which cover } \\
\text { narrow range and wide range. }\end{array}$ & \\
\hline & $\begin{array}{l}\text { pressure transmitter } \\
\text { (dp or absolute) with } \\
\text { remote } \\
\text { indication/alarm (vapor } \\
\text { space) }\end{array}$ & TBD & , & $\begin{array}{l}\text { existing PIT is calibrated for }-15.2 \text { to }+10.2 \mathrm{~cm} \\
(-6 \text { to }+4 \text { in. WG. }) \text { Needs re-calibration of the } \\
\text { loop to span from }-25.4 \text { to }+12.7 \mathrm{~cm} \\
(-10 \text { to }+5 \text { in WG). }\end{array}$ \\
\hline & $\begin{array}{l}\text { stack isokinetic } \\
\text { probe/control system } \\
\text { (exhaust flow) }\end{array}$ & TBD & $\begin{array}{l}\text { Existing system is designed for flow variations } \\
\text { of } 11.3 \text { to } 28.3 \mathrm{~m}^{3} / \mathrm{min} \text { ( } 400 \text { to } 1000 \mathrm{scfm} \text { ). }\end{array}$ & $\begin{array}{l}\text { If mixer pump/transfer pump operation does not } \\
\text { increase exhaust flow of } 28.3 \mathrm{~m}^{3} / \mathrm{min} \\
\text { ( } 1000 \mathrm{scfm} \text { ), existing system would be adequate. } \\
\text { If flow increases beyond } 28.3 \mathrm{~m} \mathrm{~m}^{3} / \mathrm{min} \\
\text { ( } 1000 \mathrm{scfm} \text { ), some changes to the systems- such } \\
\text { as verification of isokinetic nozzles, re-calibration } \\
\text { of flow monitoring loop would be required. }\end{array}$ \\
\hline & $\begin{array}{l}\text { pressure transmitter } \\
\text { with remote switch and } \\
\text { indication (tank } \\
\text { diluent) }\end{array}$ & TBD & & \\
\hline & $\begin{array}{l}\text { pressure transmiter } \\
\text { with remote switch and } \\
\text { indication (raw water) }\end{array}$ & $\therefore$ & existing instrument has adequate range. & \\
\hline & $\begin{array}{l}\text { CAM with interlock to } \\
\text { exhaust fan }\end{array}$ & TBD & $\begin{array}{l}\text { existing system design adequate if radiolytic } \\
\text { emission contains beta \& gamma only .- }\end{array}$ & \\
\hline & $\begin{array}{l}\text { differential pressure } \\
\text { transmitter with } \\
\text { local/remote indication } \\
\text { and interlock with } \\
\text { exhaust fan (HEPA) }\end{array}$ & Yes & $\begin{array}{l}\text { Existing system design has adequate } \\
\text { instrumentation to indicate HEPA filter } \\
\text { condition. }\end{array}$ & \\
\hline
\end{tabular}


Table C-7. Comparison of Process Monitoring and Control Needs to Available Monitoring and Control Equipment in 241-AZ Tank Farm in Support of Phase 1 Feed Delivery.

\begin{tabular}{|c|c|c|c|c|}
\hline Tank & $\begin{array}{l}\text { Monitoring and control } \\
\text { instrumentation/equipm } \\
\text { ent }\end{array}$ & $\begin{array}{l}\text { Is existing and planned } \\
\text { instrumentation } \\
\text { adequate? }(\mathrm{Y} / \mathrm{N})\end{array}$ & Basis for adequacy assessment & Comments/issues \\
\hline \multirow[t]{8}{*}{$\begin{array}{l}\text { AZ-101 } \\
\text { (cont.) }\end{array}$} & $\begin{array}{l}\text { conductivity prohes set } \\
\text { at proper elevations } \\
\text { (annulus leak detectors) }\end{array}$ & Yes & $\begin{array}{l}\text { Existing system has adequate instrumentation to } \\
\text { detect presence of liquid. }\end{array}$ & \\
\hline & $\begin{array}{l}\text { RTDs at elevations to } \\
\text { give temperature } \\
\text { gradients at various } \\
\text { tank levels (primary } \\
\text { tank) } \\
\end{array}$ & No & . & $\begin{array}{l}\text { existing temperature system is not adequate } \\
\text { during mixer pump operation as uniform } \\
\text { temperature gradient over the entire length of } \\
\text { liquid column will be used to determine } \\
\text { completion of mixing operation. }\end{array}$ \\
\hline & $\begin{array}{l}\text { raw water flow } \\
\text { totalizer (primary tank) }\end{array}$ & TBD & . & \\
\hline & $\begin{array}{l}\text { ENRAF }{ }^{\mathrm{rM}} \text { level system } \\
\text { (primary tk.) }\end{array}$ & Yes & $\begin{array}{l}\text { W-151 is installing ENRAF which would give } \\
\text { better accuracy of level measurement once CIU } \\
\text { is installed to transmit digital signal. }\end{array}$ & $\begin{array}{l}\text { CIU required to be installed to get accurate level } \\
\text { measurement for quantity transfer calculations. }\end{array}$ \\
\hline & $\begin{array}{l}\text { trend recorder } \\
\text { connected to waste } \\
\text { temperature monitoring } \\
\text { system }\end{array}$ & TBD & & $\begin{array}{l}\text { existing trend recorder system will need re- } \\
\text { calibration for temperature gradient data record as } \\
\text { well as rate of change anmunciation }\end{array}$ \\
\hline & $\begin{array}{l}\text { pressure and flow } \\
\text { transmitters with local } \\
\text { and remote indication } \\
\text { (instrument air system } \\
\text { for air lift circulators) } \\
\text { and air lift circulator } \\
\text { temperature indication. }\end{array}$ & TBD & $\begin{array}{l}\text { Existing system design provides this } \\
\text { information. }\end{array}$ & $\begin{array}{l}\text { Need to verify air flow and pressure adequacy to } \\
\text { maintain waste temperature below } 93^{\circ} \mathrm{C}\left(200^{\circ} \mathrm{F}\right) \\
\text { sludge temperature below } 110^{\circ} \mathrm{C}\left(230^{\circ} \mathrm{F}\right) \text { by air } \\
\text { lift circulator operation. Need to verify operating } \\
\text { time and air supply capacity. }\end{array}$ \\
\hline & $\begin{array}{l}\text { on-line analyzer } \\
\text { (continuous) for diluent } \\
\text { water chemistry }\end{array}$ & TBD & & \\
\hline & $\begin{array}{l}\text { flow totalizer with } \\
\text { remote flow indicator } \\
\text { (diluent) }\end{array}$ & TBD & & \\
\hline
\end{tabular}


Table C-7. Comparison of Process Monitoring and Control Needs to Available Monitoring and Control Equipment in 241-AZ Tank Farm in Support of Phase 1 Feed Delivery.

\begin{tabular}{|c|c|c|c|c|}
\hline Tank & $\begin{array}{c}\text { Monitoring and control } \\
\text { instrumentation/equipm } \\
\text { ent }\end{array}$ & $\begin{array}{c}\text { Is existing and planned } \\
\text { instrumentation } \\
\text { adequate? }(\mathrm{Y} / \mathrm{N})\end{array}$ & Basis for adequacy assessment & Comments/issues \\
\hline \multirow[t]{9}{*}{$\begin{array}{l}\text { AZ-101 } \\
\text { (cont.) }\end{array}$} & $\begin{array}{l}\text { ENRAF }^{T y} \text { system; } \\
\text { URSILL } \Lambda \text { system } \\
\text { (primary tank density) }\end{array}$ & TBD & & \\
\hline & $\begin{array}{l}\text { grab sample with } \\
\text { remote analysis (slurry } \\
\text { viscosity) }\end{array}$ & TBD & & \\
\hline & $\begin{array}{l}\text { mixer pump VFD } \\
\text { (rotational speed) }\end{array}$ & TBD & & \\
\hline & $\begin{array}{l}\text { accelerometer with } \\
\text { remote indication at } \\
\text { VFD control station } \\
\text { (mixer pump/motor } \\
\text { vibration) }\end{array}$ & TBD & & \\
\hline & $\begin{array}{l}\text { In-tank camera with } \\
\text { controls and air or } \\
\text { nitrogen purge pressure } \\
\text { and flow }\end{array}$ & TBD & . & - \\
\hline & $\begin{array}{l}\text { turntable drive position } \\
\text { indication (part of } \\
\text { mixer pump VFD } \\
\text { system) }\end{array}$ & TBD & . & \\
\hline & $\begin{array}{l}\text { mass flow meter } \\
\text { (siurry transfer) }\end{array}$ & TBD & & \\
\hline & $\begin{array}{l}\text { pressure transmitter } \\
\text { with remote indication } \\
\text { (transter piping } \\
\text { diluent) }\end{array}$ & TBD & & - \\
\hline & $\begin{array}{l}\text { flow totalizer (transfer } \\
\text { diluent) }\end{array}$ & TBD & & \\
\hline
\end{tabular}


Table C-7. Comparison of Process Monitoring and Control Needs to Available Monitoring and Control Equipment in 241-AZ Tank Farm in Support of Phase 1 Feed Delivery.

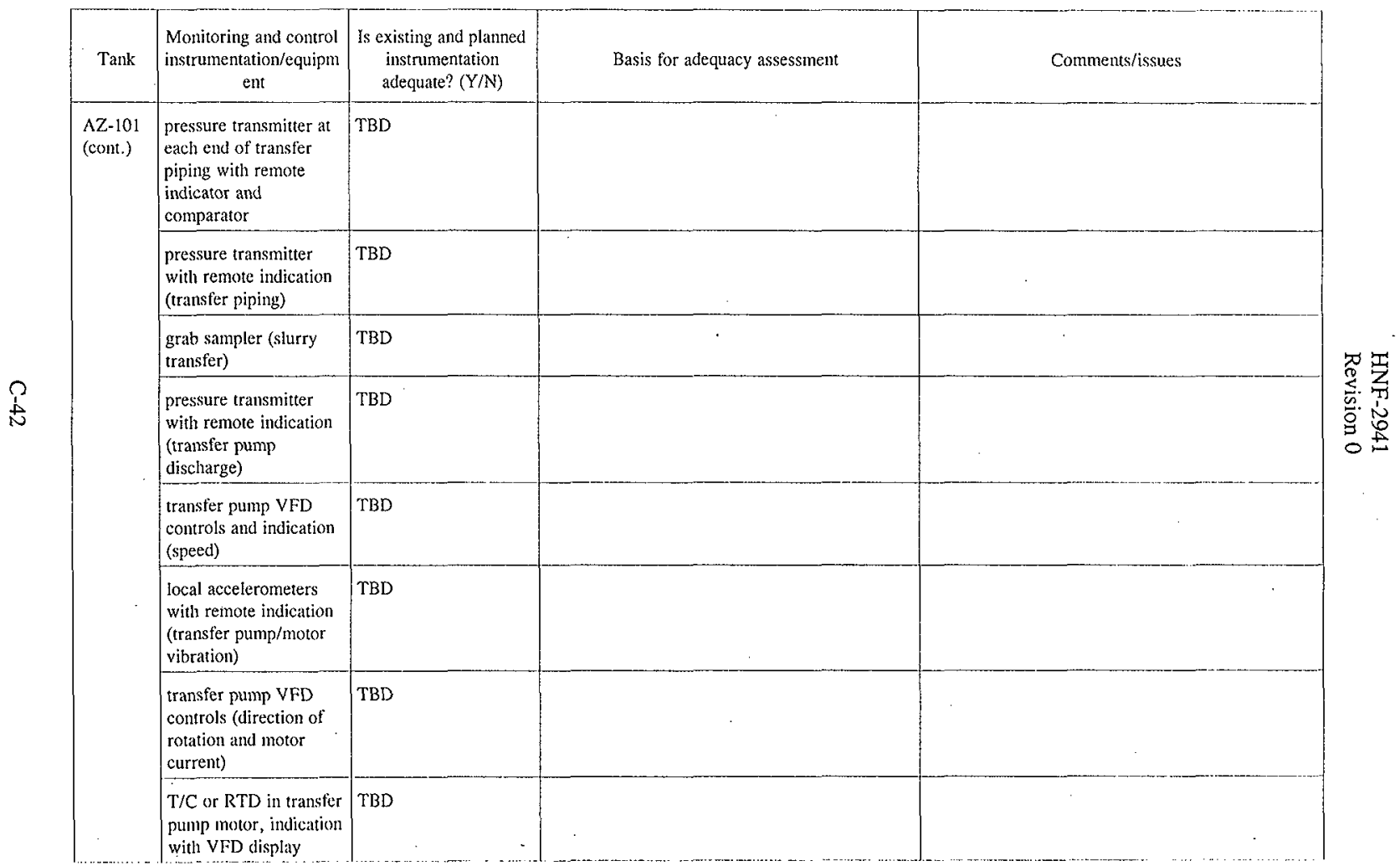


Table C-7. Comparison of Process Monitoring and Control Needs to Available Monitoring and Control Equipment in 241-AZ Tank Farm in Support of Phase 1 Feed Delivery.

\begin{tabular}{|c|c|c|c|c|}
\hline Tank & $\begin{array}{l}\text { Monitoring and control } \\
\text { instrumentation/equipm } \\
\text { ent }\end{array}$ & $\begin{array}{l}\text { Is existing and planned } \\
\text { instrumentation } \\
\text { adequate? (Y/N) }\end{array}$ & Basis for adequacy assessment & Comments/issues \\
\hline \multirow[t]{3}{*}{$\begin{array}{l}\mathrm{AZ}-101 \\
\text { (cont.) }\end{array}$} & $\begin{array}{l}\text { flow totalizer with } \\
\text { remote indication } \\
\text { (transfer line flush } \\
\text { water) }\end{array}$ & TBD & & \\
\hline & $\begin{array}{l}\text { on-line sampler } \\
\text { (transfer flush water } \\
\text { chemistry) }\end{array}$ & TBD & & \\
\hline & $\begin{array}{l}\text { flow totalizer with } \\
\text { remote indication } \\
\text { (transfer flush water) }\end{array}$ & TBD & & \\
\hline
\end{tabular}


Table C-7. Comparison of Process Monitoring and Control Needs to Available Monitoring and Control Equipment in 241-AZ Tank Farm in Support of Phase 1 Feed Delivery.

\begin{tabular}{|c|c|c|c|c|}
\hline Tank & $\begin{array}{c}\text { Monitoring and control } \\
\text { instrumentation/equipm } \\
\text { ent }\end{array}$ & $\begin{array}{l}\text { Is existing and planned } \\
\text { instrumentation } \\
\text { adequate? }(\mathrm{Y} / \mathrm{N})\end{array}$ & Basis for adequacy assessment & Comments/issues \\
\hline \multirow[t]{7}{*}{$A Z-102$} & $\begin{array}{l}\text { hydrogen analyzer } \\
\text { (continuous, on-line } \\
\text { sampling) }\end{array}$ & Yes & $\begin{array}{l}\text { Existing system has two channels which cover } \\
\text { narrow range and wide range. }\end{array}$ & \\
\hline & $\begin{array}{l}\text { pressure transmitter } \\
\text { (dp or absolute) with } \\
\text { remote } \\
\text { indication/alarm (vapor } \\
\text { space) }\end{array}$ & TBD & . & $\begin{array}{l}\text { existing PIT is calibrated for }-15.2 \text { to }+10.2 \mathrm{~cm} \\
(-6 \text { to }+4 \text { in. WG). Needs re-calibration of the } \\
\text { loop to span from }-25.4 \text { to }+12.7 \mathrm{~cm} \\
(-10 \text { to }+5 \text { in. WG }) \text {. }\end{array}$ \\
\hline & $\begin{array}{l}\text { stack isokinetic } \\
\text { probe/control system } \\
\text { (exhaust flow) }\end{array}$ & TBD & $\begin{array}{l}\text { Existing system is designed for flow variations } \\
\text { of } 400-1000 \mathrm{scfm} \text {. }\end{array}$ & $\begin{array}{l}\text { If mixer pump/transfer pump operation doesn't } \\
\text { increase exhaust flow of } 28.3 \mathrm{~m} 3 / \mathrm{min} \\
(1000 \mathrm{scfm} \text { ), existing system would be adequate. } \\
\text { If flow increases beyond } 28.3 \mathrm{~m}^{3} / \mathrm{min} \\
\text { (1000 scfm), some changes to the systems- such } \\
\text { as verification of isokinetic nozzles, re-calibration } \\
\text { of flow monitoring loop would be required. }\end{array}$ \\
\hline & $\begin{array}{l}\text { pressure transmitter } \\
\text { with remote switch and } \\
\text { indication (tank } \\
\text { diluent) }\end{array}$ & TBD & & \\
\hline & $\begin{array}{l}\text { pressure transmitter } \\
\text { with remote switch and } \\
\text { indication (raw water) }\end{array}$ & Yes & existing instrument has adequate range. & 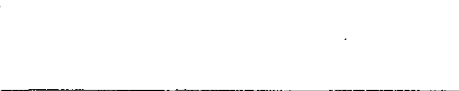 \\
\hline & $\begin{array}{l}\text { CAM with interlock to } \\
\text { exhaust fan }\end{array}$ & TBD & $\begin{array}{l}\text { existing system design adequate if radiolytic } \\
\text { emission contains beta \& gamma only. }\end{array}$ & \\
\hline & $\begin{array}{l}\text { differential pressure } \\
\text { transmitter with } \\
\text { local/remote indication } \\
\text { and interlock with } \\
\text { exhaust fan (HEPA) }\end{array}$ & TBD & $\begin{array}{l}\text { Existing system design has adequate } \\
\text { instrumentation to indicate HEPA filter } \\
\text { condition. }\end{array}$ & \\
\hline
\end{tabular}


Table C-7. Comparison of Process Monitoring and Control Needs to Available Monitoring and Control Equipment in 241-AZ Tank Farm in Support of Phase 1 Feed Delivery.

\begin{tabular}{|c|c|c|c|c|}
\hline Tank & $\begin{array}{c}\text { Monitoring and control } \\
\text { instrumentation/equipm } \\
\text { ent }\end{array}$ & $\begin{array}{l}\text { Is existing and plauned } \\
\text { instrumentation } \\
\text { adequate? }(\mathrm{Y} / \mathrm{N})\end{array}$ & Basis for adequacy assessment & Comments/issues \\
\hline \multirow[t]{8}{*}{$\begin{array}{l}\text { AZ-102 } \\
\text { (cont.) }\end{array}$} & $\begin{array}{l}\text { conductivity probes set } \\
\text { at proper elevations } \\
\text { (annulus leak detectors) }\end{array}$ & Yes & $\begin{array}{l}\text { Existing system design has adequate } \\
\text { instrumentation to detect presence of liquid. }\end{array}$ & \\
\hline & $\begin{array}{l}\text { RTDs at elevations to } \\
\text { give temperature } \\
\text { gradients at various } \\
\text { tank levels (primary } \\
\text { tank) }\end{array}$ & No & & $\begin{array}{l}\text { existing temperature system is not adequate } \\
\text { during mixer pump operation as uniform } \\
\text { temperature gradient over the entire length of } \\
\text { liquid column will be used to determine } \\
\text { completion of mixing operation }\end{array}$ \\
\hline & $\begin{array}{l}\text { raw water flow } \\
\text { totalizer (primary tank) }\end{array}$ & TBD & + & \\
\hline & $\begin{array}{l}\text { ENR } F^{\mathrm{ra}} \text { level system } \\
\text { (primary tk.) }\end{array}$ & Yes & $\begin{array}{l}\text { W-151 is installing ENRAF } F^{\mathrm{Tu}} \text { would give better } \\
\text { accuracy of level measurement once CIU is } \\
\text { installed to transmit digital signal. }\end{array}$ & $\begin{array}{l}\text { CIU required to be installed to get accurate level } \\
\text { measurement for quantity transfer calculations. }\end{array}$ \\
\hline & $\begin{array}{l}\text { trend recorder } \\
\text { connected to waste } \\
\text { temperature monitoring } \\
\text { system }\end{array}$ & TBD & & $\begin{array}{l}\text { existing trend recorder system will need re- } \\
\text { calibration for temperature gradient data record as } \\
\text { well as rate of change amnunciation }\end{array}$ \\
\hline & $\begin{array}{l}\text { pressure and flow } \\
\text { transmitters with local } \\
\text { and remote indication } \\
\text { (instrument air system } \\
\text { for air lift circulators) }\end{array}$ & TBD & $\begin{array}{l}\text { Existing system design provides this } \\
\text { information. }\end{array}$ & $\begin{array}{l}\text { Need to verify air flow and pressure adequacy to } \\
\text { maintain waste temperature below } 93^{\circ} \mathrm{C}\left(200^{\circ} \mathrm{F}\right) \\
\text { sludge temperature below } 110^{\circ} \mathrm{C}\left(230^{\circ} \mathrm{F}\right) \text { by air } \\
\text { lift circulator operation. Need to verify operating } \\
\text { time and air supply capacity. }\end{array}$ \\
\hline & $\begin{array}{l}\text { on-line analyzer } \\
\text { (continuous) for diluent } \\
\text { water chemistry }\end{array}$ & TBD & & \\
\hline & $\begin{array}{l}\text { flow totalizer with } \\
\text { remote flow indicator } \\
\text { (diluent) }\end{array}$ & TBD & & $\cdot$ \\
\hline
\end{tabular}




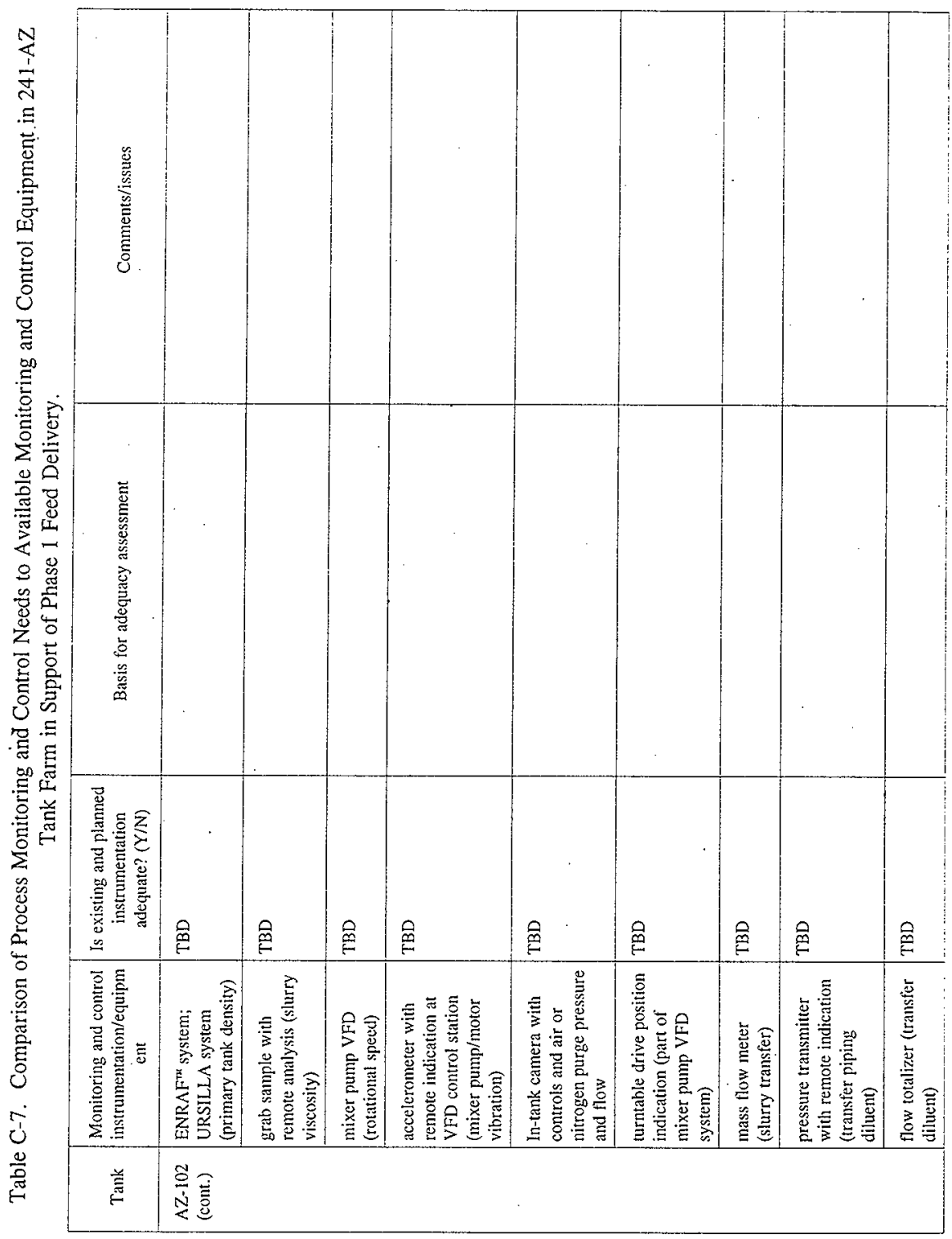


Table C-7. Comparison of Process Monitoring and Control Needs to Available Monitoring and Control Equipment in 241-AZ Tank Farm in Support of Phase 1 Feed Delivery.

\begin{tabular}{|c|c|c|c|c|}
\hline Tank & $\begin{array}{c}\text { Monitoring and control } \\
\text { instrumentation/equipm } \\
\text { ent }\end{array}$ & $\begin{array}{l}\text { Is existing and plamned } \\
\text { instrumentation } \\
\text { adequate? }(\mathrm{Y} / \mathrm{N})\end{array}$ & Basis for adequacy assessment & Comments/issues \\
\hline \multirow[t]{8}{*}{$\begin{array}{l}\text { AZ-102 } \\
\text { (cont.) }\end{array}$} & $\begin{array}{l}\text { pressure transmitter at } \\
\text { each end of transfer } \\
\text { piping with remote } \\
\text { indicator and } \\
\text { comparator }\end{array}$ & TBD & & \\
\hline & $\begin{array}{l}\text { pressure transmitter } \\
\text { with remote indication } \\
\text { (transfer piping) }\end{array}$ & TBD & . & \\
\hline & $\begin{array}{l}\text { grab sampler (slurry } \\
\text { transfer) }\end{array}$ & TBD & . & \\
\hline & $\begin{array}{l}\text { pressure transmitter } \\
\text { with remote indication } \\
\text { (transfer pump } \\
\text { discharge) }\end{array}$ & TBD & . & . \\
\hline & $\begin{array}{l}\text { transfer pump VFD } \\
\text { controls and indication } \\
\text { (speed) }\end{array}$ & TBD & & \\
\hline & $\begin{array}{l}\text { Iocal accelerometers } \\
\text { with remote indication } \\
\text { (transfer pump/motor } \\
\text { vibration) }\end{array}$ & TBD & & \\
\hline & $\begin{array}{l}\text { transfer pump VFD } \\
\text { controls (direction of } \\
\text { rotation and motor } \\
\text { current) }\end{array}$ & TBD & . & \\
\hline & $\begin{array}{l}\text { T/C or RTD in transfer } \\
\text { pump motor, indication } \\
\text { with VFD display }\end{array}$ & TBD & & \\
\hline
\end{tabular}


Table C-7. Comparison of Process Monitoring and Control Needs to Available Monitoring and Control Equipment in 241-AZ Tank Farm in Support of Phase 1 Feed Delivery.

\begin{tabular}{|c|c|c|c|c|}
\hline Tank & $\begin{array}{c}\text { Monitoring and control } \\
\text { instrumentation/equipm } \\
\text { ent }\end{array}$ & $\begin{array}{l}\text { Is existing and planned } \\
\text { instrumentation } \\
\text { adequate? }(\mathrm{Y} / \mathrm{N})\end{array}$ & Basis for adequacy assessment & Comments/issues \\
\hline \multirow[t]{2}{*}{$\begin{array}{l}\text { AZ-102 } \\
\text { (cont.) }\end{array}$} & $\begin{array}{l}\text { flow totalizer with } \\
\text { remote indication } \\
\text { (transfer line flush } \\
\text { water) }\end{array}$ & TBD & . & . \\
\hline & $\begin{array}{l}\text { on-line sampler } \\
\text { (transter tlush water } \\
\text { chemistry) }\end{array}$ & TBD & & . \\
\hline
\end{tabular}


HNF-2941

Revision

\section{APPENDIX D}

\section{VENTILATION SYSTEM PROCESS NEEDS AND ASSESSMENT}


HNF-2941

Revision

This page intentionally left blank.

D-2 
HNF-2941

Revision

\section{APPENDIX D}

\section{VENTILATION SYSTEM PROCESS NEEDS AND ASSESSMENT}

Table 4-1 has identified quantitative process needs that must be met in order to enable tank waste remediation system (TWRS) to adequately deliver appropriate waste feed during Phase 1 privatization. A number of these quantitative process needs are specific to and rely on specific performance of the ventilation system. The ventilation system must be present to support feed delivery to the Phase 1 privatization contractor as well as ongoing TWRS operations during the Phase 1 privatization time frame. For the purposes of this evaluation of 241-AZ tank farm, the ventilation system consists of both the primary ventilation system and the annulus ventilation system. The quantitative process needs identified in Table 4-1 that apply to the ventilation system are presented in the sections below. Quantitative safety-related expectations are presented in Table 4-2.

\section{D.1 VENTILATION SYSTEM EXPECTATIONS}

The primary ventilation system must remove heat, air, evaporated water and evolved gases and particulate from the primary tank. The annulus ventilation system must remove heat and moisture and sweep the annular space to radiation detectors. The quantitative process needs that apply to the ventilation system are summarized as part of Table D-1. The safetyrelated requirements for the ventilation system are summarized in Table D-2.

\section{D.2 EXISTING AND PLANNED VENTILATION SYSTEM}

\section{D.2.1 Previous Aging Waste Facility Primary Ventilation System (241-A-702)}

The original design of the 241-A-702 primary ventilation system was an active ventilation system that provided primary tank ventilation for the four aging waste facility (AWF) tanks (241-AY-101, 241-AY-102, 241-AZ-101 and 241-AZ-102) and for the 241-AX-152 diverter station. Several other miscellaneous structures (e.g., the 241-AZ-151 and 241-AZ-154 catch tanks) were ventilated indirectly through waste transfer lines. The primary ventilation system was designed specifically for plutonium-uranium extraction (PUREX) generated aging waste (or boiling waste), which is exceptionally "hot" both thermally and radiologically. 
Table D-1. Comparison of Process Needs to Existing and Planned Equipment for Ventilation in 241-AZ Tank Farm.

\begin{tabular}{|c|c|c|c|c|}
\hline $\begin{array}{c}\text { Quantitative tank-specific } \\
\text { process need }\end{array}$ & $\begin{array}{l}\text { Existing or planned structure, } \\
\text { system or component }\end{array}$ & $\begin{array}{l}\text { Is existing and planned } \\
\text { equipment adecquate } \\
\text { (Yes/No) }\end{array}$ & Basis & Conments/issues \\
\hline $\begin{array}{l}\text { 5.P2.2. HLW: The } \\
\text { variability of suspended } \\
\text { solids concentrations } \\
\text { should vary <20\% (TBR) } \\
\text { over the full depth prior to } \\
\text { sampling and prior to } \\
\text { beginning each feed } \\
\text { transfer. }\end{array}$ & $\begin{array}{l}\text { Primary Ventilation - } \\
\text { Air Inlet \& Intiltration, } \\
\text { Recirculation Ventilation } \\
\text { Cooling System, Recirculation } \\
\text { Condenser Cooling System, } \\
\text { Ducting, Primary Condenser, } \\
\text { Primary High Efficiency Mist } \\
\text { Eliminator, Primary Heaters, } \\
\text { HEPA Filter and HEGA } \\
\text { Train, Exhaust Fan, Stack } \\
\text { During mixer pump operation, } \\
\text { provide ventilation air flow to: } \\
\text { 1. maintain tank head space at } \\
\text { negative pressure; and } \\
\text { 2. remove heat generated } \\
\text { during mixer pump operation } \\
\text { to homogenize tank contents. }\end{array}$ & $\begin{array}{l}\text { Maintain Tank Head } \\
\text { Space at Negative } \\
\text { Pressure - TBD } \\
\text { Remove Heat Generated } \\
\text { During Mixer Pump } \\
\text { Operation to Homogenize } \\
\text { Tank Contents - TBD }\end{array}$ & See comments. & 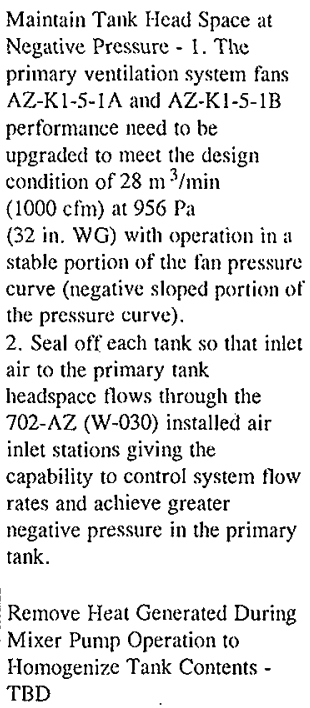 \\
\hline
\end{tabular}


Table D-2. Comparison of Safety-Related Needs to Existing And Planned Equipment For Ventilation in 241-AN Tank Farm.

\begin{tabular}{|c|c|c|c|c|}
\hline $\begin{array}{c}\text { Quantitative tank-specific } \\
\text { process need }\end{array}$ & $\begin{array}{l}\text { Existing or planned structurc, } \\
\text { system, or component }\end{array}$ & $\begin{array}{l}\text { Is existing and planned } \\
\text { equipment adequate } \\
\text { (Yes/No) }\end{array}$ & Basis & Comments/issues \\
\hline $\begin{array}{l}\text { 1.S1.3. Maintain } \\
\text { flammable gases } \\
\text { concentrations no greater } \\
\text { than } 25 \% \text { of the lower } \\
\text { flammability limit }\end{array}$ & $\begin{array}{l}\text { Primary Ventilation - } \\
\text { Exhaust Fan }\end{array}$ & TBD & Calculation F.5.2 & $\begin{array}{l}\text { Primary ventilation flow rates to } \\
\text { maintain flammable gas } \\
\text { concentrations below } 25 \% \text { of the } \\
\text { lower flammability limit have } \\
\text { not been completed. } \\
\text { For comparison, the primary } \\
\text { tank flow rate to maintain waste } \\
\text { temperature to } 73.9^{\circ} \mathrm{C}\left(165^{\circ} \mathrm{F}\right) \\
\text { is more than ten times the flow } \\
\text { rate required to maintain } \\
\text { hydrogen concentration below } \\
25 \% \text { of LFL except for the } \\
\text { Watch List Tanks. }\end{array}$ \\
\hline $\begin{array}{l}\text { 1.S2.3. An active primary } \\
\text { ventilation system shall be } \\
\text { operable for all DSTs and } \\
\text { AWTs }\end{array}$ & $\begin{array}{l}\text { Primary Ventilation - } \\
\text { Ducting, Primary Condenser, } \\
\text { Primary High Efficiency Mist } \\
\text { Eliminator, Primary Heaters, } \\
\text { HEPA Filter and HEGA } \\
\text { Train, Exhaust Fan, Stack }\end{array}$ & Yes. & The existing system is operable. & \\
\hline $\begin{array}{l}\text { 1.S7.1. Primary tank } \\
\text { ventilation stack CAM } \\
\text { interlock systems shall be } \\
\text { operable when active } \\
\text { ventilation is operating. }\end{array}$ & Primary Ventilation - Stack & TBD & TBD & \\
\hline $\begin{array}{l}\text { 1.S8.1. An active primary } \\
\text { tank ventilation system for } \\
\text { DSTs and AWF tanks shall } \\
\text { be operable. }\end{array}$ & $\begin{array}{l}\text { Primary Ventilation - } \\
\text { Air Inlet \& Infiltration, } \\
\text { Ducting, Exhaust Fan, Stack } \\
\\
\text { Annulus Ventilation - } \\
\text { Air Inlet, Ducting, Exhaust } \\
\text { Fan, Stack }\end{array}$ & TBD & TBD & . \\
\hline
\end{tabular}


Table D-2. Comparison of Safety-Related Needs to Existing And Planned Equipment For Ventilation in 241-AN Tank Farm.

\begin{tabular}{|c|c|c|c|c|}
\hline $\begin{array}{c}\text { Quantitative tank-specitic } \\
\text { process need }\end{array}$ & $\begin{array}{l}\text { Existing or planned structure, } \\
\text { system, or component }\end{array}$ & $\begin{array}{l}\text { Is existing and planned } \\
\text { equipment adequate } \\
\text { (Yes/No) }\end{array}$ & Basis & Comments/issues \\
\hline $\begin{array}{l}\text { 1.S9.1. Either the annulus } \\
\text { conductivity probe system } \\
\text { or the annulus continuous } \\
\text { air monitor system shall be } \\
\text { operable for DSTs and } \\
\text { AWF tanks. }\end{array}$ & $\begin{array}{l}\text { The annulus ventilation } \\
\text { system for } 241-A Z \text { is not } \\
\text { currently operating. }\end{array}$ & Yes & Conductivity probe system is operable & \\
\hline $\begin{array}{l}\text { 1.S10.1. Tank waste } \\
\text { temperature shall be either: } \\
\leq 90.6^{\circ} \mathrm{C}\left(195^{\circ} \mathrm{F}\right) \text { in all } \\
\text { levels of the waste; or } \\
\leq 90.6^{\circ} \mathrm{C}\left(195^{\circ} \mathrm{F}\right) \text { in the } \\
\text { top } 4.6 \mathrm{~m}(15 \mathrm{ft}) \text { of the } \\
\text { waste and } \leq 102^{\circ} \mathrm{C} \\
\left(215^{\circ} \mathrm{F}\right) \text { in the waste below } \\
4.6 \mathrm{~m}(15 \mathrm{ft}) \text {. }\end{array}$ & $\begin{array}{l}\text { Primary Ventilation - } \\
\text { Recirculation Ventilation } \\
\text { Cooling System, } \\
\text { Recirculation Condenser } \\
\text { Cooling System, Ducting, } \\
\text { Primary Condenser, Exhaust } \\
\text { Fan } \\
\text { Provide ventilation air flow } \\
\text { to remove heat generated } \\
\text { during waste feed delivery } \\
\text { operations. }\end{array}$ & $\begin{array}{l}\text { Yes, based on } \\
\text { preliminary results }\end{array}$ & See Calculation F.5.1 & $\begin{array}{l}\text { Upon settling, this solids layer is } \\
\text { expected to rise in temperature } \\
\text { above the bulk temperature of } \\
\text { the solution (i.e., higher than the } \\
82.8^{\circ} \mathrm{C}\left[181^{\circ} \mathrm{F}\right] \text { calculated in the } \\
\text { preliminary calculations). More } \\
\text { detailed analysis will be required } \\
\text { to verify the preliminary } \\
\text { calculations, but the initial } \\
\text { results indicate that the } 702-\mathrm{AZ} \\
\text { (W-030) revised } \mathrm{AWF} \\
\text { ventilation system will } \\
\text { adequately remove } \\
\text { heat/condensate for mixer pump } \\
\text { operation in one tank and } \\
\text { provide adequate ventilation for } \\
\text { the other three AWF tanks. }\end{array}$ \\
\hline
\end{tabular}


Table D-2. Comparison of Safety-Related Needs to Existing And Planned Equipment For Ventilation in 241-AN Tank Farm.

\begin{tabular}{|c|c|c|c|c|}
\hline $\begin{array}{l}\text { Quantitative tank-specific } \\
\text { process need }\end{array}$ & $\begin{array}{l}\text { Existing or planned structure, } \\
\text { system, or component }\end{array}$ & $\begin{array}{l}\text { Is existing and planned } \\
\text { equipment adequate } \\
\left(\mathrm{Yes}_{\mathrm{No}} \mathrm{No}\right)\end{array}$ & Basis & Comments/issues \\
\hline $\begin{array}{l}\text { 1.S10.2. Waste: } \\
\text { temperature shall not } \\
\text { exceed } 121^{\circ} \mathrm{C}\left(250^{\circ} \mathrm{F}\right) \text {. } \\
\end{array}$ & $\begin{array}{l}\text { Primary Ventilation - } \\
\text { Recirculation Ventilation } \\
\text { Cooling System, } \\
\text { Recirculation Condenser } \\
\text { Cooling System, Ducting, } \\
\text { Primary Condenser, Exhaust } \\
\text { Fan } \\
\text { Provide ventilation air flow } \\
\text { to remove heat generated } \\
\text { during waste feed delivery } \\
\text { operations. }\end{array}$ & $\begin{array}{l}\text { Yes, based on } \\
\text { preliminary results }\end{array}$ & See Calculation F.5.1 & $\begin{array}{l}\text { Upon settling, this solids layer is } \\
\text { expected to rise in temperature } \\
\text { above the bulk temperasure of } \\
\text { the solution (i.e., higher than the } \\
82.8^{\circ} \mathrm{C} \mathrm{(}\left(81^{\circ} \mathrm{F} \text { ) calculated in the }\right. \\
\text { preliminary calculations). More } \\
\text { detailed analysis will be required } \\
\text { to verify the preliminary } \\
\text { calculations, hut the initial } \\
\text { results indicate that the } 702-\Lambda Z \\
\text { (W-030) revised } \Lambda W F \\
\text { ventilation system will } \\
\text { adequately remove } \\
\text { heat/condensate for mixer pump } \\
\text { operation in one tank and } \\
\text { provide adequate ventilation for } \\
\text { the other three AWF tanks. }\end{array}$ \\
\hline $\begin{array}{l}\text { 2.S1.I. Maintain tank } \\
\text { headspace flammable gases } \\
\text { concentrations no greater } \\
\text { than } 25 \% \text { of the lower } \\
\text { flammability limit. }\end{array}$ & $\begin{array}{l}\text { Primary Ventilation - } \\
\text { Exhaust Fan }\end{array}$ & . & Calculation F.5.2 & $\begin{array}{l}\text { Primary ventilation flow rates to } \\
\text { maintain flammable gas } \\
\text { concentrations below } 25 \% \text { of the } \\
\text { lower flammability limit have } \\
\text { not been completed. } \\
\text { For comparison, the primary } \\
\text { tank flow rate to maintain waste } \\
\text { temperature to } 73.9^{\circ} \mathrm{C}\left(165^{\circ} \mathrm{F}\right) \\
\text { is more than ten times the flow } \\
\text { rate required to maintain } \\
\text { hydrogen concentration below } \\
25 \% \text { of LFL except for the } \\
\text { Watch List Tanks. }\end{array}$ \\
\hline
\end{tabular}


Table D-2. Comparison of Safety-Related Needs to Existing And Planned Equipment For Ventilation in 241-AN Tank Farm.

\begin{tabular}{|c|c|c|c|c|}
\hline $\begin{array}{l}\text { Quantitative tank-specitic } \\
\text { process need }\end{array}$ & $\begin{array}{l}\text { Existing or planned structure, } \\
\text { system, or component }\end{array}$ & $\begin{array}{l}\text { Is existing and planned } \\
\text { equipment adequate } \\
\text { (Yes/No) }\end{array}$ & Basis & Comments/issues \\
\hline $\begin{array}{l}\text { 5.S1.1. Tank waste } \\
\text { temperature shall be either: } \\
\leq 90.6^{\circ} \mathrm{C}\left(195^{\circ} \mathrm{F}\right) \text { in all } \\
\text { levels of the waste; or } \\
\leq 90.6^{\circ} \mathrm{C}\left(195^{\circ} \mathrm{F}\right) \text { in the } \\
\text { top } 4.6 \mathrm{~m}(15 \mathrm{ft}) \text { of the } \\
\text { waste and } \leq 102^{\circ} \mathrm{C} \\
\left(215^{\circ} \mathrm{F}\right) \text { in the waste below } \\
4.6 \mathrm{~m}(15 \mathrm{ft})\end{array}$ & $\begin{array}{l}\text { Primary Ventilation - } \\
\text { Recirculation Ventilation } \\
\text { Cooling System, } \\
\text { Recirculation Condenser } \\
\text { Cooling System, Ducting, } \\
\text { Primary Condenser, Exhaust } \\
\text { Fan } \\
\text { Provide ventilation air flow } \\
\text { to remove heat generated } \\
\text { during waste feed delivery } \\
\text { operations. }\end{array}$ & $\begin{array}{l}\text { Yes, based on } \\
\text { preliminary results }\end{array}$ & See Calculation F.S.1 & $\begin{array}{l}\text { Upon settling, this solids layer is } \\
\text { expected to rise in temperature } \\
\text { above the bulk temperature of } \\
\text { the solution (i.e., higher than the } \\
82.8^{\circ} \mathrm{C}\left(181^{\circ} \mathrm{F} \text { ) calculated in the }\right. \\
\text { preliminary calculations). More } \\
\text { detailed analysis will be required } \\
\text { to verify the preliminary } \\
\text { calculations, but the initial } \\
\text { results indicate that the } 702-\Lambda Z \\
\text { (W-030) revised AWF } \\
\text { ventilation system will } \\
\text { adequately remove } \\
\text { heat/condensate for mixer pump } \\
\text { operation in one tank and } \\
\text { provide adequate ventilation for } \\
\text { the other three AWF tanks. }\end{array}$ \\
\hline $\begin{array}{l}\text { 5.S1.2. Temperature } \\
\text { clangeover time for } \\
\text { solutions in tanks shall be } \\
\leq 5.5^{\circ} \mathrm{C}\left(10^{\circ} \mathrm{F}\right) / \mathrm{hr} \\
\left(<52^{\circ} \mathrm{C}\left[125^{\circ} \mathrm{F}\right]\right) \text { or } \\
\leq 11^{\circ} \mathrm{C}\left(20^{\circ} \mathrm{F}\right) / \text { day } \\
\left(\geq 52^{\circ} \mathrm{C}\left[125^{\circ} \mathrm{F}\right]\right)\end{array}$ & $\begin{array}{l}\text { Primary Ventilation - } \\
\text { Recirculation Ventilation } \\
\text { Cooling System, } \\
\text { Recirculation Condenser } \\
\text { Cooling System, Ducting, } \\
\text { Primary Condenser, Exhaust } \\
\text { Fan } \\
\text { Provide ventilation air flow } \\
\text { to remove heat generated } \\
\text { during waste feed delivery } \\
\text { operations. }\end{array}$ & $\begin{array}{l}\text { Yes, based on } \\
\text { preliminary results }\end{array}$ & See Calculation F.S.1 & $\begin{array}{l}\text { Upon settling, this solids layer is } \\
\text { expected to rise in temperature } \\
\text { above the bulk temperature of } \\
\text { the solution (i.e., higher than the } \\
82.8^{\circ} \mathrm{C}\left(181^{\circ} \mathrm{F} \text { ) calculated in the }\right. \\
\text { preliminary calculations). More } \\
\text { detailed analysis will be required } \\
\text { to verify the preliminary } \\
\text { calculations, but the initial } \\
\text { results indicate that the } 702-\Lambda Z \\
\text { (W-030) revised AWF } \\
\text { ventilation system will } \\
\text { adequately remove } \\
\text { heal/condensate for mixer pump } \\
\text { operation in one tank and } \\
\text { provide adequate ventilation for } \\
\text { the other three AWF tanks. }\end{array}$ \\
\hline
\end{tabular}


Table D-2. Comparison of Safety-Related Needs to Existing And Planned Equipment For Ventilation in 241-AN Tank Farm.

\begin{tabular}{|c|c|c|c|c|}
\hline $\begin{array}{c}\text { Quantitative tank-specific } \\
\text { process need }\end{array}$ & $\begin{array}{l}\text { Existing or planned structure, } \\
\text { system, or component }\end{array}$ & $\begin{array}{l}\text { Is existing and planned } \\
\text { equipment adequate } \\
\text { (Yes/No) }\end{array}$ & Basis & Comments/issues \\
\hline
\end{tabular}


Air was introduced into an AWF tank headspace through air lift circulators and air purge instruments. Also, outside air was drawn into the tank through pit cover blocks and risers due to the vacuum created by the exhaust blower. Two $113-\mathrm{m}^{3} / \mathrm{min}(4,000-\mathrm{cfm})$ exhausters (blowers) operated one at a time to draw the gases through a particle and condensate removal system before discharging the gases to the atmosphere. Vapor was exhausted to the K1-5-1 deentrainer. After passing through the deentrainer, the vapor was routed to the 241-A-401 Surface Condenser Building. Three condensers (two in operation at a time) for removing moisture from the exhaust system were located in this building. The offgases from the three surface condensers were vented through a second deentrainer (K1-5-2A) before entering the 241-A-702 Ventilation Building. The vapor stream then continued into the K1-3-1 steam heater housing before reaching the filter banks. Twelve high-efficiency particulate air (HEPA) filters, in six banks, simultaneously filtered the exhaust air flowing through the 241 A-702 Primary Ventilation System. After filtration the vapor was discharged by the blower into the atmosphere via the stainless steel exhaust stack. A continuous air monitor (CAM) monitored effluent radioactivity levels, and a record sampler collected representative samples before the vapor stream was discharged to the atmosphere.

\section{D.2.2 Modification to Aging Waste Facility Primary Ventilation System through Project W-030 (241-AZ-702)}

The original AWF primary ventilation system was modified by Project 702-AZ (W-030) by incorporating several changes. The primary tank ventilation system contains individual controlled air inlets and a common ventilation off-gas exhaust for the four AY and AZ Tank Farm waste tanks (241-AY-101, 241-AY-102, 241-AZ-101, and 241-AZ-102). The individual tank air inlet consists of a heater, pre-filter, HEPA filter, flow control valve, manifolded into a common exhaust stream and then cooled and filtered prior to being exhausted to the atmosphere through a stack. The filter/fan train is redundant to maintain tank pressures during anticipated maintenance or accidental component failure.

Process ventilation is required to maintain a negative pressure in the waste storage tanks of approximately 1010 to $1005 \mathrm{~Pa}(-1$ to -3 in. WG) to provide cooling and to dilute any potentially flammable gases. Instrumentation is provided at each tank to monitor and control pressure. A negative pressure in the tank is controlled by operating a control valve on the air inlet systems.

Each tank is provided with a heated, HEPA filtered air inlet system. The air inlet system is provided with a vacuum relief valve to protect the tanks from unexpected high negative pressure.

A recirculation ventilation cooling system is provided for each waste tank to help reduce emissions and remove heat generated in the tanks. The cooling equipment is located in concrete vaults and includes a condenser, moisture separator and recirculation fan for each system. The vaults are reinforced concrete structures with equipment access from the top and 
personnel access through a door.

The recirculation ventilation cooling system draws approximately $14.2 \mathrm{~m}^{3} / \mathrm{min}$ $(500 \mathrm{scfm})$ of process gas from the waste tank with the recirculation fan, and returns from 0 to $11.3 \mathrm{~m}^{3} / \mathrm{min}$ ( 0 to $400 \mathrm{scfm}$ ), depending on the tank heat load. The remaining tank vapor from 2.83 to $14.2 \mathrm{~m}^{3} / \mathrm{min}$ (100 to $500 \mathrm{scfm}$ ) is exhausted through the primary tank ventilation system. The inlet to the recirculation fan is provided with a moisture separator to protect it from erosion. The $14.2 \mathrm{~m}^{3} / \mathrm{min}(500-\mathrm{scfm})$ flow through the shell side of the condenser is sufficient to remove approximately $257 \mathrm{~kW}(878,000 \mathrm{Btu} / \mathrm{hr})$ at a tank off-gas temperature of $88.9^{\circ} \mathrm{C}\left(192^{\circ} \mathrm{F}\right)$. (For condenser AZ101-K4-8-1 it is approximately $440 \mathrm{~kW}[1.5 \mathrm{M} \mathrm{Btu} / \mathrm{hr}]$ at a tank off-gas temperature of $96.1^{\circ} \mathrm{C}\left[206^{\circ} \mathrm{F}\right]$.) The heat is rejected with a closed-loop evaporative cooling tower to the atmosphere.

The recirculation condenser cooling system consists of an evaporative fluid cooler, two circulation pumps, an expansion tank, an air separator, and instruments for monitoring the closed loop cooling system. The cooling medium used is 40 percent by volume propylene glycol mixture that is circulated between the evaporative fluid cooler and the recirculation condenser.

When the tank off-gas temperature is sufficiently low the condenser cooling ceases to occur, the recirculation ventilation cooling system is bypassed.

When the waste tank mixer pumps are placed in operation, valves for that tank are aligned for high-heat mode and the inlet airflow out of the tank is increased from $100 \mathrm{scfm}$ to a maximum of $14.2 \mathrm{~m}^{3} / \mathrm{min}(500 \mathrm{scfm})$.

The combined exhaust stream from all four tanks flows through condenser AZ-K1-81 where it is cooled to $4.4^{\circ} \mathrm{C}\left(40^{\circ} \mathrm{F}\right)$ and then through the HEME to eliminate any water droplet carry over into the filter system. The condensate from the condenser and HEME drains to a seal pot and that drains into a condensate tank.

Upon exiting the HEME, the gas stream is heated by electric heaters to protect the HEPA and HEGA filters downstream from the effects of high humidity conditions (wetting and possible blow out of the filters).

Each heater system and an associated filter bank are contained in a train. The operating heater is determined by which filter bank is operating. Normally, one train will be in operation while the second train is in standby. Each bank consists of two HEPA filters and a Charcoal Adsorber (HEGA). Instrumentation is provided for each bank to monitor pressure differential across each stage and temperature downstream of each bank. The system shuts down and switches over to the standby train upon high differential pressure across any stage of the filter train, upon heater failure, or when the heater high temperature set point is tripped. 
The ventilation gas stream, after passing through one of the two filter banks, is exhausted by one of two exhaust fans up the exhaust stack to the atmosphere. One fan is in standby while the operating fan maintains a vacuum on the four storage tank vapor spaces.

Instrumentation is provided for each fan to monitor speed, inlet damper, outlet damper and backdraft damper position status. Controls are provided to operate the fan while providing status via current monitoring.

The exhaust stack is external to the ventilation building and extends $16.8 \mathrm{~m}(55 \mathrm{ft})$ above the ground. The stack provides the point of discharge for the primary tank ventilation system. The primary exhaust air stream is sample for the particulate and iodine, and is monitored for beta/gamma radioactivity at the exit duct prior to discharge via the stack. The exhausted air stream is also monitored for flow.

For a more detailed description of how the 702-AZ (W-030) ventilation upgrades are designed to perform refer to HNF-1903, "Project 702-AZ (W-030) Tank Farm Ventilation Upgrade System Descriptions".

\section{D.2.3 Existing Aging Waste Facility Annulus Ventilation System}

The annulus system for the 241-AZ tanks is a combined system for both tanks. At this time the annulus system is not operational and leak detection for the primary tank is provided by conductivity probes in the tank annulus. Next year plant maintenance plans to restore the system to operation under its original configuration (one for one replacement of failed components). It is not known at this time if the Project W-151 mixer pump tests will require a functional annulus exhaust system or if the system will be functional to support the testing.

\section{D.3 COMPARISON OF EXISTING AND PLANNED EQUIPMENT TO EXPECTATIONS}

\section{D.3.1 Primary Ventilation Exhaust Fan}

Suspension of solids within the Aging Waste Facility tanks is provided by operation of mixer pumps. The mixer pumps generate heat which in turn increases water and particulate generation. The ventilation system must be adequately sized to accommodate the tank mixing operations during Phase 1 privatization feed delivery by removing heat, particulate, and water while maintaining vacuum within the tank headspace. Table D-1 identifies that the existing primary ventilation exhaust fan is not adequate to provide the necessary level of vacuum and too much air in leakage is occurring into the Aging Waste Facility tanks to allow control of the ventilation flows through each tank. 
The primary ventilation fans in the $702 \mathrm{AZ}$ Building, AZ-K1-5-1A and AZ-K1-5-1B, performance has been reviewed against Project 702-AZ (W-030) design requirements. The "Results and Conclusions" for Calculation 702-AZ (W-030)-23, "Primary Ventilation Exhaust Fan Capacity" specified $1093 \mathrm{~Pa}(32 \mathrm{in.} W G) @ 28.3 \mathrm{~m}^{3} / \mathrm{min}(1000 \mathrm{cfm})$ maximum and $1050 \mathrm{~Pa}\left(15 \mathrm{in}\right.$. WG)@11.3 $\mathrm{m}^{3} / \mathrm{min}(400 \mathrm{cfm})$ minimum. Procurement Specification W-030P3 "Primary Ventilation Air Clean-up Trains," paragraph 3.1.5, specifies fan design conditions are:

Normal Operation -

Min flow: $11.3 \mathrm{~m}^{3} / \mathrm{min}(400 \mathrm{cfm}) 400 \mathrm{scfm} @ 1050 \mathrm{~Pa}(15 \mathrm{in} . \mathrm{WG})$ Max flow: $28.3 \mathrm{~m}^{3} / \mathrm{min}(1000 \mathrm{cfm}) @ 1093 \mathrm{~Pa}(32 \mathrm{in.} W G)$

Vendor Information for Project 702-AZ (W-030), 0022525 supplement 113, Ellis \& Watts, Air Clean-up Train has a subset of data supplied by American Fan with the following pertinent data:

1. Quality Assurance Final Inspection Centrifugal Fan: motor 20hp Westinghouse 1755 RPM and running RPM $=3600$ for one fan and 3590 RPM for the other with a vibration analysis at both speeds.

2. Certificate of Analysis and Tests, 18.0 American Fan for R13-303-3575-195 (pressure curves)

TB-8996@ 2685 RPM (1050 Pa [15 in.WG] @ $\left.19.8 \mathrm{~m}^{3} / \mathrm{min}[700 \mathrm{cfm}]\right)$ TB-8998@ 3895 RPM (1093 Pa [32 in. WG] @ $28.3 \mathrm{~m}^{3} / \mathrm{min}[1000$ cfm])

It appears the variable speed control on the $1800 \mathrm{RPM} 15 \mathrm{~kW}(20 \mathrm{HP})$ motor limits the fan speed to $3600 \mathrm{RPM}$ and it is estimated that the fan would operate at approximately $1080 \mathrm{~Pa}$. (27 in. WG)@ $@ 26.2 \mathrm{~m}^{3} / \mathrm{min}(925 \mathrm{cfm})$ which is below the design point of $1093 \mathrm{~Pa}$ (32 in. WG)@28.3 $\mathrm{m}^{3} / \mathrm{min}(1000 \mathrm{cfm})$.

The following is referenced from "Fan Engineering," published by Buffalo Forge Co.: The fan should be selected on the negatively sloping portion of the pressure curve and adequate margin should be provided so that a disturbance will not force the fan to operate at the peak. If the fan is forced to operate on the positively sloping portion of the pressure curve, instability may result accompanied by changes in pressure power and noise. In discussion with Mark Fritzjerld from the American Fan Co., he confirmed that this model fan should only be operated on the negative sloped portion of the pressure curve. Review of the performance data indicates that the primary ventilation system fan operates on the positive sloped portion of the pressure curve and the system design performance requirement is at the peak of the curve (3895 RPM) and is not attainable since the fan maximum speed is 3600 RPM.

For the AWF to meet the design and performance requirements for Project 702-AZ (W-030) the fan and drive apparatus will require design modifications. These modifications 
are currently being reviewed by the PHMC. The primary ventilation system fans AZ-K1-5-1A and $\mathrm{AZ}-\mathrm{K} 1-5-\mathrm{iB}$ performance need to be upgraded to meet the Procurement Specification W030-P3 fan design condition of $28.3 \mathrm{~m}^{3} / \mathrm{min}(1000 \mathrm{cfm})$ at $1093 \mathrm{~Pa}(32 \mathrm{in}$. WG) with operation in a stable portion of the fan pressure curve (negative sloped portion of the pressure curve).

\section{D.3.2 Primary Ventilation System Filter Train}

During operation of the 702-AZ (W-030) upgraded system there have been two instances where the filter plenum housings have had moisture collection problems. When the system initially started up the sealpot drain line tie in at 241-151-AX catch tank was blocked and liquid flooded the sealpot and backed up into the filter plenum housings. The next time moisture collected in the filter plenum housings the condenser and HEME in the 702-AZ building were operated in a by-pass mode and after 4 days approximately 1321 ( $35 \mathrm{gal}$ ) had accumulated in the housing. The operations engineers stated there was no time for planned outages of the condenser and HEME because of the flooding problem and a redundant system (condenser and HEME or just HEME) would be desired. Additionally, the primary ventilation system HEPA and HEGA filter plenums are not in compliance with ANSI N509, Section 5.6.2. "The drain system shall be designed so that no unacceptable backup of liquids into the housing will occur" and "Each housing compartment shall have floor drains which meet all allowable air leakage criteria." Both filter housings should have drain capability added for all compartments.

\section{D.3.3 Equipment Installation and Removal from Aging Waste Facility Tanks}

Equipment (thermocouple tree, transfer pumps and mixing pumps) will require installation or removal from the DST which will create openings in the DST dome to atmosphere during this operation. To insure the containment of the DST vapors, a negative pressure in the tank dome needs to be maintained. The largest riser in the DST dome is $1.07 \mathrm{~m}$ (42 in.) in diameter which has an area of $0.89 \mathrm{~m}^{2}\left(9.6 \mathrm{ft}^{2}\right)$ open to the atmosphere. The existing ventilation system may not have enough capacity to insure that the tank dome can be maintained at a negative pressure and perform all its other functions for the other three tanks in the system.

The recirculation module for each AWF tank has two 20-cm (8-in.) connections and required valving options to install a portable exhauster to increase the ventilation flow in conjunction with the existing ventilation system capacity and a negative pressure is expected to be maintained in the primary tank dome. Verification needs to be performed or existing documentation substantiated to assure how the ventilation system will be configured to maintain a negative pressure in the tank dome during equipment change out. 
HNF-2941

Revision 0

\section{D.3.4 Slurry Distribution}

An evaluation was performed by J.R. Kriskovich, on the slurry distribution in 241-AY-101 and its affects on the AWF ventilation system, Slurry Distributor Affects on Ventilation System (Kriskovich 1998). The conclusions were:

- Primary tank dome vapor space can be maintained at a negative pressure during slurry distributor operation.

- Aerosol/moisture removal was achieved.

- Higher radiation in the re-circulation module was occurring due to aerosol/moisture settling out in piping, ductwork and equipment.

The report concluded in order to reduce the radiation buildup in the re-circulation modules a dropleg or some other method of transferring directly into the tank contents is recommended over the current practice of using a slurry distributor. Use of slurry distributor as delivery point of waste being transferred into an AWF DST tank should be abandoned and an evaluation of alternate delivery methods for transferring waste into the tank should be pursued (minimization of aerosol distribution into the tank vapor space) (Kriskovich 1998 Draft).

\section{D.3.5 Annulus Ventilation System}

The annulus system for the 241-AZ tanks is a combined system for both tanks. At this time the annulus system is not operational and leak detection for the primary tank is provided by conductivity probes in the tank annulus. Next year plant maintenance plans to restore the system to operation under its original configuration (one for one replacement of failed components). It is not known at this time if the Project W-151 mixer pump tests will require a functional annulus exhaust system or if the system will be functional to support the testing.

\section{D.3.6 Air In Leakage and Vacuum Control}

The primary tank air inlet stations are not now in operation and are valved shut. The inlet air is from air lift circulation (if operating) and outside air drawn into the tank through pit cover blocks, risers or uncapped transfer lines that are open to other sources such as the 241-AX-152 diverter station. If the in leakage air can be controlled to a minimal amount then the 702-AZ (W-030) primary tank air inlet stations can be utilized in the overall ventilation control. Sealing off each tank so that inlet air to the primary tank headspace flows through the 702-AZ (W-030) installed air inlet stations woulld give the capability to control system flow rates and achieve greater negative pressure in the primary tank. 
HNF-2941

Revision 0

\section{D.3.7 Thermal Analysis of Tank 241-AZ-101 Waste Removal}

A preliminary thermal analysis (Appendix E-1) of tank temperature rise with mixer pump operation in tank AZ-101 predicts a final temperature of $82.8^{\circ} \mathrm{C}\left(181^{\circ} \mathrm{F}\right)$ after 138 hours of operation associated with the first transfer to the private contractor. The waste temperature prior to mixer pump operation was $65.6^{\circ} \mathrm{C}\left(150^{\circ} \mathrm{F}\right)$ with $88 \mathrm{~kW}(300,000 \mathrm{BTU} / \mathrm{Hr})$ radionuclide heat generation from the waste, annulus flow rate of $22.7 \mathrm{~m}^{3} / \mathrm{min}(800 \mathrm{scfm})$ and primary ventilation flow rate of $14.2 \mathrm{~m}^{3} / \mathrm{min}(500 \mathrm{scfm})$. This preliminary calculation does not account for temperature profiles within the non-convective layer of solids at the bottom of the tank. Upon settling, this solids layer is expected to rise in temperature above the bulk temperature of the solution (i.e., higher than the $82.8^{\circ} \mathrm{C}\left[181^{\circ} \mathrm{F}\right]$ calculated in the preliminary calculations).

More detailed analysis will be required to verify the preliminary calculations, but the initial results indicate that the 702-AZ (W-030) revised AWF ventilation system will adequately remove heat/condensate for mixer pump operation in one tank and provide adequate ventilation for the other three AWF tanks.

\section{D.4 REFERENCES}

Kriskovich, J. R., 1998, Slurry Distributor Affects on Ventilation System, HNF-2783, Rev. 0 Draft, Lockheed Martin Hanford Corporation, Richland, Washington. 
Appendix D, Attachment 1: Assessment of In-Tank Concentration of NCAW Supernate

In tank concentration of the Neutralized Current Acid Waste (NCAW) in tanks 241-AZ-101 and 241-AZ-102 to approximately 5.0 M Sodium may be desired. The duration of concentration of the waste must be compatible with the Waste Feed Delivery Schedule for the Vitrification Plant. Concentration of this waste would serve two purposes: to provide additional usable DST storage space and to provide the private contractor a better waste feed. Concentration would be performed through removal of evaporated supernate (water vapor) using the tank ventilation system. The ventilation system uses condensers to remove moisture from its exhaust stream. This condensed liquid would then be collected in a Catch Tank.

On March 20, 1998, a new ventilation system (702-AZ) for the AWF was placed into service. The old system (702-A) ventilated all four tanks in the AWF in a once through fashion, in other words, the system had no recirculated air. The flow rate was approximately $14.2 \mathrm{~m}^{3} / \mathrm{min}$ (500 SCFM) per tank through the exhaust stack. The new ventilation system also ventilates all four AWF tanks. This system recirculates 80 percent $\left(11.3 \mathrm{~m}^{3} / \mathrm{min}\right.$ [400 CFM]) of the airflow through the tank and exhausts 20 percent $\left(2.83 \mathrm{~m}^{3} / \mathrm{min}[100 \mathrm{CFM}]\right)$ per tank through the stack. The new system is not as efficient at removing evaporated condensate from the tank due to the reduced air removal rate from the tank and because the condensate in the recirculation system is returned to the tank it was removed from. The 20 percent that is exhausted is routed through the system condenser and the condensate is transferred to the AZ-151 Catch Tank where it is stored.

Condensate removed by the 702-AZ system is currently collected at Catch Tank AZ-151. At present, there is one RCRA compliant route from Catch Tank AZ-151 and it routes the condensate back into the $241-\mathrm{AZ}$ tank farm. If concentration of the waste in both AZ-101 and AZ-102 is desired, a new, RCRA compliant route from Tank AZ-151 to another tank farm may be required.

Condensate could be transferred to Tank AY-101 via the following route: Catch Tank $\mathrm{AZ}-151$ to $\mathrm{AZ}-152$ and $\mathrm{AZ}-152$ to $\mathrm{AX}-155$, although there are a number of concerns. This transfer would be routed through two lines that are presently considered RCRA non-compliant. Line V-719 is a pipe-in-pipe line from $A Z-152$ to $A X-155$. The transfer from $A X-155$ to AY-101 could be performed through either of two lines, 4603 or 4506 , neither of which are RCRA-compliant. Presently, plans were to make Tank AX-152 inactive. In order for this transfer to occur two new jumpers will have to be designed, constructed, tested and installed. The first jumper would be installed between Nozzles LI and U4 at Catch Tank AZ-152. The second jumper would be installed between Nozzles U-13 and U-3 in AX-155. Additionally, Tank AX-152 would have to remain active as a Catch Tank for AX-155 in order to allow these transfers. The Project Hanford Management Company position on these lines is that they may be used as long as non-RCRA material being transferred through them. It is also PHMCs position that condensate is a non-RCRA waste (RCRA Integration Team, 1996).

A new line could be designed, constructed, tested and installed between Catch Tank 
HNF-2941

Revision 0

AZ-151 and tank 241-AY-101 to allow condensate removal from tanks 241-AZ-101 and 241-AZ-102. However, this option would likely be non-cost effective.

Liquid levels in tanks 241-AZ-101 and 241-AZ-102 are monitored on a daily basis. Liquid level decline in the 241-AZ tank farm can be attributed entirely to evaporation (Tardiff 1998). A distinct change in the liquid level trend for tank 241-AZ-101 occurred from 1/1/98 to $5 / 31 / 98$ due to tow distinct operational phases. The first being the 702-A system operational phase. The decline in liquid level for this time frame is nearly constant. The second phase is from the initial startup of 702-AZ to the present. Once again the decline in liquid level has a nearly constant slope, however, the slope is less steep. Therefore, the system has a lower efficiency at vapor removal than the 702-A system. The decline in liquid level is quite constant in this case with the exception of a condensate transfer to the tank on $2 / 25 / 98$. The second phase is during the $702-\mathrm{AZ}$ operational phase, $3 / 20 / 98$ to present. This region can be broken down into five subregions. The first region is a fairly constant decline in liquid level in the tank. The data indicates the liquid level declines at a slower rate using the $702-\mathrm{AZ}$ system than the 702-A system. The next four subregions are similar in nature and are summarized as follows: a condensate waste transfer from Catch Tank AZ-151 to tank 241-AZ-102 followed by a slow decline in liquid level in the tank due to evaporation ending with the next condensate transfer into the tank. Refer to Appendix F.5.3 for depictions of these phenomena. These graphs allow determination of an evaporation rate per unit time. This is an important parameter which will allow determination of the feasibility of concentration of waste by evaporation.

At present, tank 241-AZ-101 contains $4.78 \mathrm{M}$ Sodium concentration. The tank currently contains $3077 \mathrm{~m}^{3}$ (813,000 gal) of supernate and $132 \mathrm{~m}^{3}$ (35,000 gal) of sludge (Refer to calculations in Appendix F). The heat load is estimated to be $76.2-89.7 \mathrm{~kW}$ (260,000-306,000 Btu/hr) (Interoffice Memorandum 74650-97-013). It is desirable to deliver the waste at $5.0 \mathrm{M}$ sodium. Calculations performed based on data collected (Refer to Appendix F) show at the average current rate of evaporation using the 702-AZ system it will take approximately 31.2 months to concentrate the supernate to $5.0 \mathrm{M}$, assuming that Catch Tank AZ-151 nor any other waste will be transferred into 241-AZ-101.Presently, tank 241-AZ-102 contains 2.36 M Sodium concentration (Refer to calculations in Appendix F.5.3). The tank currently contains $2964 \mathrm{~m}^{3}(783,000 \mathrm{gal})$ of supernate and $359.6 \mathrm{~m}^{3}(95,000 \mathrm{gal})$ of sludge. The current heat load is estimated to be $49 \mathrm{~kW}$ (168,000 Btu/hr) (Interoffice Memorandum 74650-97-013). It is desirable to deliver the waste at $5.0 \mathrm{M}$ sodium. Calculations performed based on data collected (Refer to Appendix ??) show at the current average rate of evaporation using the 702-AZ system it will take approximately 1500 months to concentrate the supernate to $5.0 \mathrm{M}$ assuming that Catch Tank AZ-151 nor any other waste will be transferred into $\mathrm{AZ}-102$.

The present evaporation rate in tank 241-AZ-101 may be acceptable. However, at present the liquid level in the tank must remain above $7.82 \mathrm{~m}$ (308 in.) to allow mixer pump testing. This testing is scheduled to complete sometime in Fiscal Year (FY) 2000. At the time of completion concentration activities may begin. A possible solution to allow higher 
HNF-2941

Revision 0

evaporation rates in $241-\mathrm{AZ}-101$ is to run the mixer pumps intermittently after testing has been successfully completed. The mixer pumps produce a great deal of heat $(403 \mathrm{~kW}$

$[1,375,000 \mathrm{Btu} / \mathrm{hr}])$. Assuming one hundred percent of the heat generated went to evaporation and the mixer pumps were allowed to operate six hours a day (during the lifetime of concentration) the 241-AZ-101 supernate would be concentrated 2.12 times faster (approximately 15.5 months). This operation should be monitored closely to ensure none of the Safety Limits or Limiting Conditions of Operations are violated. Another alternative would be to run the system in bypass mode, i.e. without the recirculation system operating. The tank could then be evaporatively concentrated in approximately 6 months. Finally, if the mixer pumps were to be run without the recirculation system operating 241-AZ-101 supernate could be concentrated to $5.0 \mathrm{M}$ Sodium a little less than 3 months.

The present evaporation rate in tank 241-AZ-102 is not acceptable. A possible solution to allow higher evaporation rates would be to return the 702-A system to service for tank 241-AZ-102 only. The 702-AZ system would need to be valved off from the tank. Using the collected Data and calculations shows the tank can be concentrated to $5.0 \mathrm{M}$ in approximately 49 months (Refer to Appendix F.5.3). Another concern is that the condensate collected at the 702-AZ system is only routed into the 241-AZ tank farm. At present, this condensate is transferred to tank 2241-102-AZ. Therefore, dilution not concentration is occurring, which leads to even longer evaporation times. 
HNF-2941

Revision 0

This page intentionally left blank. 
HNF-2941

Revision 0

\title{
APPENDIX E
}

\section{SAMPLING SYSTEM PROCESS NEEDS AND ASSESSMENT}

\author{
(Reserved)
}

E-1 
HNF-2941

Revision 0

This page intentionally left blank. 
HNF-2941

Revision 0

\section{APPENDIX F}

\section{CALCULATIONS AND ANALYSES}




\section{HNF-2941}

Revision 0

This page intentionally left blank. 
HNF-2941

Revision 0

APPENDIX F

CALCULATIONS AND ANALYSES

F.1 CALCULATIONS AND ANALYSES DEVELOPED FOR THE TECHNICAL BASES OF PROCESS NEEDS PRESENTED IN TABLE 4-1

F.1.1 Sodium Removal Efficiency: Phase I Low Activity Waste Feed Delivery

F.1.2 Removal of Flammable Gases Retained in Waste

F.1.3 Use of Inhibited Flush Water

F.1.4 Calculation of Solids Deposition Velocity

F.1.5 Calculation of NPSHa for Mixer Pump Operation

F.1.6 Reserved

F.1.7 Reserved

F.1.8 Reserved

F.1.9 Reserved

F.1.10 Adjustment of Tanks 241-AN-102 and 241-AN-107 Waste To Meet Corrosion Specifications

F.1.11 Transfer Line Heating

F.1.12 Decant Pump Adjustable Inlet (TBP)

F.1.13 Reserved

F.1.14 Reserved

F.1.15 Reserved

F.1.16 Reserved

F.1.17 Transfer Line Flush Volumes

F.1.18 Reserved

F.1.19 Flush Water System Configuration (TBP)

F.1.20 Reserved

F.1.21 Reserved

F.2 CALCULATIONS AND ANALYSES DEVELOPED FOR THE TECHNICAL BASES FOR ADEQUACY OF WASTE PREPARATION AND TRANSFER SYSTEMS PRESENTED IN APPENDIX A

F.2.1 Calculation of Operating Transfer Rates

F.2.2 Calculation of Transfer Line Water Hammer

F.2.3 Reserved

F.2.4 Reserved

F.2.5 Reserved

F.3 CALCULATIONS AND ANALYSES DEVELOPED FOR THE TECHNICAL BASES FOR ADEQUACY OF UTILITY DISTRIBUTION SYSTEM PRESENTED IN APPENDIX B 
HNF-2941

Revision 0

F.3.1 Electrical Distribution System - DAPPER Model Results (To Be Produced)

F.4 CALCULATIONS AND ANALYSES DEVELOPED FOR THE TECHNICAL BASES FOR ADEQUACY OF INSTRUMENTATION, MONITORING AND CONTROL SYSTEM PRESENTED IN APPENDIX C

F.4.1 Assessment of Available Tank Camera Systems

F.5 CALCULATIONS AND ANALYSES DEVELOPED FOR THE TECHNICAL BASES FOR ADEQUACY OF VENTILATION SYSTEM PRESENTED IN APPENDIX D

F.5.1 241-AZ Farm Ventilation Thermal Analysis Model Results

F.5.2 241-AZ Farm Minimum Ventilation Flow Rate to Remove Flammable Gas (To be produced)

F.5.3 241-AZ Farm Mist Generation and Effect to Tank Vacuum During Mixer Pump Operation (To be produced)

F.6 CALCULATIONS AND ANALYSES DEVELOPED FOR THE TECHNICAL BASES FOR ADEQUACY OF SAMPLING SYSTEM PRESENTED IN APPENDIX E

F.6.1 Reserved 
HNF-2941

Revision 0

\section{F.1.1 SODIUM REMOVAL EFFICIENCY:}

\section{PHASE 1 LOW ACTIVITY WASTE FEED DELIVERY}




\section{DESIGN CALCULATION}
(1) Drawing N/A
(2) Doc No. HNF-2938
(3) Page 1 of 5
(4) Building N/A
(5) Rev. 0
(6) Job No. N/A
(7) Subject Sodium Removal Efficiency: Phase 1 Low Activity Waste Feed Delivery
(8) Originator A. B. Carison
Date $\underline{07 / 13 / 1998}$
(9) Checker
B.B. Peters
Date $8(11) / 1998$

(10) Objective: Determine the percentage of sodium existing in the low-activity waste feed tanks which must be delivered in solution in order to meet low activity waste feed delivery requirements.

Design inputs:

1. Total sodium to be delivered during phase 1 privatization is 6,000 metric tons sodium calculated as Envelopes $\mathrm{A}+\mathrm{B}+1.15^{*} \mathrm{C}$.

2. Initial batch will contain 300 to 600 metric tons sodium of waste and may be transferred along with the privatization contractor's feed tank

3. Additional batches shall be larger than 100 metric tons sodium.

4. Top-off transfers may occur once space is available in the private contractor's feed tank. The top-off transfers may be completed 30 days after the waste transfer date.

5. The objective is to transfer as much retrievable material from each source tank as possible during feed delivery. The minimum order quantities shall be delivered in the following sequence:

Envelope $\mathrm{C}=500$ to 1300 metric tons sodium

Envelope $A=750$ to 1200 metric tons sodium

Envelope $C=500$ to 1300 metric tons sodium

Envelope $A=1410$ to 3700 metric tons sodium

$\therefore \quad$ Envelope $B=400$ metric tons sodium previously pretreated feed

Other constraints

Envelope $A+1.15^{*} \mathrm{C}=5600$ metric tons sodium

Envelope $C \leq 1900$ metric tons sodium

6. Deliver up to 1100 metric tons sodium per year

7. Transfers shall occur no more frequently than once every 30 days per 100 metric tons of sodium delivered.

8. Envelopes $A$ and $B$ : maximum total organic carbon (TOC) increased to $0.5 \mathrm{~mole} \mathrm{TOC} / \mathrm{mole}$ sodium.

9. Envelopes $A, B$, and $C$ : maximum aluminum increased to 0.25 mole aluminum/mole sodium. 10. Envelope $A$ : maximum sulfate $\left(\mathrm{SO}_{4}^{-2}\right)$ increased to 0.01 mole sulfate/mole sodium.

11. For feed staging purposes only, assume that corrosion inhibitors are not added to the tanks.

12. The equivalent Cs- 137 concentration in all of the transferred feed shall be less than 6 Ci/gallon.

13. Envelope $A, B$, and $C$ limits only apply to the soluble fraction of the low activity waste feed. 14. The insoluble fraction for the low activity waste feed is limited to 2 wt\% (dry basis). 


\section{- DEsign CALCULATION}
(1) Drawing N/A
(2) DOC No.HNF-2938
(3) Page_ 2 of 5
(4) Building N/A
(5) Rev. 0
(6) Job No. N/A
(7) Subject Sodium Removal Efficiency: Phase 1 Low Activity Waste Feed Delivery
(8) Originator_A. B. Carlșon
Date $07 / 13 / 1998$
(9) Checker
Date

15. The sequence of tanks, envelope, quantities and sources of available sodium are as follows:

$\begin{array}{llll}\text { Tank } & \text { Envelope } & \text { Quantity } & \text { Source } \\ \text { 241-AN-107 } & \text { C } & 620 \text { metric tons sodium } & \text { liquid phase } \\ \text { 241-AN-105 } & \text { A } & 1090 \text { metric tons sodium } & \text { entire tank } \\ \text { 241-AN-102 } & \text { C } & 1060 \text { metric tons sodium } & \text { liquid phase } \\ 241-A N-104 & \text { A } & 1100 \text { metric tons sodium } & \text { entire tank } \\ 241-A W-101 & \text { A } & 991 \text { metric tons sodium } & \text { entire tank } \\ \text { 241-AN-103 } & \text { A } & 1234 \text { metric tons sodium } & \text { entire tank } \\ \text { 241-AP-108 } & \text { B } & 556 \text { metric tons sodium } & \text { entire tank }\end{array}$

\section{Sources:}

1. Design Inputs 1-14. Taylor 1998, Letter 98-WDD-062, W. J. Taylor, RL, to R. F. Green, FDH, Contract No. DE-AC06-96R113200 - Evaluation of Tanks Waste Disposal Second Alternative Within Privatization, May 27, 1998.

2. Design Input 15. DeLozier 1998, Letter LMHC-9854671 A R1, M. P. DeLozier, Lockheed Martin Hanford Corporation, to A. M. Umek, FDH, Subonctract number 80232764-9K001, Evaluation of Tank Waste Disposal Altematives Within Privatization, June 15, 1998.

\section{Ássumptions:}

Constituent concentrations (e.g., TOC, sulfate, aluminum, transuranic content, Cs-137) will be within the required limits for the calculated sodium retrieval efficiencies.

\section{Computer Calculation: None}

Reference: None

\section{Calculations:}

For variables let Tank 241-AN-107 be represented as C1, AN-105 as A1, AN-102 as C2, $\mathrm{AN}-104$ as A2, AW-101 as A3, AN-103 as A4, and AP-108 as B1. Let retrieval efficiency $=\eta$.

Minimum retrieval efficiency is minimum order quantity divided by available sodium. Maximum retrieval efficiency is maximum order quantity divided by available sodium, however, this value can not be greater than 1.0 . 


\section{DESIGN CALCULATION}
(1) Drawing N/A
(2) Doc No. HNF-2938
(4) Building N/A
(5) Rev. 0
(3) Page 3 of 5
(6) Job No. N/A
(7) Subject Sodium Removal Efficiency: Phase 1 Low Activity Waste Feed Delivery
(8) Originator A. B. Carlson
Date $\underline{07 / 13 / 1998}$
(9) Checker
Date

$$
\begin{gathered}
\eta_{\text {Tank }_{\min }}=\frac{\text { Minimum Order Quantity }}{\text { Available Sodium }} \text { (Eqn.1) } \\
\eta_{\text {Tank }_{\text {nux }}}=\frac{\text { Maximum Order Quantity }}{\text { Available Sodium }} \text { but no greater than } 1.0 \quad \text { (Eqn.2) }
\end{gathered}
$$

A minimum and maximum sodium removal efficiency can be calculated for each sequential envelope of feed based on the range of the order quantity specified in design input 5 above. Note that tanks 241-AN-104, 241-AW-101, and 241-AN-103 comprise the second batch of Envelope A waste transferred to the private contractor.

$$
\begin{aligned}
& \eta_{C I_{\min }}=\frac{500 \text { metric tons }}{620 \text { metric tons }}=0.806 \quad \eta_{C I_{\max }}=\frac{1300 \text { metric tons }}{620 \text { metric tons }}=1.0 \\
& \eta_{A l_{\min }}=\frac{750 \text { metric tons }}{1090 \text { metric tons }}=0.688 \quad \therefore \quad \eta_{A s_{\operatorname{mas}}}=\frac{1200 \text { metric tons }}{1090 \text { metric tons }}=1.0 \\
& \eta_{C 2_{\mathrm{mit}}}=\frac{500 \text { metric tons }}{1060 \text { metric tons }}=0.472 \quad \eta_{C_{C_{\mathrm{mut}}}}=\frac{1300 \text { metric tons }}{1060 \text { metric tons }}=1.0 \\
& \eta_{A 2+\lambda 3+\lambda s_{\min }}=\frac{1410 \text { metric lons }}{1100+991+1234 \text { metric tons }}=0.424 \\
& \eta_{B I_{\min }}=\frac{400 \text { metric tons }}{556 \text { metric tons }}=0.719 \quad \cdot \eta_{B t_{\operatorname{mu}}}=\frac{400 \text { metric tons }}{556 \text { metric tons }}=0.719
\end{aligned}
$$

For both envelope $C$ wastes the available sodium is based on the liquid phase portion of the tank contents. Retrieving all liquid phase sodium in the envelope $C$ tanks is within the feed quantity limits. The minimum retrieval efficiency for envelope $C$ waste is 0.806 based on the minimum acceptable amount of sodium to be delivered from tank 241-AN-107. For the four tanks of envelope A, retrieving all liquid and solid phase sodium is within the feed quantity. limits. The minimum retrieval efficiency for envelope $A$ waste is 0.688 based on the minimum acceptable amount of sodium to be delivered from tank 241-AN-105.

Design input 5 also states the objective is to transfer as much retrievable material from each source tank as possible during feed delivery. Therefore, greater sodium retrieval efficiency should be strived for rather than lesser sodium retrieval efficiency. 
HNF-2941

Revision 0

\section{DESIGN CALCULATION}

\begin{tabular}{|c|c|c|c|}
\hline (1) Drawing N/A & (2) Doc No. HNF-2938. & (3) $P a$ & ge 4 of 5 \\
\hline (4) Building N/A & (5) Rev. 0 & (6) Jo & No. N/A \\
\hline Sodium Remova & ncy: Phase 1 Low Activity W & Feed & elivery \\
\hline A. B. Carlson & & $\begin{array}{l}\text { Date } \\
\text { Date }\end{array}$ & $07 / 13 / 1998$ \\
\hline
\end{tabular}

Additional constraints exist from design input 1 \& 5 :

Envelope $A+B+1.15 * C=6000$ metric tons sodium (Eqn. 3 )

Envelope $A+1.15 * C=5600$ metric tons sodium (Eqn. 4)

Envelope $C \leq 1900$ metric tons sodium (Eqn. 5)

By inspection of design input 15 it is seen that the sodium content of tanks AN-107 and AN-102 is 1680 metric tons which is less than 1900 metric tons so the constraint of equation 5 is met regardless of sodium retrieval efficiency. Also, Envelope B is specifically limited to 400 metric tons sodium by design input 5 , making equations 3 and 4 equivalent. Therefore a minimum average sodium retrieval efficiency can be specified for retrieval from envelope $A$ and $\mathrm{C}$ tanks by the following equation:

$$
\eta_{\text {Minimum Average }}=\frac{5600 \text { metric tons sodium }}{1.15 * C 1+A 1+1.15 * C 2+A 2+A 3+A 4}
$$

Inputing tank available sodium:

$$
\eta_{\text {Minimum Average }}=\frac{5600 \text { metric tons sodium }}{1.15 * 620+1090+1.15 * 1060+1100+991+1234}=0.882
$$

This minimum average is greater than the minimum sodium removal efficiency to meet the minimum envelope-specific sodium delivery quantities.

Conclusions:

The low activity waste feed minimum sodium delivery requirement to the private contractor during phase 1 privatization is 6,000 metric tons. To meet this requirement a minimum of 90 weight percent (rounded from $88.2 \%$ ) of sodium: in the liquid phase in tanks 241-AN-102 and 241-AN-107; and in the solid and liquid phase in tanks 241-AN-103, 241-AN104, and 241-AN-105, needs to be delivered to the private contractor. 


\section{DESIGN CALCULATION}
(1) Drawing N/A
(2) Doc No. HNF-2938
(3) Page 5 of 5
(4) Building N/A
(5) Rev. 0
(6) Job No. N/A
(7) Subject Sodium Removal Efficiency: Phase 1 Low Activity Waste Feed Deliven
(8) Originator A. B. Carlson
Date $\underline{07 / 13 / 1998}$
(9) Checker
A. Peters
Date $8 / 11 / 1998$

\section{Design Review Checklist for Design Calculation}

Documents/ECNs Reviewed:

Affected Document(s):

Yes No NA

[] [] Previous reviews complete and cover analysis, up to scope of this review, with no gaps.

[1 [] [] Problem completely defined.

[] []

Accident scenarios developed in a clear and logical manner.

[] []

Necessary assumptions explicitly stated and supported.

[] [ ]

Computer codes and data files documented.

Data used in calculations explicitly stated in document.

Data checked for consistency with original source information as applicable.

Mathematical derivation checked including dimensionsal consistency of results.

Models appropriate and used within ragne of validity or use outside range of established validity justified.

[1] []

Hand calculations checked for errors. Spreadsheet results should be treated exactly the same as hand calculations.

Software input correct and consistent with document reviewed.

[] []

Software output consistent with input and with results reported in document reviewed.

[] [] $\mathbb{2}$

Limits/criteria/guidelines applied to analysis results are appropriate and referenced. Limits/criteria/guidelines checked against references.

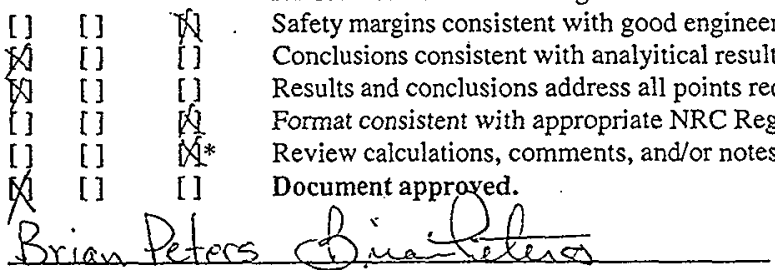

Reviewer(Printed Name and Signature)

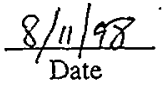


HNF-2941

Revision 0

\section{F.1.2 CALCULATION OF RETAINED GAS REMOVAL}

NECESSARY TO AVOID A GRE EXCEEDING 25\% OF THE LFL 


\section{DESIGN CALCULATION}

(1) Caleulation No.
(2) Drawing _N/A
(3) Doc No. HNE-2938
(4) Page 1 of 3
(5) Building _ N/A
(6) Calc Rev. 0
(7) Job No. N/A
(8) Subject Calculation of Retained Gas Removal Necessary to Avoid a GRE Exceeding $25 \%$ of the
LFL
(9) Originator B. B. Peters
Date $\quad 8 / 10 / 98$
(10) Checker A. B. Carlson
Date

(11) Objective: Determine the volume of retained gas to remove from each of tanks 241-AN-103, 241-AN-104, 241-AN-105, 241-AW-101, and 241-SY-103 such that a subsequent major gas release event (GRE) would not exceed $25 \%$ of the lower flammability limit (LFL) in the tank headspace.

Design Inputs:

\begin{tabular}{|l|c|c|c|c|c|}
\hline & AN-103 & AN-104 & AN-105 & AW-101 & SY-103 \\
\hline Release Vol. for LFL (m3) & 124 & 96 & 77 & 150 & 306 \\
\hline Retained Gas Vol. (m3) & 363 & 197 & 148 & 115 & 150 \\
\hline Re!. Fraction for LFL & 0.34 & 0.49 & 0.52 & 1.30 & 2.04 \\
\hline
\end{tabular}

Data taken from Table 5.5 (pg 5.8) of Stewart, et. el. (1996) attached.

\section{Sources:}

1. Stewart, C.W., J.M. Alzheimer, M.E. brewster, G, Chen, R.E. Mendoza, H.C.Reid, C.L. Shepard, G. Terrones, September 1996, In Situ Rheology and Gas Volume in Hanford Double-Shell Waste Tanks, PNNL-11296, Pacific Northwest National Laboratory, Richland, Washington.

2. Stewar, C.W., 1998, Personal Communication:

\section{Assumptions:}

1. Historically the maximum GRE has released about $75 \%$ of the total estimated retained gas inventory (Stewart, C.W., 1998). Assume that $25 \%$ of the maximum retained gas inventory is unavailable for release during a GRE.

2. Assume the same conditions as in Sicwart ct. al. (1996). That is that the tanks are at their current level and during a GRE, the released gases are uniformly mixed in the tank. headspace.

3. Assume that the tank waste can be slowly and in a controlled manner "degassed" using a mixer pump or other means such that head'space flammable gas concentrations don't exceed $25 \%$ of the LFL.

4. Assume that waste retrieval would occur soon ( $<30$ days $)$ after degassing so that retained flammable gases couldn't build back up in the waste.

Computer Calculation: None

Reference: None 


\section{DESIGN CALCULATION}

(1) Calculation No.

(2) Drawing N/A

(3) Doc No. HNF-2938

(4) Page 2 of 3

(5) Building N/A

(6) Calc Rev, 0

(7) Job No. N/A

(8) Subject Calculation of Retained Gas Removal Necessary to Avoid a GRE Exceeding $25 \%$ of the LEL

(9) Originator 8,8 , Peters

(10) Checker A. B. Carlson

Date $8 / 10 / 98$

Date

Calculations:

1) Calculate the release volume necessary to reach $25 \%$ of the LFL.

2) Calculate the fraction of the maximum inventory which historically is not released during a maximum GRE ( $25 \%$ of total inventory)

.3) Calculate gas volume which needs to be removed so that the waste can be retrieved without exceeding $25 \%$ of the LFL (= Maximum retained gas inventory -minus- Fraction needed to reach $25 \%$ of LFL -minus- $25 \%$ of total inventory which doesn't release during a GRE)

\begin{tabular}{|c|c|c|c|c|c|c|}
\hline & & $A N-103$ & AN-104 & AN-105 & AW-101 & SY-103 \\
\hline R1 & Release Vol. for LFL $\left(\mathrm{m}^{3}\right)$ & 124 & 96 & 77 & 150 & 306 \\
\hline R2 & Max, Retained Gas Vol. $\left(\mathrm{m}^{3}\right)$ & 363 & 197 & 148 & 115 & 150 \\
\hline R3 & $\begin{array}{l}\text { Release Vol. for } 25 \% \text { of LFL } \\
\left(\mathrm{m}^{3}\right)[0.25 * \mathrm{R} 1]\end{array}$ & 31 & 24 & 19 & 38 & 77 \\
\hline R4. & $\begin{array}{l}\text { Yol. retained and not released } \\
(25 \% \text { of max. inventory })\left(\mathrm{m}^{3}\right) \\
{\left[0,25 * \mathrm{R}^{2}\right]}\end{array}$ & 91 & 49 & 37 & 29 & 38 \\
\hline R5 & $\begin{array}{l}\text { Vol. To Remove }\left(\mathrm{m}^{3}\right) \\
{[\mathrm{R} 2-\mathrm{R} 3-\mathrm{R} 4]}\end{array}$ & 241 & 124 & 92 & 49 & 36 \\
\hline
\end{tabular}

\section{Conclusions:}

An appropriate Quantitative Tank-Specific Process Need is to remove sufficient retained gas from the waste such that a GRE releasing $75 \%$ of the remaining gas would not exceed an averaged concentration of $25 \%$ of the LFL. This equates to a gas removal of $241 \mathrm{~m}^{3}$ for AN-103,124 $\mathrm{m}^{3}$ for AN-104, $92 \mathrm{~m}^{3}$ for AN-10S, $49 \mathrm{~m}^{3}$ for AW-101, and $36 \mathrm{~m}^{3}$ for $S Y-103$. 
(1) Calculation No.
(2) Drawing _. N/A
(3) Doc No. HNF-2938
(4) Page 3 of 3
(5) Building N/A
(6) Calc Rev. 0
(7) Job No. N/A

(8) Subject Calculation of Retained Gas Removal Necessary to Avoid a GRE Exceeding $25 \%$ of the LFl.

(9) Originator B. B, Peters

(10) Checker A. 8. Carlson

Date $8 / 10 / 98$

Date

Design Review Chectilist for Design Calculation

Documents/ECN's Review'ed:

Affected Document(s):

Yes No NA

[] [] [] Previous reviews complete and cover analysis, up to scope of this review, with no gaps

[] [] [] Problem completely defined.

[] [] [] Accident scenarios developed in a clear and logical manner.

[] [] [j Necessary assumptions explicitly stated and supported.

[3 [] [] Computer codes and data files documented.

[] . [] [] Data used in calculations explicitly stated in document.

[] [] [] Data checked for consistency with original source information as applicable.

[] [] [] Mathematical derivation checked including dimensional consistency of results.

[] [ [ [ [ ]

Models appropriate and used within range of validity or use outside range of established validity justified.

[ ] [ ] [ ]

Hand calculations checked for errors. (Spreadsheet results should be treated exactly the same as hand calculations)

[ ] [ ] [ ] [ ]

Software input correct and consistent with document reviewed.

[] [] [] Software output consistent with input and with results reported in document reviewed.

[ ] [ ] [] Limits/criteria/guidelines applied to analysis results are appropriate and referenced. Limits/criteria/guidelines checked against references.

[ ] [] []

Safety margins consistent with good engineering practices.

[] [] []

Conclusions consistent with analytical results and applicable limits.

[1. [] [] Resuits and conclusions address all points required in the problem statement.

(] [] [] Format consistent with appropriate NRC Regulatory Guide or other standards.

[] [] [] Review calculations, comments and/or notes are attached.

[] [] [1 Document Approved

Reviewer (Printed Name and Signature)

Date 
HNF-2941

Revision 0

\section{F.1.3 USE OF INHIBITED FLUSH WATER}




\section{FLUOR DANIEL NORTHWEST, INC.}

1100 Jodwin

P.O. Box 1050

Richland, Washington 99352-1050

August 11, 1998

LMHC96W0-0006

CO-98-TWRS-384

Mr. I. G. Papp

Numatec Hanford Corporation

P.O. Box 1300

Richland, Washington $9 \$ 352-1300$

Dear Mr. Papp:

TASK ORDER 44-10-02, PREPARE PIPING AND INSTRUMENTATION DIAGRAMS

Rèsponse Requested By: N/A

Responds To: N/A

Enclosed are two deliverables in support of the additional work that Randy Hallum is providing. They are: 1) Dynamic Thermal Analysis of Waste Transfer Piping and 2) Review of Raw Water Versus Inhibited Water for Transfer Pipe Flushing. The letler report for use of Raw Water Versus inhibited Water is based on reviews of existing site documents. A defensible technical justification has not yet been prepared.

Please feel free to contact Randy Hallum at 376-7089 or myself at 373-2198 if you have any questions.

Sincerely,

huce. Mardubere

M. W. Manderbach

Projecl Manager

MWM:sst

Attachments (2) 
HNF-2941

Revision 0

LMḦC9620-0006

CO-98-TWRS-384

Attachment 2

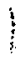


HNF-2941

Revision 0

FLUOR DANIEL NORTHWEST

INTEROFFICE CORRESPONDENCE

$\begin{array}{llll}\text { To: } & \text { M. W. Manderbach } & \text { Date: } & 7 / 31 / 98 \\ \text { Location: } & \text { Richland, B4-57 } & \text { Reference: } & \end{array}$

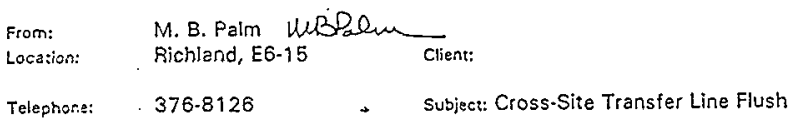

C: MBP.File/LB .
References 1) Project W-058M-028, Material of Construction Position Paper, C. Van Katwijk, June 22, 1994.
2) WHC-SD-W236A-TRP-001, Multi-Function Waste Tank Facility Corrosion Test Report (Phase 1), W.C. Carlos, Dated December 14, 1993.

This letter discusses the issue of whether to use inhibited water or raw water to flush the cross-site transfer line following waste transfer between tanks.

In 1994 a position paper, Reference 1 was written which re-evaluated the materials of construction for projects W-058/W-028 which are very similar to Project $W-314$. Two of the goals were to determine what would be the best piping material to use, and what should be the chemical composition of the liquids that flow within the pipe. The results of the study showed that $304 \mathrm{~L}$ SS, which has been used for waste transfer lines since the 1950's, was confirmed to be the material of choice for the primary (inner) piping. It also reported that one of the requirements for all liquids within the storage system would be to minimize corrosion. Therefore the chemical composition requirements for the liquids flowing in the transfer piping system, whether it be tank waste or flushing liquid, would need to minimize corrosion.

Also in Reference 1 , the results of past corrosion studies done at the Hanford site have indicated that corrosion in the vapor space and liquid/vapor interface zones of the waste tanks is more severe than in the waste solution (liquid) zone. In the transfer piping lines, this would occur after the waste had been transferred and the line flushed out. Any remaining flushing liquids would cause a puddling effect and a liquid/vapor interface zone. The study also pointed out that the pudoling was confirmed to be a major contributor to corrosion problems such as pitting and stress corrosion cracking (SCC) in the life of the line. Since the life of the transfer-line system is intended to be 40 -years, every effort needs to be made to minimize corrosion that could occur on a day to day basis. For this reason it was determined that only liquid solutions that meet the chemical 
M. W. Manderbach

July 31,1998

Page 2

composition requirements put on the liquids in the double-sheil tanks are allowed in the cross-site transfer lines. Therefore, since the double-shell tank minimum chemical requirements for nitrite and hydroxide respectively are $0.01 \mathrm{M}(\mathrm{NaOH})$ and $0.01 \mathrm{M}$ ( NaNO2) for corrosion inhibition, that should also be established as a requirement for the transfer line. Of course, the liquids flowing through the transfer piping from the tank would have the correct chemical composition for the transfer piping. The issue needing to be resolved is what chemical composition does the flush water need to be. Can the water be raw, for example (out of the tap), or does it need to be inhibited water, which would have an elevated pH level.

The summary statement of Reference 2 says that in the case of 304L SS the tendency to pit and the possibility of SCC can be effectively eliminated if the $\mathrm{pH}$ level in the tanks are kept above a value of approx. 10.5 and temperature is kept below approx. $60 \mathrm{C}(140 \mathrm{~F})$. With this information, the minimum requirement for the flush water should be at least a pH of 10.5 .

Therefore, to minimize corrosion, inhibited water rather than raw water should be used to flush the transfer line.

The requirements for flushing water to be used in carbon steel transfer lines has not been specifically defined. The requirements used for stainless steel transfer lines could also be used for carbon steel lines with the understanding that the corrosion rate for carbon steel is greater than that for stainless steel. 
HNF-2941

Revision 0

\section{F.1.4 CALCULATION OF SOLIDS DEPOSITION VELOCITY}


HNF-2941

: - :

Revision 0
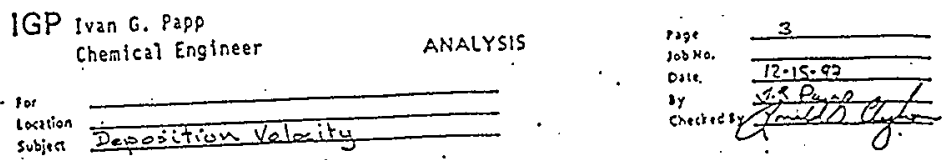

Deposition velocity represents the lowest velocity at which the system can be operated such that stable flow conditions prevail.

- Relative density ( $\left.S_{s}\right)$ a density of Suds/ density of water - Vim. Mean velocity at limit of deposition ..........

At a pipe diameter of 3.068 inches and a particle diameter of $70 \mathrm{~mm}$ the $y$, on the center vertical axis (fig 6.4 attached) fer. sand. would be near or less than / $/ 5$, connecting. this line to the $S_{s}$ of 2.2 would result in a $V_{\text {sin }}$ on the right of thor less than

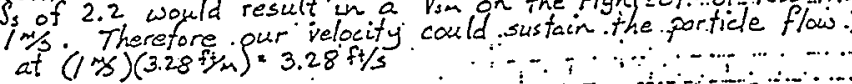

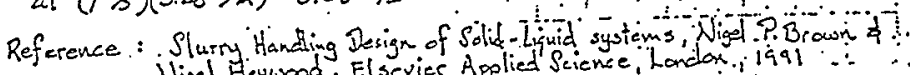
Nigel Heywood, El sexier Applied Science, London, if 91 We now ing to apply or alternate approach The terminal velocity as referenced by 0 Ge $\omega \cdot 058-00 \%$ Rev

$$
\begin{aligned}
& V_{D}=F_{L}^{\prime}\left[2 g D\left(\frac{e_{3}-e_{L}}{e_{L}}\right)\right]^{1 / 2}\left(\frac{d}{D}\right)^{1 / 6} \\
& \quad V_{D}=(4)\left[2(32.2)(.256)\left(\frac{136.84-62.2}{62.2}\right)\right]^{1 / 2}\left(\frac{.0028}{3.068}\right)^{1 / 6}
\end{aligned}
$$

$$
\begin{aligned}
& V_{D}=(4)(4.45)(.311) \quad F_{1} \cdot \text { constant based on solid concentration } \\
& v_{2}=5.53 \mathrm{ft} \quad \cdots . \quad g=32.2 \mathrm{ft} / \mathrm{s}^{2} \\
& D=3.068 \dot{2}(.256 \mathrm{ft}) 3^{*} \text { sch } 40
\end{aligned}
$$

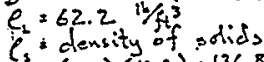

$$
\begin{aligned}
& \left.C_{s}=\text { density of }=13.2\right)(62.2)=136.8416 / \mathrm{ft}^{3} \\
& d=70 \text { ur }: .0028 \mathrm{in}
\end{aligned}
$$

$\frac{24,500 \mathrm{~cm}}{\text { in }}$

BEST AVAILABLE COPY

- F-21 
5

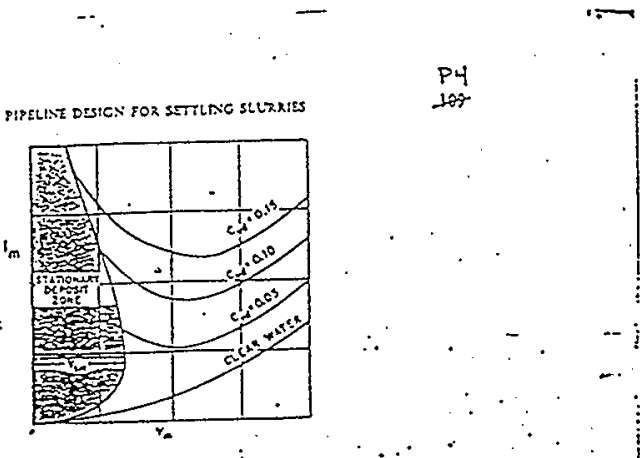

Fo. 6.3. Definition steteh for linit ol sidionir deposit zone.

is value enstres that Eeposition will not $\alpha$ cot. The conguter output shows bow $Y$ ries with interal pipe ciame:st, particle diameter and telative density. The Fre

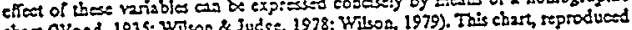
chan (Hood, 1935; Witon \& Jud ge, 1978 ; Wial desig aid.

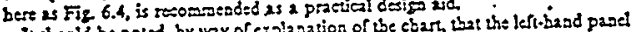

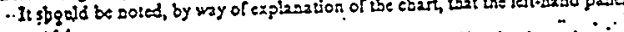
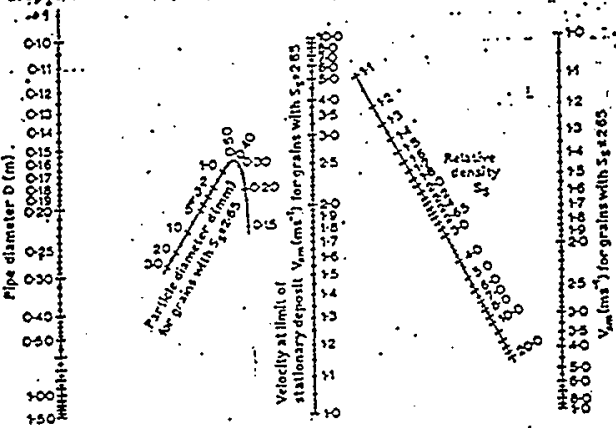

Fig. 6.4. Nomogra hie chart for maximum velotin at limit of stationiry ceposition (Átapled tiem Wilson, 1979.) 


\section{IGP ivail.. $\mathrm{izr}$}

Cherical Engineer

ANALYSIS

for

losition

subjes

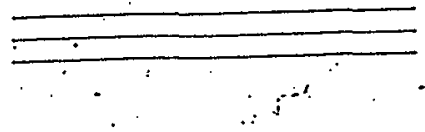

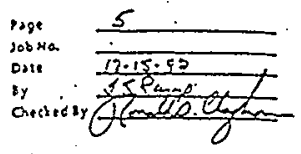

If we are to apply - some -margin of safety to our deposition velocity a typical value usould. - be:. 1.3 times oje - calculated value: This -would equate. ato $a$ - $30 \%$. safefy -marsin. Wo then have:

$(1.3)(5.5 \% 1 \%)=7.21 \%$

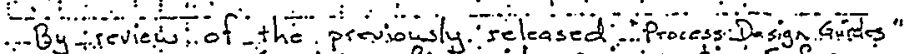
$\because$ SD- $2 E-P D a-\infty$ l (RHo), we find-guidanee in section: 5 for... ... slurpy tran fers. . ....

. This guidave calls for fluds containg solids to be transferred at $a$ velocity between : 6-9 fi/s as areasonable:

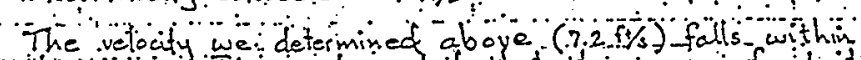
this raige? It may be noted that the range of velocities was developed from operational exporiene-gained to y!

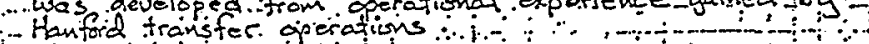
; Hanford trarster of a :

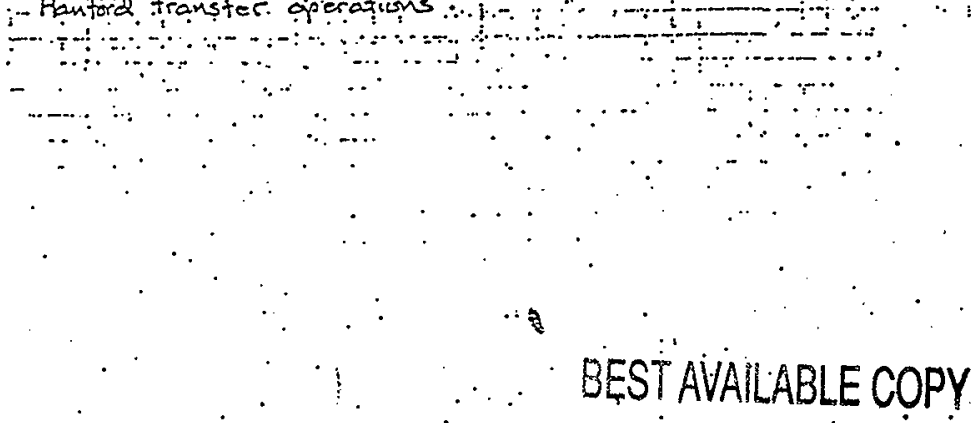


HNF-2941

Revision 0

\section{F.1.5 CALCULATION OF NPSHa FOR MIXER PUMP OPERATION}


HNF-2941

Revision 0

\begin{tabular}{l|l} 
Evaluation of Min \\
Cavitation in tran \\
Assumptions:
\end{tabular}

- Sulzer- Brnginam Transfer Pump. see attach er pump curve. Don - Transfer occurs at 140 gallons per minute.

- Sp G fo waste $=1.41$

- Vapor pressure of waste = water (thin is conservative)

We wish to draw the waste in the tanks down to $10 "$. What is the maximum temperature at which that is possible? From pump curve $8140 \mathrm{GPM}$ NPSHR $\cong 18 \mathrm{ft}$.

$$
\begin{aligned}
\text { NPSHA }= & H_{s}+H_{a}-H_{\text {rap }}-H_{f} \\
& H_{s}=\text { Static Head }
\end{aligned}
$$

$H_{a}=$ atmospheric pressure Head

$M_{\text {rap }}=$ Vapor pressure of liquid

$H_{f}=$ friction loss in intake piping

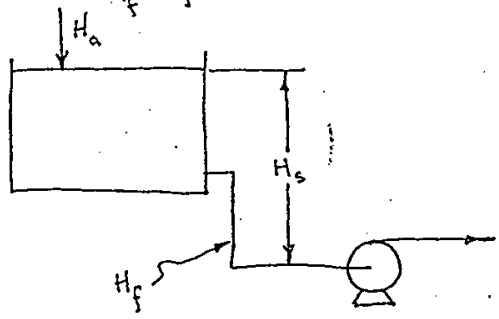

(1.)

F-25 
HNF-2941

Revision 0

or in our tanks

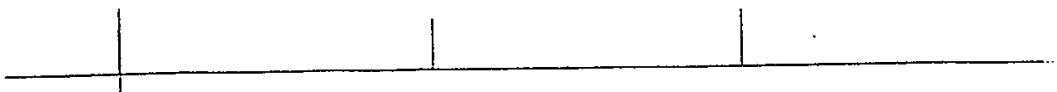
the length of the flex the intake is $\approx 20 \mathrm{ft}$.

for a flow rate of 150 op m

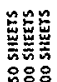

Hs

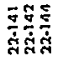

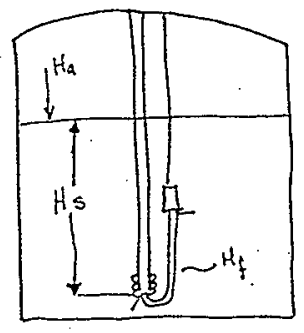

- The friction loss in? $3^{4}$ schedrite 40 pipe is $2.24 \frac{\mathrm{kb}}{\mathrm{ln}^{2}}$ per $100 \mathrm{ft}^{-}$

reference CRANE Technical paper No. 410

Flow of Fluids through Valves, Fittings, and Pipe.

As a Conservative estimate assume that the friction loss trivongh the flex in e is - 2.5 psi

converting to Head $2.5 \mathrm{psi} \times \frac{33.9 \mathrm{ft}}{14.7 \mathrm{psi}}=5.8 \mathrm{ft}$.

$$
H_{f} \simeq 6 \mathrm{ft}
$$

$H_{a}$ - Maximum Elevation in the transfer line is $690 \mathrm{ft}$.

$$
\frac{e^{\text {air }}}{e_{\text {water }}}=\frac{\text { Height of water Column }}{\text { Height of dir Column }}
$$

at sea level standard pressure is 1 atm. or $33.9 \mathrm{ft}$ water

$$
\begin{aligned}
& \text { ear }=0.0752 \mathrm{lb} / \mathrm{ft}^{3} \\
& e_{\text {water }}=62.416 / \mathrm{ft}^{3} \\
& \text { Height of Air Column }=\frac{\left(33.9 \mathrm{ft} \mathrm{H}_{2} \mathrm{O}\right)\left(62.4 \mathrm{bb} / \mathrm{ft}^{3} \mathrm{H}_{2} \mathrm{O}\right)}{0.0752 \mathrm{bm} / \mathrm{ft}^{3} \text { air. }} \\
& =28130 \mathrm{ft} \text { air }
\end{aligned}
$$

(2)

F-26 
HNF-2941

Revision 0

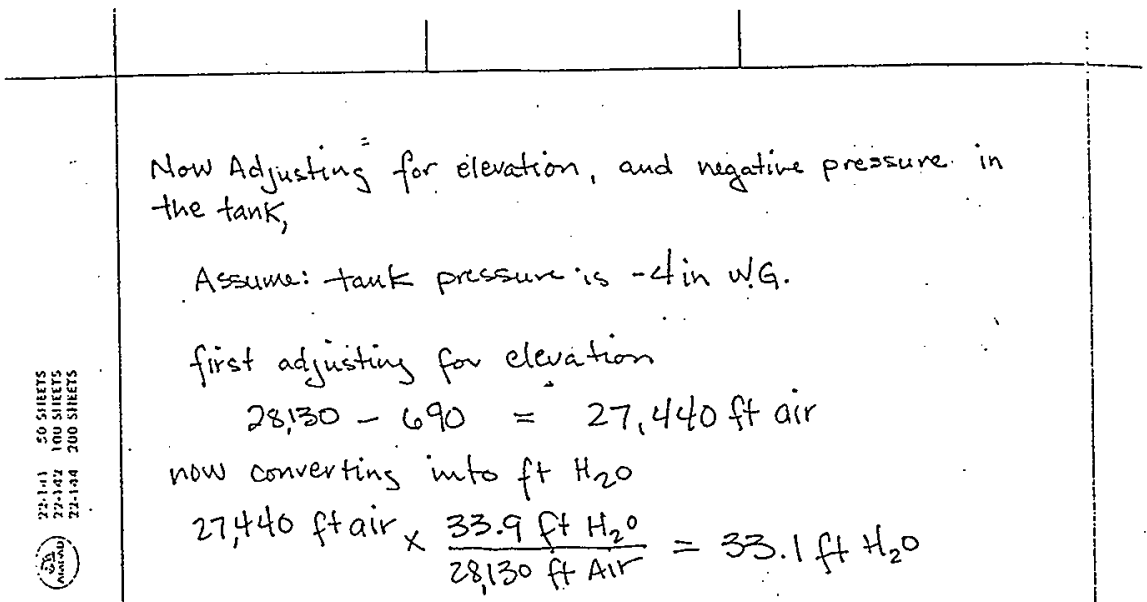

Now Adjusting for the negative press un in the tank

$$
\begin{array}{r}
33.1 \mathrm{ft} \mathrm{H}_{2} \mathrm{O}-.33 \mathrm{ft} \mathrm{H}_{2} \mathrm{O}=32.8 \mathrm{ff} \\
\\
32.7 \mathrm{ft} \mathrm{H}_{2} \mathrm{O}
\end{array}
$$

the maximum Allowable temperature in the Tank is $95^{\circ} \mathrm{F}$

(3) $195^{\circ} \mathrm{F}$ the vapor presume of water is $\sim 10.4 \mathrm{psi}$ converting to $\mathrm{ft} \mathrm{H}_{2} \mathrm{O}$

$$
10.4 \mathrm{psi} \times \frac{33.9 \mathrm{ft} \mathrm{H}_{2} \mathrm{O}}{14.7 \mathrm{psi}}=24 \mathrm{fH} \mathrm{H}_{2} \mathrm{O}
$$

There fore at the maximum allowable temperature, where NPSHA = NPS:HR

$$
\begin{aligned}
H_{\min } & =N P S H R+H_{V A P}+H_{f}-H_{q} \\
& =18 \mathrm{ft}+24 \mathrm{ft}+6 \mathrm{ft}-32.7 \mathrm{ft} \\
& =15.3 \mathrm{ft}
\end{aligned}
$$

Adjusting for a $S_{p} G$ of 1.41 yields

$\sim 11 \mathrm{ft}$ of. Submergence

(3.)

F-27 
HNF-2941

Revision 0

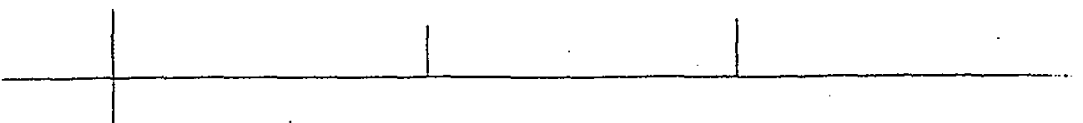

At the maximum allowable tank temperature, we will not be able to draw the tanto down to $10 \mathrm{in}$.

At what temperature can the tank be drawn down to $10^{\prime \prime}$

$$
H_{\text {rap }}=H_{s}+H_{q}-H_{f}-N P S H R
$$

from PROS. W-2ll drawings bottom of tank to first impeller is $27 \mathrm{~m}$. With the tank dram n

down to 10 in., $H_{S}=-17$ in

$$
=-1.4 \mathrm{ft}
$$

Adjusting for $S_{p} G=1.41$

$$
\begin{gathered}
H_{3}=-2.0 \mathrm{ft} H_{2} \mathrm{O} \\
H_{\text {VP }}=-2.0+32.7-6-18 \\
=6.7 \mathrm{ft} \mathrm{H}_{2} \mathrm{O}
\end{gathered}
$$

converting to $p$ si

$$
6.7 \mathrm{ft} \mathrm{H}_{2} \mathrm{O} \times \frac{14.7 \mathrm{psi}}{33.9 \mathrm{f}+\mathrm{H}_{2} \mathrm{O}}=2.9 \mathrm{psi}
$$

from Combustion Engineering Steam Tables maximum Temperature allowable is $140^{\circ} \mathrm{F}$

(4.)

F-28 
HNF-2941

Revision 0

F.1.10 ADJUSTMENT TO TANKS 241-AN-102 AND 241-AN-107 WASTE TO MEET CORROSION SPECIFICATIONS 
HNF-2941

Revision 0

DESIGN CALCULATION

(1) Drawing N/A

(4) Building 241-AN

(7) Subject Côustio

(9) Checker A.B. Carlson
(8) Originator W.L. Will is

(2) Doc No: HNF - 2938

(5) Rev. 0

(10) Objective: Determine the minimum volume of $19 \mathrm{M} \mathrm{NaOH}$ necessary to bring the supernatant waste in 241-AN-102 and 107 into compliance with the corrosion specification.

Design Inputs:

1. The supernatant volumes in the tanks are as follows (Hanlon 1998);

-241 -AN-102 3,700,000 liters (978,000 gallons)

- 241-AN+107 3,030,000 liters (801,000 gallons)

2. The volume of each tank corresponds to approximately 410,0001 per meter $(2750 \mathrm{gal} / \mathrm{in}$.) of tank depth.

3. The corrosion specification is as follows (OSD 1998):

$$
\begin{aligned}
& \text { for }\left[\mathrm{NO}_{3}\right] \leq 1.0 \mathrm{M} ; \quad 0.010 \mathrm{M} \leq\left[\mathrm{OH}^{\prime}\right] \leq 5.0 \mathrm{M}, 0.011 \mathrm{M} \leq\left[\mathrm{NO}_{2}\right] \leq 5.5 \mathrm{M},\left[\mathrm{NO}^{\prime}\right] /\left[\left[\mathrm{OH}^{\prime}\right]+\left[\mathrm{NO}_{2}\right]\right)<2.5 \\
& \text { for } \left.1.0 \mathrm{M}<\mathrm{NO}_{3}\right] \leq 3.0 \mathrm{M} ; \quad 0.1\left(\left[\mathrm{NO}_{3}\right]\right) \leq[\mathrm{OH}]<10 \mathrm{M},\left[\mathrm{OH}^{\prime}\right]+\left[\mathrm{NO}_{2}\right] \geq 0.4\left(\left[\mathrm{NO}_{3}\right]\right) \\
& \text { for }\left[\mathrm{NO}_{3}\right]>3 \mathrm{M} ; \quad 0.3 \mathrm{M} \leq[\mathrm{OH}]<10 \mathrm{M}[\mathrm{OH}]+\left[\mathrm{NO}_{2}\right] \geq 1.2 \mathrm{M},\left[\mathrm{NO}_{3}\right] \leq 5.5 \mathrm{M}
\end{aligned}
$$

4. Tank Supernatant concentrations for 241-AN-102 are as follows (Herting 1998):

$$
\left[\mathrm{OH}^{\top}\right] \cdot 0.22 \mathrm{M} \quad\left[\mathrm{NO}_{2}\right] \cdot 1.71 \mathrm{M} \quad\left[\mathrm{NO}_{3}\right]-3.74 \mathrm{M}
$$

5. Caustic demand for supernate in tank 241-AN-107 is 0.391 per liter of supemate (Herting 1995).

Assumptions:

1. The supernatant liquid will be retrieved down to within $0.25 \mathrm{~m}$ ( 10 in.) of the solids layer in each tank

\section{Reference:}

Hanlon 1998, Waste Tank summary Report for Wonth ending June 30, 1998, HNE-EP-0182-123, Fluor Daniel Hanford Corporation, Richland Washington

OSD 1998, Tank Farms Operating Specification Doctment, OSD-T-151-00007, Rev. H-21, released 9/29/98, Lockheed Martin Hanford. Corporation, Ricliland Washington

Herting 1994, Process Aids 1994, WHC-IP-0711-26, Westinghouse Hanford Company, Richland Washington

Herting 1995, Process Aid's 1995, WHC-1P-0711-27, Westinghouse Hanford Company, Richland Washington

Calculations:

1. Based on design inputs 3 and 4 above, the minimum required $\mathrm{OH}$ concentration to meet corrosion specifications for $241-\mathrm{AN}-102$ is $0.3 \mathrm{M}$. We need to solve the following equation to determine the necessary volume of caustic to add to Tank 241-AN-102.

$$
A \times \lambda+X \times N=(A+X) \times Q
$$

\section{Where:}

$A=$ supernate volume to be transferred

$\mathrm{MI}=$ supernate concentration [OH' or $\mathrm{OH}^{\circ}+\mathrm{NO}_{2}$ ] $\mathrm{N}=$ caustic solution concentration [ $\left.\mathrm{OH}^{*}\right]$

$\mathrm{Q}=$ desired concentration [OH' or $\left.\mathrm{OH}^{+}+\mathrm{NO}_{2}^{-}\right]$
$\mathrm{X}=$ volume added caustic solution

. 


\section{DESIGN CALCULATION}

(1) Drawing $N / A$

(4) Building_241-AN

(7) Subject Caus
(2) Doc No. HNF - 2938

(5) Rev. 0
(3) Page 2 of 2

(6) Job No. N/A

(8) originator W.L. Will is

(9) Checker A.B. Carlson

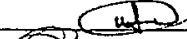
,

$\begin{array}{ll}\text { Date } & \frac{10 / 06 / 1998}{10 / 06 / 1998} \\ \text { Date }\end{array}$

Rearranging yields the following:

$$
\begin{aligned}
& A \times M+X \times N=A \times Q+X \times Q \\
& A \times M-A \times Q=X \times Q-X \times N \\
& A \times M--A \times Q=X \times(Q-N)
\end{aligned}
$$

$\rightarrow$

Solving for $X$ yields:

$$
X=\frac{(A \times M-A \times Q)}{(Q-N)}
$$

For Tank 241-AN.102 in order to met the [OH] requirement for waste with > 3 M [NO, ], the following apply (Herting 1994):

$$
A=3,700,0001-103,0001=3,600,0001 \quad M=0.22 \mathrm{M} \quad \mathrm{N}=19 \mathrm{M} . \quad Q=0.30 \mathrm{M}
$$

Solving for $X$ in equation 2 above yields $15,4001(4100 \mathrm{gal}) 19 \mathrm{M} \mathrm{NaOH}$ as a minimum volume to be added to Tank 241-AN-102 supernatant to comply with the corrosion specification

2. Based on designi input 5 above, we can determine the volume of caustic needed in Tank 241-AN-107 as follows:

$(3,030,000$ liters supernate $-103,000$ liters supemate remaining in tank) $\mathrm{X} 0.039$ liters $19 \mathrm{M} \mathrm{NaOH} / \mathrm{liter}$ supernate $=114,000$ liters $19 \mathrm{M} \mathrm{NaOH}$ Concluslons:

,A1 a minimum, 15,4001 (4100 gal) of $19 \mathrm{M} \mathrm{NaOH}$ would need to be added to the supernatant in Tank 241-AN-102 to comply with the corrosion - specification in the receiving tank.

At a minimum, $114,0001(30,200 \mathrm{gal})$ of $19 \underline{\mathrm{M} \mathrm{NaOH}}$ would need to be added to the supernatant in Tank 241.AN-107 to comply with the corrosion specification in the receiving tank. 
HNF-2941

Revision 0

F.1.11 TRANSFER LINE HEATING 
HNF-2941

Revision 0

FLUOR DANIEL NORTHWEST, INC.

1100 Jadwin

P.O. Box 1050

Richlond, Woshinglon $99352 \cdot 1050$

August 11, 1998

LMHC96WO-0006

CO-98-TWRS-384

Mr. I. G. Papp

Numalec Hanford Corporation

P.O. Box 1300

Richland, Washington 99352-1300

Dear Mr. Papp:

TASK ORDER 44-10-02, PREPARE PIPING AND INSTRUMENTATION DIAGRAMS

Rëponse Requested By: N/A

Responds To: N/A

Enclosed are two deliverables in support of the additional work that Randy Haltum is providing. They are: 1) Dynamic Thermal Arialysis of Waste Transfer Piping and 2) Review of Raw Water Versus Inhibited Water for Transfer Pipe Flushing. The letter report for use of Raw Water Versus Inhibited Water is based on reviews of existing site documents. A defensible technical justification has not yet been prepared.

Please feel free to contact Randy Hallum a! 376-7089 or myself at 373-2198 if you have any questions.

Sincerely,

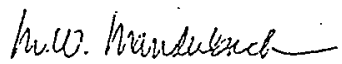

M. W. Manderbach

Project Manager

MWM:sst

Attachments (2) 
HNF-2941

Revision 0

LMHC $9620-0006$

CO-98-TWRS-384

Attachment 1

$!$ 
HNF-2941

Revision 0

\section{MEMO}

To: $\quad$ Mark Manderbach

From: Ed Smith

Subject: Heat Up/Heat Loss Through Routes

Date: August 6,1998

The attached report contains a dynamic thermal analysis of the Hanford waste transfer double buried pipe.

The analysis was performed using AspenTech's Speedup computer modeling program. Two cases were considered for the waste transfer with differing assumptions made for the initial waste temperature and surrounding soil/pipe temperatures.

The results of the analysis show that the transfer pipe will heat up from it's initial temperature to nearly waste temperature over a very short period of time. It also shows the steady state temperature will be within a few degrees of the waste's initial temperature but that it will take a period much greater than twenty-four hours to reach this state as the soil takes a long time to heat up.

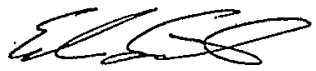


Fluor Daniel Applied Computer Solutions (ACS) has completed a dynamic simulation analysis of the Hanford double buried pipe. The pipe design includes a $3^{n}$ inch inner pipe and a $6^{n}$ outer pipe. The annular space between the pipe contains air. The objectives of the simulation are to:

- Determine outlet fluid temperature at steady state conditions

- "Determine time required to heat the pipe to steady state conditions

Casès

Two Cases were considered. The following table summarizes the two simulation cases.

\begin{tabular}{|c|c|c|}
\hline & $\operatorname{Cas} \theta 1$ & Case 2 \\
\hline Fluid Temperature $\left({ }^{\circ} \mathrm{F}\right)$ & 200 & 904 \\
\hline Fluid Velocity (ft/soc) & 5 & 6 \\
\hline Pipe Length (fit) & 4007 & 4007 \\
\hline Soil Temperature $\left({ }^{\circ} \mathrm{F}\right)$ & 50 & 33.5 \\
\hline
\end{tabular}

The initial conditions for both cases are zero flow with the pipe at the ambient soil temperature. a Case $I$ is the same conditions as reference calculation W314-P-006 dated Mar 121998 by Fluor Daniel Northwest.

\section{Dynamic Model}

The model includes the following assumptions:

- The line is broken into 10 segments.

- The fluid is assumed to bo water.

- Heat transfer from the fluid to the $3^{n}$ pipe wall in each segment is based on the equation for heat transfer for turbulent flow:

$$
N u=0.023 \operatorname{Re}^{0.8} \mathrm{Pr}^{0.3}
$$


HNF-2941

\section{Revision 0}

- Heat transfer in the annular space between the pipes is based on natural convection and radiation per the reference calculation. Natural convection uses the equation:

$$
N u=0.19 \mathrm{Gr}^{0.25}
$$

- The model neglects the thermal conductivity in the pipe wall (infinite conductivity). The pipe material is assumed to be carbon steel.

- The soil surrounding each segment is broken into 50 concentric rings for heat transfer and heat capacitance calculations. The soil heat transfer is based on conduction with conductivity and heat capacitance based on dry sand. The soil temperature is assumed to be constant at a five foot radius from the center of the pipe

- AspenTech's Speedup program was used to perform the analysis. The model is linked to Aspen Plus for physical properties of wates.

The Speedup modal developed for this study is appended to the report.

\section{Results}

Results for each case are attached to this report and are summarized by the following table.

\begin{tabular}{|c|c|c|c|c|}
\hline & \multicolumn{2}{|c|}{ Case 1} & \multicolumn{2}{|c|}{ Case 2} \\
\hline - & $\begin{array}{l}\text { Al } 24 \\
\text { minutes }\end{array}$ & $\begin{array}{l}>>24 \\
\text { hours }\end{array}$ & $\begin{array}{l}\text { At } 30 \\
\text { minutes }\end{array}$ & $\begin{array}{l}>24 \\
\text { hours }\end{array}$ \\
\hline Fluid Temperature Loss ( $\mathrm{F}$ ) & 10 & 2.7 & 2 & 0.6 \\
\hline $\begin{array}{l}\text { Fluid and Inner Pipe Wall } \\
\left.\text { Temperature ( }{ }^{\circ} \mathrm{F}\right)\end{array}$ & 190 & 197 & 102 & 103 \\
\hline Outer pipe Temperature ( $\left.{ }^{\circ} F\right)$ & 46 & 149 & 55 & 84 \\
\hline
\end{tabular}

Speedup was run in dynamic mode for the results at 24 and 30 minutes and in steady state mode for the results greater than 24 hours. An extended dynamic run for Case 1 indicated that the pipe still had not reached steady conditions after 40 hours.

\section{Case 1}

The lluid temperature reaches a new value of $190^{\circ} \mathrm{F}\left(88^{\circ} \mathrm{C}\right), 24$ minutes atier the start of flow. However, the fiuid does not reach its final steady state value of $197^{\circ} \mathrm{F}\left(92^{\circ} \mathrm{C}\right)$ at a time much greater than 24 hours as the soil takes a long time to heat up. Figure 1 shows the temperatures for the fiutid, inner pipe, outer pipe, and thres layers of soil one inch thick each closest to the outer pipe. Figure 1a is a close-up of the fluid temperature.

\section{Case 2}

The fluid temperature reaches a new value of $102^{\circ} \mathrm{F}\left(39^{\circ} \mathrm{C}\right), 30$ minutes after the start of flow and reaches its final steady state value of $103^{\circ} \mathrm{F}\left(39.4^{\circ} \mathrm{C}\right)$ at a time greater than 24 hours.

Figure 1 shows the temperatures for the fluid, inner pipe. outer pipe, and threa layers of soil one inch thick closest to the outer pipe. Figure 1a is a close-up of the fluid temperature. 
Revision 0

RUG Q4 1998 17:40 FR FLUDR DFNIEL ACS $\$ 495755855$ TO 1515993736471 P. Q3/13

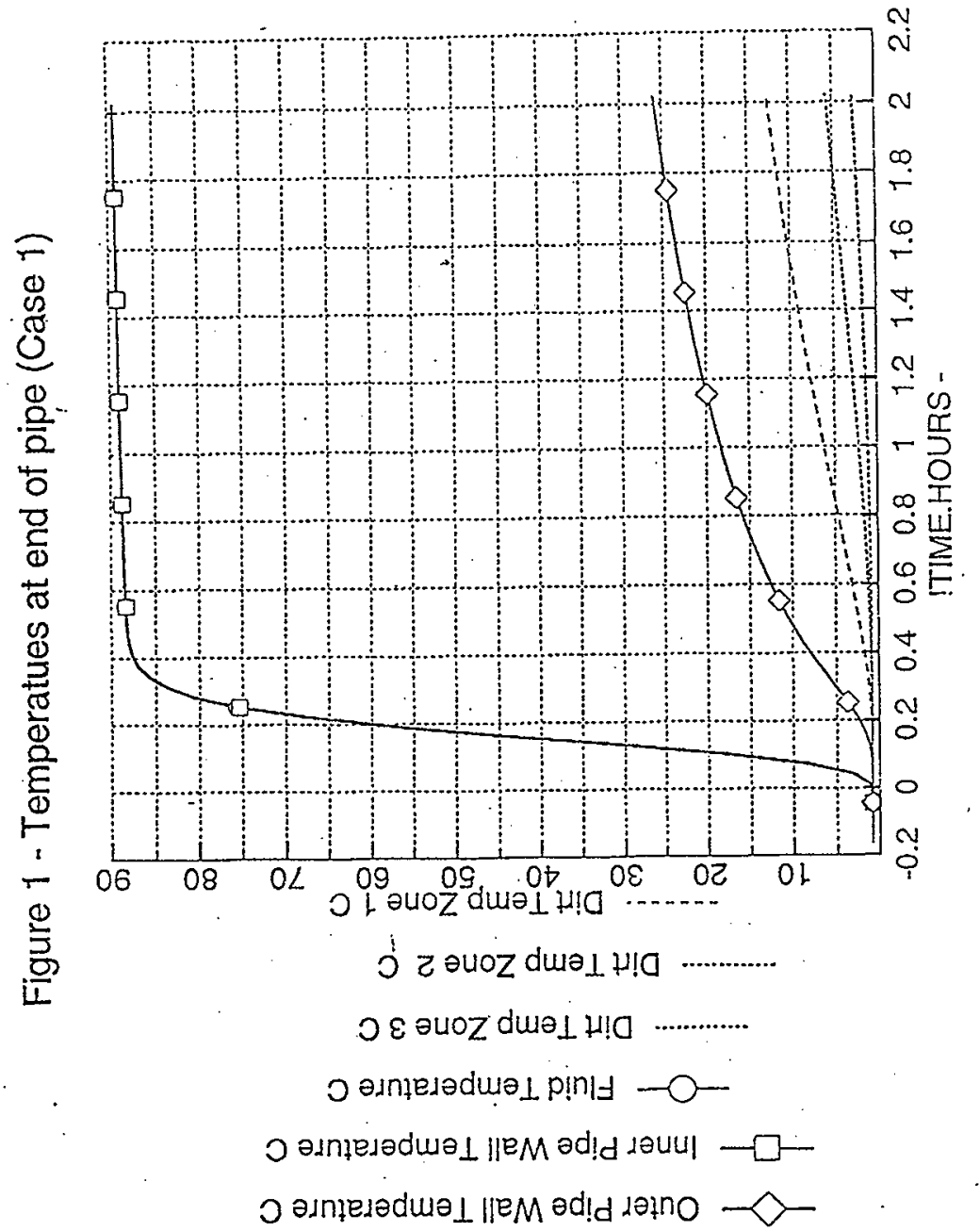




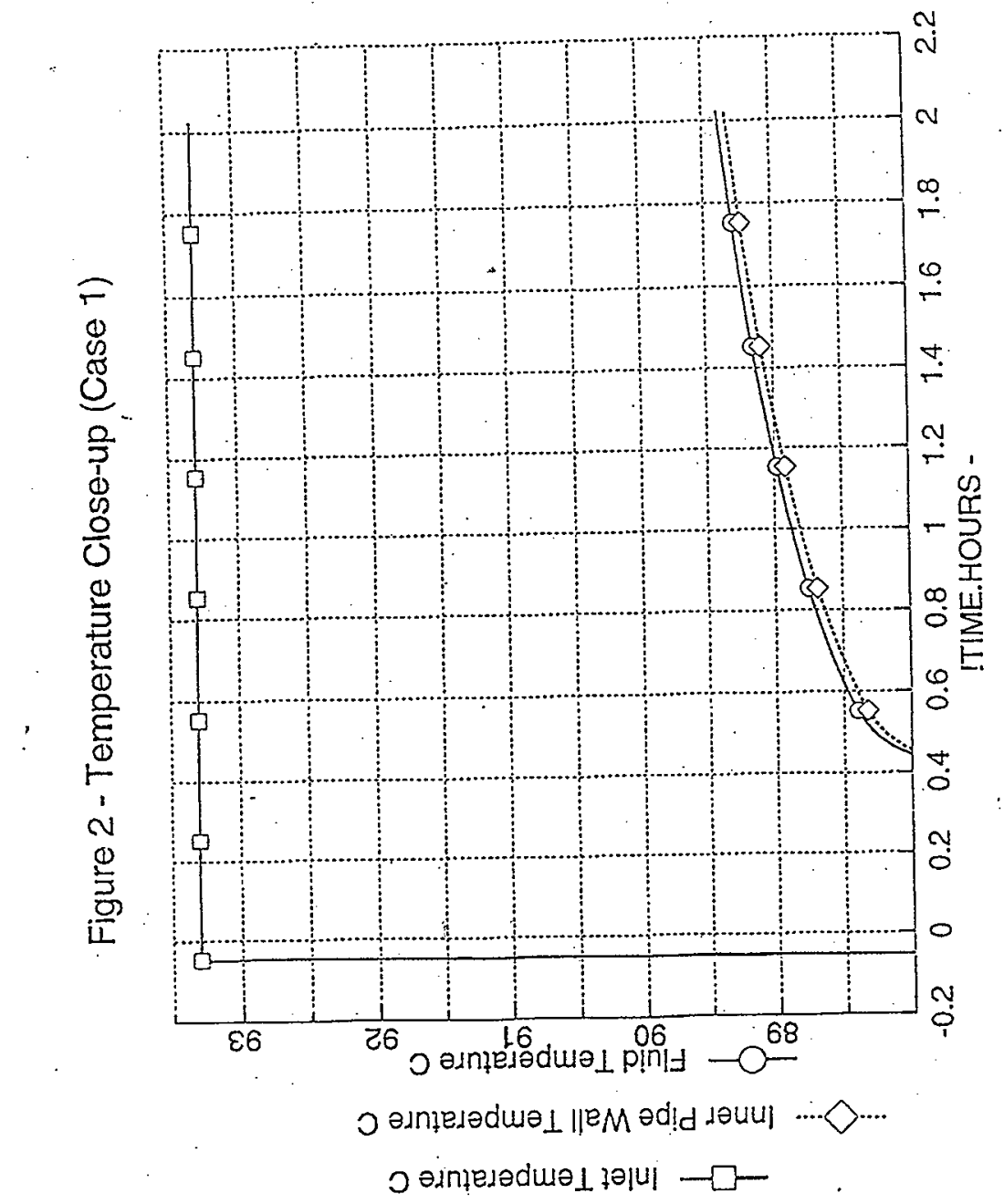




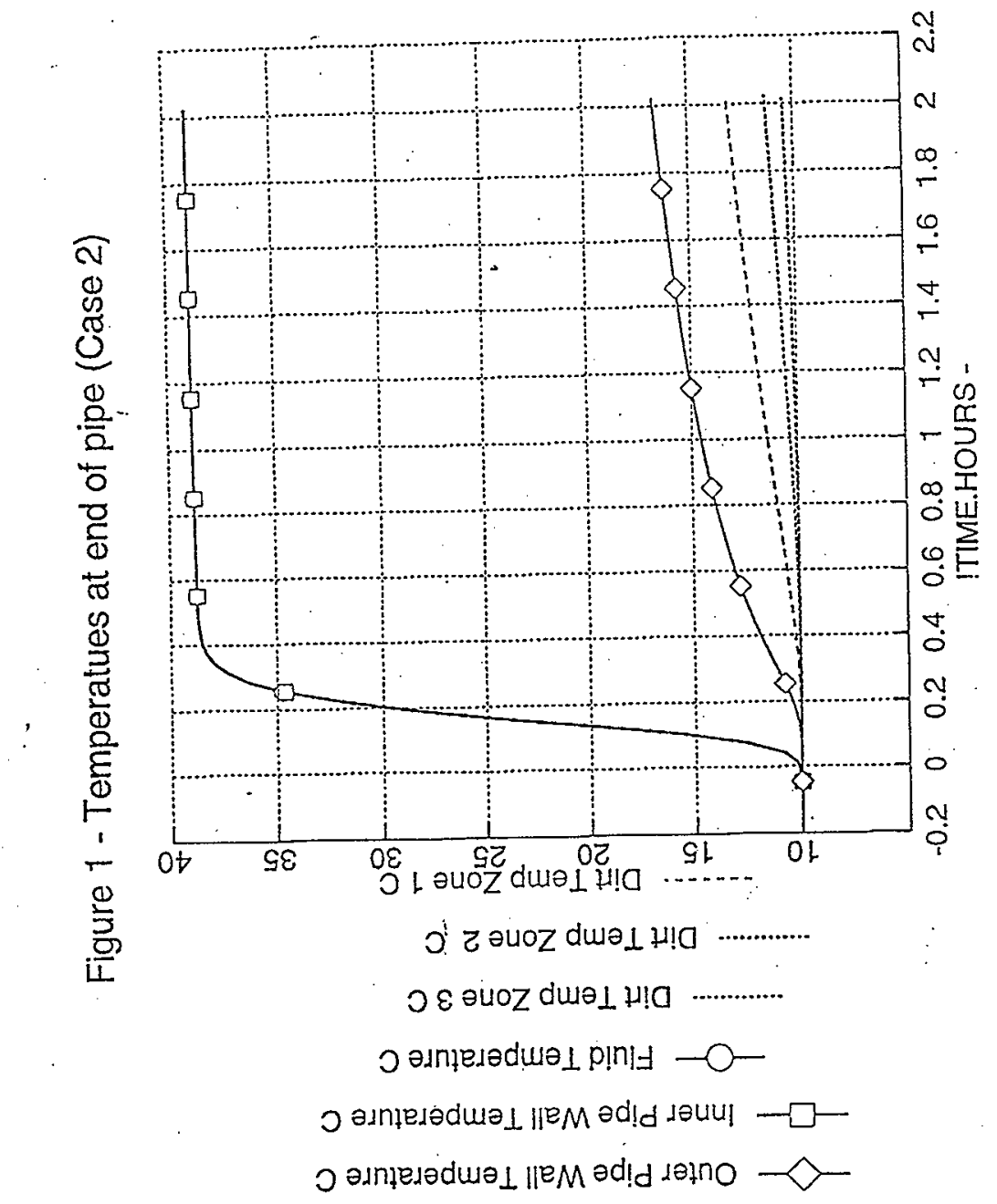




\section{Revision 0}

RUG 641998 17:41 FR FLUOR DANIEL ACS S49575 5E56 TO 1915E93736471 P.ES/13

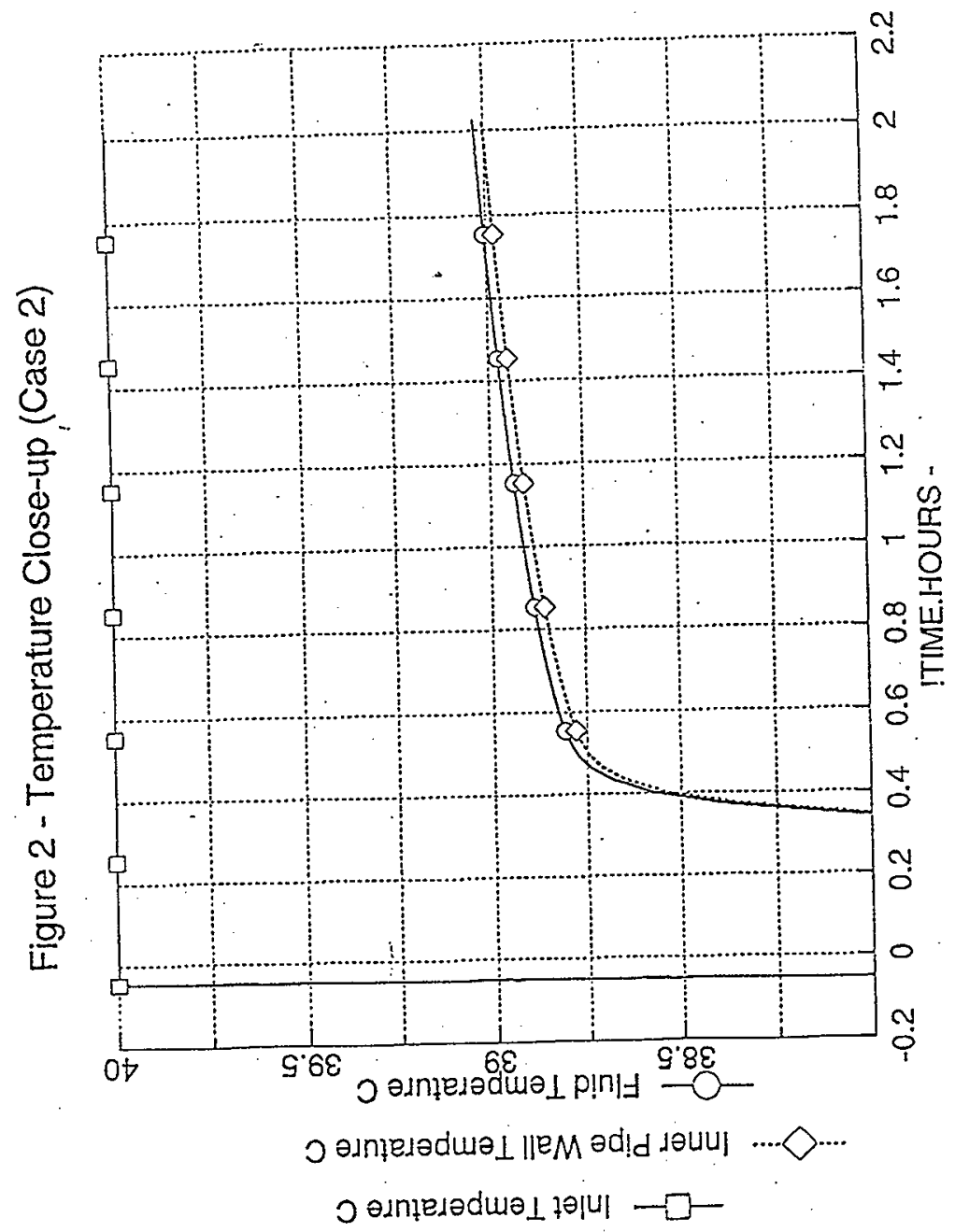


MODEL TPIPEDW

$\because 4$

leanford

- Double pioe

- Double pioe and natural convection from inner pipe to ourer pipe

- radiation and natural convecton for heaviér fluids with solids has not been completed and tested.

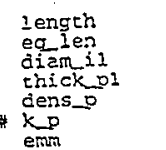

$=$
$=$
$=$
$=$
$=$
$=$

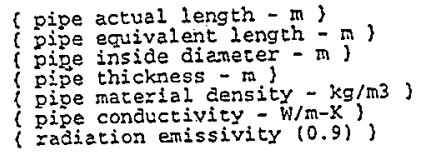

Notes

reguires procedure cp.nol_liq

Thermal zipe model to calculate wall cenerature

mext process many segments together

)

?set zero_ilo*to ?end \# tzy not using anymore

?set nuings $=50$ ?end 4 number of rings of dirt

SET

NOCOMP $20=1$ \# number of components

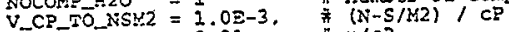

$V$ GRAVITY $=9.81, \quad \pi \mathrm{m} / \mathrm{s2}$

V_HRFO_SEC $=3600.0, \# \mathrm{~s} / \mathrm{hr}$

V.KJTO_GJ $=1.0 \mathrm{E}-6$, \# GJ / kJ

$V J T O \bar{G}=1.0 \mathrm{E}-9 ; \quad$ GJ $/ \mathrm{J}$

$V_{H M}{ }_{0} H \quad=1.0 \mathrm{~B}-3, \quad \# \mathrm{~m} / \mathrm{mm}$

$V$ NEG $=-i .0 E 10$.

$\checkmark$ ONE $=1.0$

VPOS $=1.0210$.

V_W_TO_GUAR $=3.6 \mathrm{z}-6$,

V_ZERO $=0.0$.

VPI $\quad 3.14159$.

$V$-PI TO_ET2 $=10.75$. \# ft $2 / \pi 2$

$\mathrm{V} B \mathrm{U}$

VKC2ISTO W $=1.162$.

V_KK_O_M $=1.00+3$.

FE_CONV $=-0.010125$

FF POWER $=-0.217$.

VVIN DIZM $=0.00001$

$V$ SM_DIAY $=0.1384$

VLGDIAK $=0.1410$

$S \bar{B}_{-} \operatorname{CONST}=5.675 \mathrm{E}-8$

\# minus infinity (ish)

* plus infinity (ish)

in. (GJ/hr) / w

65 \#(W/m2-K)/(Stu/hr-tt2-z)

$\mathrm{h} / \mathrm{xcal} / \mathrm{h})$

$\mathrm{X} / \mathrm{xH}$

f Minimum dian for power linearisation

* Diar to switch correlations

- Dian to switch correlations

- stephar bolzman constant

$\# 0.1714 \mathrm{e}-8$ Etu/ft2-ht-R4 (5.67e-8 W/m2-K4)

A Ai: properties
CP_A
$\mathrm{KV} \overline{\mathrm{I} S C_{-}} \mathrm{A}$
$=1007$
$\mathrm{K}$ A
$1.93 \mathrm{E}-5$
$\times 0.02537$
$B \equiv \mathrm{TA}$
$=0.003225$
- heat capzcity of a1r, J/kg-X
t kinematic visc of zir. $\mathrm{m} 2 / \mathrm{s}$
\# conductivity of eix.

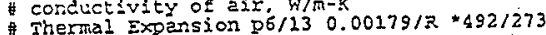
\# Dire Froperties (dry sand) 


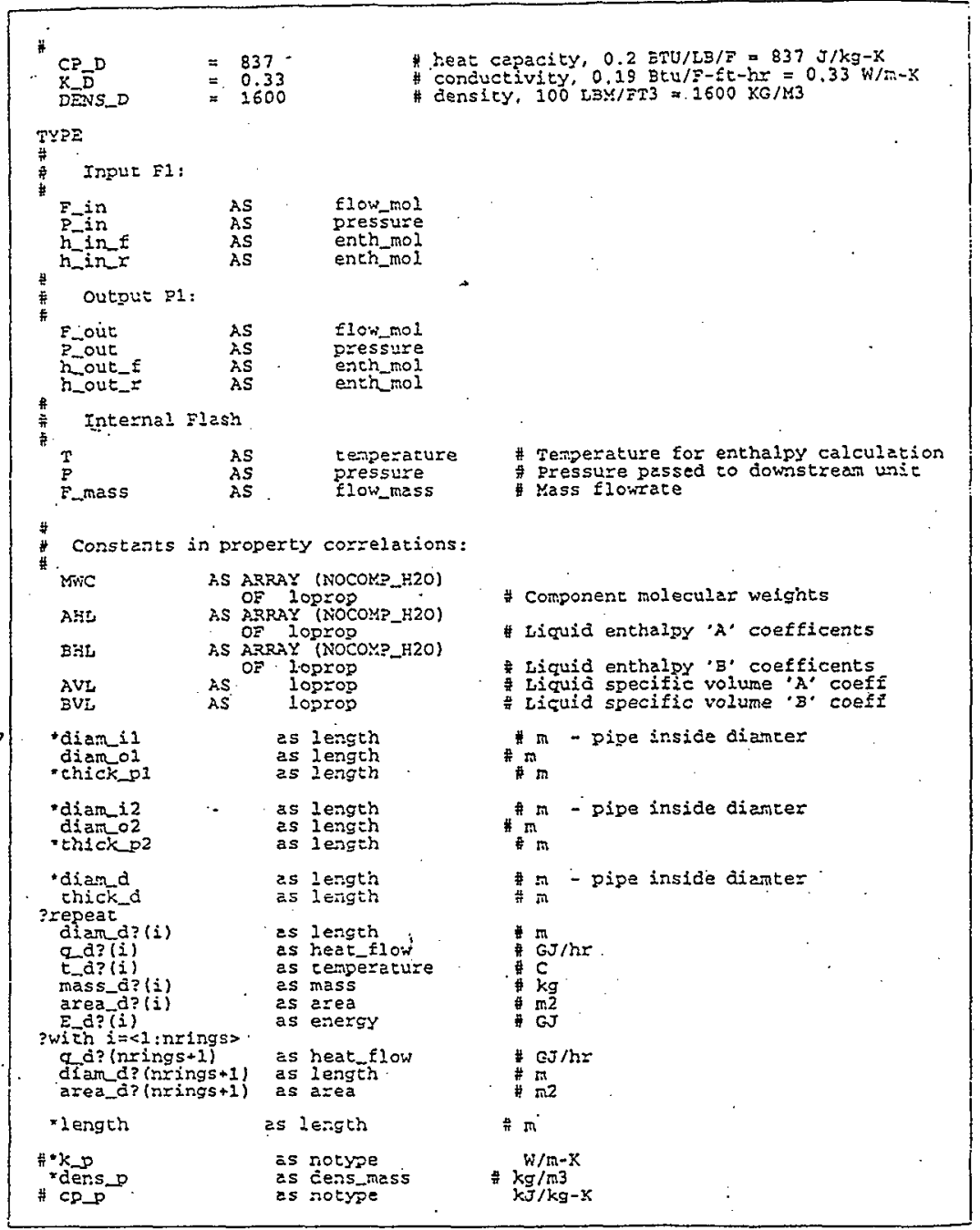



..

$$
\begin{aligned}
& \text { vel } \\
& \text { vel_km } \\
& \text { vel_sqro } \\
& \text { k_I } \\
& \text { visc_l } \\
& \text { cp_Imol } \\
& \text { tho_mol } \\
& \text { rho_mass } \\
& \text { spgr }
\end{aligned}
$$

dP_frict fric_fact

$d t, d \tau_{-} x$

* U_anb

hec_lp

htc_lp_t

hee $D$ D

hte ooc_t

coef

-equier

$$
\begin{aligned}
& \text { q_p } \\
& \text { appe } \\
& \text { qupp } \\
& \text { qupd }
\end{aligned}
$$

T- 1

mass. 01

mass $D 2$

area flow

area_ip

area_ppc

erea par

\# area pa

$$
\frac{E D 1}{E-D 2}
$$

Re, $P x$, Nu

Re_exp; PI_exp.

low_flow

- emrn T_amb

$$
\begin{aligned}
& \text { as velocity } \\
& \text { as velocity } \\
& \text { as notype } \\
& \text { as cond_id } \\
& \text { as visc } \\
& \text { as cp_nol } \\
& \text { as dens_nol } \\
& \text { as dens_mass } \\
& \text { as notype }
\end{aligned}
$$

As press_diff

AS

as notype

as hear_trans_coeff

as heat_trans_coeft

as heat_trans_coeff

as heat_trems coeff

es heat_trans_coeff

as positive

as ler.gin

as heat_flow
as heat_flow
as heat_flow
as heat_flow

as temperature

as temperatire

as temperature

as mass

as mass

as area

es area

as area

as area

as area

as energy

as energy

as energy

as notype

es $20=y p e$

as fzection

as notype :

as tenperature
$\# \mathrm{~m} / \mathrm{s}$

\# $\mathrm{km} / \mathrm{s}$

* Velocity ir pipe squared

* Lia Conductivity, $w / m-k$

\# $\mathrm{CP}$

\# $\mathrm{KJ} / \mathrm{kgmol}-\mathrm{K}$

. $\mathrm{kgmol} / \mathrm{m}^{3}$

$\# \mathrm{~kg} / \mathrm{m} 3$

\# Pressure change due to friction

"Friction Eacto:

\# Deg C

$W / m 2-K$

\# $W / m^{2}-K$

* $w / m 2-x$

* $W / \pi^{2}-\mathrm{x}$

\# $w / m 2-K$

\#GJ/hr

* GJ/hr

\# $G J / h r$

\# $\stackrel{C}{\mathrm{C}}$

\# C

$\# \mathrm{~kg}$

\# $\mathrm{kg}$

$\# \mathrm{~m} 2$

\# 12

न $\mathrm{m} 2$

चै $m^{2}$

* GJ

\# GJ

\# GJ

$\#$

\# Air Natural Convection

$\begin{array}{ll}\text { Nu_a } & \text { as notype } \\ \text { Gr_a } & \text { as notype } \\ \text { Gr-25 } & \text { as notype } \\ \text { dens_a } & \text { as dens mess } \\ \text { del } & \text { as lexgth }\end{array}$

h20_ounting AS PRRMY ( 1$)$ or molesraction

\# Air Prandlt

* Aix Grashoze

* ambient teng set in ser_globals 
HNF-2941

Revision 0

AUT 04 1SSO 17:42 FP FLLOR DANIEL FCS

STREAM

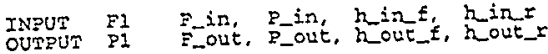

EQUATION

Eressure drop zelationships with flow and elevation change

P_out = ?_in - de_frict ;

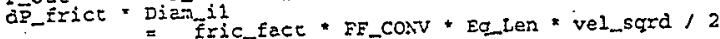

+ rhomass * 10 ;

area_flow $=(\mathrm{V}, \mathrm{PI} / \overline{4}) *($ diam_il*dian_iI $)$

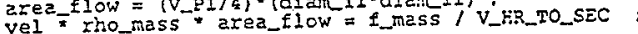

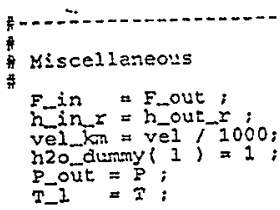

* rho_nol = $1.0 /$ (AVL + BVI * $\mathrm{T}$ ):

rho mass = rno_mol * MWC (1) * spgr :

F_mess $=$ F_out $\operatorname{mit}(1)+\operatorname{spgr}$ :

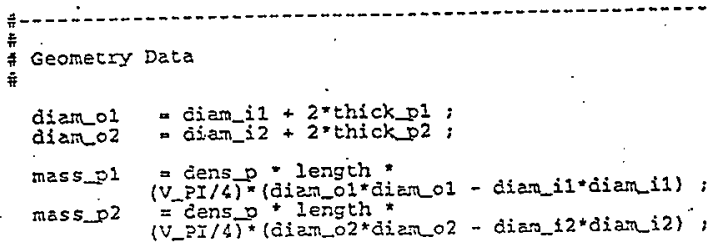

Forced convection fron liq to pipe

Se * visc_l * V_CP_TO_NSH2 = diamil * vel * tho_mass;

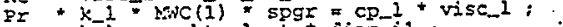

su $k^{-1}=$ htc_lp_t * aian_il:

* The following correlation is for Warm Gas to cold hozizontal pipe

\# $\mathrm{Nu}=0.023 * \mathrm{Re} 0.8 * P x^{\prime} 0.3$ i

Nu $=0.023 *$ Re_exp * PE_exp.

area_ip $=$ length $\times V_{-P I} \times$ diam_il

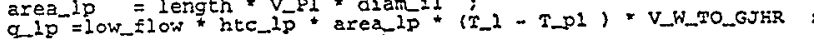

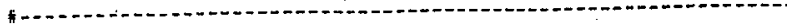


HNF-2941

Revision 0

FLU Q4 1598 17:42 FR FLUOP DANIEL RCS

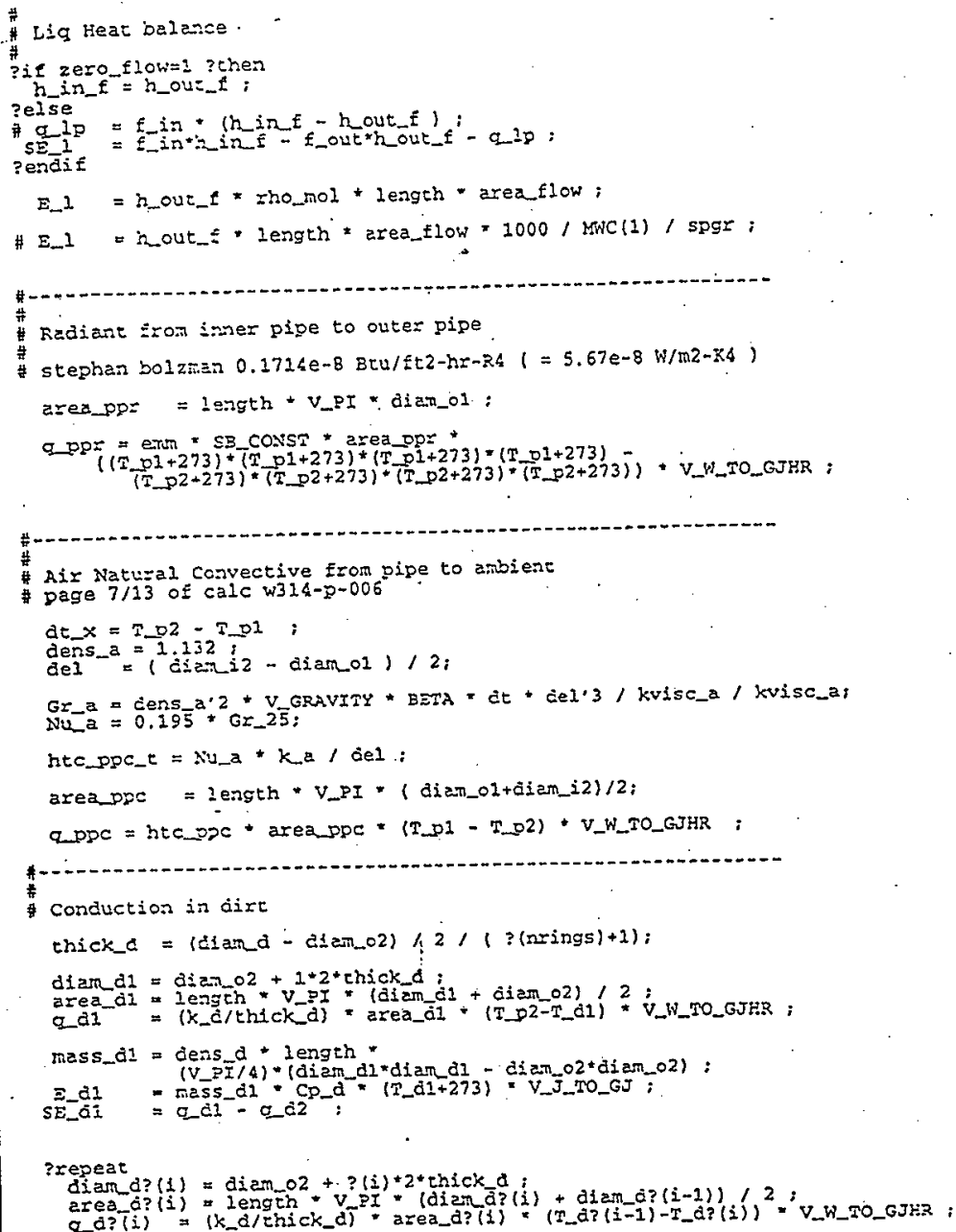




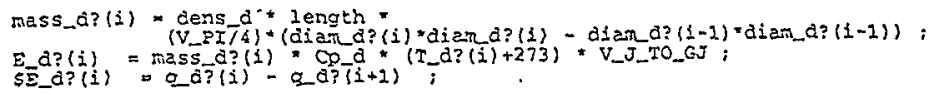

?with $i=<2$ : nxings $>$

dien_d? (nrings+1) = diam_o2 + ?(nrings+1)*2*thick_d :

area $d$ ? $(n \operatorname{nings+1})=$ length $V_{\text {LI }}$ * (dian_d? (nrings+1) + aian_d?(nrings)) /2; q_a? (nxings+1) $=$

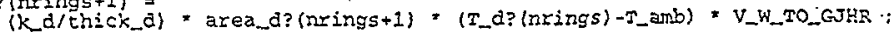

( area $p d=1 \in A g t h * V_{-} P I *($ dian_o $2+d i a m d) / 2$ : chickd $=\left(0 i a n \_d-\overrightarrow{\left.d i a n \_02\right) / 2}\right.$

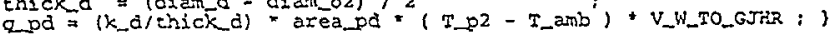
" Concuction through pipe wall

pipe is assumed to have a constan cemperature throughout

F

(5)

\# Ripe Dynemics

"SE_Dl $=q i p-q D D C-q$ Qp

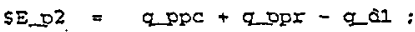

* fudged nole weight of steel (Se) of 50 go give CP=.5 ac $295 \mathrm{~K}$ $H C_{p}=4.13+0.00638 \times \mathrm{T}$

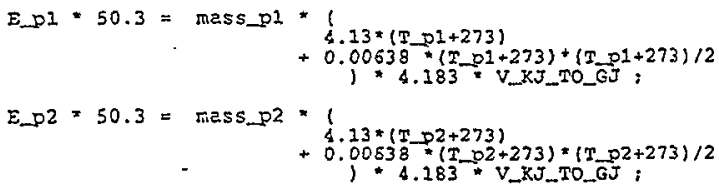


-

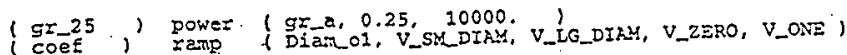

".

Friction Eactor

\# ( Eric_fact) power (Dian_i1,FE_POHER,V_MIN_DIAM)

* Elash

( h_out_f , Drop_calc_hl ( $\mathrm{s}$, h2o_dunmy. AHL, BHL)

( MNC,

AHE, BHL,

AVL, BVL

) prop_coxr...ind

( T, P, h20_dumany

) INPUT E1, TERR

(2_amb) get_param ("TaMs") 
HNF-2941

Revision 0

\section{F1.1.17 TRANSFER LINE FLUSH VOLUMES}


(1) Drawing $N / A$

(4) Building 241-AN Farm

(7) Subject Transfer Line Flush

(8) Originator T.R. Benegas

(9) Checker Wh WiTis
(2) DoC No. HNF-2838

(5) Rev. 0
(3) Page 1 of 1

(6) Job No. N/A

(10) Objective: Verify the diluent volume specified in Table 4.1 is sufficient to flush transfer lines.

Design inputs:

Longest transfer line route $-5627 \mathrm{ft}$.

Diameter of transfer lines -3 inches

Volume required to flush lines - 1.5 times pipeline volume

Volume available to flush transfer pipeline -Up to $I$ tank volume

Sources:

Longest transfer line route - HNF-2941, Figure A-4.

Diameter of transfer lines - HNF-2941, Table A-5

Volume required to flush lines - HNF-2938, Table 4.1, 7.P4.2

Yolume available to flush transfer pipeline - HNE-2938, Table 4.1, 4.P1.2, 4.P1.2, 4.P2.2

\section{Assumptions:}

None

'Reference:

\section{Calculations:}

Volume $=$ Area $\times$ Length.$\quad$ Area for circle $=P i \times R^{2} ; R=P i p e$ radius, $\mathrm{Pi}=3.14$

Volume $=\mathrm{Pi} \times \mathrm{R}^{2} \times$ Length $\quad$ Length $=5627 \mathrm{ft}$.

Volume $=3.14 \times(3 / 2)^{2}\left(\right.$ inches $\left.^{2}\right) \times(1 \mathrm{ft} / 12 \mathrm{in})^{2} \times 5267 \mathrm{ft}$

Volume $=258.5 \mathrm{ft}^{3}$

or

Volume $=258.5 \mathrm{ft}^{3} \times 7.48 \mathrm{Gal} / \mathrm{ft}$

Volume $=1933.1 \mathrm{Gal}$ or $\sim 2000 \mathrm{Gal}$.

\section{Conclusions:}

Diluent system is to be capable of delivering up to one tank volume or approximately I million gallons. Therefore, the diluent system can sufficiently supply the transfer line flushing requirements. 
HNF-2941

Revision 0

F.2.1 CALCULATION OF OPERATING TRANSFER RATES 
Subject: Estimation of operating transfer rates for waste transfers

This calculation will establish a methodology for estimating the transfer rates for waste being transferred from one double shell tank to another or from one double shell tank to the private immobilization facility. The transfer rate will be estimated by plotting the pump head curve versus flow rate given us by the manufacturer of the pump. Superimposed on the pump curve will be the operating head loss versus flow rate curve. The intersection of the two curves gives us an estimate of the flow rate and total head loss through the piping system.

The operating head loss versus flow rate curve is obtained using Bernoulli's Therom (Crane 1982 equation 3.5) which can be stated as follows:

$$
h_{L}=\left(Z_{1}-Z_{2}\right)+\left(144\left[\frac{P_{1}}{\rho_{1}}-\frac{P_{2}}{P_{2}}\right]\right)+\left(\frac{v_{1}{ }^{2}-v_{2}^{2}}{2 g}\right)
$$

Where:

$h_{L}$ is the total head loss, in feet

$Z$ is the elevation of the transfer, in feet

. $\quad \mathrm{P}$ is the pressure of the system, in pounds per square inch (gauge)

$\rho$ is the fluid density, pounds per cubic foot

$v$ is the mean velocity of flow, in feet per second

The total head loss is the sum of the head loss from the elevation change, the pressure loss due to friction and the change in velocity. If we assume that the fluid is incompressible, and the piping has a constant 3 " diameter, Then equation 1 can be simplified to:

$$
h_{L}=(\Delta Z)+\left(144 \frac{\Delta P}{\rho}\right)
$$

The two factors on the right hand side of equation 2 define the total head loss in a piping system. The first term on the right in equation 2 is the elevation rise or drop in the transfer line which is listed in Table A-5 for each route. The second term on the right in equation 2 is the frictional head loss. The frictional head loss can be calculated using Darcy's formula which can be expressed as the following equation (Crane 1982 equations $1-4$ and 3-5.): 


$$
h_{L_{\text {friction }}}=f \times \frac{L}{D} \times \frac{\nu^{2}}{2 g}=144 \frac{\Delta P}{P}
$$

Where:

$$
\begin{aligned}
& h_{L f \text { fricion }}=\text { frictional head loss, in feet } \\
& L=\text { length of pipeline, in feet } \\
& D=\text { internal diameter of transfer pipe, in feet } \\
& g=\text { acceleration due to gravity, in feet per sqare second }
\end{aligned}
$$

The inside diameter of the pipeline is known (throughout this evaluation 3 in pipe is assumed.

The inside diameter of three inch pipe is 3.068 inches), the acceleration due to gravity is assumed to be constant ( 32.2 feet per square second). We therefore are left with the the friction factor, pipe length, and velocity terms. The friction factor $f$ can be determined graphically using a Moody diagram. Alternatively, a method has been developed by M. Shacham (Olujic 1981) wherein $f$ can be calculated using the following formula:

$$
f=\left(-2 \log \left[\frac{\epsilon / D}{3.7}-\frac{5.02}{R e_{D}} \log \left(\frac{\epsilon / D}{3.7}+\frac{14.5}{R e_{D}}\right)\right]\right)^{-2}
$$

Where:

$\epsilon=$ surface roughness factor $(0.0018 \mathrm{in}$. for commercial steel (DeNevers 1977)) $R e_{\mathrm{D}}=$ Reynolds Number for flow in pipe

Reynolds Number for flow through pipe is given by:

$$
R e_{D}=\frac{D v \rho}{\mu !}
$$

Where:

$$
\mu=\text { fluid viscosity }
$$

With $f$ determined by calculation, the next parameter is line length. The line length for each of the transfer lines was estimated from the best available drawings and is listed in table A-5. The bulk velocity of the fluid is related to the flow rate and the cross sectional area of the pipe as follows: 


$$
v=\frac{\text { flow rate } .}{\text { cross-sectional area }}
$$

A spreadsheet was developed (see table 1) which calculated first the Reynolds Number using equation 5 , then the friction factor using equation 4 , and finally the head Joss using equations 2 and 3 for a series of volumetric flow rates and viscosities. Curves were generated for flow rates from 40 to 250 gallons per minute, and for viscosities of between 5 and 30 centipoise.

With the pressure drop versus flow-rate curve developed, the next step is to compare the pressure-drop versus flow rate curve to the pump curve to determine where the two curves interssect. In order to do this the computer program Tablecurve-2d \& was used to fit the pump curve in the form of a cubic equation. The pump curve and pressure drop versus flow rate curve were plotted in an Excel (B) Spreadsheet. Table 1 is the result of the spreadsheet. Figure 1 is a plot of the operating curves for a transfer from Tank 241-AN-101 to Tank 241-AP-103 for a density of $1.41 \mathrm{~g} / \mathrm{ml}$, and viscosities of $5,10,15$, and 20 centipoise and the pump curve for the pump located in tank 24I-AN-101. The transfers to and from 241-An and 24I-AZ were done using the same spreadsheet with the transfer length and hydraulic change adjusted to the appropriate levels. 


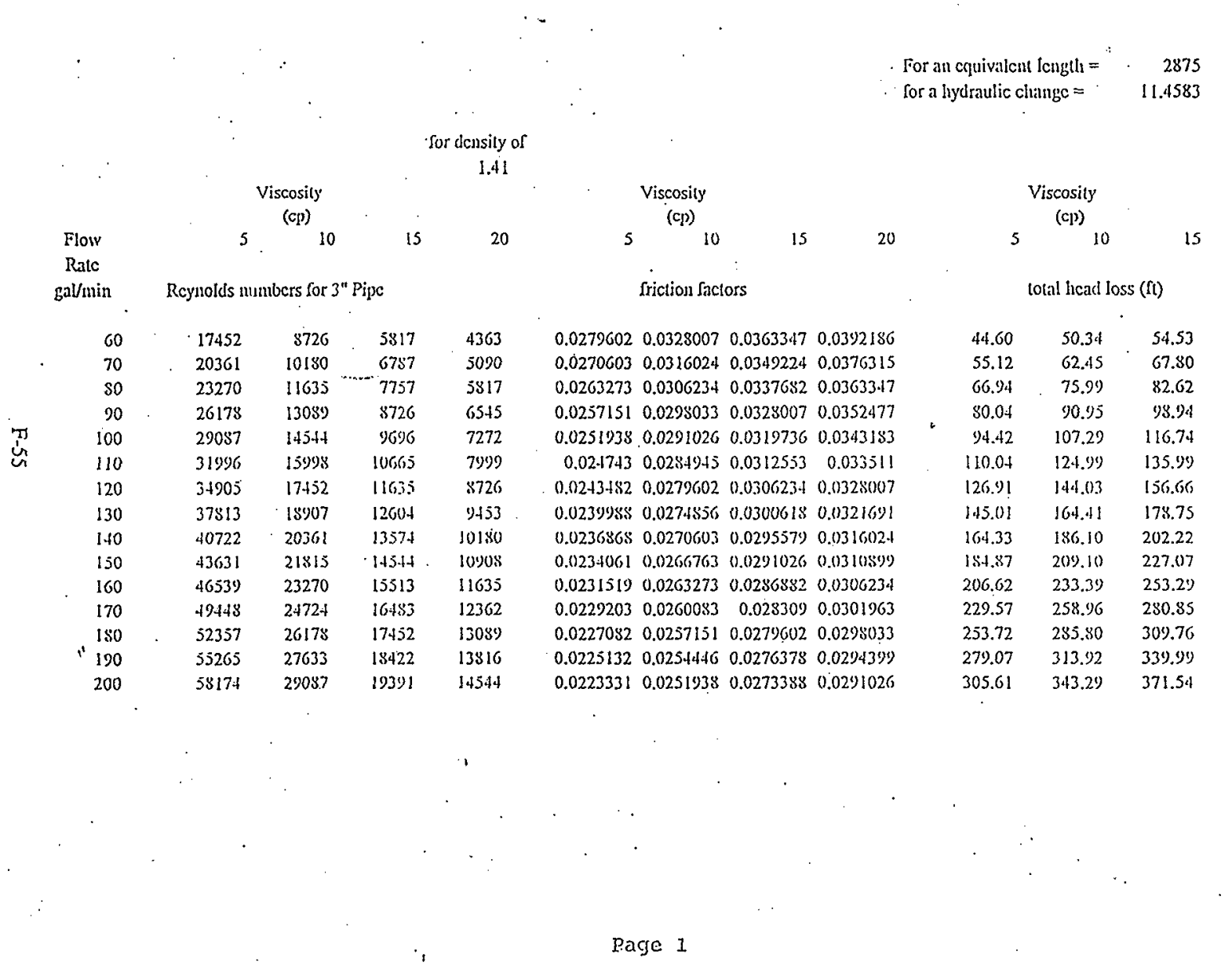




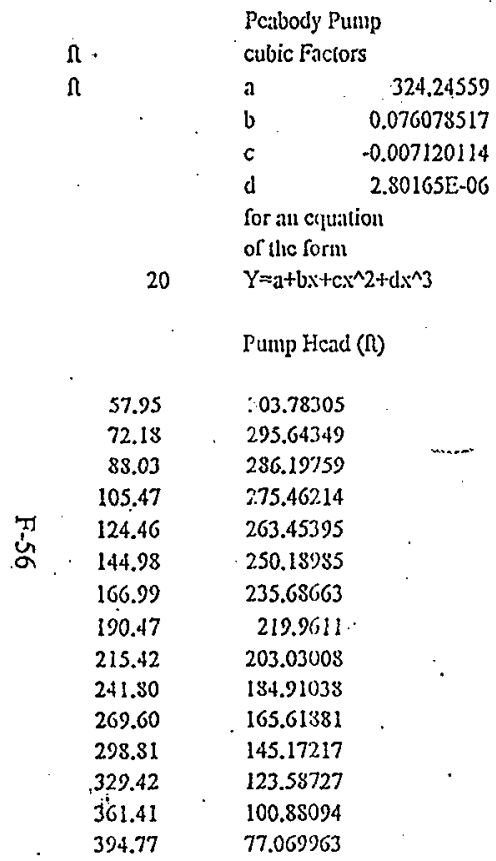




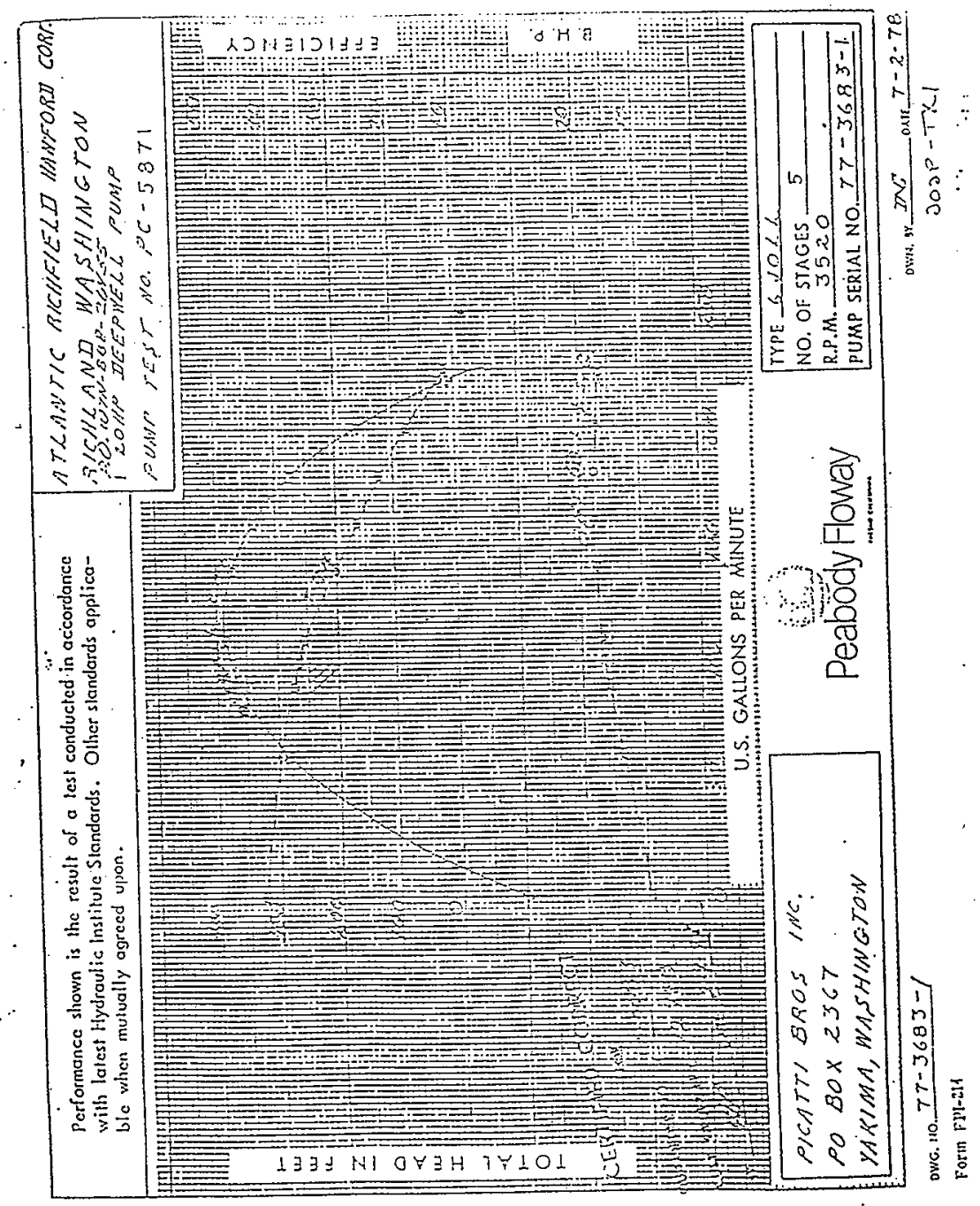


Revision 0

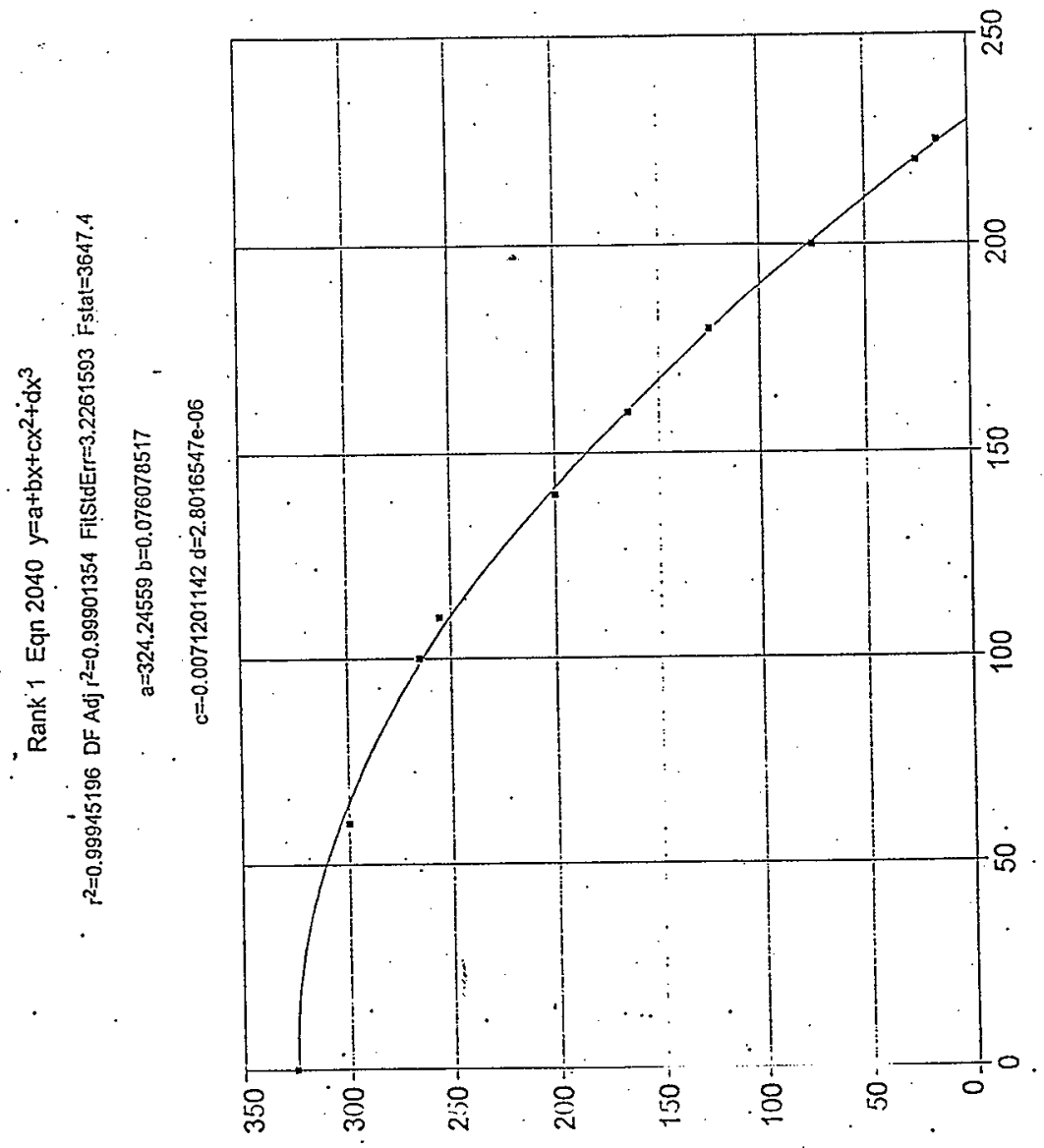




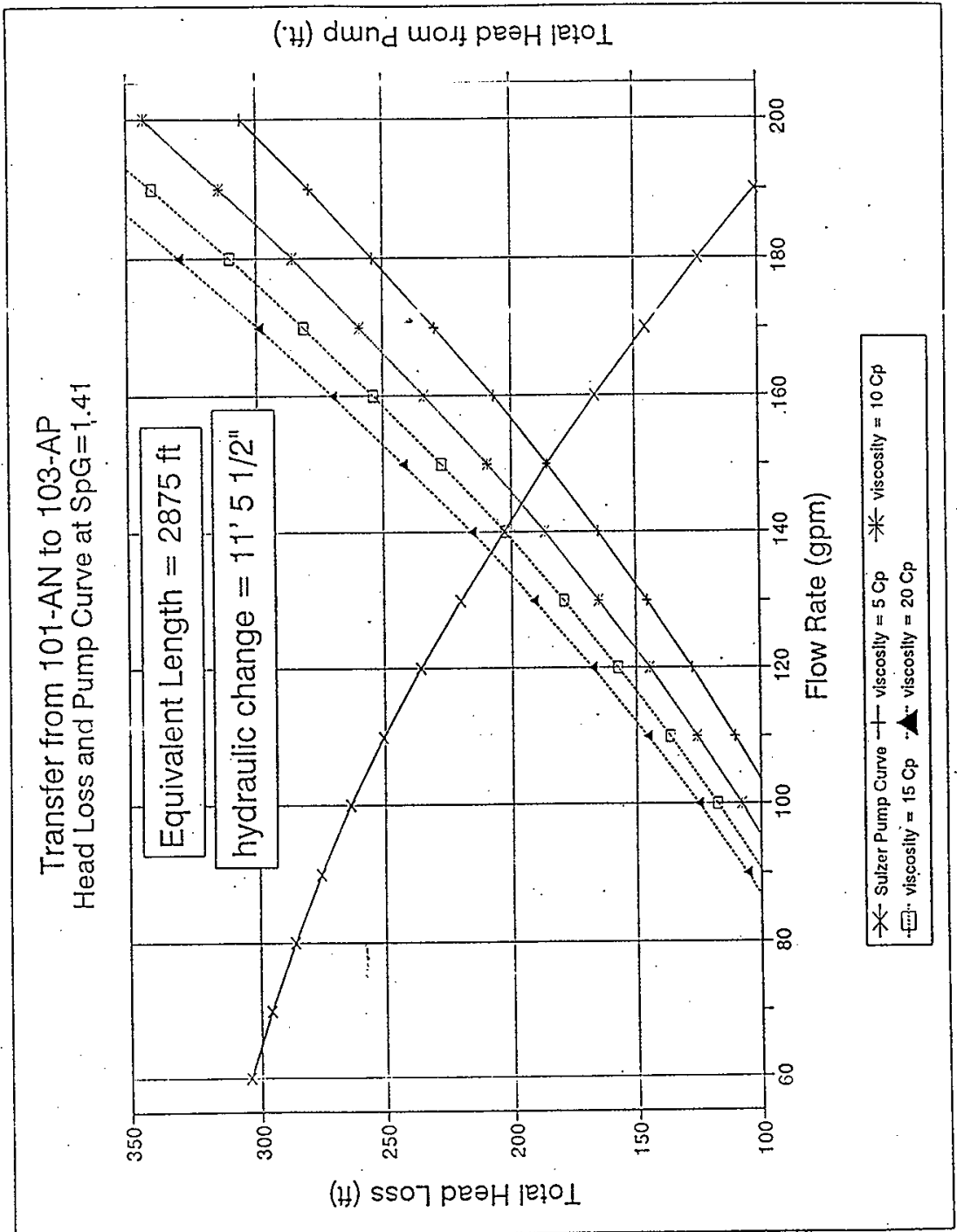


HNF-2941

Revision 0

F.2.2 CALCULATION OF TRANSFER LINE WATER HAMMER 


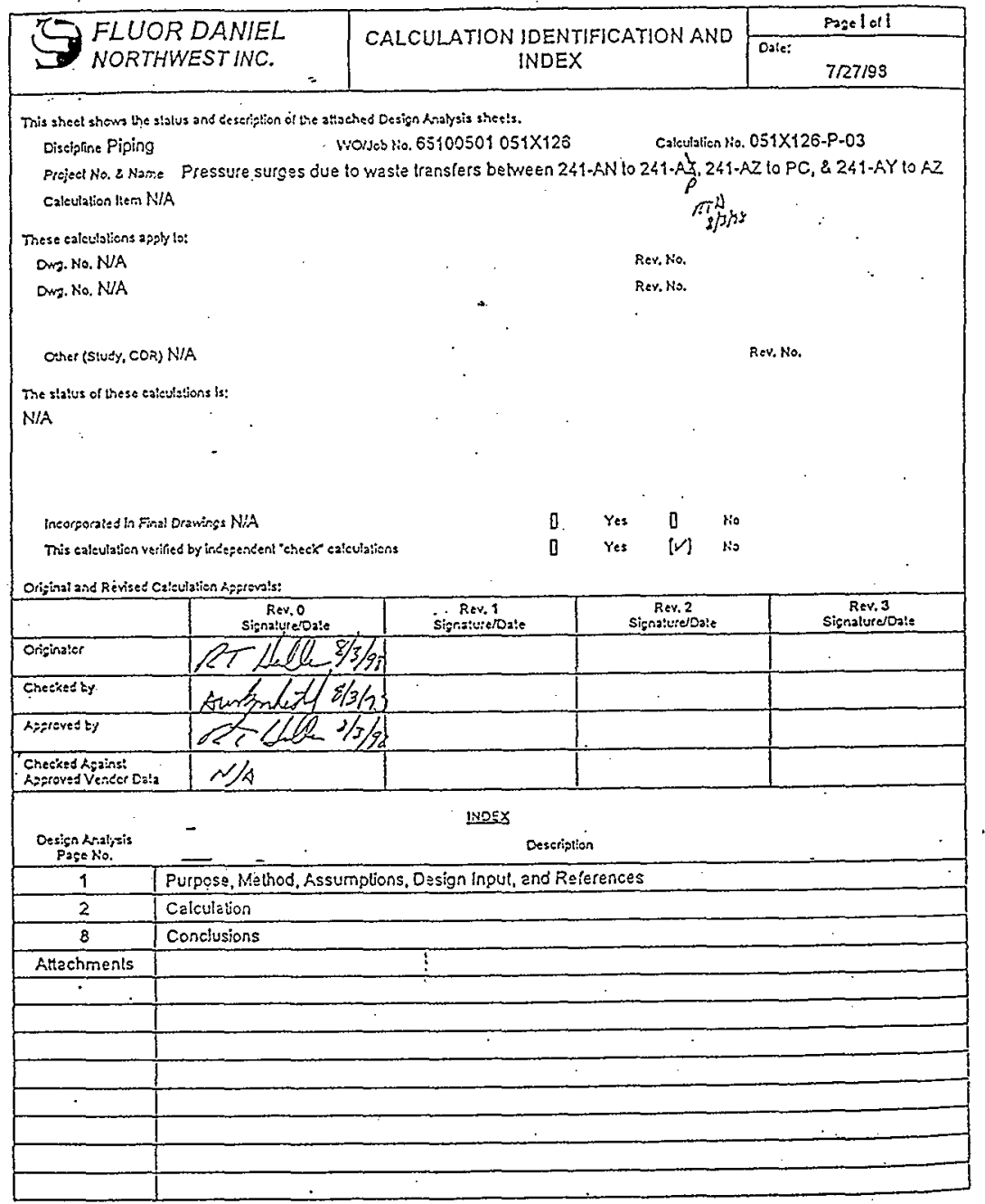

romp erie covtz 


\begin{tabular}{|c|c|c|c|}
\hline \multirow{2}{*}{$\begin{array}{l}\Rightarrow \text { FLUOR DANIEL } \\
\text { NORTHWESTINC. }\end{array}$} & & \multirow{2}{*}{$\begin{array}{l}\text { CALCULATION IDENTIFICATION AND } \\
\text { INDEX }\end{array}$} & Paset ol i \\
\hline & $=$ & & $7 / 27 / 98$ \\
\hline
\end{tabular}

This sheel shews the stalus and Cesctiption of the atspehed Design Aistyeis shee!s.

These calcutations apply to:

Dry. No. N/A

Org. No. NAA

Rev. No.

Rev. No.

Oher (s:usy, con) N/A

Rev. No.

The stalus of these caliculaticns 1s:

N/A

Insorporstes in Firal Oranings N/A

This caleulation yerifies by incependent "check" calcutations

$\begin{array}{llll}0 & \text { Yes } & 0 & \mathrm{Ns} \\ 0 & \text { Yes } & {[r]} & \mathrm{Ns}\end{array}$

Otiginal and Revised Caleutztion haprovats:

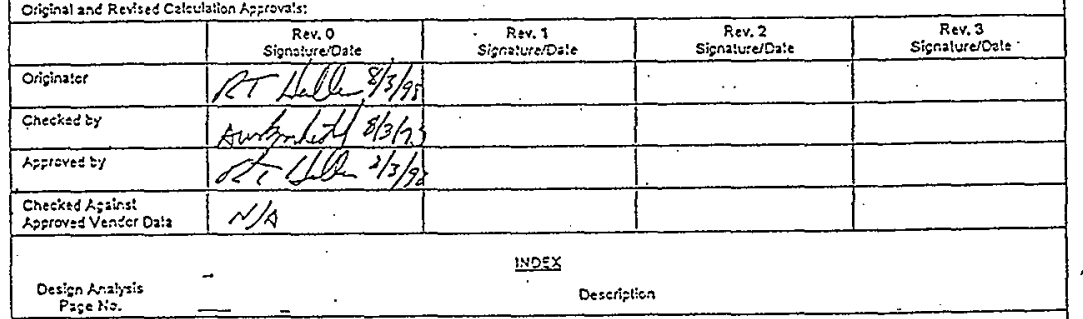

\begin{tabular}{|c|l|}
\hline 1 & Puipose, Melhod, Assumptions, Design Input, and References \\
\hline 2 & Calculation \\
\hline 8 & Conclusions \\
\hline Attachmenls & \\
\hline & \\
\hline & \\
\hline & \\
\hline & \\
\hline
\end{tabular}

roner cute cover 


\begin{tabular}{|c|c|c|}
\hline Fluor Daniel Northyest & & $\begin{array}{l}\text { Coti: No. } 051 \times 126-\mathrm{P}-03 \\
\text { smision } 0\end{array}$ \\
\hline DESIGN ANALYSIS & & P + ze io. I ol 9 \\
\hline Clint Niac & Hodsobsio. 65100501 & $0 \$ 1 \times 128$ \\
\hline 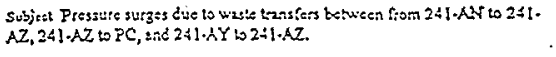 & $\begin{array}{l}\text { Dose } 72789 \\
\text { Chested } \$ 13 / 94\end{array}$ & 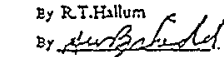 \\
\hline Loustion Riehland, WA & Rex:=1 11 & $\mathrm{sy}$ \\
\hline
\end{tabular}

\section{PURPOSE}

The pupose of this calculation is to deternine the pressure transient, or water hanmer, from the instantaneous end a s!ow closing valve in a waste tansfer piping system. The waste transfer systems analyzed ase the transfers from $241-K N \cdot 105$ to 241-AP-102, 241-AZ-101 to the privatization contractor (PC), and 241-AY-102 to 241.AZ-101. The transfers analyz:d are the conceptual wast: tiansfer line routings discussed in HNF-2500 (teferenee 5).

\section{METHED}

Hand calculations using formulas and cata doun from sources listed under references.

\section{ASSUMPTIONS}

1. This calculation assumes the closure of the valve at the end of the waste trans fer line is instantareousily closed.

2. Waste characteristics and wasto trazsfer requisemerts are based on information provided by NHC (see Design Input).

3. The distance from the PHMC/PC interface to the closing valve in the PC facility is 2,600 feet (see attschnent).

4. The location of the PC's fociling is within Parcel $A$ and the routing of the waste line is along existing roads (sse aitachment).

\section{DESIGNDNUT}

1. Electronie memo from Alan B Carison to Rancall Hallum, dated 7/13/9s and atlashment.

\section{REFERENCES}

1. Anolvis end Cor?al of Unsendv Flow in Piosines, Gar Z. Watters, Second Edition.

2. Precess Pinity Code, ASME B31.3̈6.1997

3. W-314.C1. Construction Specification, Tarl Fem Restontion and Safe Operations, AN Valre Pit Upsaces

4. Flow of Fluids though Valves, Firnines, and Pine; Crane Technical Paper \$o. 410

5. HNF-2500, W-314 Woste Transfer Allemative Pining Sustem Description, Rvv. 0 .

6. Standord Handbook of Enginesrine Cnlculations, Tyler G. Hicks, P.E., Editor.

7. H-2-71986, Piping Flan 241-AN Tank Fam

8. H-2.71984, Piping Plan Tarik104

9. H-14-102033, Piping Tarl's AP-102/104 Asea Plan (Projetr W-211, crowing is not released for constziction)

10. Piang Handisodi, sixth edition, Mohinder I. Nayyir, Editor. 


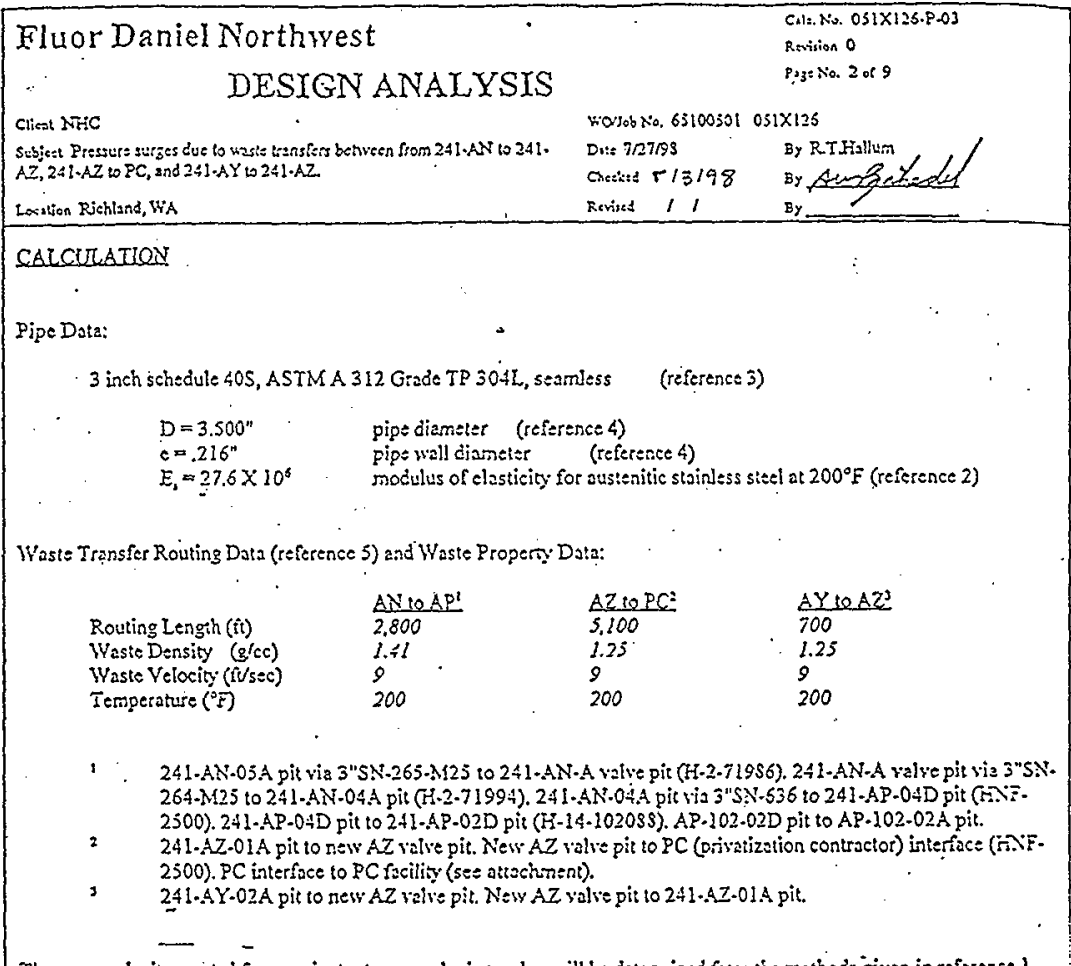

The wave velocity cteated from an instantaneous closing valse will be deiemine fom the methods given in referense l.

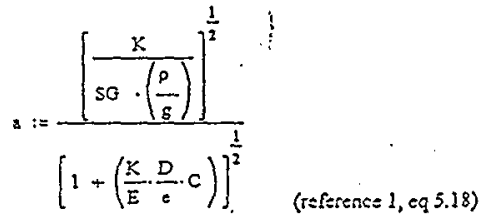


Citi. Nis. $051 \times 126-2-03$ Envion 0

$p_{1 j}=$ No. 3 of 9

Climt inc

\section{DESIGN ANALYSIS}

Subject Pressure surges due to usste tansters between from 241 -Avt 10241 . $A Z, 241 \cdot A Z$ to $F C$, and 241 . AY to 241 . AZ.

Locxion Richland, WA

$$
241+42 \text {. }
$$

Wojosito. 65100501 0s1X125

Dut 7/27ss

Chested 813198

Ronised $1 \cdot 1$

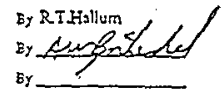

Where:

$a \approx$ weve velocity, forste

$g$ E gravitational constant, $32.2 \mathrm{fJ} / \mathrm{sec}^{2}$

$S G=$ specific gravity

$p=$ weight densing of fluid, $16 / \mathrm{ft}^{3}$

$X=$ bulk modulus of compressibility of liquid, psi (reference 1,pg 91)

$=300,000 \mathrm{psi}$

$\mathrm{D}=$ pipe inside dismeter, in

$=3.068^{*} \quad$ (iefarence 4 )

$e=$ pipe wall thichress, in

$=.216^{\prime \prime} \quad$ (reiserence 4)

$C=$ restraint condition (used case $b$ for pipes anchored against longitudinal strain) (reference 1,pg 94)

$C:=\left[\frac{1}{\left(1+\frac{c}{D}\right)}\right] \cdot\left[\left(1-\mu^{2}\right)+2 \cdot \frac{c}{D} \cdot(1+\mu) \cdot\left(1+\frac{e}{D}\right)\right]$

$c=1,033$

\section{Where $\mu=0.3$ (Poison's Ratio for steel) (reference 1,pg 91)}

\section{1-AN to 241-AP Waste Tronsfers}

Delermine the wave veiocity for waste being transfered from 241 -AN 10241 . AP (sec t2ble on routing and waste characleristics above):

Convert densty of waste being transfered from AN to AP from metric to English units (Erans/cubic centine:er to slug/eubic foot):

$$
\begin{aligned}
& \text { Density: }=0.00141 \cdot \frac{\mathrm{kg}}{\mathrm{cm}^{3}}, \text { Density of waste being transiensd. } \\
& \text { Vol_convis } 3.531 \cdot 10^{-5} \cdot \frac{\mathrm{t}^{3}}{\mathrm{~cm}^{3}} \quad \text { Conversion of cubic centimeters to cubic fet. }
\end{aligned}
$$

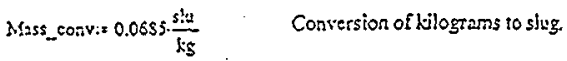


Eluor Daniel Northyest

C.le. No. 051X126.8.03

Revision 0

DESIGN ANALYYSIS

Clim: 2F:C

-

susjeet Prissure surges due to waste transfers berween from 241-.4N to 241 $A Z, 241 . A Z$ to $P C$, ind 2 A $A Y$ is $241-A Z$.

Lectien Richind, WA

$$
\begin{aligned}
& \text { Density }=\frac{\text { DensityMass_con }}{\text { Vol_conV }} \\
& \text { Densitg } \text { AN }=2.735 \cdot \frac{\text { slus }}{E^{3}}
\end{aligned}
$$

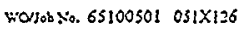

Dile 7/27/s

By RT.Hillum

Chetked $f /$

anised $I /$

By

By

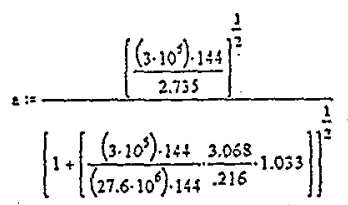

$a=3.691 \cdot 10^{3}$ fiste (wave relocity)

Determine the increase in pressure from inst antineous valve closure for waste transfers from AN to AP:

$$
\Delta H:=\left(\frac{2}{s}\right) \cdot v
$$

Where $\Delta Y$ is the increase in piessure head from the valve closure and $v$ is the change in velocity of the futd (reference 1, equation 5.4).

$$
\Delta:=2\left(\frac{569 !}{32.2}\right) \cdot 9
$$

$\Delta y=1.052 \cdot 10^{3}$ frofliquid

Or $p_{t}=1032$ ft of liqgid $\cdot 1.41 \cdot .433=630$ psig increase it piessure due to water hammer.

Determine the increase in pressure from a slow closing valve for waste teans fers from AN to A. Slow closing will th defined as a closing time equal to one wave cjele (the time a pressure wave trasels to the other end of the pipeline and relums to the closing volve).

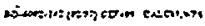


Fluor Daniel Northivest DESIGN ANALYSIS

Cite Nio, $051 \times 126.903$ Revision 0

PugeNo. 5 ol 9

Clien ATEC

Susjet Pretsure suiges cue to wes:= tansfers between from 241-A ti to 341 . $A Z, 241-A Z$ w $P C$, and 241-AY o 241-AZ.

Horob No. 65100501 ostxi2s

Losation Richisnd, WA

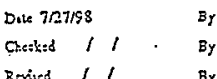

Find the wave cycle for the trensfer line from $241-$ AN to $241-4 \mathrm{P}$ :

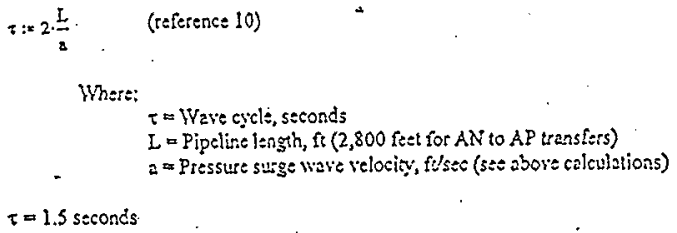

Pressure surge for various time periods based on the wave cycle:

$$
\left.p_{i}:=\frac{2 \cdot p_{s}^{2}}{2 \cdot i \div} \text { (relerence } 6\right)
$$

Hัnere:

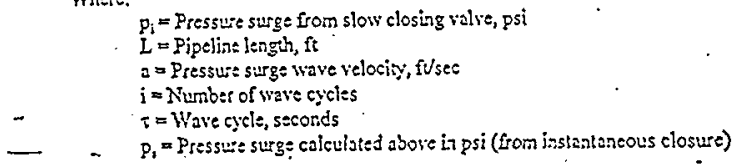

Results:

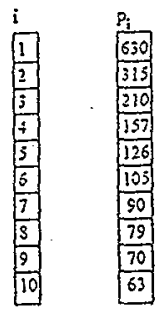

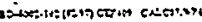




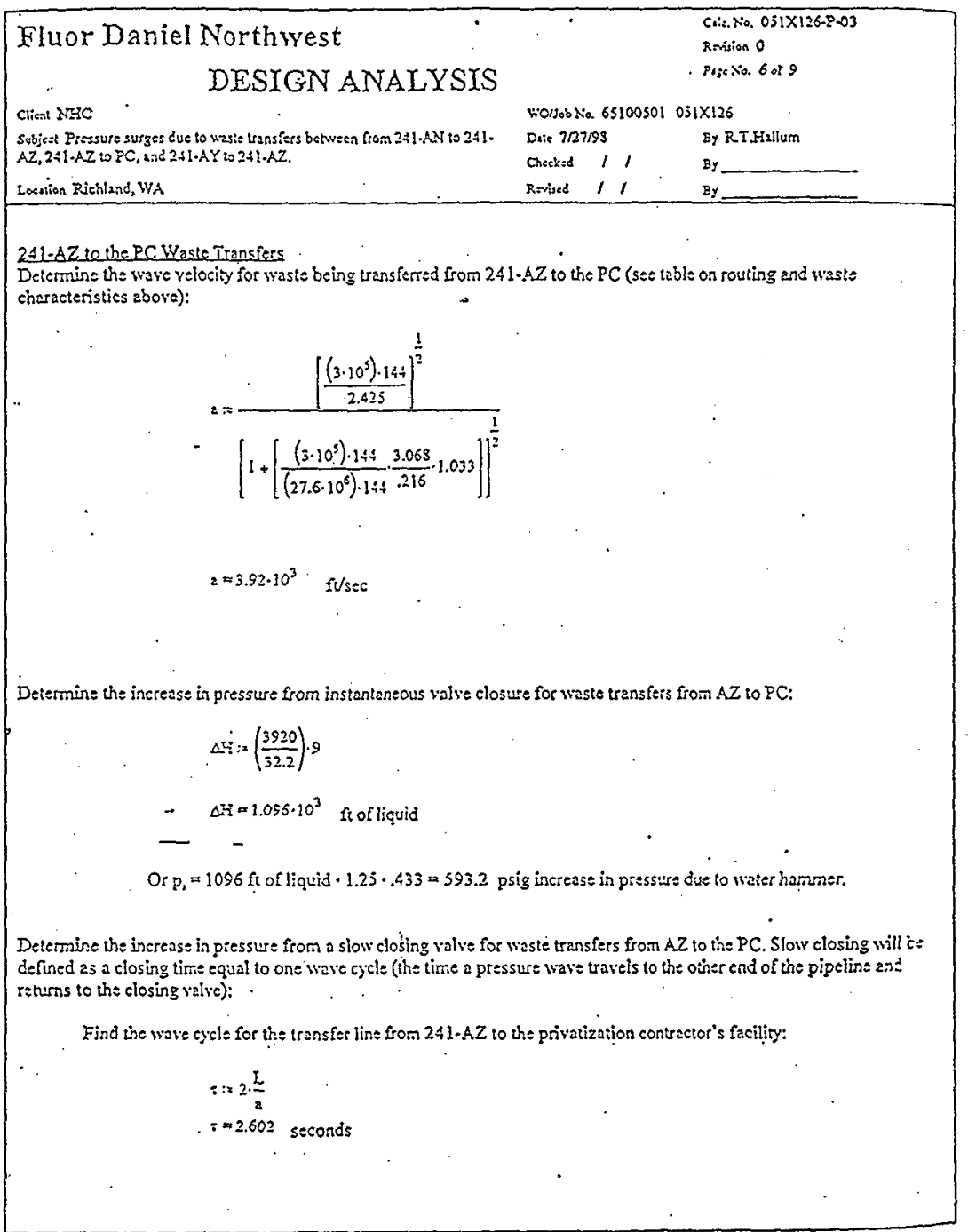

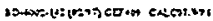




\begin{tabular}{|c|c|c|}
\hline $\begin{array}{l}\text { Eluor Daniel Northyest } \\
\text { DESTGN ANALXSYS }\end{array}$ & & 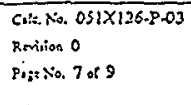 \\
\hline Clime hịTC & Wortos :No. 65100502 & $1 \times 125$ \\
\hline 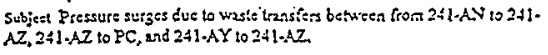 & $\begin{array}{l}\text { Dise 7n7iss } \\
\text { Cheti:d }, 1\end{array}$ & $\begin{array}{l}\text { By R.T.FE:Ilum } \\
\text { By }\end{array}$ \\
\hline Losution Riehingd, WA & R=nis=d 11 & \\
\hline
\end{tabular}

Pressure surge for various tinte periods based on the wave cycle:

$$
\begin{aligned}
& p_{i}:=\frac{2 \cdot p_{s} L}{2 i=}
\end{aligned}
$$

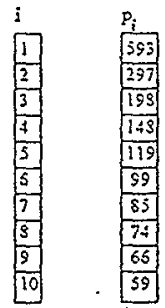

Where $i=$ wave cyeles and $p_{i}=$ pressure increase, in psi, based on the number of wave cycles.

\section{AY to 241..4ZWaste Transfers}

The calculations to determine surge pressure wave velocity and increose in pressure from the instantaneous valve clost:ars ideatical to the calculations persomed for 241 .AZ to the PC (s=e above). The difference beween $241-A Y$ to 241 - $A Z$ and $241-A Z$ to the PC waste transfers are the length of the transfer routes. Below is the calculations which are dependent on the jength of the transfer routes which ate the weve cyele time and the pressure surges for slow closing valves.

Find the wave cycle for the trans fer lise from $2+1-3 Z$ to the privatization contractor's facility:

$$
\begin{aligned}
& s:=2 \frac{Z}{a} \\
& s=0.357 \text { seconds }
\end{aligned}
$$

Pressure surge for various time periods based on the wave cycle:

$$
p_{i}=\frac{2 \cdot p_{s}+L}{a \cdot i=}
$$


HNF-2941

Revision 0

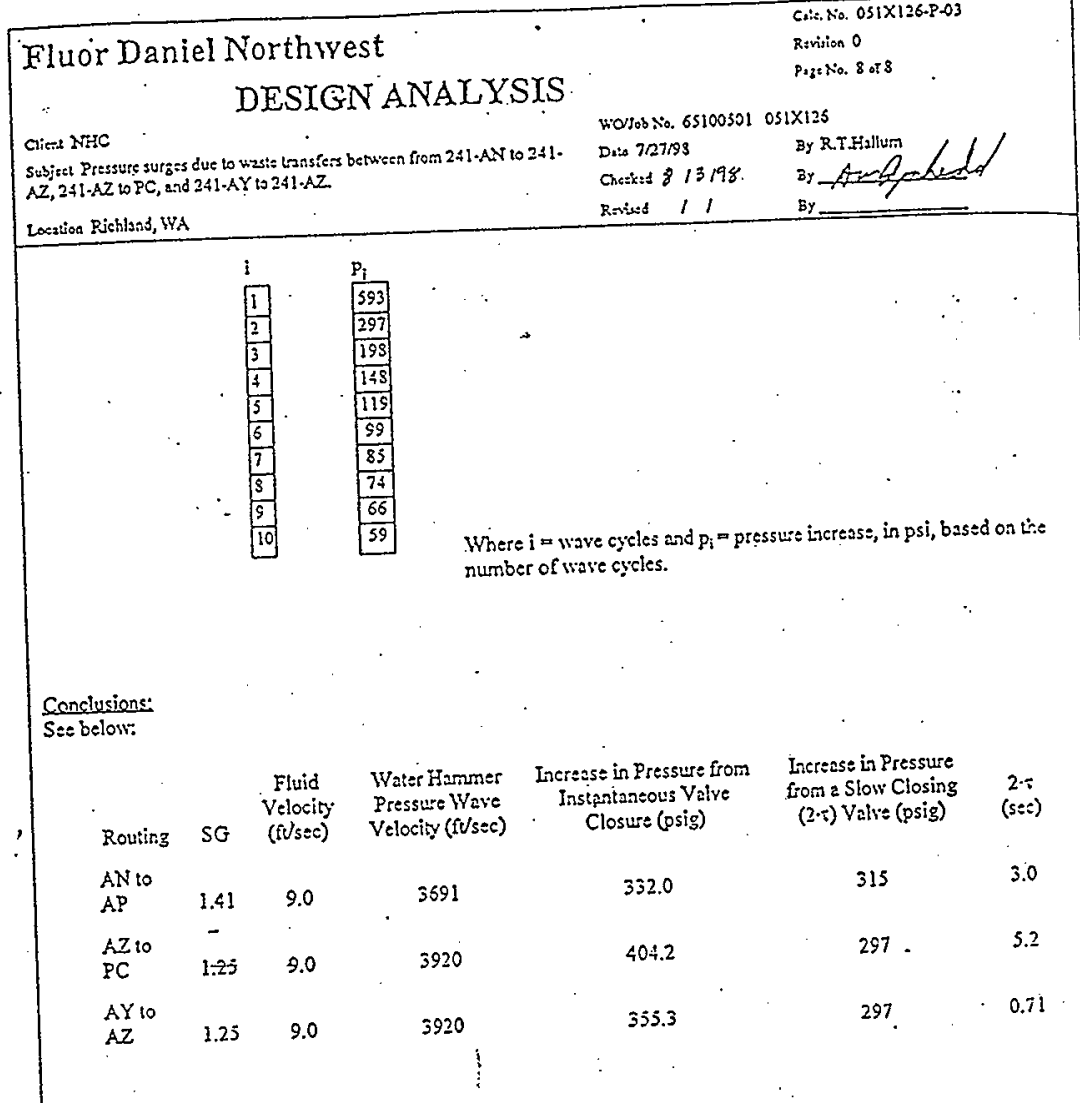

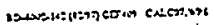


HNF-2941

Revision 0

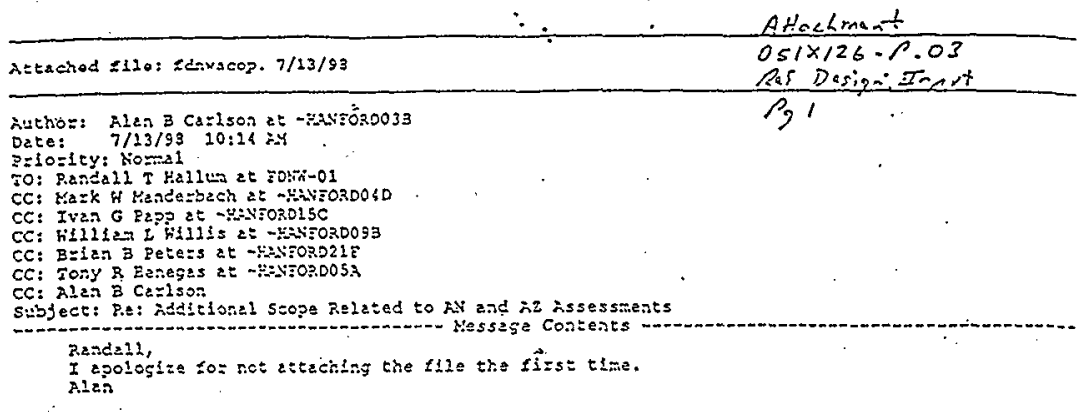

Reply seperz:oz

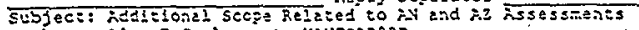

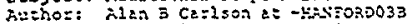

Dafe: 7/23/93.5:07 is

P.zAce11,

r.:teched is an electron!c vezston of the wotx scope which you, BIII

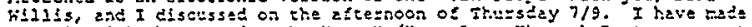

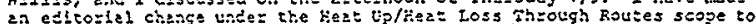

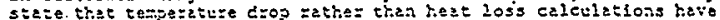

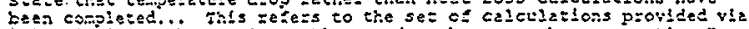

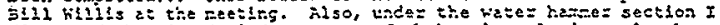
discossed the time pesod to assite for she slow closing velve bused ca the veloctty of wive gropegation.

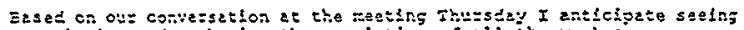

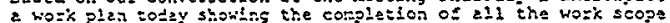
acsivities by $7 / 3$ :

Thaniss,

ixien $C=1502$

\section{REST AVALILABLE COPY}




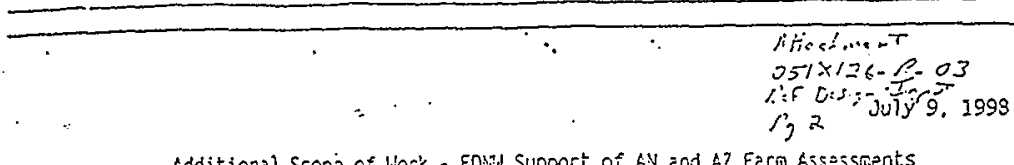

Additional Scopa of Work - FDi*il Support of AV and A? Farm Assassments

Heat Uolieat Loss Throveh Rolites

Temperature drop calculations have been completed for waste transfers (see attached). Verify the previous calculations bound the cases he are exentining and provida a writeup of the findings.

Calculate tha time required to heat up the transiar pipe to stady state conditions end specify the internal pipe terperatura at the steady state condition. The conditions to consider shall be weste transfersed at $400 \mathrm{C}(1040 \mathrm{~F})$ through a $3^{n}$ pipe within a $6^{\prime \prime}$ pips. The $3^{n}$ pipe sterts at arbient underground tenp=rature of 500F. The biaste ilowing thrcugh the pipe is at 6 it/s (turbulent hell-nixed flow). Assune a constent temporature boundery of 500 f at 5 itet out redially fros the center of the pipe.

$\checkmark$

Water Hairmer Calculations

Prepere three ssperate water hansis ceiculationis for trie waste feso delivery transiers (1) fron AV to AP farm. (2) ircm fl? to the high level viaste vendor and (3) ircn AY to $A 2$ ferm. The calculations shall consider two different ceses for the transiers: a fest closing valve and a slar closing valye. For trie slon closing valve case assue that the tine to close the valve is two times the pipe time period. The pipa time period is equal to tho times the length of tha pipa divided by the velocity of keve propagetion. The velve shall be assuned to be located at the end of the transier ine.

For Aal trensier to AD water hantiser Calculations the celculation will be based on the transier iren Ay-105 to fo-102. The vieste for AN transiers shell essume a. dersity of $1.41 \mathrm{c} / \mathrm{cc}$. Fluid flow rete ci $140 \mathrm{ggm}$ and $210 \mathrm{ggm}$ (nominelly $6 \mathrm{ft} / \mathrm{s}$ and $9 \mathrm{ft} / \mathrm{s}$ respectivaly). Trensiers are trirougin $3^{*} \mathrm{SCH} 40$ carbon steel pipe.

For Az-trensfei pieter hemer celcuhations the calculation will be besed on the

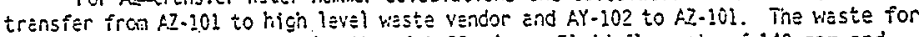

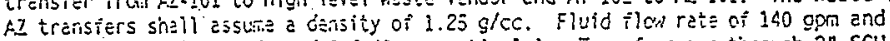
210 gpa (ricairally 6 it/s and 9 it/2 respectively). Irensfers ere trirough $3^{\prime \prime}$ SCH 40 carbon steEl pipa.

\section{Evaluztion of Lire Oreining (Hvereulic Diecrems)}

Revied the existing tenk pits end velve pits in AN and A? tonk iems (See

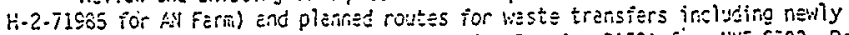

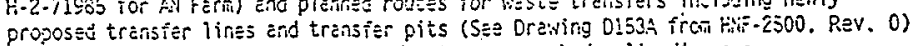
jdentified under Project $W-314$ in order to prepere hydraulio diegrans.

A hydraulic diagran shall be prepared for Al iarm snowing tita elevetions associated with weste trensiers fran AN-102. AN-103. AN-104. AN-105. AN-107 to both 


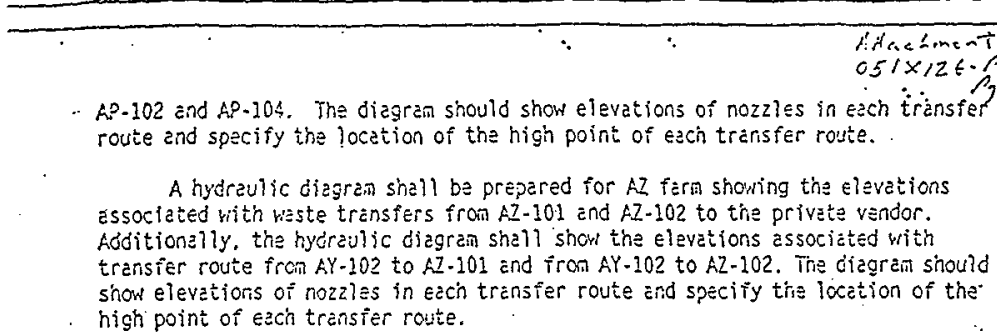

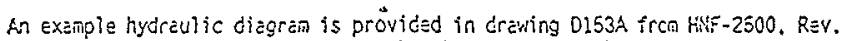
0. Darren oixon filli provide CAD support for drawing of the diagriais.

\section{Evaluation of Ventilation Condensation Routing}

Revient the existing ventilation condensetion routings for Av end AZ tank iarms. Identify the routes and receiver tenks for collected condensite in both dv and Az tenk farms.

A drewng shall ba prepered for Av ferm showing the condensation routing associated with each tank yentilation system (and eny other sources of condensate) in AN Fara. Tha Graving snall identify bihether the condensate lines are single or encased lines. A written description of the itinding sinall be corpleted.

A drawing shall be prepzred for AZ iern (end AY farn connactions as villi) shoulng tha conderisation routing associated with each tenk ventilition systen (and any other sources of condensate) in AZ Farm. The drewing shell identify yhather the condenszte lines are single or encessd linses. A viritten description of the finding shali be completed.

\section{Identiviv Trenster poutes linich Neso to be plucoed or Abendoned}

Identify nozzles which will not be rased during phase 1 privatization for any transfers. These nozzles should be plugead to reduce the risk of misrouting during transter. - hiti-2854. Rev. O evaluetes nozales for blanking.

\section{Corrosion peguirenents and Meteriels of Construction Evaluztion}

There has been in orgoing discussion regarding the neso for usirg innibited weter (Eafinad as raw riater that conteiris et least $0.01 \mathrm{M}$ liaOH and $0.011 \mathrm{M}$ liavo2) to flush the pipelines followirg weste trefistiers between tenks. The rational for the use of innibited witer is the resulting reduction in corrosion of tria transier piping reletive to the use of plain rew weter for flushing. The voluas of tlush water will renge iron $1-2$ pipelirie vollis:s.

The issue to be resolved, is whetried or not the use of iribibited heter provides a reaningful corrosion reduction. It inhibited flush water is deterinined to be ippropriate, develop specific requirenents for both céron steel pipelines (currently existing) and for the stainless steel pipelines that froject $W-314$ is 
Revision 0

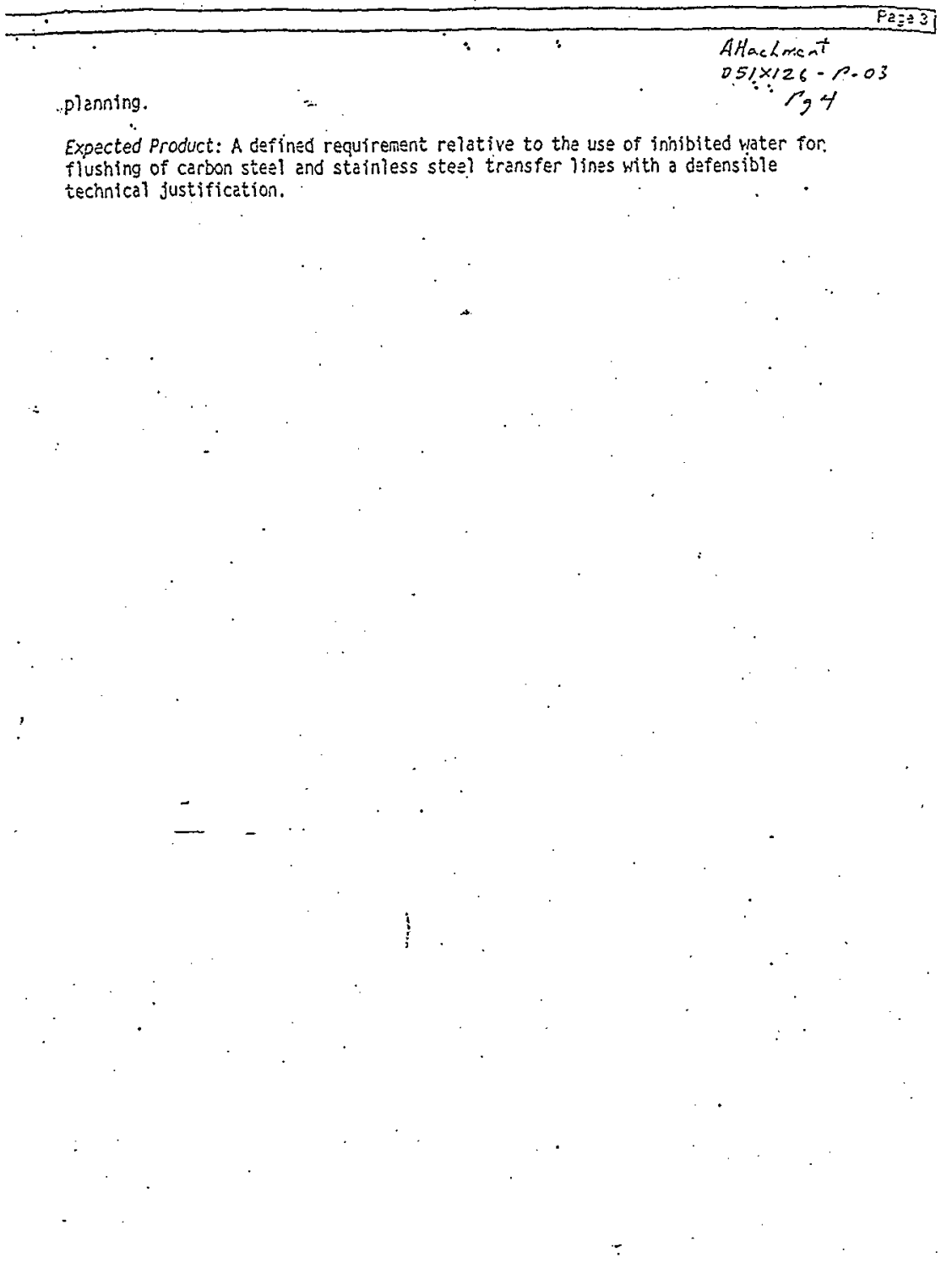




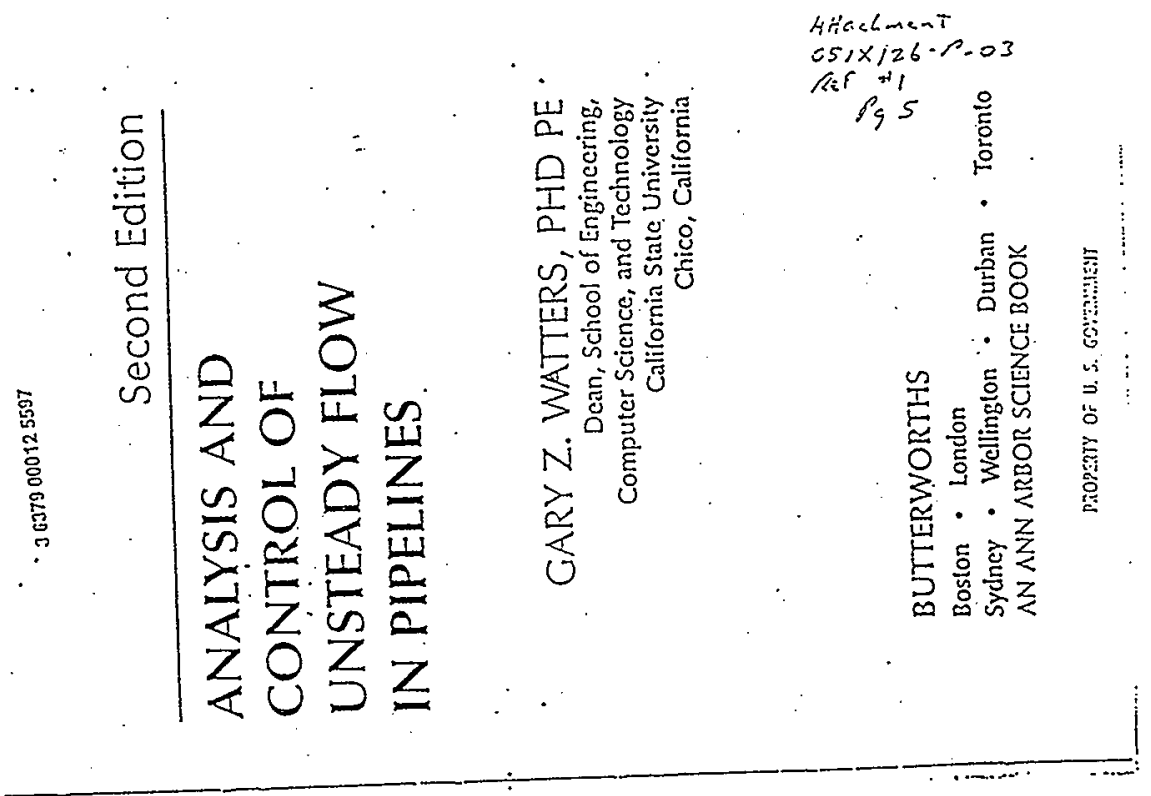


Case (a) \% change in walce volume $=100 \frac{p^{2}}{K}=100 \frac{1.94 \times 3413^{2}}{3 \times 10^{2} \times 144}$ * $52 \%$

The remainder is in pipe streleling $=48 \%$

Case (b) \% clange in water volume a $100 \frac{1.94 \times 34.18^{2}}{3 \times 10^{2} \times 1.14}=5.1 \%$ rtic remainder is in sall stretchine $x \cdot 17 \%$

Case (c) \% change in water volume $=100 \frac{1.04 \times 3371^{2}}{3 \times 10^{3} \times 1.44}=51 \%$ The renaintier is in wall stretcling $=49 \%$

\subsection{WNVE SPCEOS IN OTIER TYPES OF CONDUITS}

The simplest case of thin-walled pines has been used previously to clerive equations for wave speeth, it is olvious that many tyciratic condtuts are constructed of thick-walfed pipu and often using two or more materists constructed of thick-walled pipe and ofters using, two or more materitis and back-filted with concere. It is necessiry to be able in caleulate wive spects in ;1l dluse ctises.

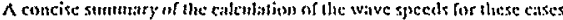
is given by Halliwell [25]. The most obvious exicusion of the previous example of thin-walted pipes is to thick-walled pipes. In a thick-walled pipe. the wall thickness is so great that stress varies noticeibly between the inter and outer surfaces and lyis affects the expression lor wave specd. An antilysis reveals shat we may continue to use the same basic form for the wave speed equation, but we must finct a diffetent value for the $C$ in Eqtation.(5.1\%).

\section{- Thick+Walled Pipes}

Summarizing the results for thick-tvalled pipes for the sane restraint conditions as before witlt $D$ as the insitle dinmeler.

Cnse (a)-lor pipes free to siress and strain boit, haterally and longiiudinally (nnchored at only onc point)

$$
C=\frac{1}{1+\frac{C}{D}}\left[\left(\frac{5}{t}-\mathrm{N}^{2}\right)+2 \frac{C}{D}(1+12)\left(1+\frac{E}{D}\right)\right]
$$

$\Lambda$ limiting process shows that as $d D \rightarrow 0$, his equation degencrates to Equation (5.19a).

Case (b) - For pipes anchored apatinst longitudinal strain

$$
C=\frac{i}{1+\frac{C}{D}}\left[\left(t-1^{2}\right)+2 \frac{C}{D}(t+\mu)\left(1+\frac{\dot{C}}{D}\right)\right]
$$
lengli

Cnse (c)-For pipes with functioning expansion joints throughout their

$$
C=\frac{1}{1+\frac{C}{D}}\left[1+2 \frac{c}{D}(1+m)\left(1+\frac{C}{D}\right)\right]
$$

As in case (a). boll ceses (b) and (c) degencrate to the thin-walled pipe values when eID $\rightarrow 0$

The gitestion arises as to wien the nore complex thick-ivalled formulas should be applied. For decieling, it is helpful to exnntine the plot of these cquations in Figure 5.1. To assist in nuking this decision, consider the uncertainties of pipe restrtint and its efrect on wave spect. Fignie 5.1 slows that tnecrtainty twith resped to the type of restrainl oceurring can enuse differences of about 10 pereent between $C$-vaities at the two extremes of - sestraint. If we aceept a similar error in decieline whether to use thin-walled or thick-wadled formulas. ihen a $D / c$ value of 20 is an angroprine divitlin: line. If. however, we decile to remove as thuch unecrtainty as possible, then the thick-vatlet formulas should alwaysde used. The atditional computation required is nepligibte. It a practicat settse though, because of lise relative size of terms in the dienominator of Eguntion (5.18). using thick $\alpha+w a l l e d$ Formulas beyond Die values of 10 generally makes no sipnifient inproveinent in the value of the wave specel exeept in eases twltere sofier pipes such as I'VC are tised. It should also be noted linal using the thin-twalled formulas lends to higher (more conservalive) wive speeds, To sec the effect, consider the following cximple.

Exinuple 5.2. A stecl pipe $10 \mathrm{in}$. in dianeter is used to convey water between two reservoirs. The insicle slianeter of the pipe is 9.522 in. and the wal thickness is $0.239 \mathrm{in}$.

\begin{tabular}{|c|c|c|c|c|}
\hline & \multicolumn{2}{|c|}{ IYave Speeil (prs) } & \multirow{2}{*}{$\begin{array}{c}\text { Esror } \\
(\text { Dle }-10)^{\circ}\end{array}$} & \\
\hline Restrnins & Thin-IYalled & Thick-1Valled & & \\
\hline $\begin{array}{l}\text { Case (a) } \\
\text { Cnse (b) } \\
\text { Case (c) }\end{array}$ & $\begin{array}{l}1022 \\
1017 \\
3994\end{array}$ & $\begin{array}{l}3099 \\
1021 \\
3071\end{array}$ & $\begin{array}{l}0.6 \% \\
0.6 \% \\
0.6 \%\end{array}$ & \\
\hline
\end{tabular}

Compute the $C$-values and wave spects using both thin- and thickwalled formutas and compare results. 


\section{Unstcauy Flow in Pigrtincs}

presence of any free air in the system can be considercd an unforeseen, but fortuitous, oceurrenec, at least in the sense that it reduces $k$.

In the limit the pipe can become compictely rigid without causing tic wave speed to become intinite. Tlis lintiting value is obtained by passine $E$ to $\infty$ in Equation 5.18. With the nomizul valuc of $\alpha+300,000 \mathrm{pri}$, the resulting wave specd is approxishately 1720 [ps. This number lins no practical value in design becautse it is far too high to serve as feven an approximate wave speed for preliminary desigh. With eren a limiled amotnt of experience, the designer can make far better estimates for wave speed in the pipe lie or slue is working with.

Fxample st. As an illustration of the chastic deformations and pressute head changes causct by a watcr lianuner situation and the effect of restraixt on wave spect, the lollowing problem is asalyged

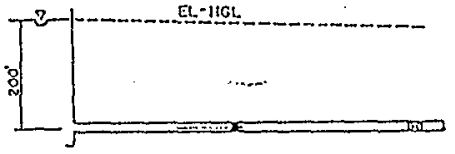

Flow in the 21-in. pipeline above oectrs at a velocity of 6 ips. The pipeline is fabricated of stecl and has a wall thickncss of 0.25 in.

a. Calculate the wave spectl for all three cinses of restraint.

$$
\text { Case (a) } a=\frac{1720}{\sqrt{1+\frac{3 \times 10^{3}}{3 \times 10^{7}} \frac{24}{25}(5 / 4-0.30)}}=3413 \mathrm{fps}
$$

$$
\text { Casc (b) } a-\frac{4720}{\sqrt{i}+0.06(1-0.3015)}=3448 \mathrm{sps}
$$$$
\text { Crsc (c) } n=\frac{1720}{\sqrt{1+0.96(1.0)}}=3371 \mathrm{ips}
$$

In a practical sense, lite dillerences nie negligible.

b. Find the lread inctense tesulting from studden valve closure for all three cases of restraint

$$
\text { Case (in) } \Delta I 1=\frac{3113}{322} \times 6=636 \mathrm{ft}
$$

$$
\begin{aligned}
& \text { Case (i) } \Delta H I=\frac{3448}{32.2} \times 6=612 \mathrm{ft} \\
& \text { Case (c) } \Delta H=\frac{3.371}{32.2} \times 6=628 \mathrm{t}
\end{aligned}
$$

The variation in licad increasc amone the three cases is about 2 pereent.

c. Compute tlic axial and circtumferential pipe wall siresses before and after valve elosture lor all three chses of restraint.

$$
\text { Cise (a) Deforc } \begin{aligned}
\sigma_{2} & =\frac{200 \times 62.4 \times 24}{144 \times 2 \times .25}=4160 \mathrm{psi}_{+} \sigma_{1}=1 / 2 \sigma_{2} \\
& =2080 \mathrm{pii} \\
\Delta \mathrm{rr}_{2} & =\frac{636 \times 62.1 \times 24}{144 \times 2 \times .25}=13,230 \text { psi, } \Delta \sigma_{1}=6615 \text { psi }
\end{aligned}
$$

Alier $\sigma_{1}=\sigma_{2}+\Delta \sigma_{2}=17,390 \mathrm{psi}, \sigma_{1}=8605 \mathrm{psi}$

Case (b) Before $\sigma_{2}$ a sitne as above, $\sigma_{1}=12 \sigma_{2}=1250 \mathrm{psi}$

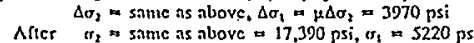

Case (c) Before $\alpha_{2}=$ sane as aluove, $\alpha_{2}=0$

$$
\Delta w_{3}=\text { sime as above } \Delta \sigma_{1}=0
$$

Afice $\sigma_{3}=$ sime as above $=17.790$ psi, $\sigma_{3}=0$

d. Cilculate the pereent inerense in dianetes of the pipe caused by stiduen valve closure.

$$
100 \frac{8 D}{D}-100 \Delta \epsilon_{2}=\frac{100}{E}\left(\Delta \sigma_{2}-1 \Delta \Delta \sigma_{i}\right)
$$

Case (a) \% cliange $=\frac{100}{30 \times 10^{4}}(13,230-0.3 \times 6615)=0.037 \%$

Case (b) $\%$ change $=\frac{100}{30 \times 10^{4}}(13,230-0.3 \times 3970)=0.010 \%$

Casc (c) \% change $=\frac{100}{30 \times 10^{6}}(13,230-0.3 \times 0)=0.044 \%$. This resull substantiates many of our previous assumprions used in
neplecting small terms.

c. Colculate the pereent of the water entering the pipe during wave passnec which can he atuributed to pipe strciching att to warer contgression. 
90 Unstad rlow in Plirctines

Now considering conservation of mass, we alrendy lave Equation (5.5) cxpressing the amount of mass which has accunulaled in the $\delta L$ pipe section in to seconds. We can write a different expression for the mass ctange in the $\$ L$ pipe section after wave passage. Thic mass cliange in the section is

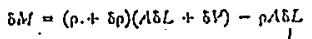

Equating this expression with Equation (5.5), cxpanding, and dropping sntitl terms gives

$$
\operatorname{ton} \lambda \delta L+\rho \delta \psi=A \rho \Delta V \frac{\delta L}{A}
$$

To arrange this cquation itl more useable torm, note that for a mass of a given substance, an incrense in pressure causes a decrease in volume and an inerease in density.

$$
\begin{aligned}
& p V=\text { constint } \\
& V \delta p+p i H=0
\end{aligned}
$$

Sulsstituting Equation (5.6) isto this equntion fives

$$
\left[1,=p\left(\frac{\Delta p}{K}\right)\right.
$$

Replacing Ap with yolt is the preceling cquation, substituting it and Equntion (5.1.1) into Equation (5.15),

$$
\psi \Delta /\left[\frac{1}{K} *\left(\frac{1-\mu^{2}}{E}\right) \frac{D}{C}\right]=\frac{\Delta V}{\pi}
$$

Combining this equation with Equation (5.A) gives

$$
=0\left[\frac{1}{K}+\frac{D}{c}\left(\frac{1-\mu^{2}}{E}\right)\right]=1
$$

or in a more conventionsl form for wave specd,

$$
n=\frac{[K / \rho]^{n}}{\left[1+\frac{K D}{R} \frac{D}{r}\left(i-1 n^{3}\right)\right]^{n / n}(\cos h)}
$$

It is now possibic for us to compute wave speed and pressure increase in simple situations whitse Enuation (5.4) can be used.

Strecter and Wylic [I] have shown that the equation for wave speed can be more conveniently expressed ns

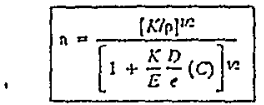

where

$$
\begin{aligned}
& C=S / 4-\mu \text { tor case (a) restraint } \\
& C=1-\mu^{2} \text { for case (b) restraint. } \\
& C=1.0 \text { tor case (c) restmint }
\end{aligned}
$$

Recall that this set of eqiutions applics only to thin-walted pipes where DJr is Eenerally Ere:ter. lian alyout to (see Section 5.3).

To assist in calculating wave speeds in pipes constructed of common

\begin{tabular}{|c|c|c|}
\hline $\begin{array}{l}\text { Slecl } \\
\text { Ductile Gist tron } \\
\text { Copper } \\
\text { Drass } \\
\text { Aluminun } \\
\text { PVC } \\
\text { Mberglass reintorced plastic (FIT) } \\
\text { Aslestos Cemett } \\
\text { Concrele }\end{array}$ & $\begin{array}{l}E=30 \times 10^{4} \mathrm{psi} \\
E=21 \times 10^{\circ} \mathrm{psi} \\
E=16 \times 10^{4} \mathrm{psi} \\
E=15 \times 10^{4} \mathrm{psi} \\
E=10.5 \times 10^{6} \mathrm{psi} \\
E=4 \times 10^{4} \mathrm{psi} \\
E=1.0 \times 10^{4} \mathrm{psi} \\
E_{1}=1.3 \times 10^{6} \mathrm{psi} \\
E=3.4 \times 10^{4} \mathrm{psi}^{2} \\
E=57.000 \sqrt{T}\end{array}$ & $\begin{array}{r}k=0.30 \\
\mu=0.2 k \\
k=0.36 \\
\mu=0.34 \\
\mu=0.33 \\
\mu=0.45 \\
\mu_{1}=0.27=0.30 \\
\mu_{1}=0.20-0.24 \\
\mu=0.30 \\
k=0.24 \text { (dynamically) }\end{array}$ \\
\hline
\end{tabular}
materials, liae following titble of Evvalues andi te-values is includect. The value of $\mathcal{X}$ for water can be tilien as approximatcly 300,000 psi. Whilc some eferences cite values ranging as hiph as 320,000 psi. the value of 300,000 psi scems to represent in average figtre. "I stoutel be roted that a smatt nmotnn of free air suspented as bubbles in the water can drastically reduce the K-vulue (see Section S.3). Jowever, cvaluating the amount of air, its distribution, its pervasiveness, and the exnet eftect on $K$ is most difficult. Conseguently, in the design siluation, the inreer conservative value is gen. erally used because it predicts the most severe water hammer pressures. The

Table 5.1. . Mochlit of Filasticity ant Poisson's Ratio for Common Pipe Nisterials

where $f:-28$ - thay sirenpith. 
HNF-2941

Revision 0

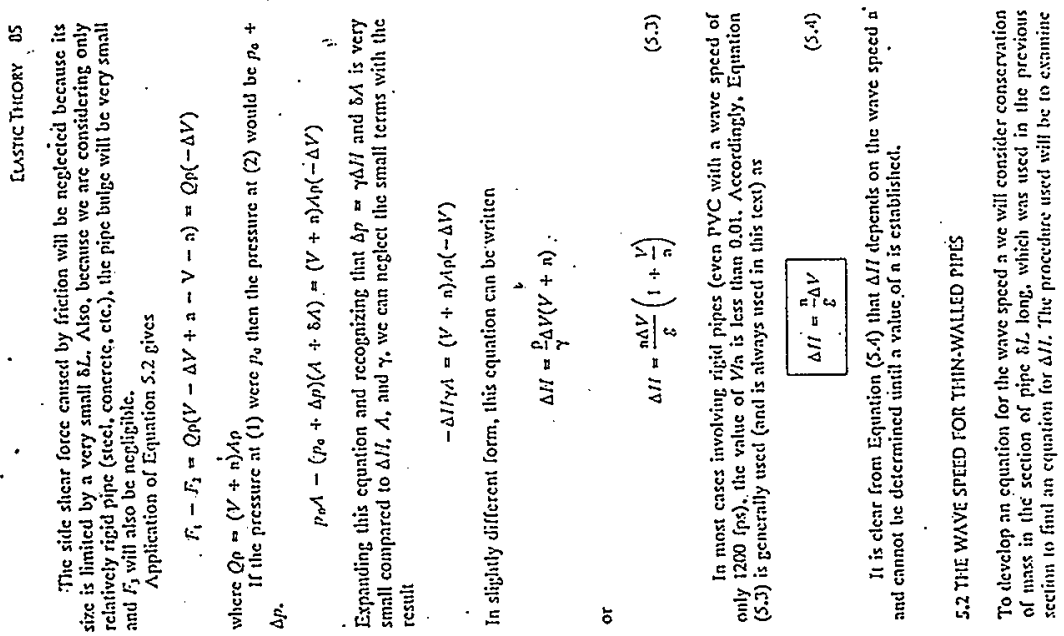

. $\quad$.
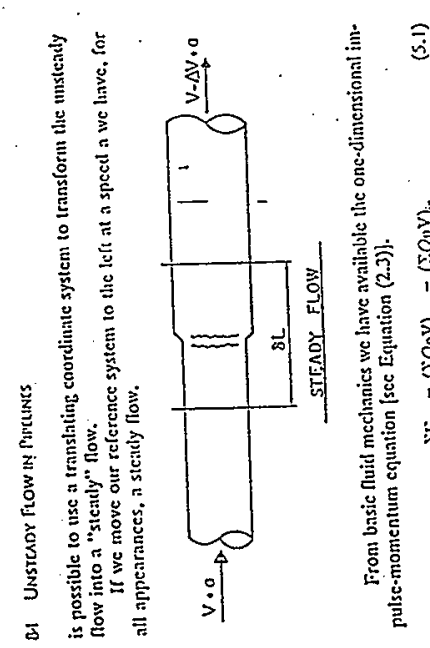

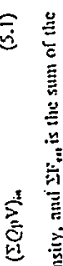

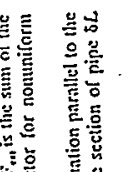

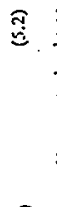

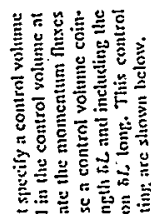

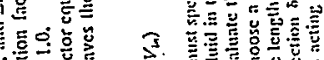

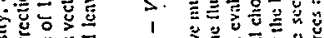

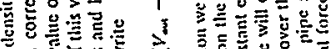

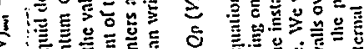

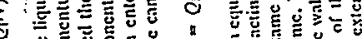

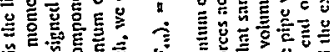

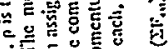

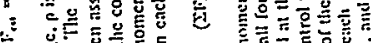

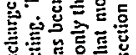

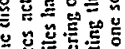

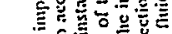

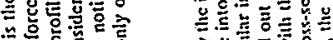

व

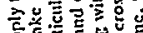

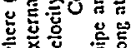

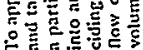

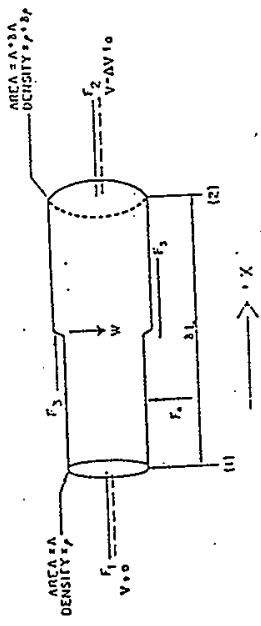


HNF-2941

Revision 0

Tabie C.6

firtatiment

$051 \times 126 \cdot \rho 03$

ASTín B31.3.1996 Edition

rig 10

TASLE C.6
MOÖULUS OF ELASTCITY, U.S. UNITS, FOR METALS

$E=$ Moculus of Elasticity, Wsi (Millions el fsi), a! Tempera!ture, 9

\begin{tabular}{|c|c|c|c|c|c|c|c|c|c|c|c|}
\hline \multirow[b]{2}{*}{ Ma:trial } & \multirow[t]{2}{*}{. } & \multicolumn{10}{|c|}{$E=$ Moculus of Elasticity, Wsi (Stiltions of gsi), $a !$ Temperattre, ${ }^{\circ} \mathrm{F}$} \\
\hline & & -425 & -400 & -350 & -325 & -200 & $-1 \div 0$ & 70 & 200 & 300 & $4 \mathrm{CO}$ \\
\hline Ferrous Metals & & . & & & & & & & & · & \\
\hline Geaycastirsn & & $\ldots$ & $\ldots$ & $\cdots$ & $\cdots$ & $\cdots$ & $\because$ & 13.4 & 23.2 & 22.9 & 12.6 \\
\hline criten stats, $c \leq 0.3 \times$ & & 32.9 & $\ldots$ & $\ldots$ & 31.4 & 30.8 & 30.2 & 27.5 & 23.8 & 29.3 & 27.7 \\
\hline Carban stitsts, $C>0.3 \%$ & & 31.7 & $\ldots$ & $\ldots$ & 31.2 & 30.6 & 30.0 & 29.3 & 28.6 & 23.1 & 27.5 \\
\hline Carser-moly stats & & 31.7 & $\cdots$ & $\ldots$ & 31.2 & 30.5 & 29.9 & 29.2 & 23.5 & $23.0 \%$ & 27.4 \\
\hline Nickst stesls, Ni $2 \%-9 \%$ & & 30.1 & $\ldots$ & & 29.6 & 29.1 & 23 & 27.8 & 27.1 & $2 b .7$ & 25.1 \\
\hline$C r-k i s$ sis:els, Cr, $2 / 2 \%-2 \%$ & & 32.1 & $\ldots$ & $\ldots$ & 31.6 & 31.0 & 30.4 & 29.7 & 29.0 & 23.5 & 27.9 \\
\hline Cr-Ho st: $15, \mathrm{Cr} 21 / 4 \%-3 \%$ & & 33.2 & $\ldots$ & $\cdots$ & 32.6 & 32.0 & 31.4 & 30.6 & 29.8 & 29.4 & 25.8 \\
\hline Cr-Mositsts, Crs $\approx-9 x$ & $\cdot$ & . 33.4 & $\cdots$ & $\cdots$ & 32.9 & 32.3 & 31.7 & 30.9 & 30.1 & 29.7 & 29.0 \\
\hline Chrosiun st:tis, Cr 12\%, 1 & $27 \%$ & 31.8 & & $\ldots$ & 31.2 & 30.7 & 30.1 & 29.2 & 29.5 & 27.9 & 27.3 \\
\hline Austeritic st:tls (7) 304,31 & $316,321,3472$ & 30.3 & $\ldots$ & $\ldots$ & 30.3 & 29.7 & 27.0 & 23.3 & 27.6 & 27.0 & 26.5 \\
\hline
\end{tabular}

Cosper and Coprer Allcys WU:S Nos.?

Cent, and lest:d-Sn braria (C83600, C92200)

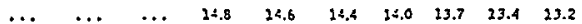

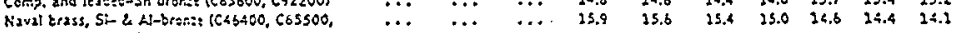

C95200, C95:00)

Confor $(C 12000)$

Copita, red briss, Albrarze (C10200, C12000, C12200, C12500, C14200, C23000, C6:400)

SOCL-20Sil (C) 6500$)$

Leated Ni-ere:-2:

coci-20\%: $(C) 2000)$

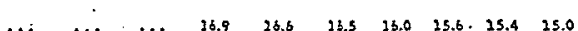

7oCu-30Mi (CT150O)

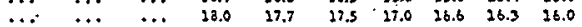

Nicktl 2.08 Nicksi Anleys (UNS Nos.)

Norel 400 Noi40O

Alteys 106007,103320

Alleys Nos600. NOEe 10, KO6002

Alicys Nos455, N10276

Alleys Nez220, $1020201, N 2 \$ 6 \overline{25}$.

Alley NOSt00

Alliey N30001

Allay N10665

$\begin{array}{llllllllll}\ldots & \ldots & \ldots & 19.0 & 23.7 & 23.5 & 19.0 & 17.6 & 27.3 & 26.9\end{array}$

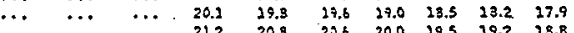

$\begin{array}{llllllllll}\ldots & \ldots & \ldots & 21.2 & 20.5 & 29.6 & 20.0 & 29.5 & 19.2 & 28.8\end{array}$

$\begin{array}{lllllllllll}\ldots & \ldots & \ldots & 25.3 & 22.9 & -22.7 & 22.0 & 22.5 & 21.2 & 20.7\end{array}$

Uasiloyted Titsiy

Grates 1, 2, 3, and 7

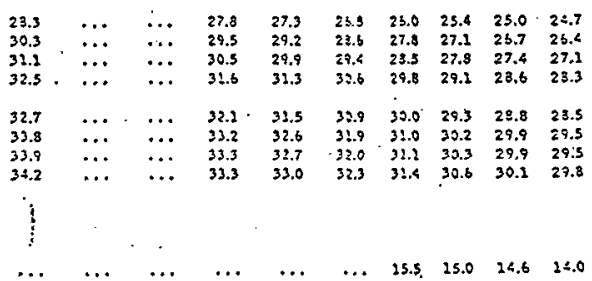


HNF-2941

Revision 0

F.2.5 CALCULATION OF TRANSFER LINE HEAT UP/HEAT LOSS 
HNF-2941

Revision 0

F.3.1 ELECTRICAL DISTRIBUTION SYSTEM - DAPPER MODEL RESULTS (TO BE PRODUCED) 


\section{CORRESPONDENCE DISTRIBUTION COVERSHEET \\ $=$}

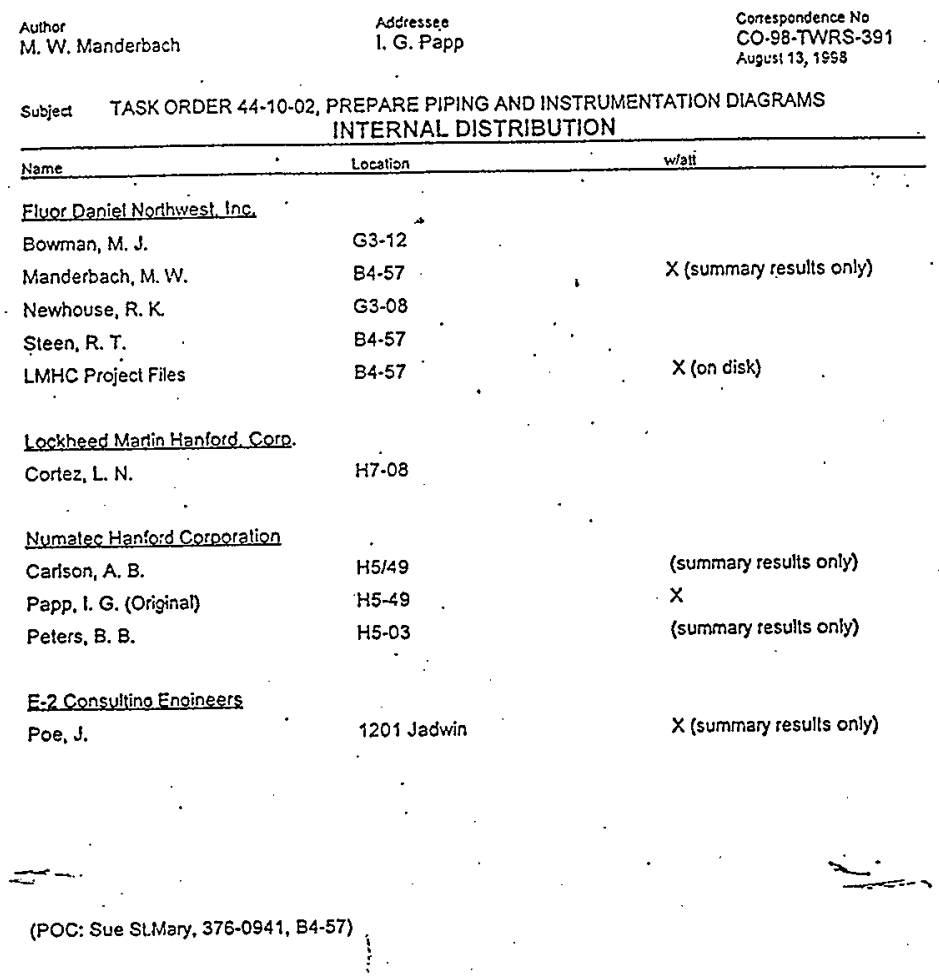


HNF-2941

Revision 0

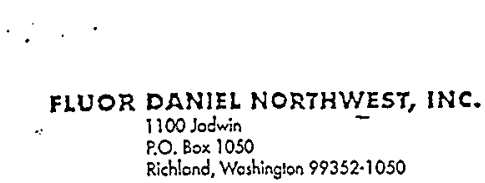

August 13, 1998

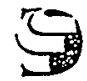

Mr. 1. G. Papp

Numatec Hanford Corporation

P.O. Box 1300

Richland, Washisgton $99352-1300$

Dear Mr. Papp:

TASK ORDER 44-10-02, PREPARE PIPING AND INSTRUMENTATION DIAGRAMS

Response Requested By: N/A

Responds To: N/A

Enclosed is a load flow and voltage drop analysis of $13.8 \mathrm{kV}$ line number $\mathrm{C} 8-16$, which provides electrical power to the tank farms in the 200 East Area. The analysis evaluates the effects of running nine mixing pumps simullaneously and starting nine mixer pumps simultaneously.

Sincerely,

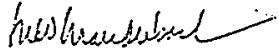

M.W. Manderbach

Project Mariager

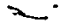

MWM:sst

Attachment 
HNF-2941

Revision 0

DAPPER STUDY OF 13.8KV LINE C8-L6

Description of Study

Line C8-L6 originates at Substation 251-W located north of the 200 East and 200 West areas. It travels east and southeast to the 200 East Area, continues southeast toward the east side of 200 East and then turns south to the general area of the Purex plant. This portion of the line is constructed of $\frac{\| 4}{\pi} 4 / 0$ copper. The line is tapped west of the AN tank farm with a \#2/0 copper line which then splits into a $\frac{\| 2}{\pi 2}$ ACSR (aluminum conductor, steel reinforced) branch that serves AN and AZ farms and a $\# A$ ACSR branch that travels south down Buffa?o Avenue and then east to serve AY, AW, and AP tank farms and other loads in the vicinity of the 242-A evaporator. Purex plant, grout vauits, and points east. The line was modeled Using SKM Systems Analysis. Inc. DAPPER software in order to evaluate its performance under various loading conditions.

The $251-W$ bus voltage used in the studies was 1.07 per. unit, or 14.766 volts as was recommended by Dyncorp Electrical Utilities group for DAPPER studies that were previous7y performed for lines C $8-15$ and C $8-L 8$ in support of the Project $W-505$ CDR.

ANSI Standard C84.1 requires that electric supply systems (utilities) be so designed and operated that most service voltages will not be less than 13.460 volts for systems with a nominal voltage of 13.800 volts. This represents a maximum voltage drop of $2.5 \%$ for the purposes of the DAPPER analysis.

The basic model represents the line in its present configuration; loaded to conform to Electrical Utilities' historical watthour meter data for the last two years, and with no mixing pumps in operation. Under these conditions the - voitage drop in the vicinity of the tank farrs is less than $1 \%$.

Another model was created (by copying the electronic file for the basic model and adding data) by adding two $300 \mathrm{HP}$ mixer pumps at AZ farm, four $150 \mathrm{HP}$. mixer pumps at AY farm, two $300 \mathrm{HP}$ mixer pumps at AW farm, and one $300 \mathrm{HP}$ mixer pump at AP farm. These pumps were modelied as if they were running at full speed with ail other loads the same as modeled in the basic model. Under these conditions the voltage drops on the secondary (480 volt) sides-of the transformers serving the mixing pumps increased to approximately $7.5 \%$.

A third model was created that is the same as the second model except that in this case the mixer pump motors were modeled as starting rather than running at steady state. Starting currents vere taken as $150 \%$ of ful1 $10 a d$ amperes because the motors will be controlled by variable speed drives (VSDs) whose output current is limited to $150 \%$ of norma?. Under these conditions voltage drops increased to approximately 15\%.

\section{Discussion}

As may be seen, the voltage drops resulting when all the motors are running or starting exceed the value allowed by ANSI C84.1. 
Motor starting is a fransient condition and the C84.1 allowable isn't really relevant, the primary concern being whether the voltage will be adequate to actually start the motors. $85 \%$ of nominal voltage probably is adequate to start the motors, but what the motor actualiy sees is dependent on the characteristics of the vso coritruiling it so this situation is beyond the scope of this study. It does not seem credible that this event would ever occur anyway.

DynCorp Electrical Utilities group requires that service transformers be procured with adjustable voltage taps and so it might be possible to reduce the voltage drops at the transformer secondaries to about $2.5 \%$ by adjusting the taps. However, this would not bring the service voltage into conformance with ANSI C84.1.

Some improvement in the voltage drops could be achieved by replacing the II4 ACSR portion of the line with larger conductors, but the gain would not be sufficient to bring the system into conformance with code because most of the voltage drop occurs in the $\# 4 / 0$ copper portion of the line between substation 251-W and the tap west of AN farm. Rebuilding that portion of the line with larger conductors is probably not realistic since it is several miles long.

Probably the best solution would be to disconnect AW and AP farms from line C8-L6 and connect them to line C8-L5, which is very similar to line C8-L6 but has very little existing 10ad. Line C8-L5 presently exists adjacent to AW farm and the work described in the $W-505$ CDR includes disconnecting the portion of line C8-L6 east of Canton Avenue from 7 ine $C 8-L 6$ and connecting it to line C8-L5 (this includes the AP farm tap). Thus, $900 \mathrm{HP}$ would be removed from 7 ine $C 8-16$ and relocated to line $C 8-L 5$. If two of the postulated mixing pumps were in AN farm instead of AW farm. AY farm could be connected to line C8-L5 without great difficulty. The appropriate solution is dependent on what effect recent changes in strategic plans wi 11 have on the waste transfer schedule. In accordance with the Project W-505 CDR, line C8-L5 will be used 'to supply power for construction of the private contractor's plant. so that may affect the availability of the line for the use of the tank farms.

Line C8-L8 also exists in the vicinity of the PUREX plant and the Project W-505 CDR includes extending it east to the private contractor's plant to provide-backup construction power. In accordance with the Project W-519 CDR it will also supply power for pumping from tanks 106-AP and 108-AP-to the private contractors " pilot plants. It has less capacity than lines C8-L5 and C8-L6, but it presentiy has no load.

If the possibility of transferring loads to lines $C 8-L 5$ and $C 8-L 6$ is to be considered, the DAPPER models of these lines that were created for the Project W-505 and $W-519$ studies shoulo be updated and refined to permit evaluation of the waste transfer scenarios that are postulated. 


\section{RURPOSE:}

To study the impacts of simultaneously starting and running 5-300hP and 4150 HP mixer pumps located in Tank Farms $A Y, A Z, A W$, and $A P$ on the 251-W substation $13.8 \mathrm{kV}$ line C8-I6.

\section{METHODOTOGX:}

An SKM PowerTools for windows (PTW) line C8-L6 one-line model (C8160Ig) was created utilizing the data found on the Essential Drawing k-2-818278, sheet 5, Rev 2 \& sheet 6 , Rev 6 . The line segment impedances were validated for accuracy and found to be correct with the exception of the paraliel segments of $\$ 4 / 0 \mathrm{cu}$. The actual impedance for these parallel segments is a little higher than originally calculated by Electric Utilities (EU). The fault calculations were run and found to be very close to those found on the Essential Drawing. The values were a little lower due to the increase in parallel line impedances.

A new c8-L6 model was created from a copy of $\mathrm{C8} \mathrm{L} 60 \mathrm{rg}$ and was then updated to include field verified transformex data, which yielded a net gain of approximately 6.8 WA of additional loads and other corrections. It was then load factored to reduce the connected load $(26,660 \mathrm{Kva})$ to a level consistent with its metered two year monthly maximum demand data. The average over a two year period to date, was $4300 \mathrm{~kW}(4778 \mathrm{Kva}$ ( $90 \mathrm{PF})$. An energy audit load diversity factor of 208 yielded the closest results to the average monthiy maximum demand, which was 4783.6 Kva at 94.58 power factor $(200.1$ amperes $13.8 \mathrm{KVl}$.

Two study models were then created from this C8-L6 model to include the $A Y$, A2, $A W$, and $A F$ tank farm mixer pumps and two additional transformers. These models were c8L6mr for all mixers running, and c8L6ms for all mixer pumps 'starting. The analysis scenarios run were first a baseline $(C 8-J 6)$ with no mixer pumps, second was all mixers zunning (C8L6mr) and third (C8L6ms) was all mixers starting. In the mixers starting scenario, the starting currerits were limited to the VFD 1508 maximum values.

\section{GIVEN INFORMATION AND RSSUMPTIONS:}

The impace loads included in these scenarios are all located on the-line C8-I6 fused switch c8xill tap located west of Buffalo and north of Mo-2797:" This tap comes in as $\$ 2 / 0$ copper to Buffalo and ties into a \#4 ACSR circuit that goes south to the AY, A.w, and AP tank faxms, and 2 \#2 A.CSR that heads east and northeast to the $A N$ and $A . Z$ tank farms.

The $13.8 \mathrm{kV}$ driving voltage, for substation $251-\mathrm{W}$ that feeds 1 ine $\mathrm{C8}-26$, was set to 1.07 per unit, as recommenced by Dyncorp Electric Utilities.

The 1350 Kvar cepacitor bank 05498 , located north of 4 th street and three spans west of Mo-405, was included as opexational in ald of the studies.

RESULTS AND CONCLUSIONS:

The following table shows the two major weak points in line C8-I6, theif respective currents and cable/wire ratings. Leaving the $251-\mathrm{W}$ substation is limited by the $15 \mathrm{kV}, 500 \mathrm{Kcmil}$, copper, Araconda EP insulated cable. The

File: c8I6.std Page 1 
switch C8X1il circuit is linite: iy the 44 fCSR runing south dom Euffalo into the $A ., A$, , and $A P$ farm areas.

\begin{tabular}{|c|c|c|c|c|c|c|}
\hline & $\begin{array}{l}251-\text { W } \\
\text { Bus } 6700\end{array}$ & & & $\begin{array}{l}C 8 \times 111 \\
\text { Buis } 6720\end{array}$ & & . \\
\hline & Amperes & FEz & Rating & Amperes & PE & Rating \\
\hline Baseline & 200.1 & 94.5 & 465 & 64.7 & 80.0 & 140 \\
\hline $\begin{array}{l}\text { Motors } \\
\text { Running }\end{array}$ & 309.89 & 84.0 & $\Rightarrow \dot{65}$ & 129.91 & 79.0 & 140 \\
\hline $\begin{array}{l}\text { Motors } \\
\text { starting }\end{array}$ & 339.29 & 62.0 & 465 & 155.7 & 34.0 & 140 \\
\hline
\end{tabular}

The Load Flow study results, for the motiors running, indicates that line $08-16$ $13.8 \mathrm{KV}$ voltage drops approximately 3.71 from the $251-\mathrm{W}$ substation to the c8X111 switch tap, and to ayound $5 \%$ at the AP tank firm. The bulk of the voltage drop $(74 \%)$ is in the $\# 4 / 0 \mathrm{Cu}$ line from $251-W$ to $\mathrm{C} 8 \times 111$ switch.

Increasing the size of the $\$ 4$ ACSR on Buffalo will help improve voltage regulation some, maybe $.5 \%$ at $A P$. The main reason for recommending its size be increased to maybe $\# 2 / 0$ ACSR is for additional capacity, as the \#4 ACSR is being pushed to its current limit of 140 amperes.

Under normal loading conditions with no motors, the voltage drops at these. same locations are negligible.

,

Assuming full load conditions with the mixer pumps running and starting, the table below indicates the 480 Vac voltage drops at the main distribution - panels with the main transformer taps set at nominal:

\begin{tabular}{|c|c|c|c|c|}
\hline & Az Tanx Farm & AX Tank Farm & AH Tank Fazm & AP Task Farm \\
\hline Baseliñ - & .328 & No $x \operatorname{fm} r$ & No $x \in m r$ & $7-94 \%$ \\
\hline Running & 7.318 & .7 .338 & 7.918 & 7.158 \\
\hline starting & 14.698 & 14.628 & 15.128 & 12.558 \\
\hline
\end{tabular}

Increasing the Buffalo circuit to $\$ 2 / 0$ ACSR will reduce motor running $13.8 \mathrm{KV}$ ine voltage drop by approximately .58 . This will help decrease the 480 vac main distribution panel drops by approximately $.5 \%$ to .78 . 
HNF-2941

Revision 0

F.4.1 ASSESSMENT OF AVAILABLE TANK CAMERA SYSTEMS 
HNF-2941

Revision 0

July 1998

Mr. Ivan Papp

Numatec Hanford Corporation

Mr. Papp,

I spent several years working with visual imagery, from designing systems for access into areas where human access is impossible or has the potential for extreme danger, to the lighting requirements for various atmospheres. I managed the Remote Surveillance group in Characterization Project Operations (CPO) for the tank farms at Hanford, this was the group that introduced along with several other systems, stereo vision into the Hanford tanks giving engineering management an actual three dimensional look at the waste inside the huge Underground Storage Tanks (UST's). This was especially helpful for sampling activities, in discovering which areas in the tank had the waste in mounds and which areas were void of waste, aiding in the decision of which riser to deploy through.

In this letter you will find some information on available camera systems on the market, and which systems currently exist in the Hanford Tank Farms at the Department Of Energy (DOE) site in Richland, WA. This letter also consists of my recommendations and the estimate of costs for deploying the cameras already utilized at Hanford.

\section{INTRODUCTION:}

The Hanford Tank Farms have several mobile and permanently installed camera systems. The permanent cameras with lights are installed into tanks 241-SY-101, 103, 241-AW-101, 241-AN-103, 104, 105 and $* 107$. These systems have their equipment located at the specified farm where they can be operated when the'need arises. The mobile systems are transferred from tank to tank as necessary by way of a covered vehicle which carries all the essential equipment for operation.

\section{SUMMARY:}

The permanent cameras have been installed into the tanks through a twenty inch riser using a riser adapter and placing it on the 42 inch opening. The adapter typically has three access ports, a twenty inch, 12 inch and an eight inch port. These cameras have a life of approximately two years at $200 \mathrm{R} / \mathrm{hr}$.

There are two color cameras with lights installed in SY-10I both on the same equipment, one is an overview camera for general viewing of the waste and tank walls. This system is installed into the 42 inch riser number $5 \mathrm{~A}$ which has a muiti-port riser adapter on it with the camera system installed through the twenty inch port. This system was installed due to the occasional tank "rollover", an event which releases trapped gasses under the waste. It was believed necessary to install a system that could be used at anytime without tank farm entry.(after initial installation), to observe these significant events. From the successes at SY-101, other systems were obtained and justified for installation into other various underground storage tanks.

The only documentation that mentions the use of permanently installed cameras has been written for SY-101 which is not controlled by the Basis for Interim Operation (BIO), HNF-SD-WM-B1O-001. SY-101 has it's own specific stand alone safety requirements. The BIO however, does mention cameras, lights and 
other equipment necessary when there is waste intrusive work commencing in the tanks, these comments are only for the safety aspects of the systems in preventing sparks caused from static, electrical or mechanical means. There is no mention in the BIO with regard to specific size or installation method or whether the camera be permanent, temporary or mobile.

See attachment "A": "Item classification: Non-de minimus" appendix E from the BIO.

\section{EXISTING CAMERAS / CONFIGURATION:}

Below is a list of the tanks with a permanently installed camera system and their configuration. All systems in flammable gas atmospheres must be qualified as class I division 1 group $B$.

SY-103, AW-101, AN-103, 104, and 105 have the same configuration as SY-101 as they also use multi-port risers and are installed through the 20 inch.access port. The exception is the use of an overview camera which only SY-101 has. SY-103 is installed into riser 5B; AW-101 riser 5B; AN-103 riser 5B; AN104 riser 5B and AN-105 riser 5A.. AN-107 has an unqualified (does not meet the flammable gas requirements) color camera system with lights installed into riser 7A which is a twelve inch riser. the tanks listed above with the exceptions of SY-10I and C-106 are considered idle, or on "standby". Maintenance specifications for these particular cameras suggest that they be replaced / repaired annually. Interviews with individuals working with the group assigned the camera replacement work allude to the Maintenance Management Procedure as the document controlling that activity. The apparent lack of funds for this preventive maintenance is what has caused their current "standby" condition.

Attachment " $\mathrm{B}$ " is a section from the Maintenance Management Procedure, included is a copy of a message explaining why the cameras have been shut down.

\section{AVAILABILITY:}

There are camera systems with lights with the ability to be deployed through risers of less than six inches and some in as small as 4 inches. These cameras would lack the overall lighting used on the bigger permanent systems, though there are intrinsically safe lights available on the market which would still need a twelve inch access port and with the camera in one riser and the light in another there would be adequate resolution and two less risers available. CPO has successfully deployed both the light and the camera in the same twelve inch riser allowing CPO sampling teams another option for access into the tanks by freeing one other riser during filming. There are smaller diameter lights being developed to access a 4 inch riser and to be qualified for flammable gas atmospheres with one thousand watts of high intensity lighting by the end of this calendar year. These smaller diameter lights could possibly allow access by both a mobile camera and light through a four inch riser again giving operating crews even more desirable options to access the tank.

The smaller mobile cameras also lack the shielding the larger permanent cameras have (which is partially the reason for the permanent camera size) but, could be removed when not in use, thus potentially extending the life of the system. The flaw with deploying and removing these mobile systems is that if work was continuing on any of the tanks with trapped gasses the tank could not be opened during that "roilover" event, therefore leaving the camera exposed to the radiation. The scheduling for deployment would also have to be very precise.

FUTURE PROJECTS: 
1998.

Project W-151 plans to install a color camera system with lights into AZ-101 riser $16 \mathrm{~B}$ fiscal year

Project W-211 plans to install color camera systems with lights starting in fiscal year 1999 and going through fiscal year 2001, beginning with AP-102 and 104, both into 42 inch risers numbered; 0 degree riser 5 , (the most northem 42 inch riser). By fiscal year 2000 current plans are to have a system installed into AZ-102, and by fiscal year 2001 install a system into SY - 102 in the central pump pit using the same configuration as SY-101.

Project W-320 installed a mobile color camera system with lights into C-106 riser number 7, a twelve inch riser. They are currently looking for another mobile system.

\section{SCHEDULING AND COSTS:}

Consider the cost of permanent cameras mounted into each of the 177 UST's at Hanford, (this is very unlikely) but, if the task were to arise for a visual scan of each UST the cost would be astronomical. Each system costing well into the hundreds of thousands of dollars to purchase, install and operate not to mention the time, scheduling, additional hardware such as riser adapters, configuration changes and engineered drawings updated for each tank. These costs are also driven upwards due the severe requirements put on the flammable gas tanks.

Mobile systems available today, designed and qualified for the flammable gas requirements of the Hanford tanks cost between twenty two thousand and 45 thousand dollars to purchase. Operations personnel are already trained to operate two of these systems, procedures have been written and there are experienced individuals in the use of these systems. When new systems are introduced operations includes the training in their "Continuing Training" program which is required on a monthly basis to keep all persons who operate equipment in $\mathrm{CPO}$ at the Tank Farms familiar with their roles and responsibilities.

Wally Kennedy Field Sampling Manager and responsible manager for the In-Tank videos for CPO, gave me an estimate of one day of video inside an UST. This estimate includes a crew of approximately seven to 9 people, writing a work package, set-up of equipment at riser on tank, deploy camera and remove equipment for roughly fifteen thousand dollars. A work package is only part of the initial costs and every day thereafter could be as little as 5 to seven thousand dollars. (Contingencies of course are not included). George Stanton Programmatic Manager CPO estimates that if given between 30 and sixty days that work can be on the CPO schedule. (This also depends on time of year and strain already on the schedule of completing any milestones).

Due to the costs, consideration to ongoing operations and the consensus from Tank Farm management, several mobile systems could be purchased and utilized on a regular basis and on various forms of tasks without depleting the options for Tank Farms Operations access into the tank while remaining cost effective.

\section{RECOMMENDATIONS:}

My recommendations are to use mobile camera systems for any projects requiring the use of visual imagery during the particular activity as long as there is the option to have the camera removed from direct radiation exposure while the project is in "down" mode. There are advantages to having the larger shielded cameras, though it is not necessary for those systems to be permanently installed,(potentially hindering operational altematives for deploying equipment into the tanks). An example of this; a project continuing for an extended period of time without frequent delays. (The adverse effect of course is a larger diameter 
HNF-2941

Revision 0

riser will need to be selected). Even in this situation it is highly recommended that the system be capable of being removed, extending it's life, while other accesses into the underground storage tanks remain available . for operations.

\section{INTERVIEWS:}

** Interviews conducted with operations management show a need to use visual aides during waste intrusive activities, those visuals are required according the BIO, (as stated above). Operations agrees that the permanently installed cameras hinder the potential use of these risers in the future, (with the exception of SY-101) and serve no practical purpose unless there is a mission for that specific tank. Leaving them to sit and take a direct dose especially while idle is a mis-use of funds and equipment. Portable video systems would serve the same purpose, can be removed and te-installed into another access port 6 inches to four inches in diameter in a matter of hours allowing for more access into the tanks at various positions for other activities.

Attachment " $\mathrm{C}$ " has pictures of the permanently installed camera system prior to deployment, a sketch of the camera system and where to find drawings and vendor information.

Attachment " $D$ " is a sketch of the mobile camera system currently being used in the Tank Farms CPO organization.

* The camera installed into $241-\mathrm{AN}-107$ has not been qualified for use in flammable gas atmospheres.

** These comments are not quotes but, information gathered from the interviews. There is a mutual agreement among operations management regarding the permanently installed cameras in the Hanford tanks .

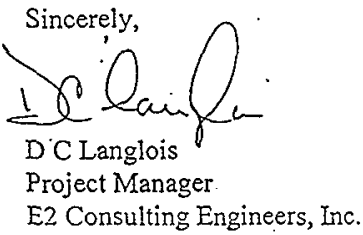


HNF-2941

Revision 0

ATTACHMENT "A" 


\section{$\therefore \quad \begin{aligned} & \text { HNF-2941 } \\ & \text { Revision } 0\end{aligned}$}

\section{ITEM CLASSIFICATION: NON-DE MIHIMUS}

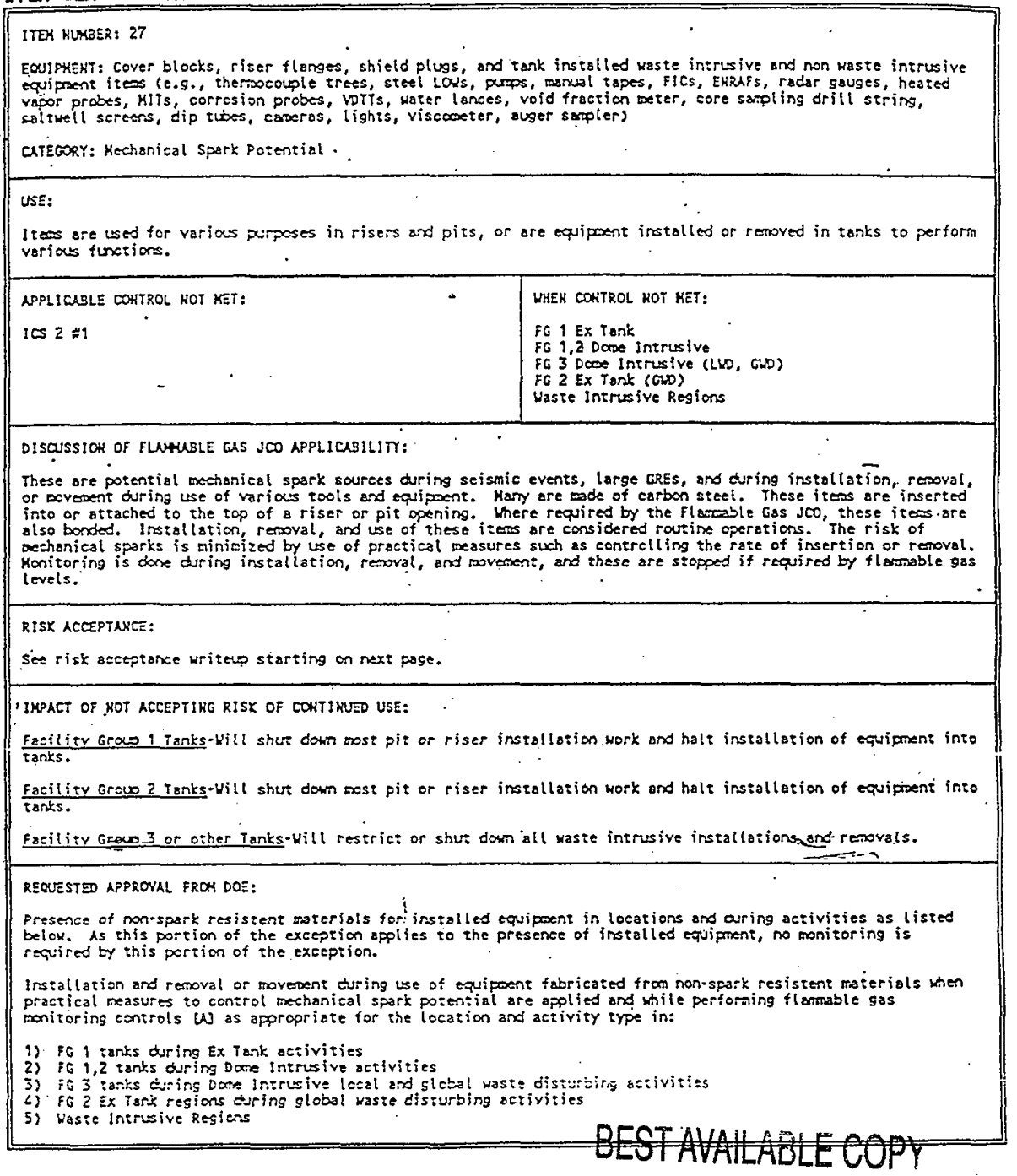


c. Kotion occurs drins the installation of equipent (c.g. As it is lowered into the tant

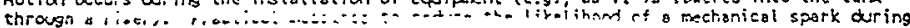
equipoent irstaliation shall be incluojed in equiphent design, work packoges, or irstallation procedures chen such movenent has significant po:ential to cause mechanical sparks. This can include: - liniting insergion speeds, water bothing of equipment, prevertion of contact with cther non-spark resistent materials by use of collars or butpers, use of eritical lift procedures where appropriate. Los monitoring during these mamed activities is perfered as rectired by this Jco.

d. Morion oecurs dring the reoval of touipment (e.g., as it is raised through a riser). Proctical measures to reduce the likelihood of a bechanical spark during equipment resoval shall be included in equipent design, work pockages, or renoval procedures when such wovenent has significant potentis! to cause pechanical spark. This con inelude: liniting removal spesds, water bathing of equipoent, preyention of eentact with other non-spark resistent manesials by use of collars or burpers, we of critical lift procedures where appropriate. Gas ponitorine during these eamed activities is performed as reatired by this $\mathrm{J} 0 \mathrm{O}$.

e. Kotion can octur as port of the aperotion of equipnent (e.g., pashing o ditill string/core bartel into the waste, land through riser), movesent of woste chardeterization sapling devices such as retained gas socplers, void fraction meiers, viscosezer, auser sampl ef as they are noved through the vaste). These coerations are generally partormed manully and are linited to low velocizies by the nature of the coeration. Practical neasures to reduce the likel ihood of a mechsnical spark during equipoert novent shall be ineluded in the work packsges and irstallation procedures witen such tovenent hes significant potential to cause pechanical sparks. This can inelude: lifitira speeds, water bathing of equipment, prevention of contact with other non-spark resistent materials by use of cellars or berpers, ise ff etitical lite procedses were aporopriate. Gas monitoring during these tamed activities is parforoed as reguired by this dCo.

The risk associated with eontiruing use of the tools and equipent is furcher reduced by performing flamble gas monitoting of the vork area frior to ond during use. This will include monitoring per tethod W. See definition of tanitoring bethocs st the and of this section.

When flamable ses levels resch 25: of the LFL, work eeases as raquited per the ponitoring requireonents of this flamable Gas Jeo. The kational Fite Protection Association (KFPh 30, 1923) recomonds that processes be controlled so thet flamable gas coneentrations ore <25 percen: of the laxe flamability limit (LFL), when relying toon vapor space flamability levels to preelute the possibility of an ignition. Dot order 5480.4 requires Hanford waste tanks to be operted within NFPA guidslines. ThLs, a constol of $<25 \%$ of the LFL has been established for performing oetivities in and around tank farm tacilities. Because of the upredictable nature of GREs, it is not possible to ensure that 25: of the LFL is never excended. Procedures and constois are thus in place to minieizis the potensial for a sank to exceed 25 a of the $1 F \mathrm{Fl}$, and to cease work in areas carron with the tant vapor space wen the fiatrable gas concentretion exiecds this value. This $25 \%$ limit is far below the sefual liafe at wich flemobility can oecur, end is conservatively chosen to allow for potential treasurexent.

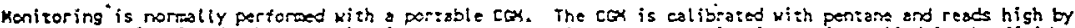

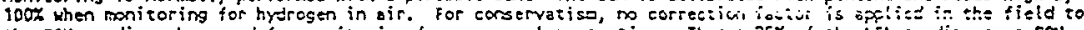
the cas reading wen used for monitoring fer persomel protection. Thus $25 \%$ of the lit reading on a cas is actuslly 12.5\% of the LFL for hydrogen in air, but is treated as if it vere 25\%. Depexding upon the

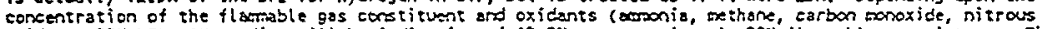

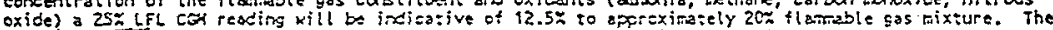

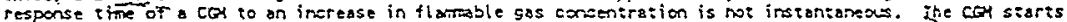
responding to an inerease in $f$ camable gas coxestrations alses: immediately won the gas reaching the $C Q x$

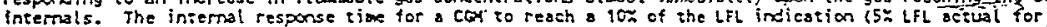
hydrogen in air) when exposed to a 23 of the LFL pentane mixiure (equivalent to a $11.5 \%$ of the LFL hydrogen in air nixtura) ratsed fron 7.92 seconds in a maber of intoral iests. Titse to reach the full $23 \pi$ test gas indication toot $20-40$ seconds.

If the cex is drawing a sample our of a sank done spoes, the siofe for the tank vapors so reach the cen is approxima:ely 26 seconds, tased upon the $500 \mathrm{c}^{3} / \mathrm{min}$ cof flow and the twoing currensty used fer flactiable gas monitoring. Thus an instanseneous change tron 0 to 12.5\% of the LFL for hydrogen in air in a tank vapor space (an indicated 25 \% of the $L F L$ ) would no: indicate any change at all on a Car for abows 25 seconds. At 23 seconds, the indicaied LFL would besin :o rise and $33-35$ seconds after the step change the CGe would

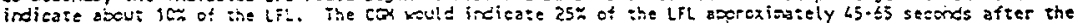
step change.

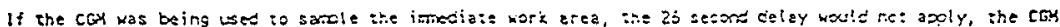

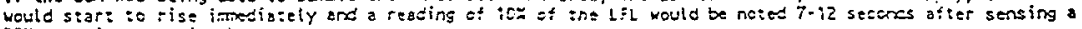
25 siep increase in the 1.7 . 
HNF-2941

Revision 0

ATTACHMENT "B"

\section{,}




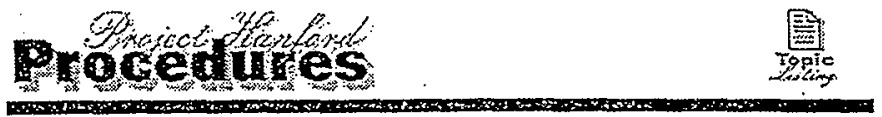

Maintenance Management

HNF.PRO-059. Rev1, Elfectye: 3/9/58

Technical Authority Approval: TR Batber 2/18/98

Functional Area Manager Approval: TJ Haper 2/27/98

Topic: Maintenance

\begin{tabular}{|c|c|}
\hline View Cross Reference and SRID Information & View Change Notice \\
\hline
\end{tabular}

\subsection{PURPOSE}

1.1 This document presents the Project Hanford Management Contract (PHMC) policy on mintenance management and work control. It establishes the minirnum reguirements for a facility or organization maintenance management program. Ir provides expectations for results of processes by which work activities are identified, initiated, analyzed, planned, approved, scheduled. coordinated, released, performed, completed. and reviewed for adequacy and completeness; to ensure that PHMC work is consistenly accomplished safely, in a timely manner, with improved efficiency and increased equipment availability.

This document applies to employees and subcontractors involved in work activities in PHMC-managed areas; facilities, and plants. Work activities include modification. corrective, preventive and predictive maintenance.

\subsection{REQULRE:HENTS}

\subsection{General Reouiremenis}

NOTE: in order to maintain uniformity and to simplify the process of teview and approval, it is recommended that document or change development involve FDH Project Direction Conduci of Operations personnel early in the process.

Each Project Hanford contractor assigned direct responsibility for mainenance of a facility or organization develops, implewents, and documents in a Maintenance Implementation Plan (MIP) a program for their facility/organization in conformance with the policy and objectives of this procedire. The program clearly defines: 
(1) The structures, sysiems, and components included, using a graded approach and the requirements derived from Techrical Safery Requirements.

(2) The manazement systems used to control maintenance activities, including the means for monitoring and measuring the effectiveness of the program and the management of maintenance backlog.

(3) The assignment of responsibilities and authority for all levels of the maintenance organization.

(4) Mecharisms for feedback of relevant information, such as trend analysis and instrumentation performance/reliability data, to identify recessary program modificätions.

(5) Provisions for identification, evaluation, and correction of possible component, system design, quality assurance, or other relevant problems.

(6) Performance indicators and-criteria to be utilized to measure equipment, systems, and personnel effectiveness in mainenance activities.

(7) Interfaces benween maintenance and other organizations (i.e., operations, engineering, quality, training, environment, safery, and health).

(8) A self-assessment program to monitor the effectiveness and eficiency of the mainkenance program.

(9) Provisions for planning, scheduling, and coordination of maintenarce activities.

Periodic inspections of strucrures, systems, components, and equipment, paricularty ihose imporant to the safe and reliable operation of a facility, are periomed to determine whether deterioration is taling place and to identify and address technical obsolescence that threatens performance, safery, or facility preservation. Where the potential is identified for any event or condition to significantly affect safety margins, a formal program for resolving the problem is documented and inplemented.

\subsection{Non-nuclear Facilities}

For DOE non-nuclear property for which the PHMC is responsible, a graded approach using the objectives, criteria, and sequence described in the 18 elements presented in Atrachment 1 is used in the development and implementation of Maintenance Programs.

NOTE: Non-ruclear fasilities may, at their option, prepare and submit for approval a Site Maintenance Plan (S.MP) in lieu of a MIP. Refer to Attachment 2. Routing and approvals remain the same as for a MIP.

Exceptions or deviations from the MIP elements are contained within the MIP and are granted by the appropriate DOE RL Management through approval of the MIP. 
HNF-2941

Revision 0

Authox: David B Smeteapincol.rl.gov at -EXCBANGE Date: $5 / 22 / \overrightarrow{97} 22: 18$ PM

Priority: Normal

Receipt Reguested

To: Gerald D (Jerry) Johnson at "HANFORDI1E

TO: RYan A Dodd at HANFORDOSE

TO: Jares J (Jim) Badder at WHC103

To: Shafik $H$ Rifaey at "HANEORDOAB

CC: I I Ir (Tom) Pedersen at - WhC213

CC: Iir I castieberry at WHC213

CC: Scott $M$ Werry at "WHC42

CC: Ronald A Harding at - WHC 42

TO: W M Michael Funderburke lapimcol.rl.gov at EXChANGE

SUbject: SHUTDOWTN OF PERMANENT CAMERA SYSTEMS

Message contents

Jerry, et al

I have been directed to discontinue maintenance on the pemanentiy installed vision systems in the 'Big 6' DST's. Since the sY-iol system maintenance was just recently completed, we will continue to allow that system to operate (it is also required to be active for any intrusive activities by the SAR).

For the systems in SY-103, AW-101, and $A N-103,104$ and 205, unless directed otherwise within the next. 24 hours, I will have them de-energized and locked out. There is a safety concern with the inability to verify safety function integrity unless properly r.aintained.

The impacts will be loss of the ability to gather valuable verification information when 'events' occur. The cost of maintaining the systems now that the maintenance and other procedures have been completed, isn't significant and is a dollar wash when compared to the costs of two to three incursions into these tanks with the portable systens (that aren't designed for the 'Big 6 environment), without taking AIARA and waste. inininization into eccount.

Dave snet 
HNF-2941

Revision 0

\section{ATTACHMENT "C" .}


HNF-2941

Revision 0

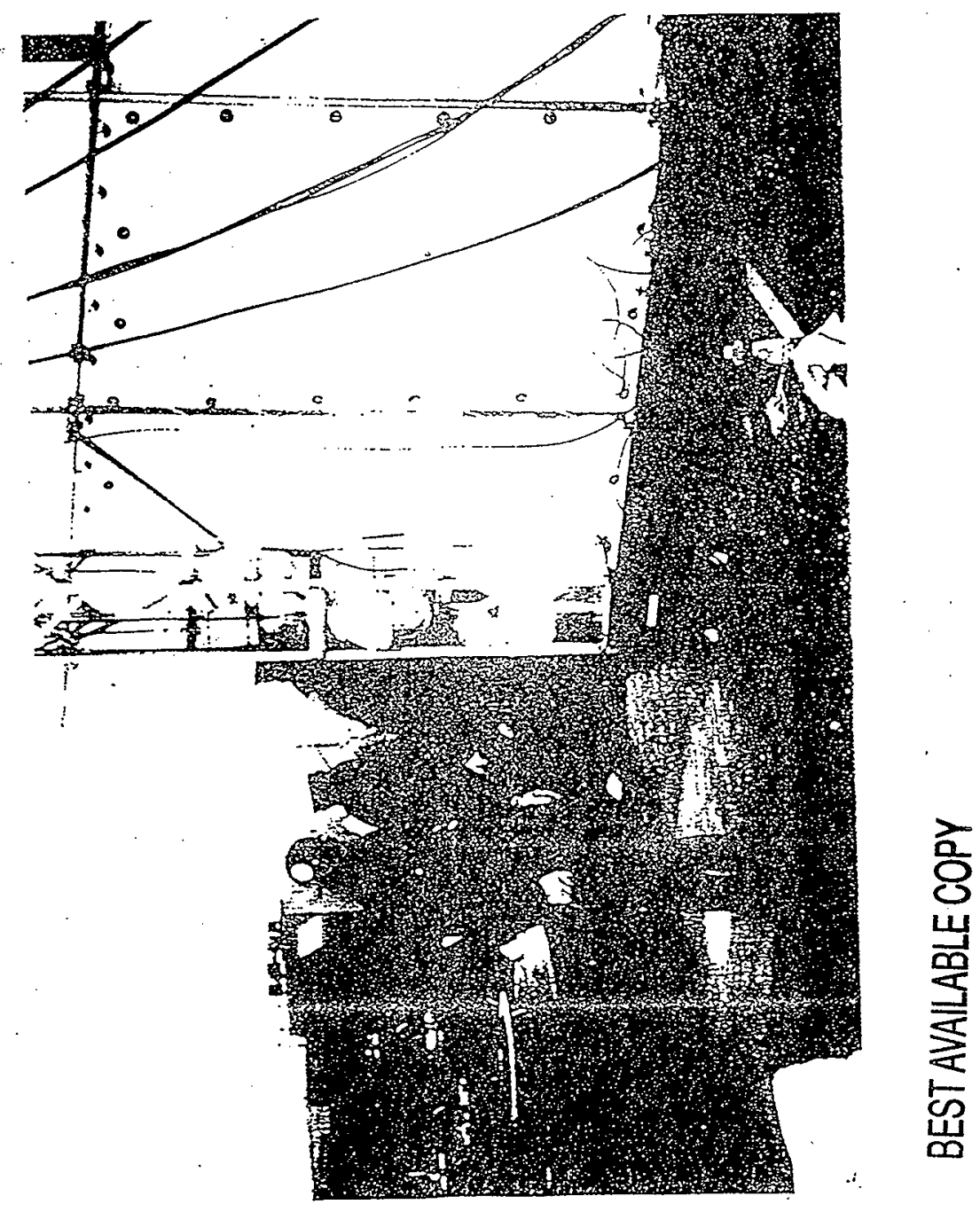

F-103 
HNF-2941

Revision 0

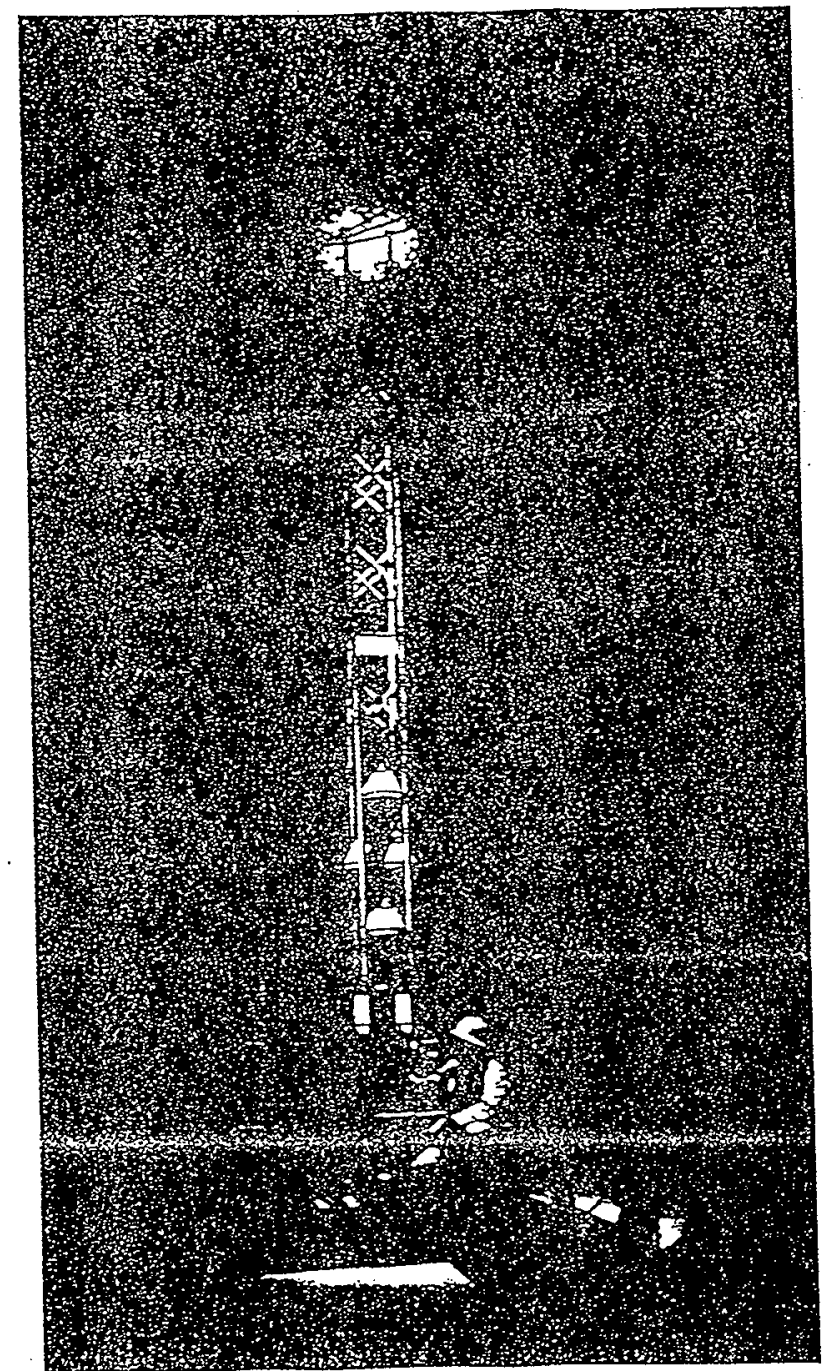

F-104 
HNF-2941

Revision 0

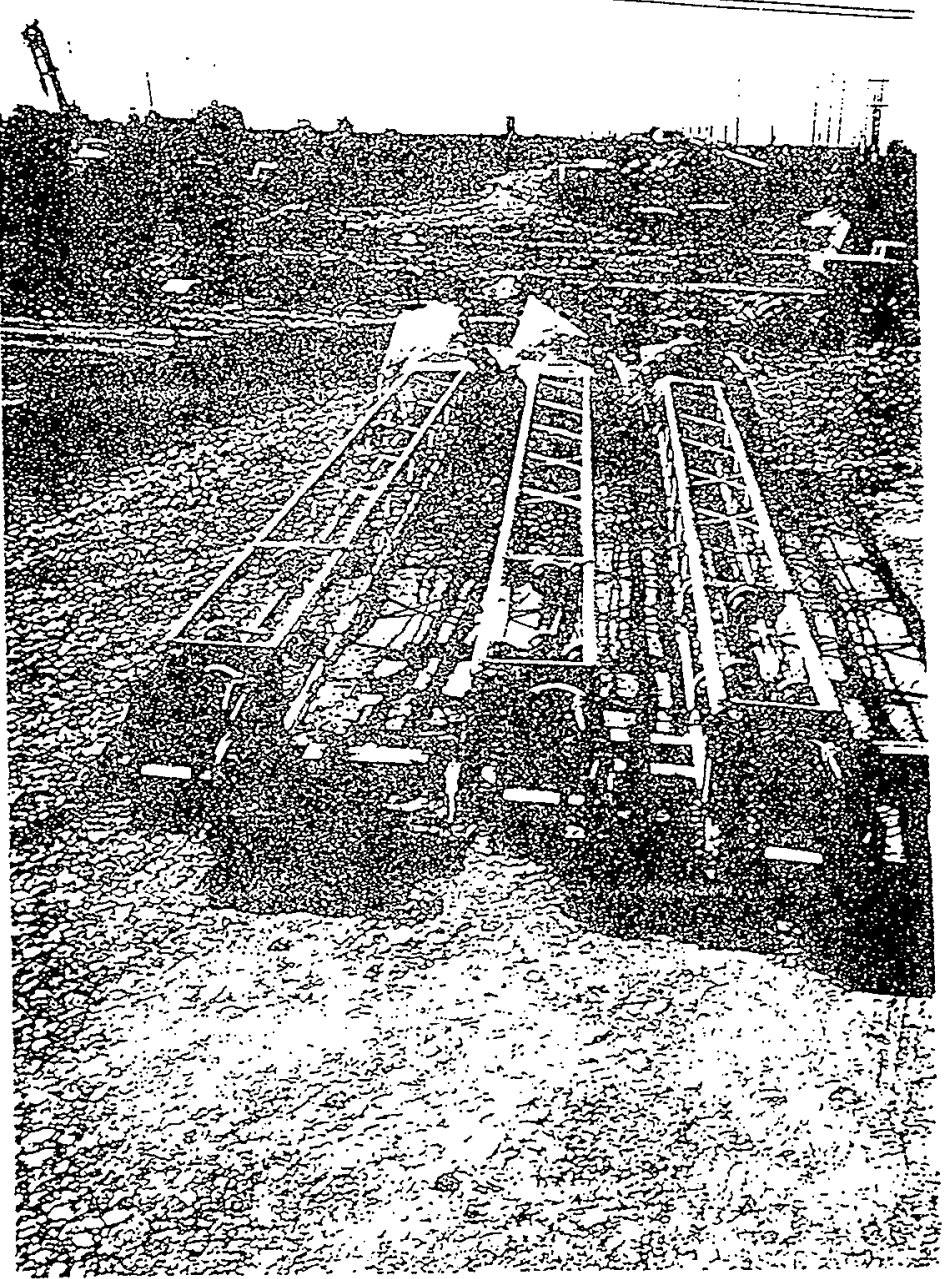


Revision 0

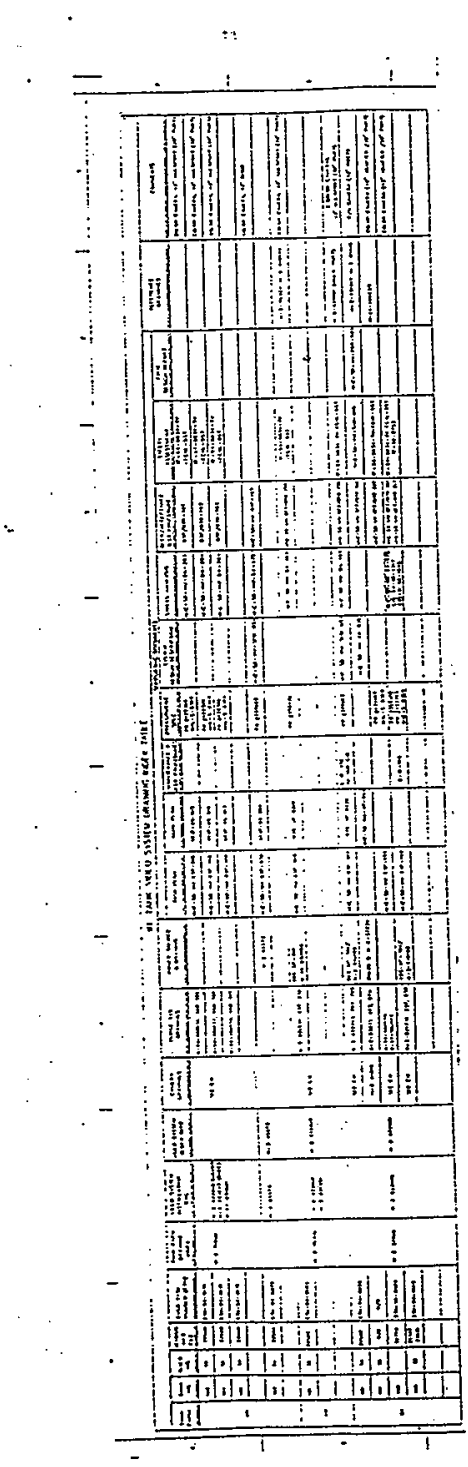


Revision 0

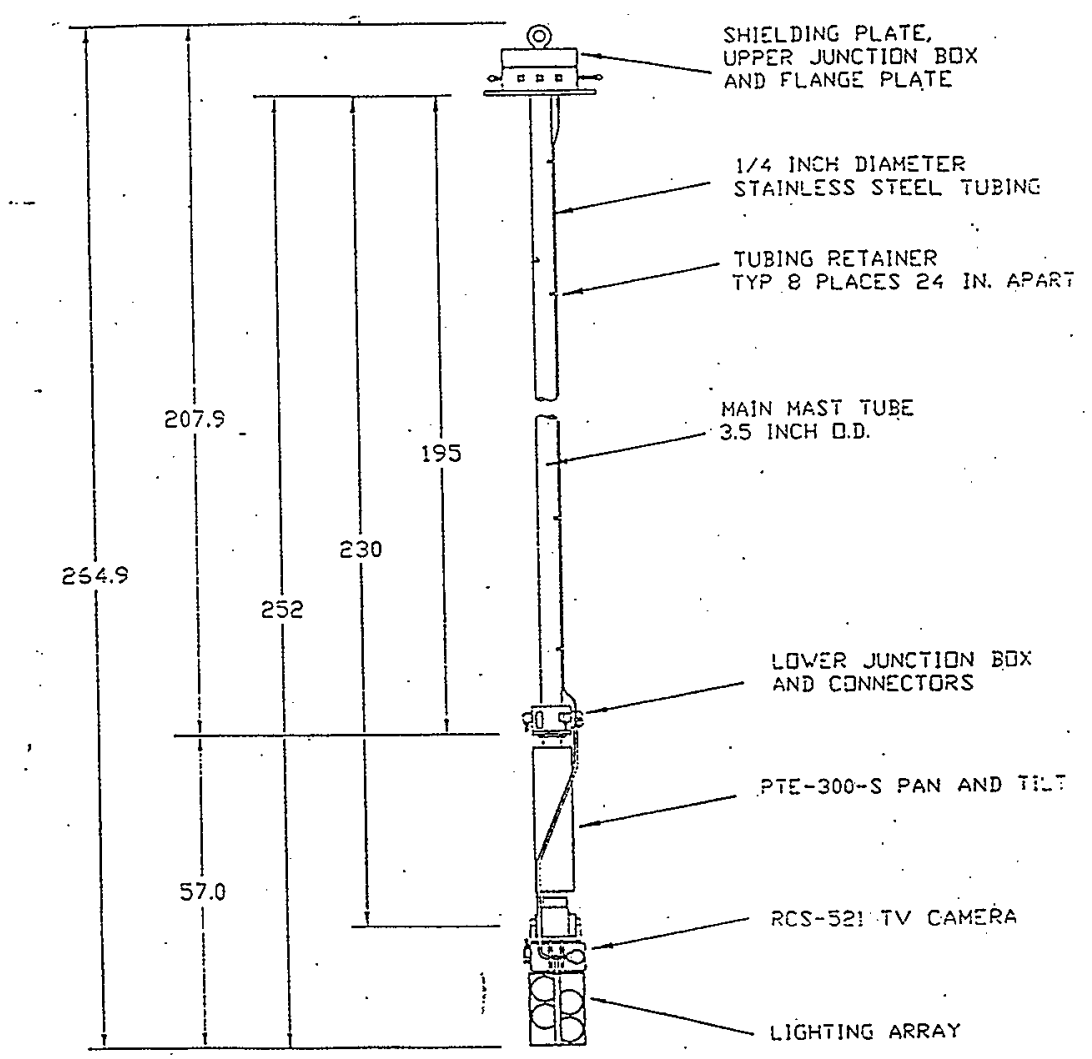

RADIATION TULERANT WASTE TANK COLOR VIDED SYSTEM FOR WASTE TANK 241-C-106 
Revision 0

ATTACHMENT "D"

F-108 


\section{HNF-2941}

Revision 0

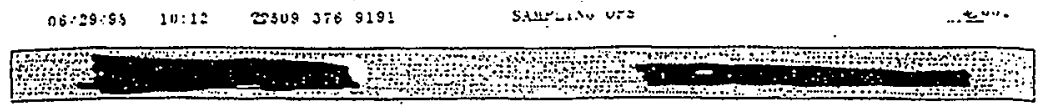

\section{FIGURE 3 - PURGE AIR ROUTTING}

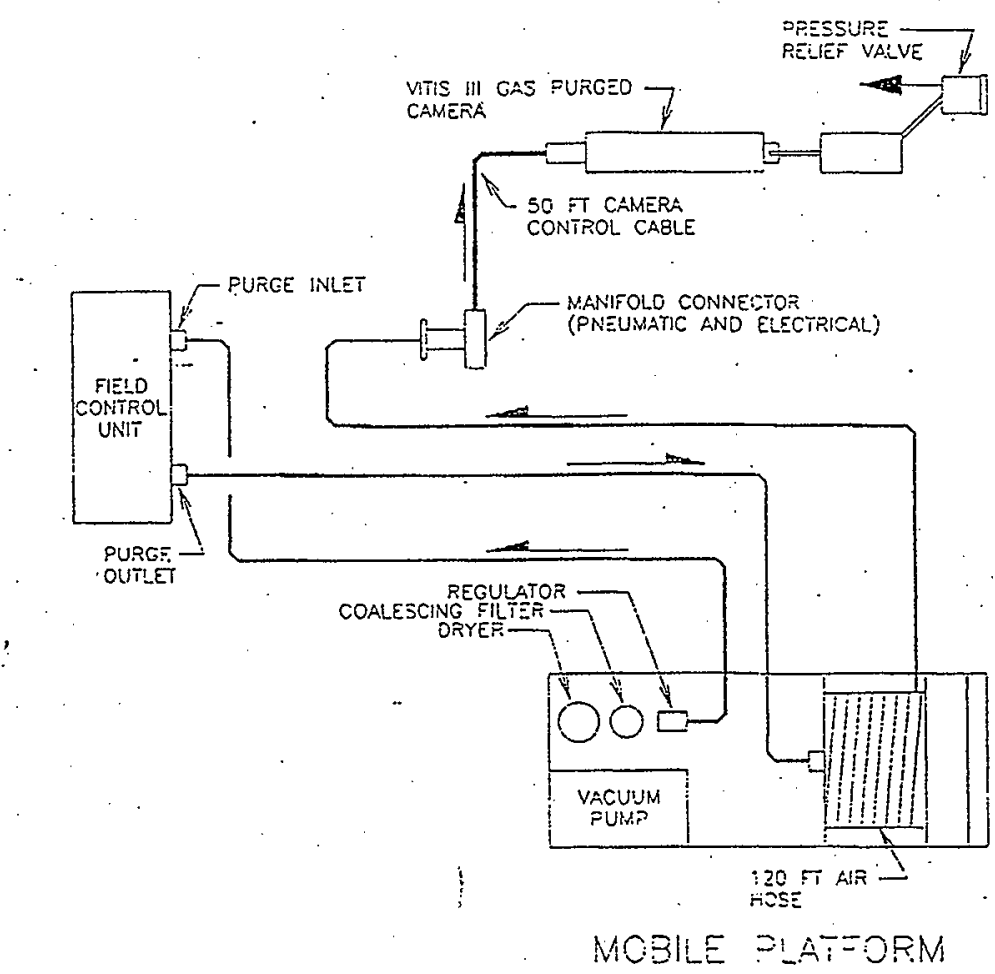

crato-

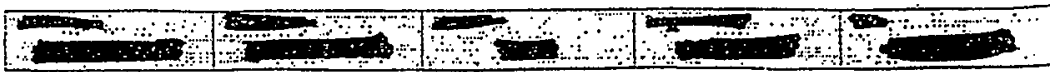


HNF-2941

Revision 0

$05.99 .98 \quad 10: 13 \quad 55093750181$

S.MYPLITG OPS.

002

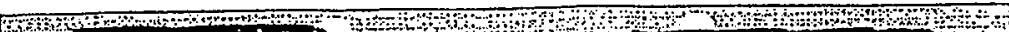

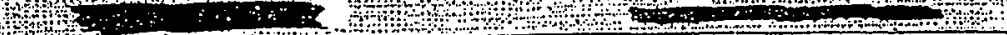

FIGURE 4 : MCCS CAMERA FIELD CONTROL UNIT
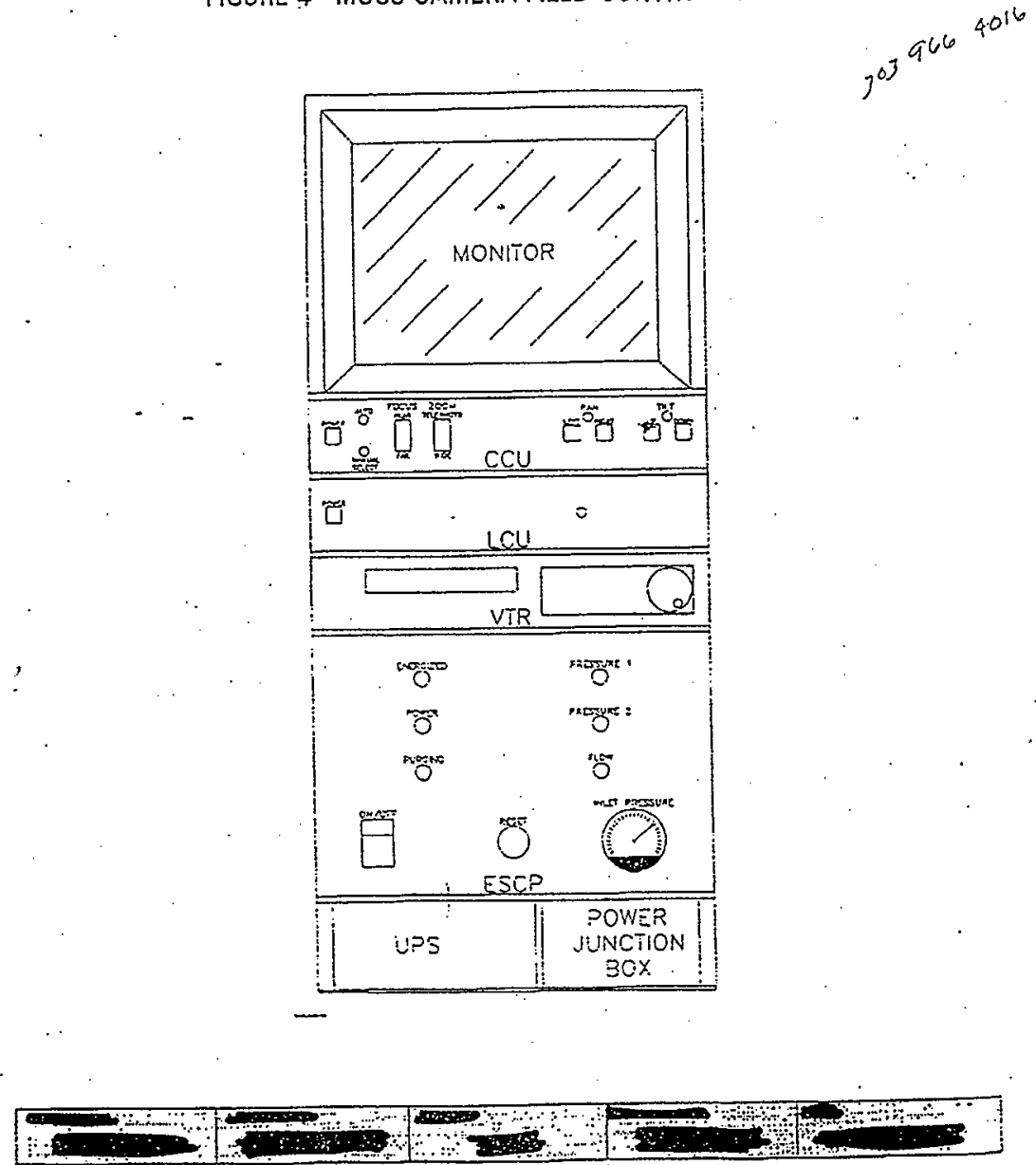
HNF-2941

Revision 0

F.5.1 241-AZ FARM VENTILATION THERMAL ANALYSIS MODEL RESULTS 
HNF-2941

Revision 0

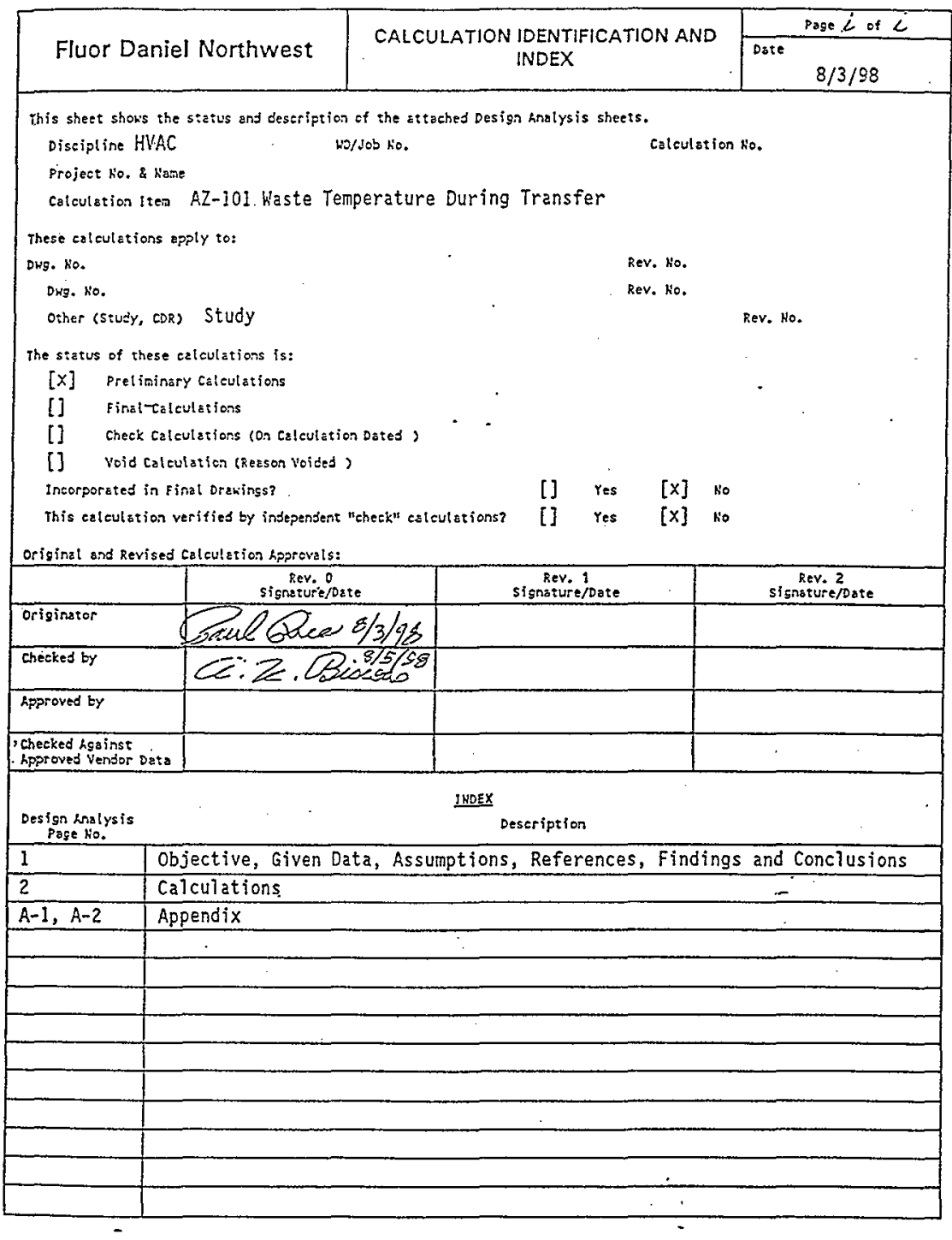

A. $6002-i 43(01 / 97)$ GEF410 
Fluor Daniel Northwest

\section{DESIGN ANALYSIS}

client Numatec Kanford Corp

subject AZ-10I Waste Temperature During

Transfer

Loestion $200 \mathrm{E}$
Calc. No.

Revision 0 .

Page No. 1 of 2

no/ Job No.

Date $8 / 3 / 98$

By P. D. Rice

checked $8 / 5 / 65$

Revised
By $A \cdot Z \cdot B$ Banso

By

\subsection{OBJECTIVE}

These calculations evaluate the adequacy of the ventilation system for tank AZ-101 of the aging waste tank farm during operation of mixer pumps totaling $600 \mathrm{hp.} \mathrm{Operation} \mathrm{of} \mathrm{the} \mathrm{mixer} \mathrm{pumps}$ will be only as needed to mobilize waste for transfer out of the tank.

\subsection{GIVENDATA}

a) Waste to be transferred in 10 batches, one per month

b) Initial batch will be 500,0001

c) Two 300 -hp mixer pumps to operate $120 \mathrm{hrs}$ prior to first transfer and for $18 \mathrm{hrs}$ during transfer

d) Last batch will be mixed for $24 \mathrm{hrs}$ prior to transfer and for $12 \mathrm{hrs}$ during transfer

e) Waste characteristics per Ref. 1) and 4)

\subsection{ASSUMPTIONS}

a) Tank waste vapor suppression factor $=0.45$

b) ALC flow rate =0

c) Average summer OSA conditions $=77^{\circ} \mathrm{F}$ @ 40\% RH

d) Annulus aiflow rate $=800 \mathrm{scm}$

e) Radionuclide heat $=300,000 \mathrm{Btu} / \mathrm{h}$ (Ref. 2)

\subsection{REFERENCES}

1) Parameters for Use in CFD Simulations of the Mixing and Settling of Tark AZ-101, COGEMA-98-521, 6/24/98

2) Tank 241-AY and 241-AZ Waste Evaporation, Letter Report E62062 IR, ICF Kaiser Hanford Co., December 1995

3) Computer Code WTVFE, Y.J. Lee et al, 4/25/96

4) cc:mail, K. Sathyanarayana to P. D. Rice, $8 / 3 / 98$

\subsection{FINDINGS AND CONCLUSIONS}

Operation of two $300 \mathrm{hp}$ mixer pumps in tank $\mathrm{AZ}-101$ prior to and during the first of ten waste transfers will raise the waste temperature from approximately $150^{\circ} \mathrm{F}$ to $181^{\circ} \mathrm{F}$ which is below the allowable operating temperature. During the last transfer, the waste temperature rise will be $2{ }^{\circ} \mathrm{F}$ per hour initially at full pump power. The existing ventilation system is adequate. 
Fluor Daniel Northwest

DESIGN ANALYSIS

client Numatec Kanford Corp

subject AZ-101 Waste Temperature During

Transfer

Losetion $200 \mathrm{E}$
Calc. No.

Revision 0 .

Page No. 2 of 2

Wo/Job no.

\begin{tabular}{|c|c|}
\hline $\begin{array}{l}\text { Deie } 8 / 3 / 98 \\
\text { checked } 8 / 5 / 58\end{array}$ & 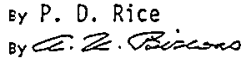 \\
\hline Revised & $B Y$ \\
\hline
\end{tabular}

\subsection{CALCULATIONS}

\subsection{Waste Temperature Prior to Mixing First Batch}

Using the computer code of Ref. 3 ) with input from Ref. 2), the calculated initial temperature of the waste in AZ-101 before starting the mixing process for the first batch is $150^{\circ} \mathrm{F}$. This equilibrium condition corresponds to a tank ventilation flow of $500 \mathrm{scfm}$ at a supply temperature of $77^{\circ} \mathrm{F}$ and $40 \% \mathrm{RH}$. See attached computer calculation results. Operation of the ventilation systern in the recirculation mode with minimal outside air flow of $100 \mathrm{scfin}$ will give slightly lower temperature, based on recent field test data.

\subsection{Waste Temperature Rise During Mixing, First Batch}

Using the waste characteristics given in Ref. 1) and 4),

$$
\begin{aligned}
\Delta \mathrm{T} & =(600 \mathrm{hp})(2545 \mathrm{Btu} / \mathrm{hp}-\mathrm{hr}) \dot{ } /\left(\left(\mathrm{C}_{\mathrm{p}}=0.75\right)(\mathrm{Sp} . \mathrm{Gr} .=1.2)(900,000 \mathrm{gal})(8.3 \mathrm{Jb} / \mathrm{gal})\right) \\
& =0.227^{\circ} \mathrm{F} / \mathrm{hr}=5.5^{\circ} \mathrm{F} / \mathrm{day}
\end{aligned}
$$

$\therefore$ Total temperature rise over the mixing period of $138 \mathrm{hrs}=(.227)(138)=31^{\circ} \mathrm{F}$

$\therefore$ The temperature of the waste is expected to increase from $150^{\circ} \mathrm{F}$ to $181^{\circ} \mathrm{F}$ during the first batch transfer.

\subsection{Waste Temperature Prior to Mixing Last Batch}

Prior to transfer of the last of ten total batches, the radionuclide heat load should be approximately $10 \%$ of the current heat load, or approximately $30,000 \mathrm{Btw} / \mathrm{h}$. Using the computer code of Ref. 3) with input from Ref. 2), the calculated initial equilibrium temperature of the waste before initiating mixing of the last batch is $88^{\circ} \mathrm{F}$. See attached computer calculation results.

\subsection{Waste Temperature Rise During Mixing, Last Batch}

Using the waste characterization given in Ref. 1),

$$
\begin{aligned}
\Delta T & =(600 \mathrm{hp})(2545 \mathrm{Btw} / \mathrm{hp}-\mathrm{hr}) /\left(\left(\mathrm{C}_{\mathrm{p}}=0.75\right)(\mathrm{Sp} . \mathrm{Gr} .=1.2)(100,000 \mathrm{gal})(8.3 \mathrm{lb} / \mathrm{gal})\right) \\
& =2.04^{\circ} \mathrm{F} / \mathrm{hr}=49^{\circ} \mathrm{F} / \mathrm{day}
\end{aligned}
$$

The rate of temperature tise will increase as the waste transfer proceeds, due to the continuous decline in waste mass. It is assumed that the pump power will be reduced as the transfer nears completion in order to avoid excessive waste temperature. 


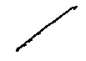

Pump Heat $=0$ Stu/h Inlet Air Temp $=77 \mathrm{~F}$ Suppression Factor $=.45$ ALC Flow Rate $=0$ scfm Tank Diameter $=75 \mathrm{ft}$ Tank Thickness $=1$ in concrete Depth $=1.25 \mathrm{ft}$

\section{$101 A Z$ Prior To Firs Translier}

Radionuclide Heat $=300000 \mathrm{Etu} / \mathrm{h}$

Relative Humidity $=40 \%$

Inlet Air Temp at Annulus $=77 \mathrm{~F}$

Annulus flow Rate $=800 \mathrm{scfm}$

Tank Height $=35 \mathrm{ft}$ Ann Gap $=30 \mathrm{in}$

Soil Depth $=10.5 \mathrm{ft}$

Outside Air Tent? $=77 \mathrm{~F}$

\begin{tabular}{|c|c|c|c|c|c|c|c|c|c|}
\hline $\begin{array}{l}\text { Soln } \\
\text { Temp. } \\
\text { F }\end{array}$ & $\begin{array}{l}\text { Soln } \\
\text { vp } \\
\text { mat Hg }\end{array}$ & $\begin{array}{c}\text { Annutus } \\
\text { Loss } \\
\text { Btu/h }\end{array}$ & $\begin{array}{c}\text { Conduct } \\
\text { Loss } \\
\text { Btu/h }\end{array}$ & $\begin{array}{c}\text { Ket } \\
\text { Evap } \\
1 \text { bH2O/h }\end{array}$ & $\begin{array}{c}\text { Exit } \\
\text { Hum Ra } \\
\text { ibw/lbda }\end{array}$ & $\begin{array}{l}\text { Required } \\
\text { Flow } \\
\text { scfm }\end{array}$ & & & $\underset{F}{\text { Ann. }} \underset{\text { Temp }}{\text { Ex. }}$ \\
\hline $\begin{array}{l}180.0 \\
178.0 \\
176.0 \\
174.0 \\
172.0 \\
170.0 \\
168.0 \\
166.0 \\
154.0 \\
152.0 \\
160.0 \\
158.0 \\
156.0 \\
154.0 \\
152.0 \\
150.0 \\
148.0 \\
146.0 \\
144.0 \\
142.0 \\
140.0 \\
138.0 \\
136.0 \\
134.0 \\
132.0 \\
130.0 \\
128.0 \\
126.0 \\
124.0 \\
122.0 \\
120.0\end{array}$ & $\begin{array}{l}213.5 \\
204.2 \\
195.3 \\
186.7 \\
178.4 \\
170.4 \\
162.7 \\
155.3 \\
148.2 \\
141.3 \\
134.8 \\
128.5 \\
122.4 \\
116.6 \\
111.0 \\
105.7 \\
100.6 \\
95.7 \\
91.0 \\
86.4 \\
82.1 \\
78.0 \\
74.0 \\
70.3 \\
66.6 \\
63.2 \\
59.9 \\
56.7 \\
53.7 \\
50.9 \\
48.1\end{array}$ & $\begin{array}{l}90065 . \\
88304 . \\
86544 . \\
84784 . \\
83023 . \\
81263 . \\
79503 . \\
77743 . \\
75982 . \\
74222 . \\
72461 . \\
70701 . \\
68941 . \\
67181 . \\
65420 . \\
63660 . \\
61900 . \\
60140 . \\
58379 . \\
56619 . \\
54859 . \\
53099 . \\
51339 . \\
49579 . \\
47819 . \\
46059 . \\
44300 . \\
42540 . \\
40781 . \\
39021 . \\
37262 .\end{array}$ & $\begin{array}{l}29407 . \\
28845 . \\
28285 . \\
27723 . \\
27160 . \\
26595 . \\
26031 . \\
25465 . \\
24898 . \\
24330 . \\
23761 . \\
23192 . \\
22621 . \\
22049 . \\
21476 . \\
20902 . \\
20327 . \\
19751 . \\
19174 . \\
18596 . \\
18017 . \\
17437 . \\
16855 . \\
16273 . \\
15689 . \\
15104 . \\
14518 . \\
13931 . \\
13342 . \\
12753 . \\
12161 .\end{array}$ & $\begin{array}{l}164.77 \\
165.97 \\
167.14 \\
168.28 \\
169.37 \\
170.44 \\
171.47 \\
172.46 \\
173.41 \\
174.33 \\
175.21 \\
176.05 \\
176.84 \\
177.60 \\
178.31 \\
178.98 \\
179.60 \\
180.18 \\
180.71 \\
181.18 \\
181.61 \\
181.98 \\
182.30 \\
182.56 \\
182.76 \\
182.89 \\
182.95 \\
182.94 \\
182.85 \\
182.67 \\
182.40\end{array}$ & $\begin{array}{l}0.226 \\
0.212 \\
0.199 \\
0.186 \\
0.175 \\
0.164 \\
0.153 \\
0.144 \\
0.135 \\
0.126 \\
0.118 \\
0.111 \\
0.104 \\
0.097 \\
0.091 \\
0.085 \\
0.080 \\
0.074 \\
0.069 \\
0.065 \\
0.060 \\
0.056 \\
0.052 \\
0.048 \\
0.045 \\
0.041 \\
0.038 \\
0.035 \\
0.032 \\
0.030 \\
0.027\end{array}$ & $\begin{array}{l}166.86 \\
179.84 \\
193.76 \\
208.70 \\
224.73 \\
241.96 \\
260.51 \\
280.48 \\
302.01 \\
325.27 \\
350.42 \\
377.66 \\
407.21 \\
439.33 \\
474.32 \\
512.50 \\
554.28 \\
600.11 \\
650.54 \\
705.19 \\
767.83 \\
836.37 \\
912.90 \\
998.77 \\
1095.65 \\
1205.60 \\
1331.24 \\
1475.96 \\
1644.14 \\
1841.63 \\
2076.37\end{array}$ & $\begin{array}{l}171.9 \\
169.8 \\
167.6 \\
165.5 \\
163.3 \\
161.2 \\
159.0 \\
156.8 \\
154.6 \\
152.4 \\
150.2 \\
148.0 \\
145.8 \\
143.5 \\
141.4 \\
139.2 \\
136.9 \\
134.7 \\
132.4 \\
130.2 \\
127.9 \\
125.6 \\
123.3 \\
121.0 \\
118.8 \\
116.4 \\
114.1 \\
111.8 \\
109.5 \\
107.1 \\
104.8\end{array}$ & $\begin{array}{l}62.4 \\
62.5 \\
62.5 \\
62.5 \\
62.5 \\
62.6 \\
62.6 \\
62.6 \\
62.6 \\
62.6 \\
62.6 \\
62.5 \\
62.5 \\
62.5 \\
62.4 \\
62.3 \\
62.2 \\
62.1 \\
61.9 \\
61.7 \\
61.5 \\
61.2 \\
60.9 \\
60.6 \\
60.1 \\
59.7 \\
59.1 \\
58.5 \\
57.9 \\
57.1 \\
56.3\end{array}$ & $\begin{array}{l}179.5 \\
177.5 \\
175.5 \\
173.5 \\
171.5 \\
169.5 \\
167.5 \\
165.5 \\
163.5 \\
161.4 \\
159.4 \\
157.4 \\
155.4 \\
153.4 \\
151.4 \\
149.4 \\
147.4 \\
145.4 \\
143.4 \\
141.4 \\
139.4 \\
137.4 \\
135.4 \\
133.4 \\
131.4 \\
129.4 \\
127.4 \\
125.4 \\
123.4 \\
121.4 \\
119.4\end{array}$ \\
\hline \multicolumn{10}{|c|}{ : declare subroutine vappress } \\
\hline \multicolumn{10}{|c|}{ DECLARE sUB vappress (temp, vap) } \\
\hline \multicolumn{10}{|c|}{$\begin{array}{l}\text { CLS } \\
\text { PRINT " } \\
\text { PRINT " } \\
\text { PRINT " } \\
\text { PRINT " } \\
\text { PRINT " } \\
\text { PRINT " }\end{array}$} \\
\hline
\end{tabular}




\begin{tabular}{|c|c|c|c|c|c|c|c|c|c|}
\hline \multicolumn{3}{|c|}{$\begin{array}{l}\text { Pump Heat }=0 \text { Btu } / \mathrm{h} \\
\text { Inlet Air Temp }=77 \mathrm{~F} \\
\text { Suppression Factor }=.45 \\
\text { ALC Flow Rate }=0 \mathrm{scfm} \\
\text { Tenk Diameter }=75 \mathrm{ft} \\
\text { Tank Thickness }=1 \text { in } \\
\text { Concrete Depth }=1.25 \mathrm{ft}\end{array}$} & \multicolumn{7}{|c|}{$\begin{array}{l}\text { Radionuclide Heat }=30000 \mathrm{Btu} / \mathrm{h} \\
\text { Relative Humidity }=40 \% \\
\text { Inlet Air Temp at AnnuTus }=77 \mathrm{~F} \\
\text { Annulus Flow Rate }=800 \mathrm{scfm}\end{array}$} \\
\hline $\begin{array}{c}\text { Soln } \\
\text { Temp. } \\
\text { F }\end{array}$ & $\begin{array}{l}\text { Soln } \\
\text { vp } \\
\text { mim } \mathrm{Kg}\end{array}$ & $\begin{array}{c}\text { Annulus } \\
\text { Loss } \\
\text { Btu/h }\end{array}$ & $\begin{array}{c}\text { Conduct } \\
\text { Loss } \\
\text { Btu/h }\end{array}$ & $\begin{array}{c}\text { Net } \\
\text { Evap } \\
1 \text { bH2O/h }\end{array}$ & $\begin{array}{c}\text { Exit } \\
\text { Hum Ra } \\
\text { lbw/lbda }\end{array}$ & $\begin{array}{l}\text { Required } \\
\text { Flow } \\
\text { scfm }\end{array}$ & & $\begin{array}{ll}x i t & A \\
d & \\
\text { XRH } & \end{array}$ & $\begin{array}{c}\text { Ann. Ex. } \\
\text { Temp } \\
F\end{array}$ \\
\hline $\begin{array}{l}100.0 \\
98.0 \\
96.0 \\
94.0 \\
92.0 \\
90.0 \\
88.0 \\
86.0 \\
84.0 \\
82.0 \\
80.0 \\
78.0\end{array}$ & $\begin{array}{l}27.0 \\
25.4 \\
23.9 \\
22.5 \\
21.1 \\
19.8 \\
18.6 \\
17.5 \\
16.4 \\
15.4 \\
14.4 \\
13.5\end{array}$ & $\begin{array}{l}13643 . \\
12286 . \\
10945 . \\
9622 . \\
8320 . \\
7041 . \\
5790 . \\
4572 . \\
3396 . \\
2274 . \\
1230 . \\
324 .\end{array}$ & $\begin{array}{l}8723 . \\
8176 . \\
7629 . \\
7083 . \\
6538 . \\
5996 \\
5459 \\
4928 \\
4407 \\
3906 \\
3439 \\
2910\end{array}$ & $\begin{array}{r}5.51 \\
6.85 \\
8.18 \\
9.50 \\
10.82 \\
12.14 \\
13.49 \\
14.87 \\
16.33 \\
17.89 \\
19.53 \\
24.03\end{array}$ & $\begin{array}{l}0.023 \\
0.021 \\
0.020 \\
0.018 \\
0.017 \\
0.016 \\
0.014 \\
0.013 \\
0.012 \\
0.011 \\
0.010 \\
0.009\end{array}$ & $\begin{array}{r}81.79 \\
114.06 \\
153.77 \\
203.38 \\
266.63 \\
349.38 \\
461.42 \\
620.33 \\
861.03 \\
252.67 \\
039.66 \\
060.44\end{array}$ & $\begin{array}{l}98.3 \\
96.3 \\
94.2 \\
92.2 \\
90.2 \\
88.2 \\
86.2 \\
84.2 \\
82.4 \\
80.6 \\
79.2 \\
77.2\end{array}$ & $\begin{array}{l}5 \\
5 \\
5 \\
5 \\
4\end{array}$ & 9 \\
\hline
\end{tabular}

Waste temperature is too high. Will try next temperature step(B).

Waste temperature is too high. Wili try next temperature step (B).

Waste temperature is too high. Hili try next temperature step (B).

Waste temperature is too high. Will try next temperature step $(B)$.

Waste temperature is too high. Will try next temperature step(B).

Annulus air inlet temperature is higher than waste temperature.

Annulus heat transfer is ignored.

Aiso, convergence problem exits for air flow rate

- declare subroutine vappress

DECLARE SUB vappress (temp, vap)

'Description of the program

CLS

PRINT " "

PRINT is "

PRINT "This is a program to evaluate the required tank air flow rate and"

PRINT "outlet conditions from the radioactive waste storage tank."

PRINT "To run this program, be prepared to input the followings:"

PRINT "radiation decay heat, pump heat, tank air inlet temperature"

PRINT "and relative humidity, ajr flowrate and temperature in the annulus,"

PRINT "and the air lift circulation flowrate. Also, vapor suppression"

PRINT "fraction for the waste in the tank, tank dimensions and desired"

PRINT "waste temperature range to be considered and tank dimensions."

PRIITT " "

PRINT "If you make a mistake duing the input phase, you can terminate"

PRINT "the program by typing (tr)-Break anytime and restart" 